Fall 1986

\title{
1986 Miracle Yearbook
}

Cedarville College

Follow this and additional works at: https://digitalcommons.cedarville.edu/yearbooks

Part of the Higher Education Commons, Organizational Communication Commons, and the Public Relations and Advertising Commons

\section{Recommended Citation}

Cedarville College, "1986 Miracle Yearbook" (1986). Yearbooks. 56.

https://digitalcommons.cedarville.edu/yearbooks/56

This Book is brought to you for free and open access by DigitalCommons@Cedarville, a service of the Centennial Library. It has been accepted for inclusion in Yearbooks by an authorized administrator of DigitalCommons@Cedarville. For more information, please contact digitalcommons@cedarville.edu. 
MIRACI I I

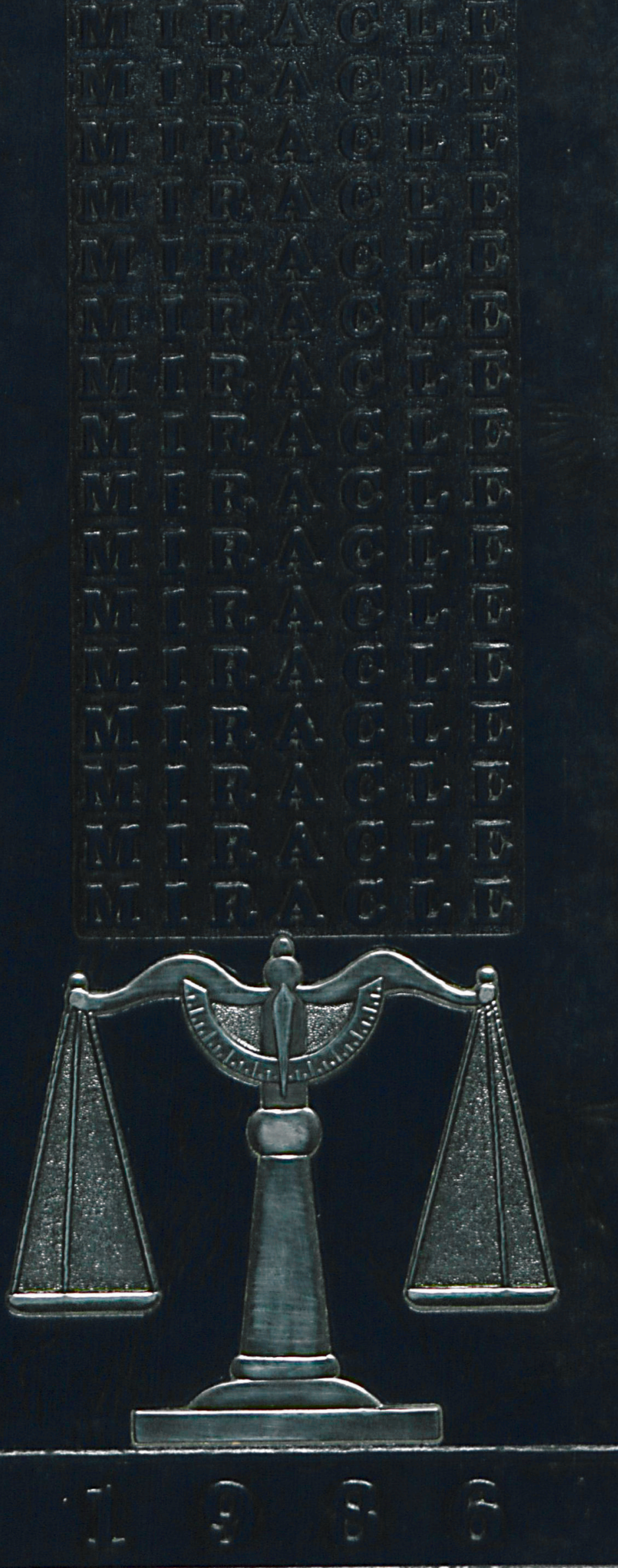







\section{God's}

"The earth is the Lord's and the fullness thereof, the world and they who dwell therein."

Psalm 24:1 


\section{Ownership ...}




\section{Demands Our}

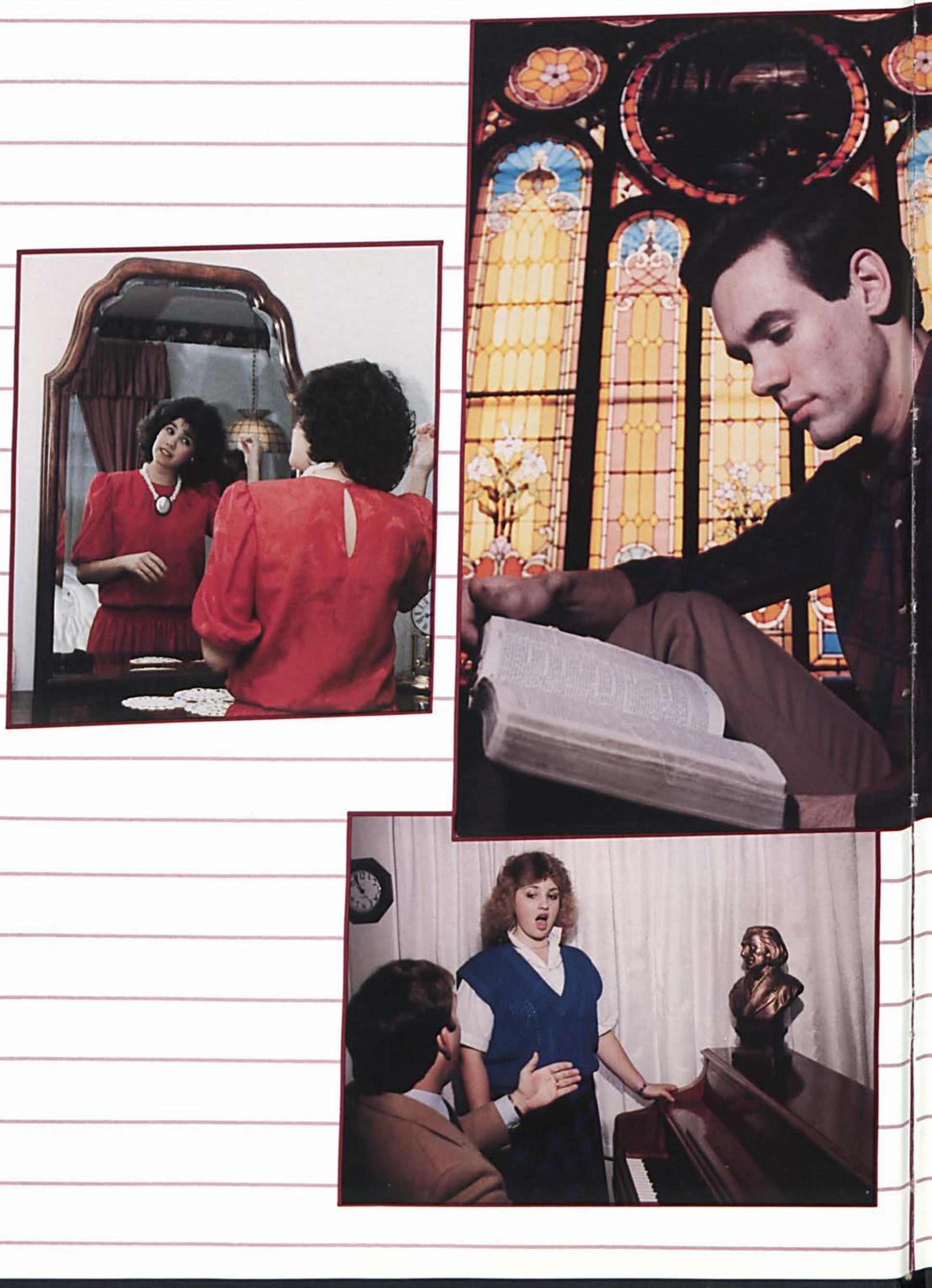




\section{Stewardship.}
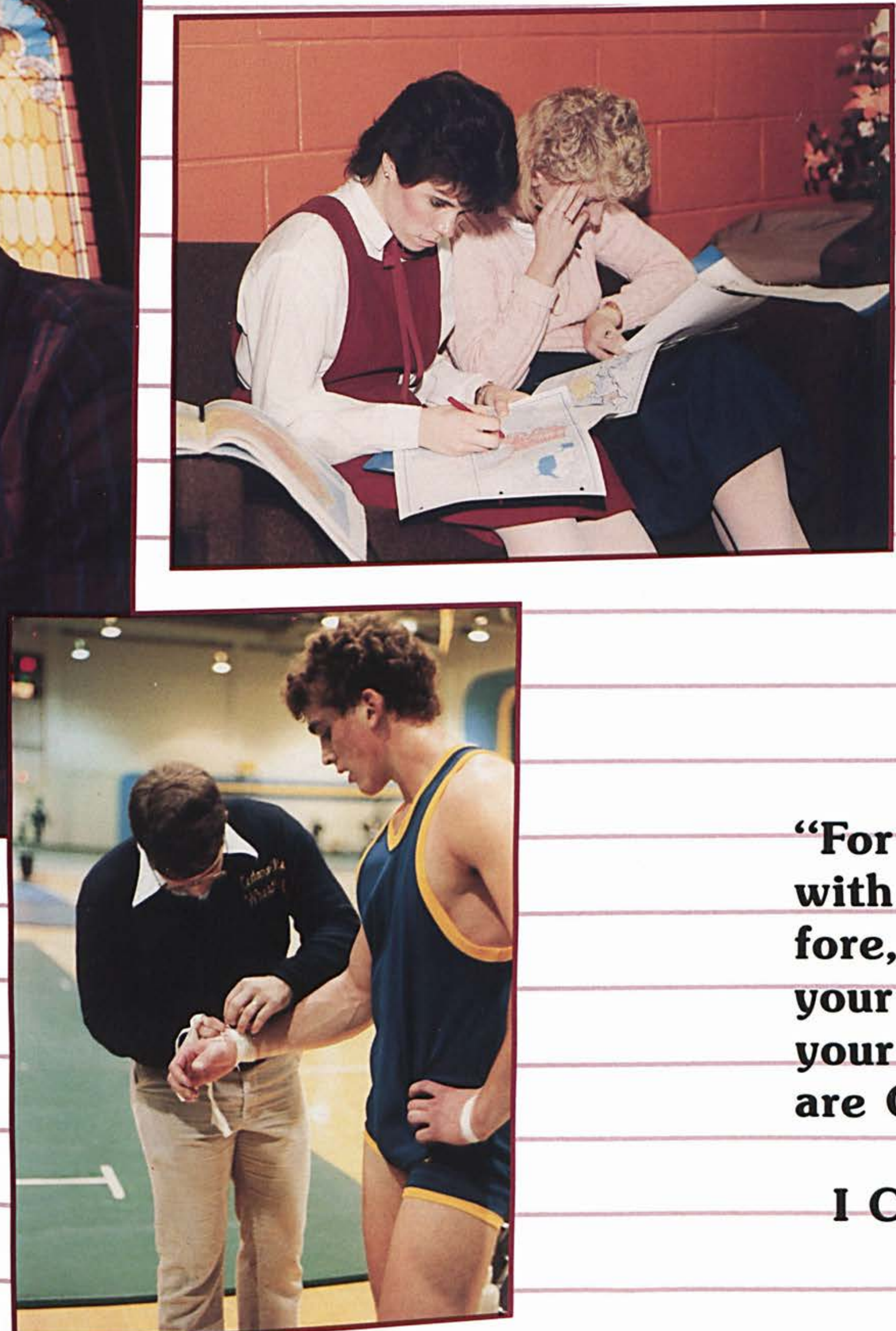

"For ye are bought with a price; therefore, glorify God in your body and in your spirit, which are God's."

\section{Corinthians $6: 20$}




\section{The Balance Of A Christian}

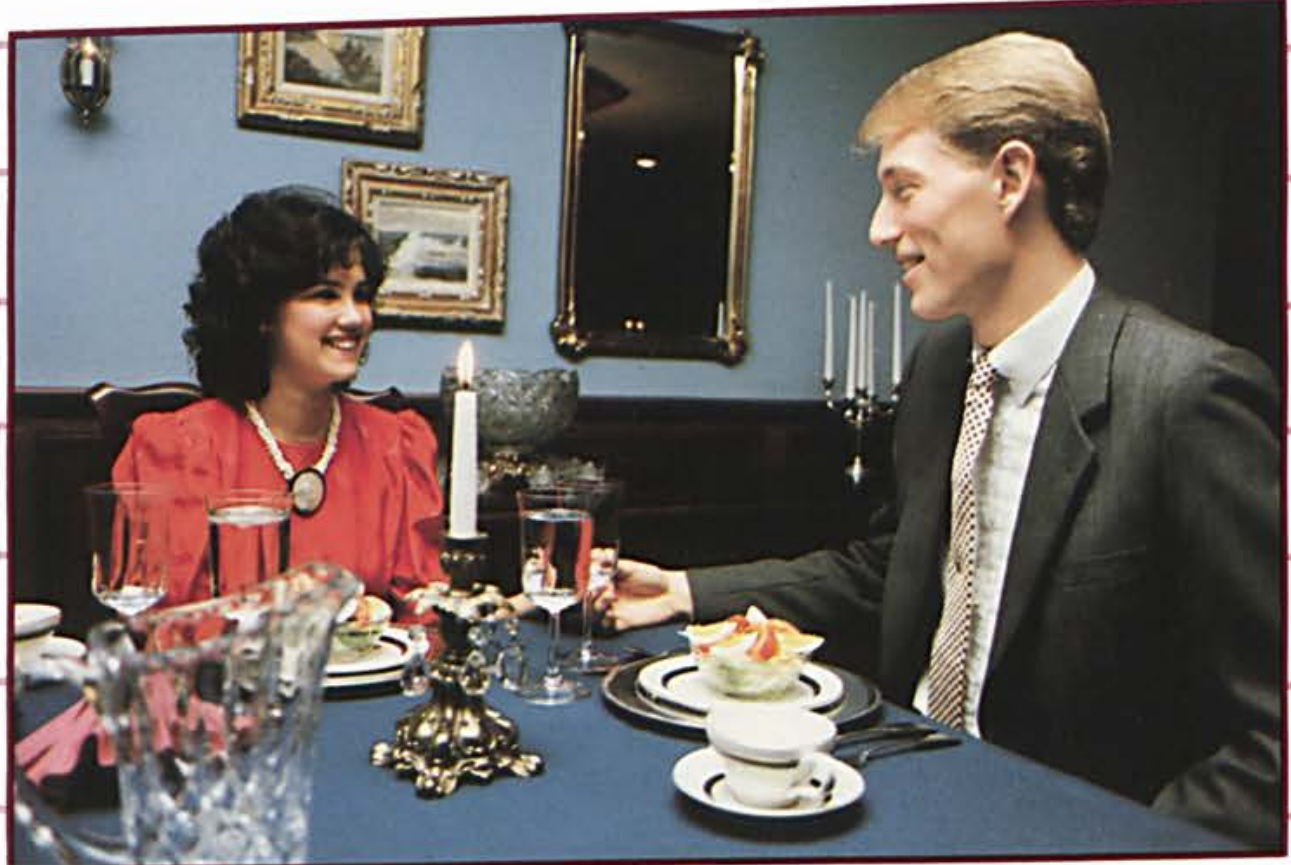

"Whether ye eat or drink or whatever ye do, do all to the glory of God."

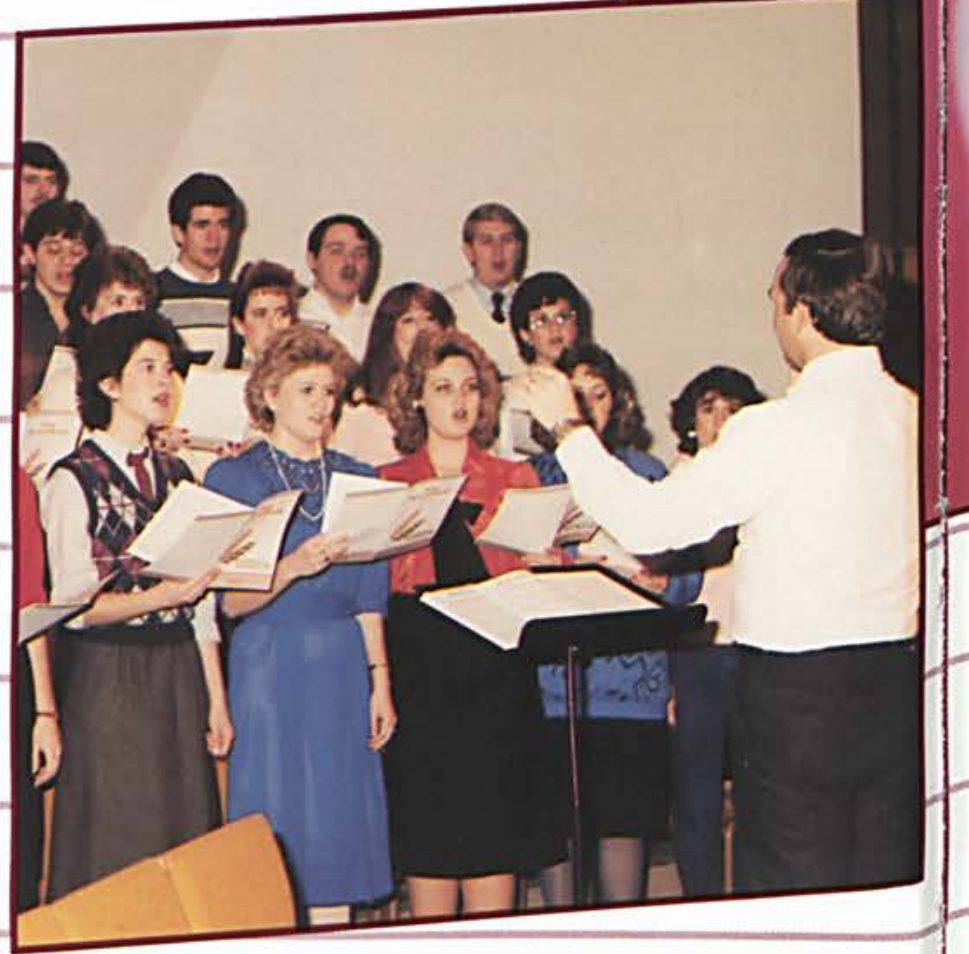

\section{Corinthians 10:31}




\section{Liberal Arts Education}

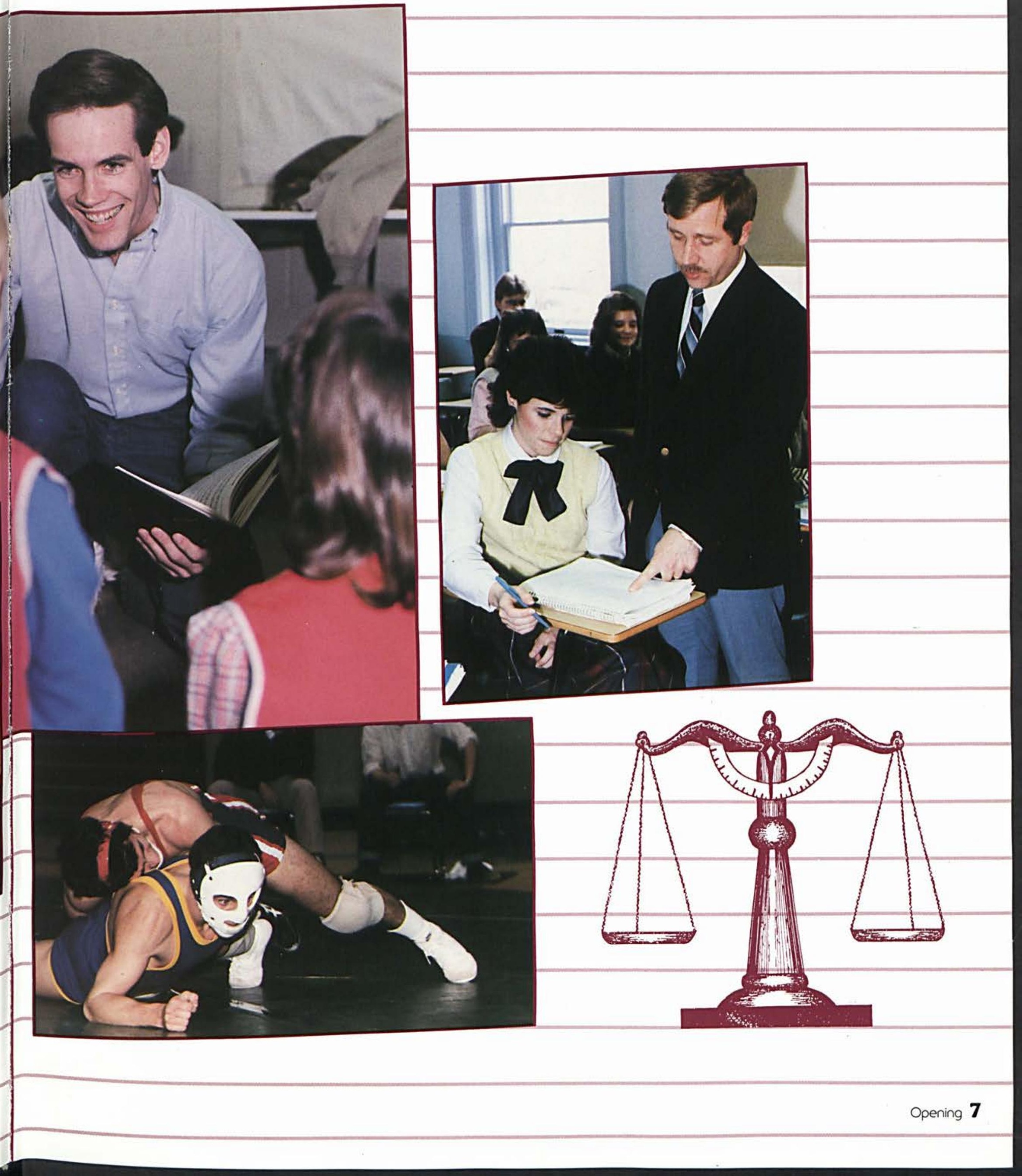




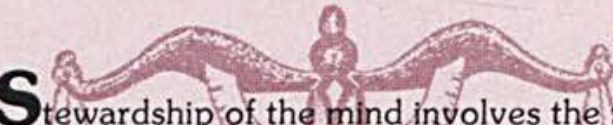

tewardship of the mind involves the recognition that man is not an autonomous being but rather a creature designed to reflect the glory of his Creator in the exercise of all his abilities, including the employment of his mental faculties. Christian minds submit willingly to the authority of God's Word, because they love him preeminently, in whose service they find de. lightful freedom.
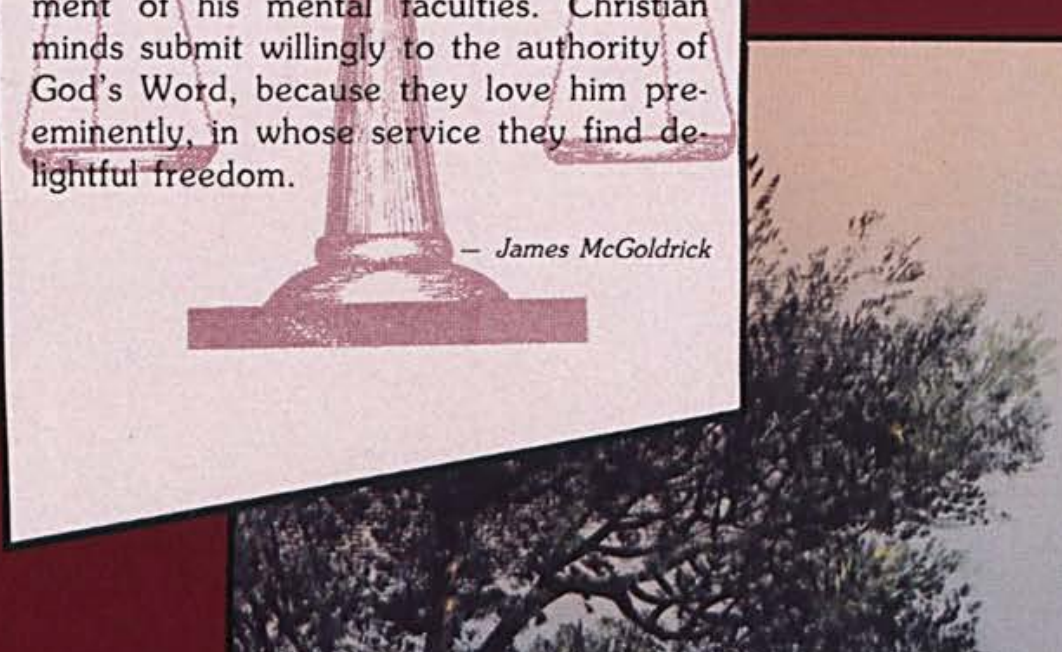
3. $x^{2}$
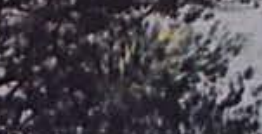

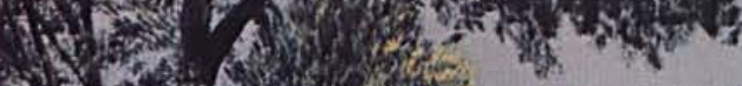

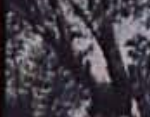

the 1

(x)

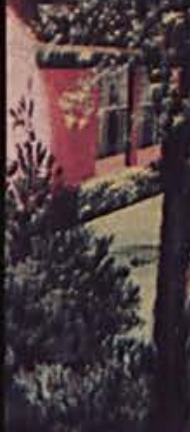

(1)

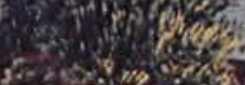

10.13:

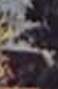

oxpe

*.4.

(9)
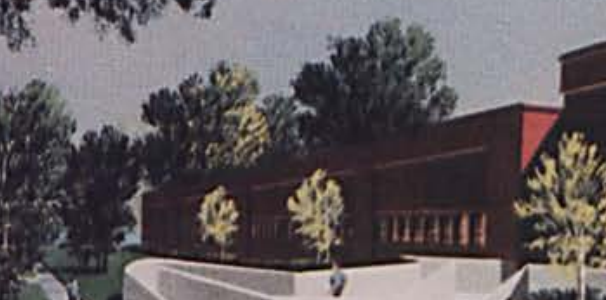
atse
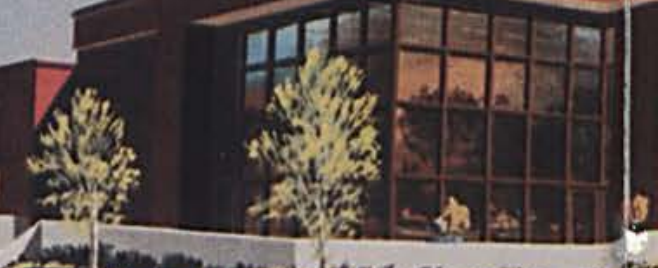

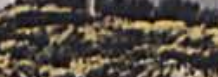

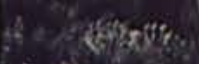

19.6)
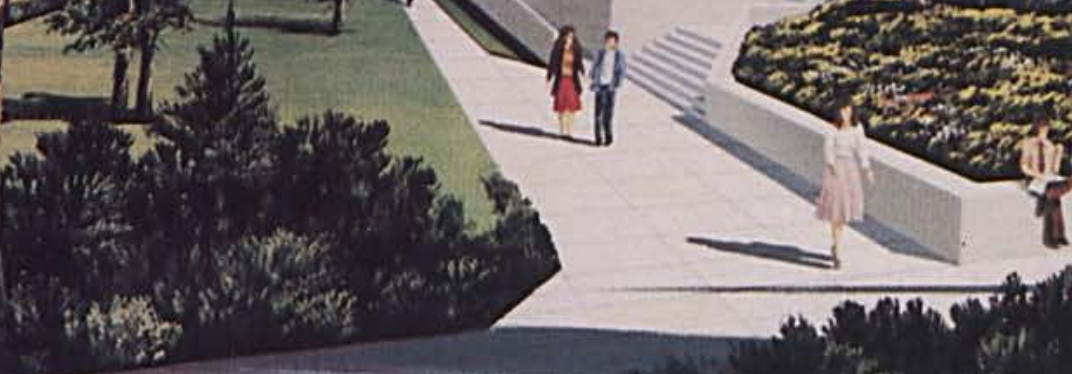

ज्ञात

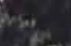

ins.

रुका

Iive sf 


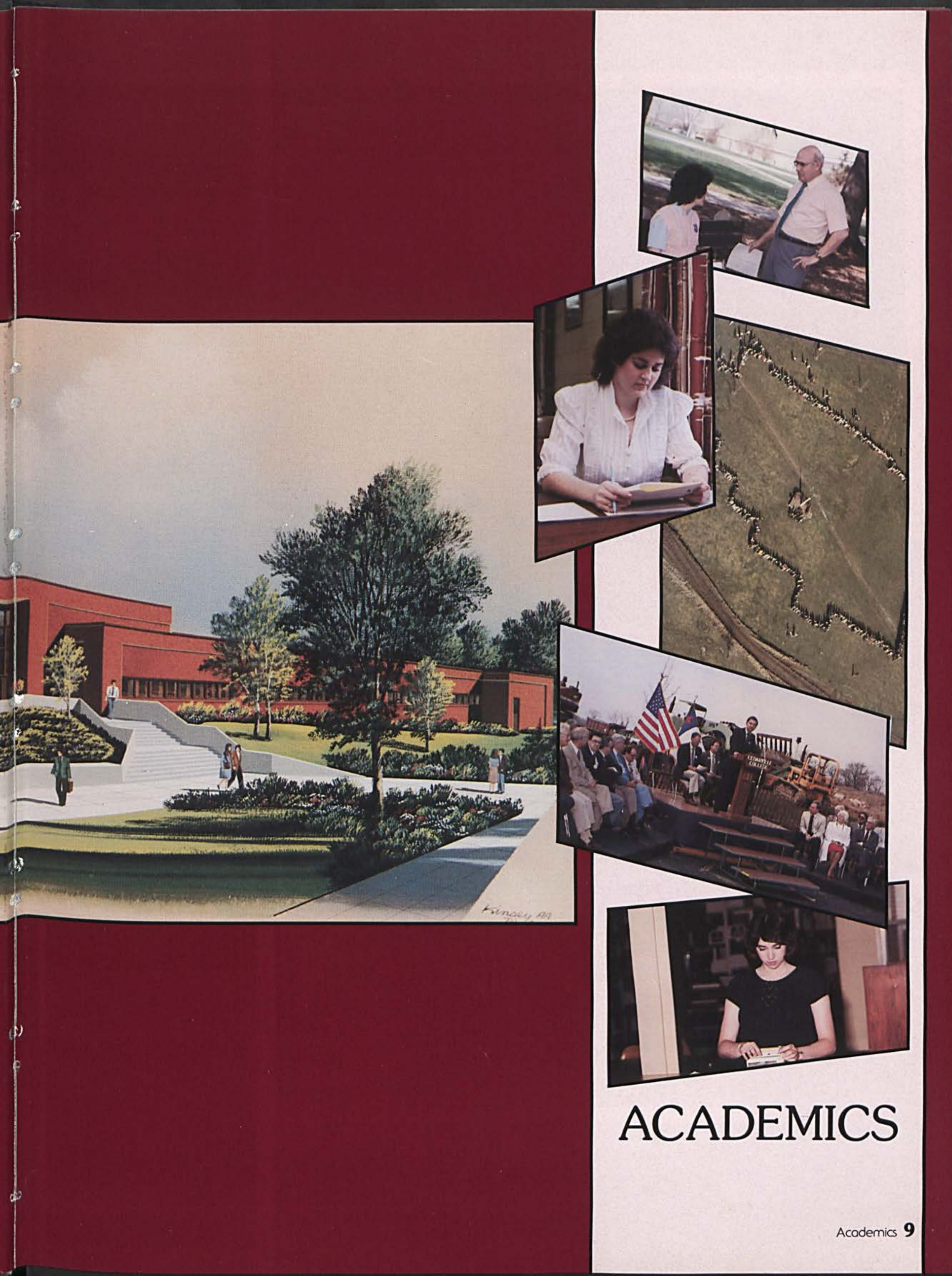




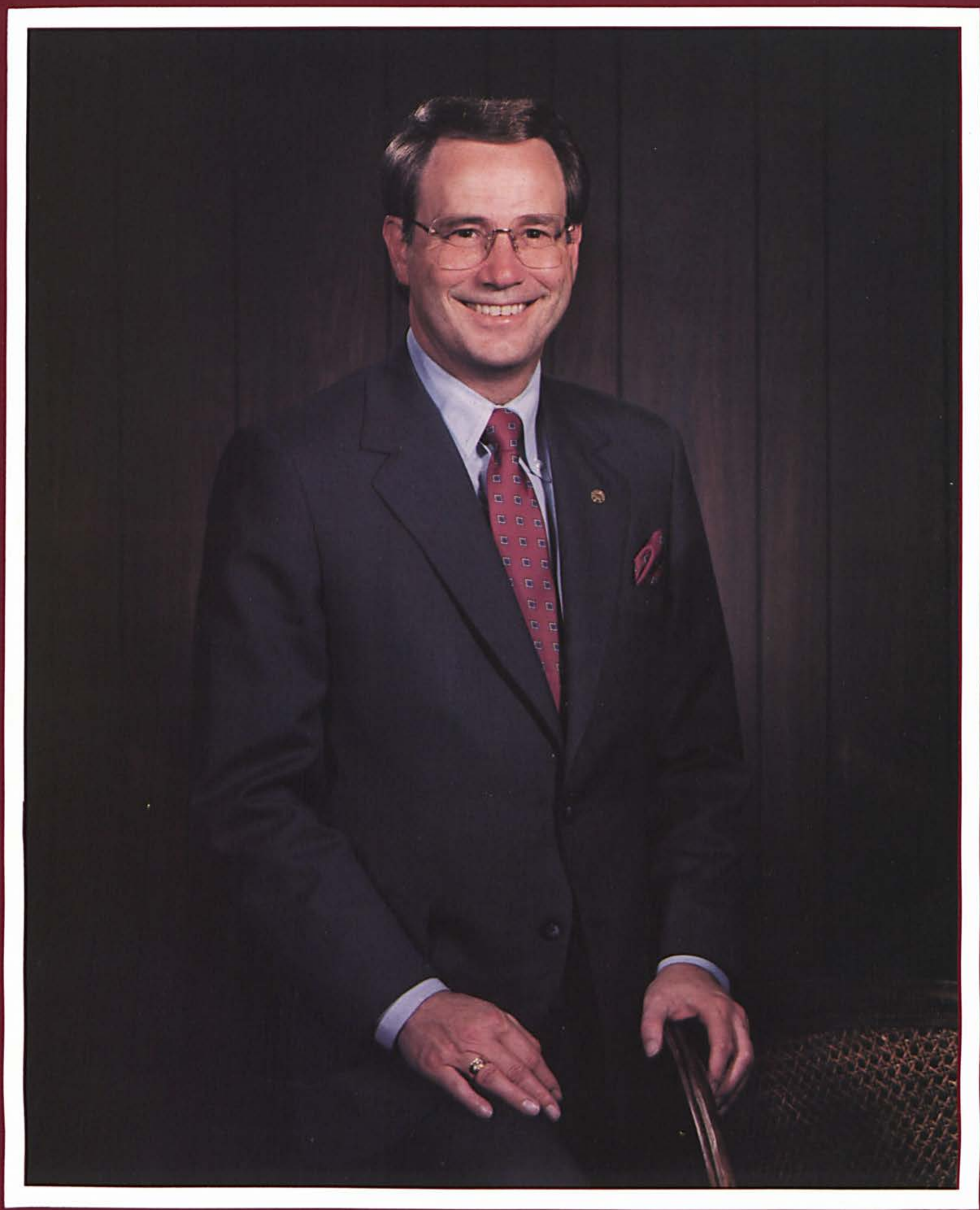

Paul H. Dixon, Ed.D., President 


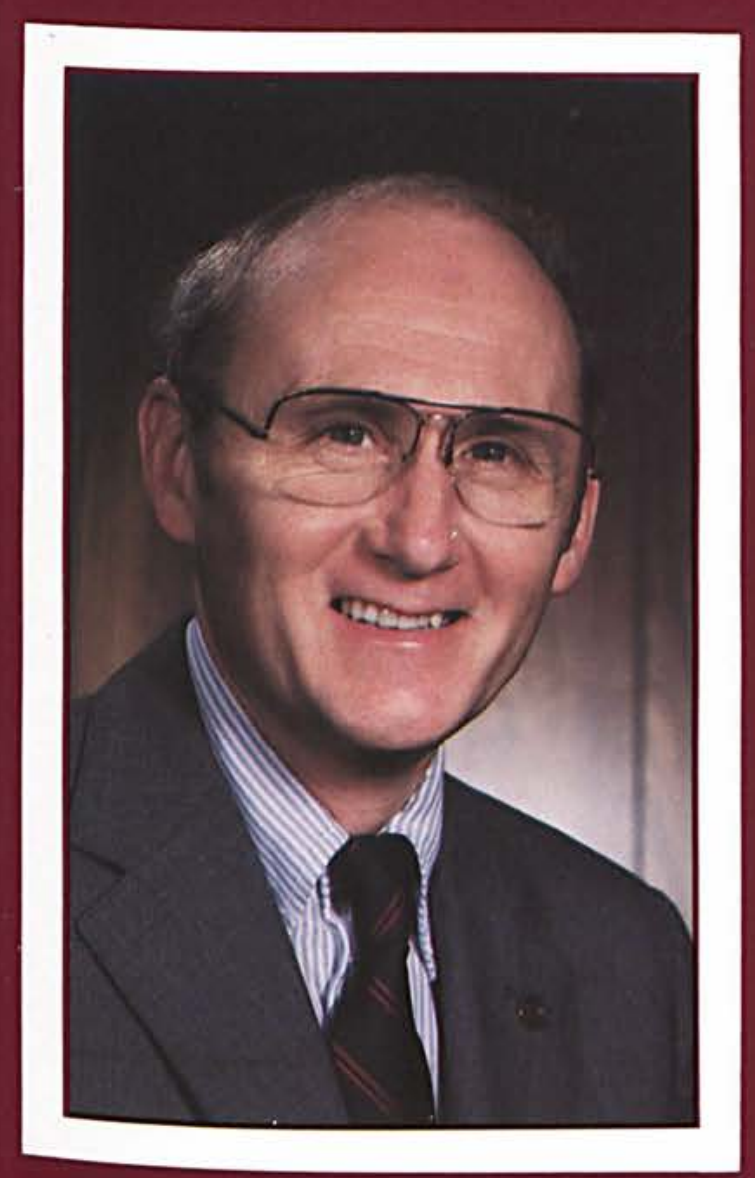

Donald Rickard, M.A.

Vice President for Student

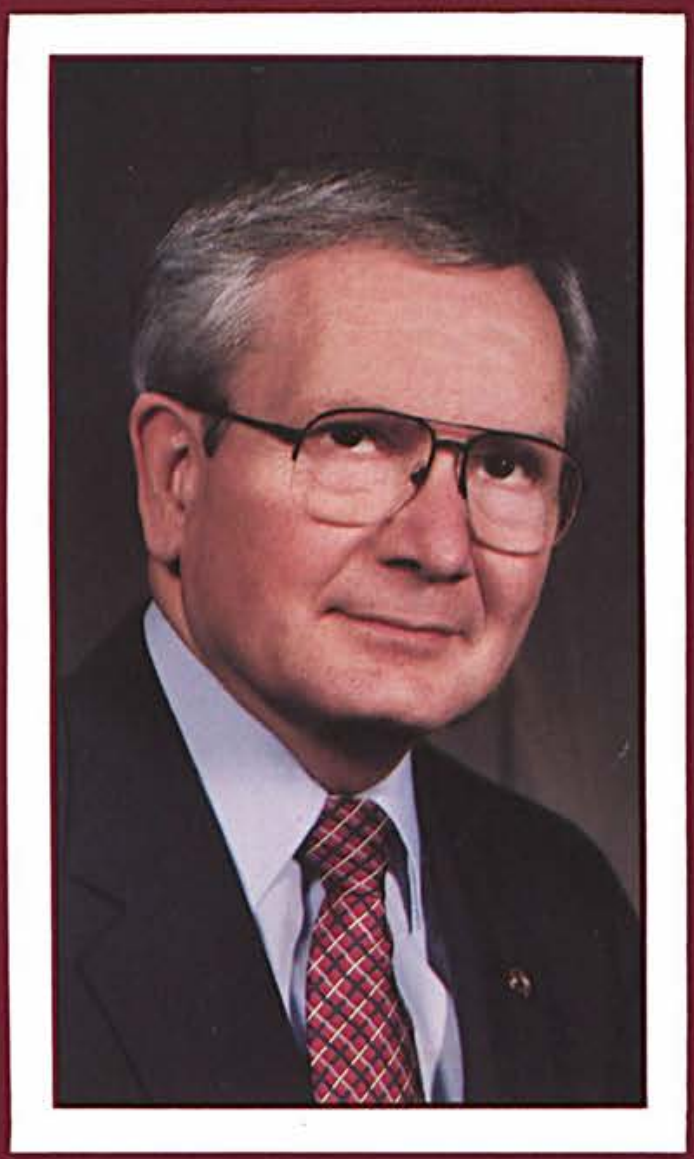

Kenneth St. Clair, M.S., C.P.A. Vice President for Business

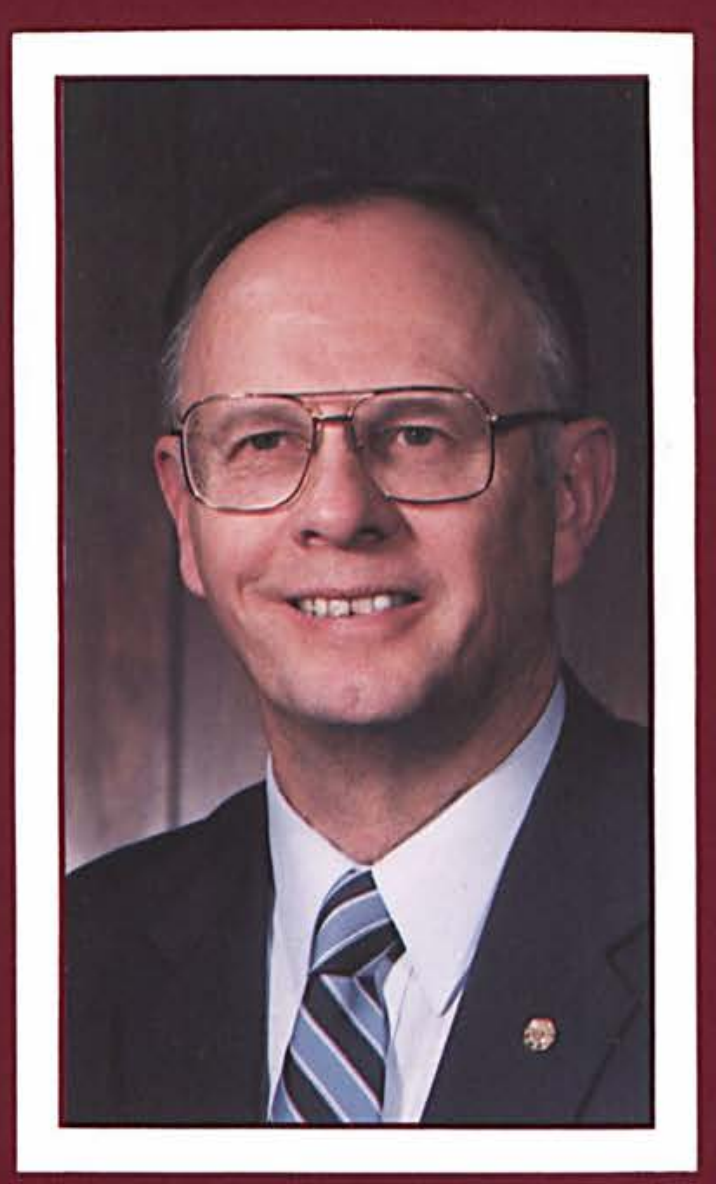

Clifford Johnson, D. Ed. Academic Vice President
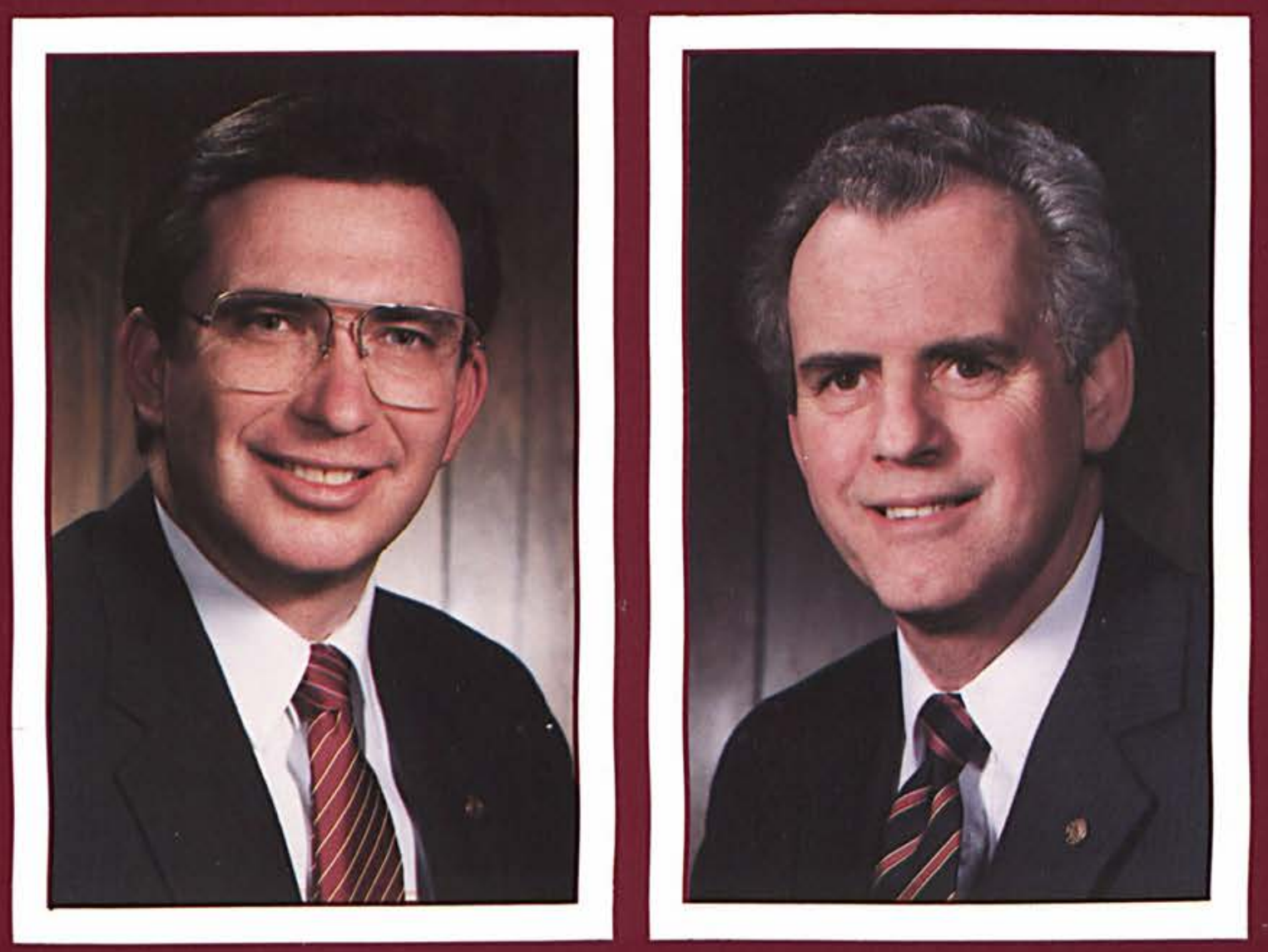

Martin Clark, Ed.D. Vice President for Dévelopment

Harold Green, Th.B.

Vice President for Campus

Ministries 


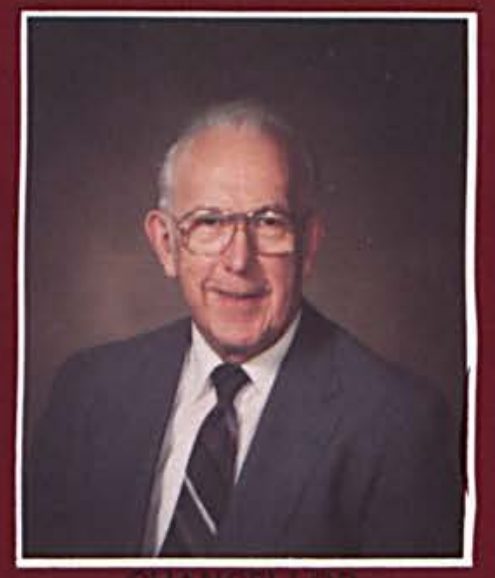

\section{Board Of Trustees}
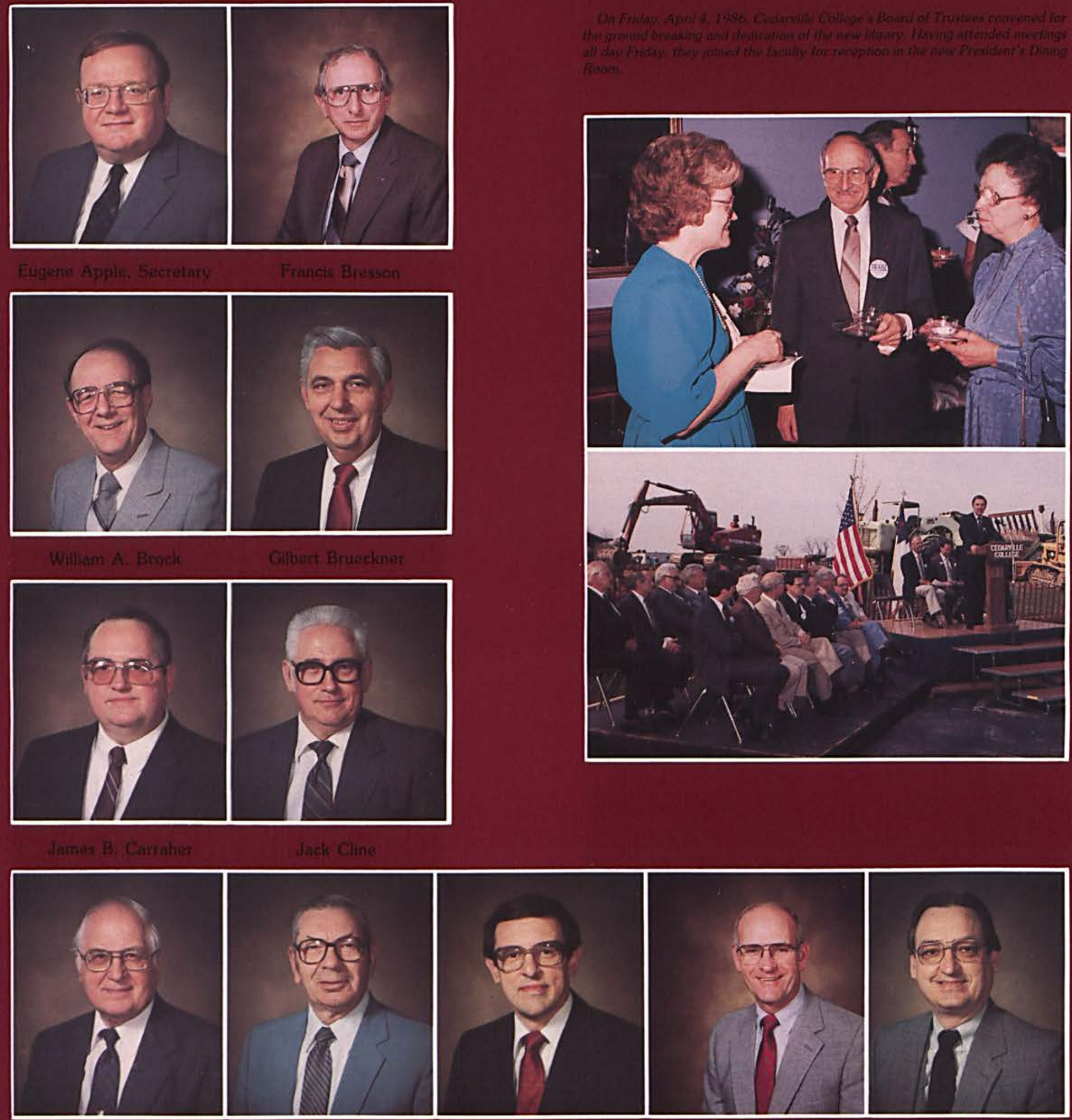


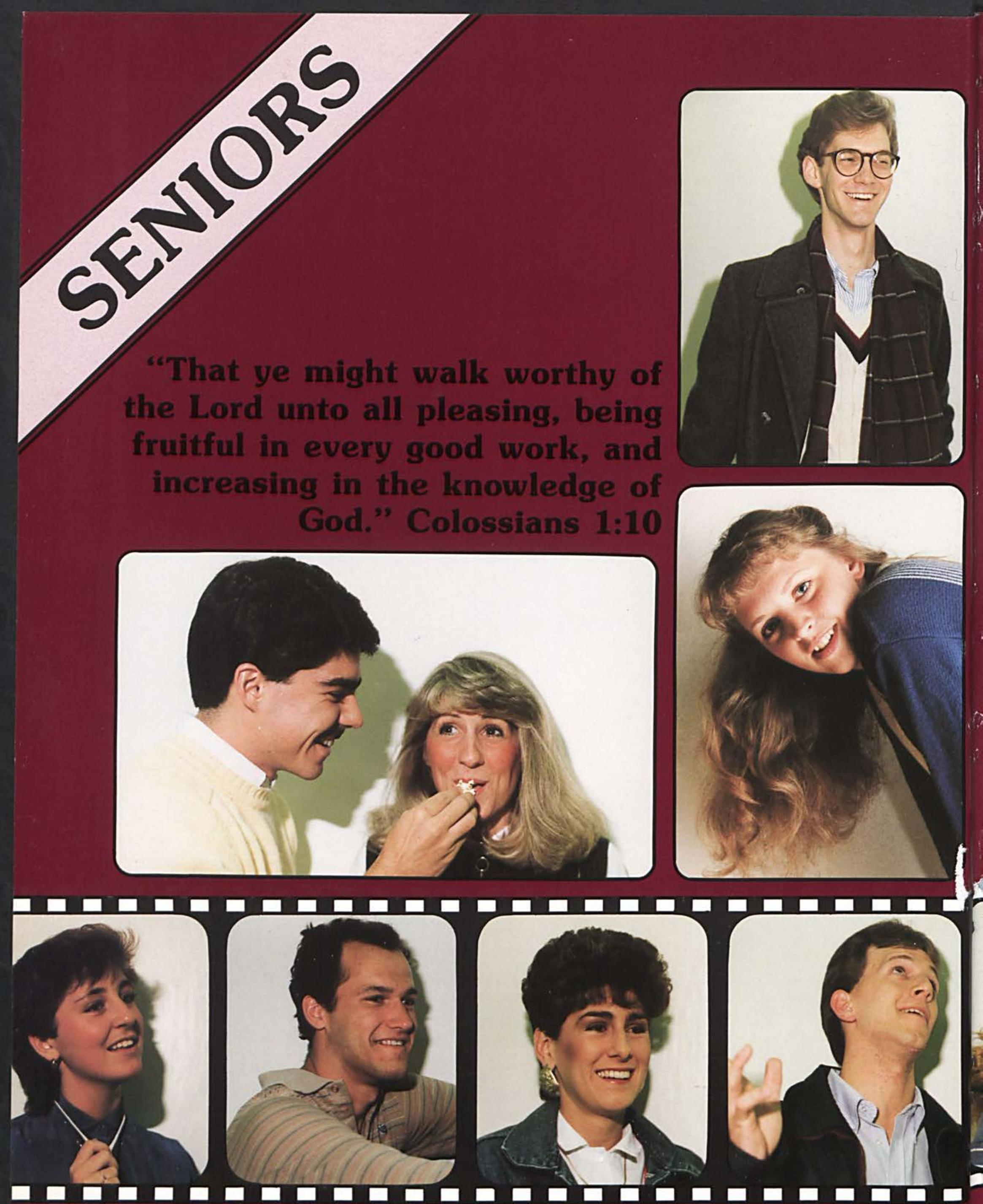


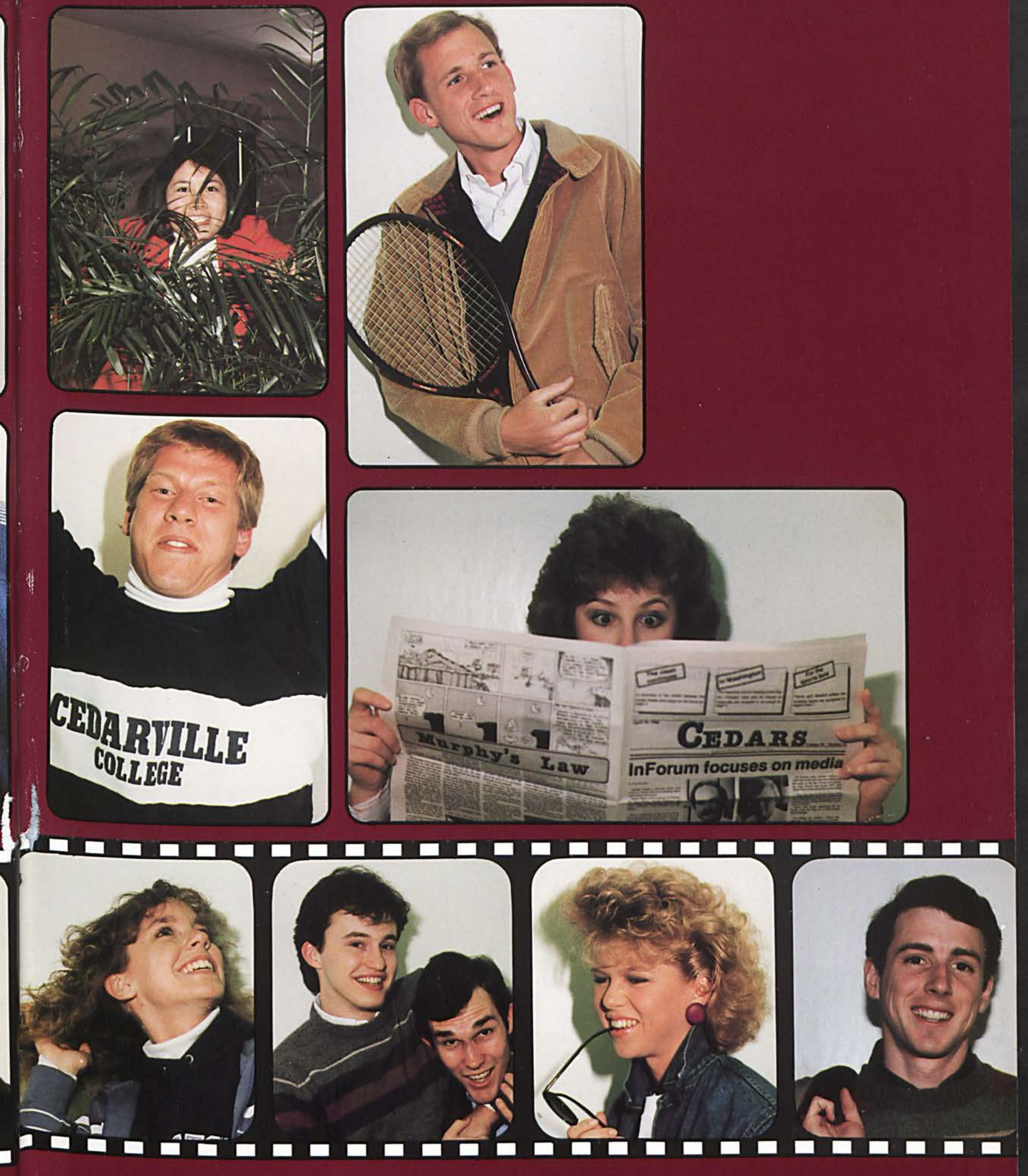


Teaching stewards to know how to interpret God's Word properly, to utilize it for effective, personal, spiritual growth, and to share its message with the saved and unsaved.

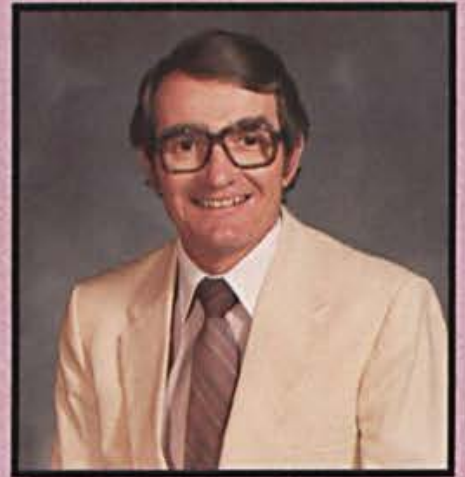

Robert Gromacki, Th.D. Chairman

Professor of Bible and Greek

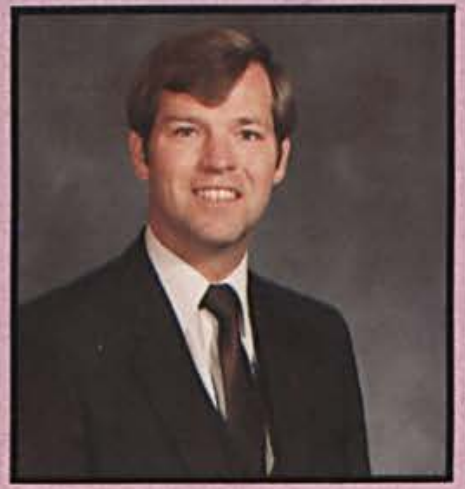

Floyd Elmore, Th.M. Assistant Professor of Bible

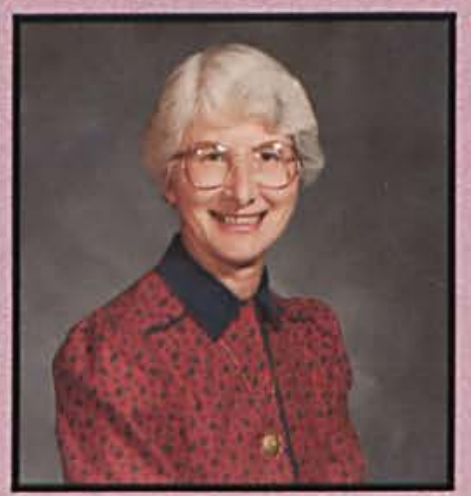

Jean Fisher, M.A. Associate Professor of Christian Education

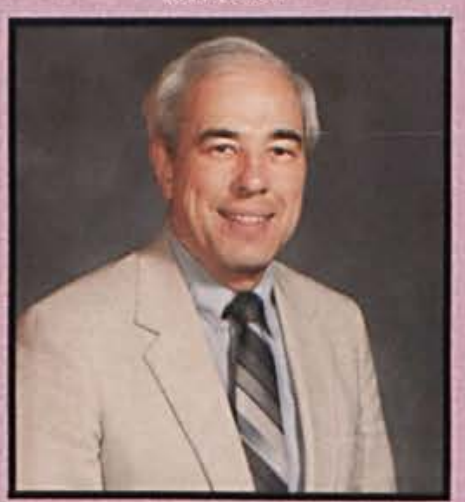

Jack Riggs, Th.D. Professor of Bible

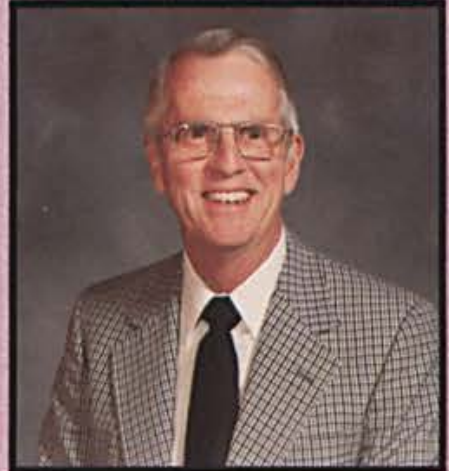

Richard Durham, Th.D. Professor of Bible and Greek

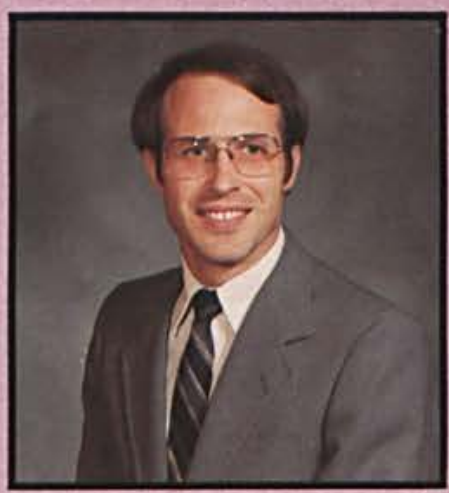

Daniel Estes, Th.M.

Assistant Professor of Bible

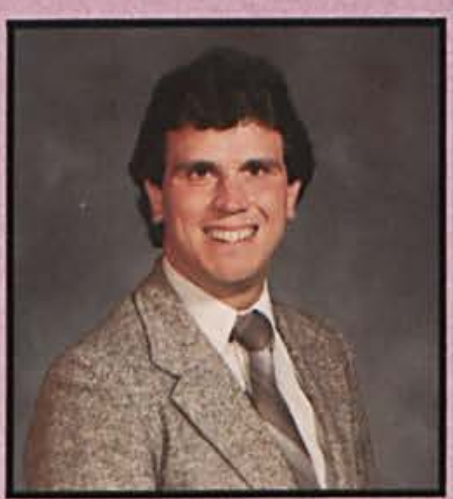

Gary Percesepe, Ph.D. Assistant Professor of Philosophy

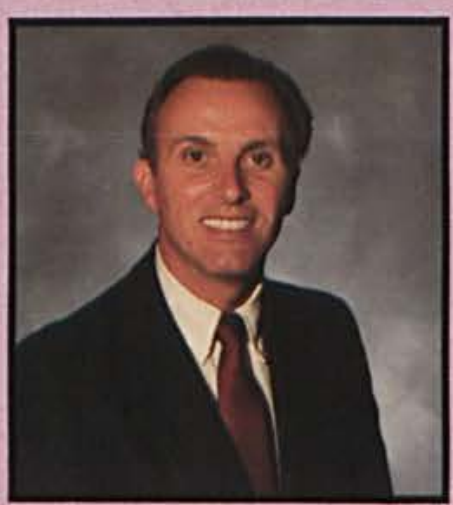

David Warren, Th.M. Associate Professor of Bible and Greek
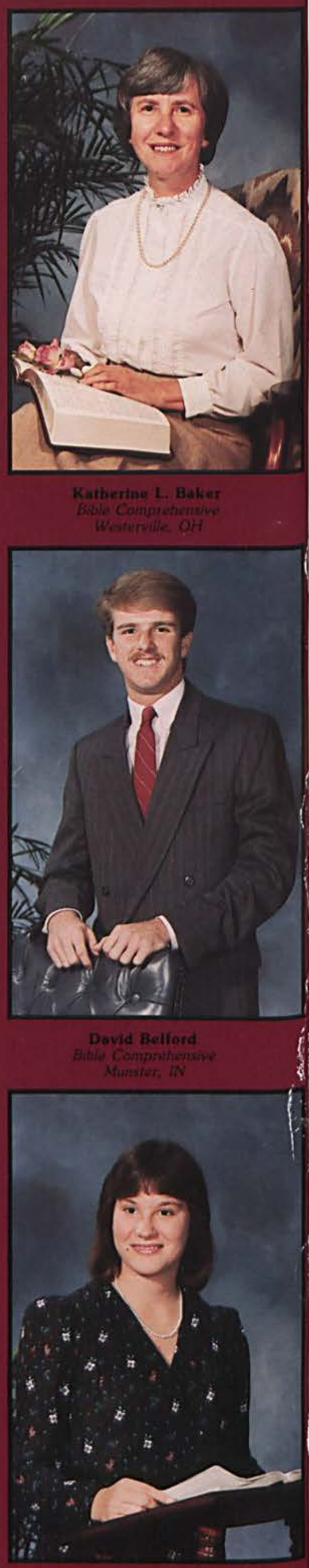

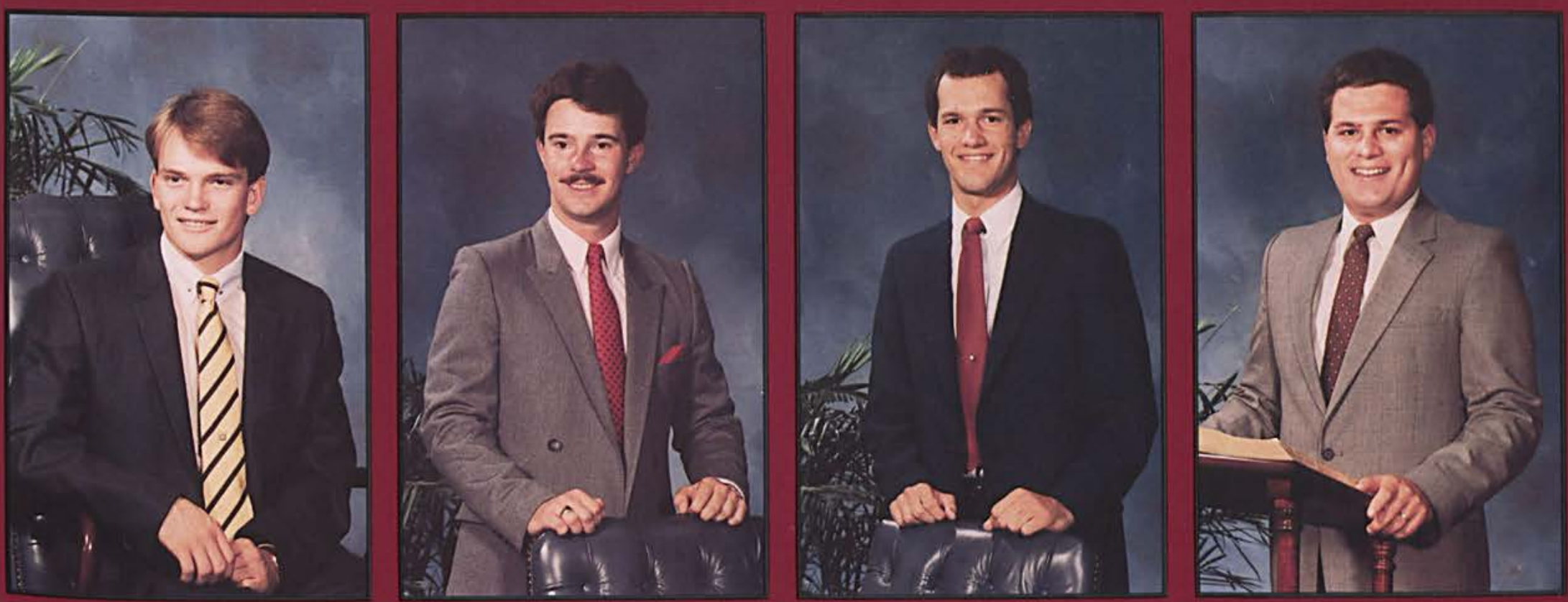

Jay R. Butche?
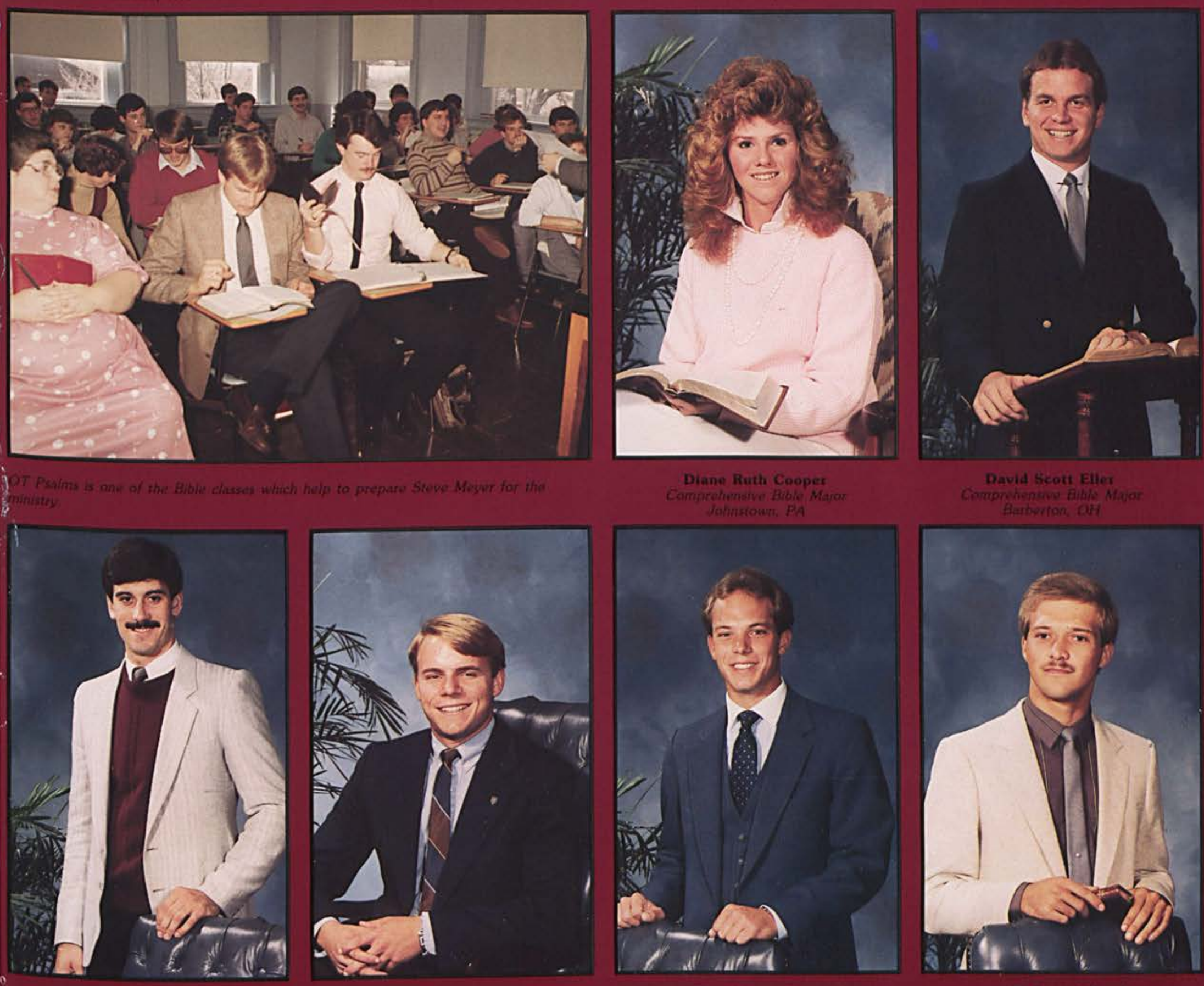


\section{Alumnus Returns To The Classroom}

To me, the unique element in the history of Cedarville College is its ministry-history. To be a part of Cedarville is to be involved in the lives of others.

Reflecting upon those occasions when Cedarville touched my life, I remember the ministry of Dr. James T. Jeremiah, who served as pastor of the church I attended as a child, and the ministry of two Cedarville seniors who influenced me during my teen years as teachers of my Sunday School class. As a missionary with Baptist Mid-Missions in 1971, Cedarville College served me. And following a term of service in Honduras, I returned to Cedarville in 1976 - this time as a student - to complete the undergraduate requirements necessary for advanced theological education. God's preparation of me for his work has included this College again and again.

Nine years ago I never would have believed that I would be asked to participate in the on going ministry-history of Cedarville College. With double the student population and almost twice as many buildings as it had just about a decade ago, Cedarville continues to make history as it faces the challenges of what may be the last generation before Christ's return. May God sanctify my contribution toward the future ministry of the College to bless children, teens, and young or mature adults as they prepare to serve him, just as $\mathrm{He}$ has blessed my life through the ministry-history which is Cedarville's!

Floyd Elmore
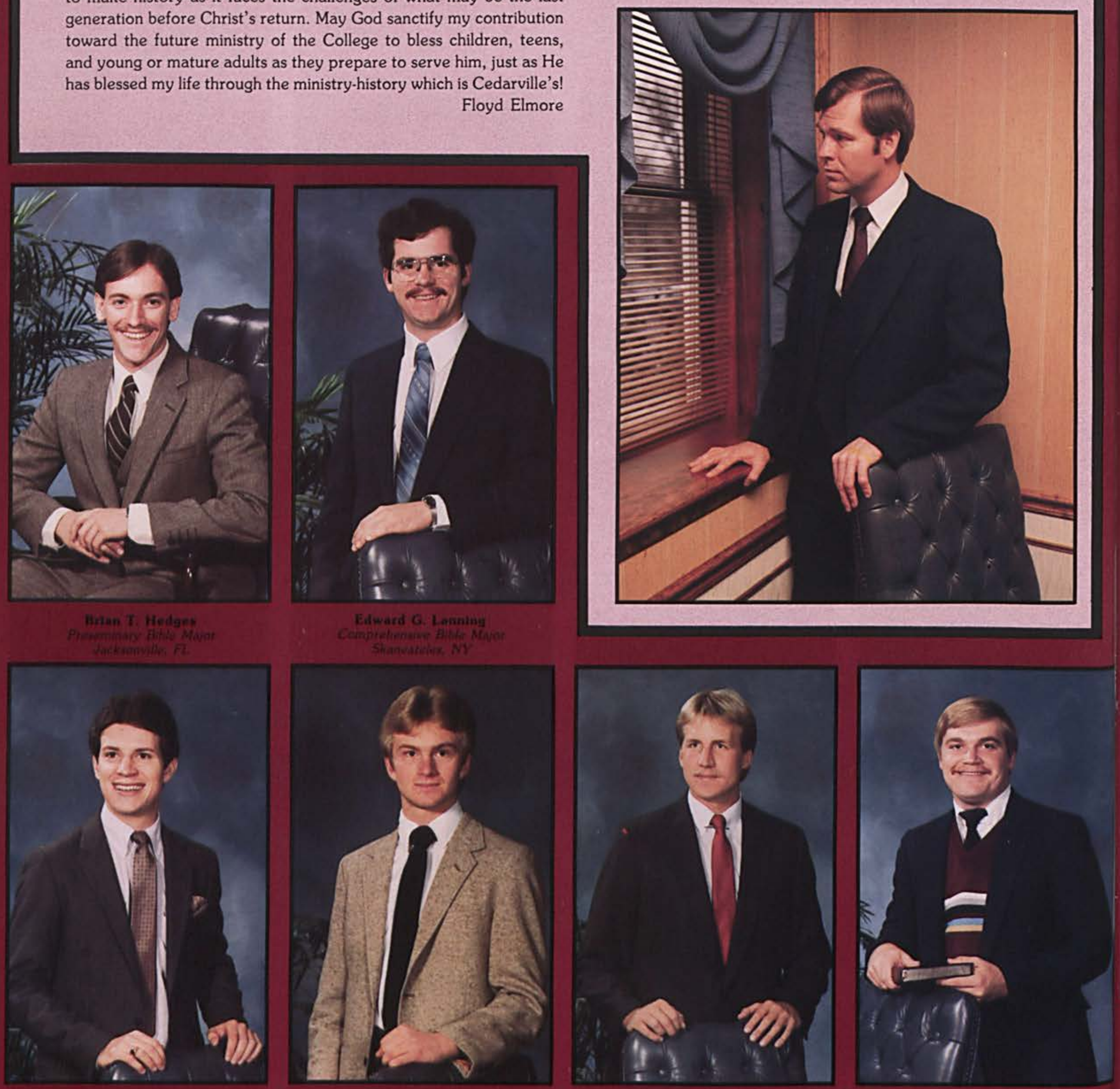


\section{Teaching}

stewards to make

wise decisions for the use of their individual talents and corporate resources in the realm of business for

the benefit of man and the glory of God.

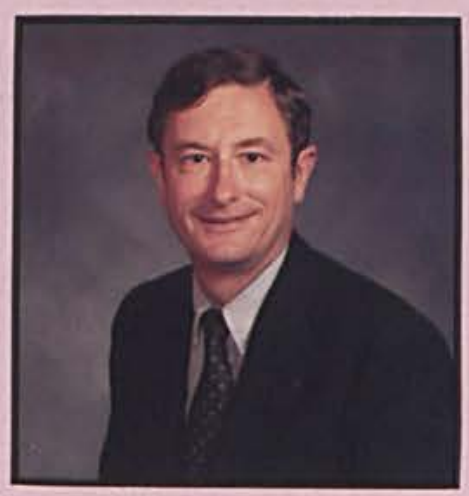

Marinus Hazen, M.B.A. Assistant Professor of Business

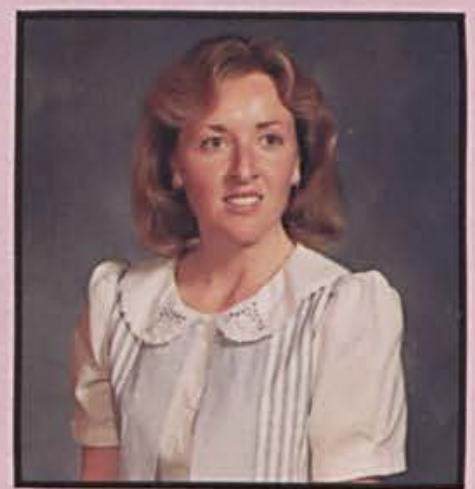

Anne Rich, M. Acct., C.P.A. Assistant Professor of Accounting

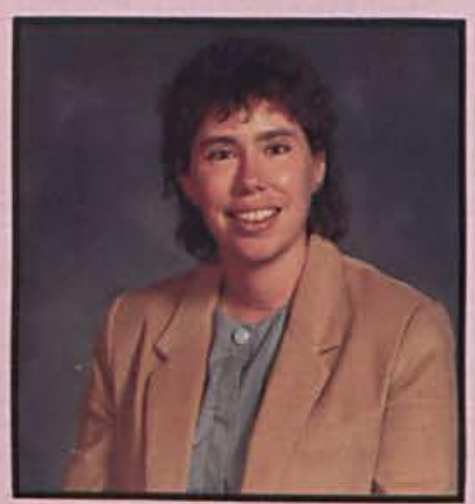

Sarah H. Smith, Ph.D. Assistant Professor of Accounting

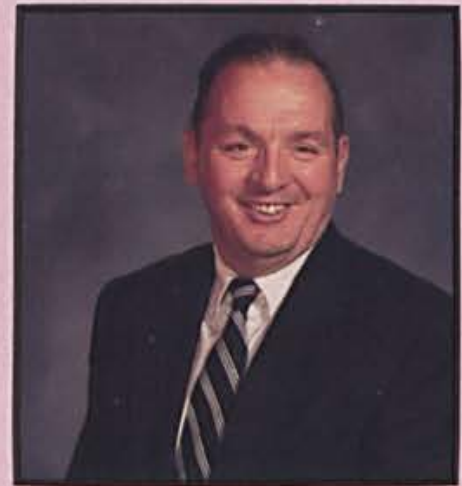

Clifford Fawcett, D.B.A.

$$
\text { Chairman }
$$

Professor of Management

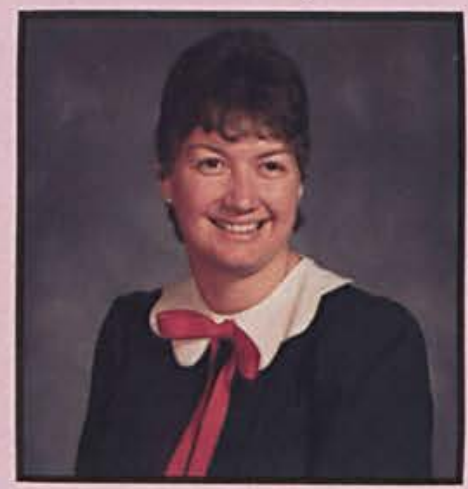

Martha J. Johnson, M.A. Assistant Professor of Secretarial Science

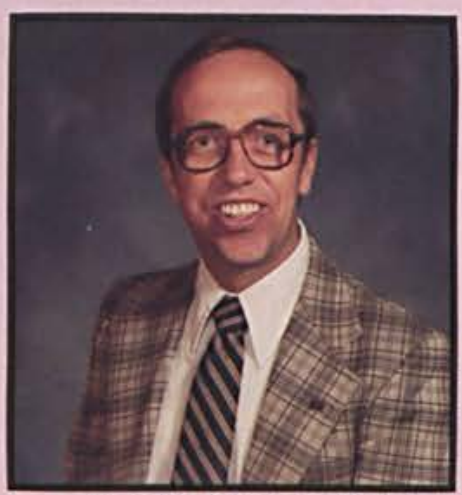

David L. Rotman, M.A.

Assistant Professor of Business Director of Academic Computer

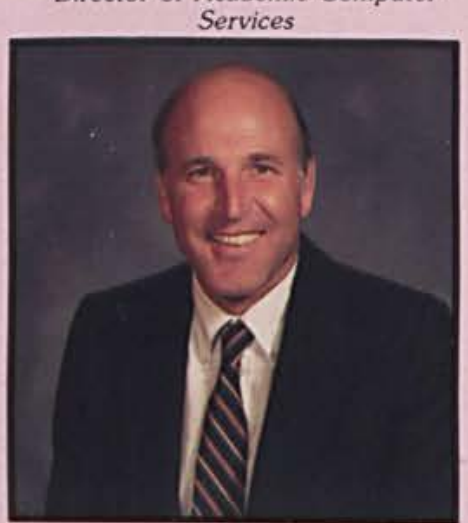

Ronald J. Walker, D.B.A. Assistant Professor of Management

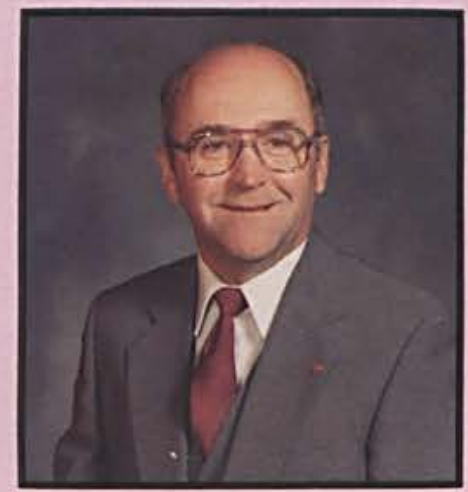

Richard Baldwin, M.B.A. Assistant Professor of Management

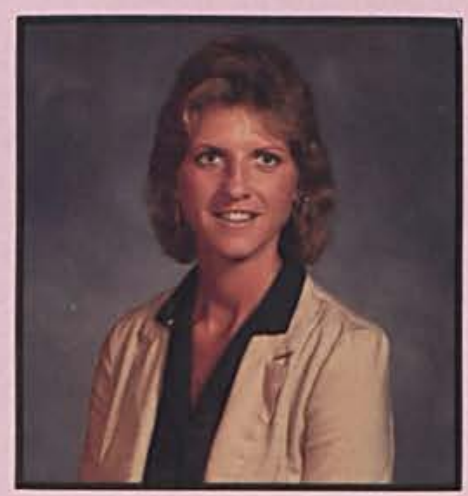

Betsy Kempf, M.A.

Assistant Professor of Secretarial Science

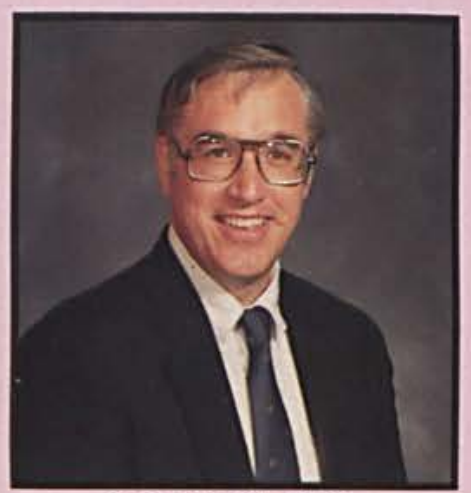

Galen Smith, M.S.

Assistant Professor of Economics

Not pictured:

Debra Brown, M.B.A Assistant Professor of Marketing

James Seaman, Ph.D. Associate Professor of Marketing and Management 


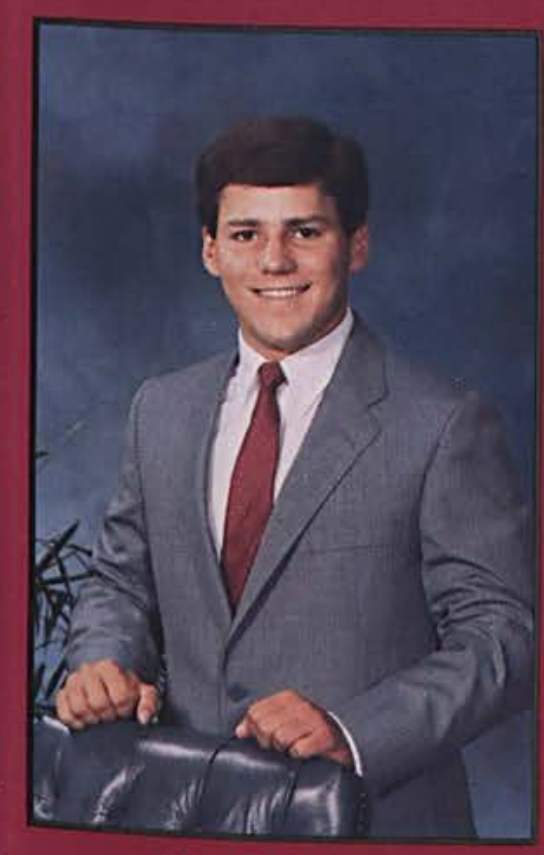

Mare R. Anthony Ex Adiministration

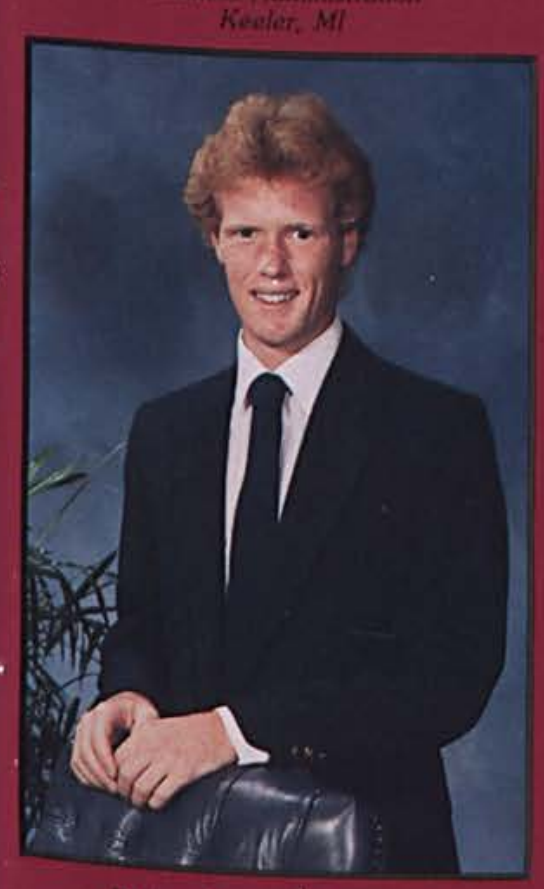

Richard Wayre Bennett

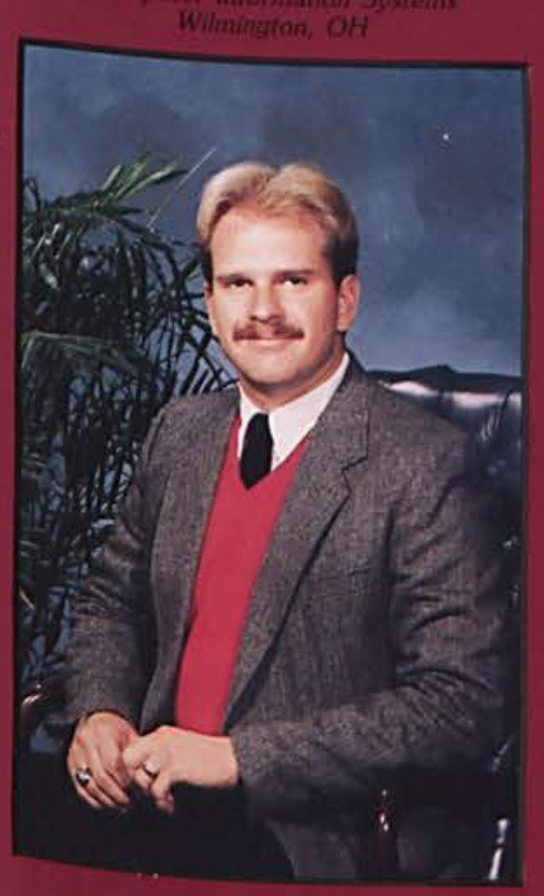

damen Paul Brewin

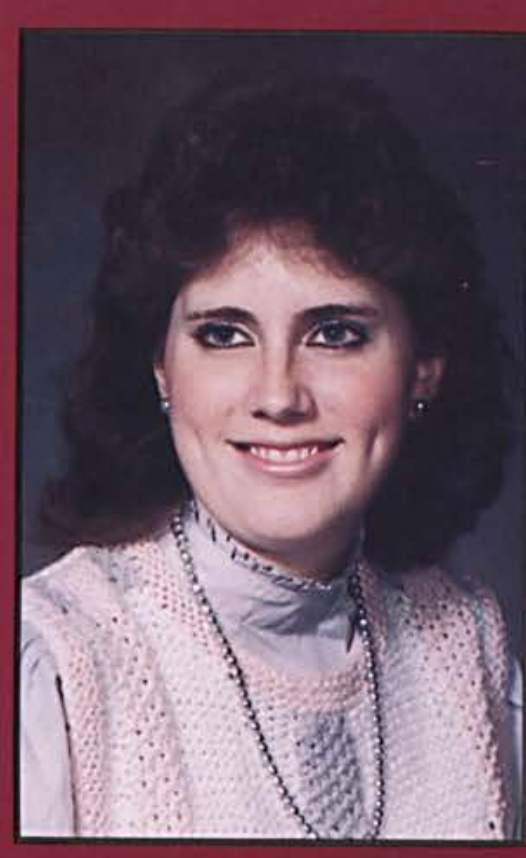

April Loulse Avey

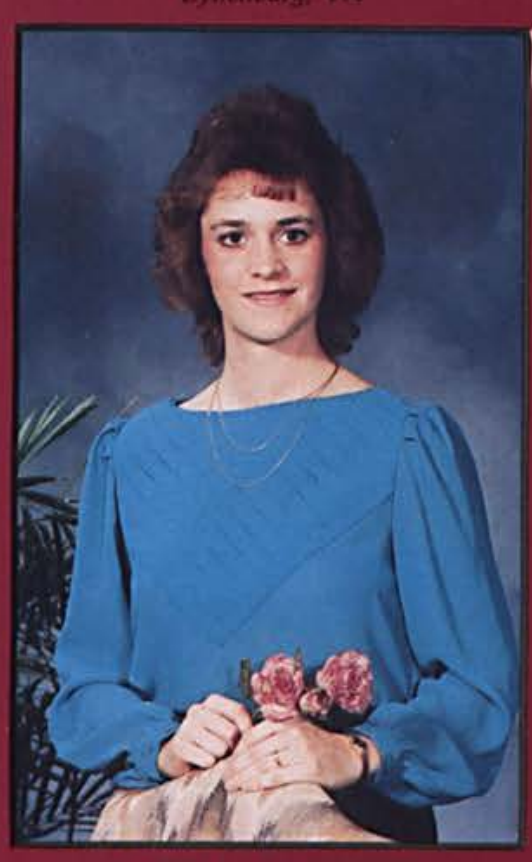

Carol Sue Blterman

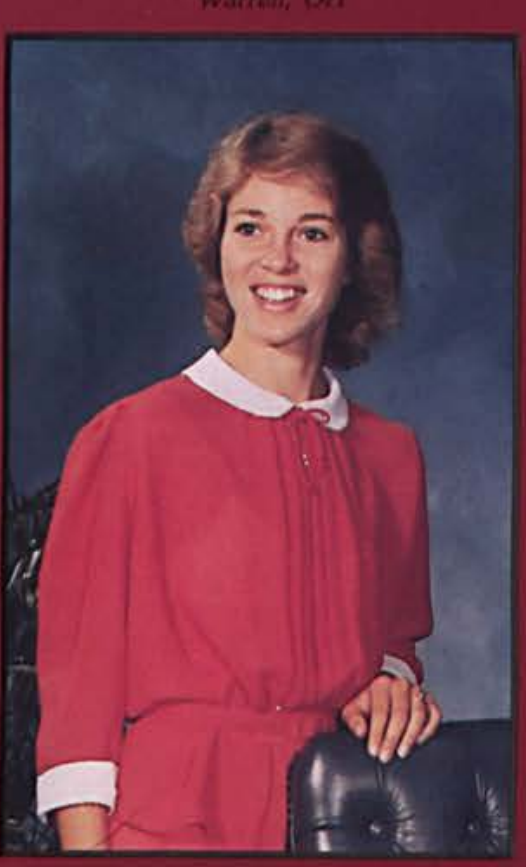

Jane Diane Broaker
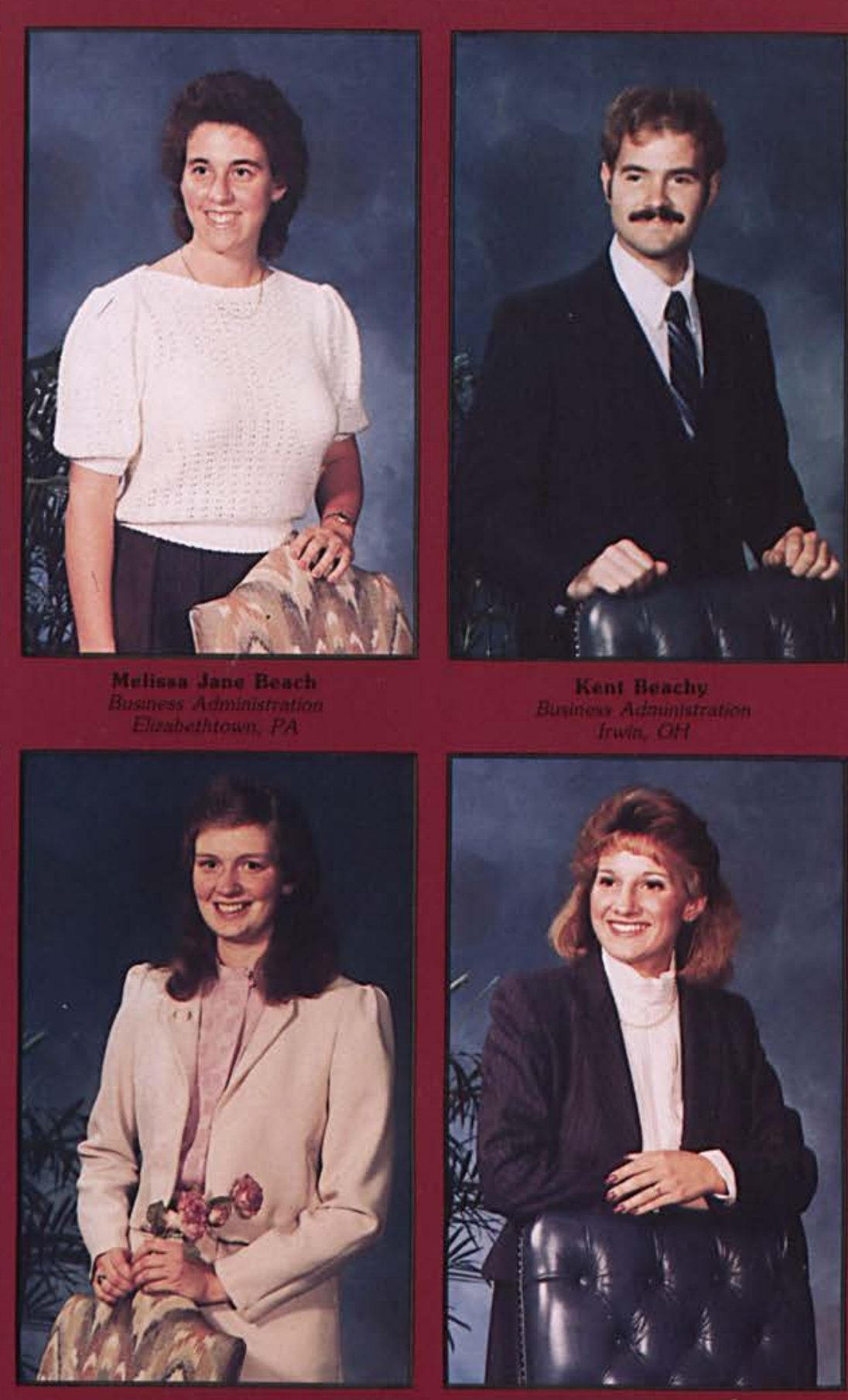

Hachel Ann Bowman
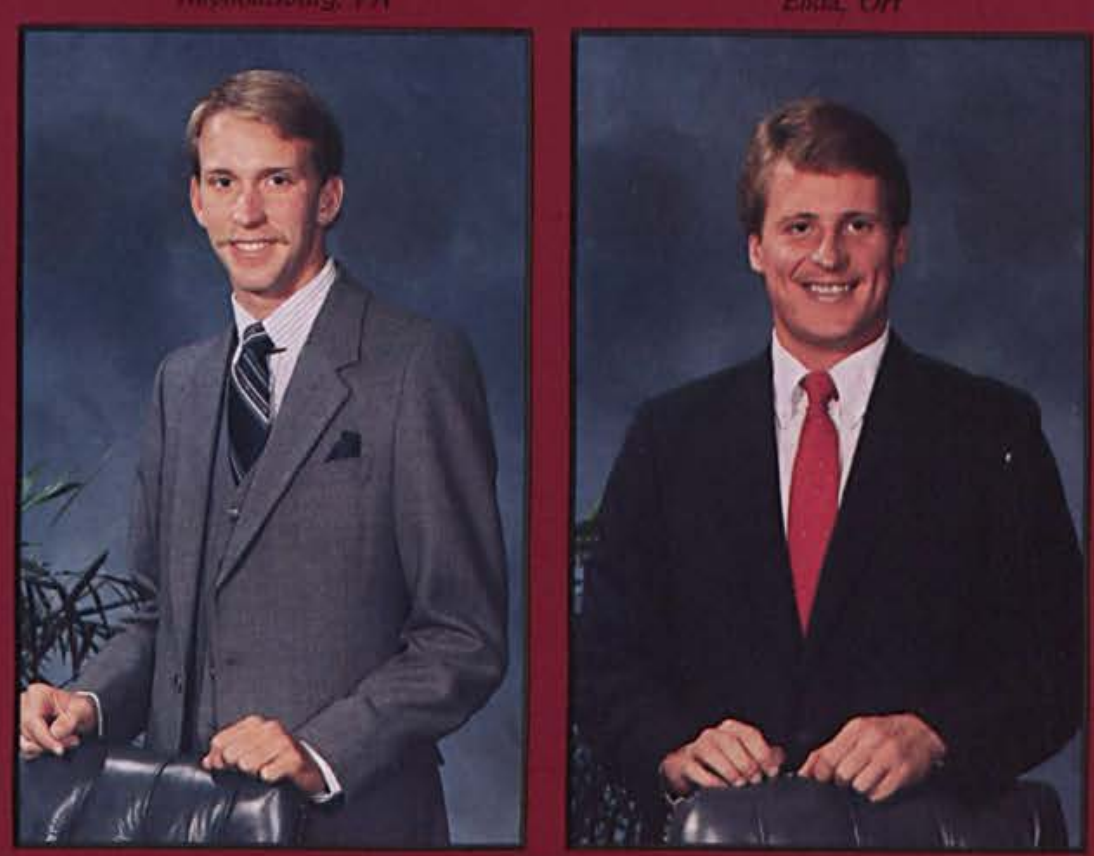

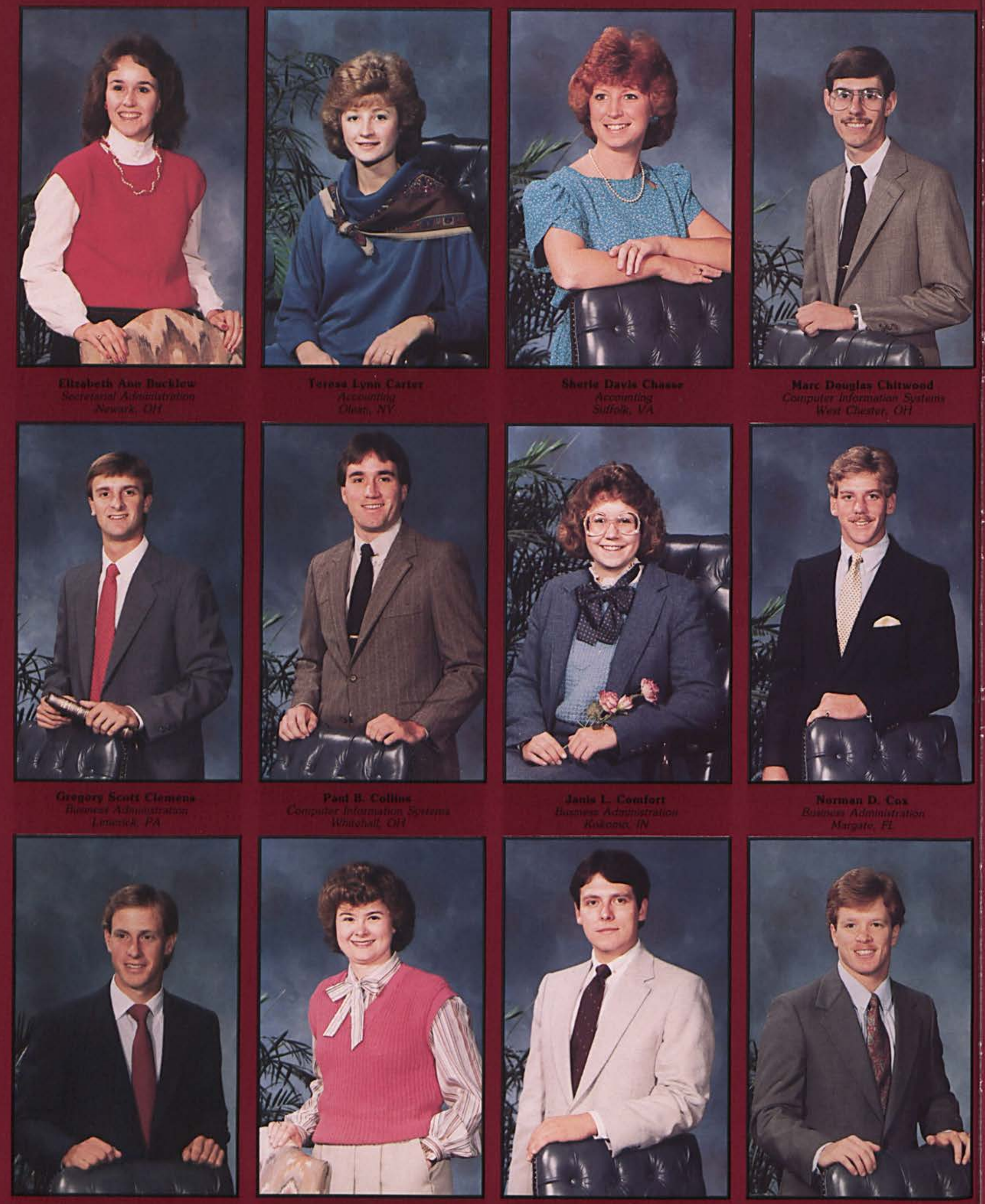

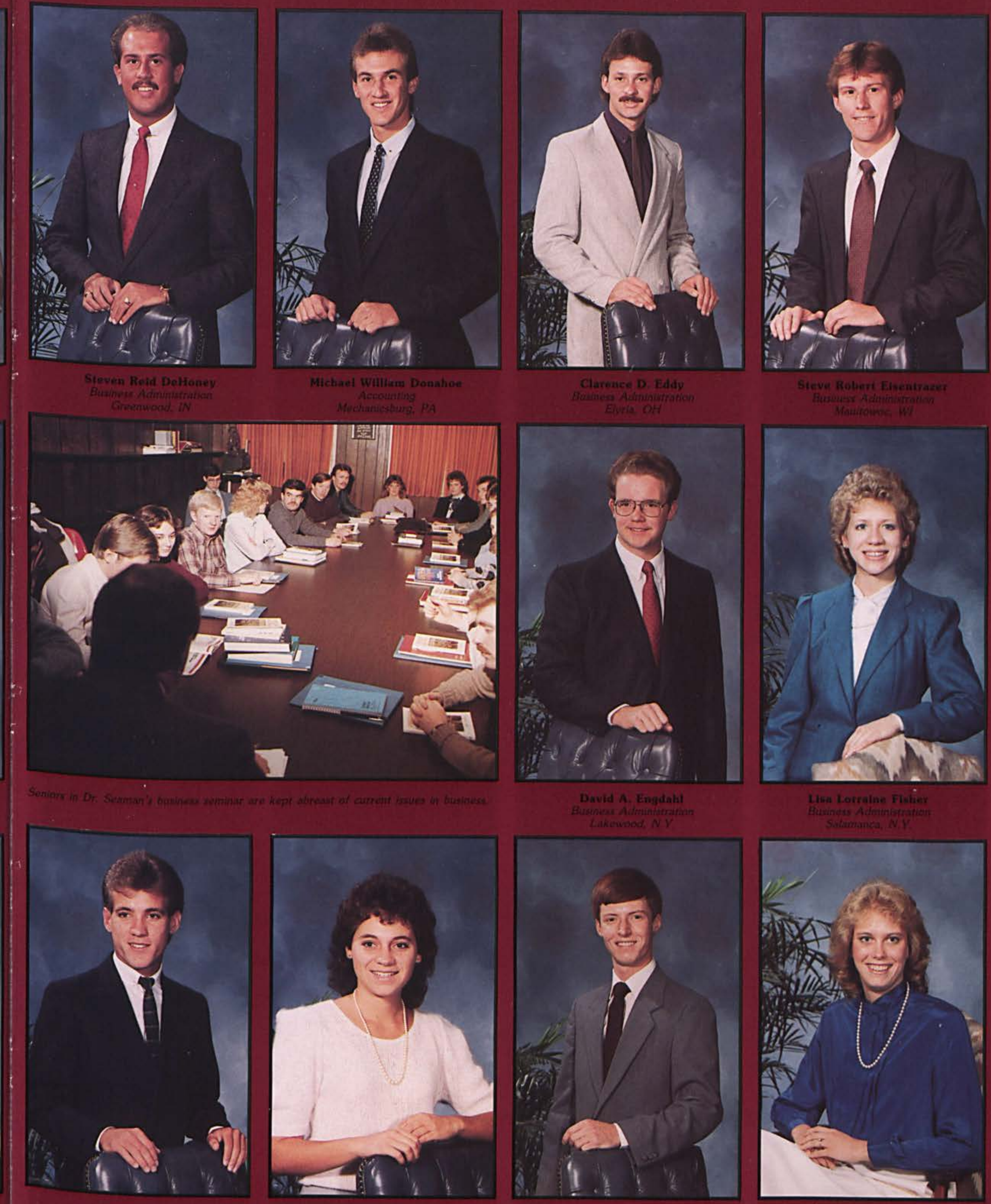

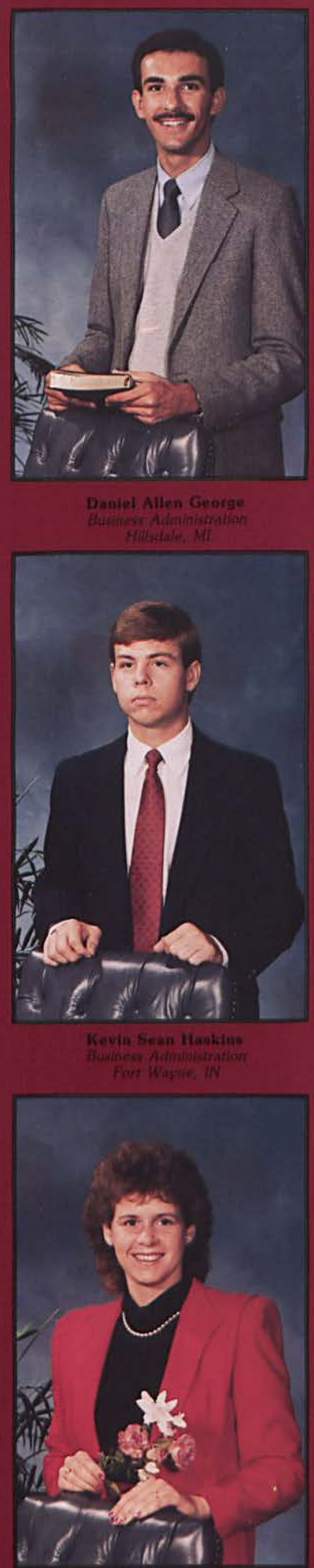
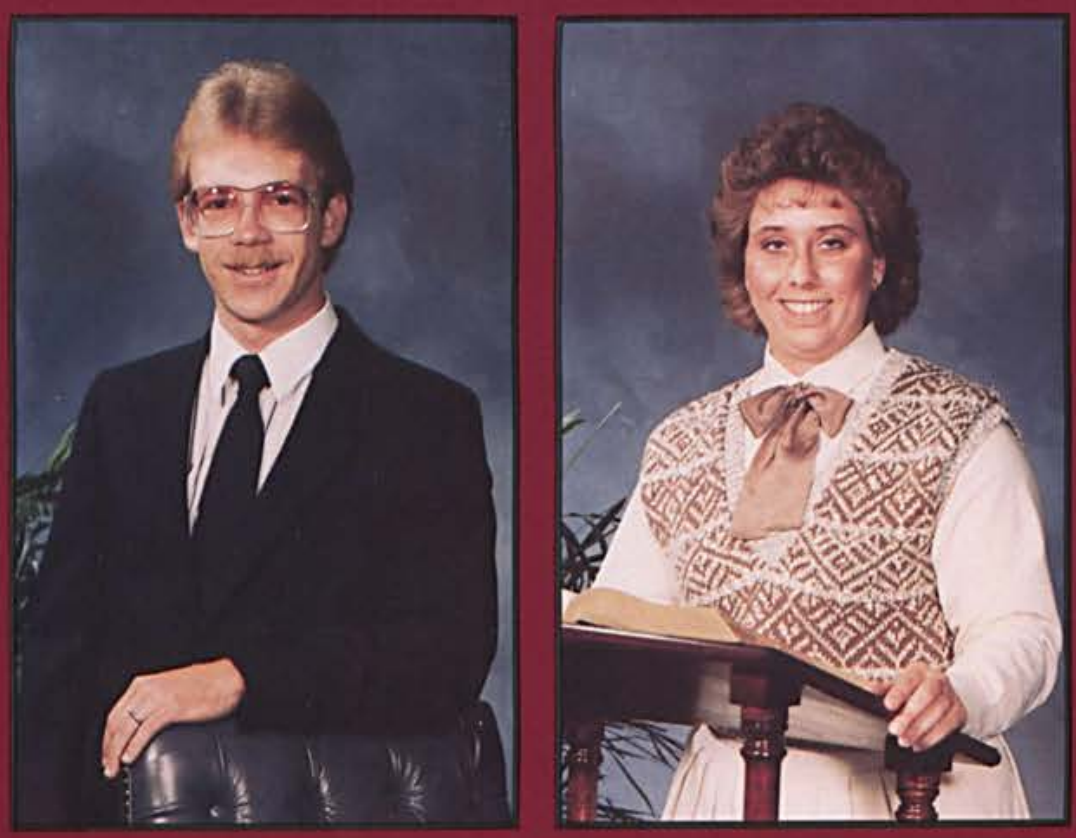

Holly A. Grumbeck

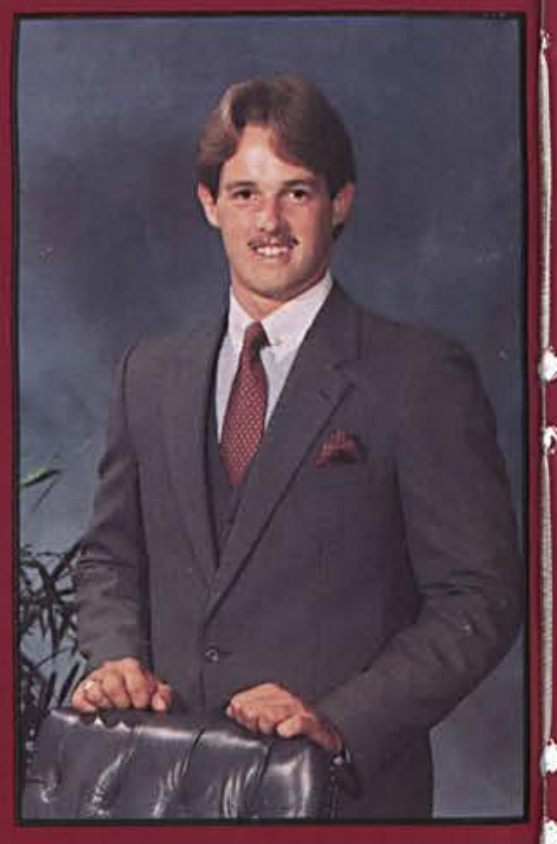

Scott R. Hannay

\section{Computer Use Increases}

Academic computers at Cedarville College serve a dual purpose: providing working tools for students and providing a laboratory for Computer Information Systems majors. Students in all disciplines are encouraged to become familiar with computer operations. The College has provided two public computing areas (18 terminals and 15 microcomputers) in addition to some departmental computing areas. Particular emphasis is placed on word processing and the use of electronic spreadsheets to improve the quality of work done by the students. Students also have access to major compilers (BASIC, COBOL, FORTRAN), statistical packages, and simulating materials. Computers are required tools in courses as diverse as music theory, educational methods, and accounting.

Christians are commanded to do their best ... computers at Cedarville help make our best better.

David Rotman

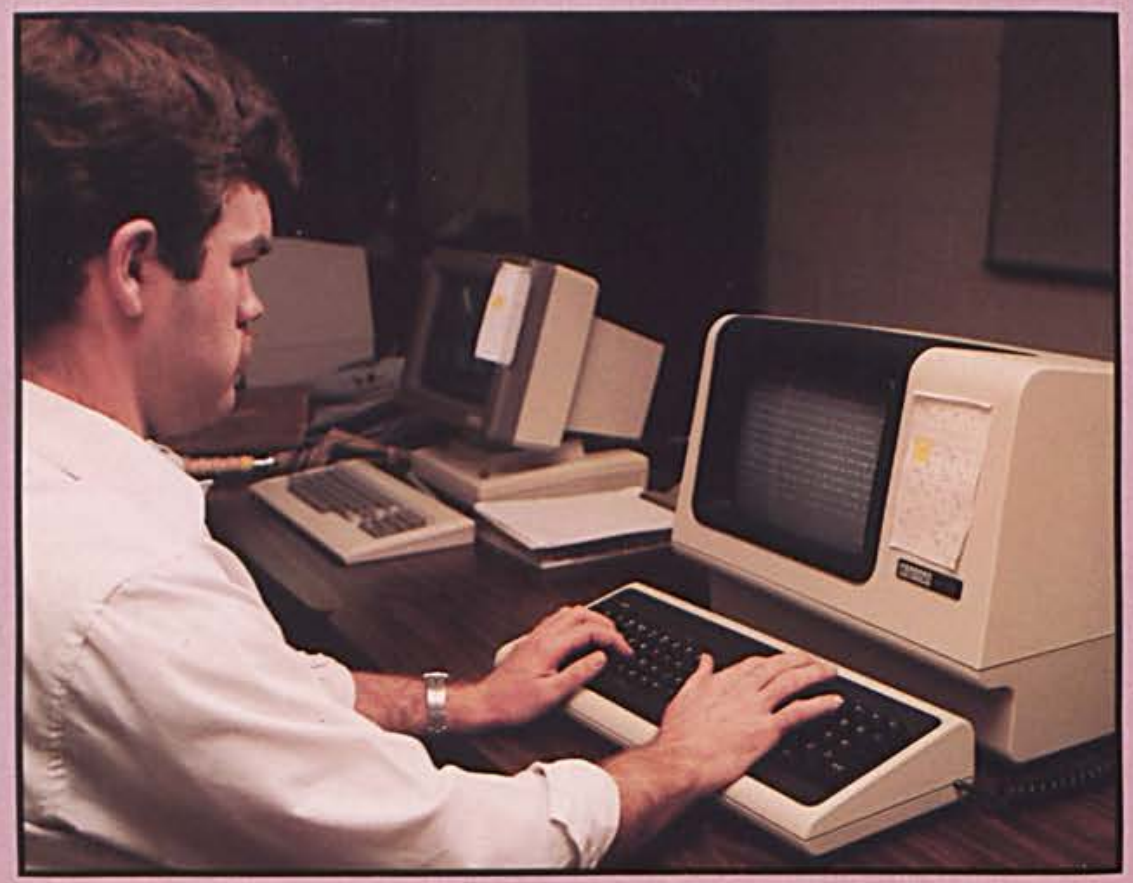




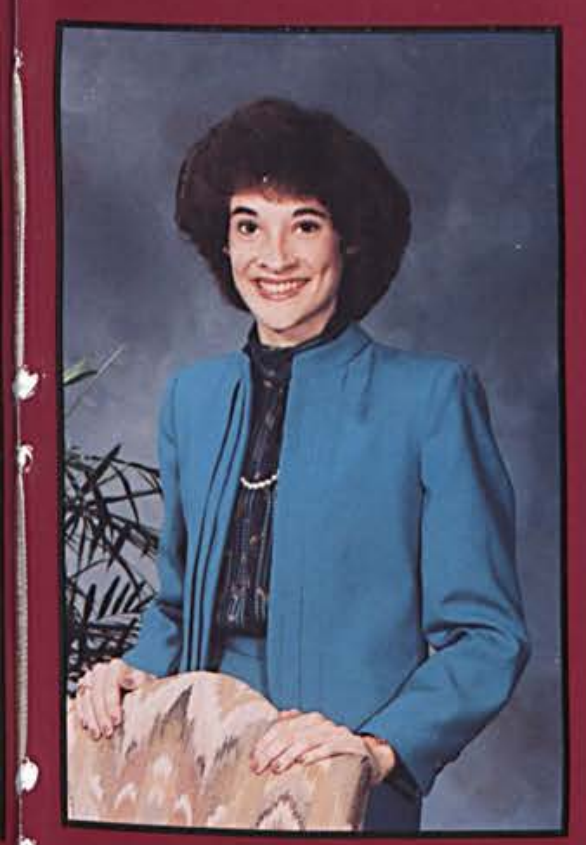

Heidi E, Hempel

Amharst of

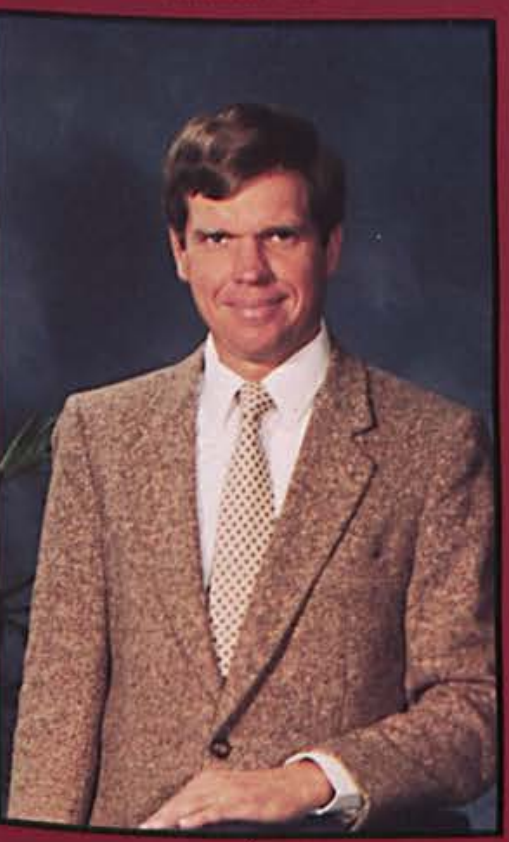

Robert B. Jacobson

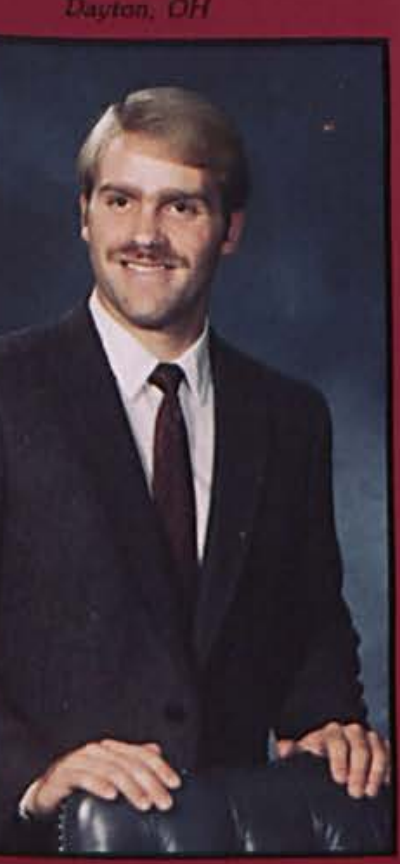

Paul tot

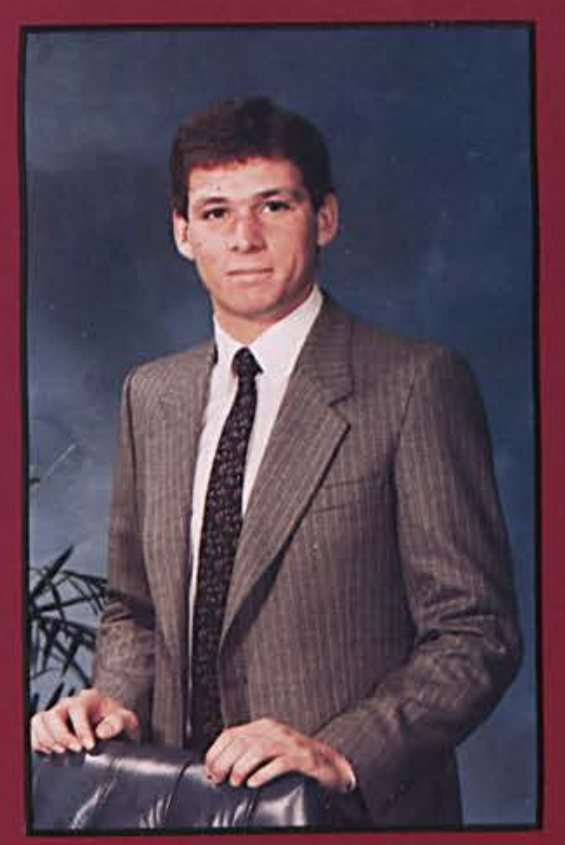

Mark Horny

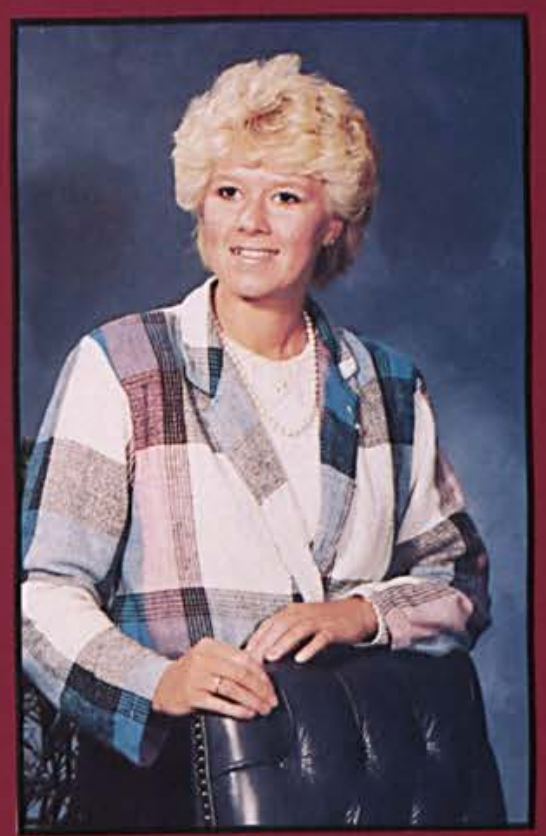

Jocelyn Johnton

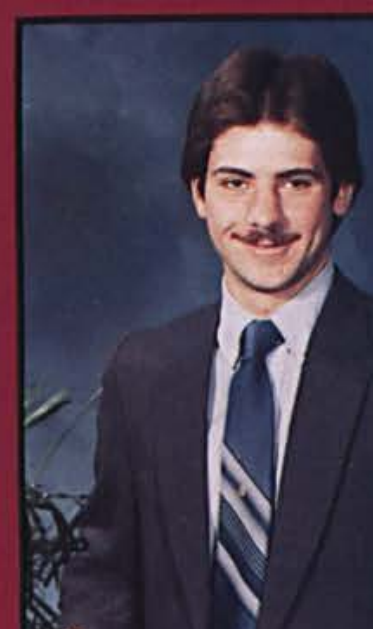

o.

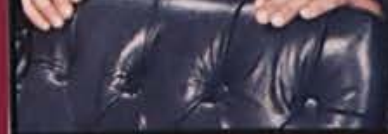

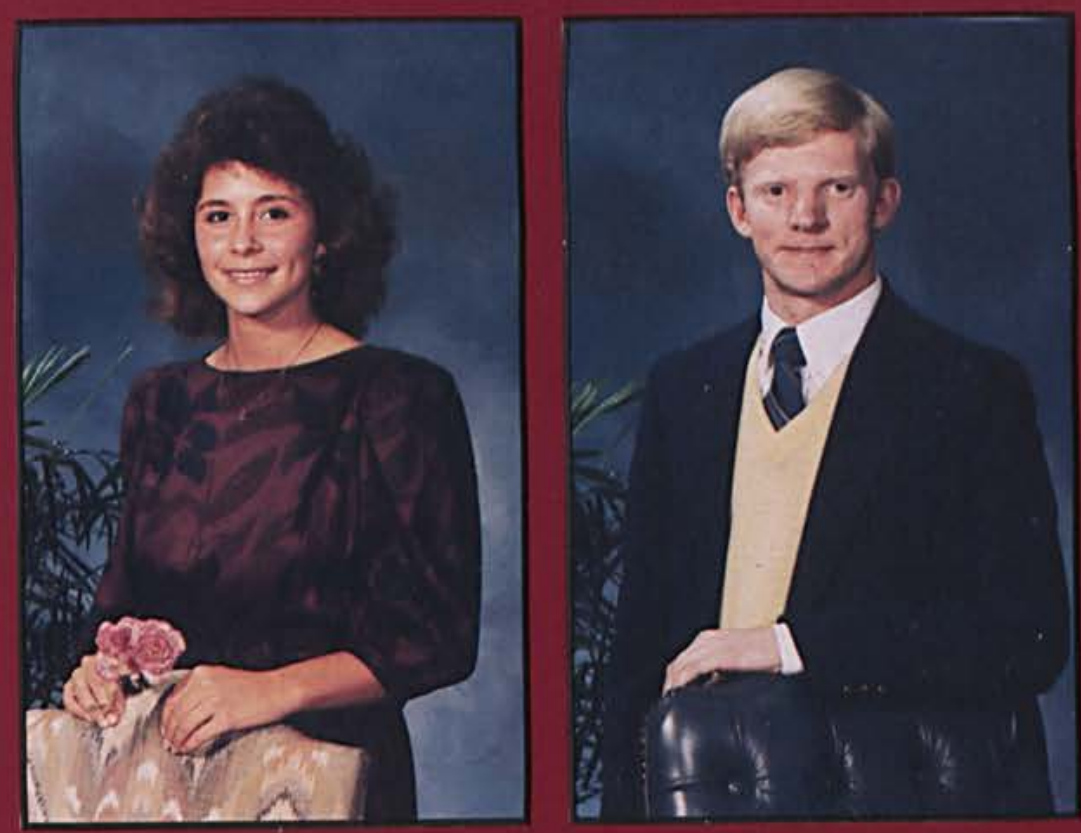

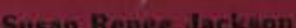

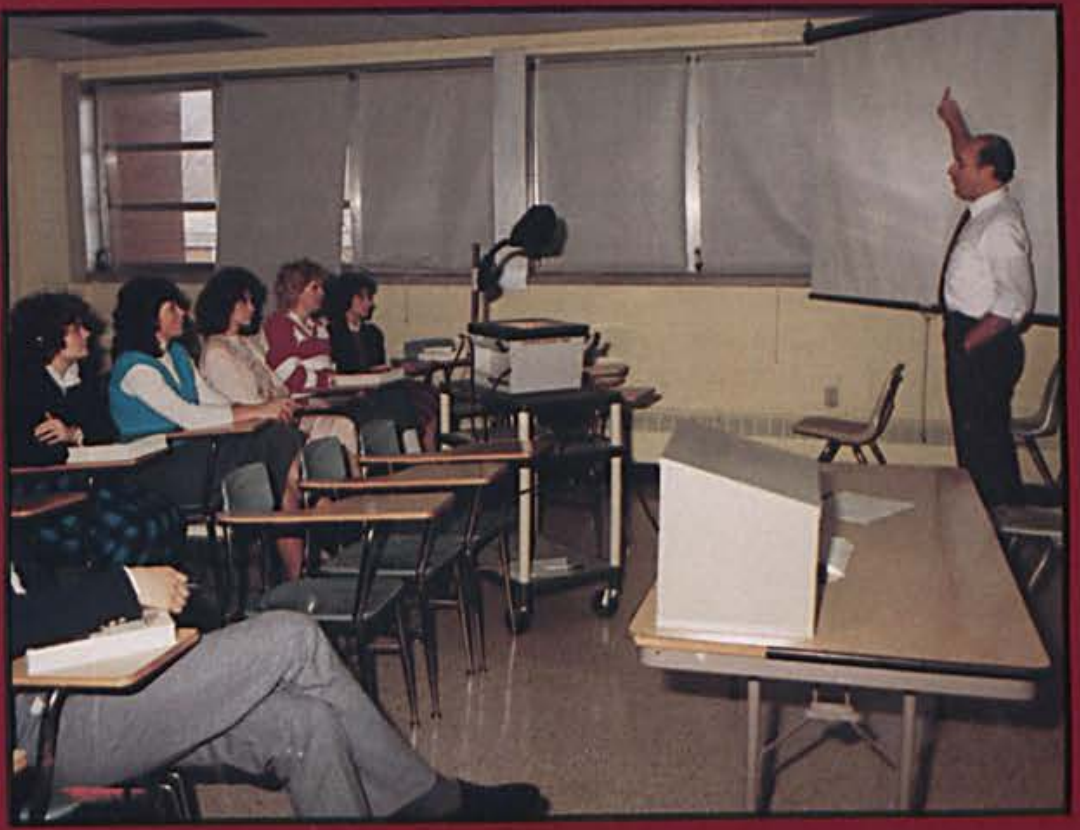

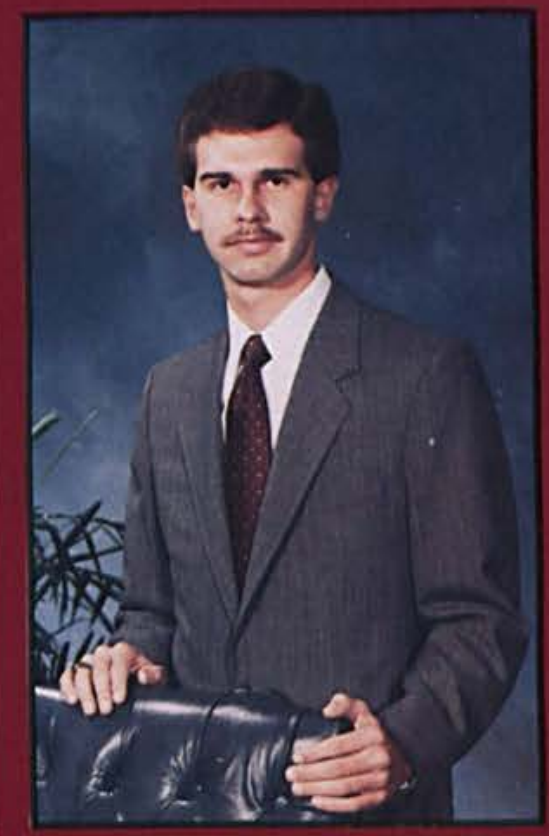




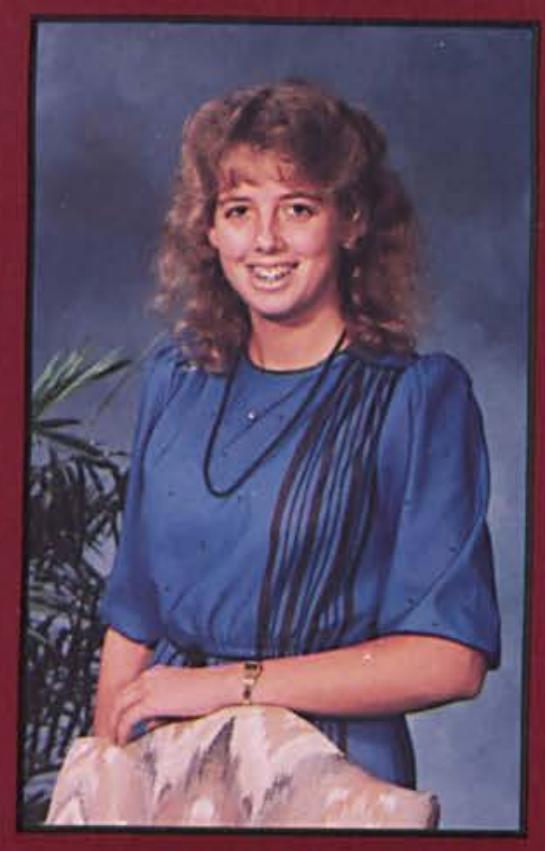

Katiryas d, Kover

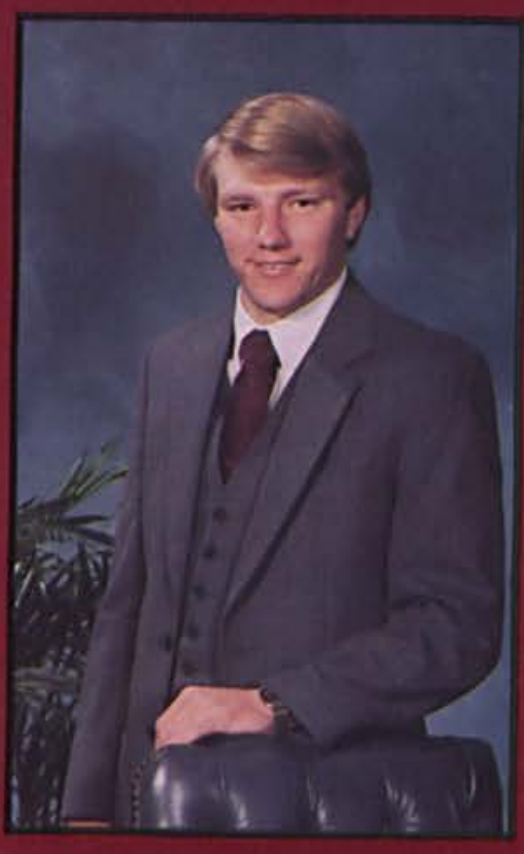

Gregory Paul Lamberti

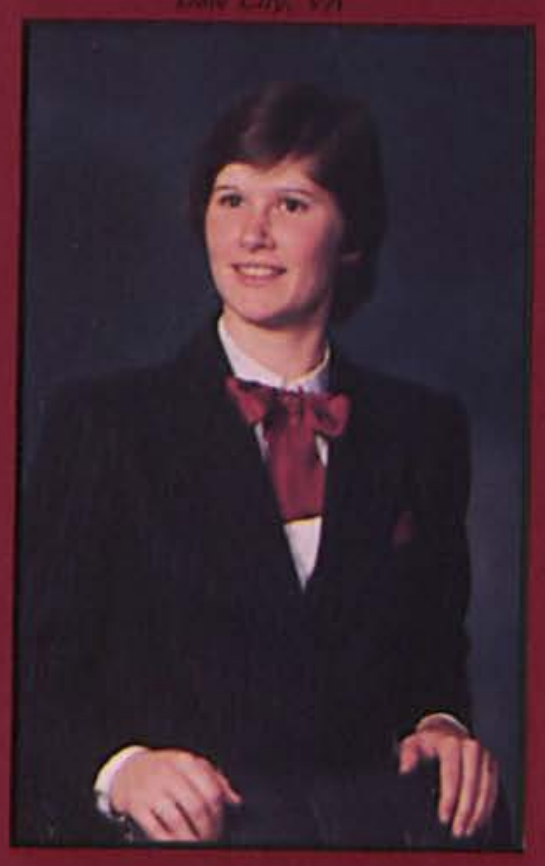

Dianu Lictavestelger

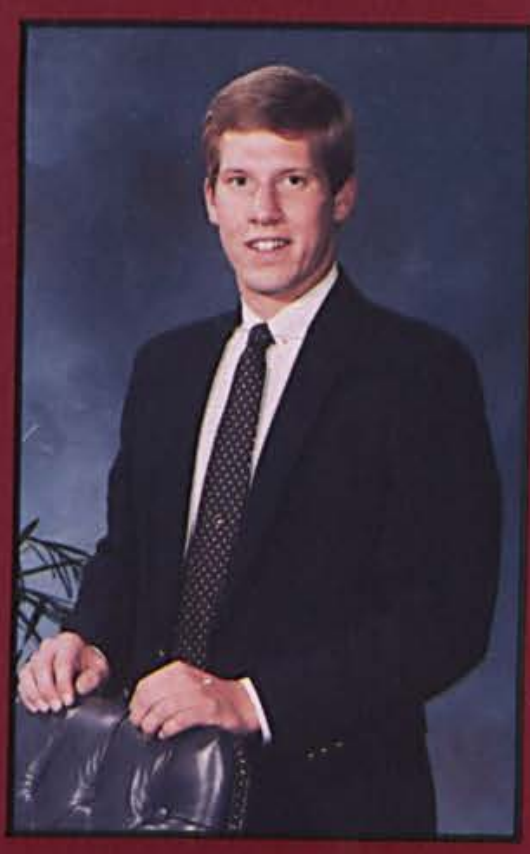

Temple Leinh Kanoles
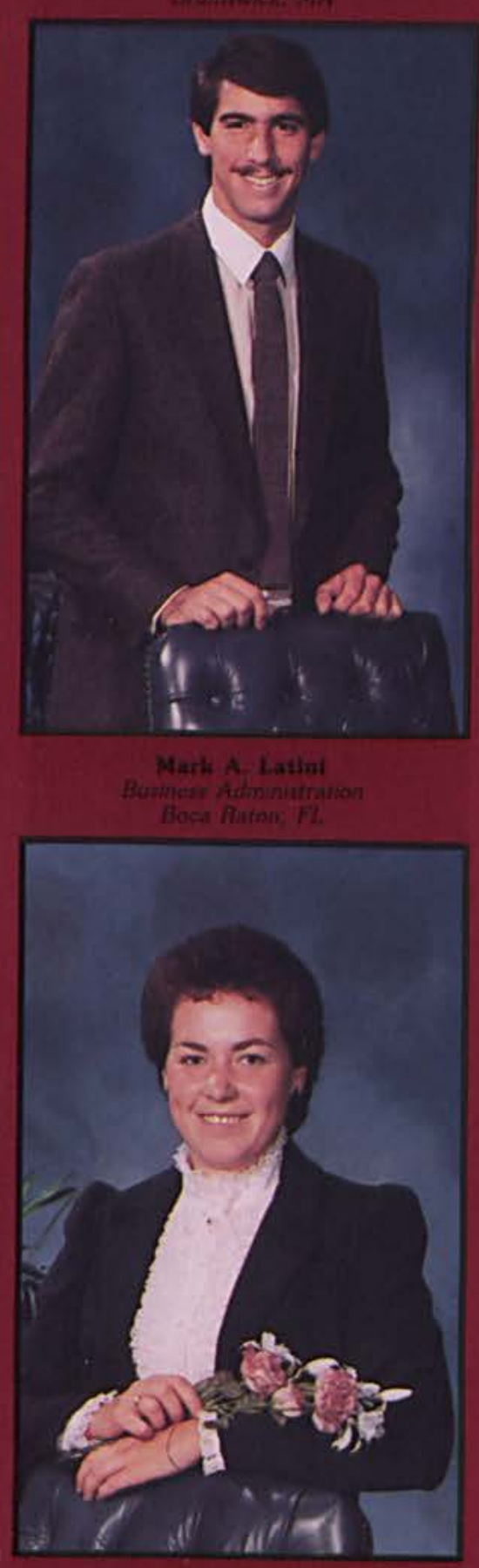
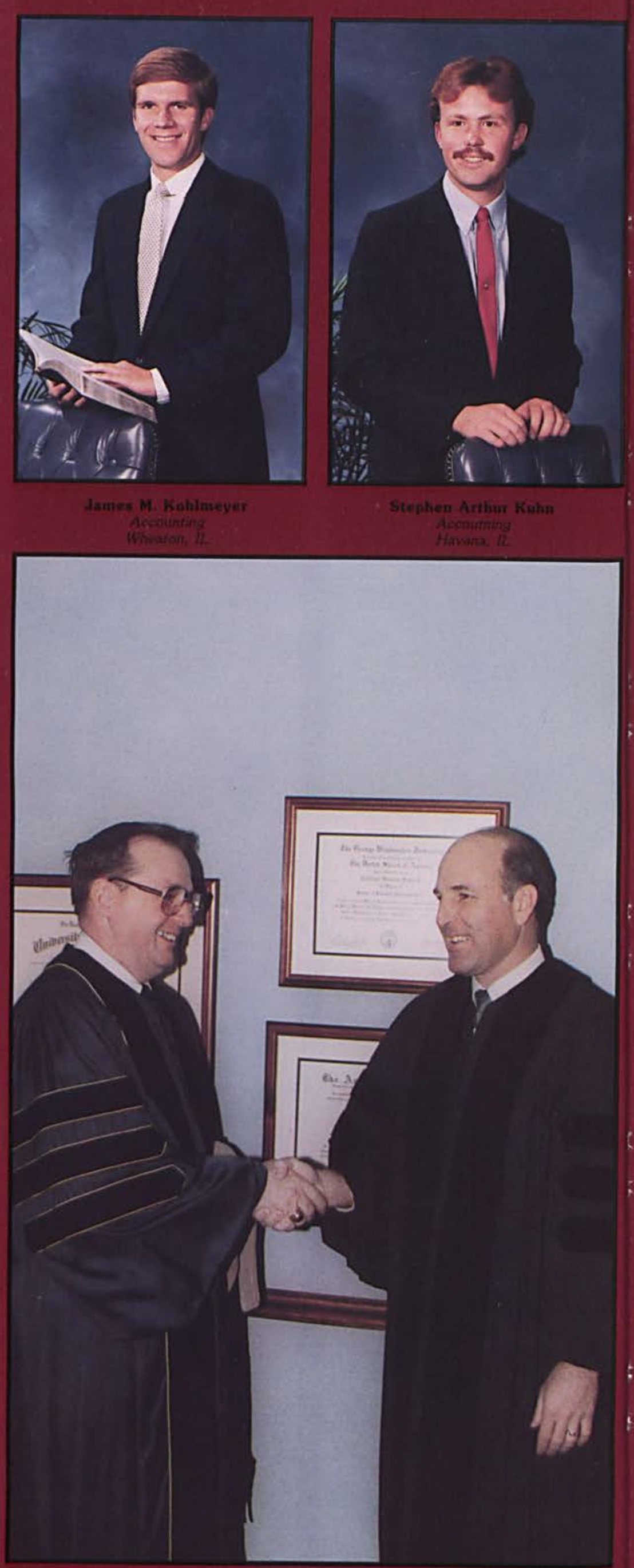


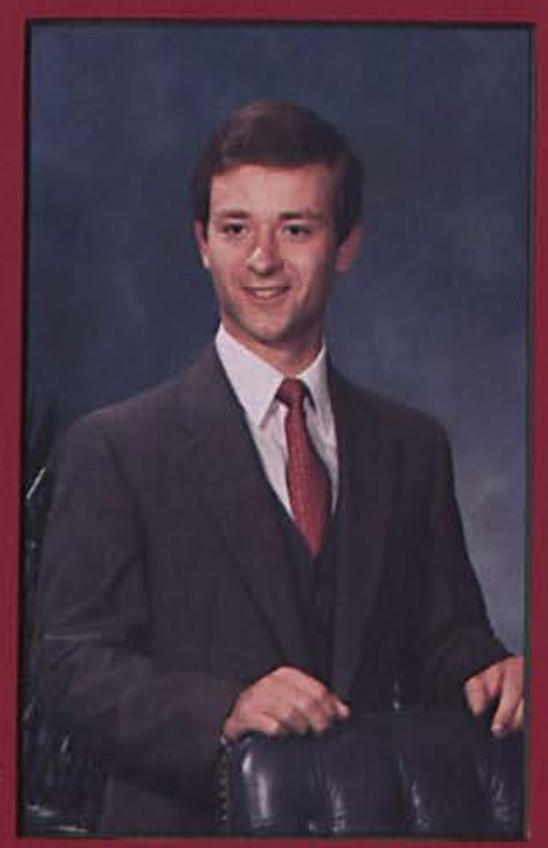

Mark Alten Mosies

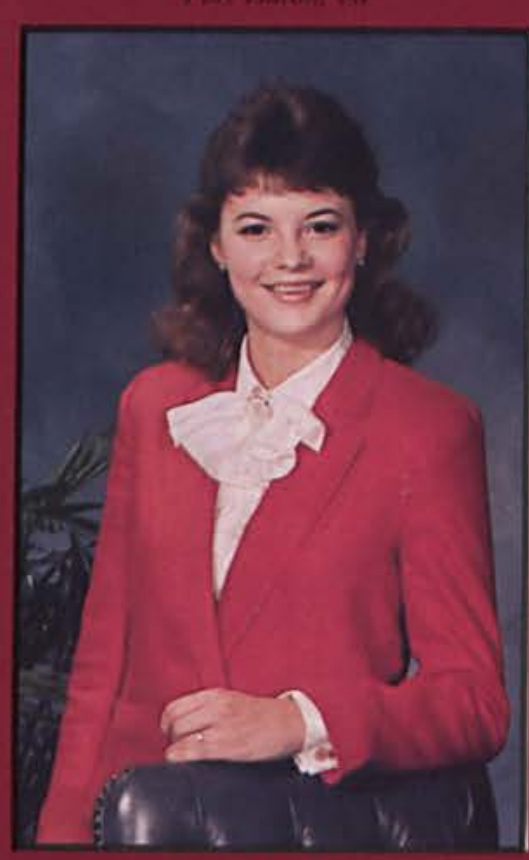

Lita M. Prall

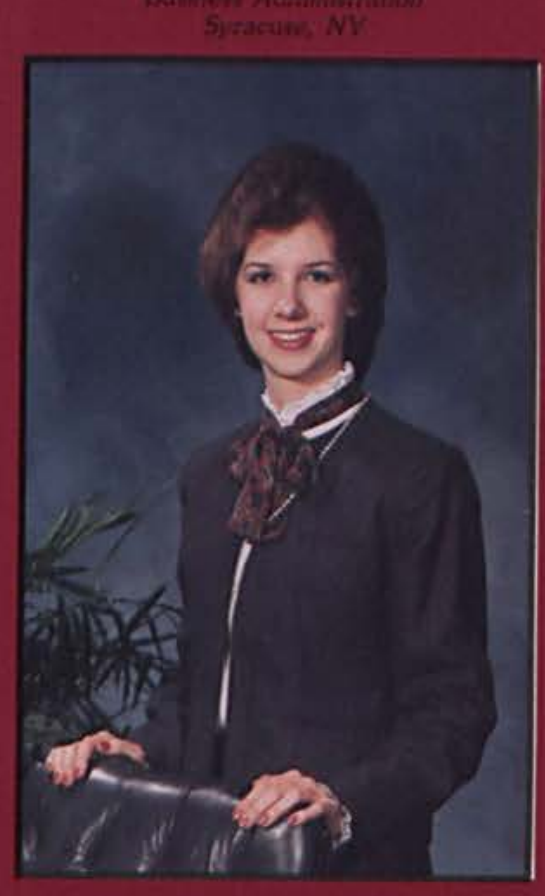

Judith L. Funge

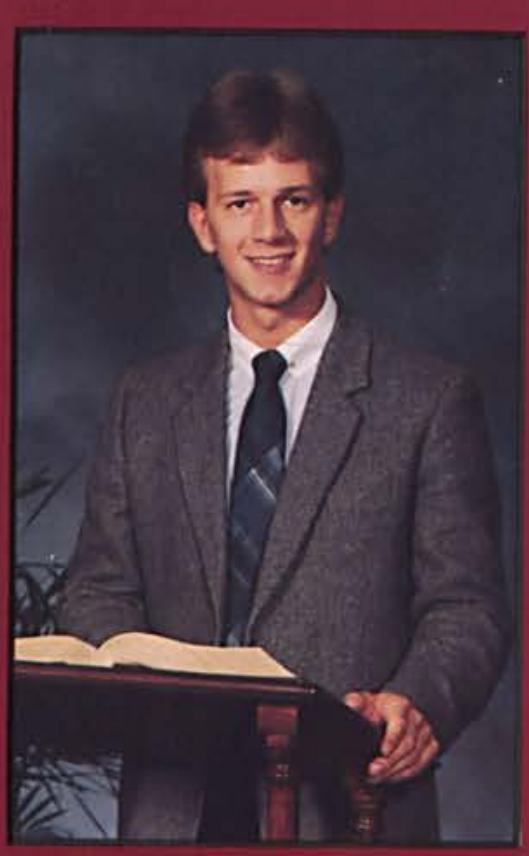

Scott Moyer

sugness Administratn

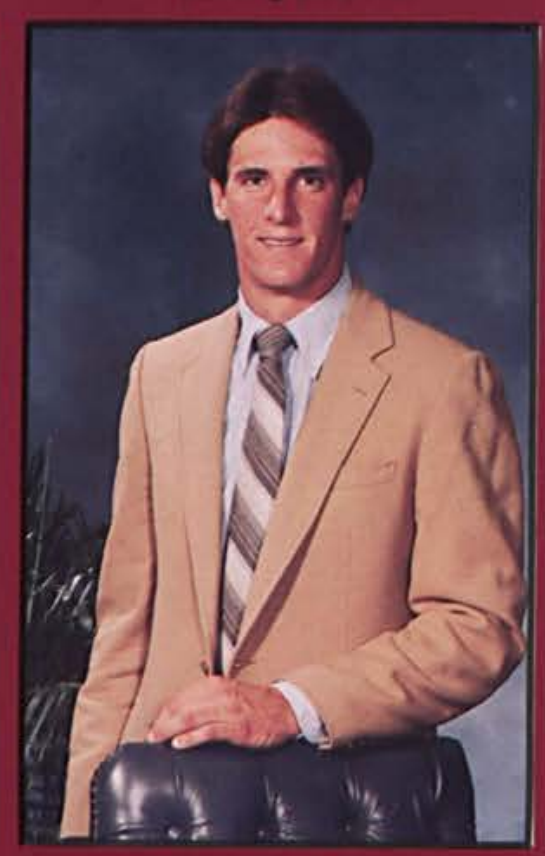

Thomas E. Pratt
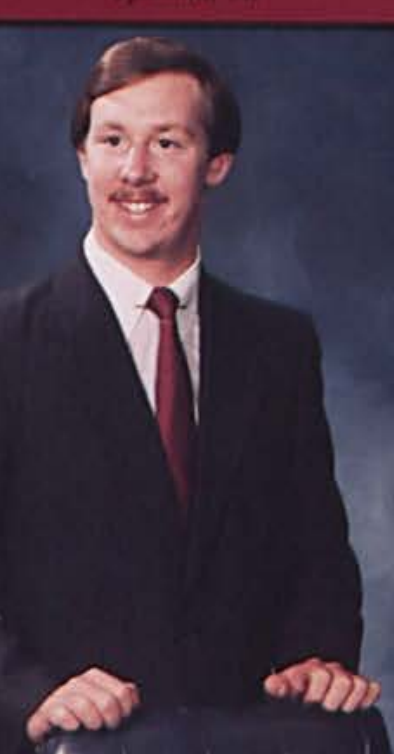

$\frac{1}{2} \cdot \frac{1}{5}, y=1$

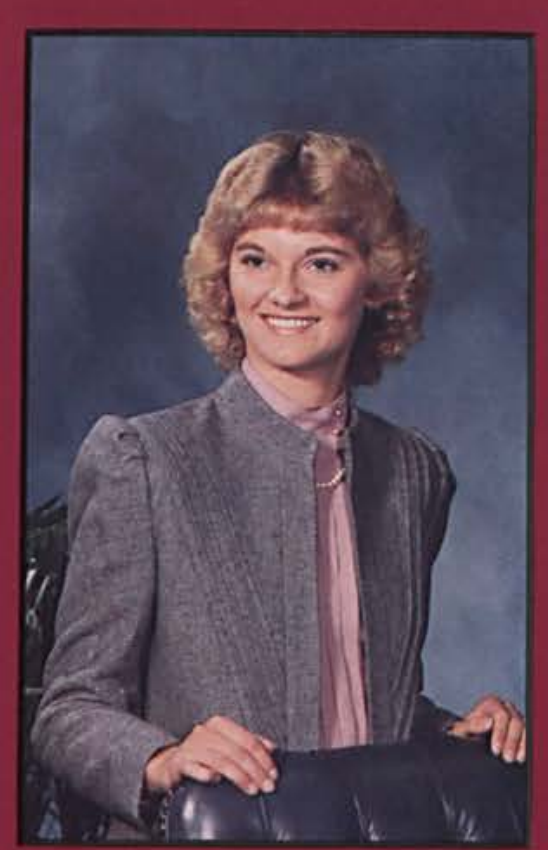

Dlane Sue Ottawas

Conn PA

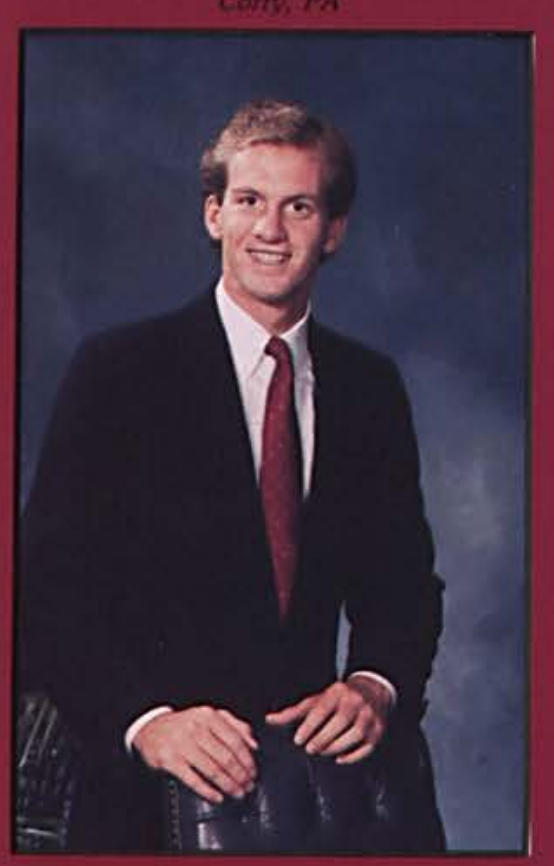

Jonathan H. Price

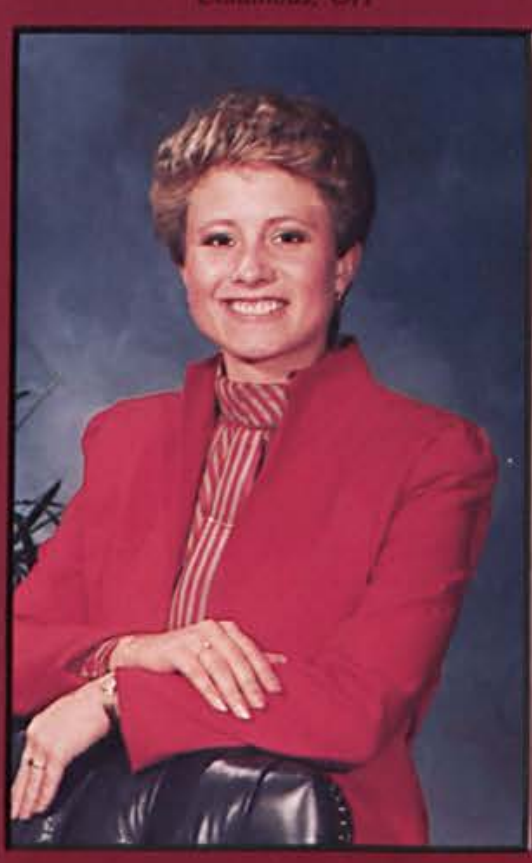

Shannon Marke Saunders

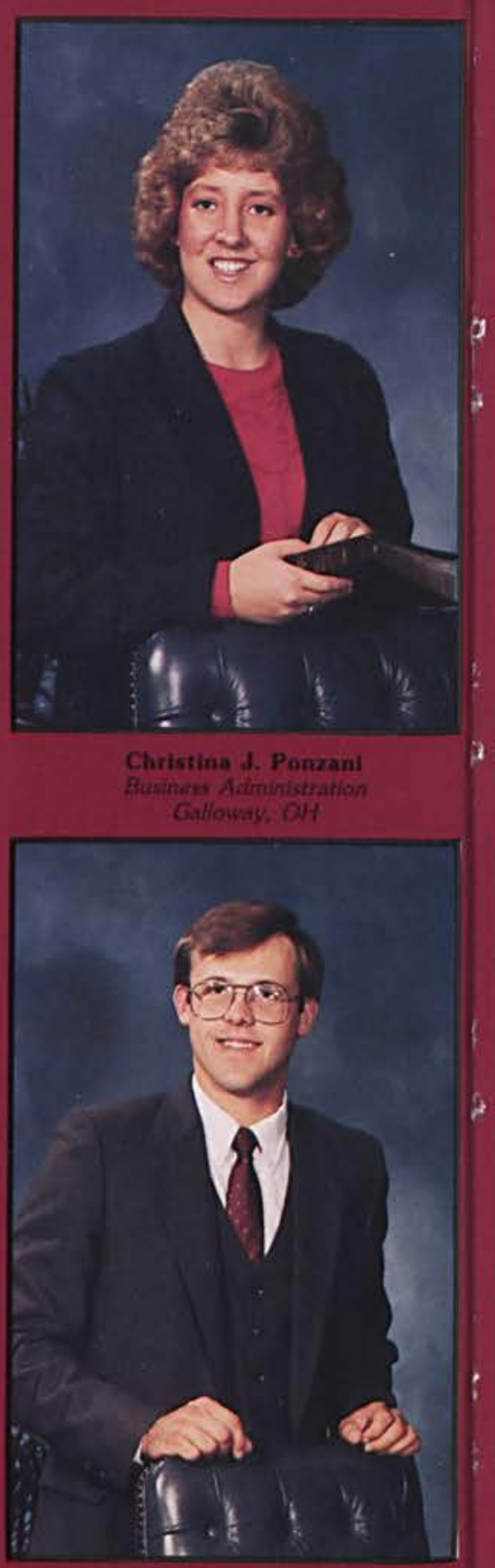

Jerry Ray Robbins

Accoumting
LuVerne, la

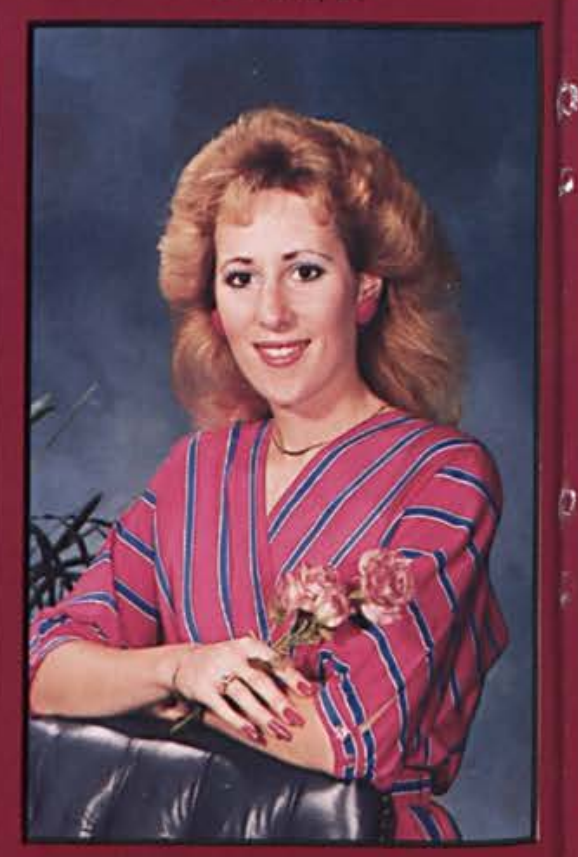

Dehorah S. Schonfely

Bovemes Aitulnianadoyly 

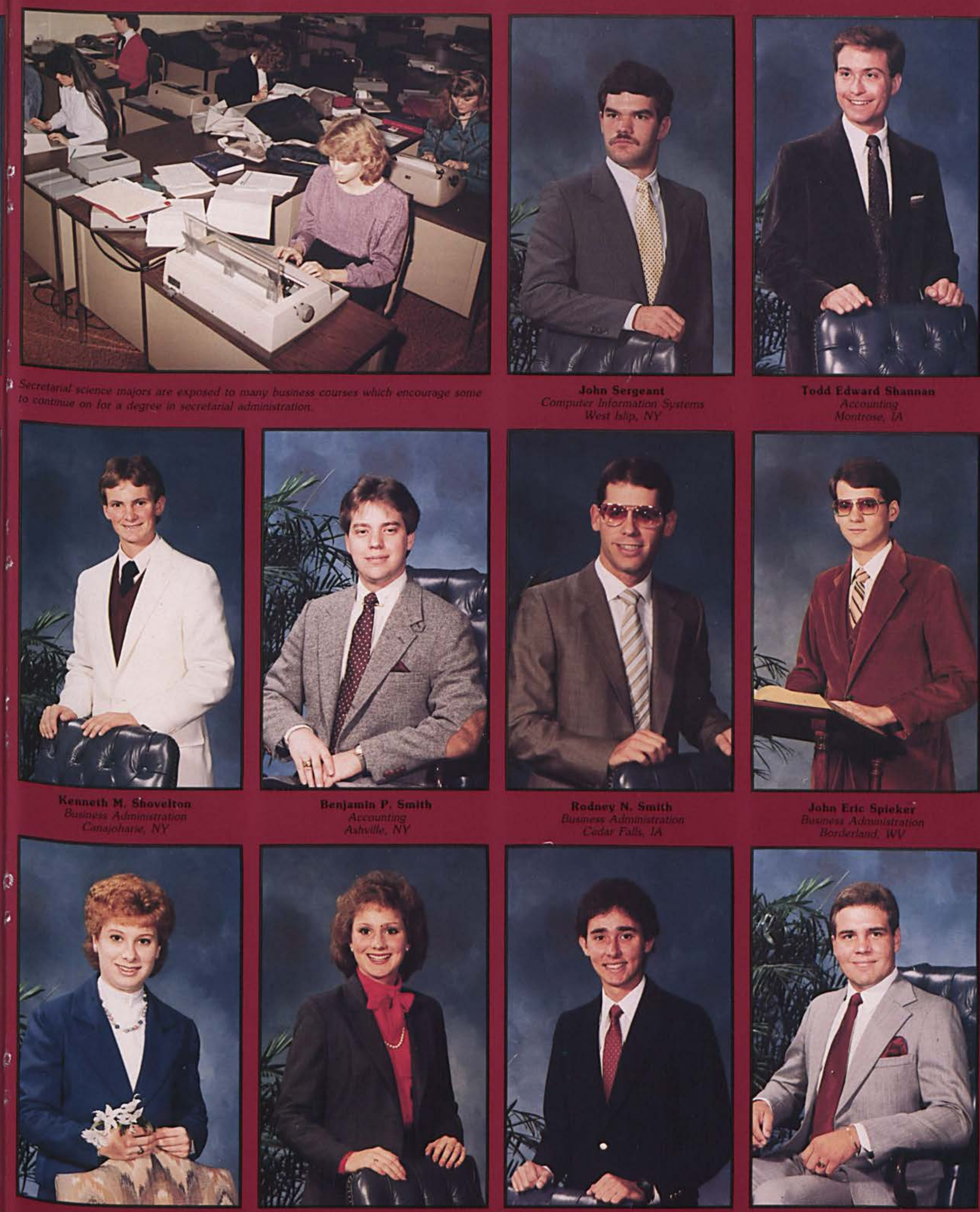

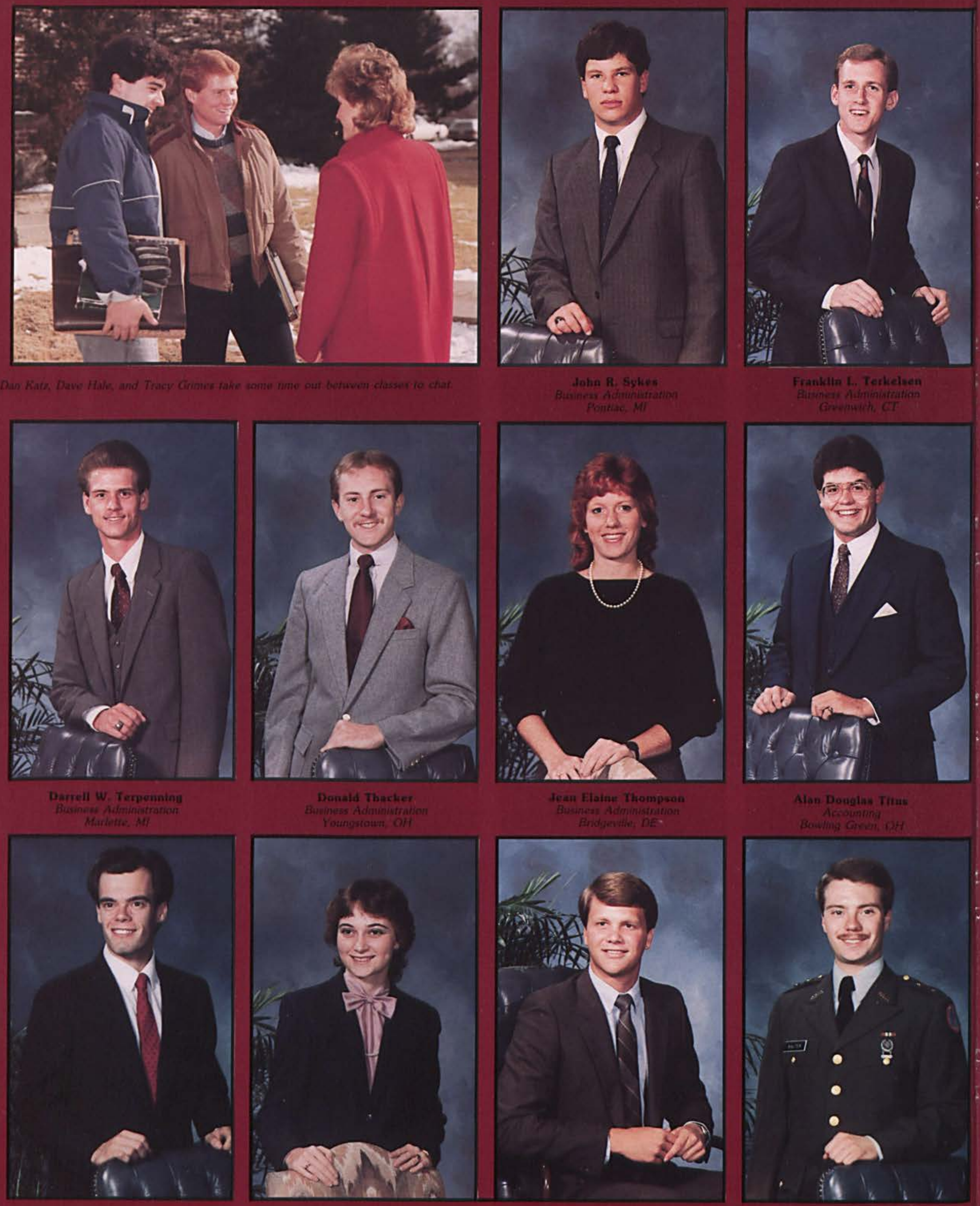

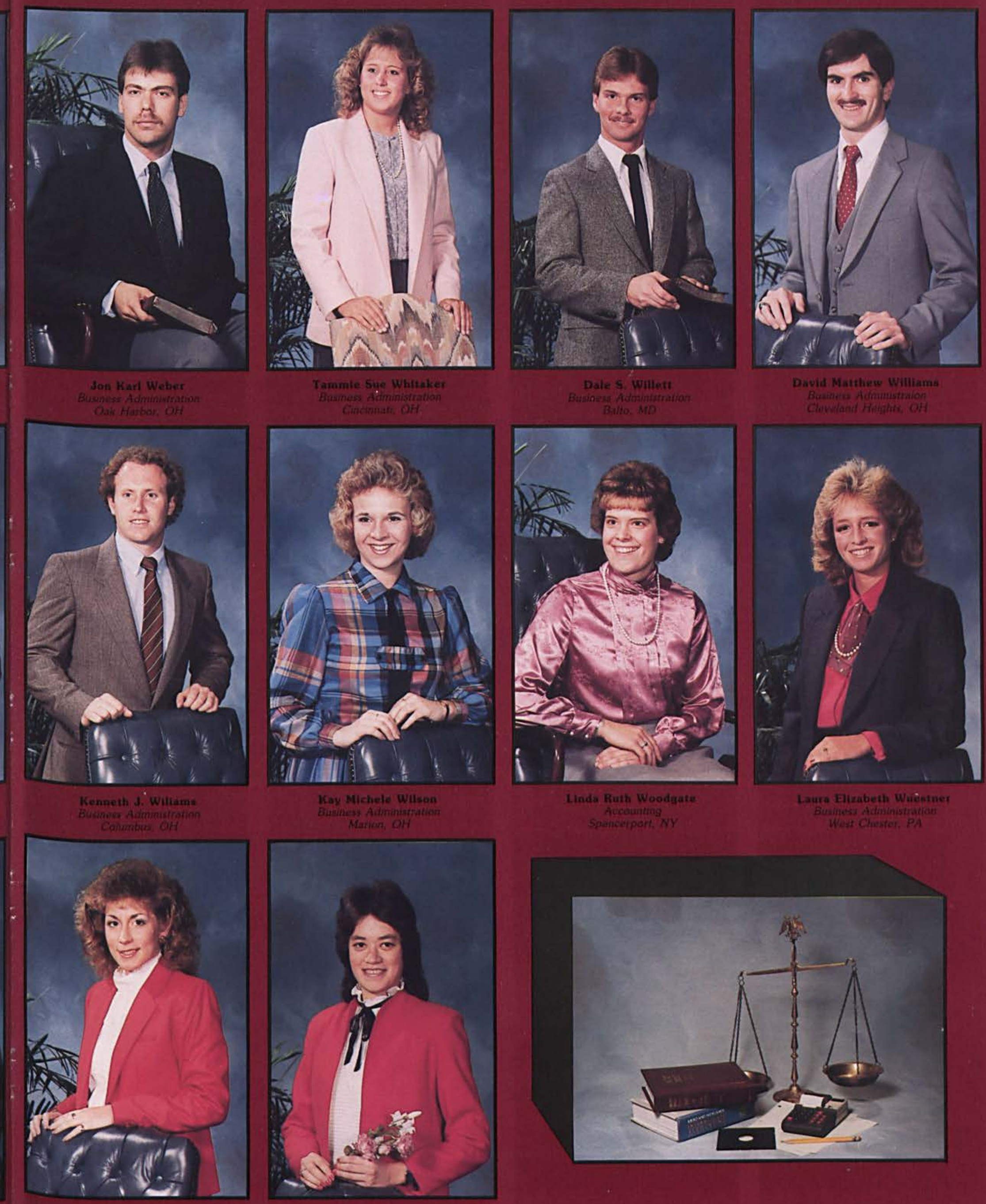

Inda Ruth Woodgat

Laura Elizabeth Wuẻstne

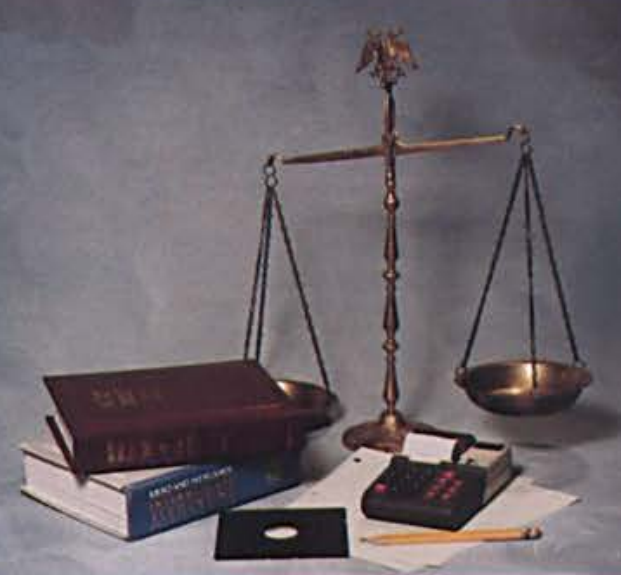




\section{Teaching stewards} to use the methods and equipment available to them to communicate a message after assuring it to be true and ethical.

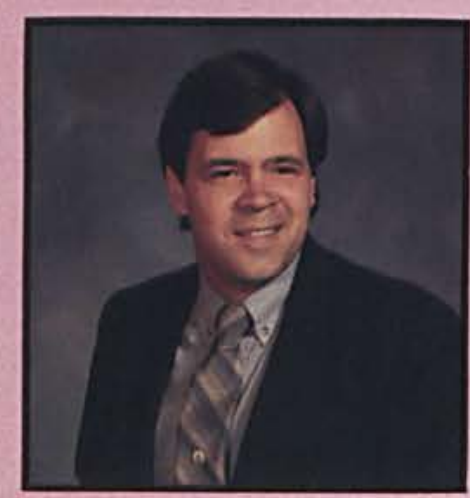

Wesley J. Baker, M.A. Assistant Professor of Speech \& Broadcasting

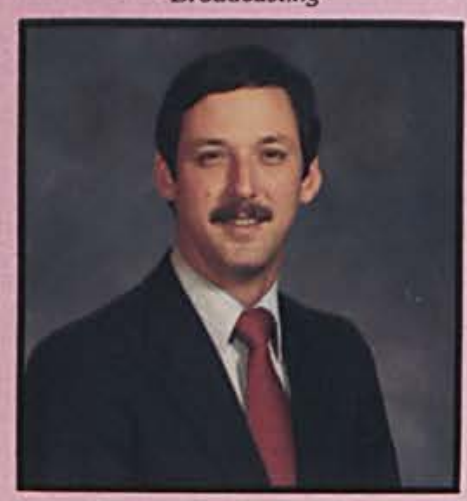

Michael Lopez, Ph.D. Assistant Professor of Speech

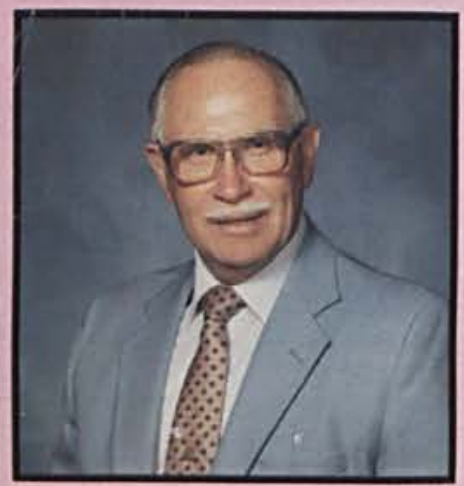

Marlin Rayburn, M.A. Associate Professor of Speech

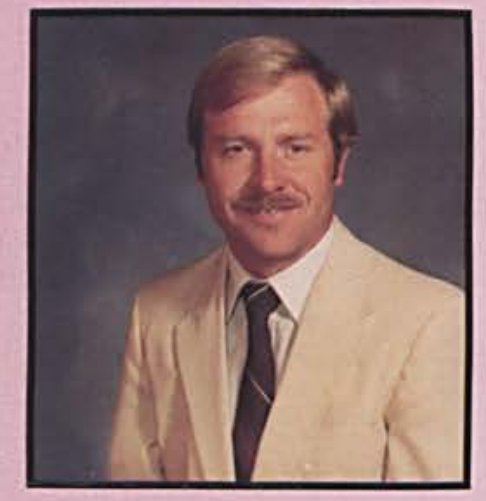

James Phipps, Ph.D. Chairman

Professor of Speech

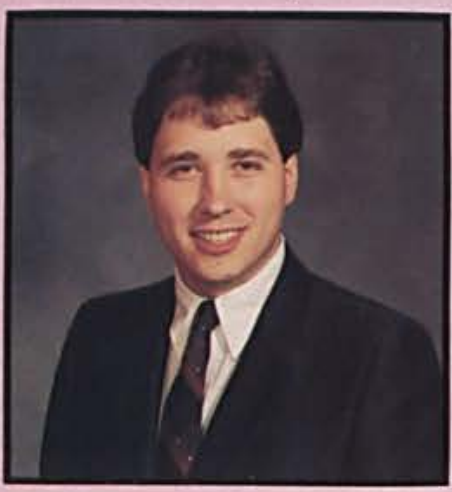

James Leightenheimer, B.A. Instructor of Broadcasting

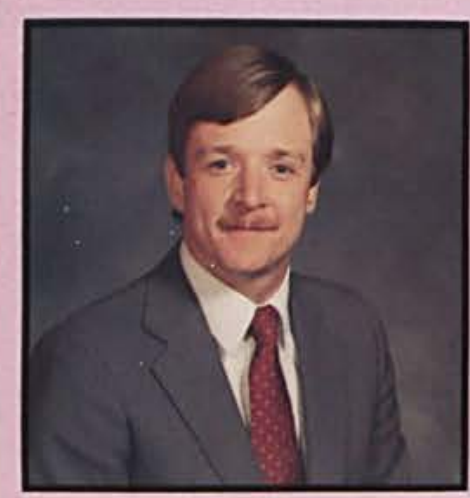

Kurt Moreland, M.A. Assistant Professor of Speech

Not pictured

David Robey, M.A. Assistant Professor of Speech and Drama
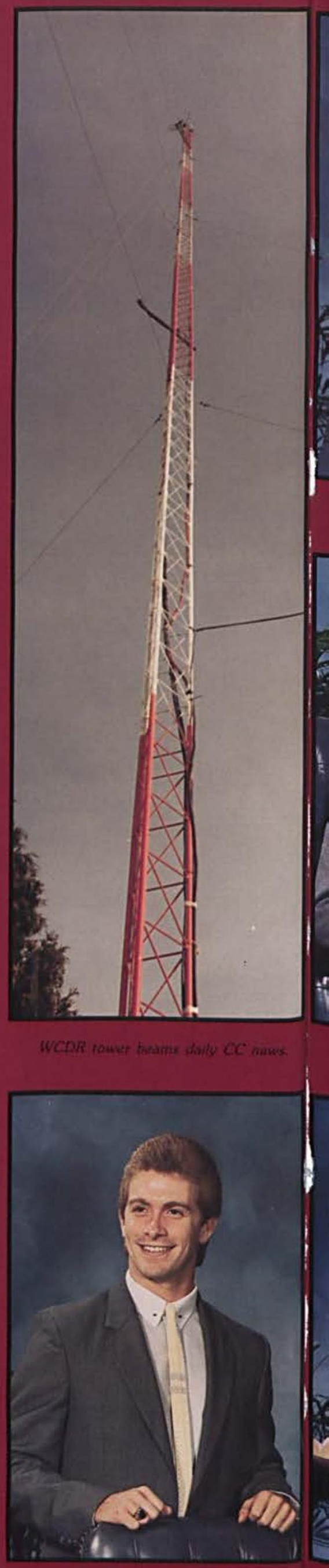


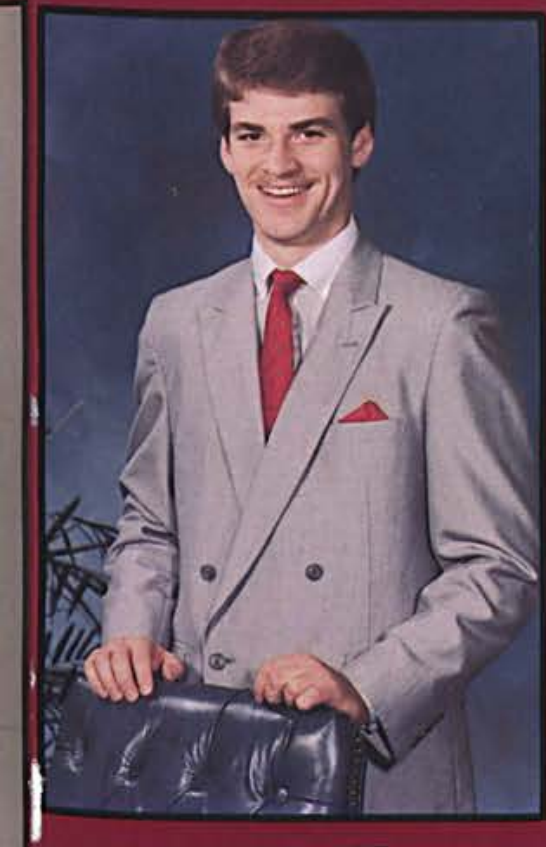

Kenneth David Ban
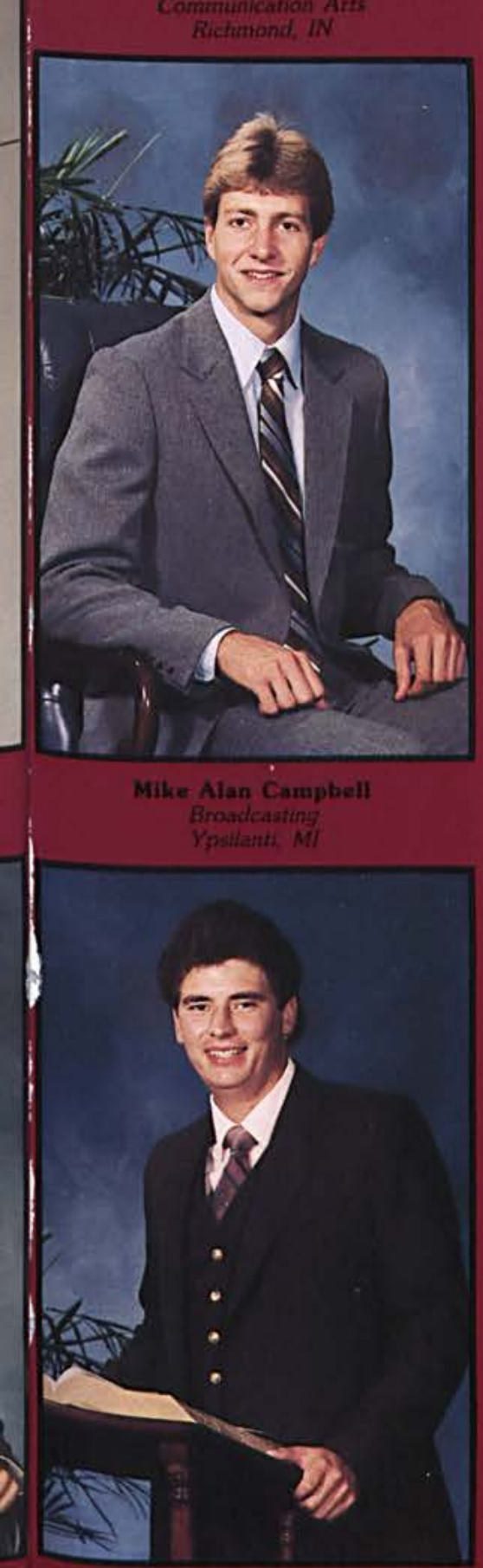

Mare Edward Lee

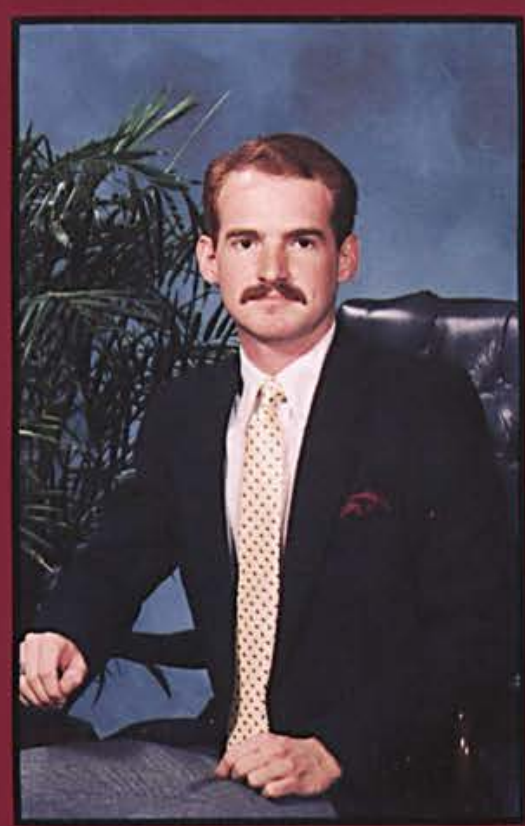

Gary W. Barker
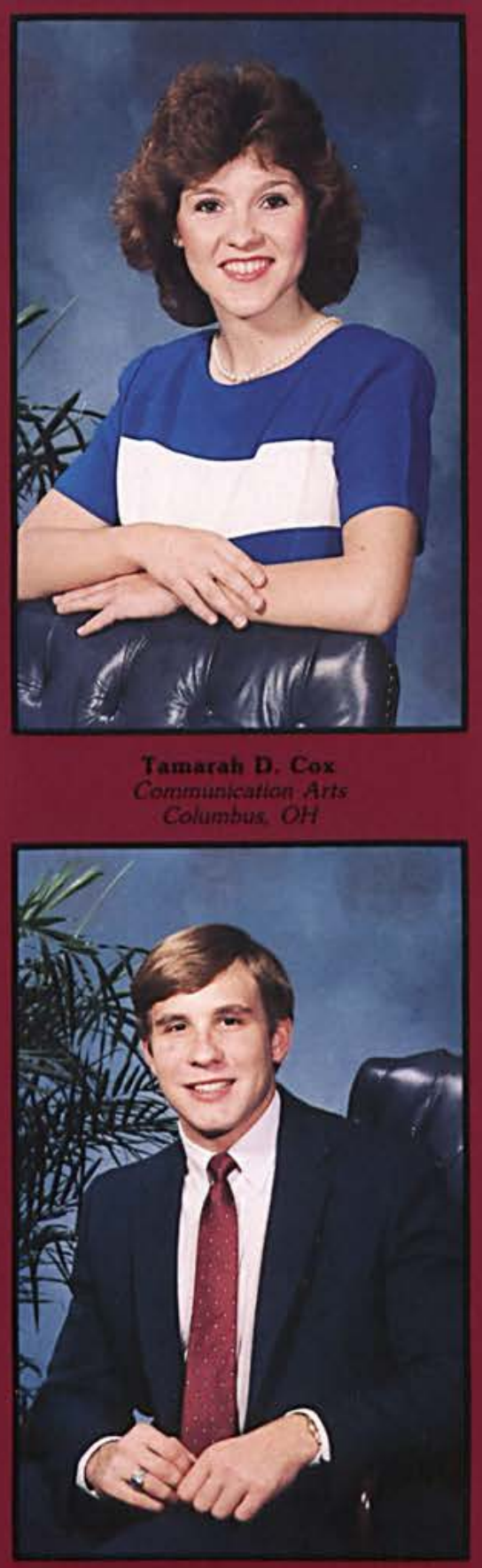
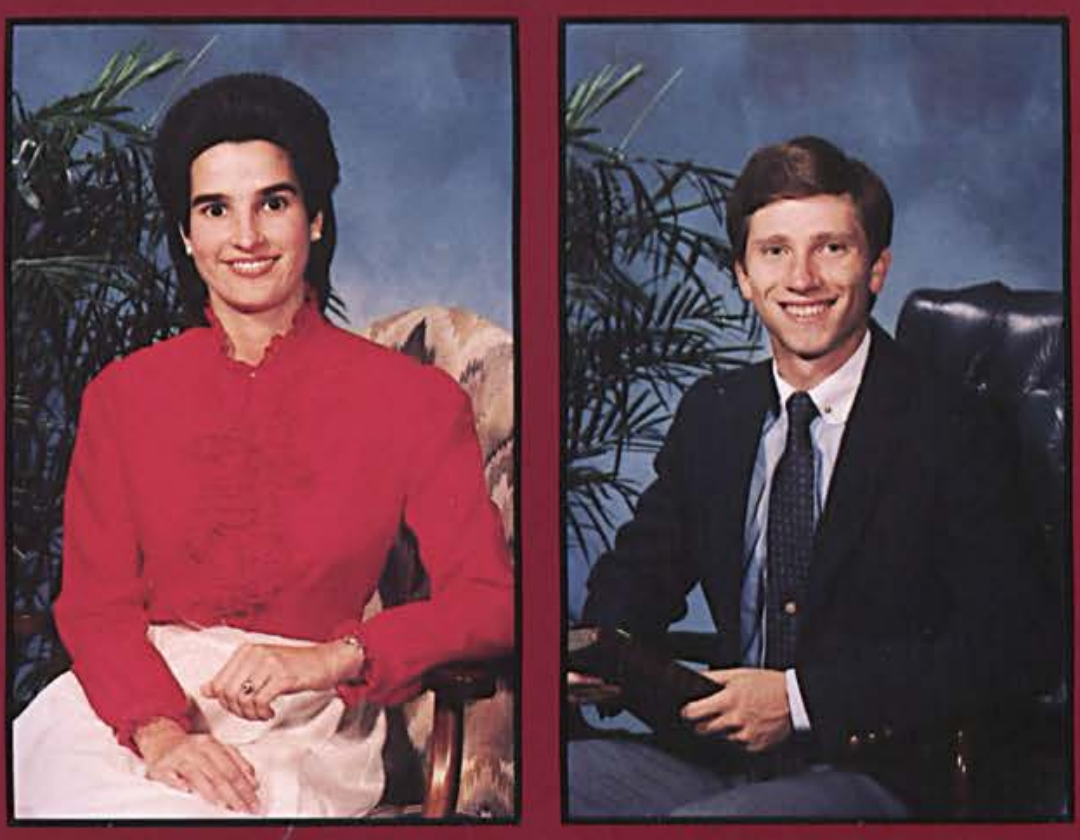

Prudence L. Benevides

Chad Richard Bresson

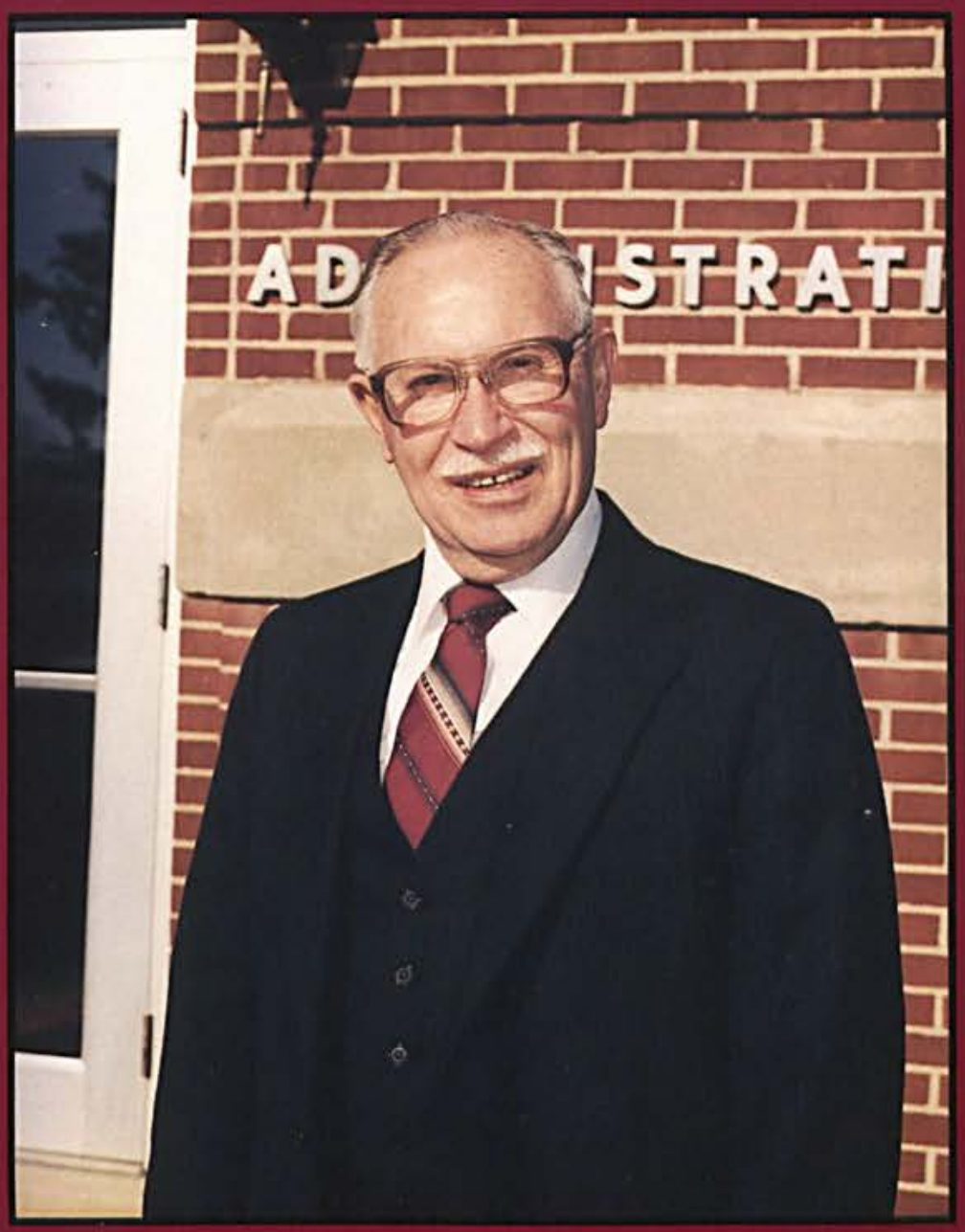




\section{Duties of Student Internship}

S

cott Zimpfer extended his learning experience beyond the classroom. He participated in an internship with Congressman Jack Kemp's staff in Buffalo, NY, and in Washington D.C. for several weeks.

Writing daily news summaries which were distributed among the various Washington staff members took most of his time. However, working with Congressman Kemp's speech writer was the highlight of his two weeks there.

Most of the internship occurred within a four week period in Buffalo. Being one of several staff office people meant having certain duties and unexpected privileges. His major assignment was to handle various types of problems from the New York constituency. These problems required his corresponding with each person and deciding which government agency

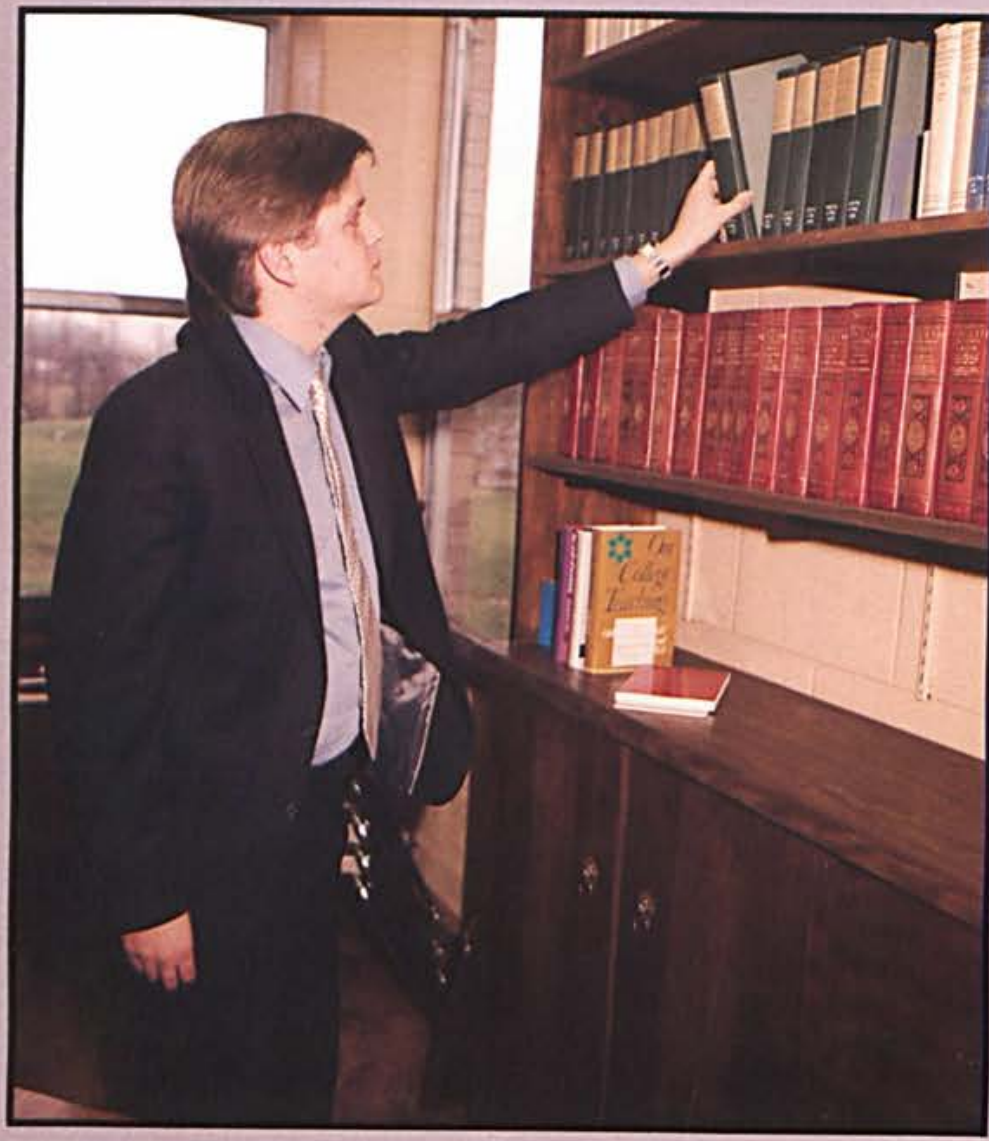
would help in solving it. In addition to this assignment, he researched current issues and reported his findings to the staff. A privilege came when he was invited to attend a dinner where William F. Buckley, Jr., spoke. That privilege made him feel very much like a member of Congressman Kemp's staff.

After attending law school, Scott plans to pursue his goal of becoming a press secretary or a campaign manager for some fortunate United States Congressman.
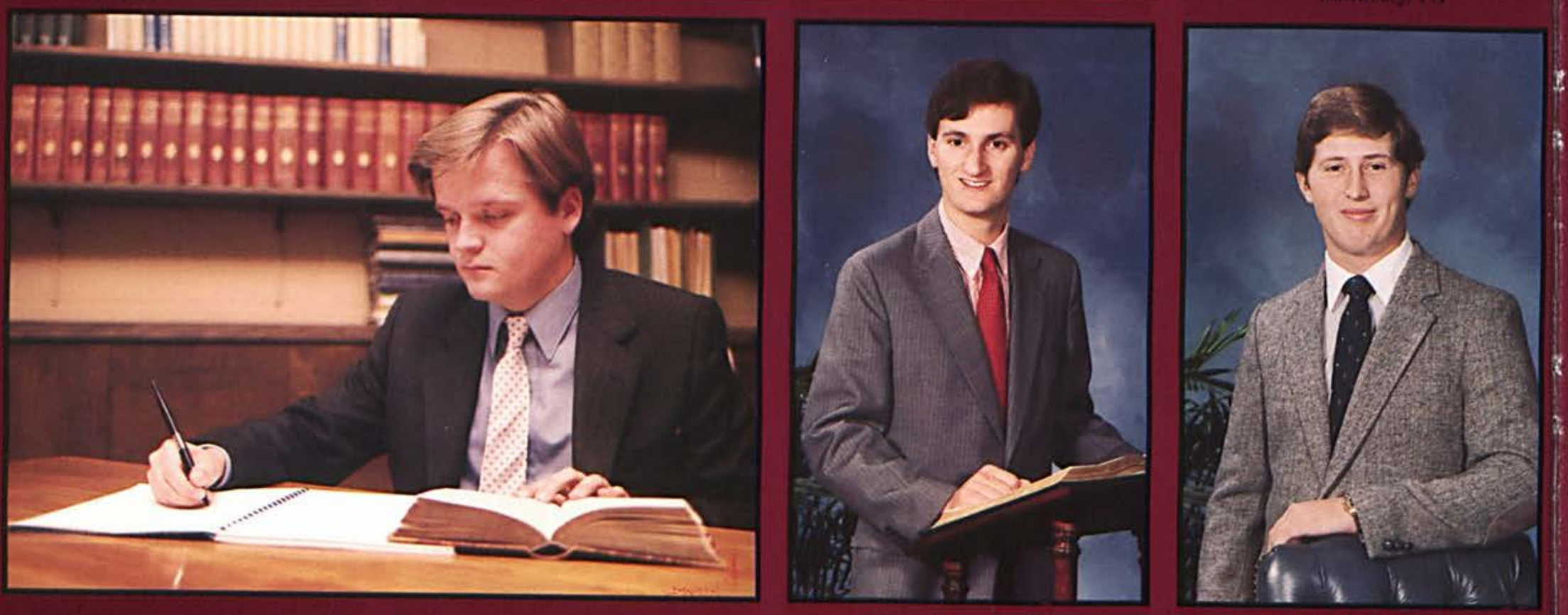

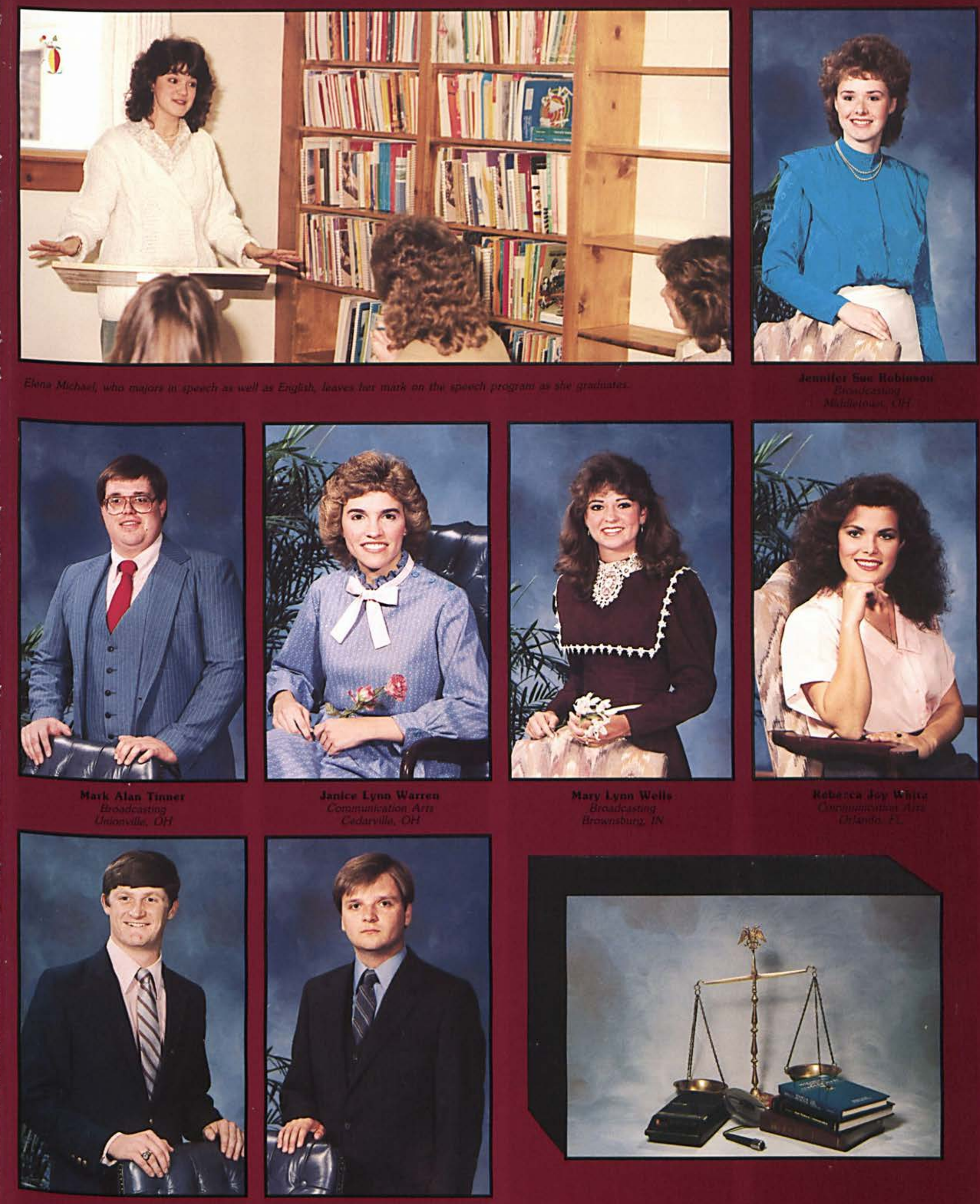
Teaching stewards to develop and cultivate the minds and morals of young people in a manner which is consistent with the teachings of scripture.

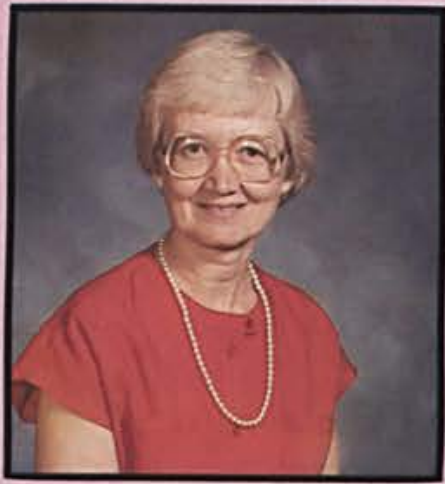

Sue H. Baker, M.A. Associate Professor of Education

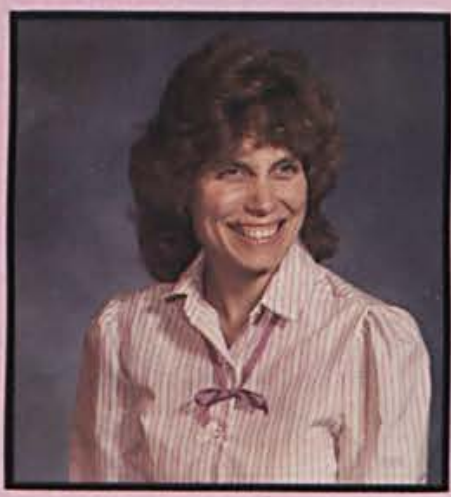

Sharon Elmers, M.Sp. Ed. Assistant Professor of Education

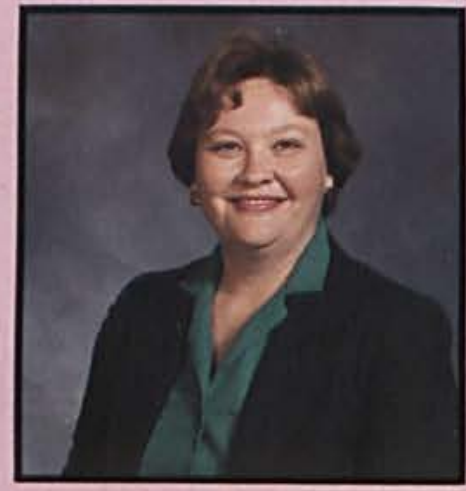

Lila Christensen Seaman, Ph.D. Associate Professor of Education

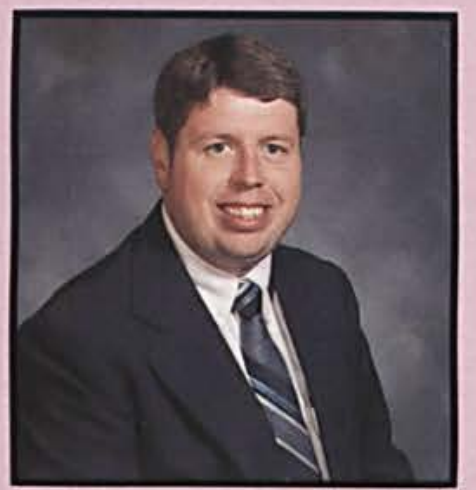

Joseph Beeson, M.A. Assistant Professor of Education

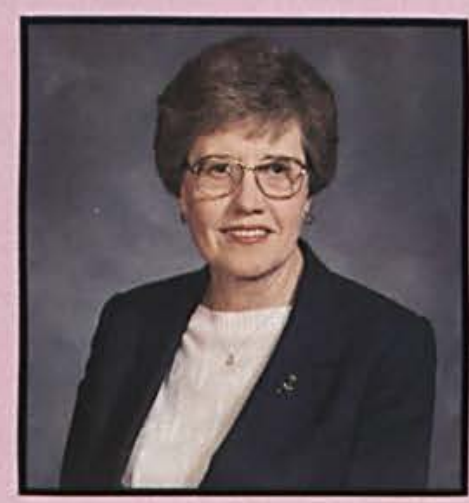

Helen L. Hall, M.A. Associate Professor of Education

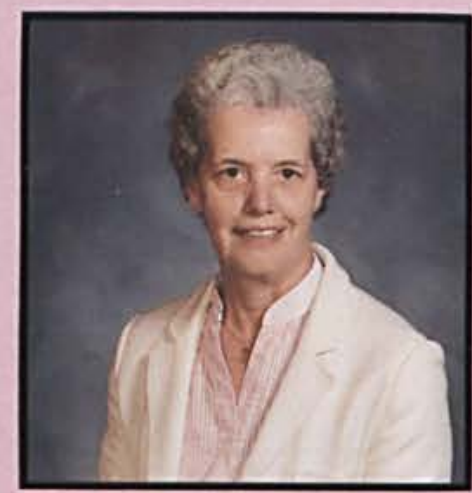

Eleanor A. Taylor, B.A Instructor of Education

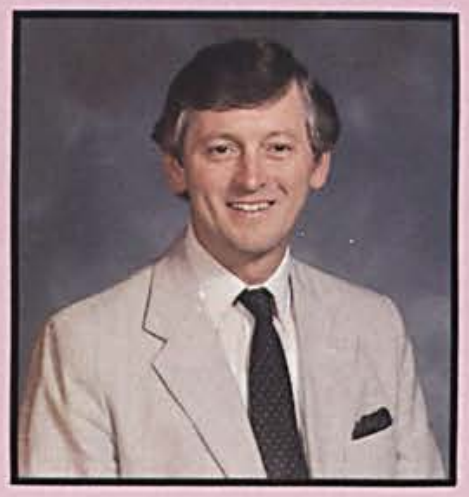

Merlin Ager, Ph.D.

Professor of Education

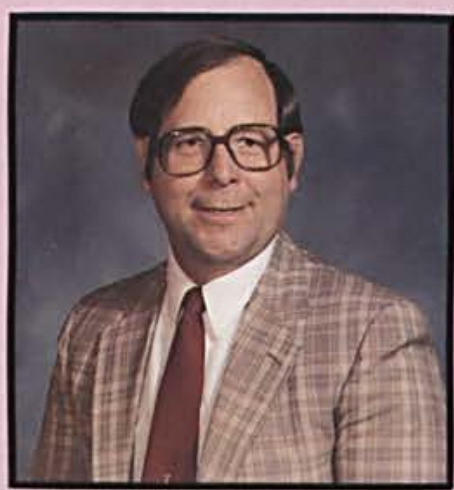

Omer Bonenberger, D.Ed. Associate Professor of Education

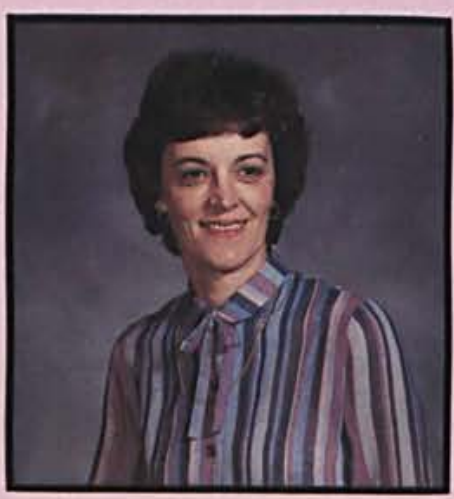

Beverly Monroe, Ph.D. Associate Professor of Education

Not pictured: (on leave) James Biddle, Ph.D. Professor of Education

Dwayne Frank, D.Ed. Professor of Education 


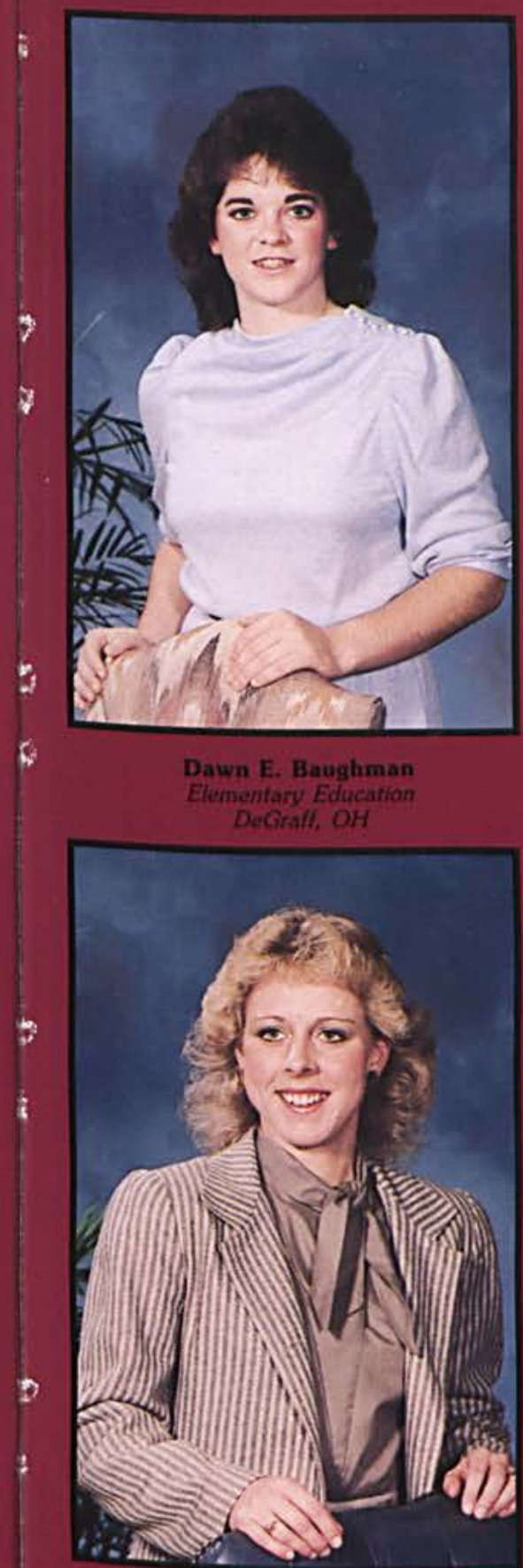

Sandy H. Carmach

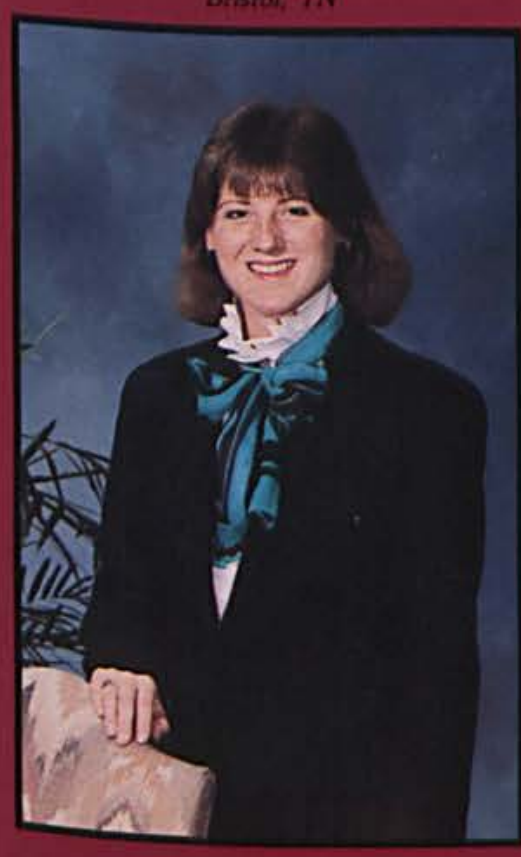

Salty d. Cochran

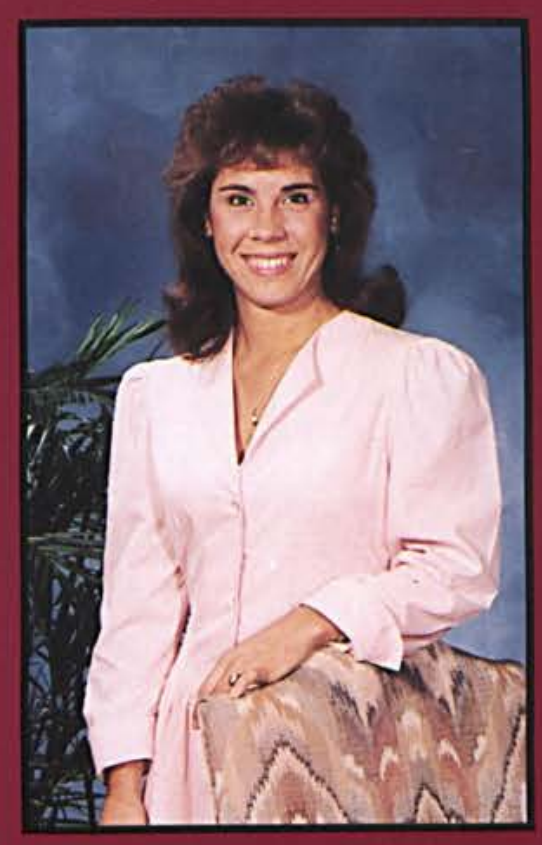

Debra d. Bell

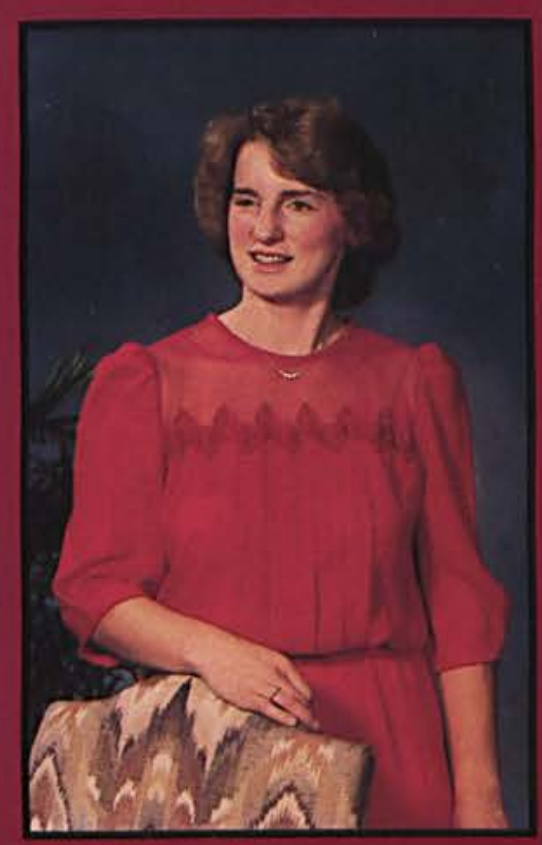

Usa Jay Chandler

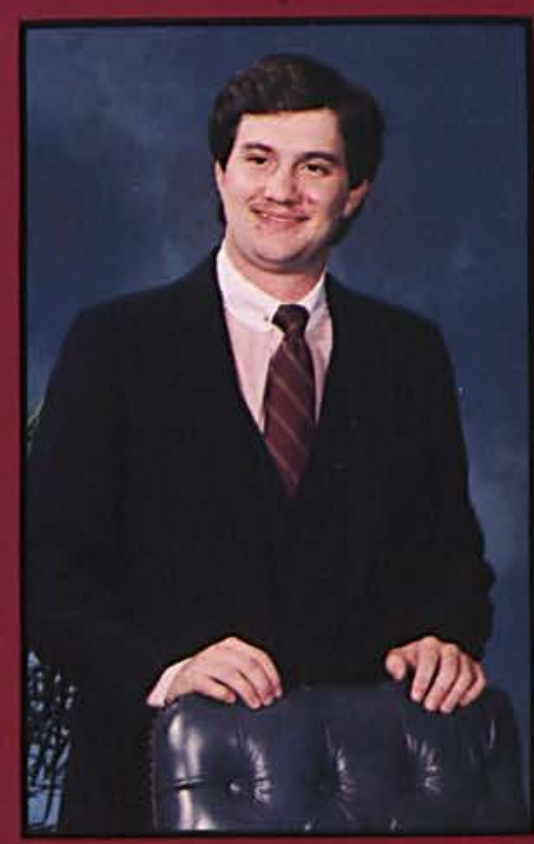

Gay A. Demetri

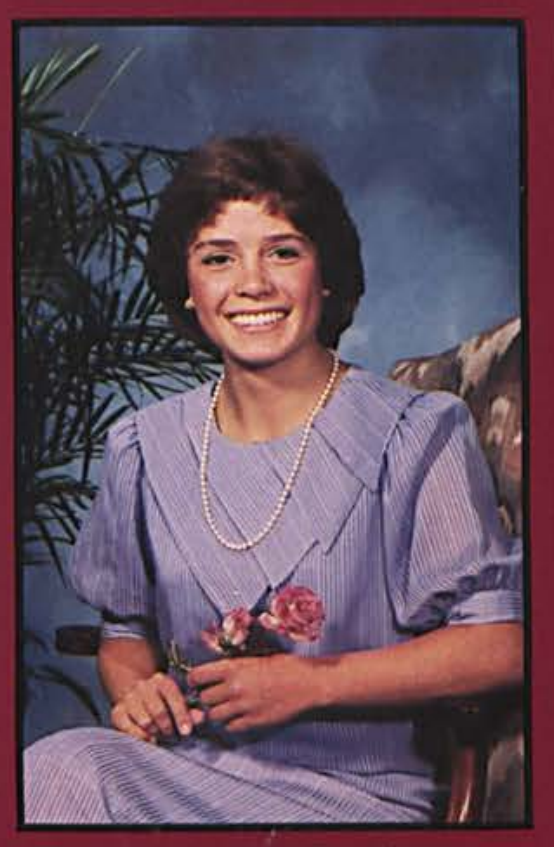

Sara Jean Brandı
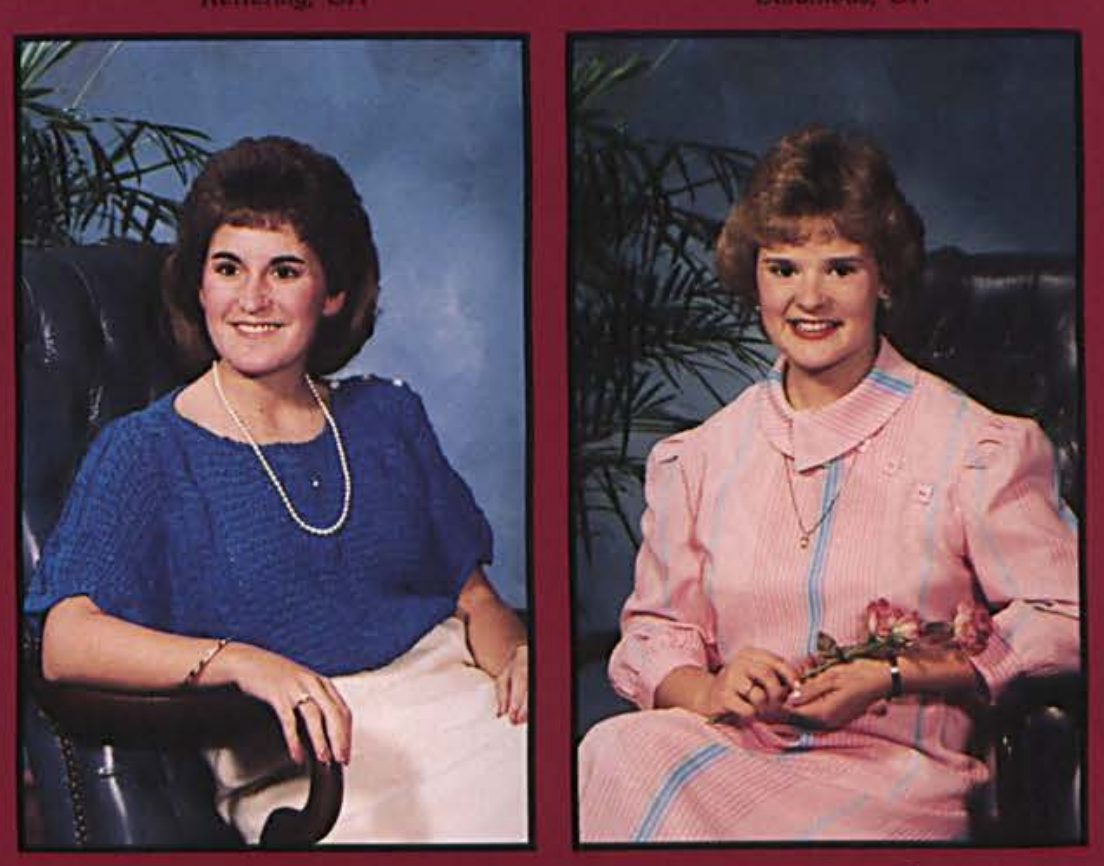

Kathlees Marle Clayton

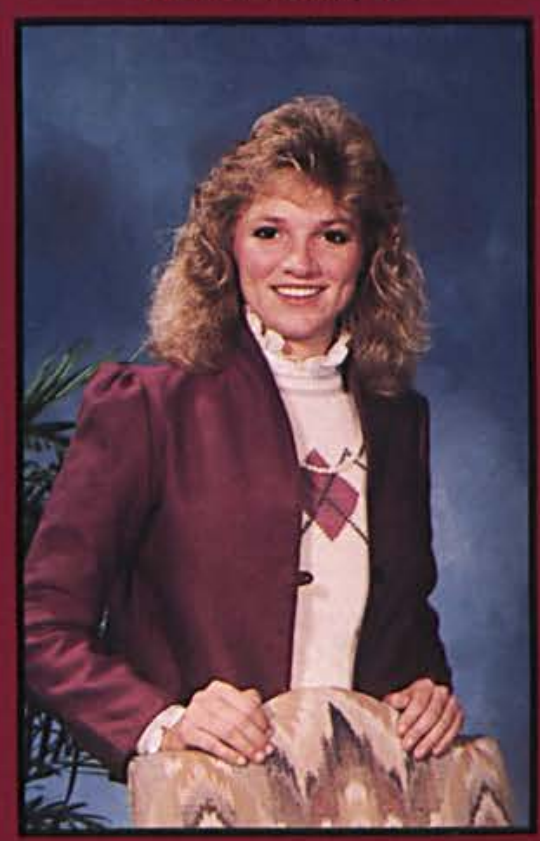

Tamela Renae Deskin:

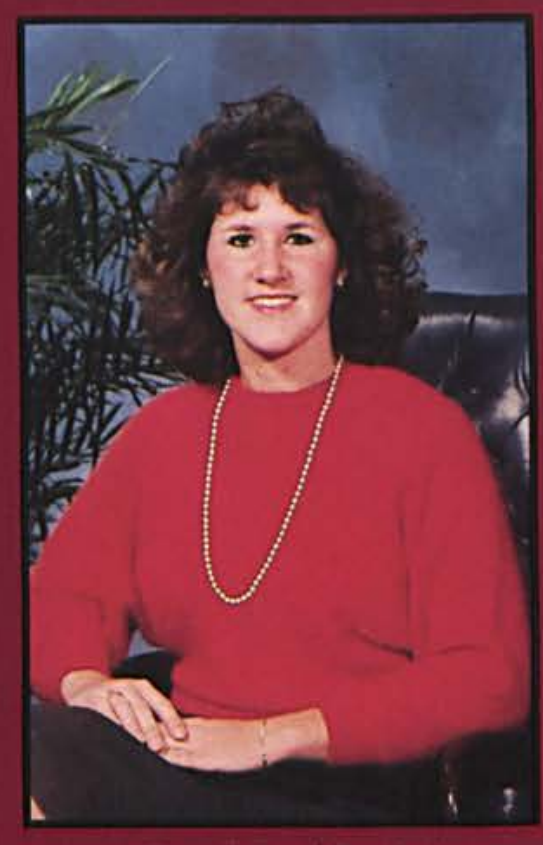

Brenda Deaé Burcheta

$$
\text { - }
$$

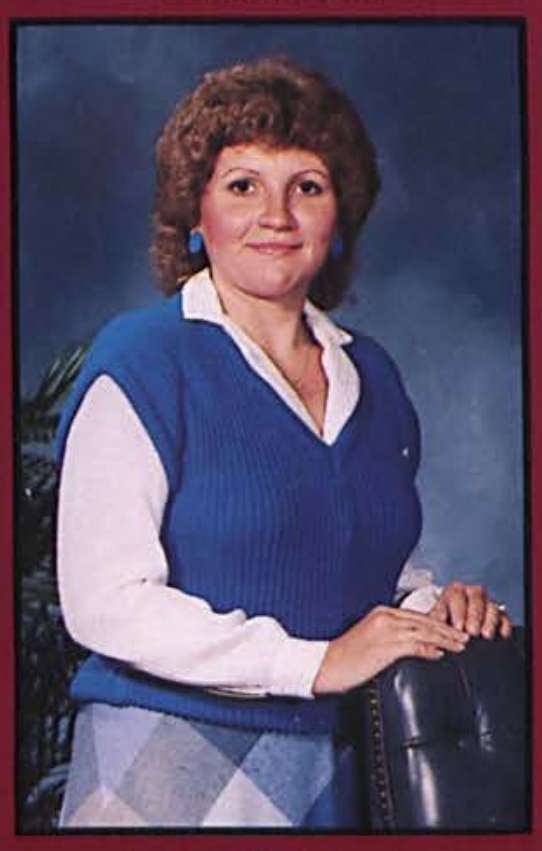



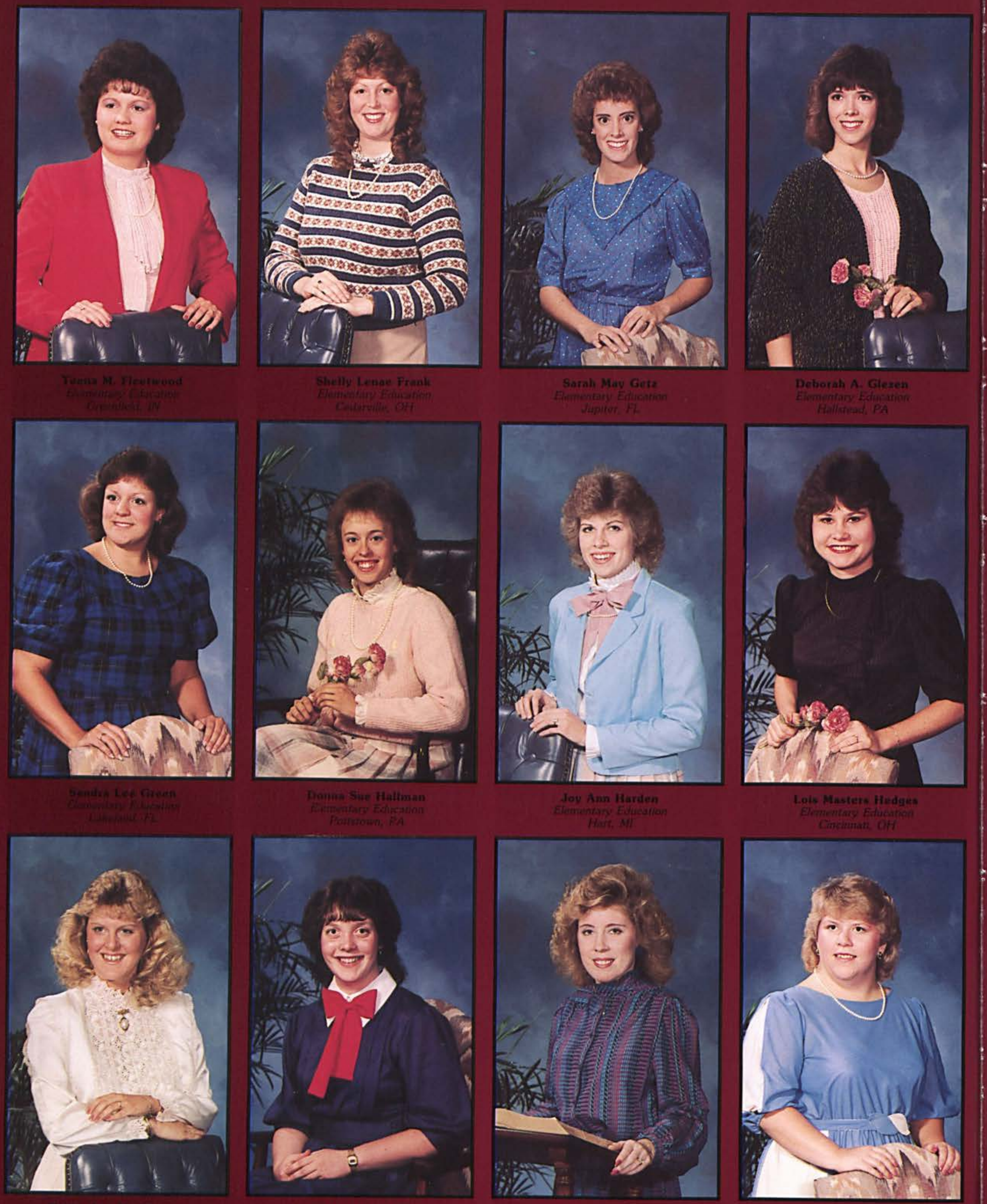

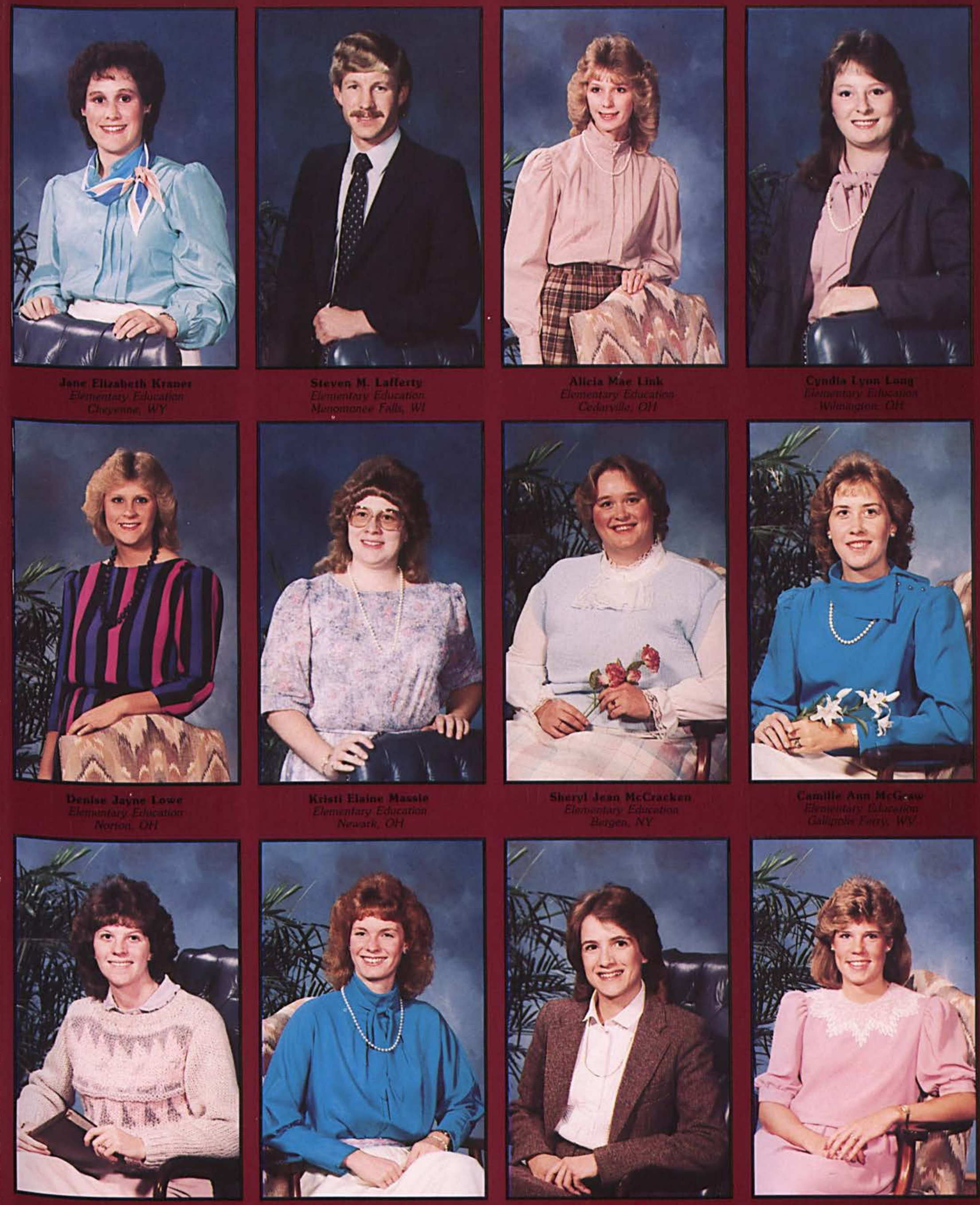


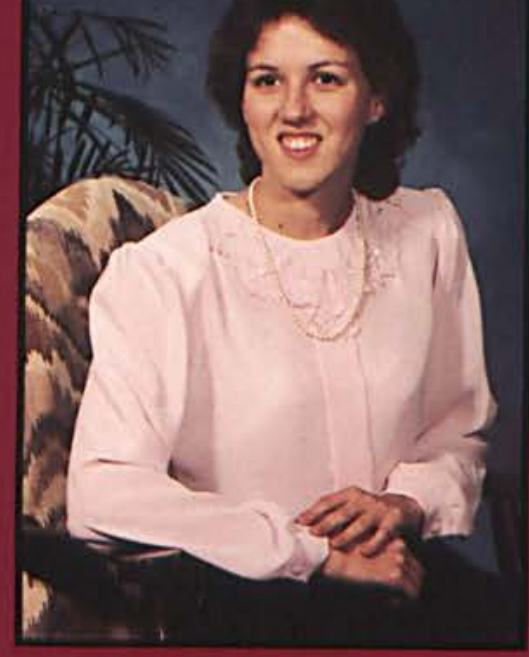

Rebecca Ellen $\mathbf{O}^{\prime}$ Connor

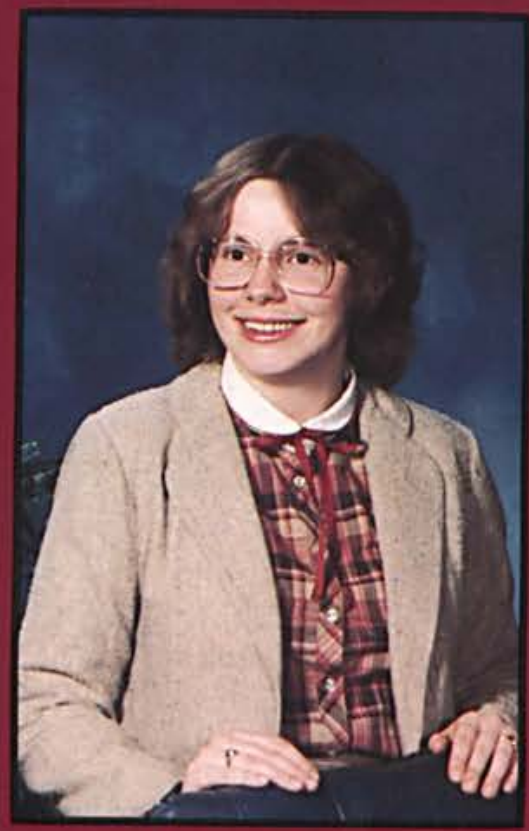

Marianne Pearson

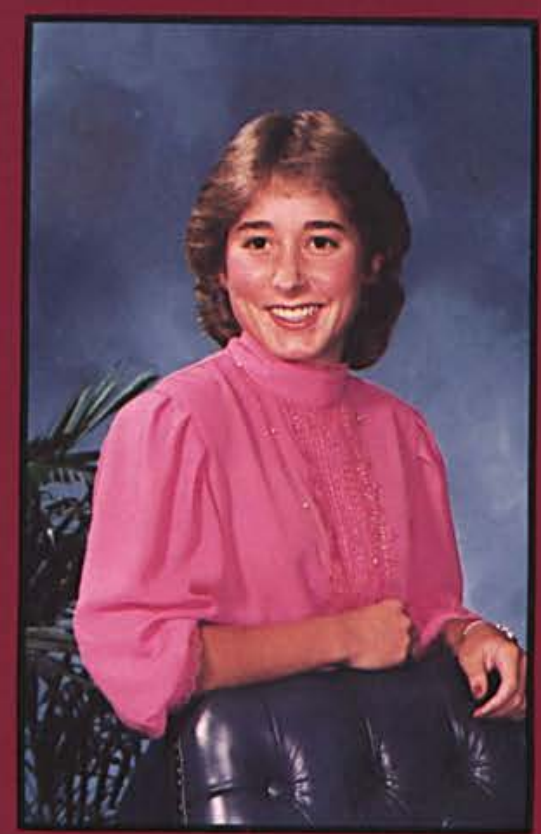

Shelley Marie Polsdorier

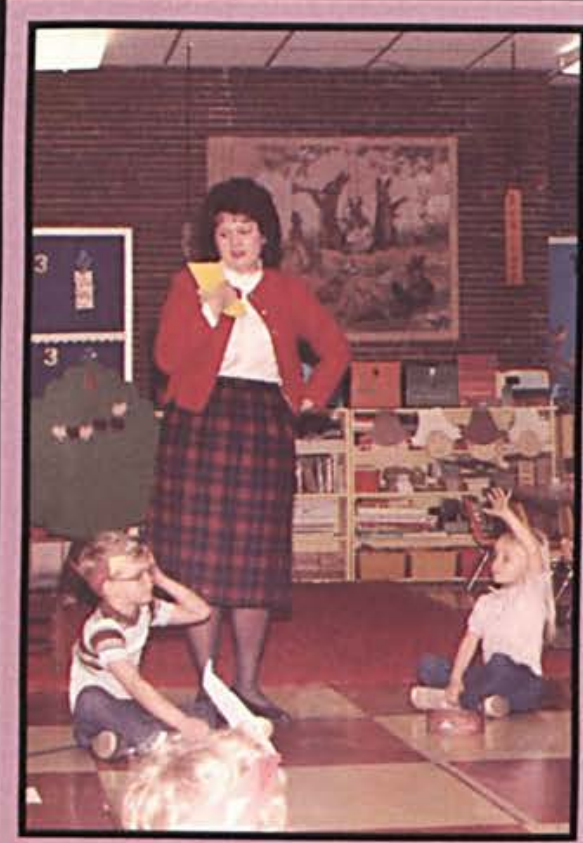

\section{Student Teaching}

$\mathbf{F}$

an elementary education major, student teaching is the pinnacle of her learning experience at Cedarville College. After three years of enduring methods classes, endless cutting and pasting, and the writing of innumerable behaviorally stated objectives, students are ready to spend ten weeks testing their wings in area public and Christian schools.

This experience proves to be both a trying and rewarding time for many students. The first few days of student teaching are often awkward and tense as the new teacher attempts to adjust to her students and as the students attempt to adjust to a new teacher. Periodic observations by a supervising professor throughout the ten weeks may also create some anxiety. However, once the student teacher actually gains control of the classes and is able to apply the skills that she has learned, a feeling of satisfaction gradually replaces her fears. She delights in delving into the reams of lesson plans, over-stuffed picture files, and dozens of ready-made visual aids which she has accumulated. Seeing the eyes of the children light up as they finally understand a difficult concept and their smile as they use a new skill makes all the hours of preparation worthwhile.
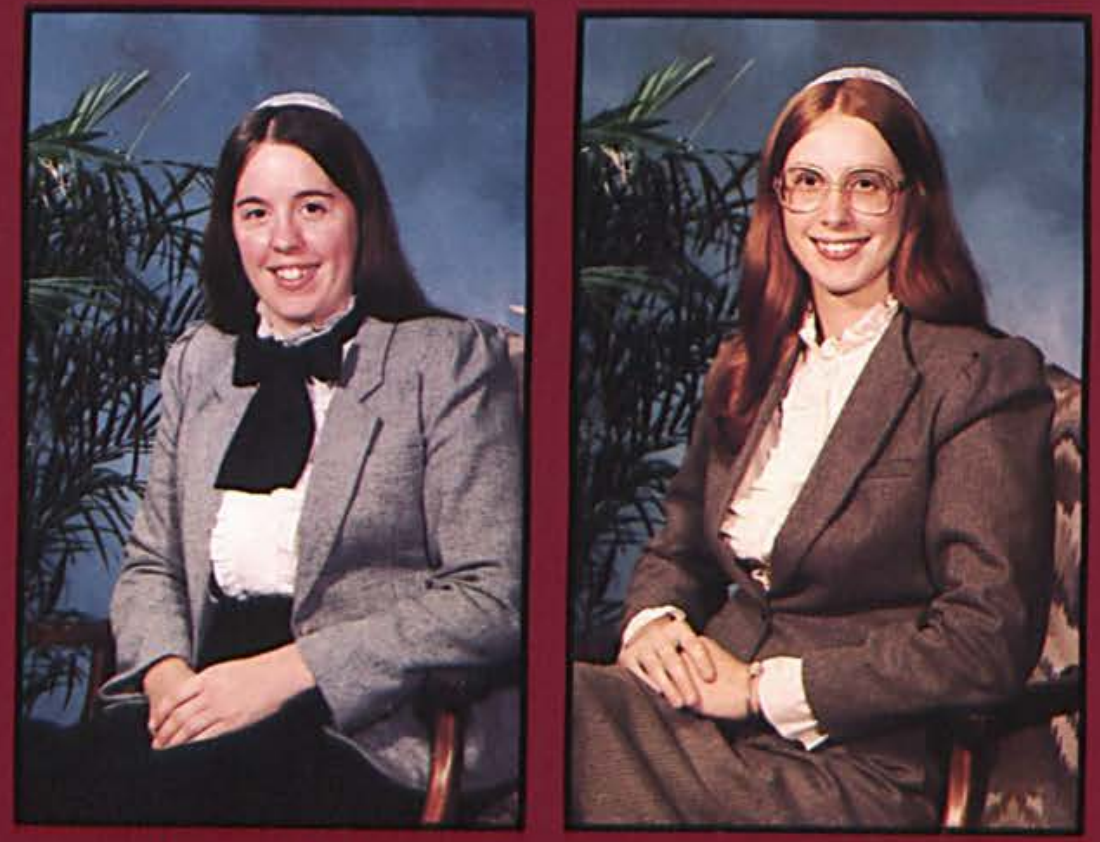

Nancy L. Ruth.

Merityn F. Rurb
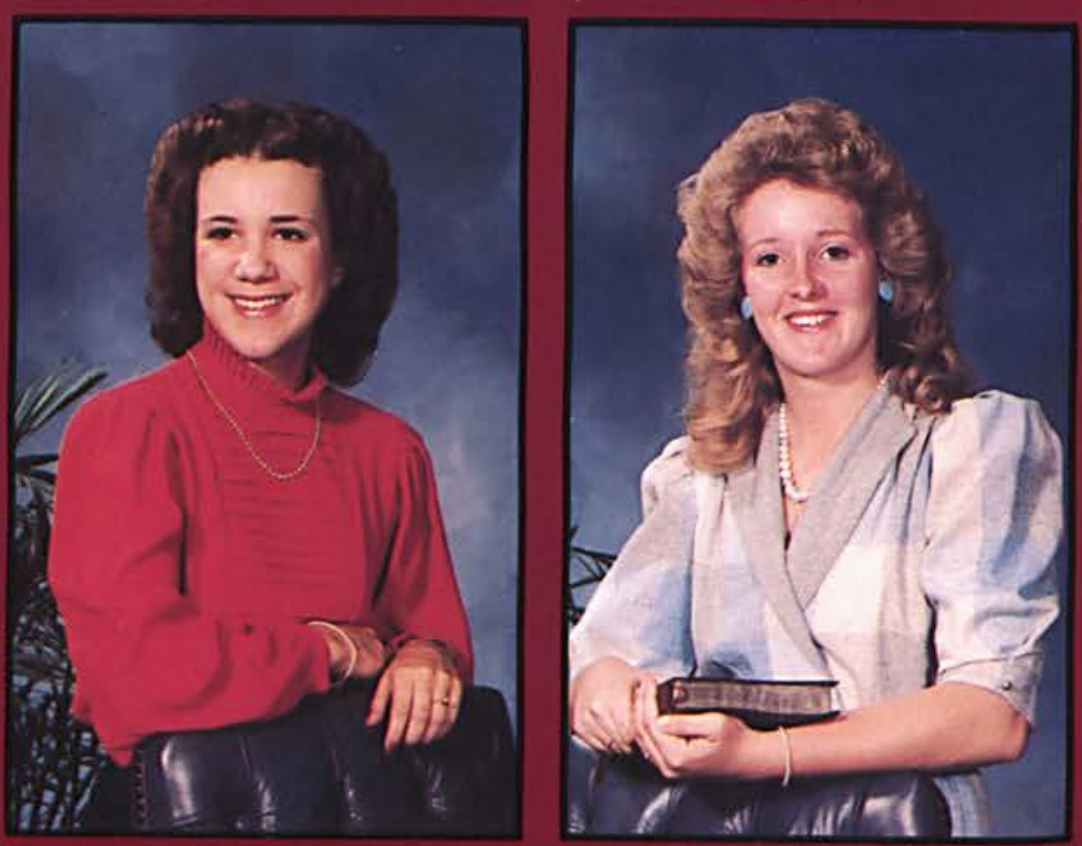

Marlene Kay Siefex

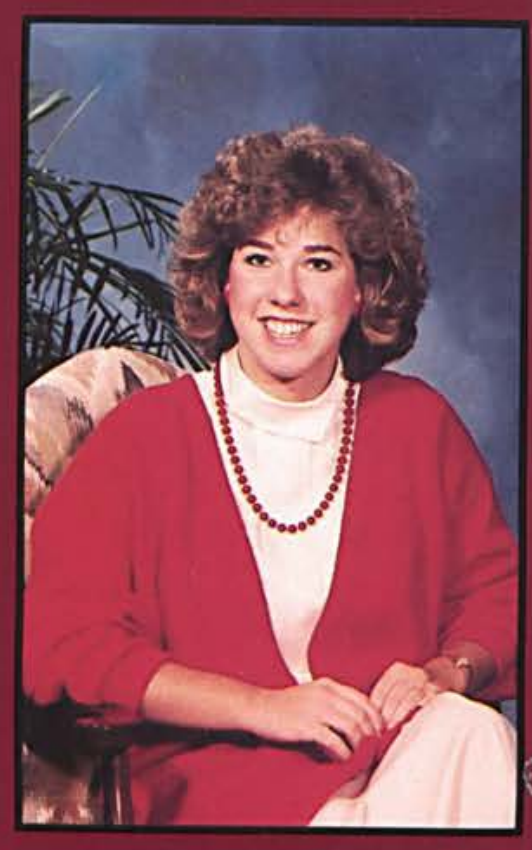

Dawn Marle Reehl

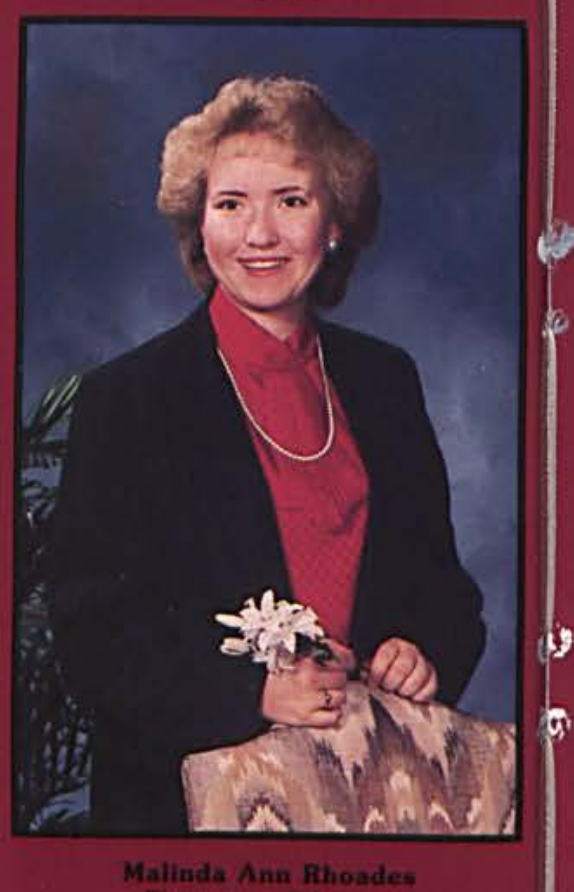

6

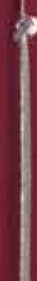



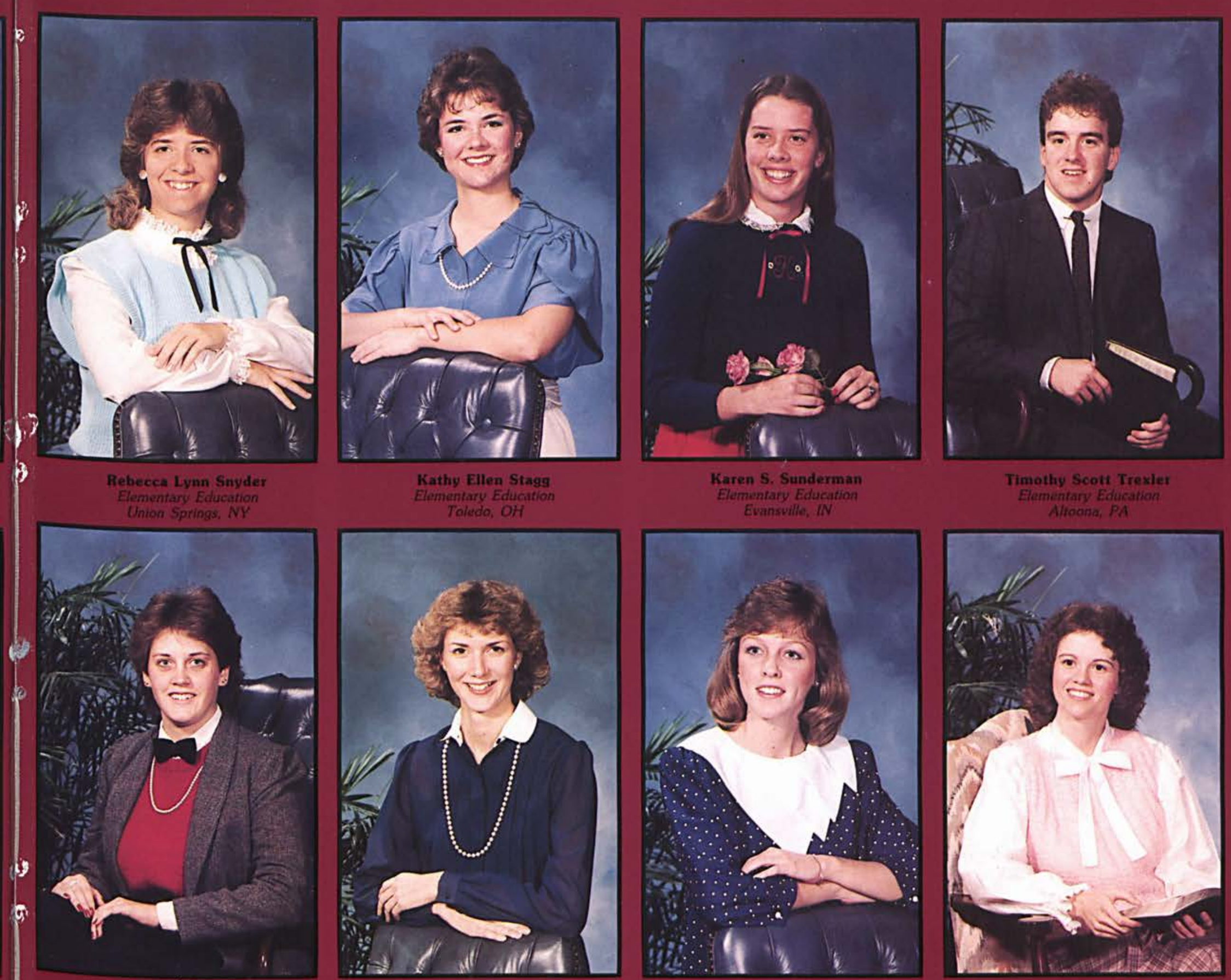

Rhonda Rae Trueman

Christine Rae Weldman

Judith Karen Whittaker.

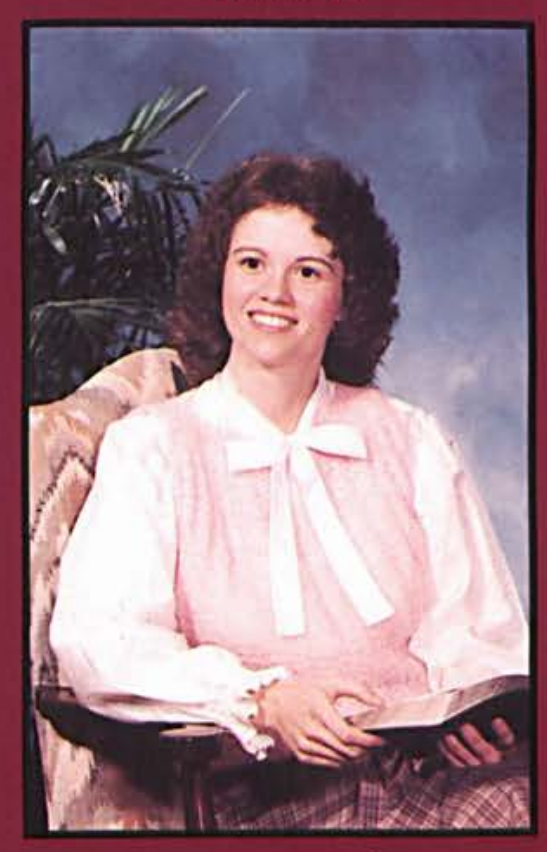

4
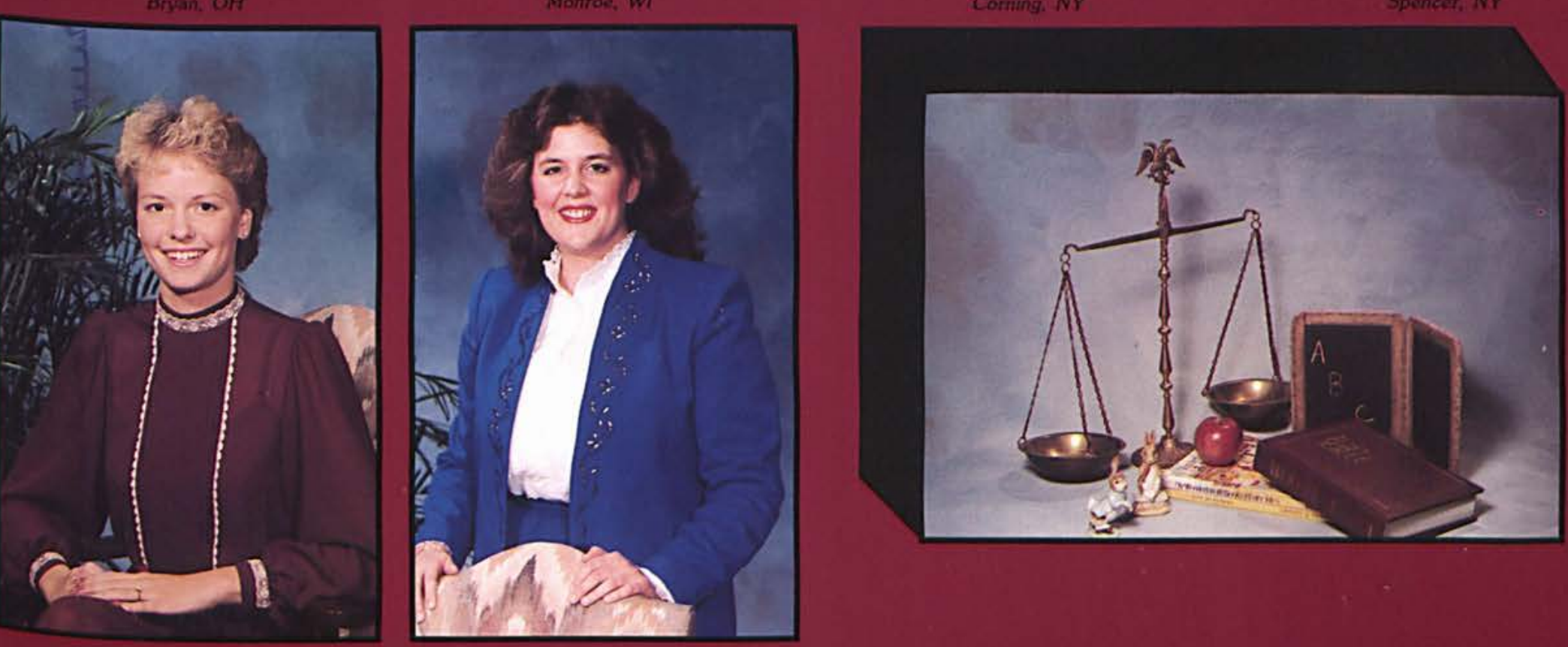


\section{Teaching stewards} to care for their total well-being so they can maximize their productivity, enjoyment, and witness on earth as long as God permits.

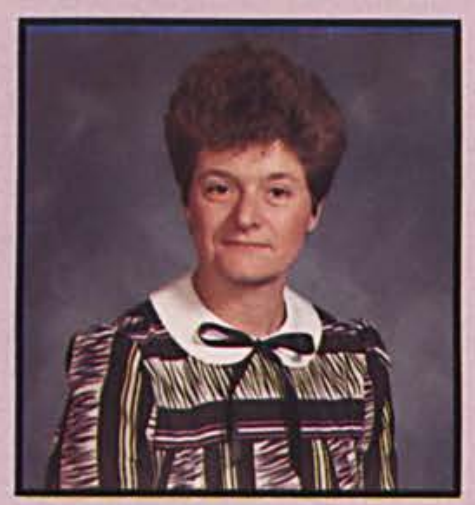

Elaine Brown, M.S.Ed. Assistant Professor of Physical Education

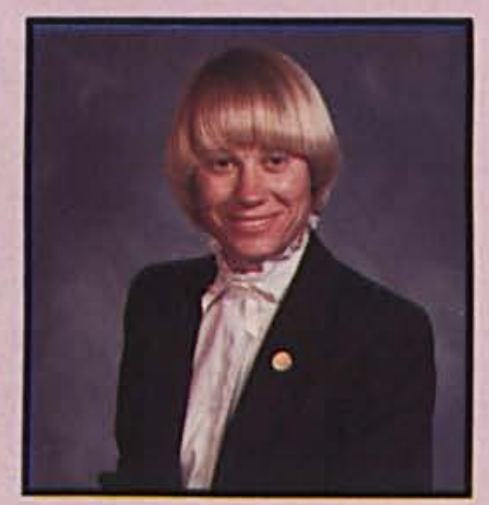

Karol Hunt, Ph.D. Assistant Professor of Physical Education

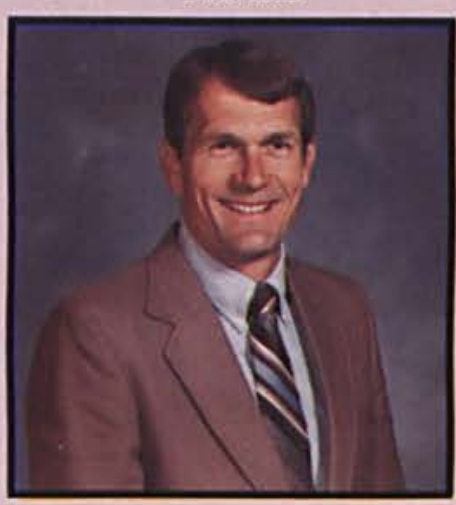

John McGillivray, M.S. Assistant Professor of Physical Education

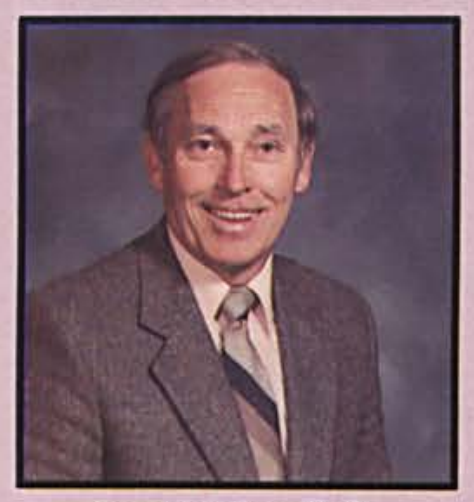

Donald Callan, Ph.D.

Chairman

Professor of Physical Education

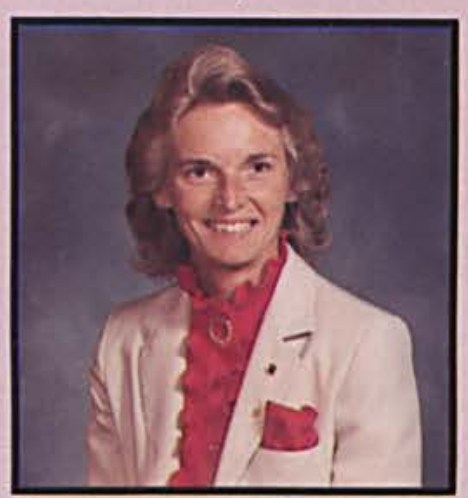

Pamela Diehl, Ph.D.

Associate Professor of Physical Education

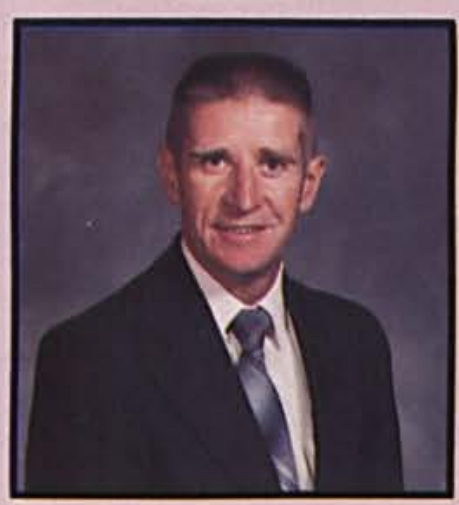

Elvin King, M.Ed. Associate Professor of Physical Education

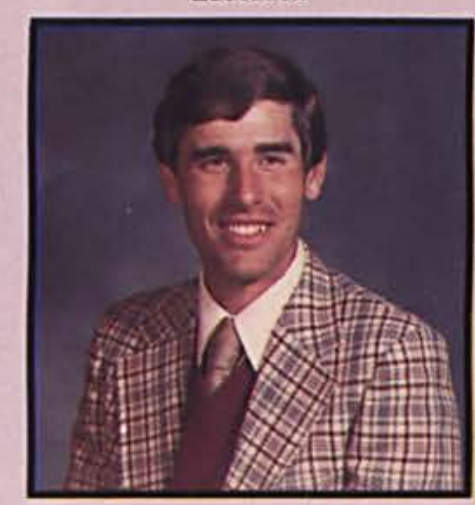

Stephen Young, B.A. Coach and Instructor of Physical Education
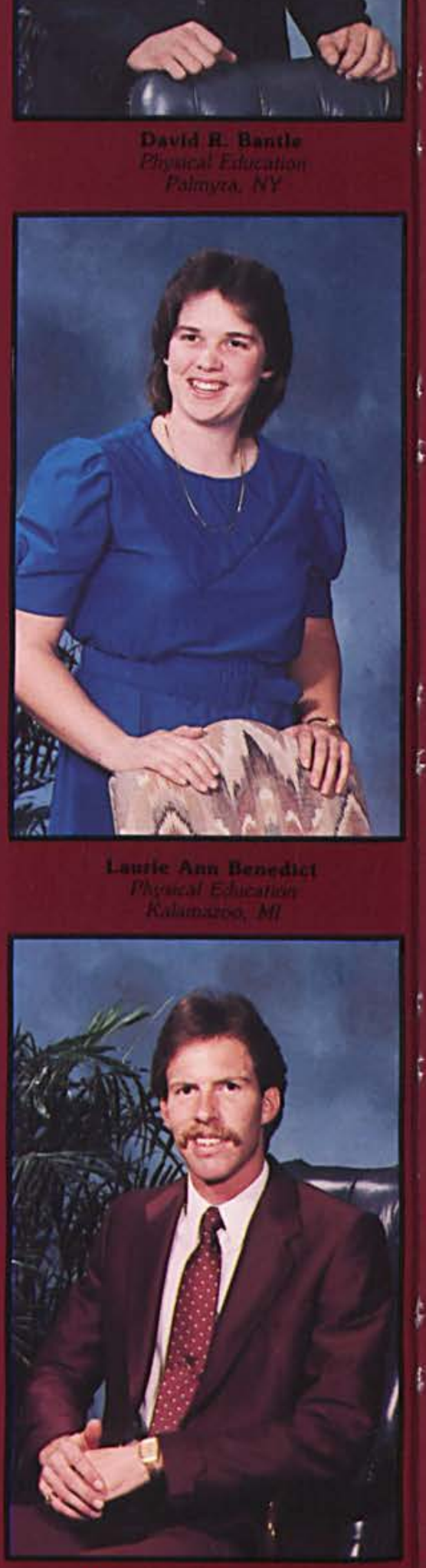

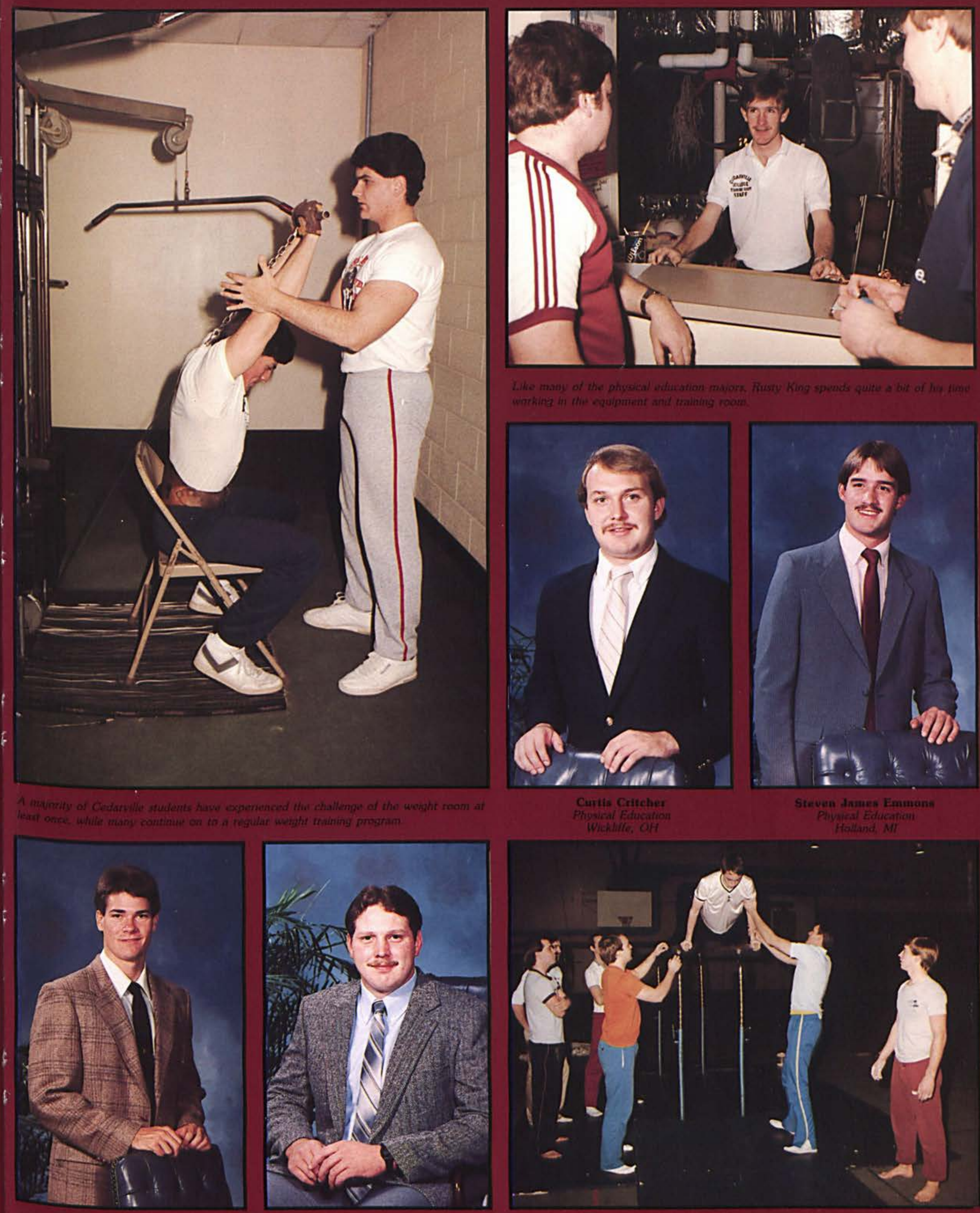


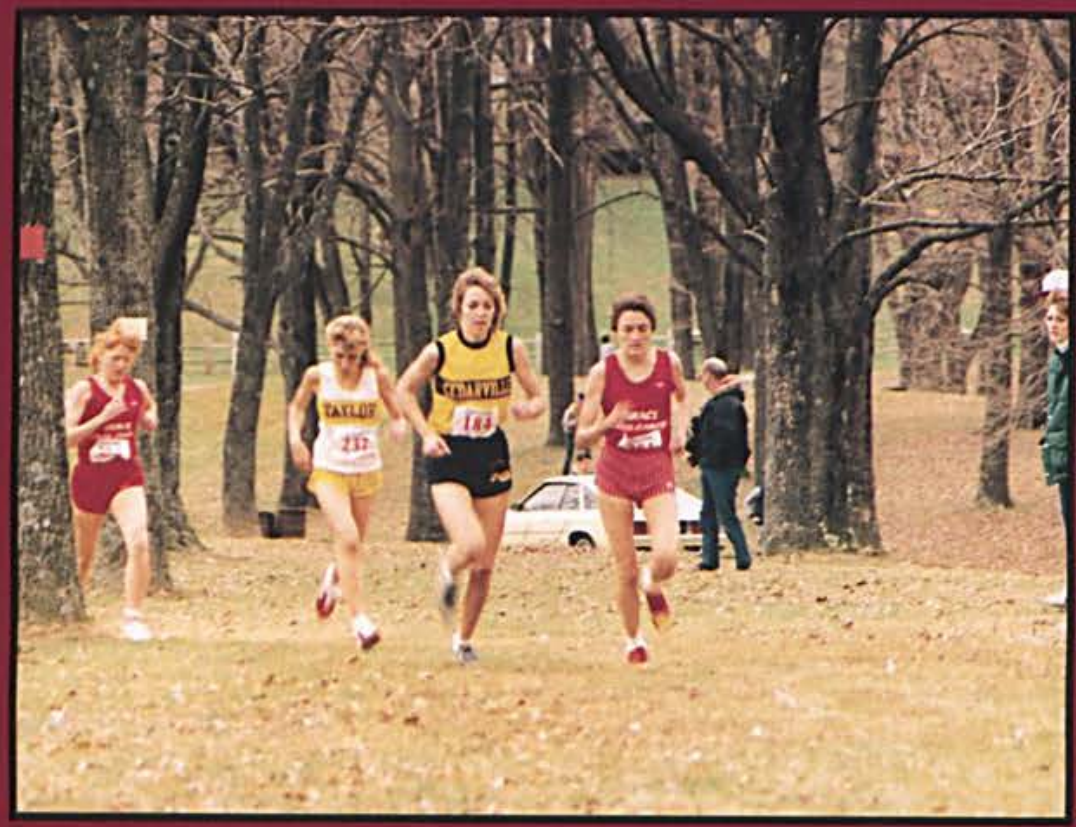

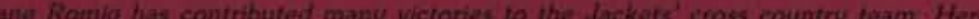

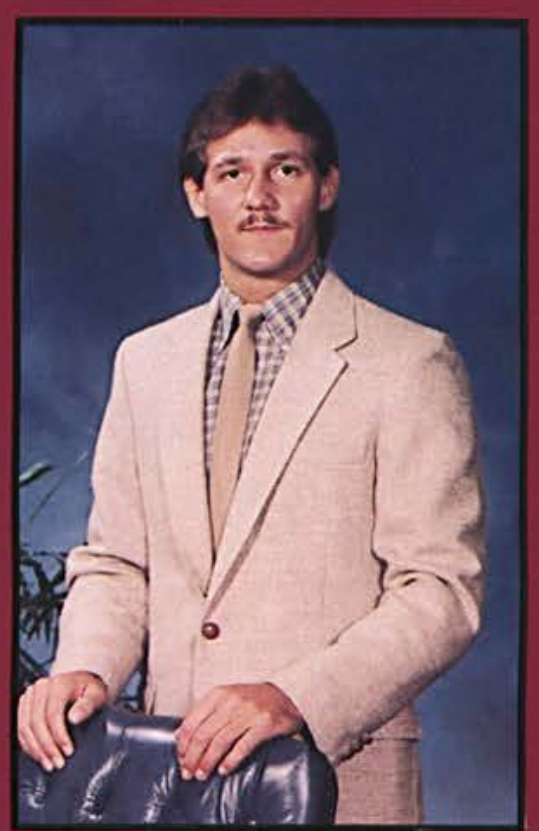

Charles Andrew Jone»

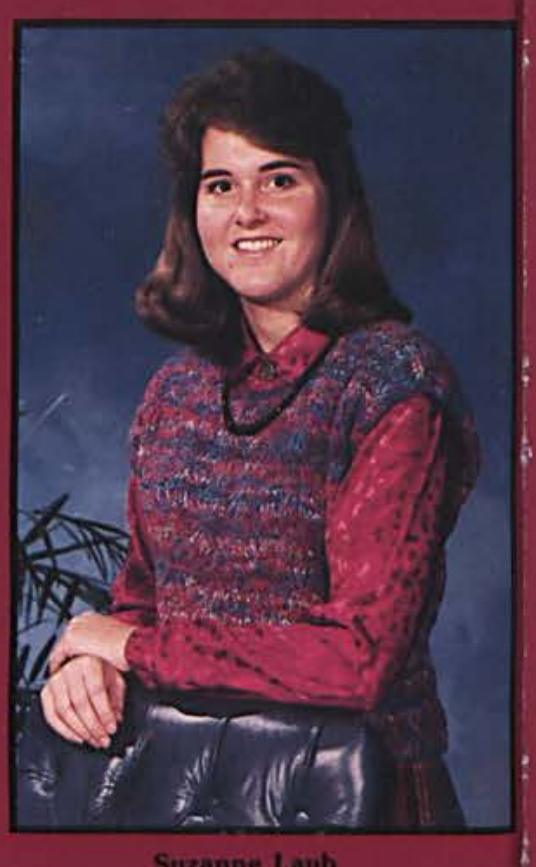

Suzanne Laub

\section{A Multiplied Ministry}

Coach Elvin King came to Cedarville College seventeen years ago after several years of coaching and teaching experience in public high schools. While he enjoyed the ministry that he had in the lives of young people in these schools, he decided that he could best serve God in a new type of ministry at Cedarville.

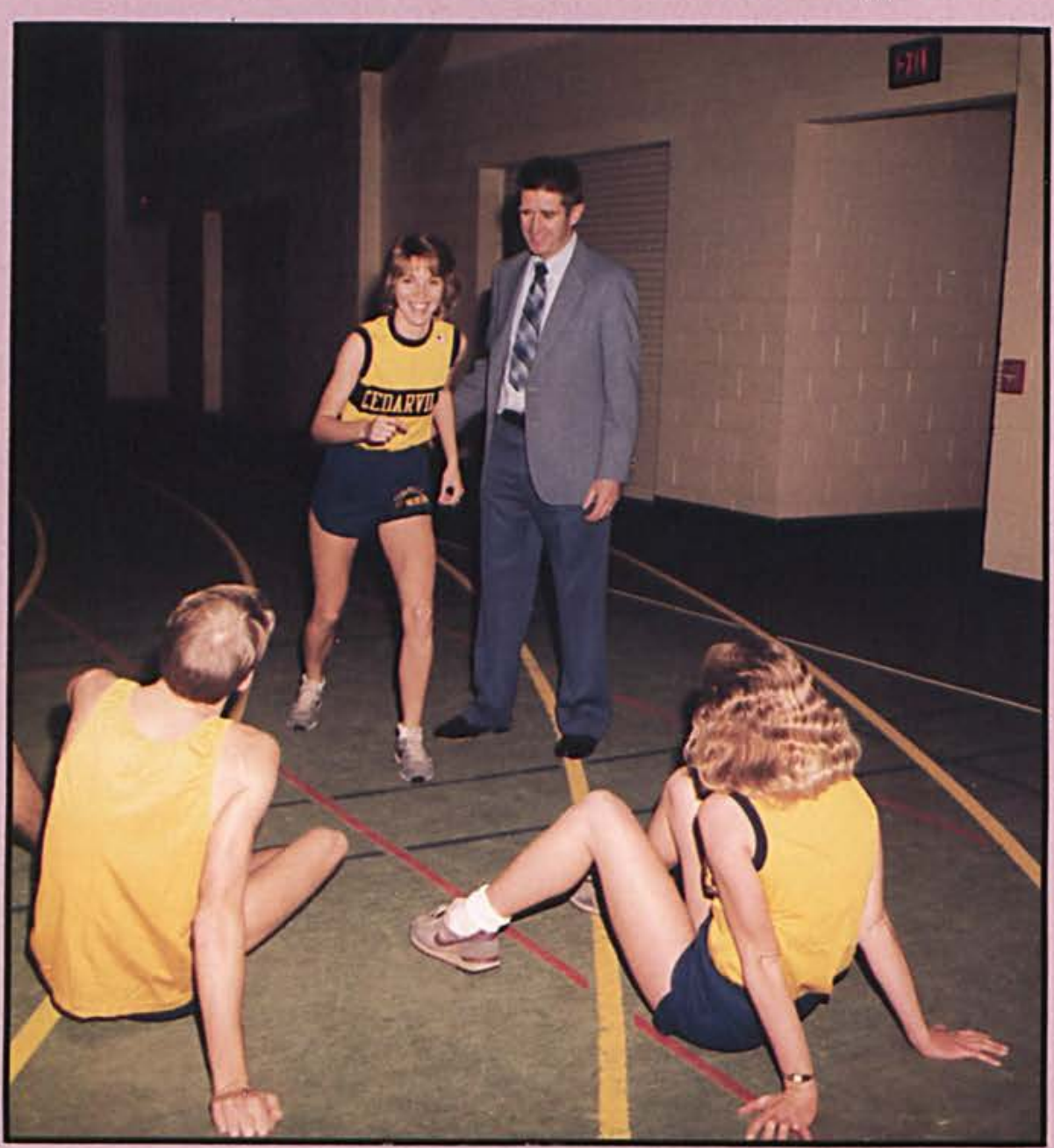

The most important reason why Coach King made the move to Cedarville is that he believed that his ministry to young people could be multiplied; he now trains Cedarville students to do the work which he once did in high schools. He estimates that about one hundred students with whom he has had contact as professor or coach are now teaching in high schools or colleges. One of the high points of being a professor, says Coach King, is seeing and hearing from his former students, many of whom are serving the Lord as his witnesses in the field of physical education. 


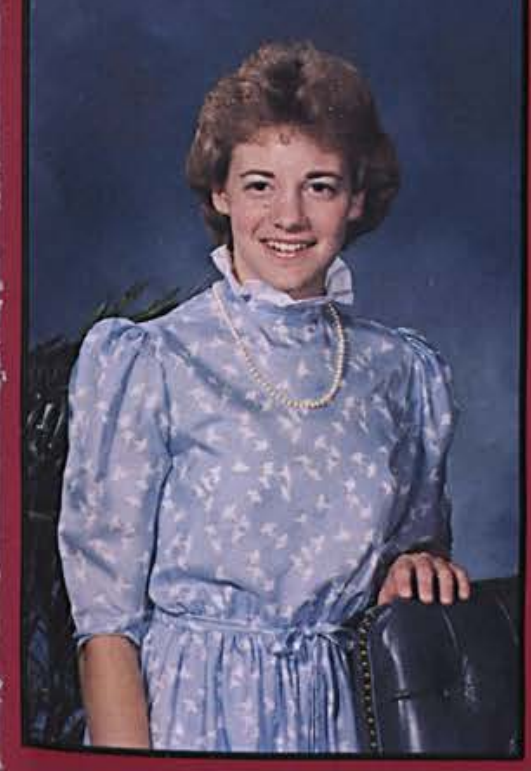

Kristine K. Parman

$$
\text { Physical Educatic }
$$

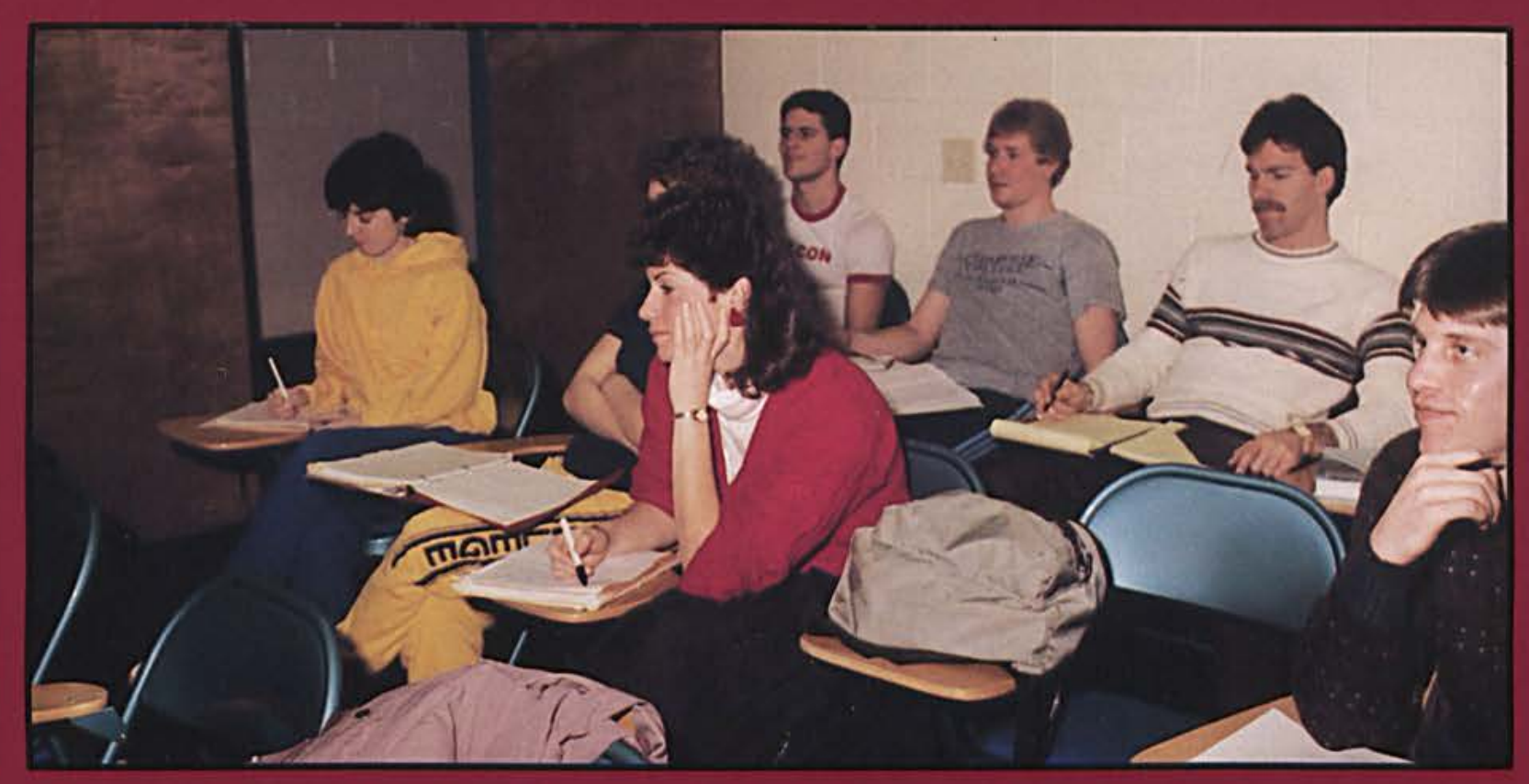

While many activity courses fill the pliysical eclucation majors' schedule, thay also spand much time in the classroom
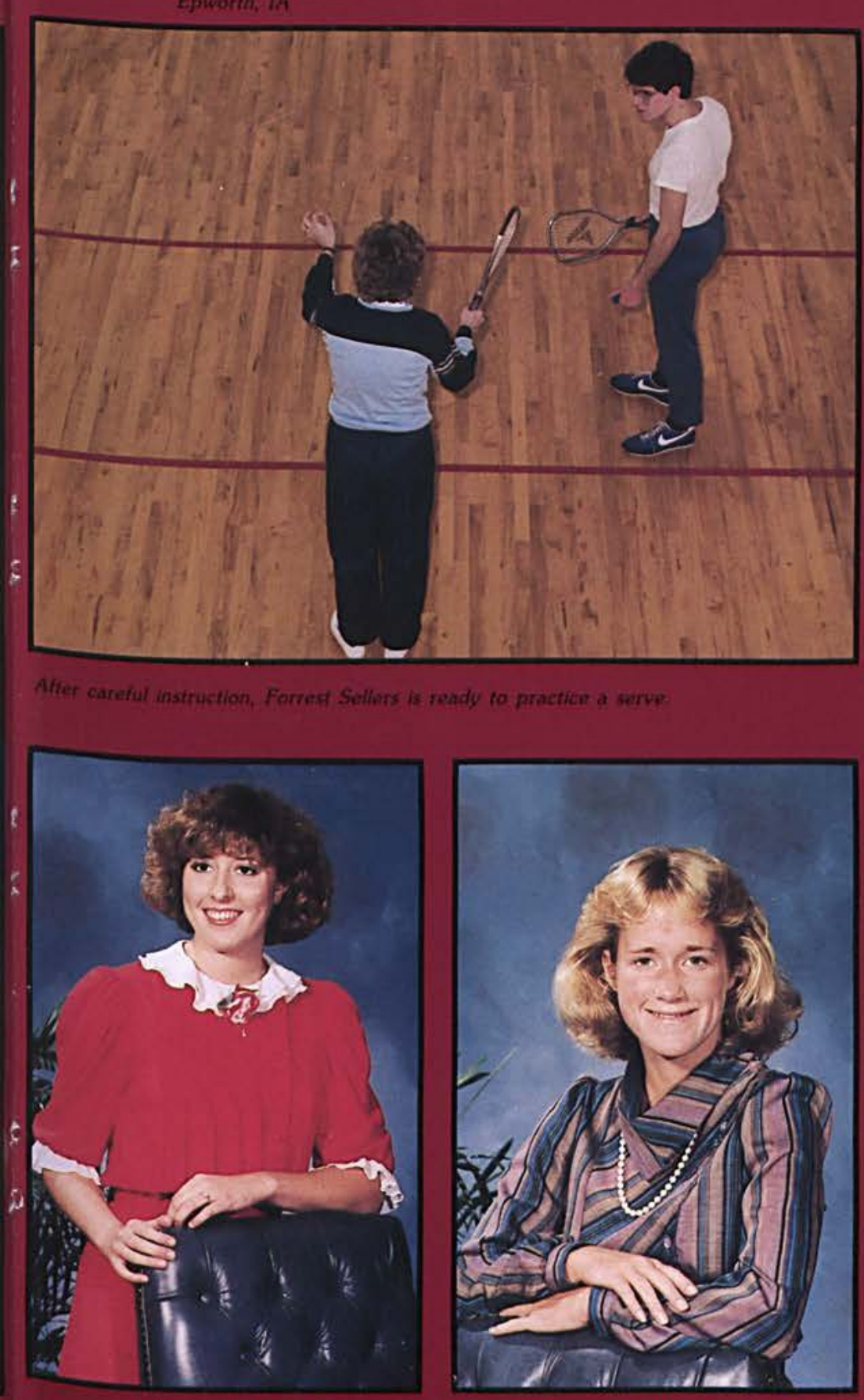

Connis L. Thibo

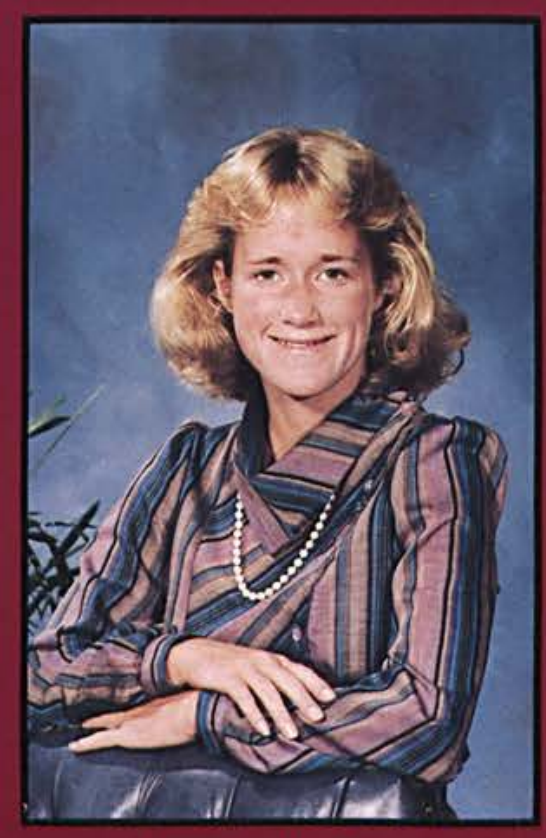

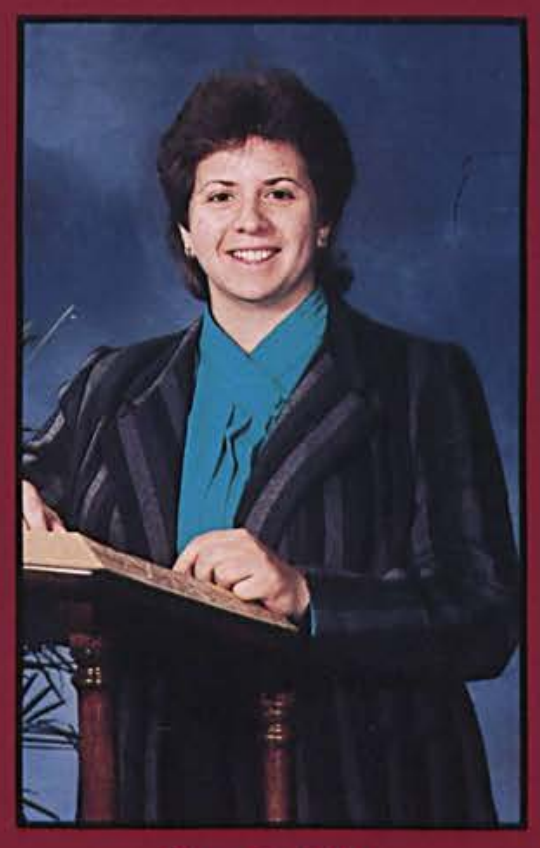

Diane M. Peffer

Slippery Rock. PA

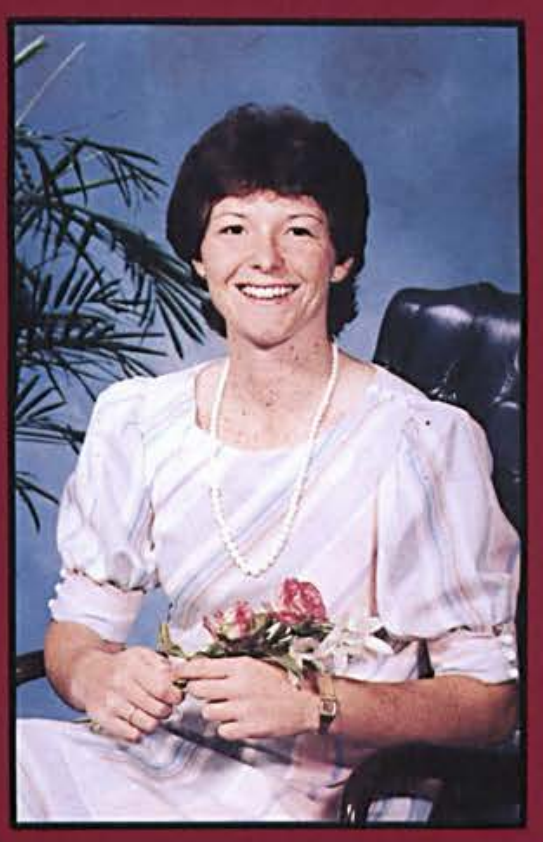

Jewel Schroder

Fergus Follis, MN

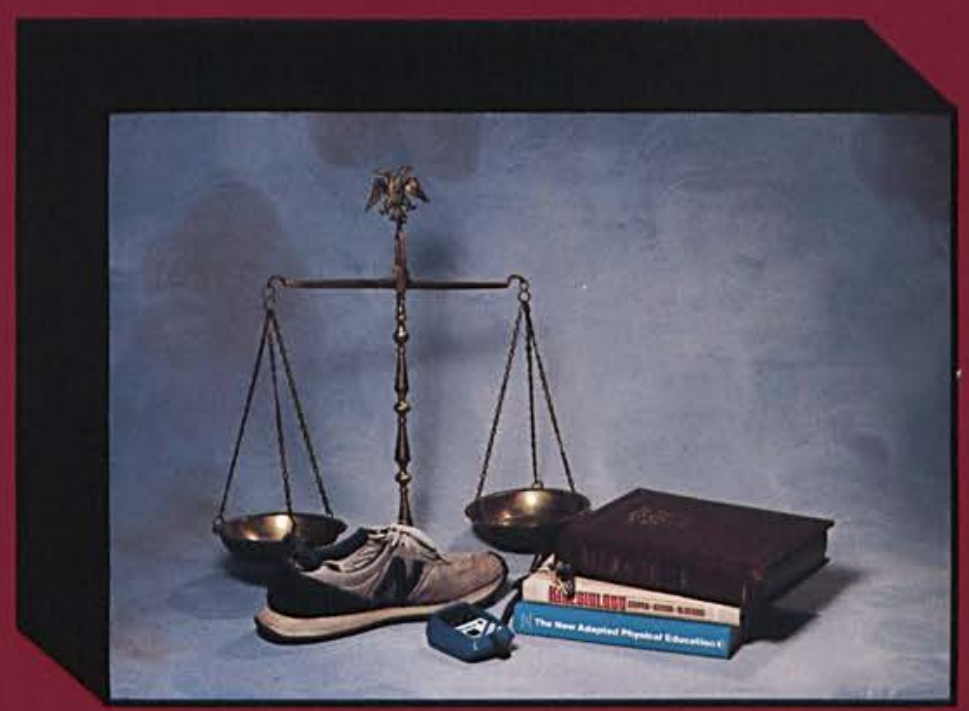


Teaching stewards to value God's gift of communication as they learn to speak and write effectively and to read, appreciate, and evaluate intelligently the great masterpieces of literature.

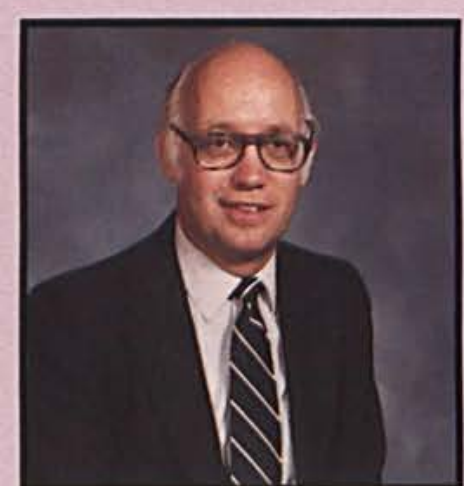

Raymond Bartholomew, Ph.D. Professor of English

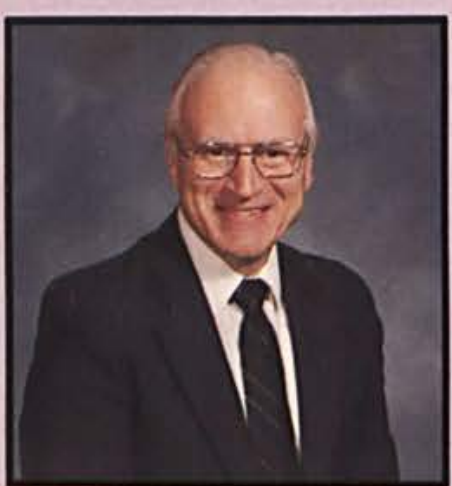

Edward Greenwood, D.A. Professor of English

Director of Summer School

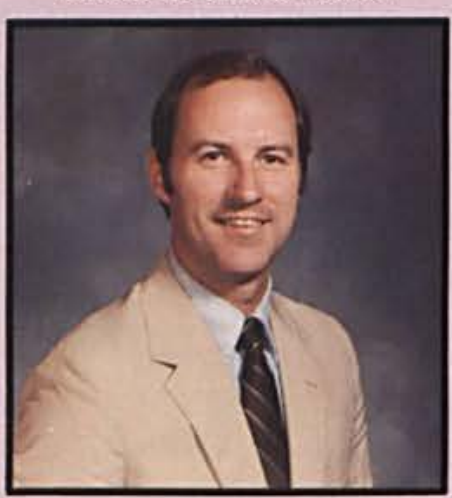

Mark Larson, M.A.

Assistant Professor of Foreign Language

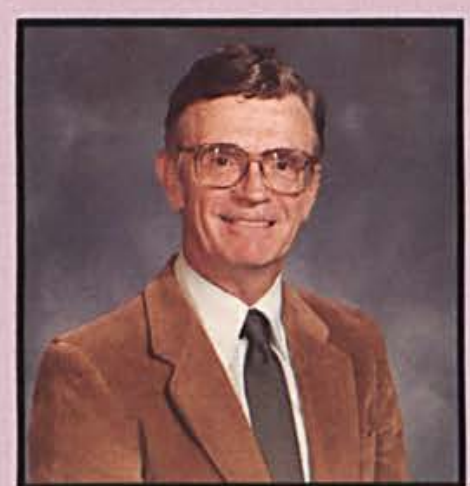

Harmon Bergen, M.A Associate Professor of Foreign Language

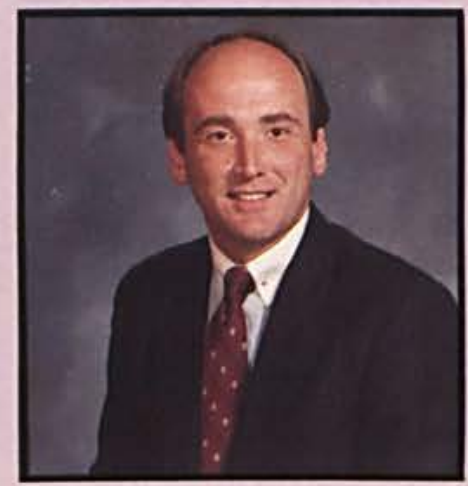

Ronald Grosh, Ph.D. Associate Professor of English

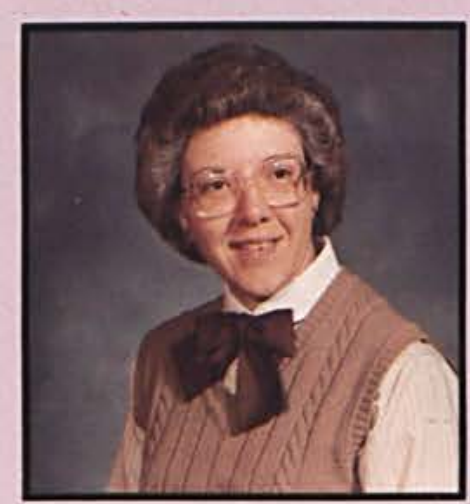

Barbara Loach, M.A. Assistant Professor of Foreign Language

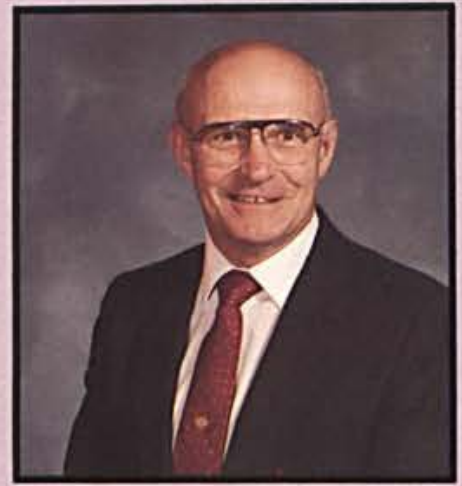

Edward Spencer, M.A.

$$
\text { Chairman }
$$

Professor of English

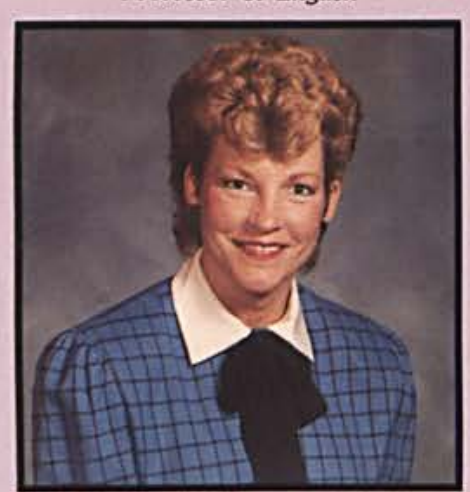

Pat Landers Dixon, M.Ed.

Associate Professor of English

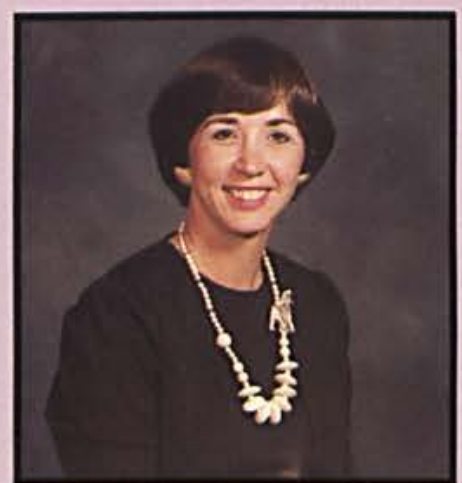

Sandra Harner, M.A. Assistant Professor of English 

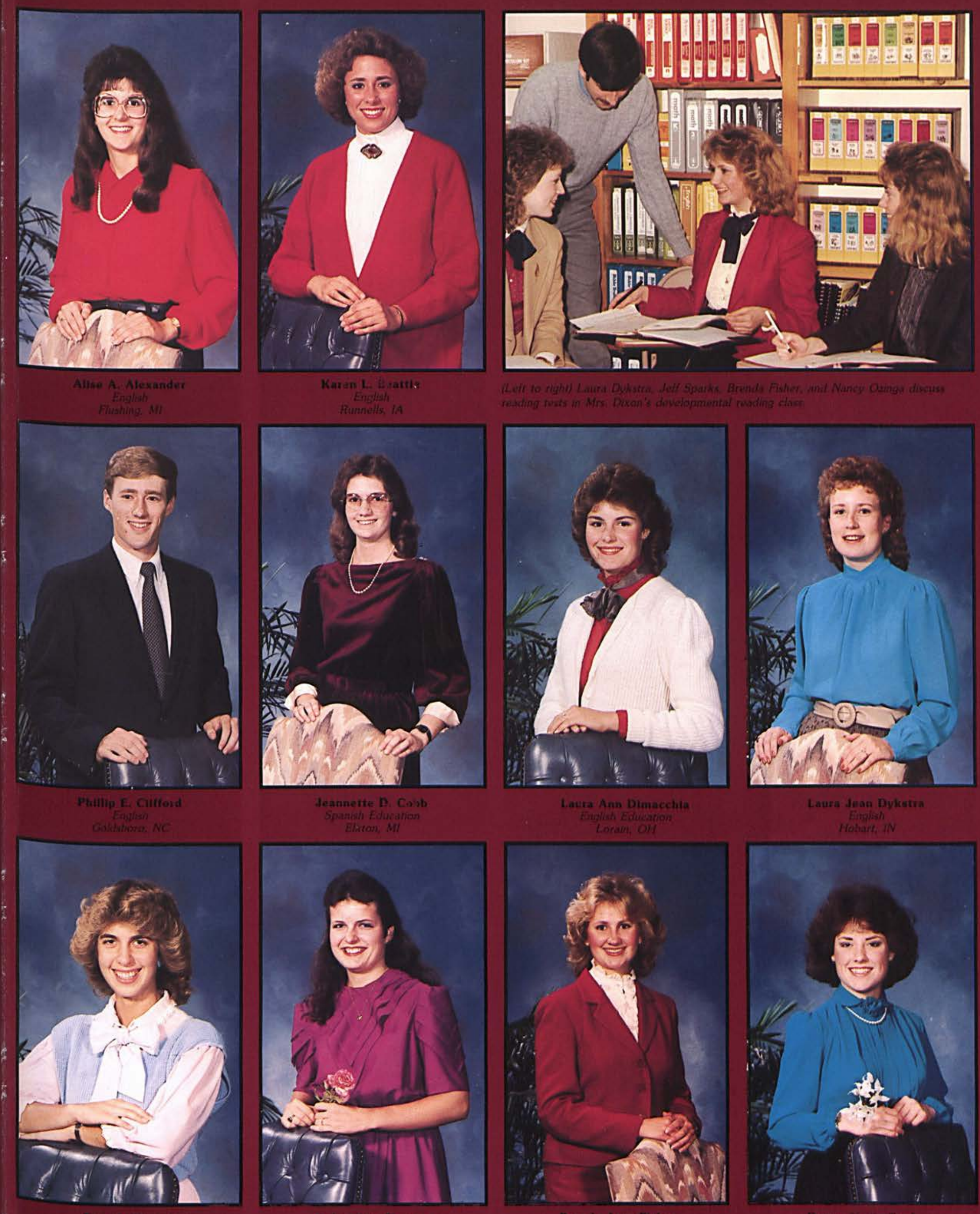


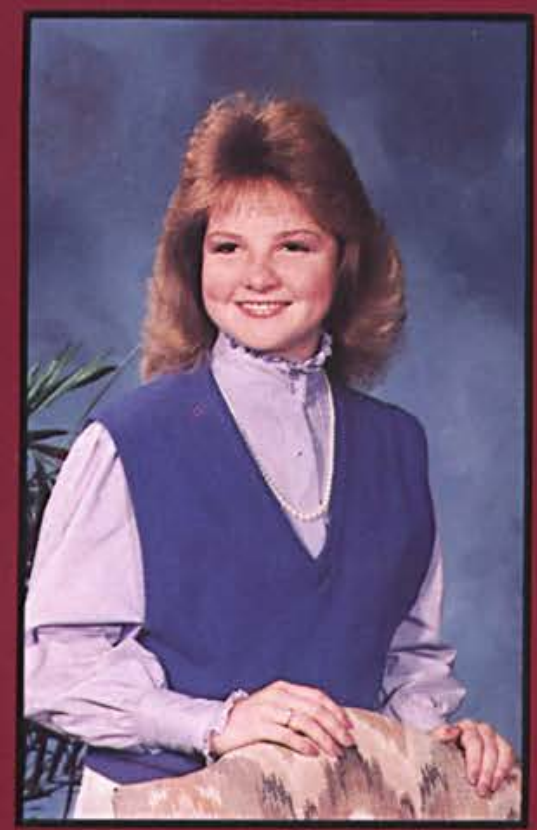

Susan Lynn Greetham

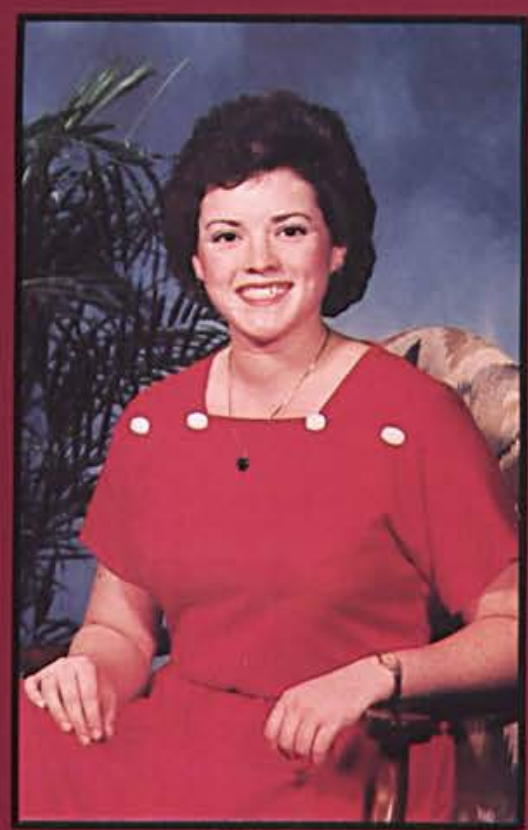

Crystal Ann Hancock

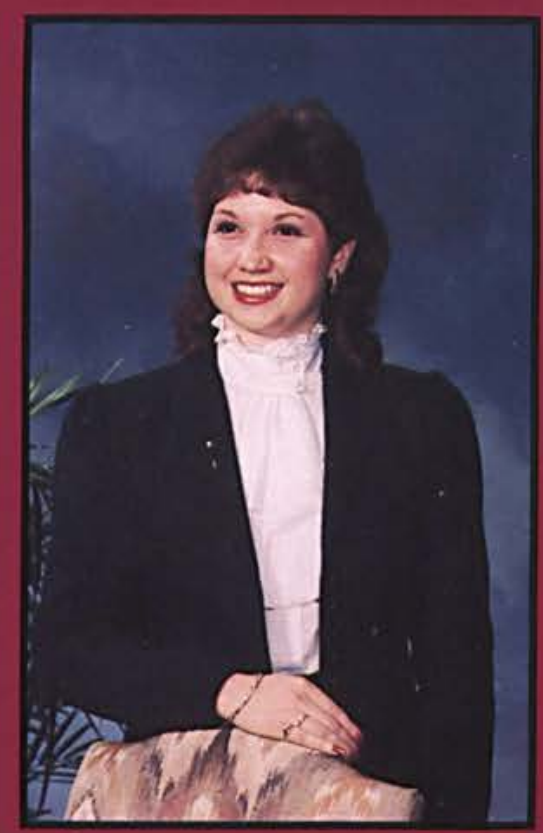

Christina J. Hart

\section{Learning For Life}

$\mathbf{L}$ aura Dykstra considers her choice of an English major to have been a wise decision for several reasons. First, the skills that she has learned in the study of language and literature will carry over into other areas of her life, skills such as the ability to think critically and to communicate effectively. Her study has also helped her to be more effective in her service to God. For example, Laura believes that through the study of literature, she has become more aware of the glory of God's creation and the needs of sinful men. Since God has shown his common grace to all men, even the writings of unbelievers contain much truth and beauty which Christians may enjoy as a good gift from God. The study of literature may also increase a Christian's sensitivity to others. As Professor Leland Ryken has said in Triumphs of the Imagination, one learns to see through the eyes of others as he or she peers through the "window to the world" which literature provides.

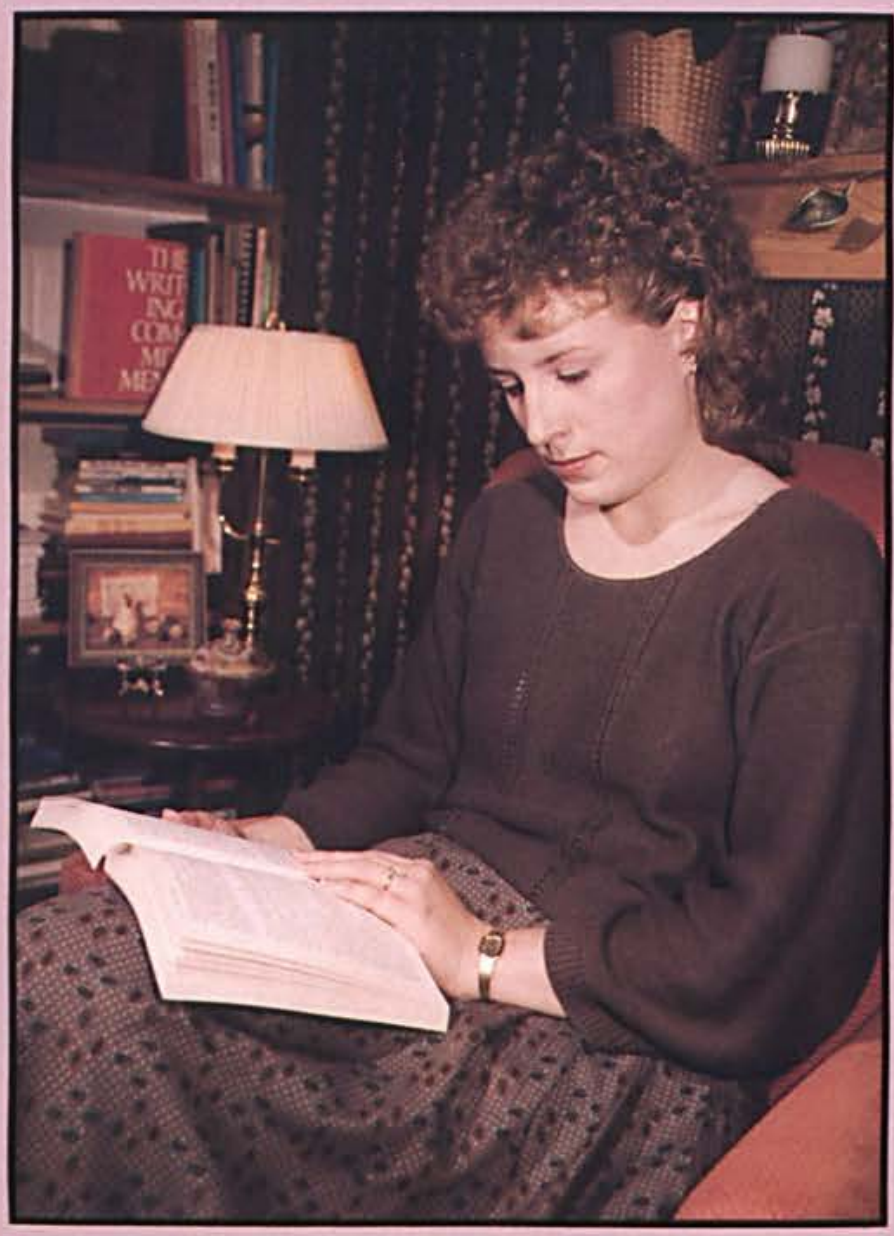

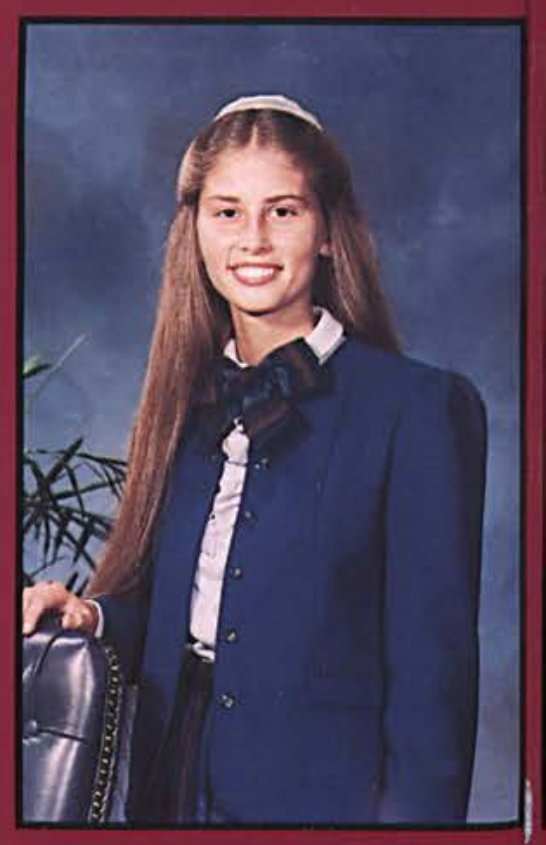

Suzanne Marie Herr

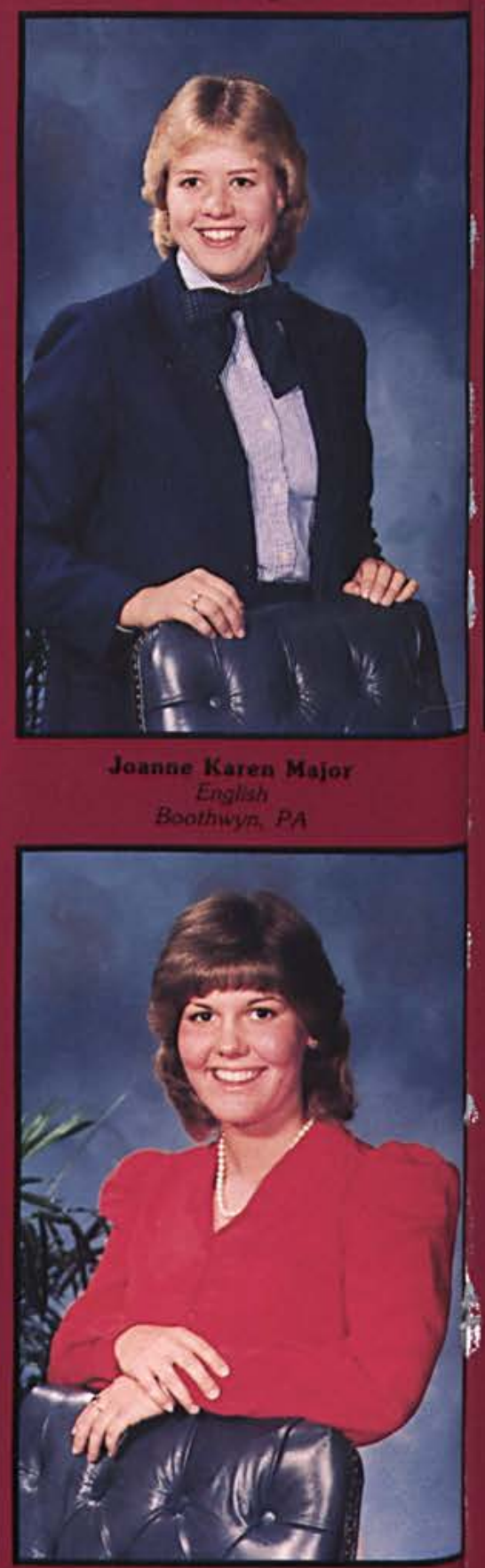

Panicia H. Marthugl 


\section{Teaching stewards} to effectively use and develop their God given talent, be it vocal or instrumental, to perform, teach, value, and understand the powerful gift of music.

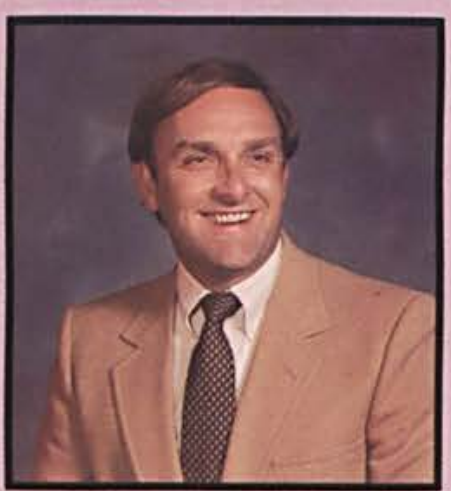

Lyle Anderson, Ph.D. Professor of Vocal Music

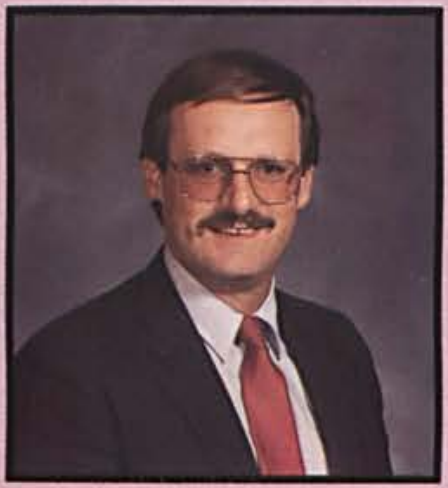

Michael DiCuirci, M.M. Assistant Professor of Instrumental Music

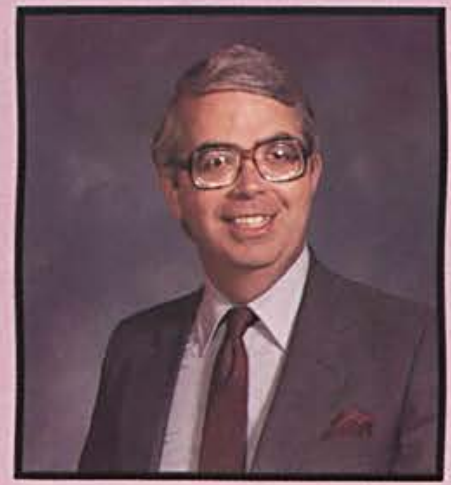

David Matson, Ph.D.

Professor of Music

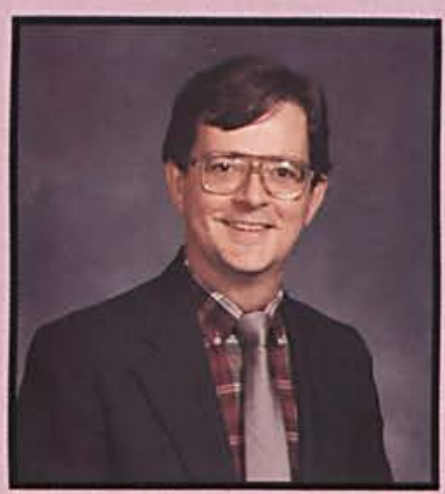

Charles Clevenger, Ph.D. Assistant Professor of Piano

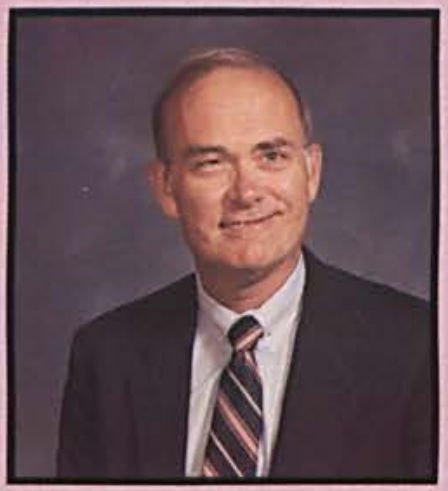

Charles Ellington, Ph.D. Professor of Vocal Music

Not pictured

Philip McClure, M.M. Assistant Professor of Piano

Charles Pagnard, M.M. Assistant Professor of Instrumental Music

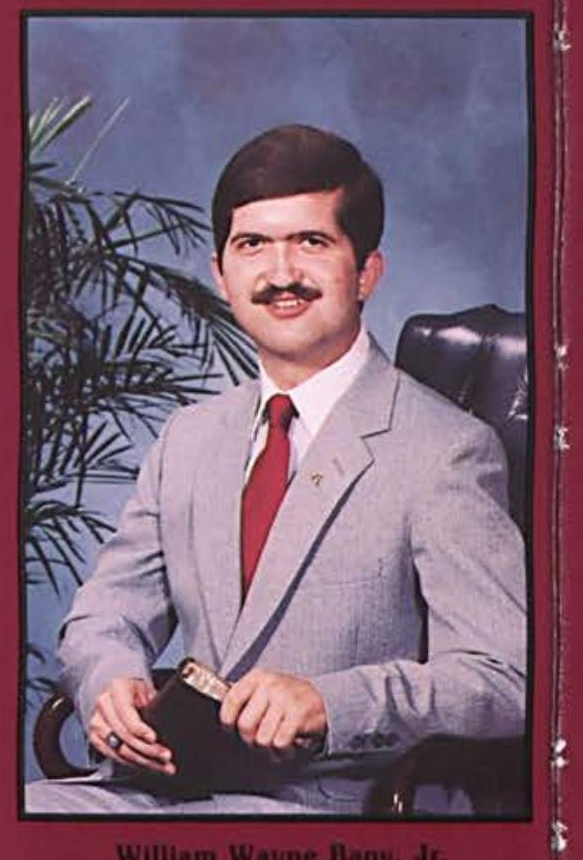

Willam Wayne Bany. Jy

(5)

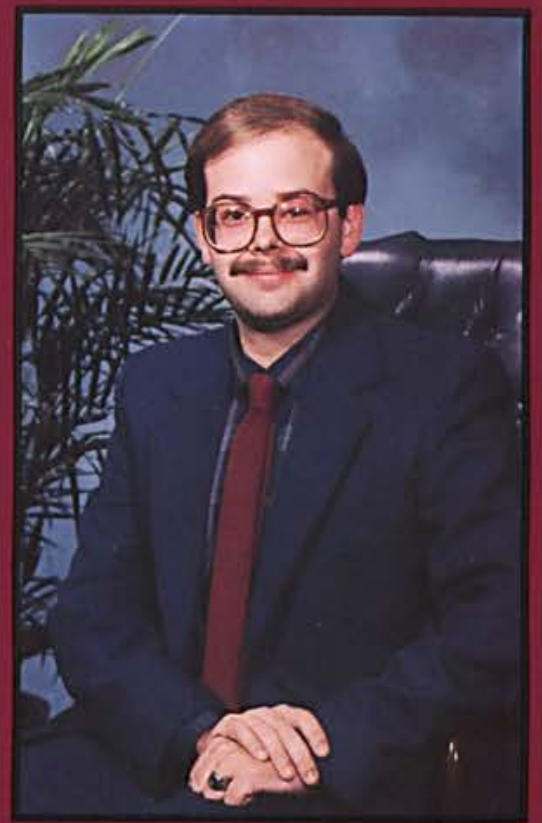

?

Warren K. Brown

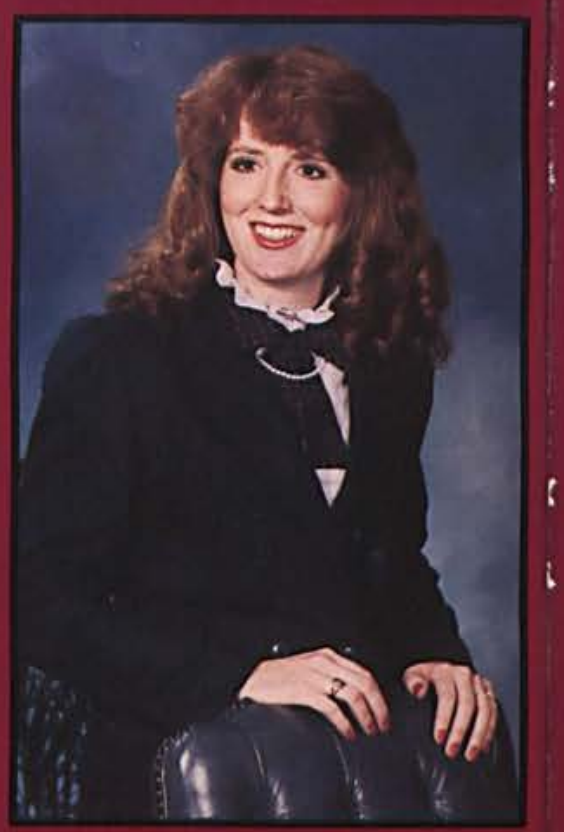

Soycelyn Kenee Burr 


\section{Teaching stewards}

accountability in the physical, emotional, intellectual, social, and spiritual dimensions of life so they, in turn, can minister to patients and families entrusted to their care.

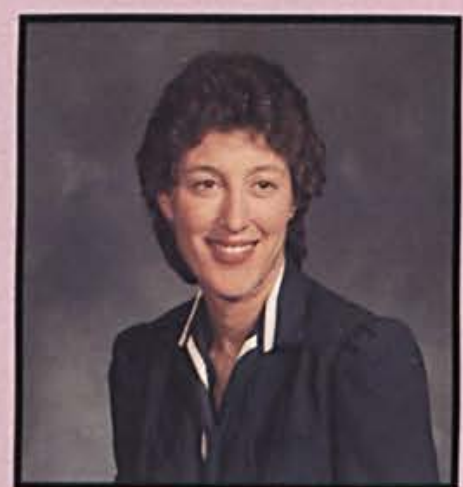

Lois Baker, M.S.N. Assistant Professor of Nursing

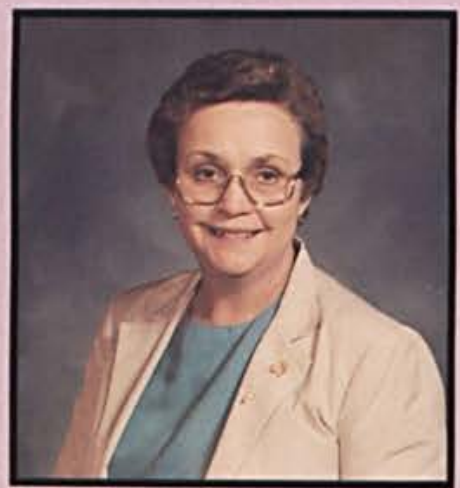

Charlotte Crawford, M.S.N. Assistant Professor of Nursing

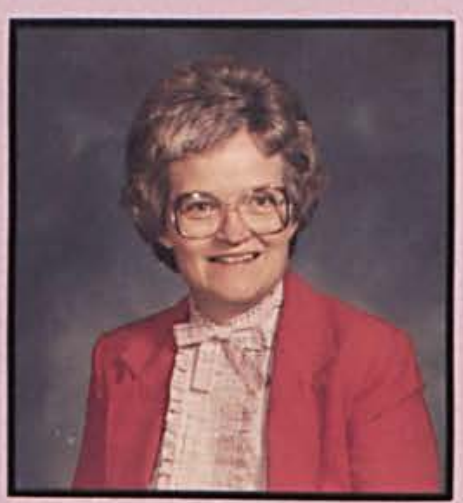

Ruth Slocum, M.S Assistant Professor of Nursing

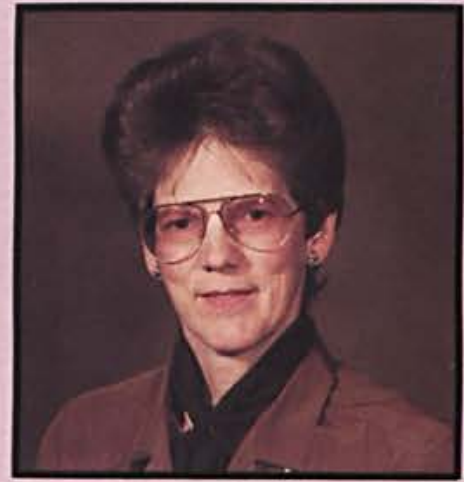

Irene Alyn, Ph.D. Chairman

Professor of Nursing

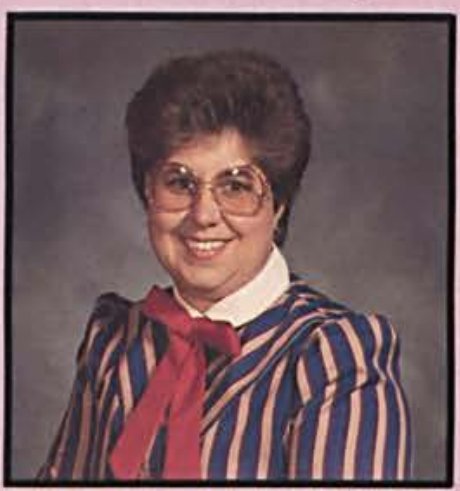

Janet Bauer, M.S. Assistant Professor of Nursing

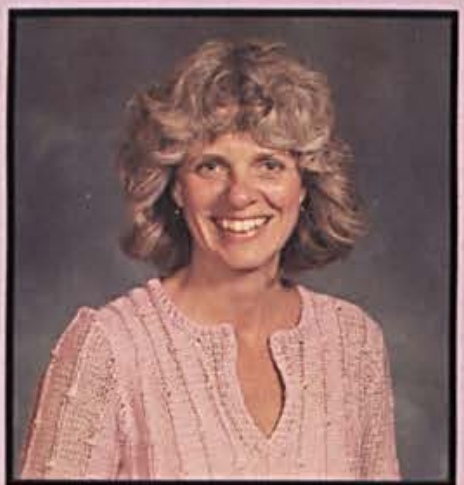

Maureen Salladay, M.P.H. Assistant Professor of Nursing

Not pictured:

Mark Klimek, M.S.N. Assistant Professor of Nursing
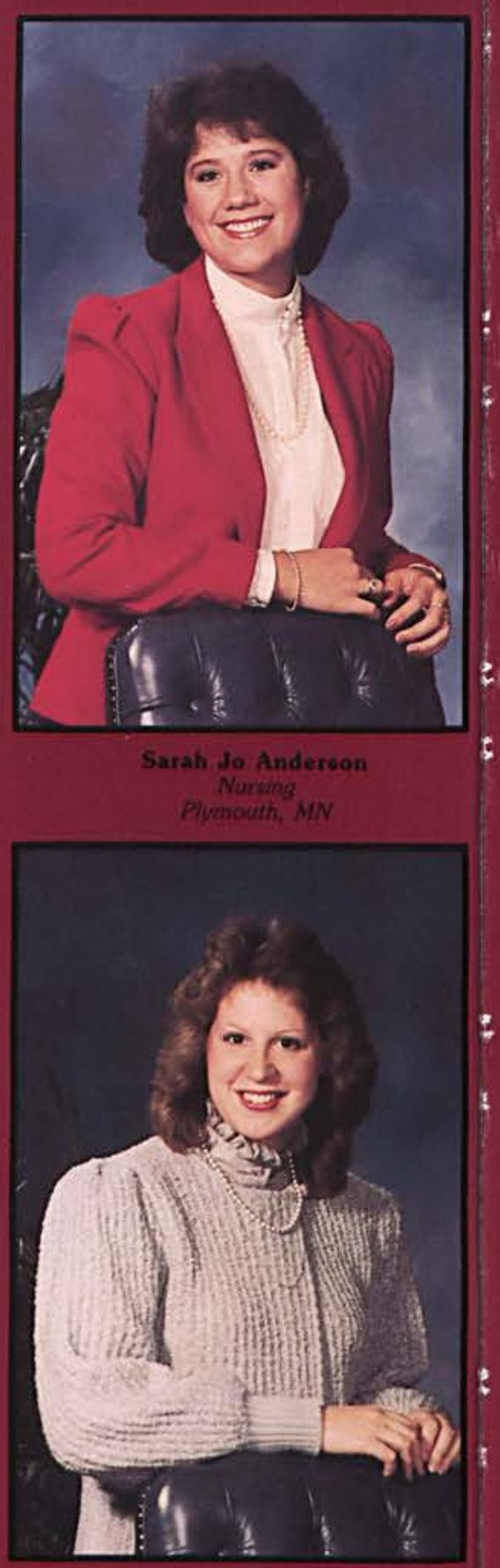

Colleen Boyer

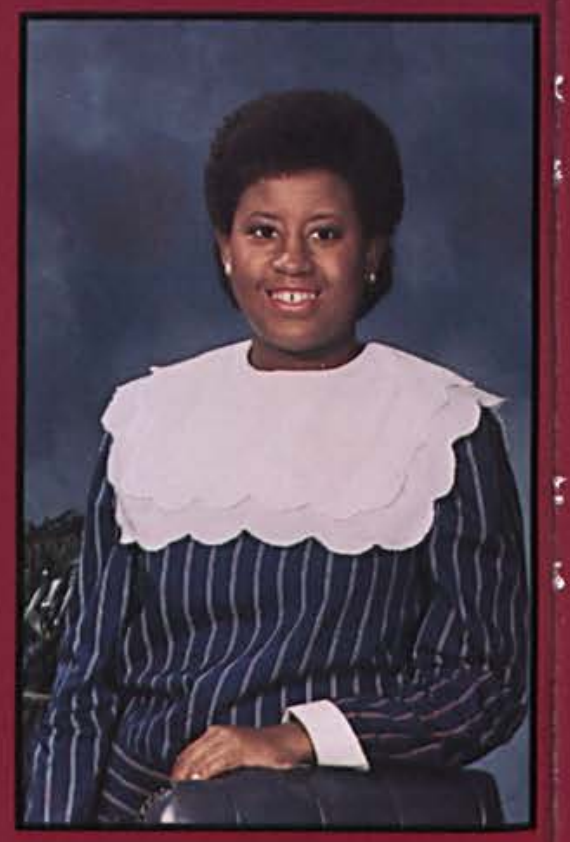

Shelley Lyna Browae 

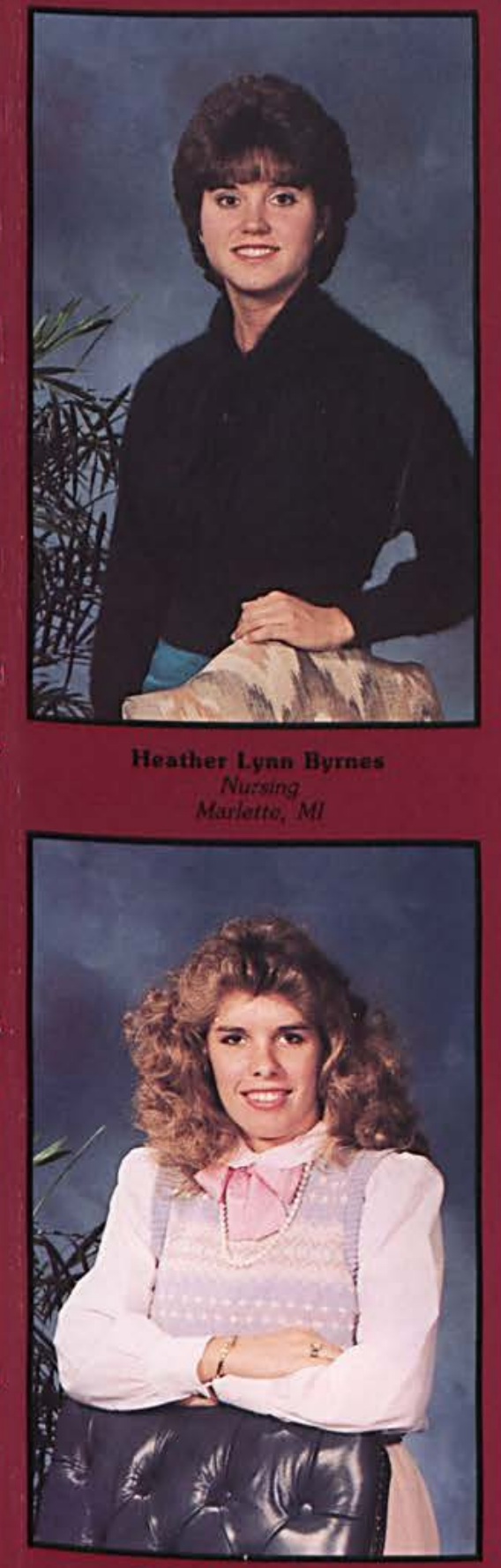

Deborah Sue Deete

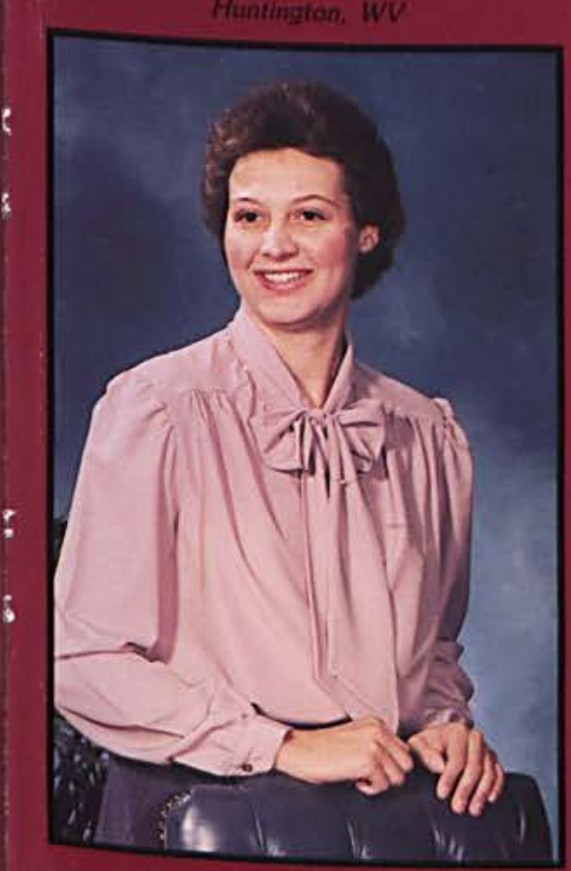

Karen Y. Headdings

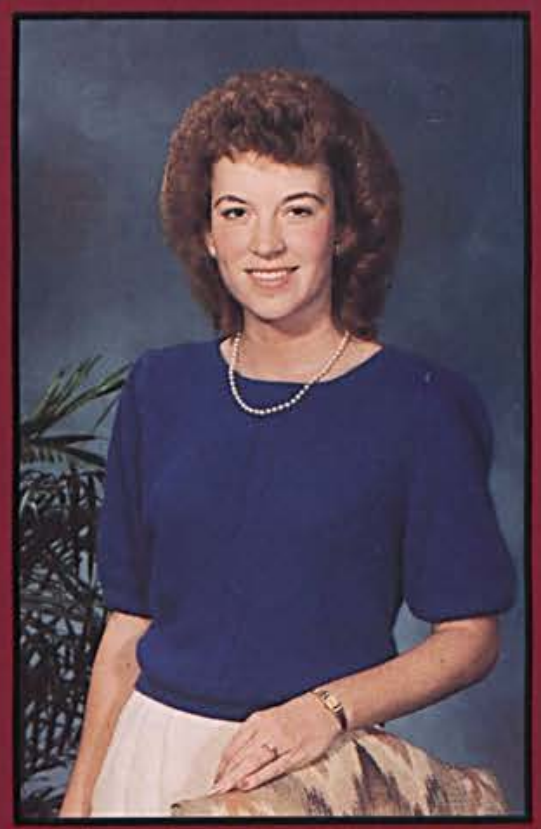

Sandra S. Carpenter

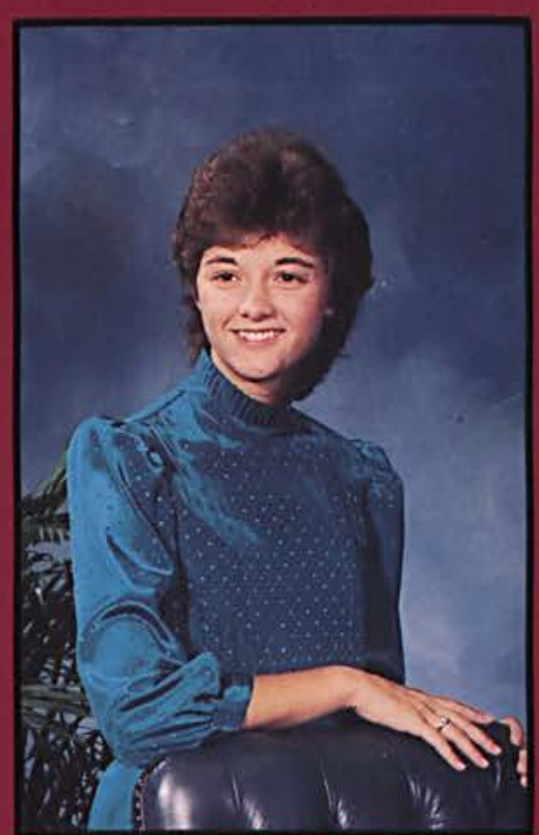

Jill Rae Gibson

Grand Rapids. M

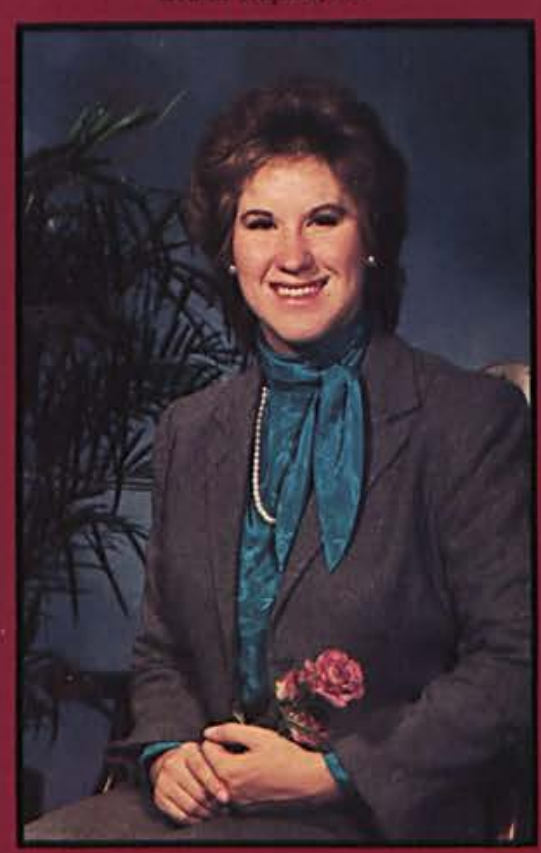

Kelley Lee Helman

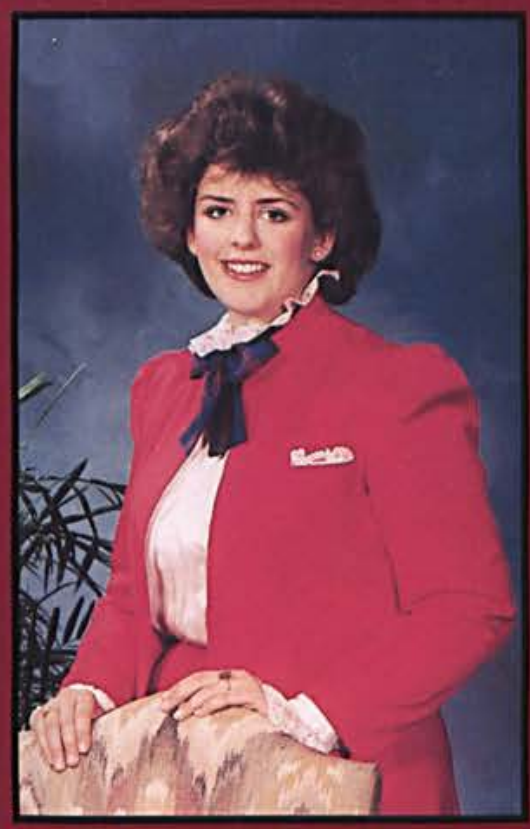

Meredith B, Collins
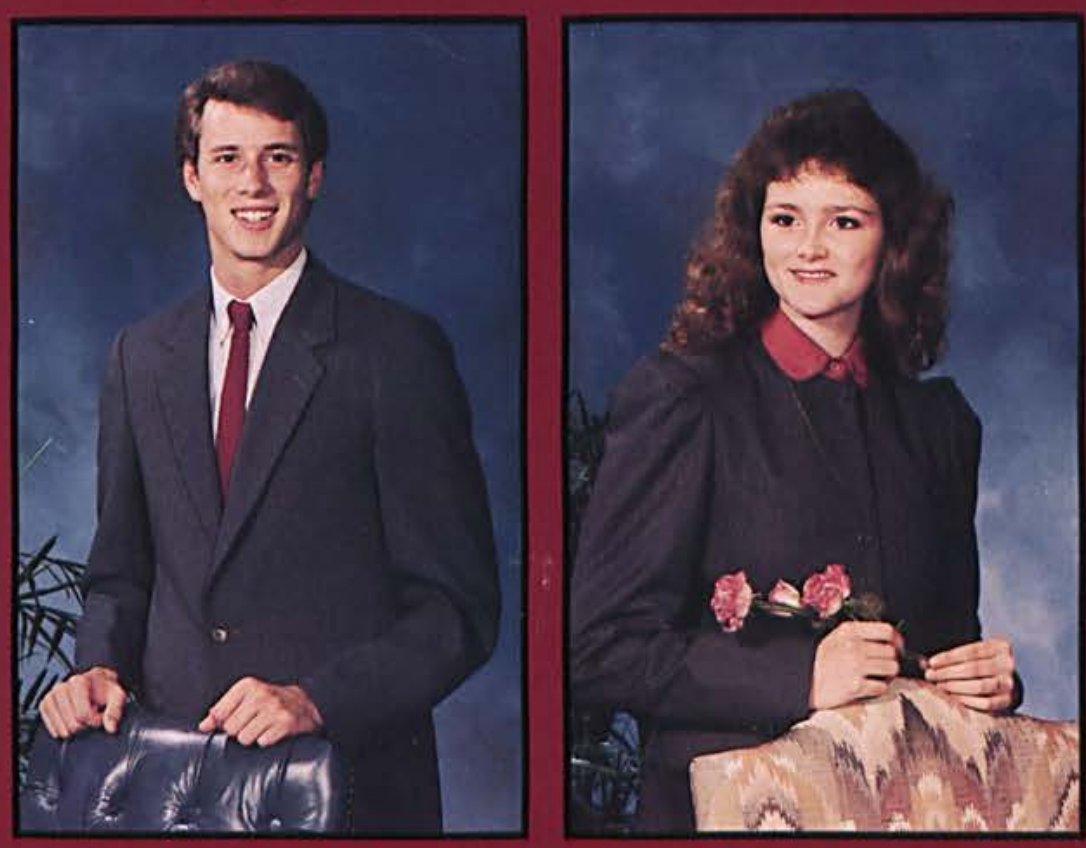

Michelle Ann Grasley

Fenton, MI

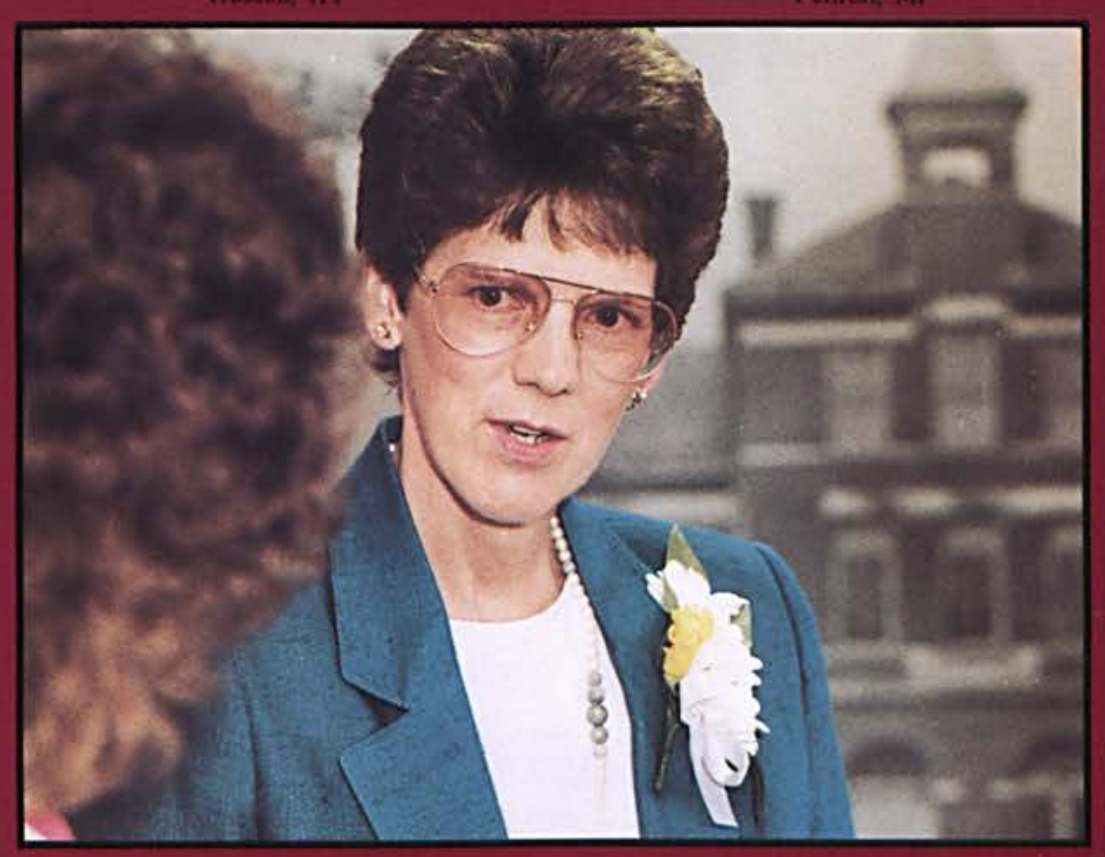



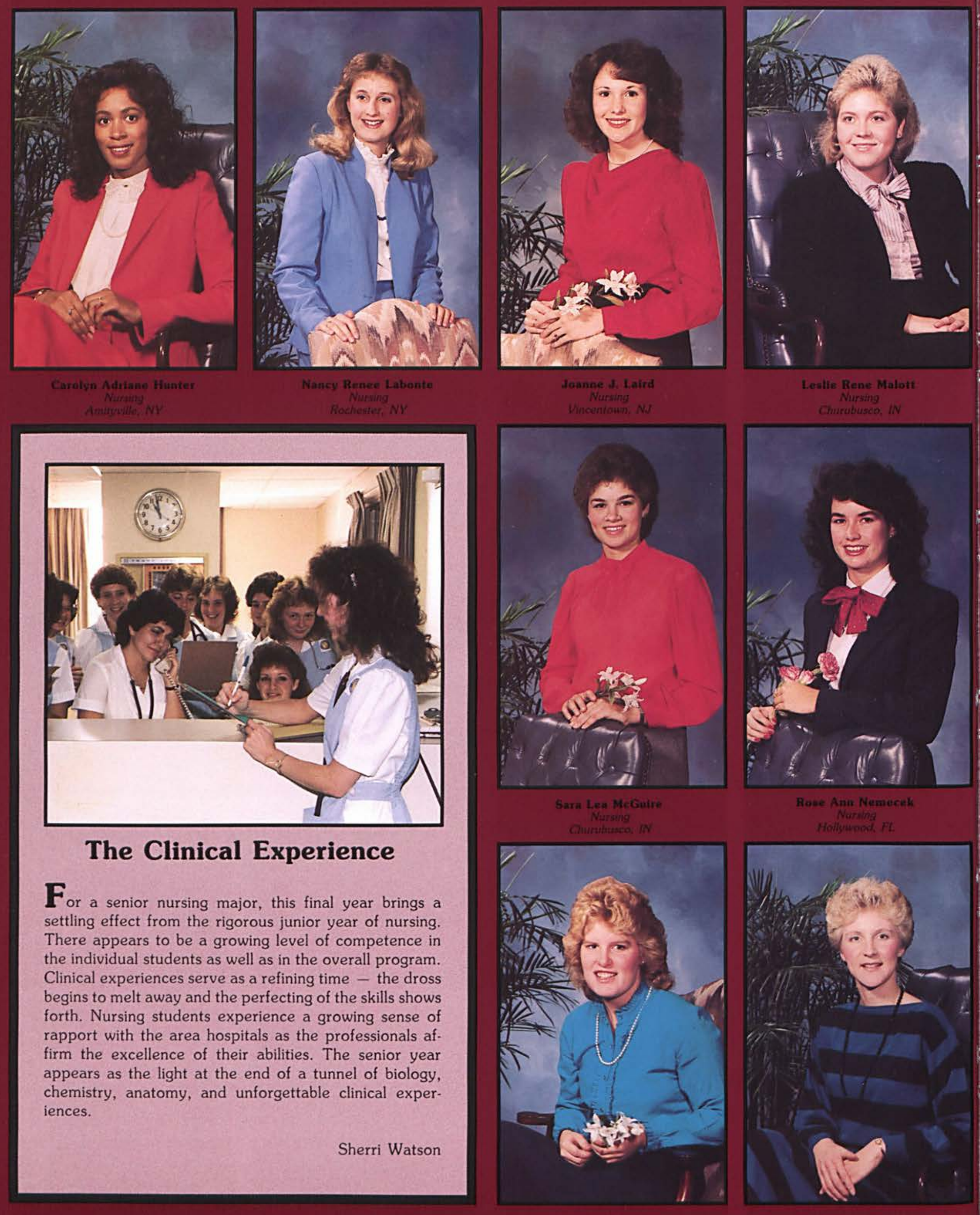

For a senior nursing major, this final year brings a settling effect from the rigorous junior year of nursing. There appears to be a growing level of competence in the individual students as well as in the overall program. Clinical experiences serve as a refining time - the dross begins to melt away and the perfecting of the skills shows forth. Nursing students experience a growing sense of rapport with the area hospitals as the professionals affirm the excellence of their abilities. The senior year appears as the light at the end of a tunnel of biology, chemistry, anatomy, and unforgettable clinical experiences.

Sherri Watson

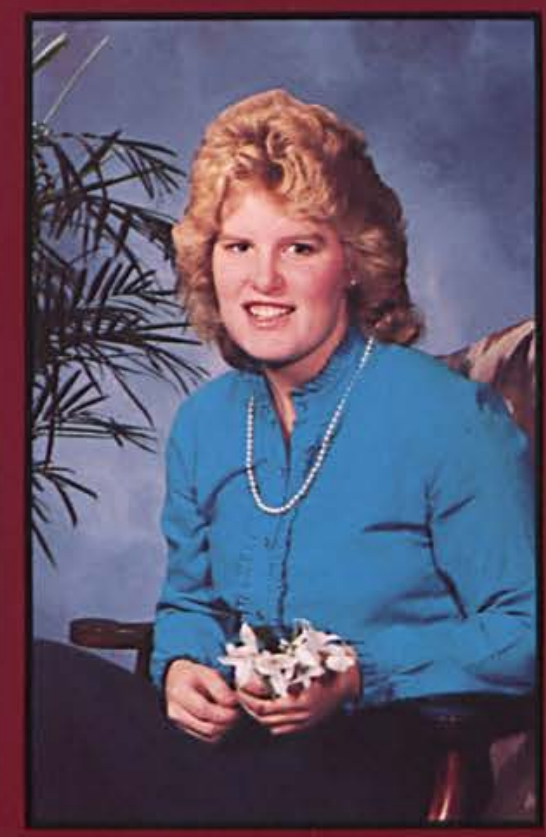



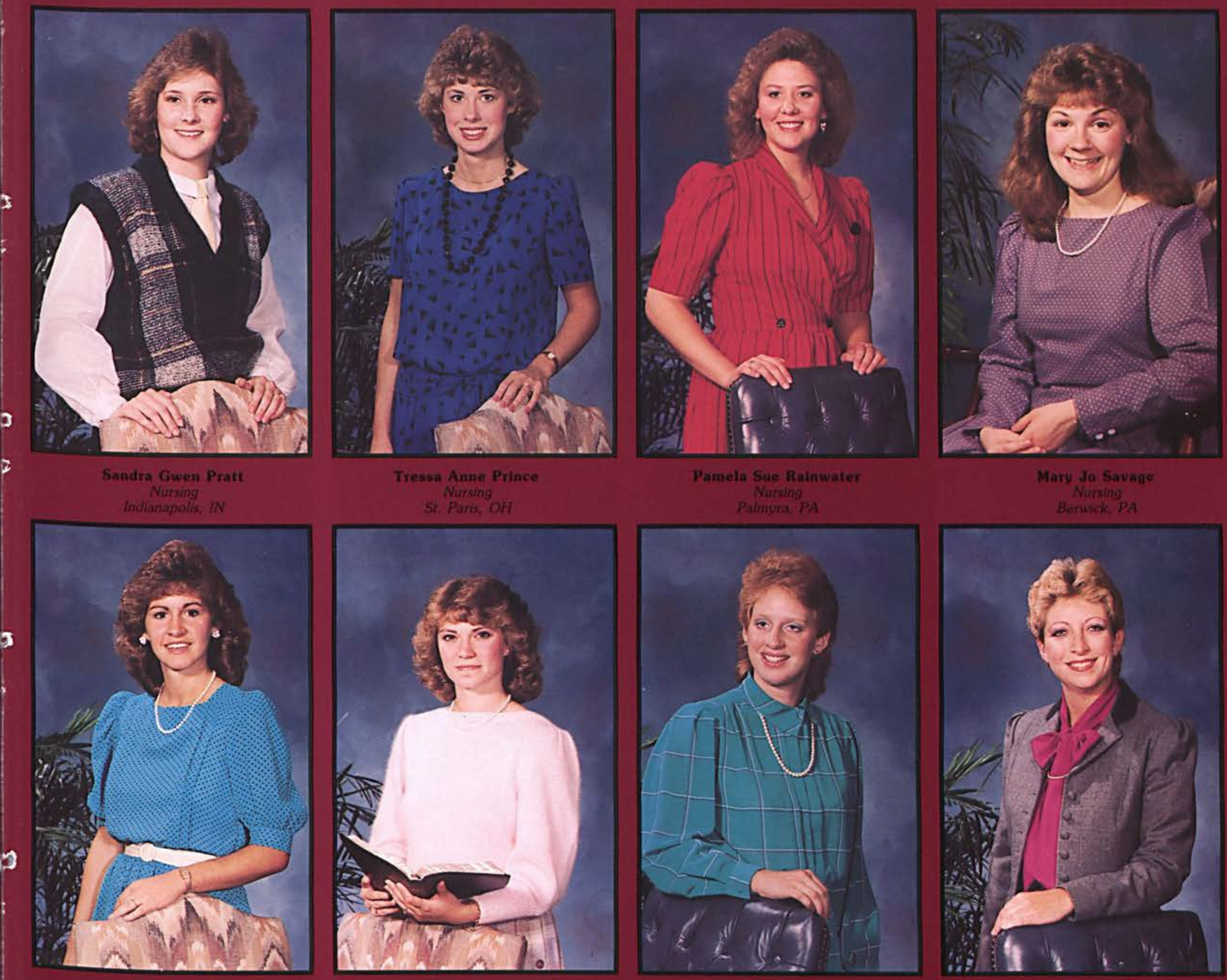

Kelly Stue Simth
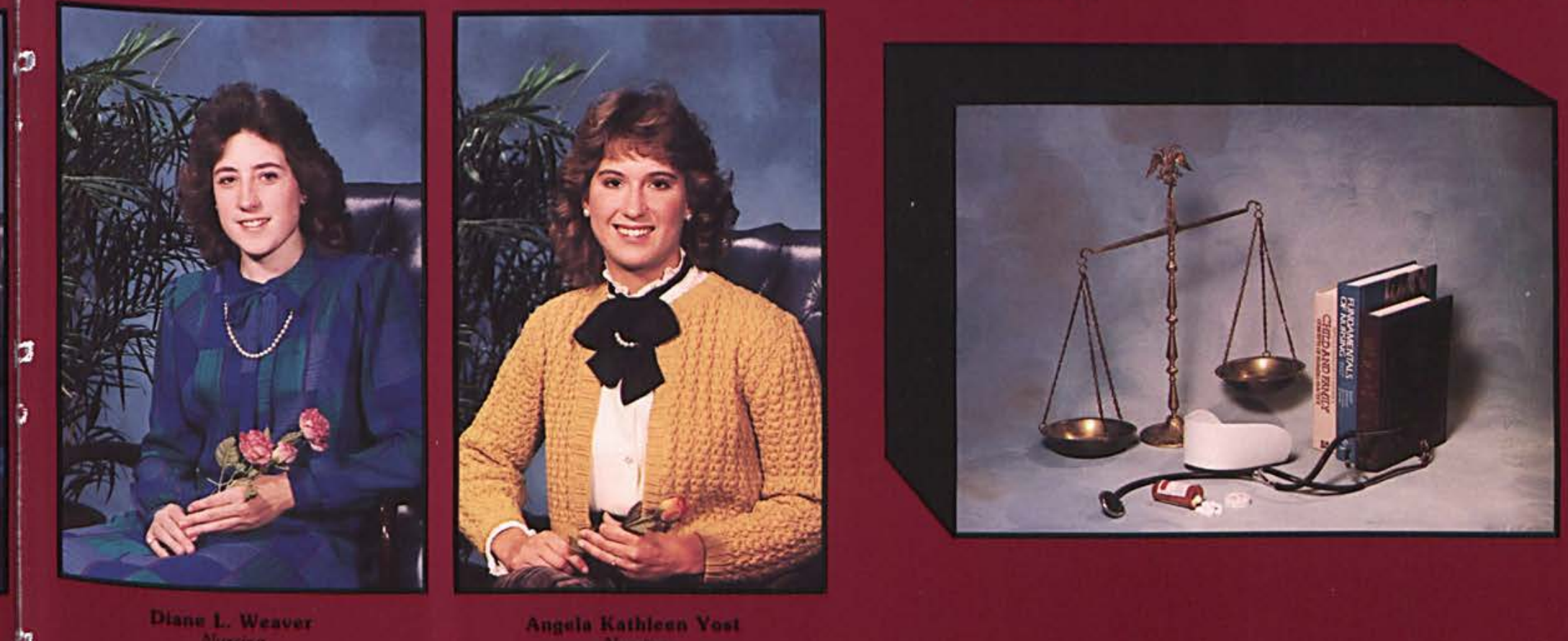
T eaching stewards to "Love the Lord your God with all your soul and with all your strength and with all your mind," and "Love your neighbor as yourself."
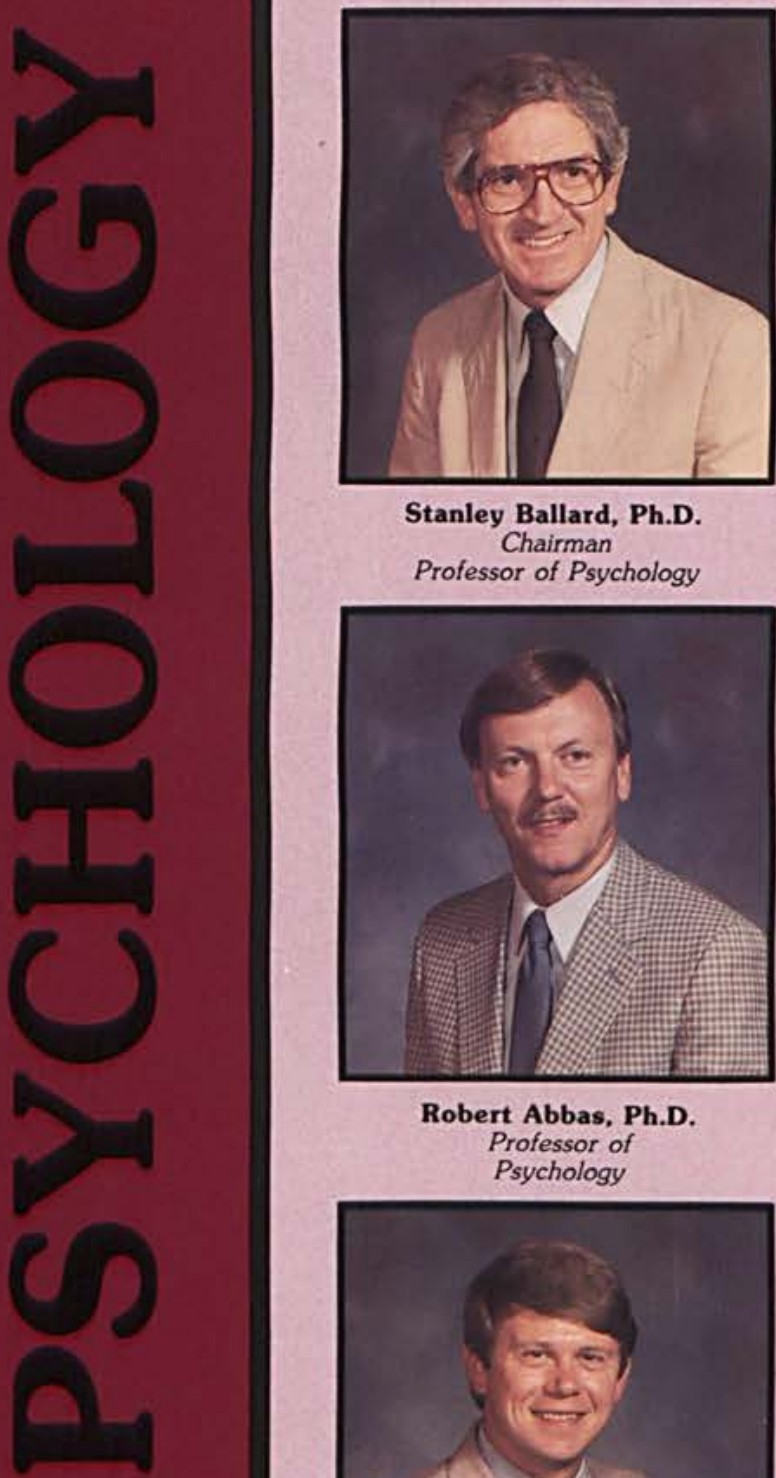

Stanley Ballard, Ph.D.

Professor of Psychology

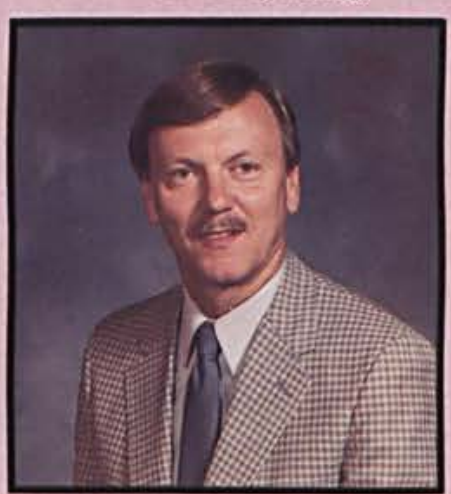

Robert Abbas, Ph.D. Professor of
Psychology

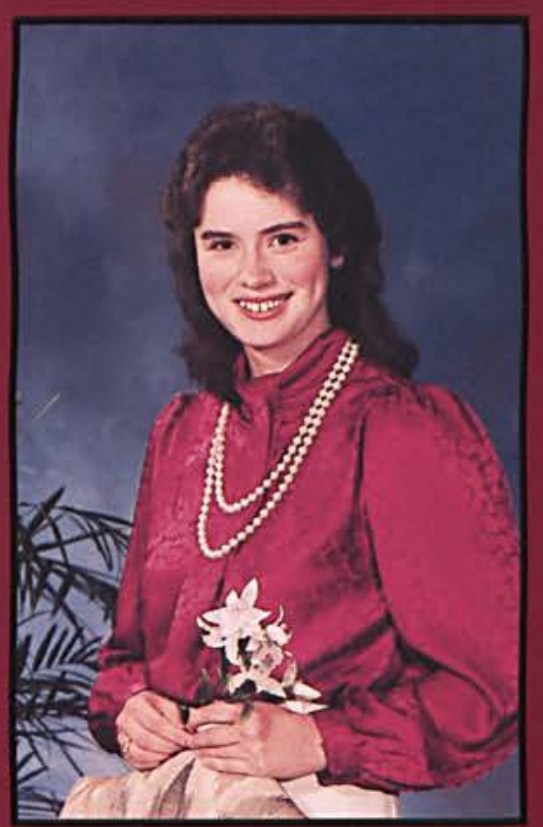

Chairman

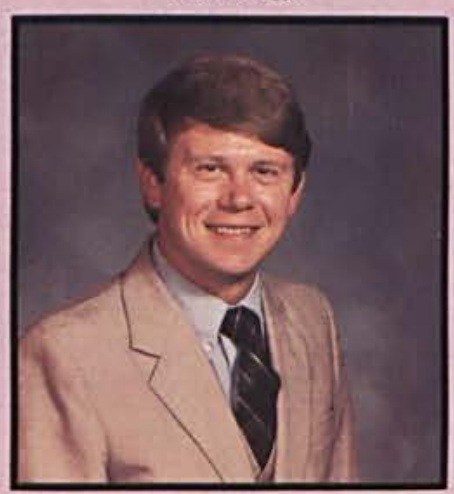

Charles Dolph, Ph.D. Assistant Professor of Psychology

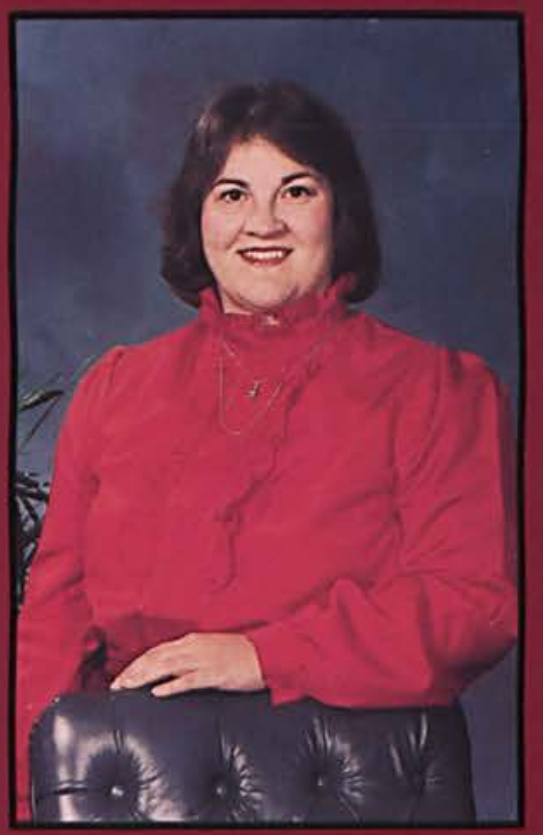

Ann Bratka
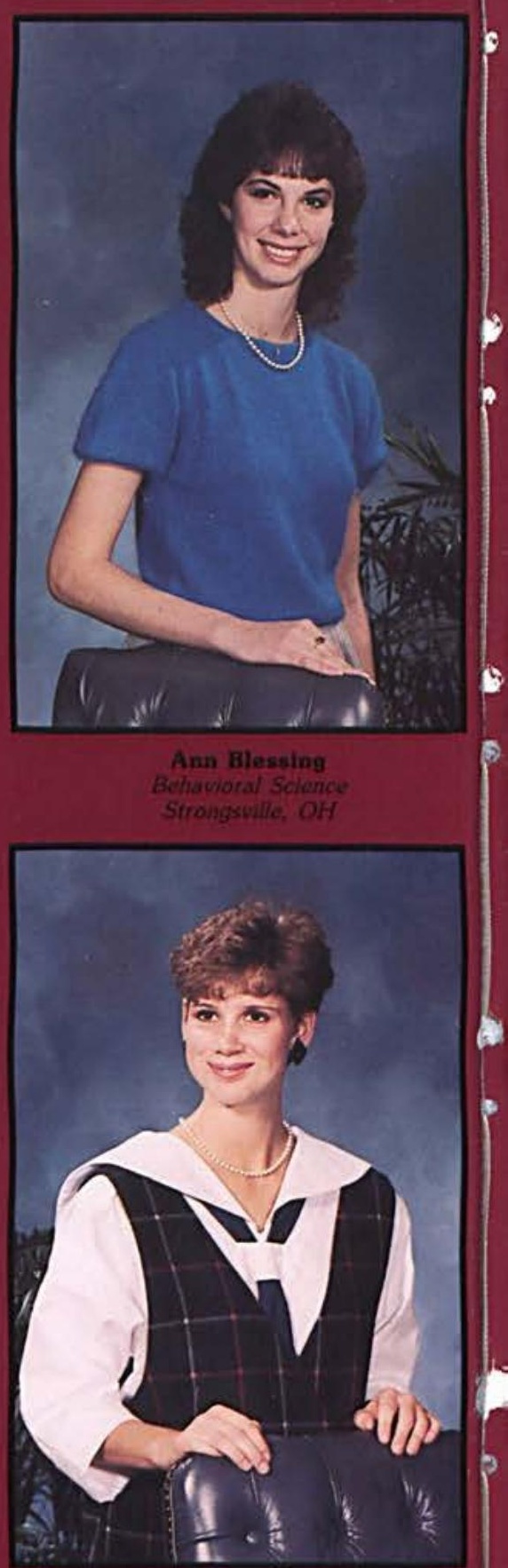

Susan Bea Briggs
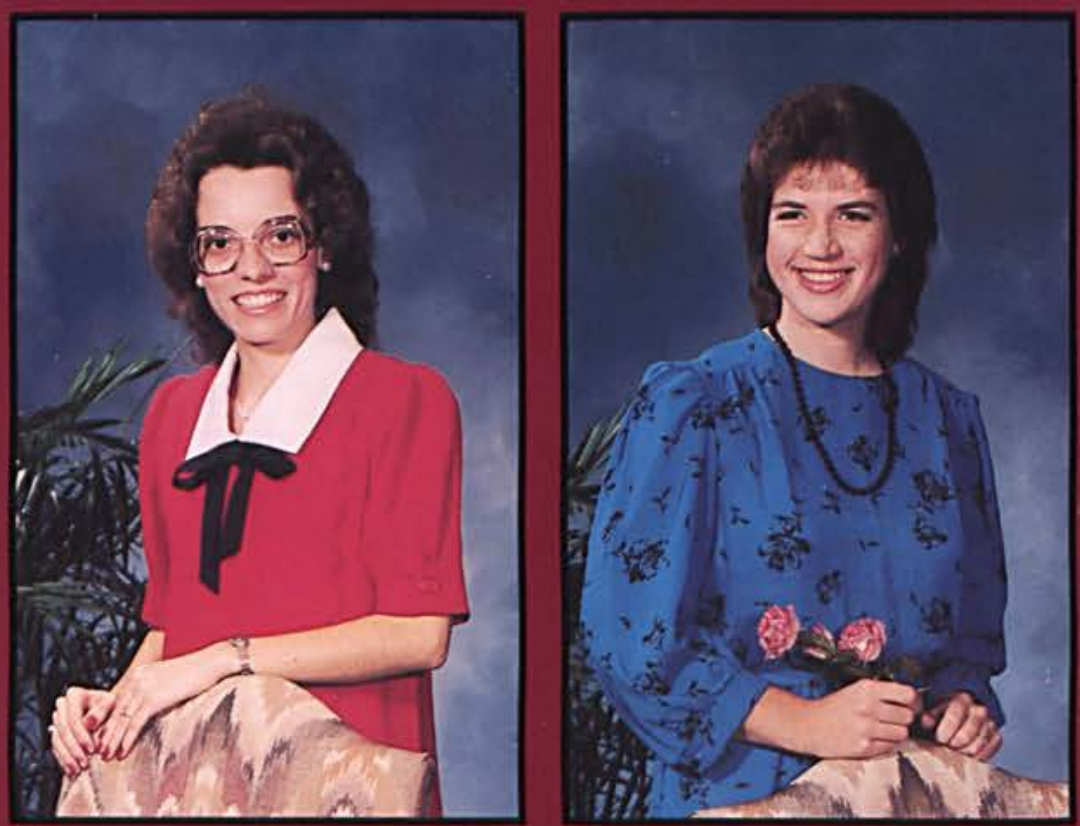


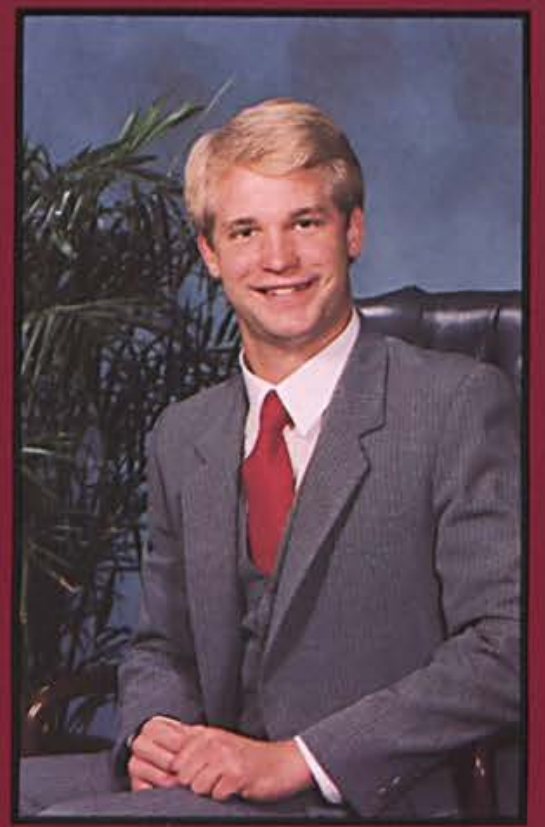

Stu Ramme:

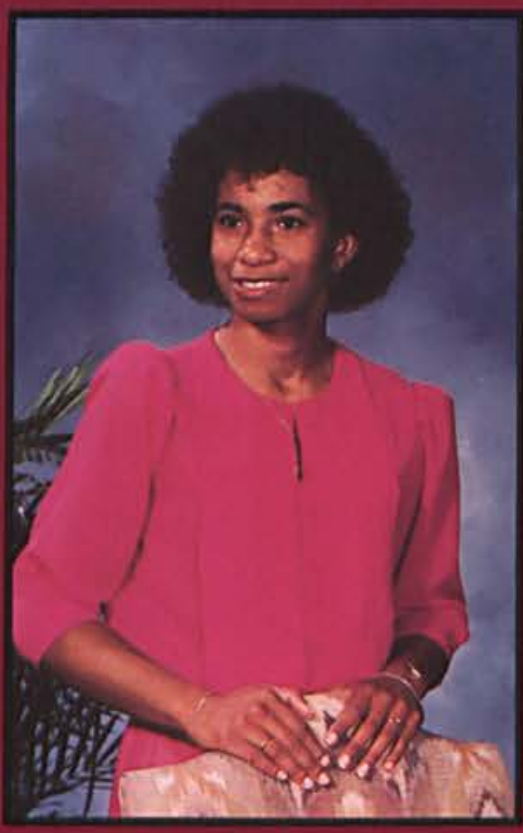

Denise Charlene Ross

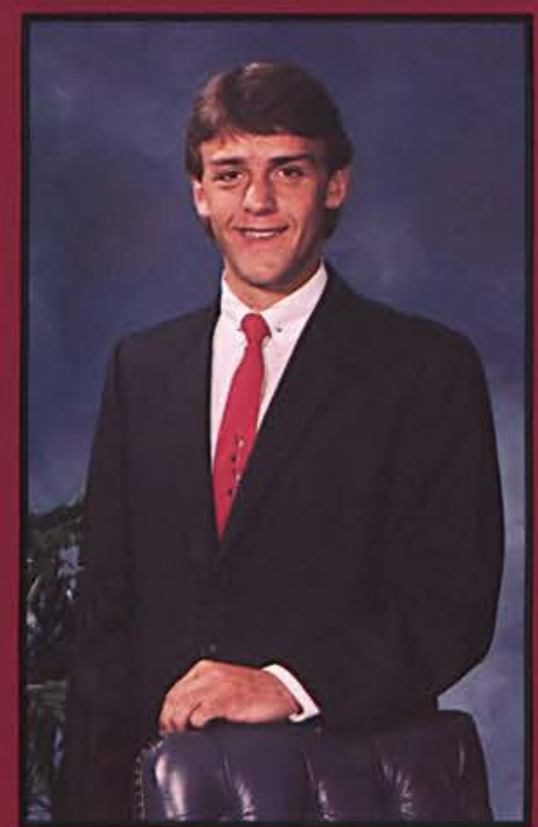

Jonathan Charles fieid

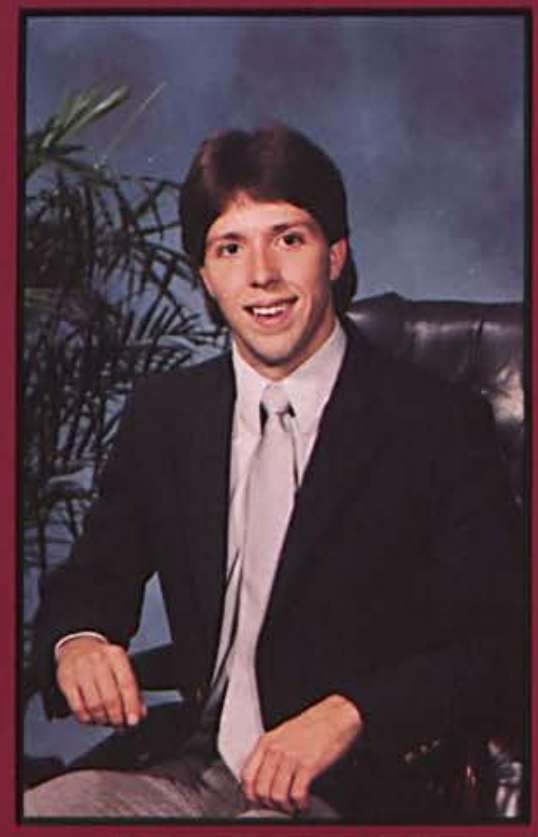

Rodaey Jemnimgs Smith

\section{Developing the Whole Person}

$\mathbf{T}$ realizes that far more than academic achievement is necessary for becoming a whole person. God's glory demands that every aspect of our being be developed. Students in an academic environment can easily forget that there is more to life than acquiring intellectual knowledge.

The Psychology Department encourages students to develop spiritually, emotionally, and communicatively. The best sacrifice we can offer to God is ourself, not merely our possessions. God wants our entire being and it is with our entire being that we minister. Devotions, dating, internships, work, organizational involvements, and ministry all play an important part in developing students who love God and his marvelously complex creations.
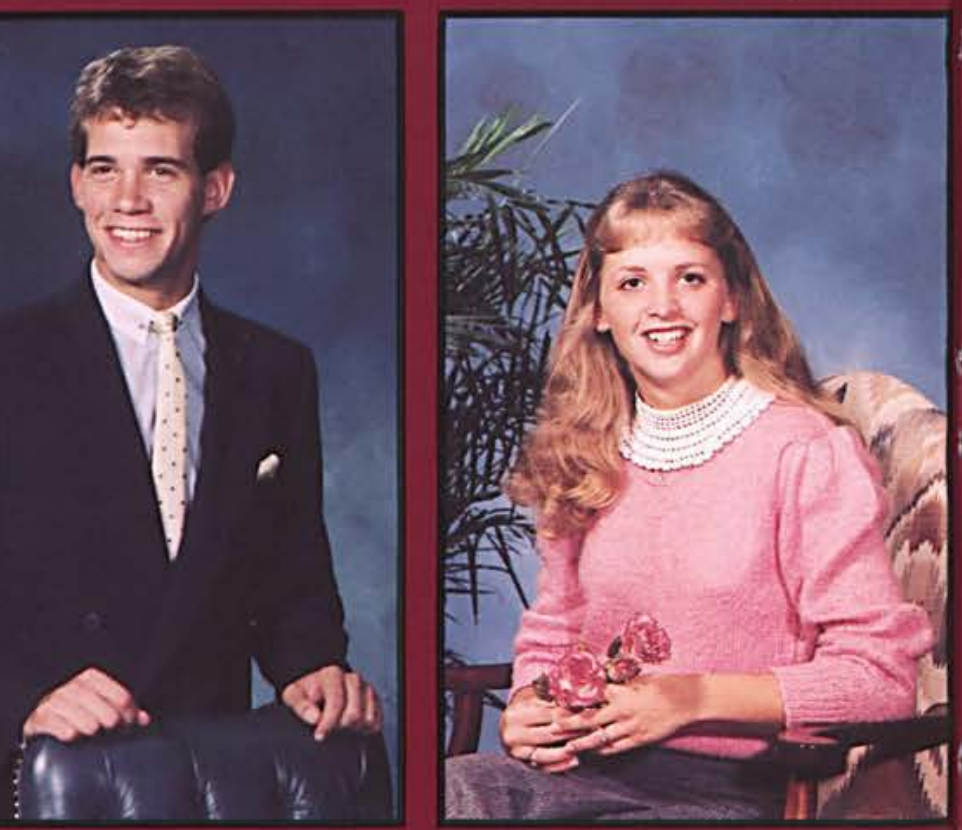

Steve Craig Rockwell

Carole Jean Roland

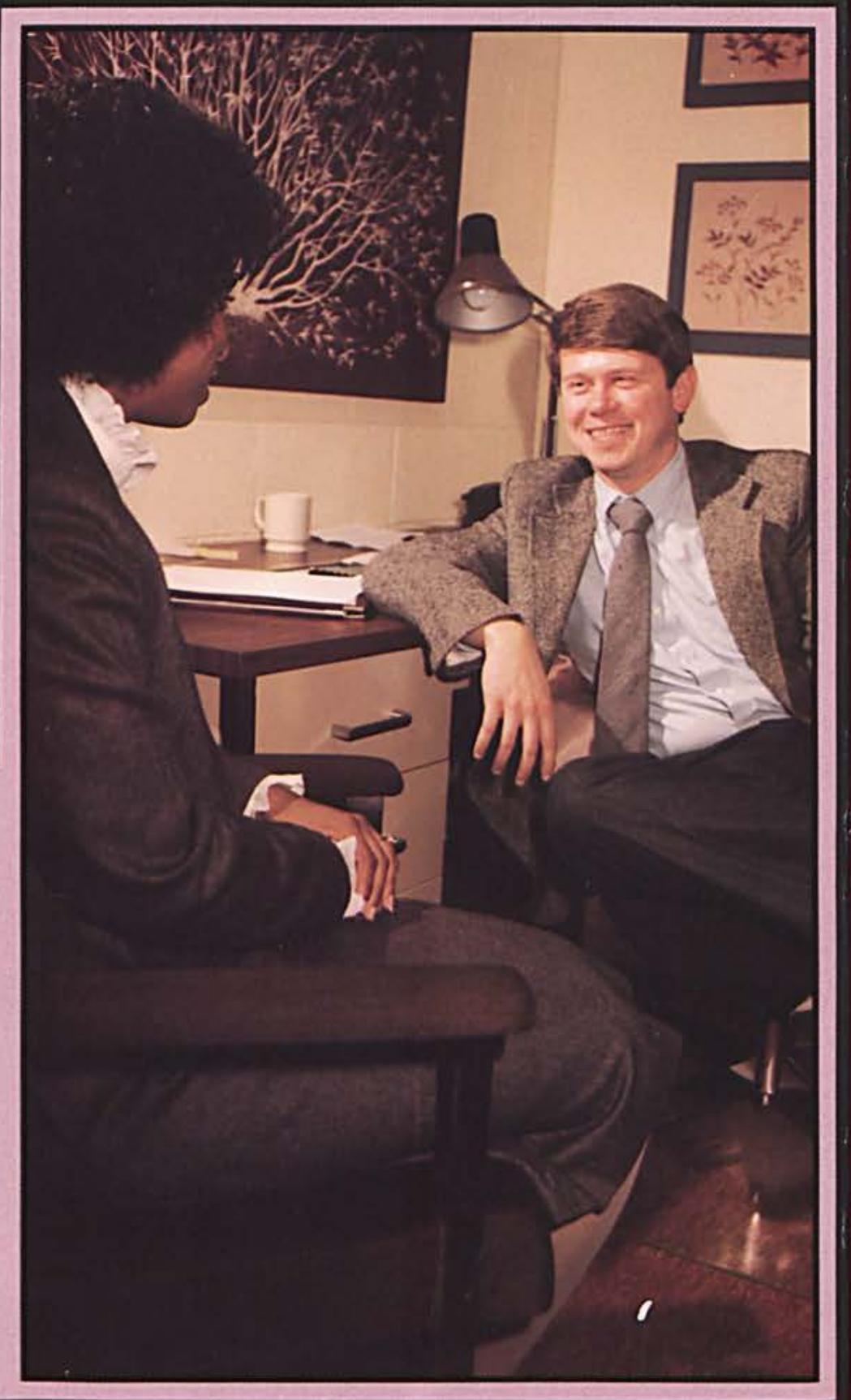


Teaching stewards to exercise responsible stewardship of the creation through a proper understanding of the processes and principles of the sciences in today's culture.

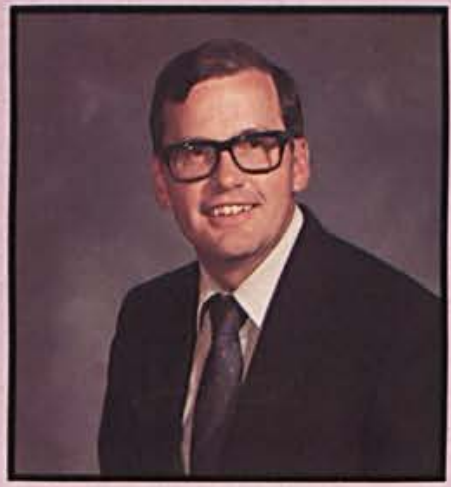

Edwin Braithwaite, Ph.D. Assistant Professor of Mathematics

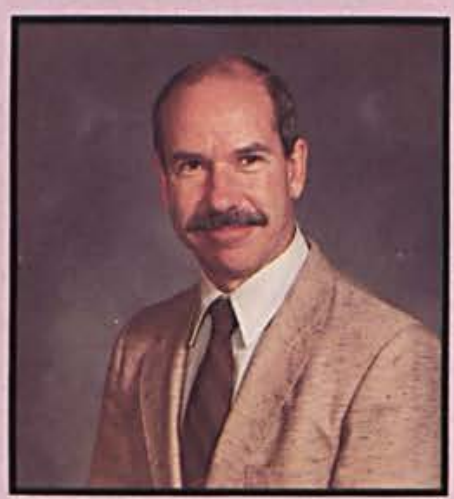

Larry Helmick, Ph.D. Professor of Chemistry

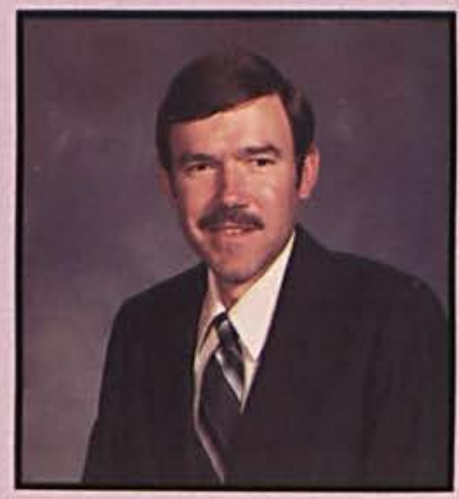

John Silvius, Ph.D.

Associate Professor of Biological Science

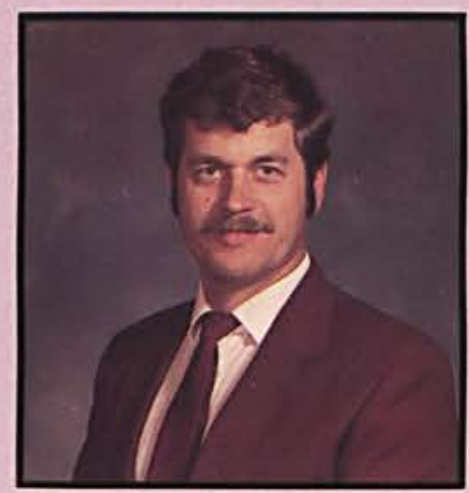

Leroy Eimers, Ph.D. Associate Professor of Physics \& Mathematics

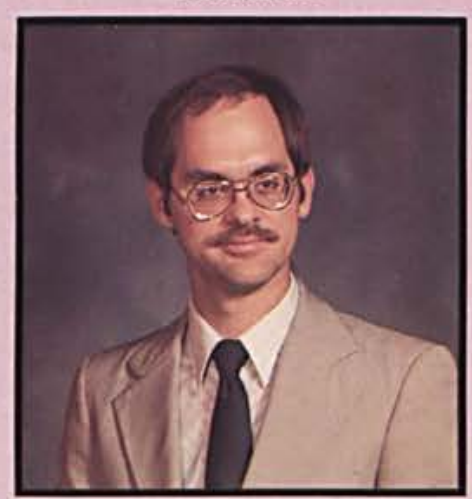

Douglas Miller, Ph.D. Assistant Professor of Chemistry

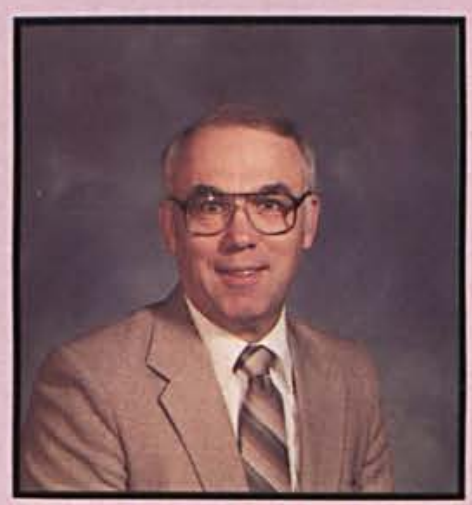

Daniel Wetzel, Ph.D. Professor of Physics and Mathematics

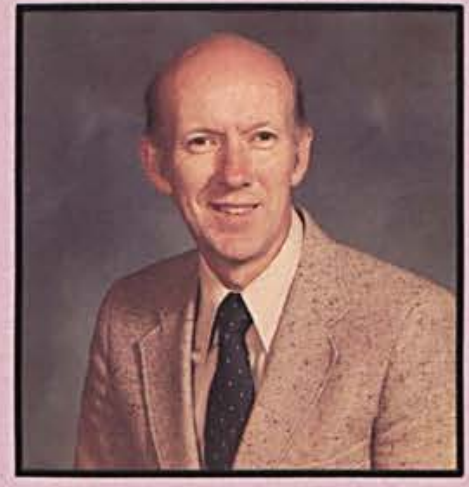

Donald Baumann, Ph.D. Chairman

Professor of Biology \& Chemistry

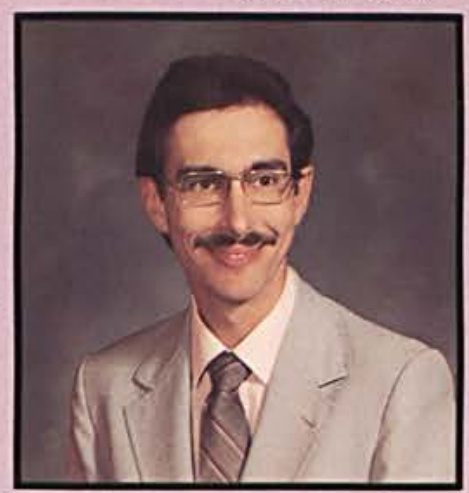

Dennis Flentge, Ph.D.

Assistant Professor Chemistry

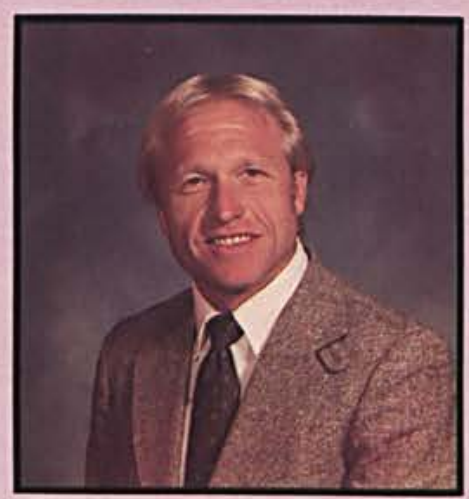

Terry Phipps, M.S.

Assistant Professor of Biological Sciences

Not pictured:

Larry Killian, M.S. Associate Professor of Biological Science 

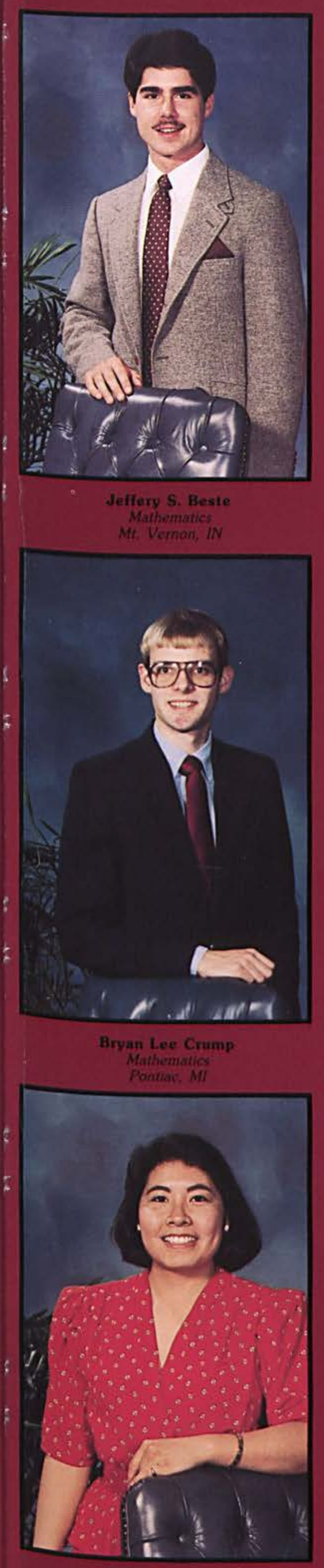

Michelle Marie Longo

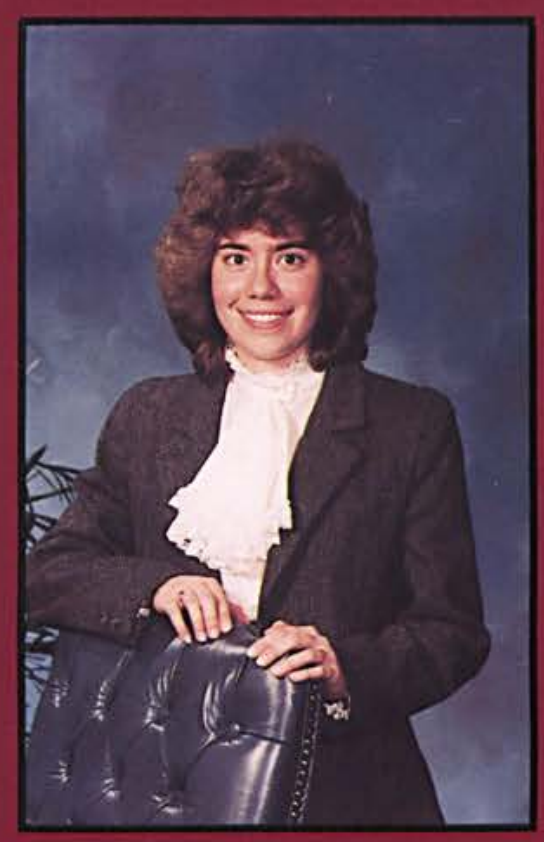

Terri Lynn Brumm

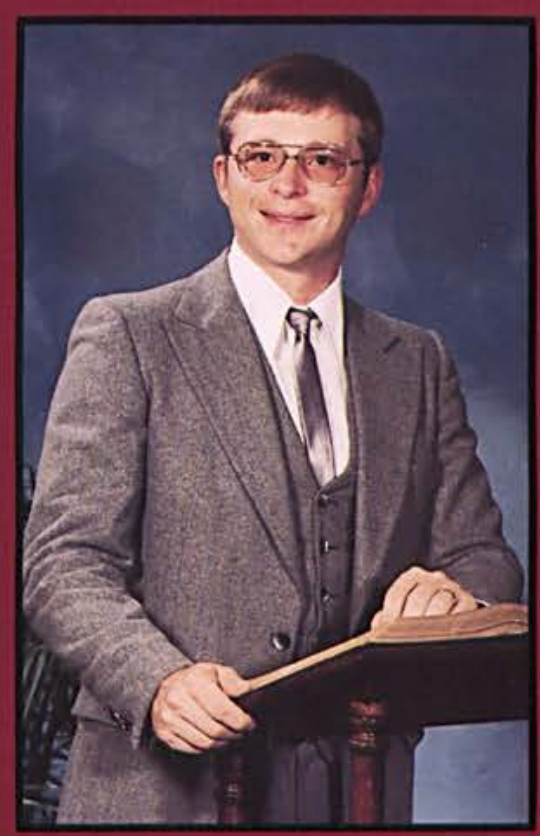

Thomas Jerome Friedman

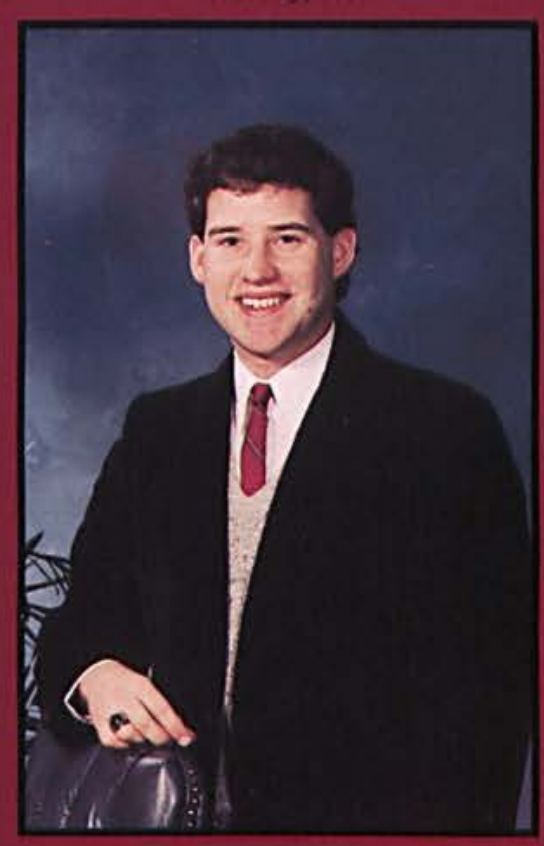

Brian Edward Maas

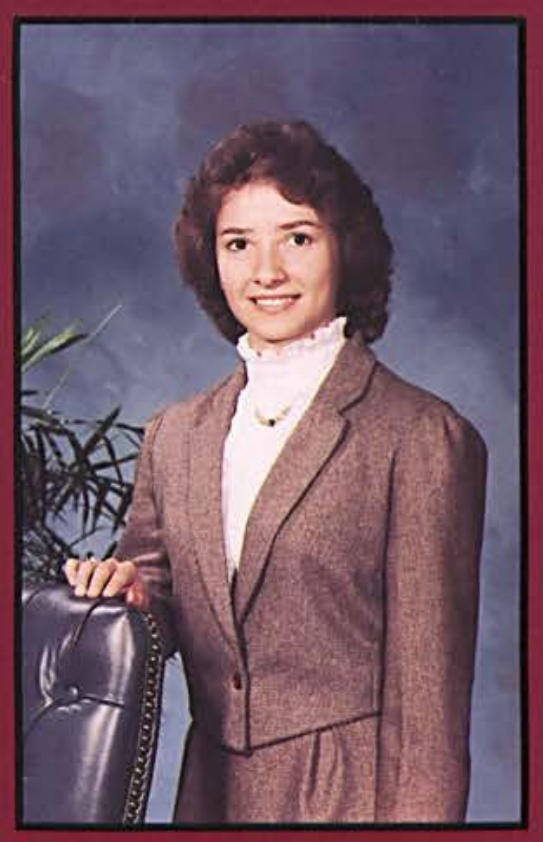

Rebecca L. Clarksar

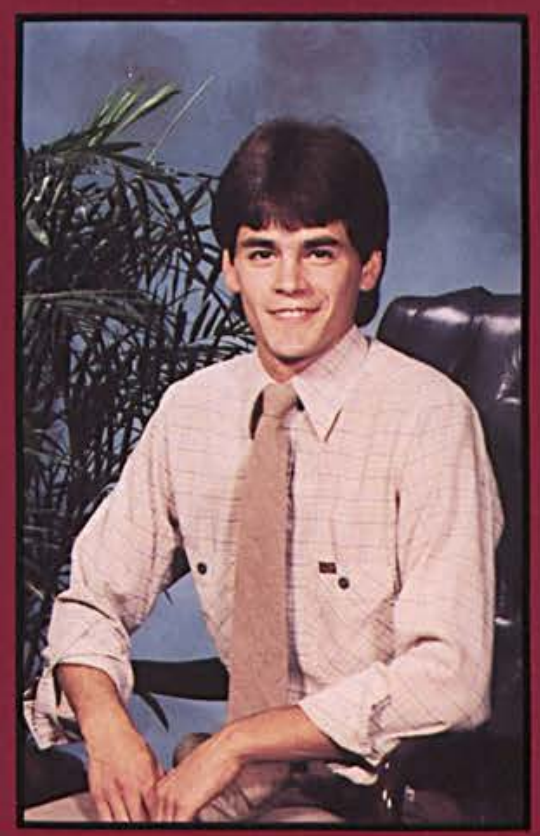

Thomas C. Hill

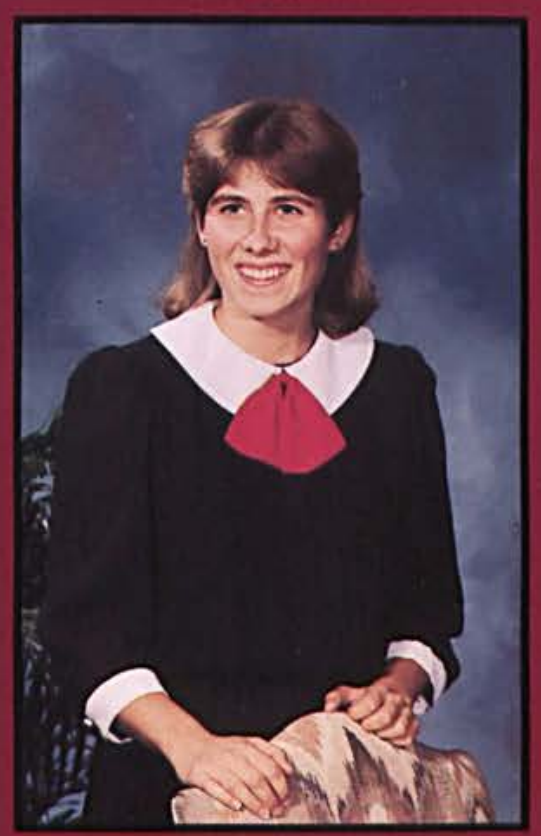

Melissa A. MacMichael

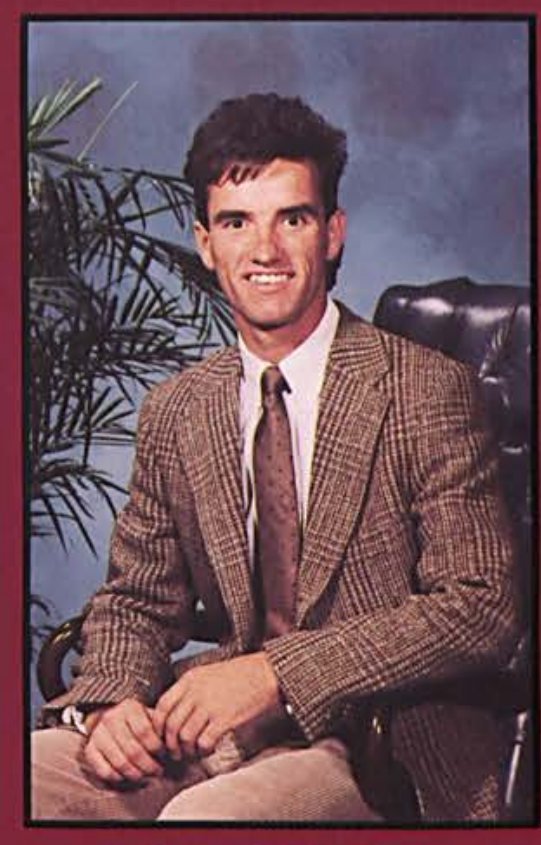

Cregan Stantey Cooke

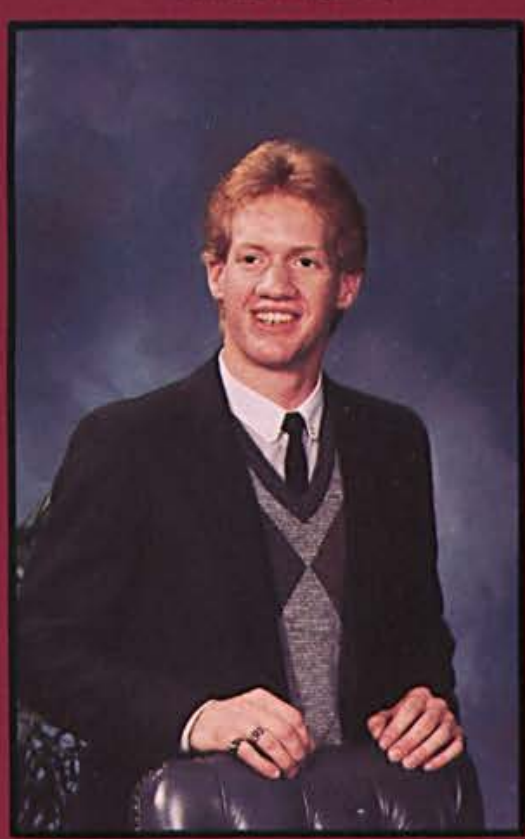

Todd E. Lee

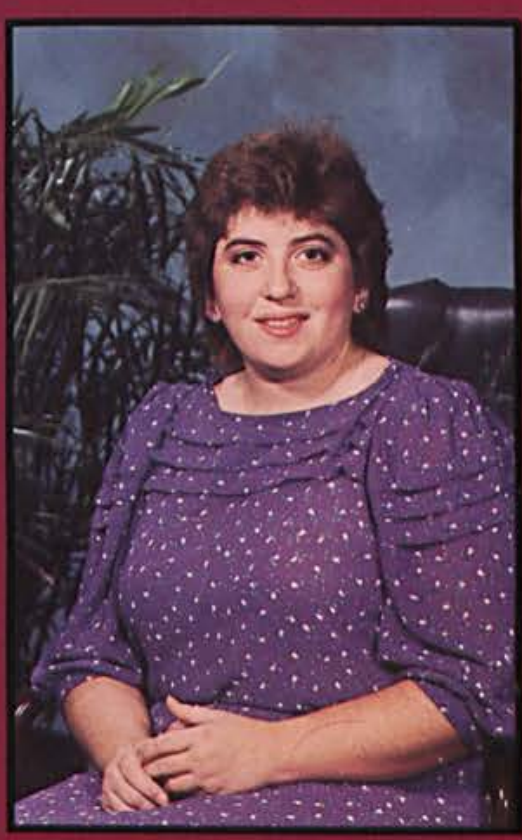

Marjorle Ann Moat: 


\section{Biology: \\ A Christian Perspective}

$\mathbf{M}$ Principles of Biology class inspired Dr. Silvius to write a new text, Biology: Principles and Perspectives. In this text, which he geared toward college students in non-science majors, Dr. Silvius attempted to integrate science with other areas of life and to present his subject matter within the framework of a Christian world view.

After fourteen months of hard work and research, he finally completed the writing of the text in the fall of 1985 . However, he stresses that the book is not finished; he is still awaiting its publication. At the time being, he has printed the book himself in paperback form.

One of the most important features of Biology: Principles and Perspectives, is that it contains a discussion of important subjects in biology of which Christians should be aware. For example, Dr. Silvius evaluates controversial issues such as abortion, genetics, and the ethics of science in light of biblical truth. This aspect is sure to make the text especially interesting and valuable to students.

Karen Beattie
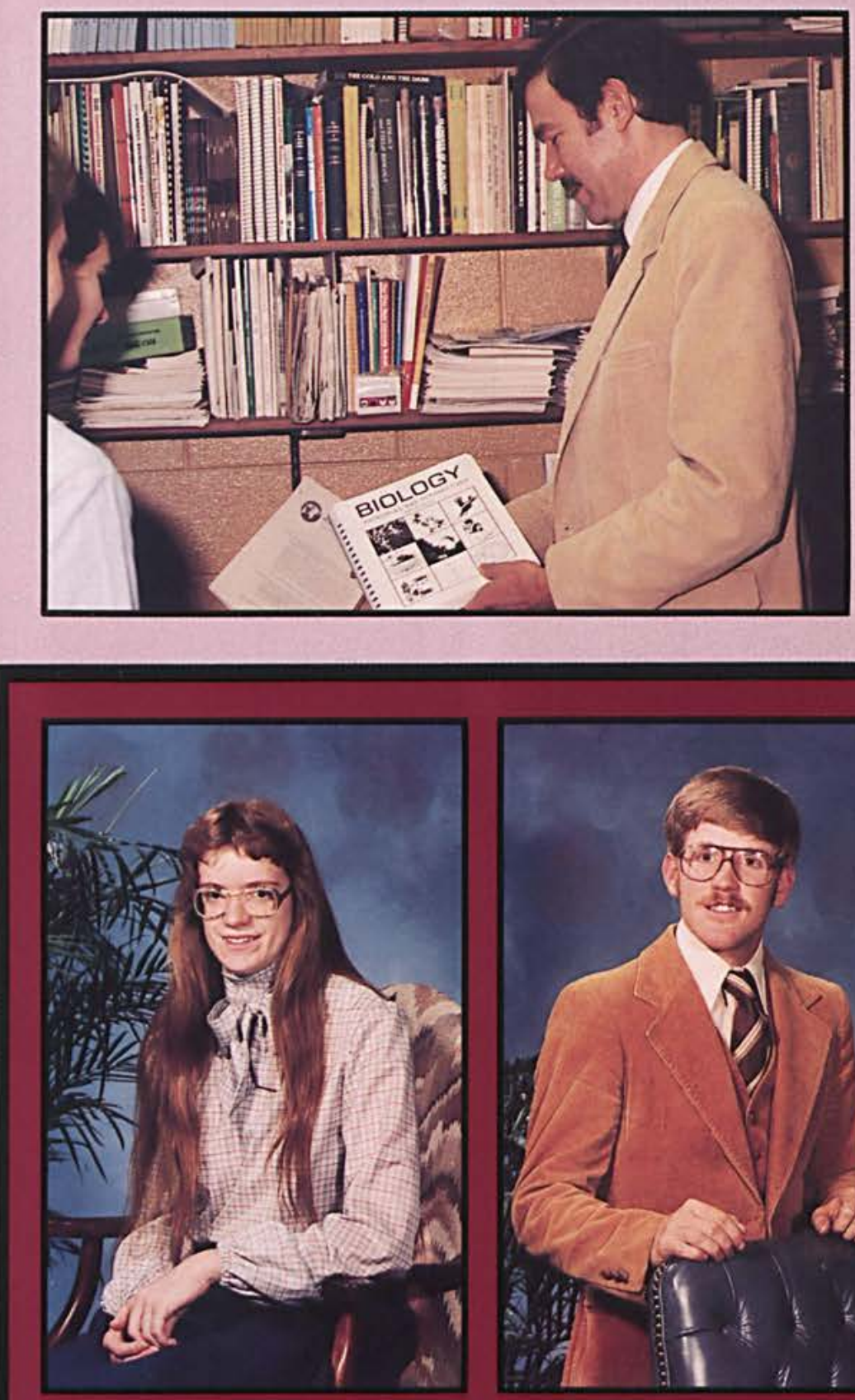

Jean May Moeser

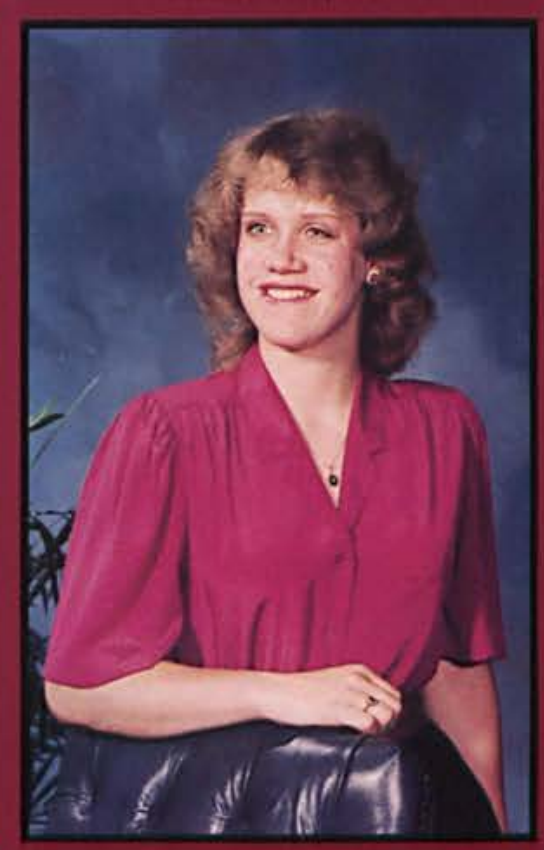

Patrick Andrew O'Donnell
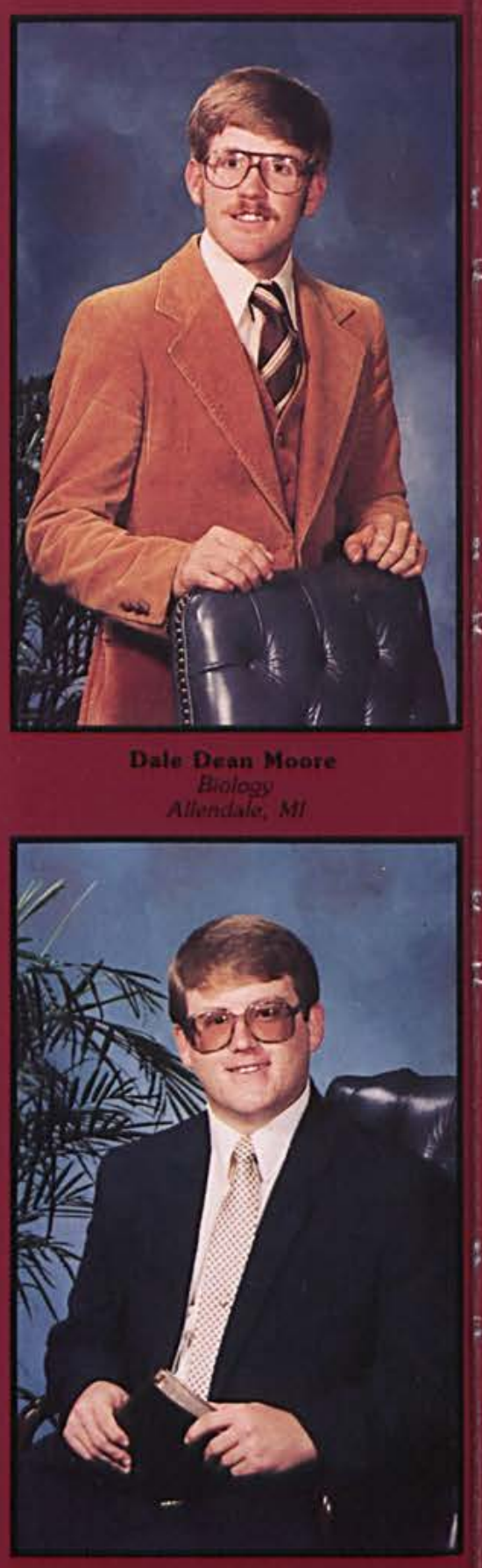

Dale Dean Moore

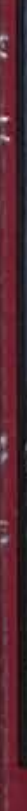

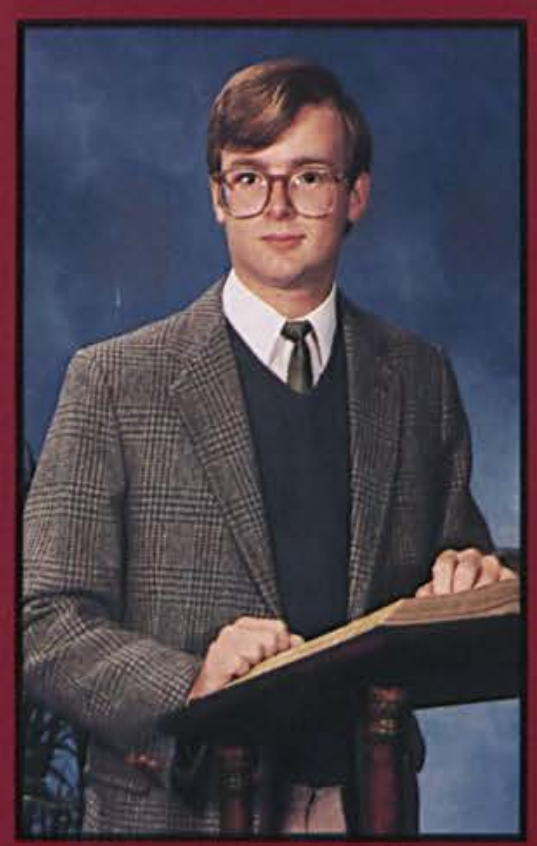

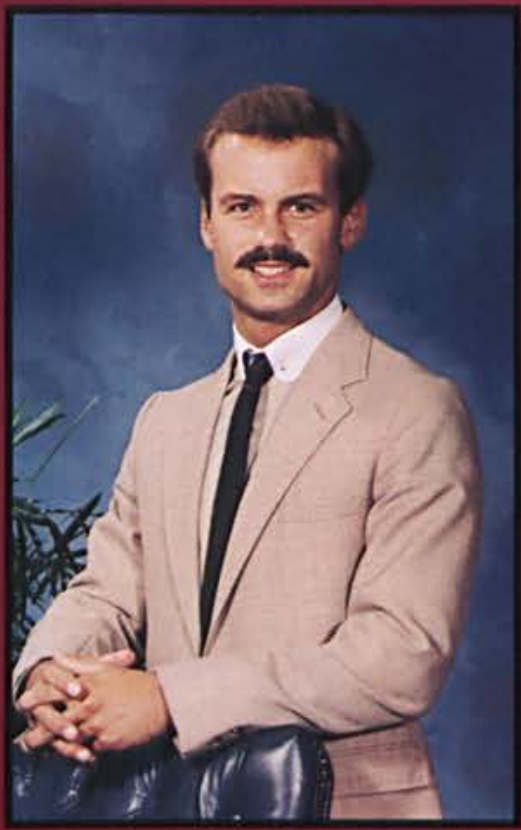




\section{Teaching stewards}

to spiritually participate in the political and social milieu of the

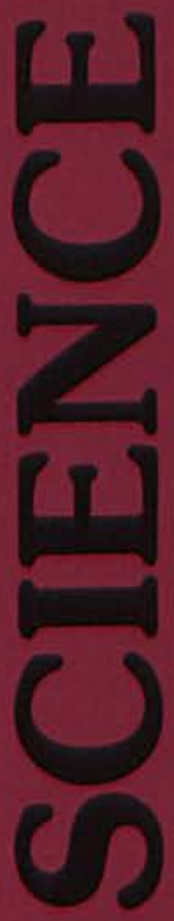
contemporary world with the purpose of making the Chief

Historian known and applicable to all aspects of life.

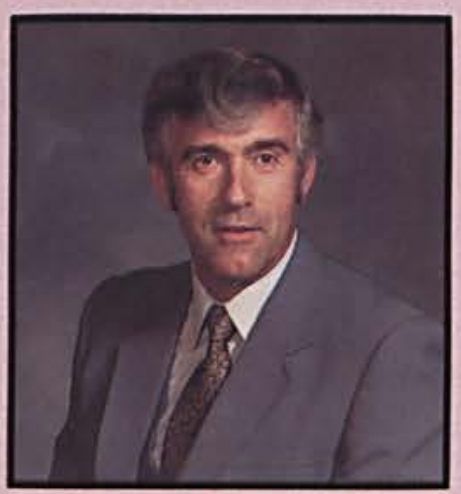

Joseph Halsey, M.Ed. Associate Professor of Political Science

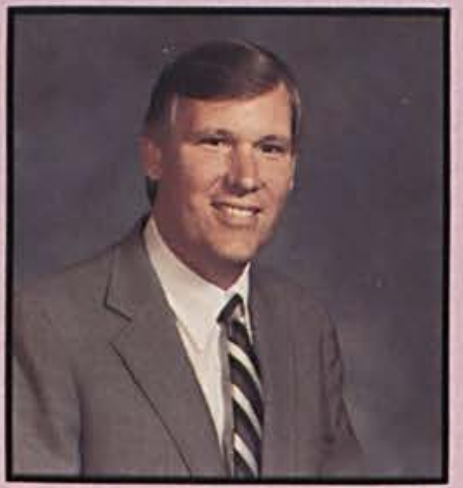

Robert Parr, M.A. Assistant Professor of Sociology Not pictured:

Allen Monroe, Ph.D. Professor of Social Science

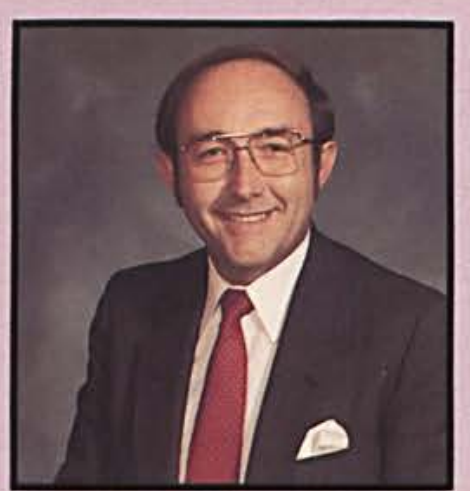

Murray J. Murdoch, Ph.D. Professor of History

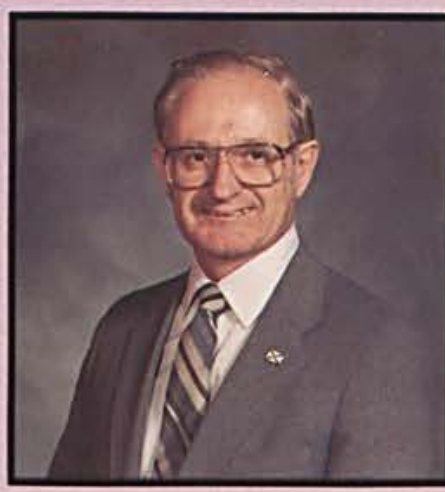

James McGoldrick, Ph.D. Professor of History

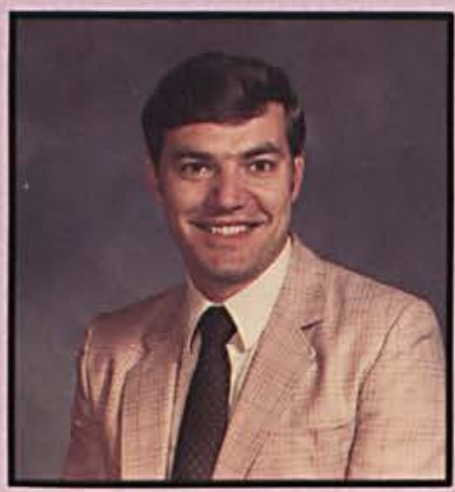

Rex Rogers, Ph.D. Assistant Professor of Political Science

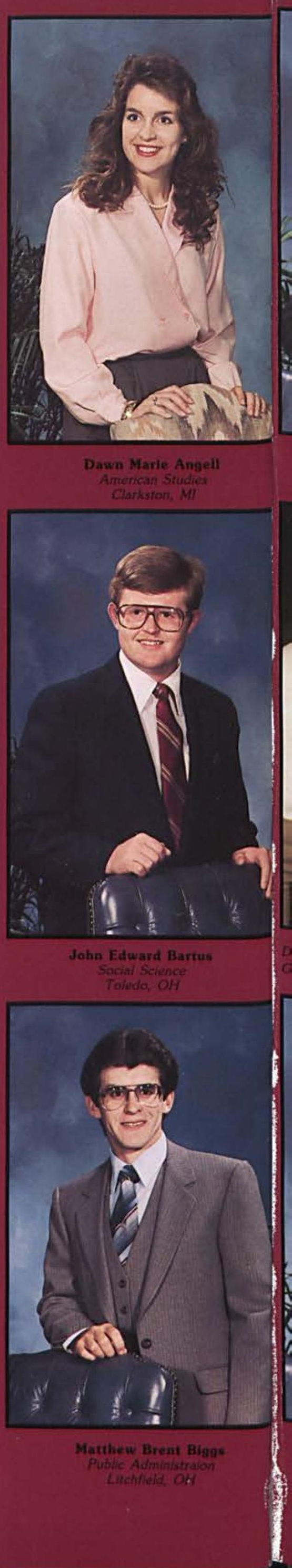



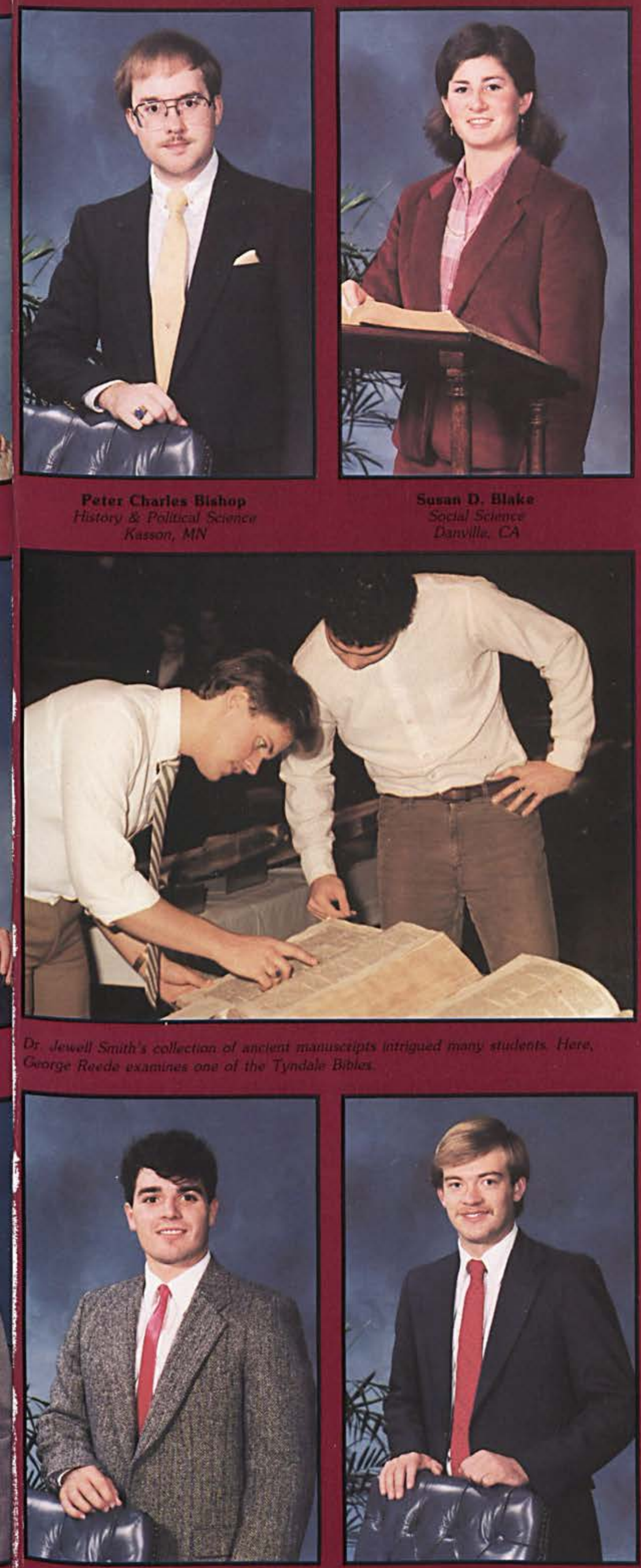

Michael F. Hammond

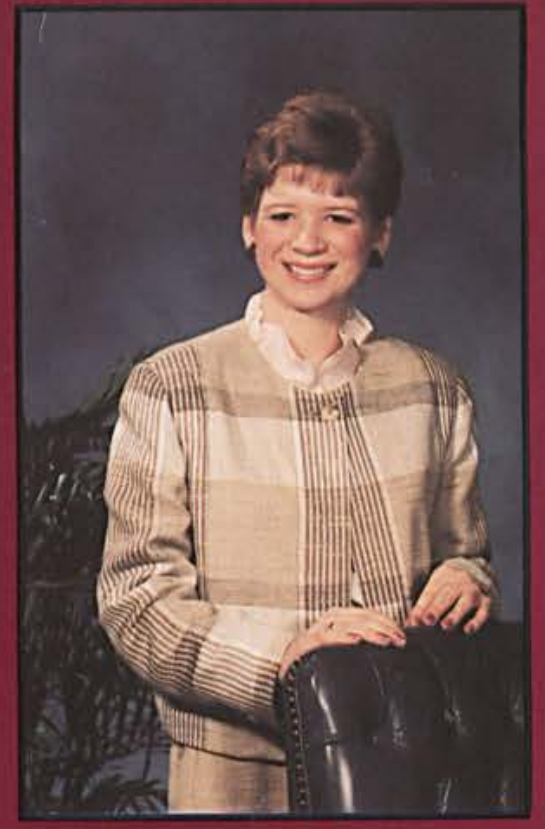

Fio
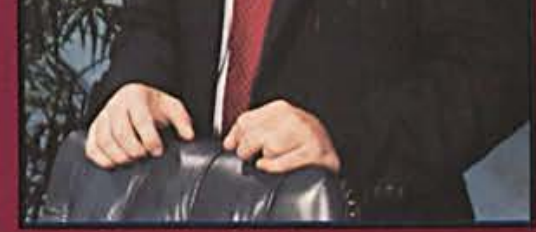

David P. Edwards

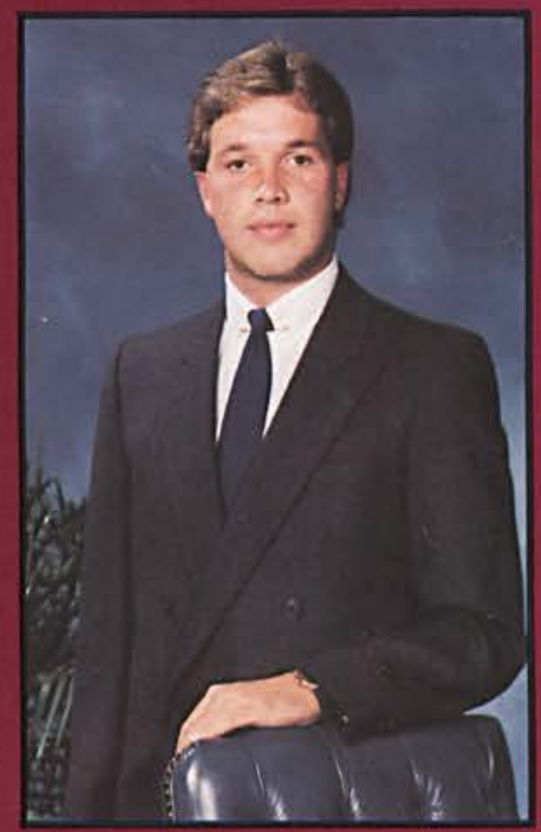

Mark W. Fleetwoos
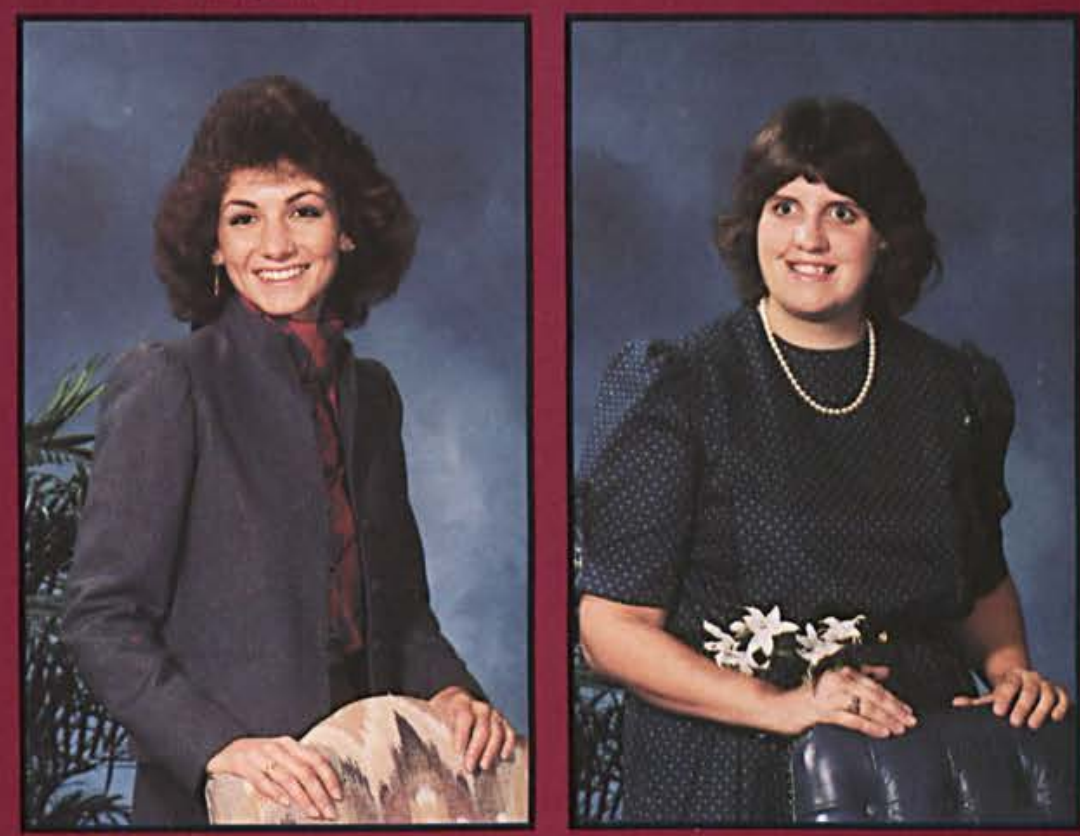


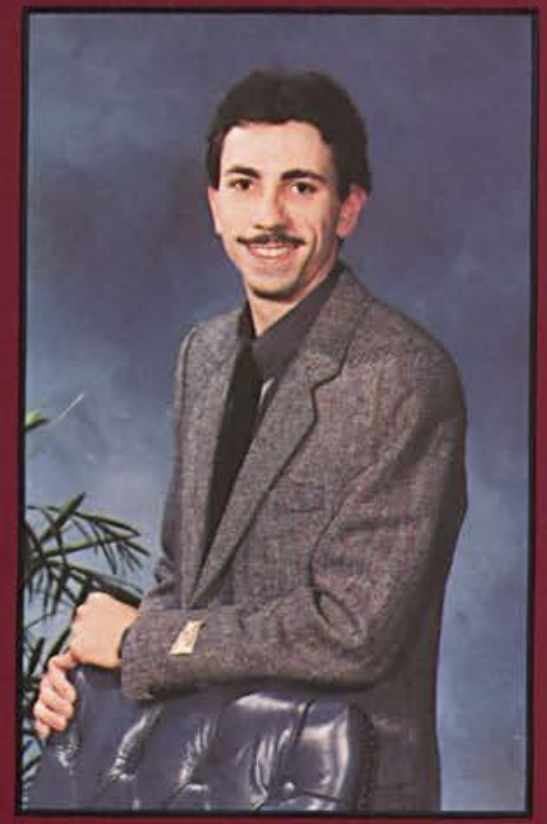

\section{Student Plans Service in Politics}

$\mathbf{T}$

oday's society is increasingly complex and confusing. Technological and social change occurs so quickly that it is difficult to keep pace with the latest trends and developments, let alone understand them. The social sciences and history provide a means for understanding our culture and civilization.

I chose a major in political science because of my fascination with government and politics. Some have maintained that politics is "dirty" and that no Christian ought to become involved in it. I object! It is my contention that if one understands how and why government operates, then one can contribute some. thing constructive to the political debate. The political sphere has been neglected for too long by our wing of Protestantism.

My understanding of the government, political behavior, and political philosophy is brought into proper balance by the lessons of history. I honestly believe that one cannot legitimately claim to understand the present without an accurate and objective knowledge of the past. The study of history provides the necessary context needed to reach any understanding of our contemporary society and civilization. Without a second major in history, my knowledge of political science and societal change would be incomplete.
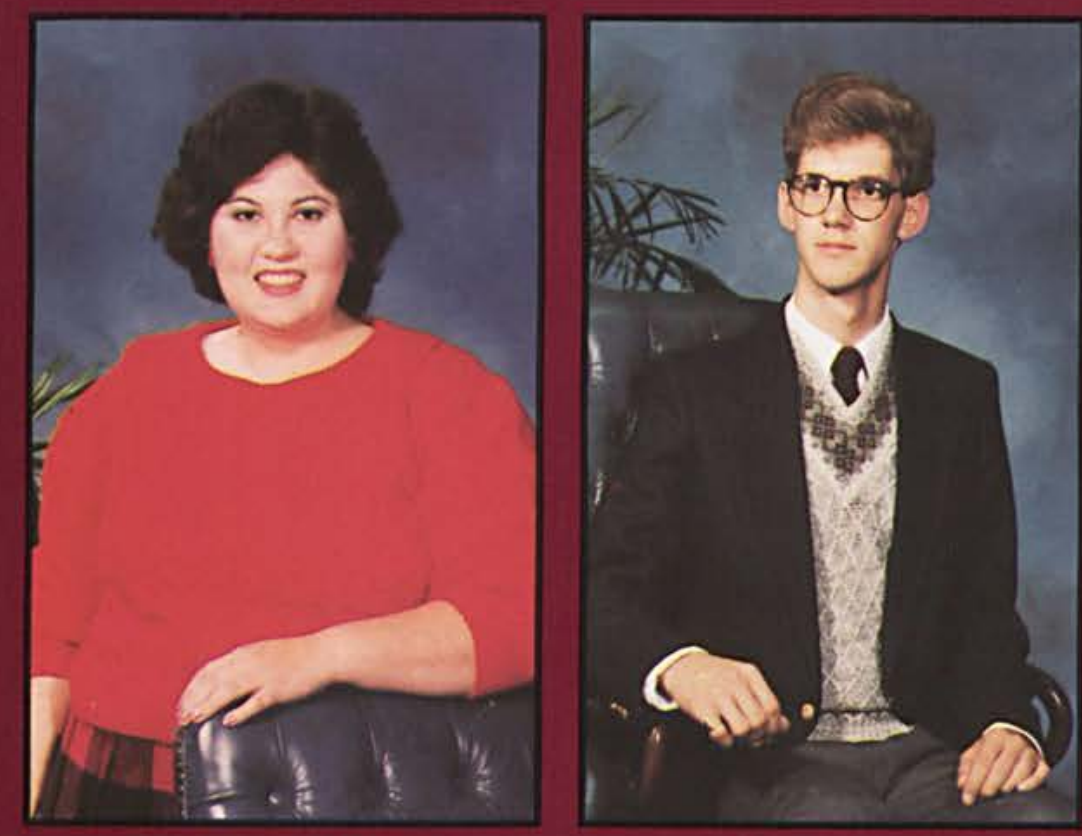

Peter Bishop

Amy Margaret dahinaton
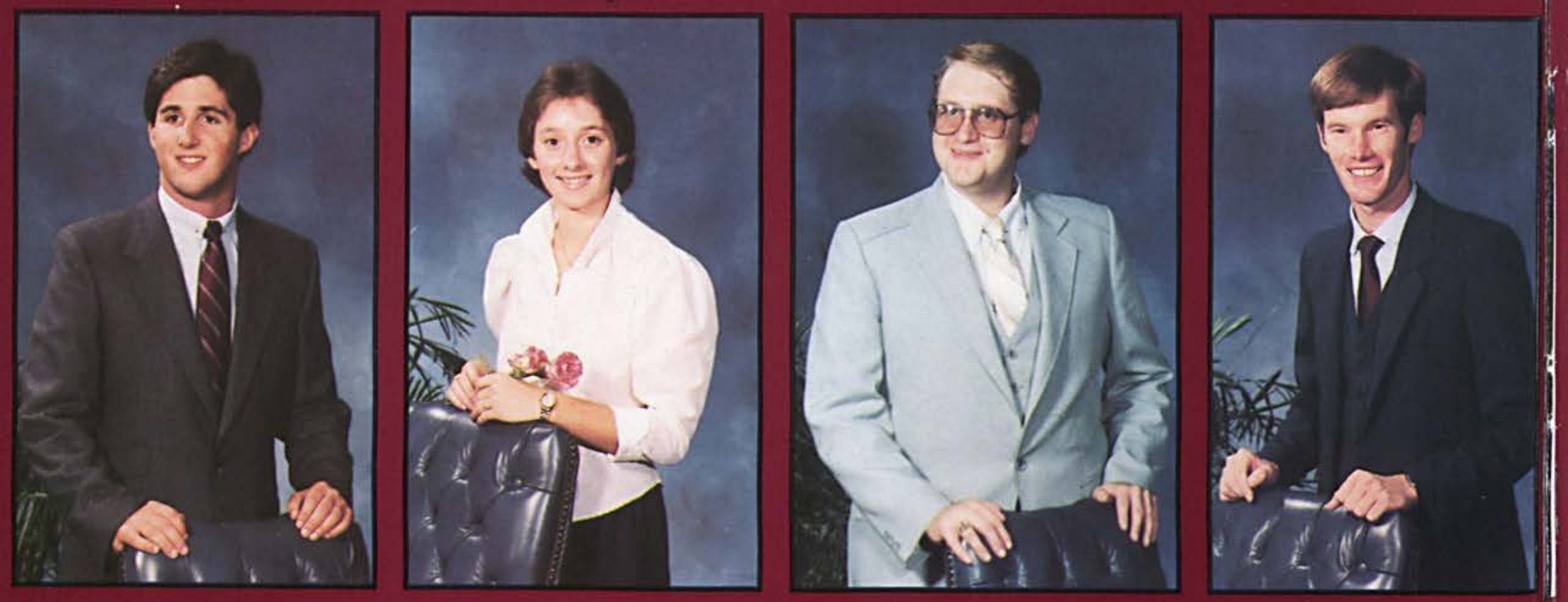

Buth M. Mason

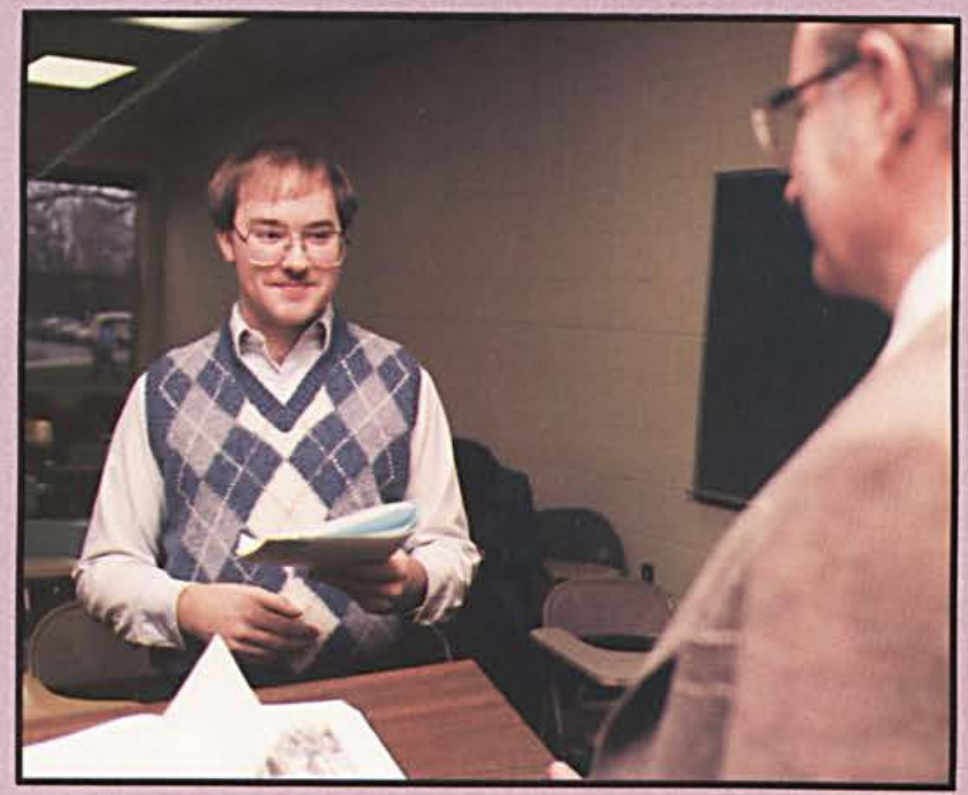




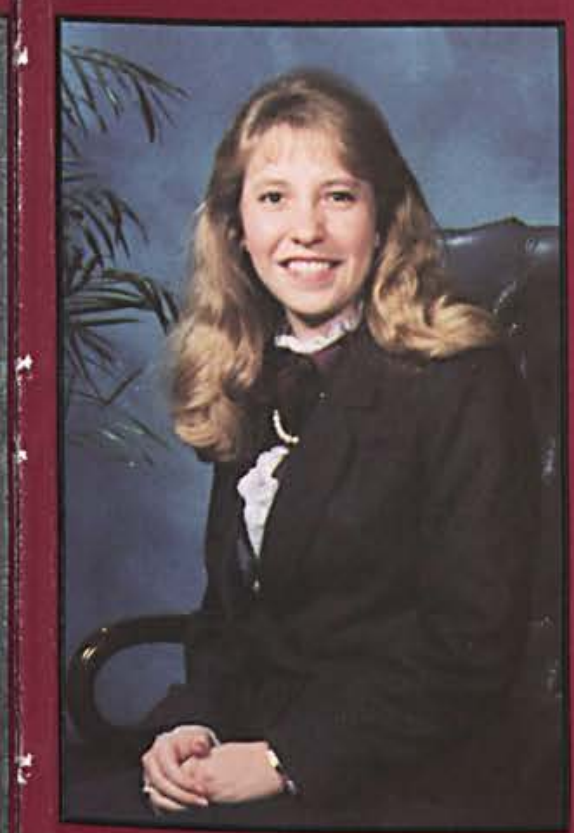

Krista Lymn Nickoson

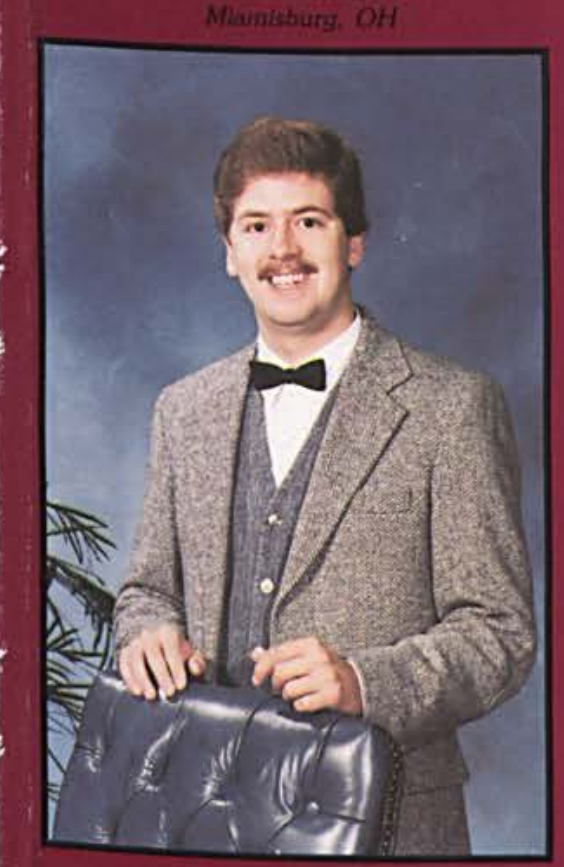

lavid Earl Shutse

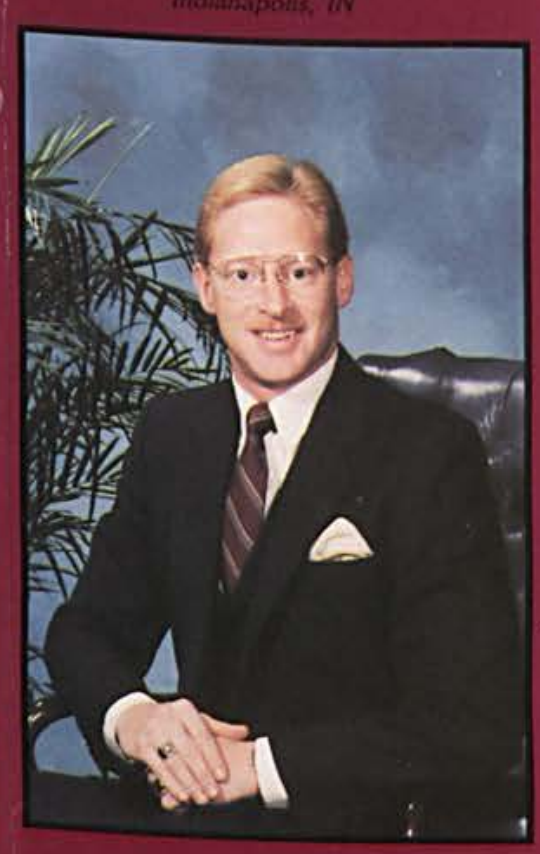

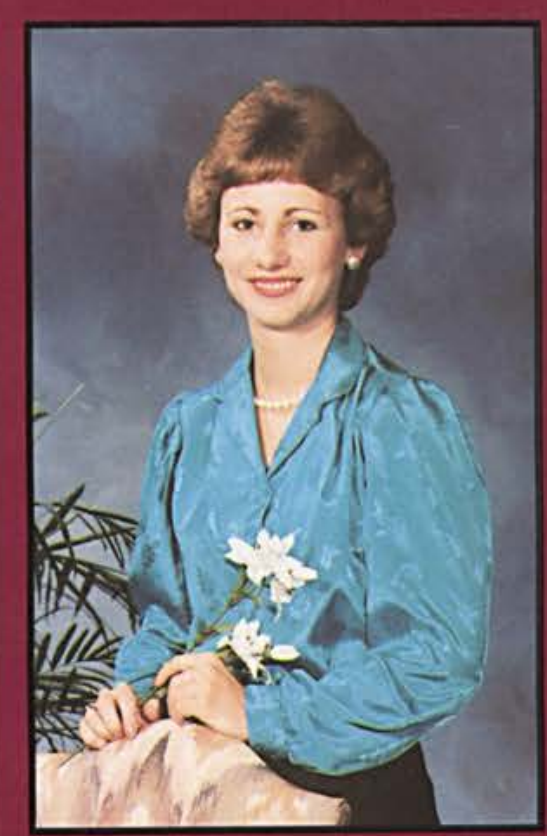

Constance Jane O'Dell

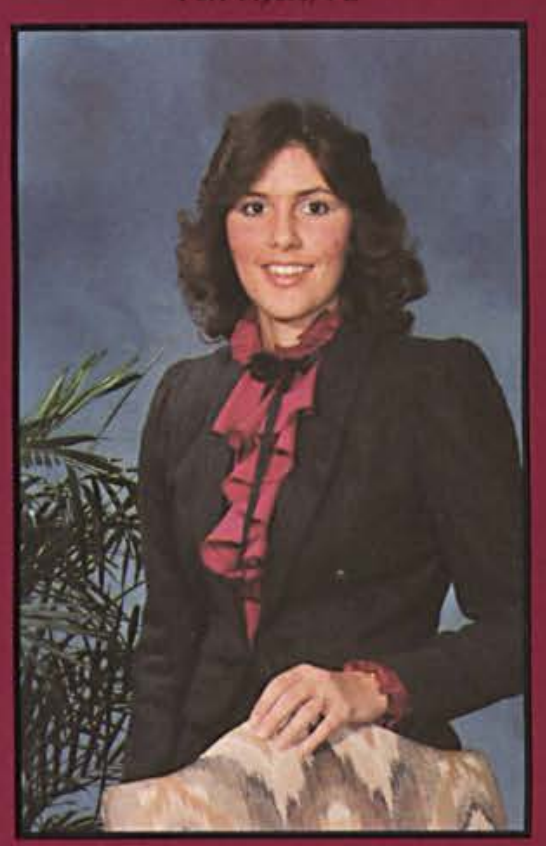

Betiy Marle Smith

Beighton. MI

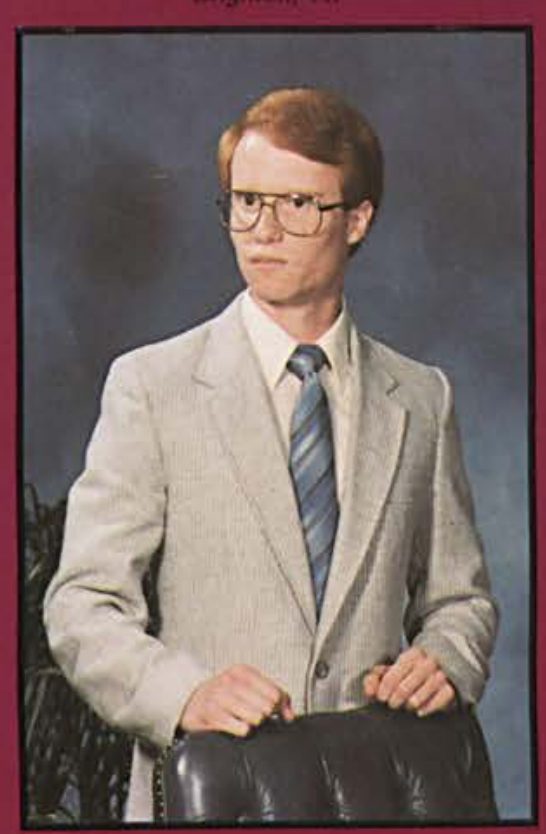

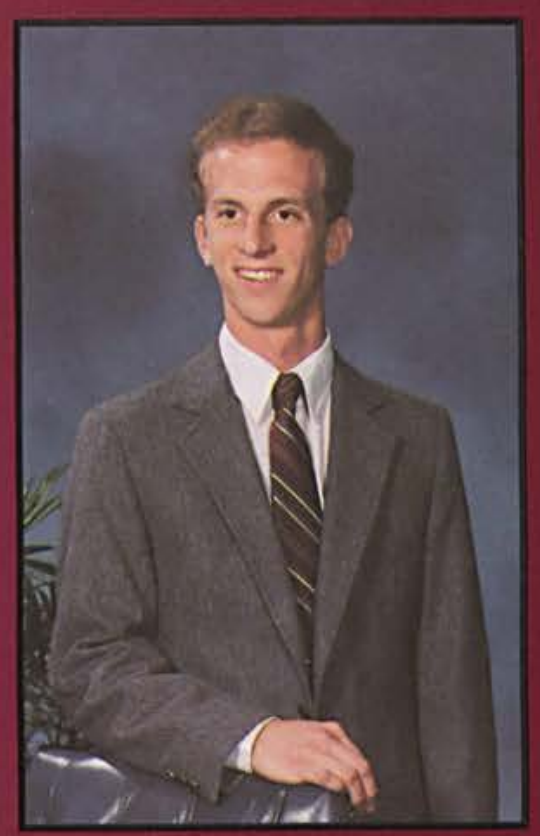
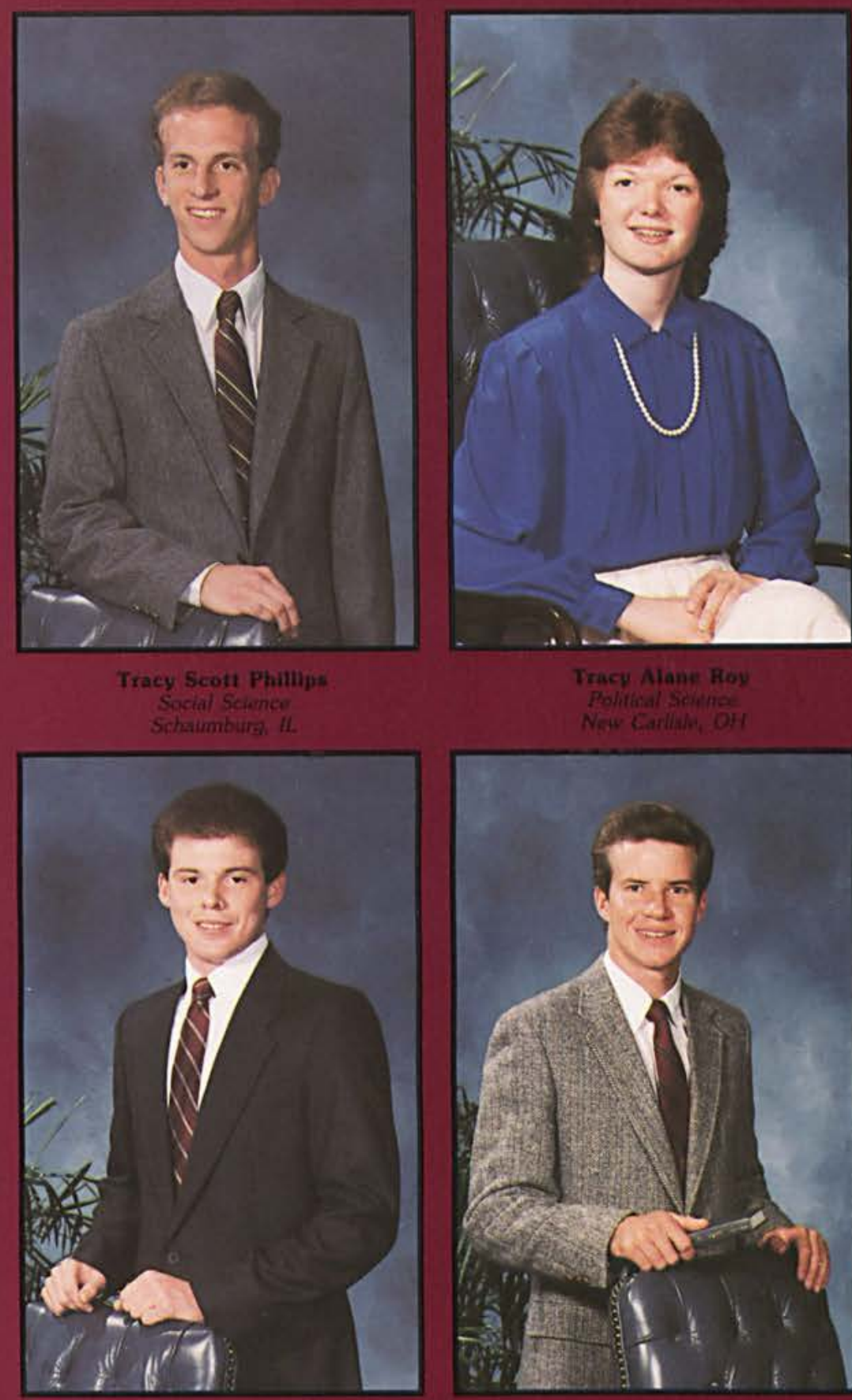

Willam G. Taft

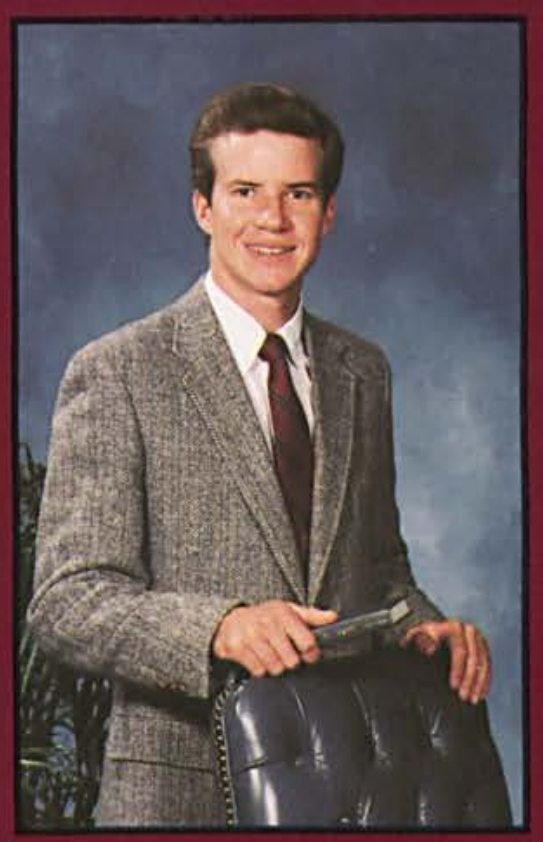

Robert K. Ward

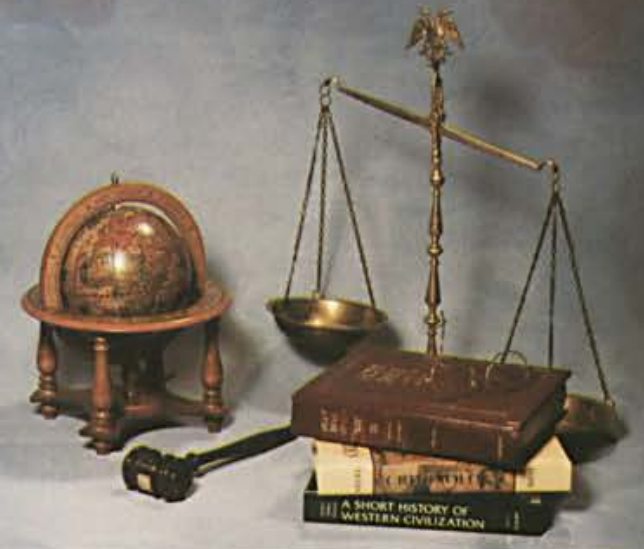



- Student Senate Officers
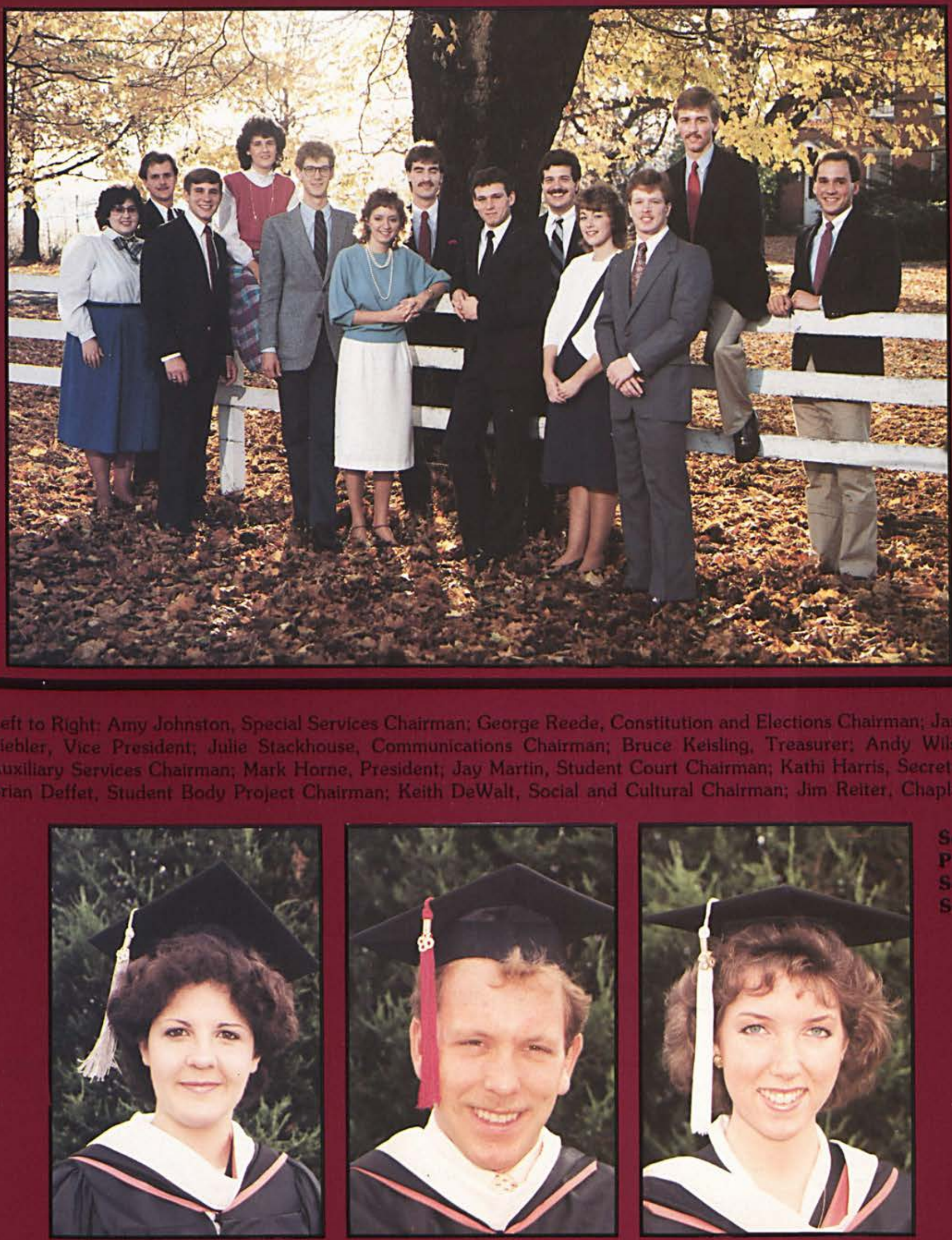

Seniors Not Plctured in Senior 


\section{Honors Day}

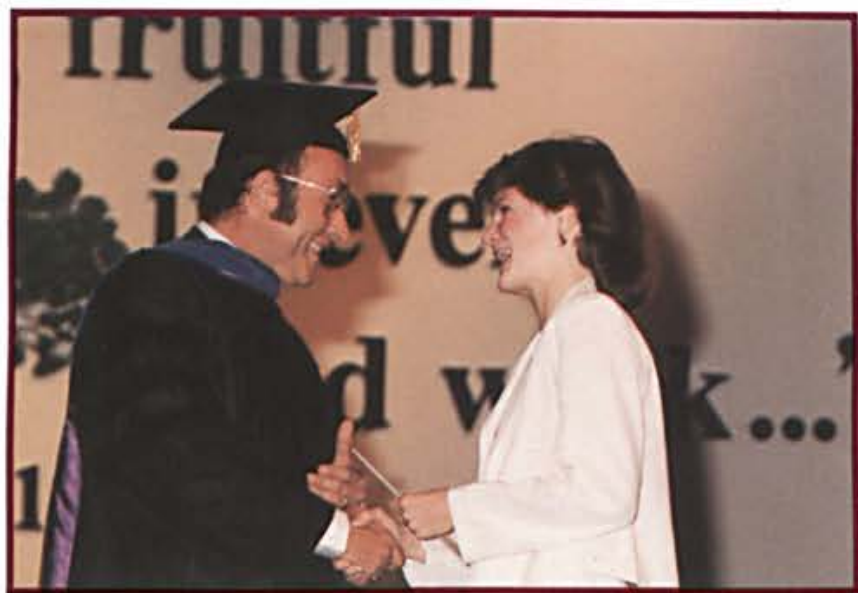

Biblical Education Awards

The Alumni Scholarship Award in Bible

The Oxford University Press Award

The Arthur Franklin Williams Award

The George W. Lawlor Greek Award

Business Administration Awards

The Alumni Scholarship Award in Business

The Wall Street Journal Award

The Boyd Accounting Award

The Ohio Society of C.P.A.'s Scholarship

Communication Arts Awards

The Alumni Scholarship Award in Communication Arts

The Rietveld Fine Arts Award

Education Awards

The J.D. "Jack" Willetts Alumni Scholarship Award

The Clara Monzelle Milner Award

The Irma M. Dodson Award

Health and Physical Education Awards

The J.F. Kearney Scholar Athlete Award

Language and Literature Awards

The Language and Literature Alumni Scholarship Award

The Edith Hart Milner Award

The Alumni Scholarship Award

in Music

The Pat Yoder Amstutz Nursing Nursina Awards

The Pat Yoder Amstutz Nur
Nursing Scholarship Award

Kimberly Kerr Memorial Scholarships

Lillian Kresge Memorial Scholarship

Psychology Awards

The Alumni Scholarship Award in Psychology

The Alton R. Brnwn Psychology Award

Science and Mathematics Awards

The Creation Research Awards

Biology: Richard Sharpe Chemistry: Amy Snook Mathematics: Rebecca Clarkson

The CRC Press Chemistry Award

History and Social Science Awards

The Alumni Scholarship Award in Social Science

The Edmund Burke Award

The Jimmy O'Quinn Evangelism Grant

The Martha Louise Brown Memorial Award

The John W. Bickett Heritage Scholarship

Staff Member of the Year Award

Faculty Member of the Year Award

Mark McClain

George Reede, Jr. Jennifer Matthews

Stephen A. Meyer Sally J. Cochran William H. Marling Eric Shrum

Betty J. Tarter Irene Alyn
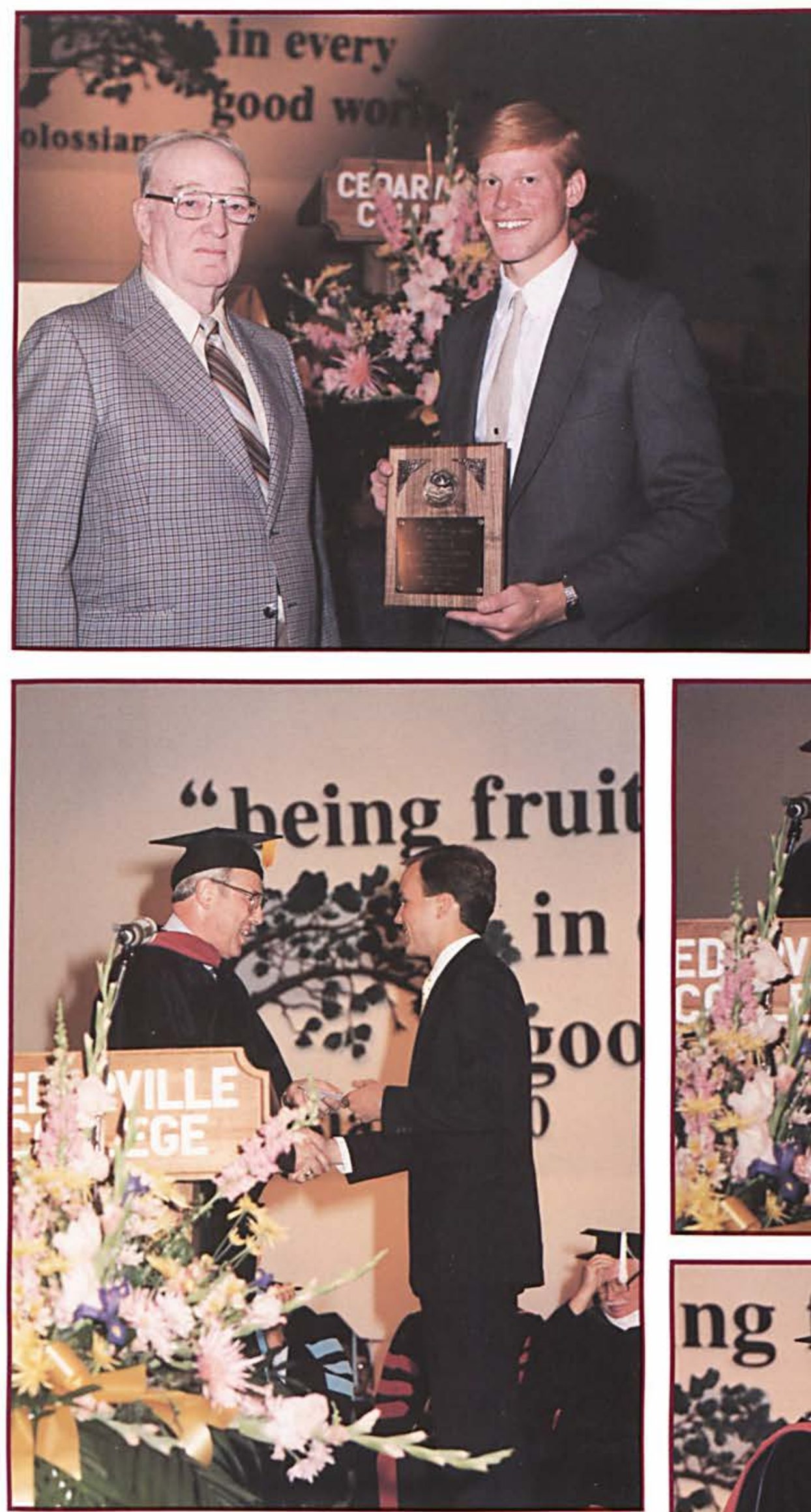

Above left: The Edmund Burke Award, Jennifer Matthews. Top: Eric Shrum, right, John W. Bickett Heritage Scholarship recipient. Below: James Reiter receives both the Arthur Franklin Williams and the George W. Lawlor Greek Awards. Opposite page, top: Clifford Johnson, Academic Vice President. Middle: Pat Yoder Amstutz Nursing Awardee Cathy Lombard. Bottom: Noel Hack, another recipient of the two awards, Oxford University Press and the Arthur Franklin William Awards.

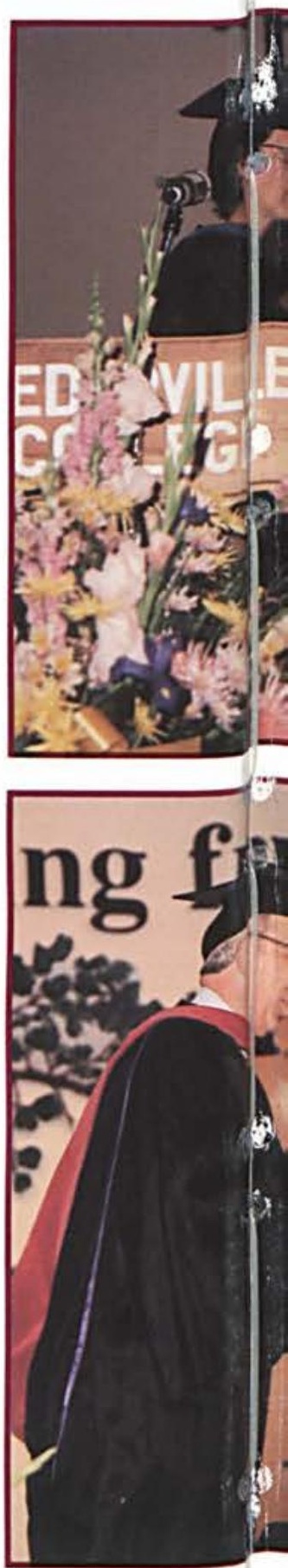




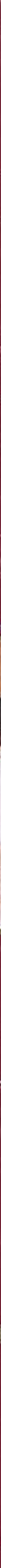




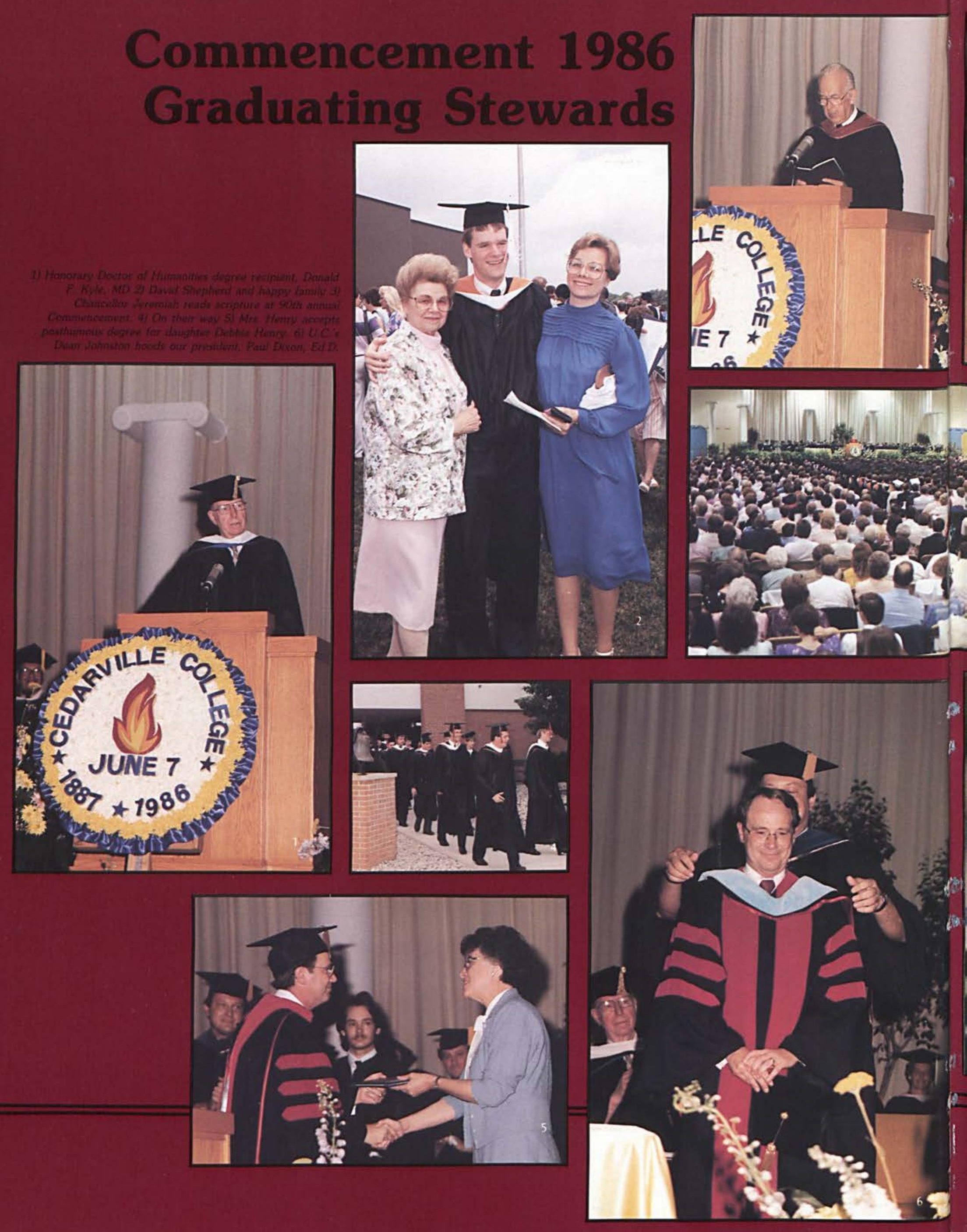




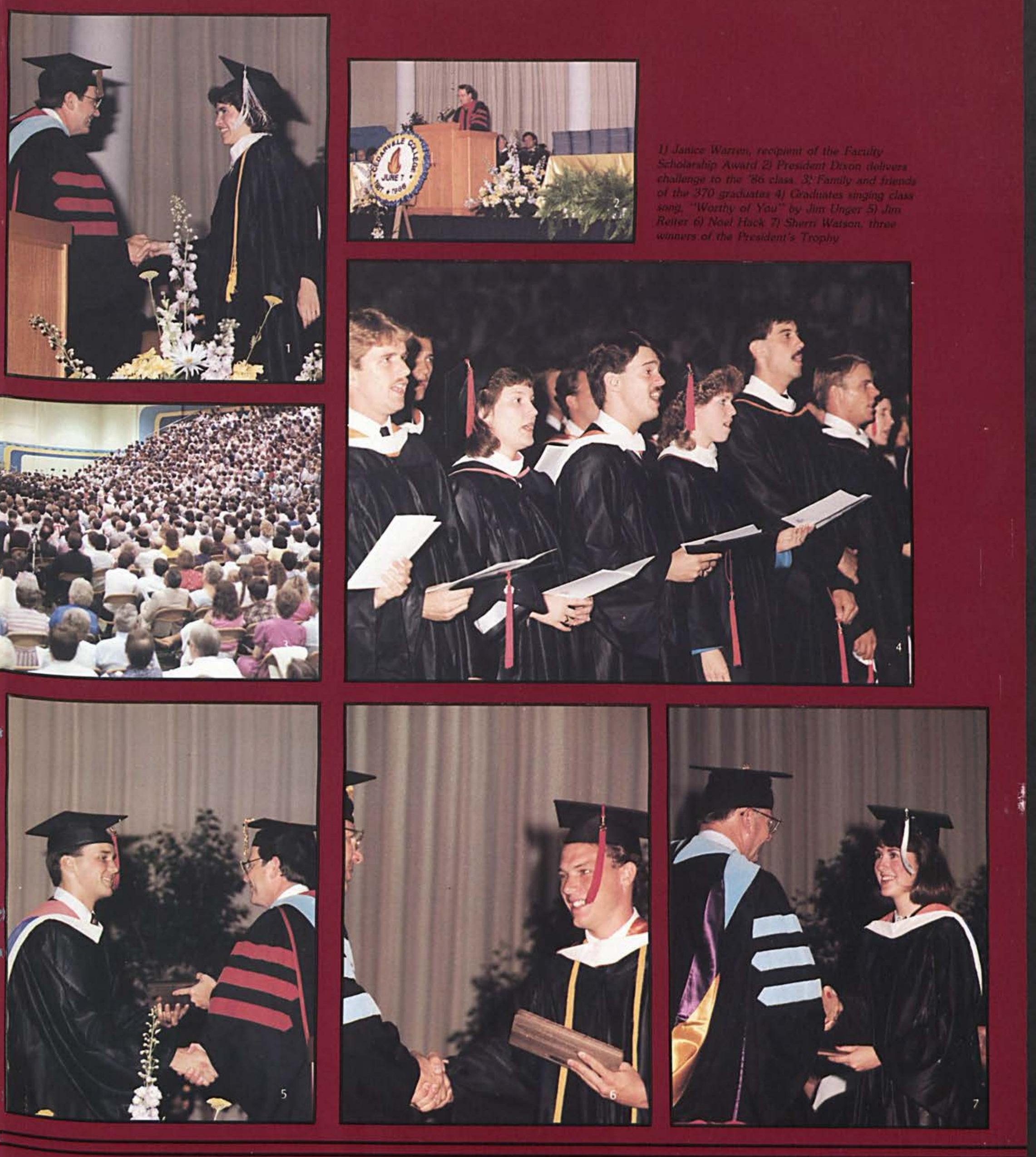

"That ye might walk worthy of the Lord unto all pleasing, being fruitful in every good work, and increasing in the knowledge of God.' 

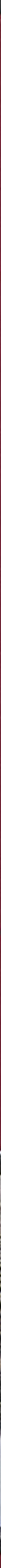

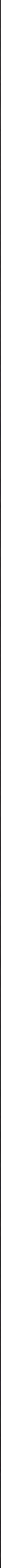


\section{JUNIORS}

Cheri Ann Abresch Joel D. Acker Amy Allen

Cynthia Ray Anderson Kurt D. Anderson Lorelei Anderson

Sharon Alexis Anderson Lisa Rene Armstrong

Denise Ann Aukland Rebecca Jeanne Averill Sharon Augenstein Cindy L. Baise

Deborah Joy Baker Susan Marie Baldis

Tammy Evans Barber Sarah Ann Barr

Tammy Jo Barton Michael Paul Basler

Dina M. Batcheider Susan R. Bauer Jane Marie Baughman Richard Anthony Beaman Marilyn Louise Bean James D. Beight

David Jay Bennett Rebekah J. Bennett Debbie Lynn Berdy David Edward Beverly

Tamra Noel Bielski John Bigelow Jr.

Suellen Marie Black Valerie Ann Blaylock Annette Joy Bloxham Joy C. Boersma Theresa Diane Bonning Reneé Ann Bowen

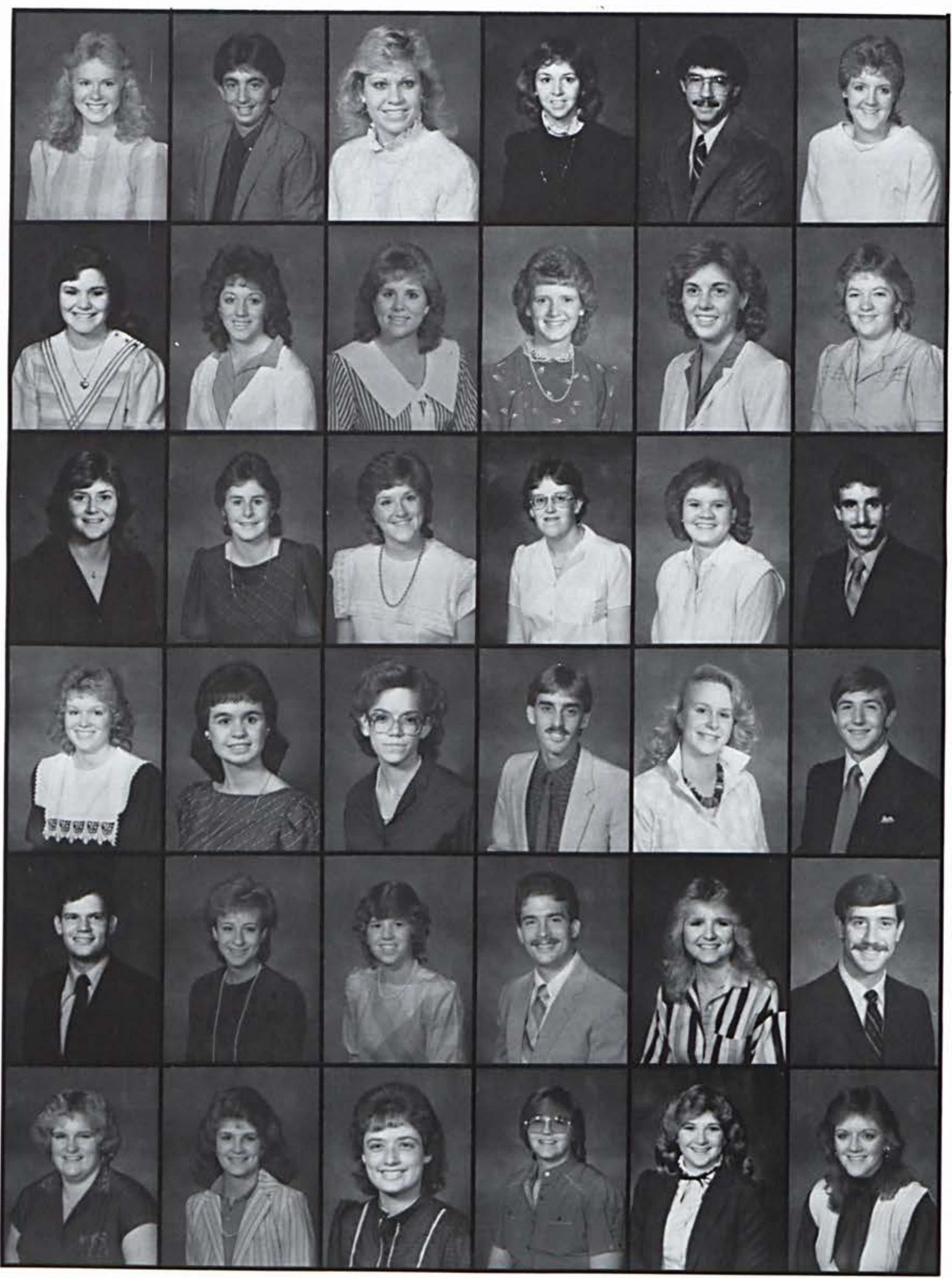




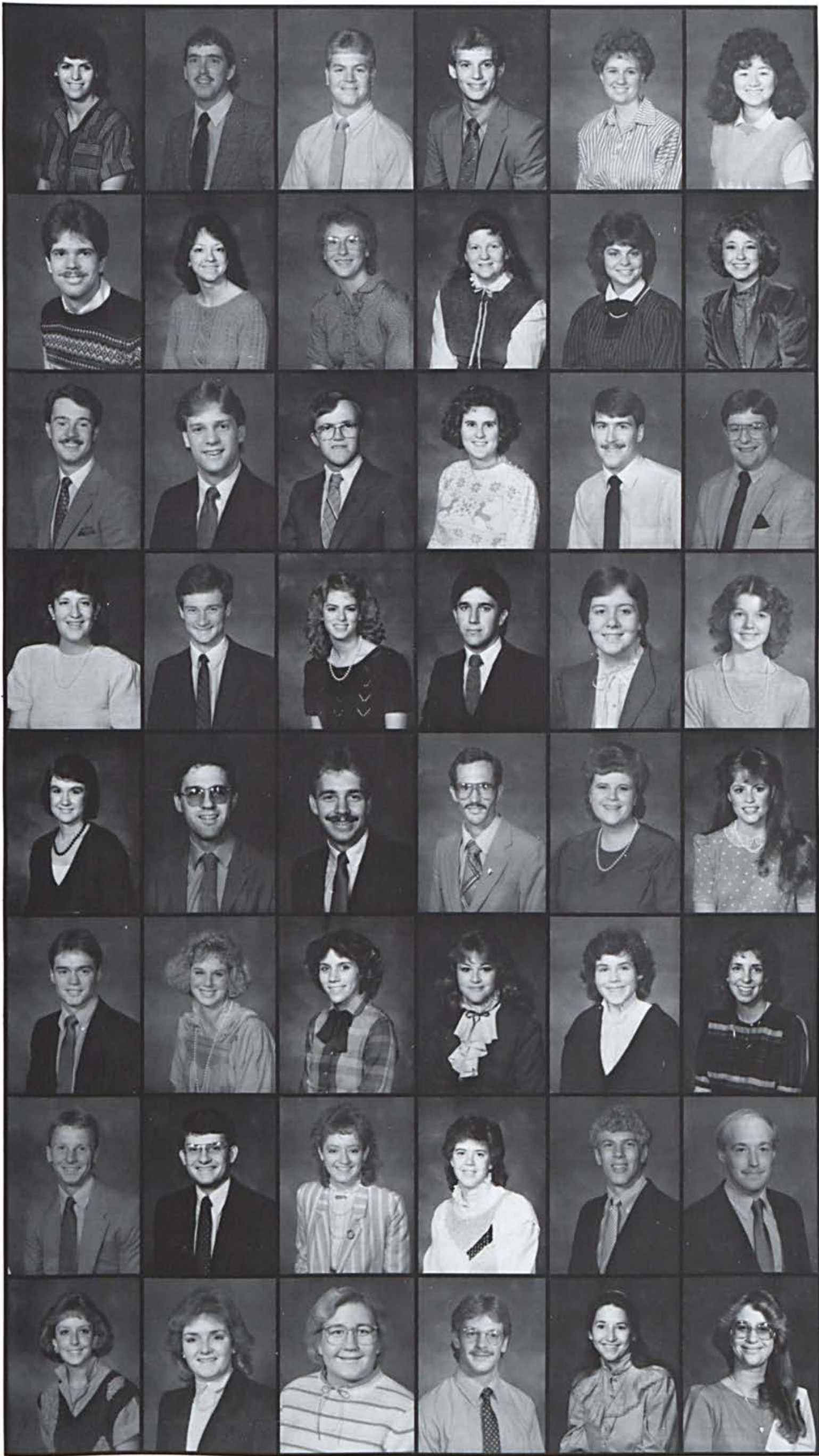

Michelle Ann Braun

Jon Bresson

Timothy A. Brock

Robert Lee Broline

Diane L. Brown

Ruth M. Brown

John Burrows

Darlene S. Butler

Julie Ann Butler

Jeanne L. Butzlaff

Lorrie A. Byrd

Lynne A. Calisti

Donald Dennis Calder

Steven Mark Campbell

Richard Jonathan Carey

Lori Renee Casteel

Doug Cherry

Perry Ercole Chiarelli

Deborah Ann Clem

Steven David Coates

Erin E. Coffman

Michael Scott Collins

Mary Ruth Cook

Rachael L. Cook

Mary E. Coons

David M. Corry

W. Todd Coston

Steve Mark Cox

Lynn Dee Cramer

Cynthia Helen Cronrath

Clancy Calvin Cruise

Gail C. Daiker

Christine Fern Dail

Cheryl Jean Dangler

Wendy Diane Datzman

Kimberly A. Davis

Timothy Paul Davis

Tim M. Day

Jenny Sue Dean

Susan Marie Dean

Steven J. DeCook

Wayne Edward Degelman

Shawna Marie Denney Judy Kay Denning Beth E. Deranek

Matthew John Dickinson

Debra Louise Diem

Kendra Jean Doctor 


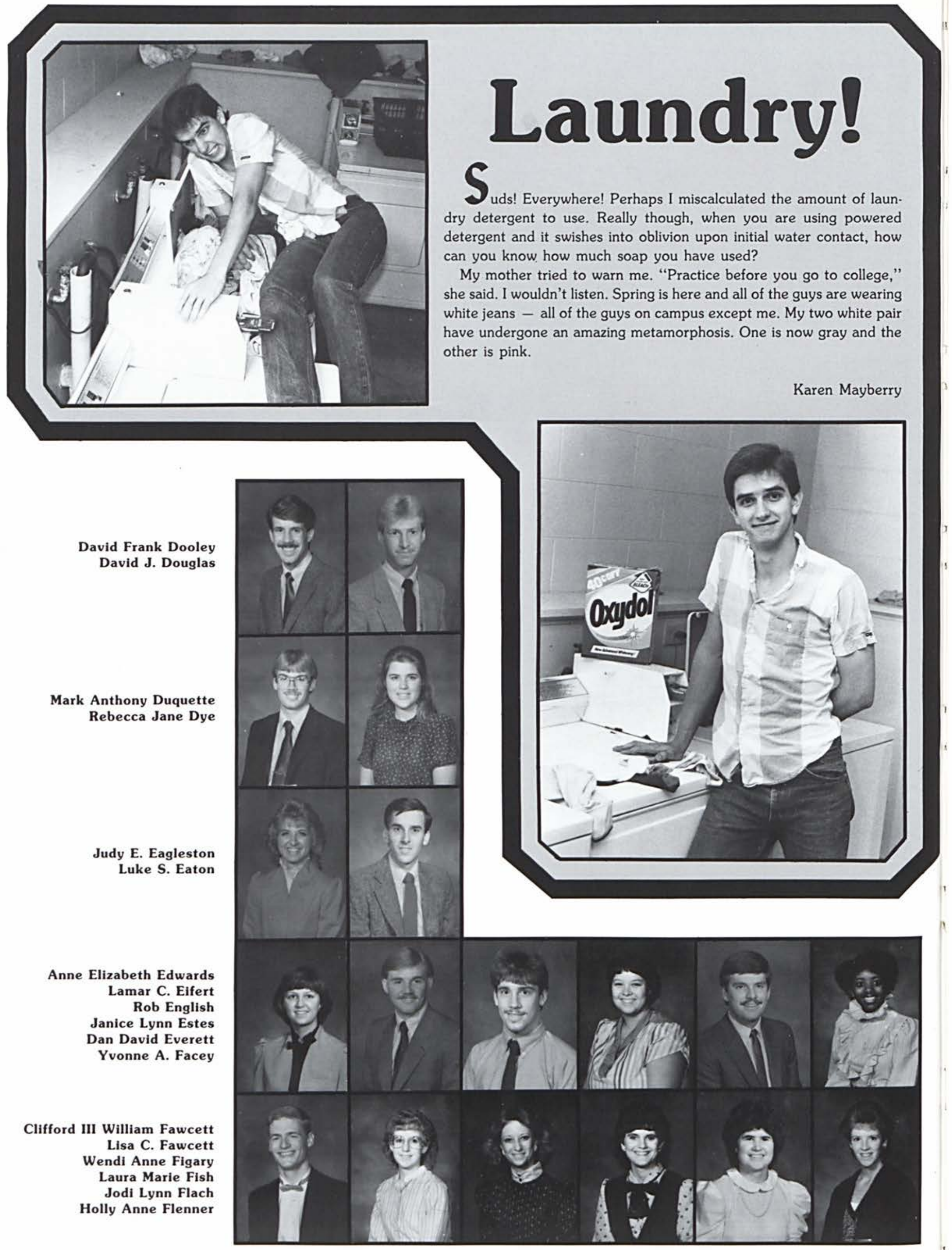




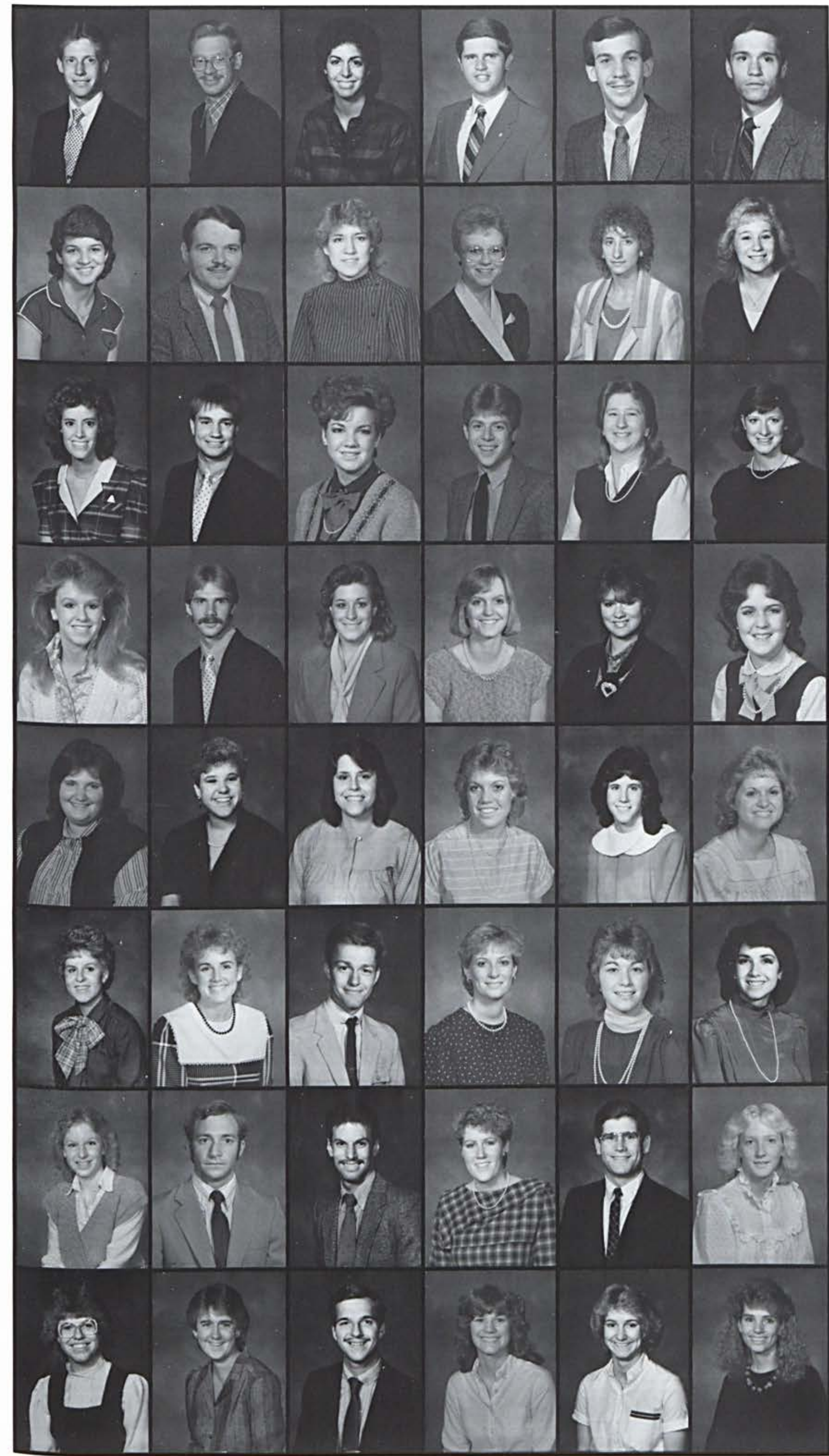

Philip R. Fogle, Jr.

Andrew S. Ford

Claire Anne Fortosis

Robert A. Fread

Todd Free

David C. Frey

Dawn L. Frey

Greg L. Frye

Marla Sue Fuller

Deanna K. Gabel

Janet Sue Garmatter

Diane Lynn Gephart

Sarah M. Getz

Kenneth A. Giesman Jodean Marie Gifford Jefferey Warren Gilbert Brenda L. Golemba

Anne L. Gorden

Wendy Grady

Steve Ronald Graef

Kelly Ann Grant

Tracy E. Grimes

Virginia Ann Gruneisen

Amy Guest

Stacy Leigh Gunther

Brenda Jo Gust

Lori R. Haberli

Lyn Marie Hackenberry

Pamela B. Hakes

Kelly J. Hamilton

Laure S. Hancock

Elizabeth Joy Hansen

Steve J. Hanson

Judy Happe

Kathi Harris

Laura Ann Hartsough

Ann Kathleen Haskowich

Richard G. Haywood

Larry Leon Heacox II

Heather Ann Healey

Jeffrey Heffelfinger

Diana L. Heitzman

Cynthia J. Helmick

Kelly Lynn Helmick

Eric D. Helmuth

Nadeen Kay Henderson

Lisa Beth Henry

Rebecca L. Henthorn 
Kendall Lynn Herrick

Hope Ann Hibbard

Karla Marie Hines

Mark Joseph Hinman

Ginger Hochstettler

Beth J. Hoecke

Chris J. Hoefler

Philip J. Hohulin

Joel Mark Hoskinson

Scott J. Howder

Dorthy Elaine Howdyshell

Mark D. Huebsher

Paul Richard Hughes

Paula M. Hunn

Judy M. Hunt

Jeffrey Allan Imhoff

John Thomas Irving, Jr. Robyn Irwin

Douglas Scott Iverson

Charles Jackson

Richard D. James

Susan L. Jessop

Diane R. Johnson

Ginger I. Johnson

Robin Lynn Johnston

Kelly Lynn Johnson

Kelly K. Jones

Marsha J. Jones

Suzanne Eve Jones

Valerie Colleen Jones

John Kejr

Sandra F. Kennedy

Richard T. Kester

David William Ketcham

James Randall Ketring

Susan Joyce Kiener

Pamela J. Kimble Beth A. King

Russell A. King

James Liddon Kirtland, Jr.

Kimberley Sue Kiser

Danielle Kay Kizer

Jeffrey W. Kline

Rebecca A. Klopp

Mary Beth Knicely

James Robert Koerber

Sonya Renee Kreidler

Lorin Kenneth Krikke

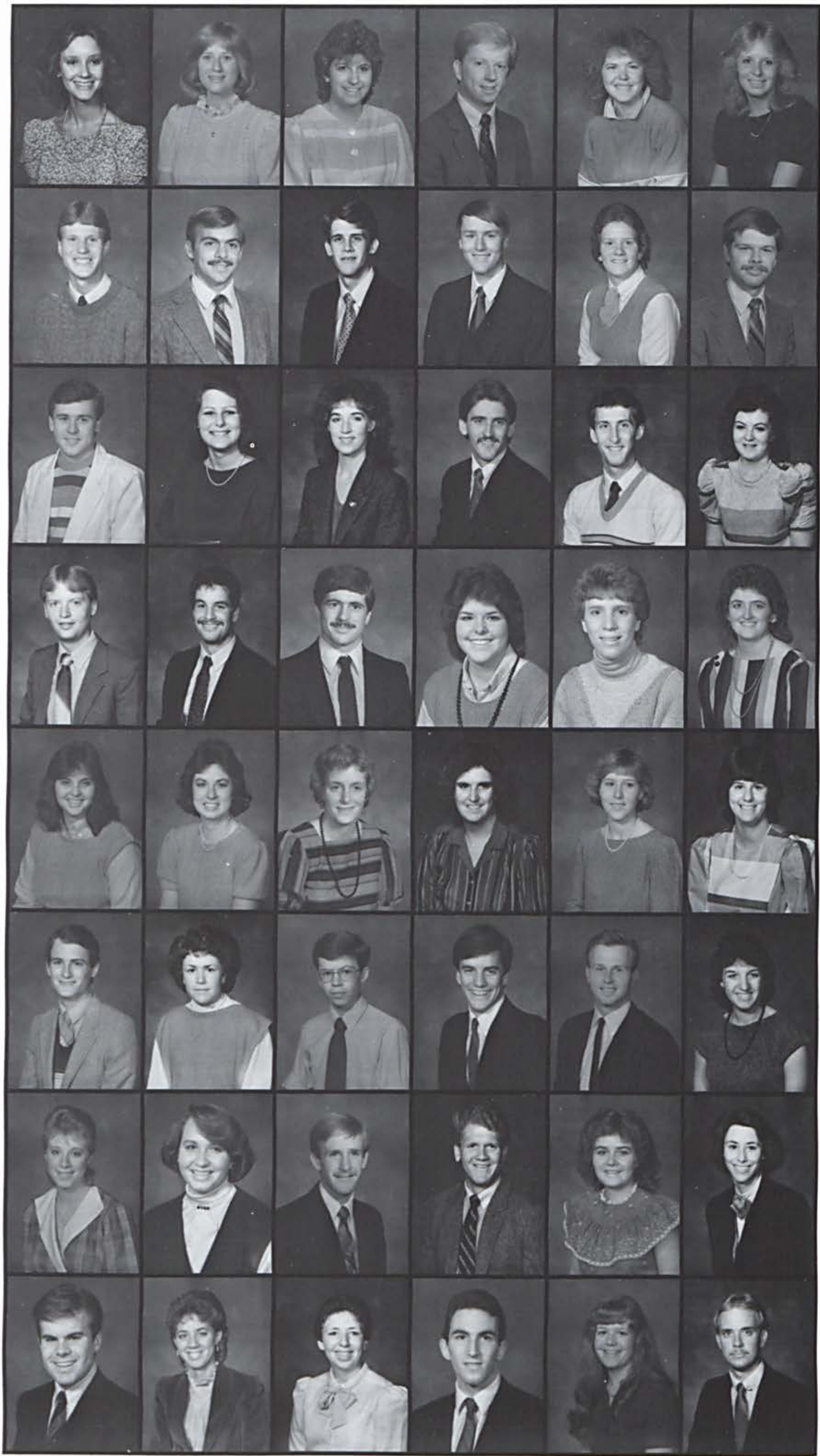




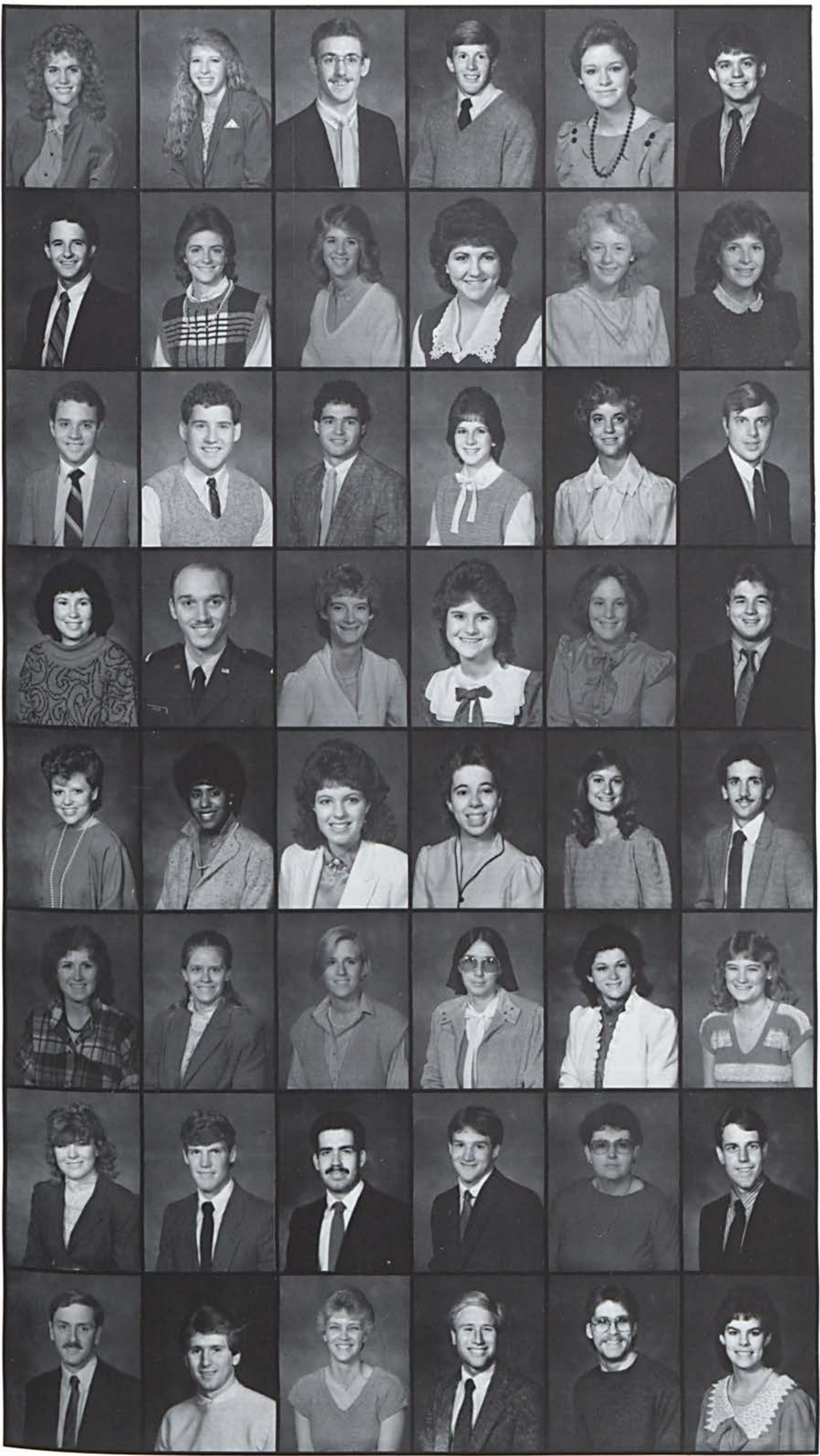

Rhonda Lee Kyser Susan Jane Lafferty Daniel A. Lahaie Michael C. Lane Sandra M. Lauterbach Michael David Law

deffrey Alan Leach Angie R. Ledford Doris Ann Lindley Michelle Livingston Catherine Mary Lombard Linda Ann Lons

Donald H. Lough, Jr. Brian Edward Maas Sheldon Scott Macgillivray

Terri Lynn Mackenzie

Lisa G. Manion

Bill Paul Marshall

Holly S. Marshall

Rodney Mark Mason

Kimberly A. Masters

Lynda L. Masters

Brenda Kay Mastin

Kelly R. Mathis

Sharon McAllester

Tanya Reneé McBee

Tracy Lynne McCoy

Lisa McDaniel

M. Elizabeth McGillivray Mark G. McIntyre

Carol M. McKinley

Dana Gayle Messinger Jill Meridith Michonski

Shirley Marie Miller

Tricia Miller

Sherrie L. Mills

Donna Gean Mitchell John Garrett Mitchel Brett E. Monford

Bryan Edward Monross

Sheila Diane Moon

John Andrew Moore

Dan L. Morris

Kevin Lawrence Moser

Lisa A. Motzer

James M. Murdoch

Patrick John Murphy

Ruth Marie Murtoff 
Nicolas Nervo

Beth Ann Nester

Edward W. Neudeck

Kenneth N. Nichols

Sherri Norrick

Wendy Norton

Sandra J. O'Boyle

Danny E. Olinger

Nancy Ann Ozinga

Teresa Joy Palmer

Deborah Carol Pate

Jeffrey Lynn Patrick

R. Michelle Perkins

Dan C. Petek

Thomas Lynn Peterson

Amy Phillips

Jean E. Pinkerton Jeffrey S. Piper

Rolando Ponce

Kim E. Potts

Amie S. Price

Douglas Edward Pugh

Ferdinand Henry Rajchel Kimberly Jean Ramsier

Roger Lee Randall

Daniel Howard Rase

Kara Ray

Patricia J. Reed

George Edwin Reede, Jr.

Lawrence G. Reeder

Jennifer Reeves

Rebecca D. Reid

Cheryl Ann Rendle

Kathy Dorris Reynolds

Pamela Jo Rickard

Timothy J. Rivetti

David Lee Robinette

James Allen Robinson

Kimberly J. Robinson

Renee Jeanne Rolfe

Sherry Marie Rotramel

Darren L. Ruby

Jill Ann Sandy

Timothy M. Schakat

Deborah S. Schwartz

Daniel R. Searles

Erick J. Seidel

Judith E. Semmelroth

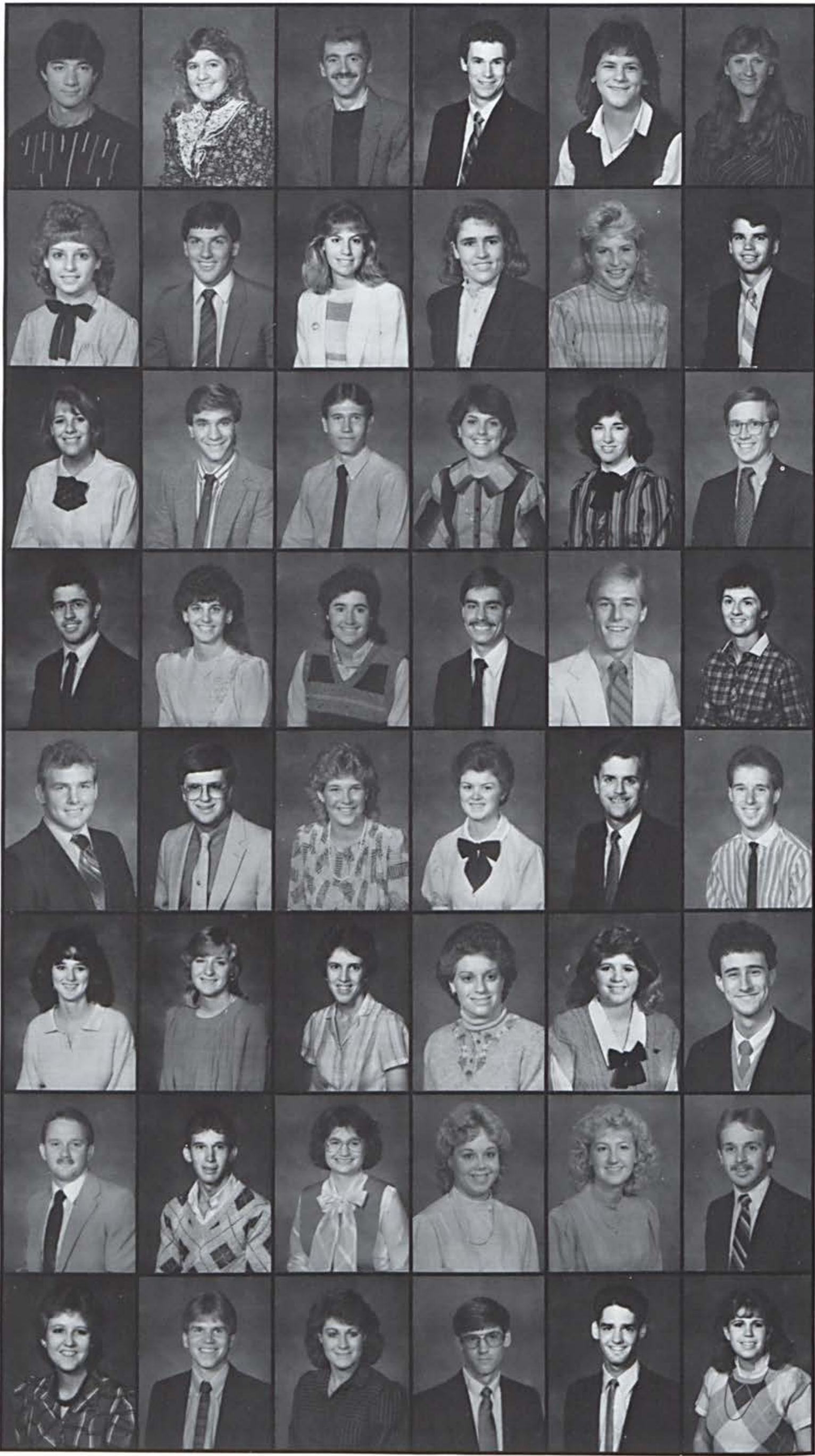



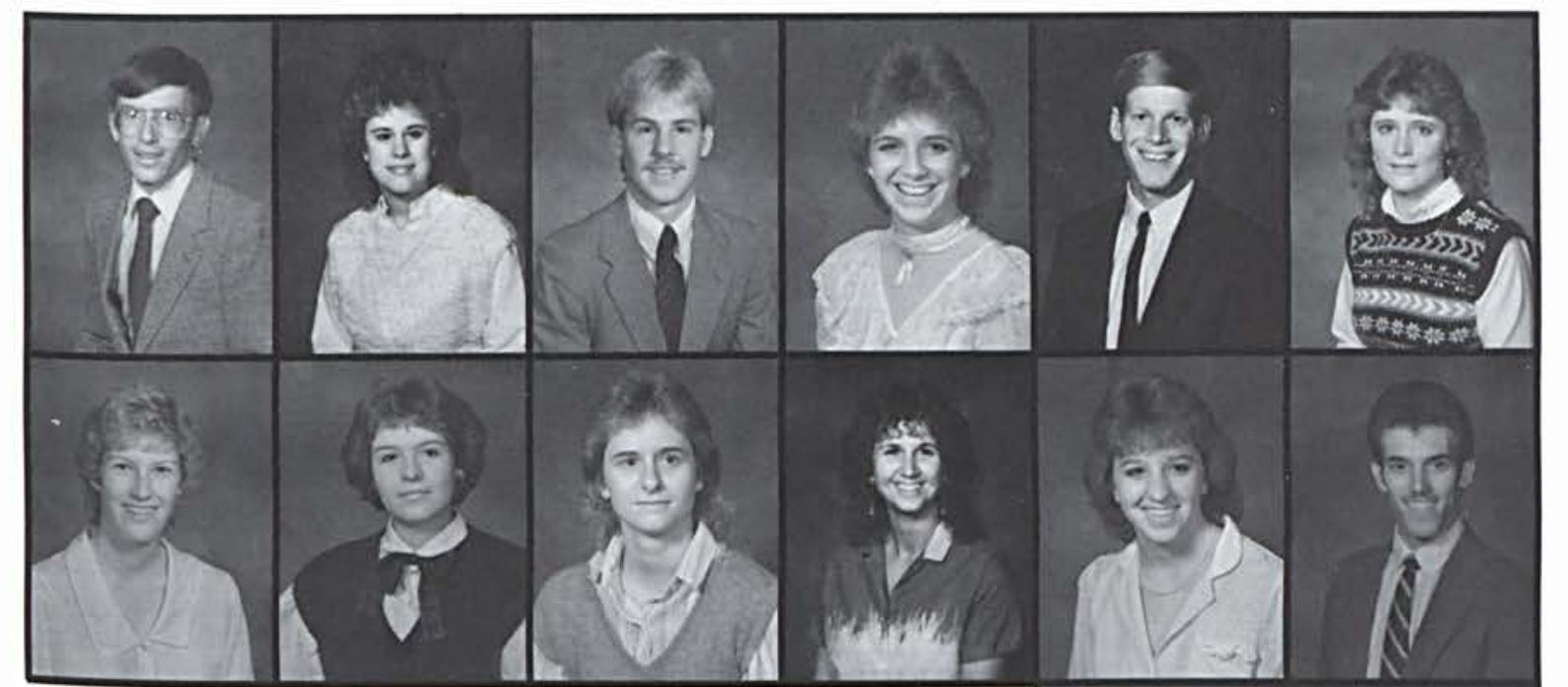

David Michael Sexton

Linda Lee Shaffer

Kevin A. Shaw

Deena Renee Shriver

Eric Lawrence Shrum

Sheri Lynn Shuler

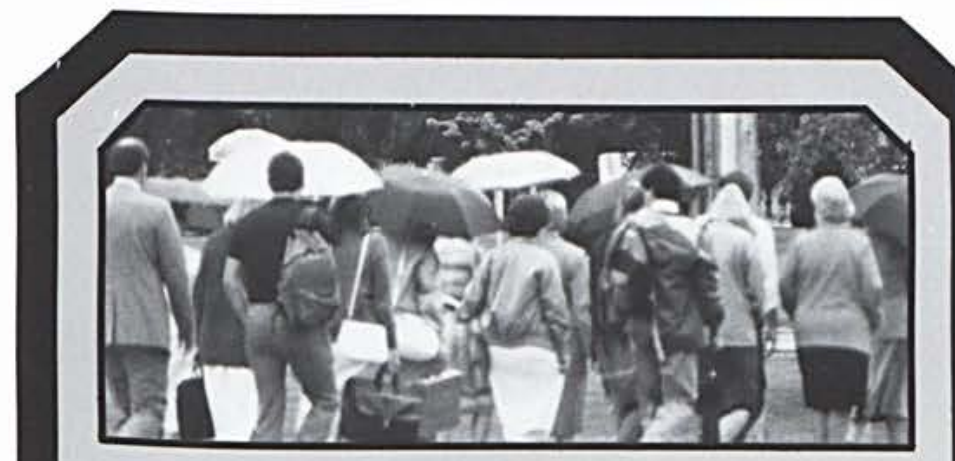

\section{Weather}

$B_{y}$ the time a person has completed three years at Cedarville College, he has experienced an average of 187 rainstorms, gone through 9 umbrel. las, and saddle-soaped salt deposits off of 31 pairs of shoes. Rainy days at Cedarville are more than common and require the students to be on their toes except for the girls. It is heel-to-toe so as to curb the mud spots in their hose.

Jeff Bergandine
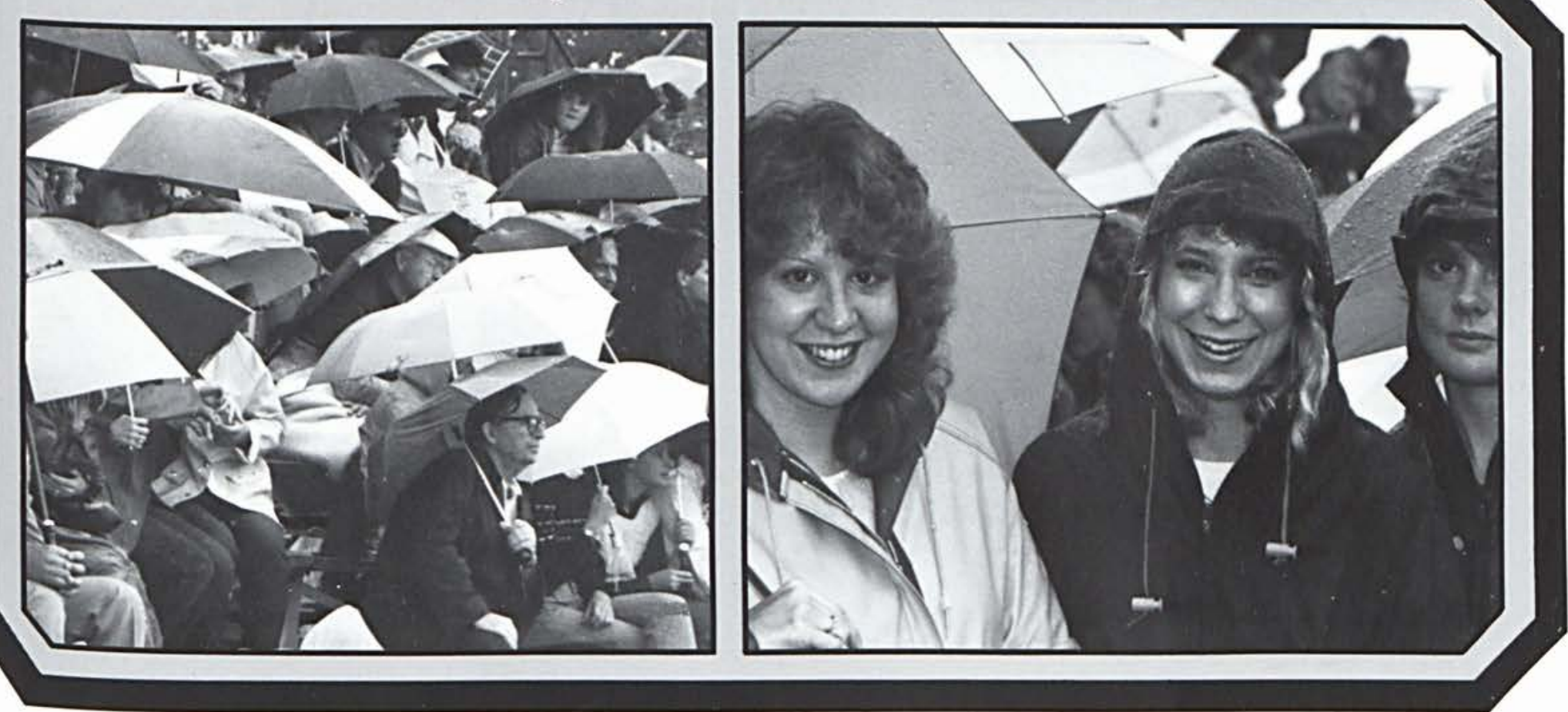
Donna J. Snyder

Dorcas Sommers

Sheila Ann Southwell

Samuel Theodore Springer Margaret Amanda Squires Julie Lynn Stackhouse

Wendy A. Stith Jill K. Store Ronald Lee Stowell Brian P. Sturgis Kurtis Summerville Pamela M. Swanson

Jill A. Swayze

Deborah Synnott Susis Marie Taddicken Carrie Marie Tansey Shelley A. Tarke Allison Kay Taylor

Diane L. Taylor

Walter L. Taylor Steven Keith Terpstra Nadine Lin Terrill Amy R. Thomas Donna J. Thomas

John Jay Thompson Lydia Bae Thornton Edward Todd

Phyllis Mae Trivett Jennifer Titus Robert John Turner

Lisa L. Tyson

Kristy Lee Vance Jeffrey L. Vander Heide

Gregg, Van Kampen

Kimberlee S. Venman Jeffrey Allen Ve Strand

Bridgot Kathleen Vissman Gerald Clayton Wallace, Jr. Kevin Lawrence Wallace Steven P. Walter Brandon Troy Waltz Andrew Jay Watson

Robert Kent Watson Kristin R. Weber David A. Wehman Amy L. Welch Douglas D. Whittenburg David Alan Wiinamaki

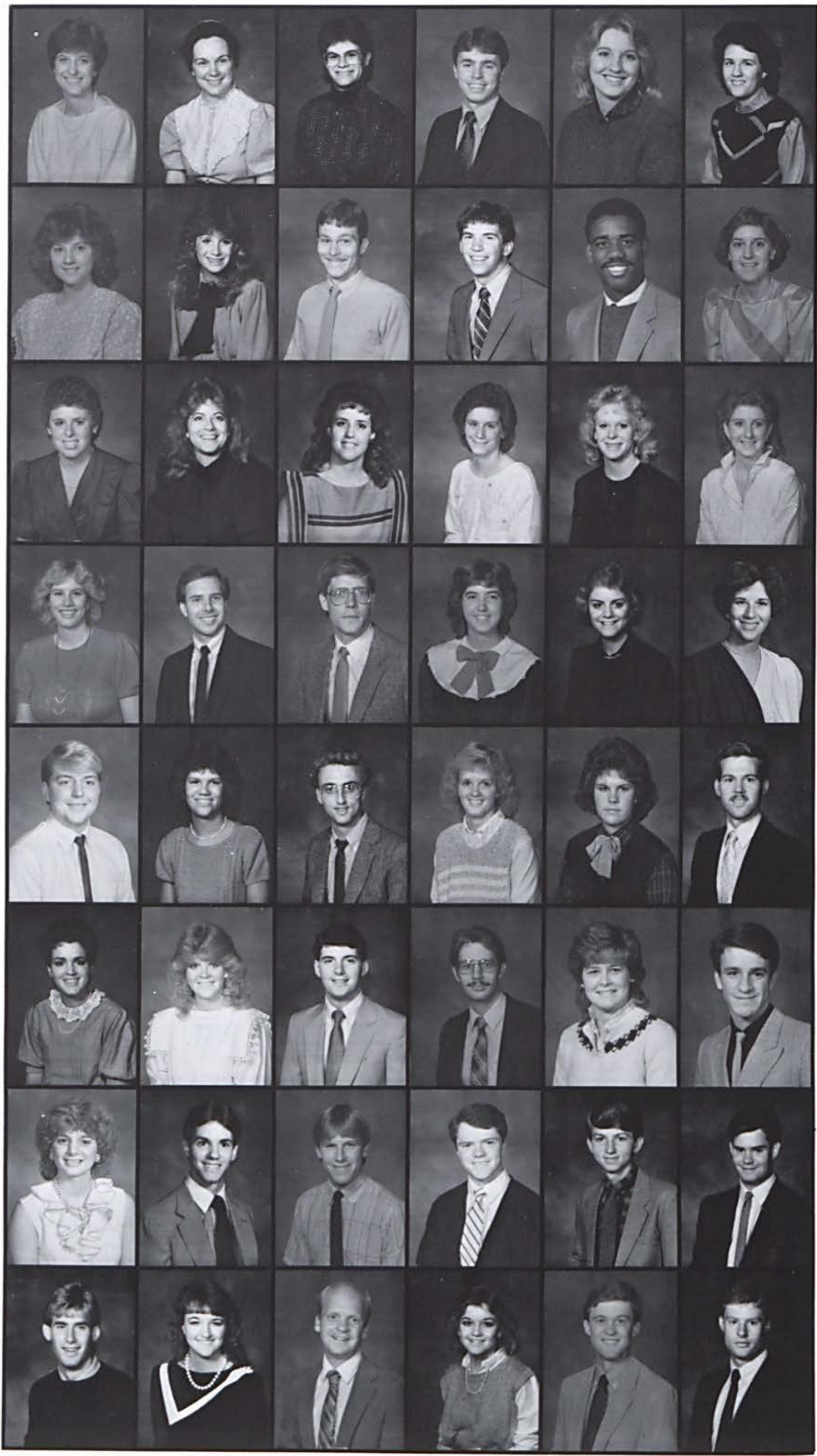




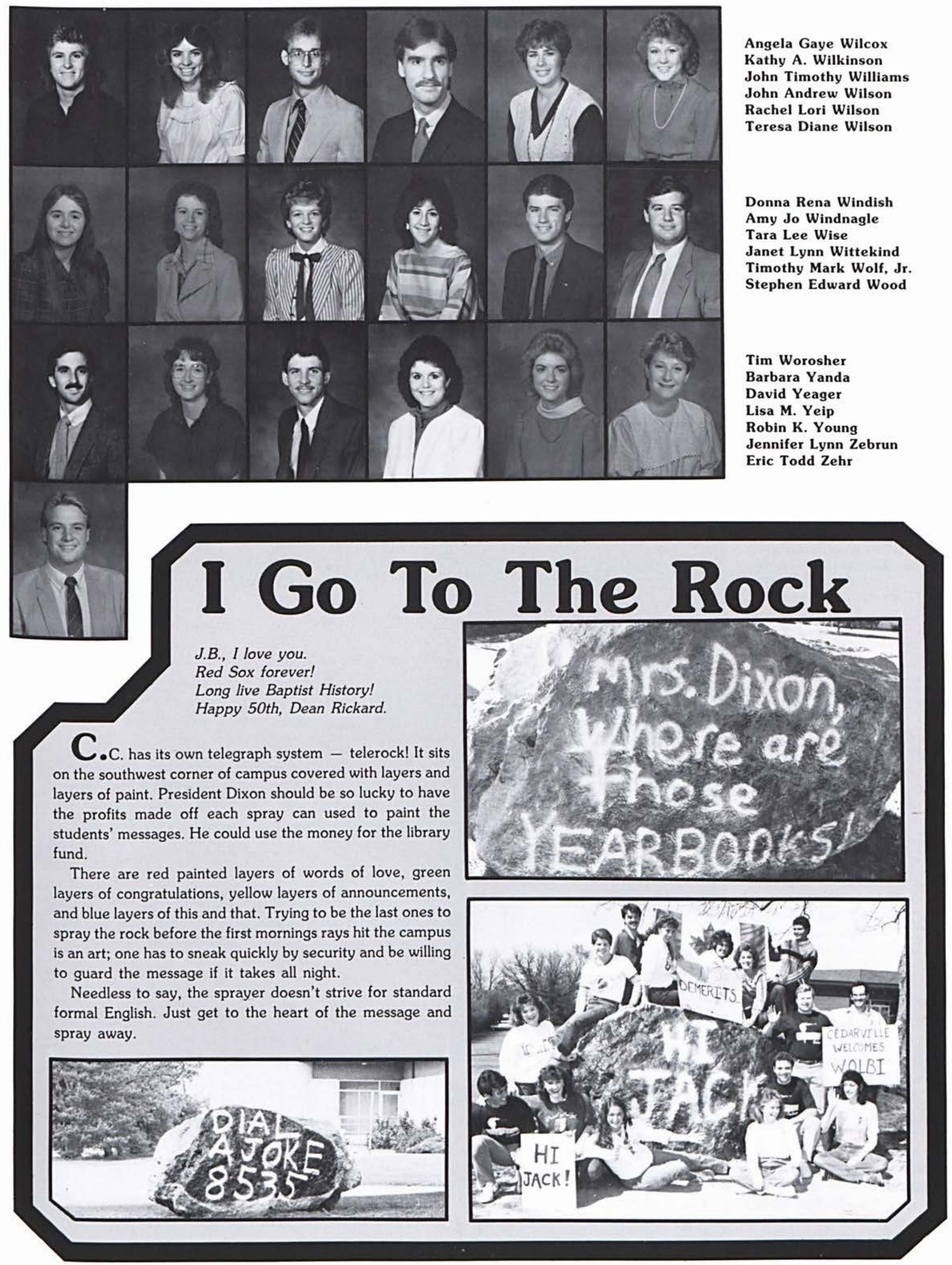




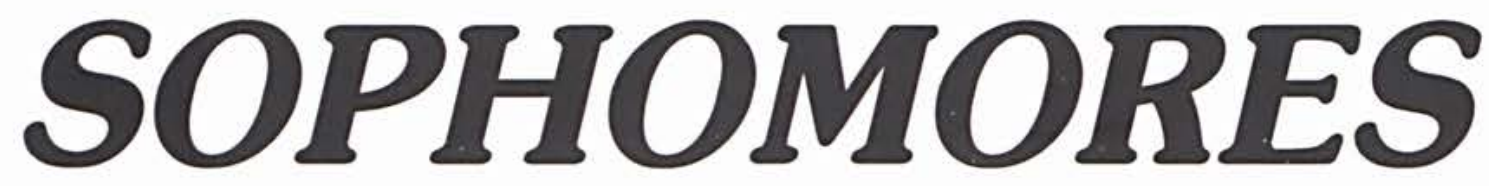

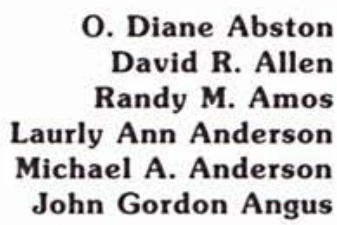

Robert A. Armor Patricia Jean Armstrong Katherine Elizabeth Augustine Lee S. Austin Debbie Jo Baker Jeffrey Alan Baker

Doug F. Baldwin April Leann Banks Caryn Lynn Barber Joel B. Barker Albert G. Barrett Denise Marie Bass

L. Daniel Bayes Timothy N. Beach Dawn E. Beachum David Jonathan Beal Deborah Lee Beaujean Linda Sue Belford

Wendy $\mathrm{K}$. Bell Joan H. Beltz Kelli Larae Bensink John Andrew Bercaw Jeffrey $W$. Bergandine Judith Lynn Bianco

William Eugene Bianco II Kimberly Kaye Biddinger Steve Douglas Billingsley Carol Joy Bliss Rebecca Dawn Bliss Debbie R. Borleis

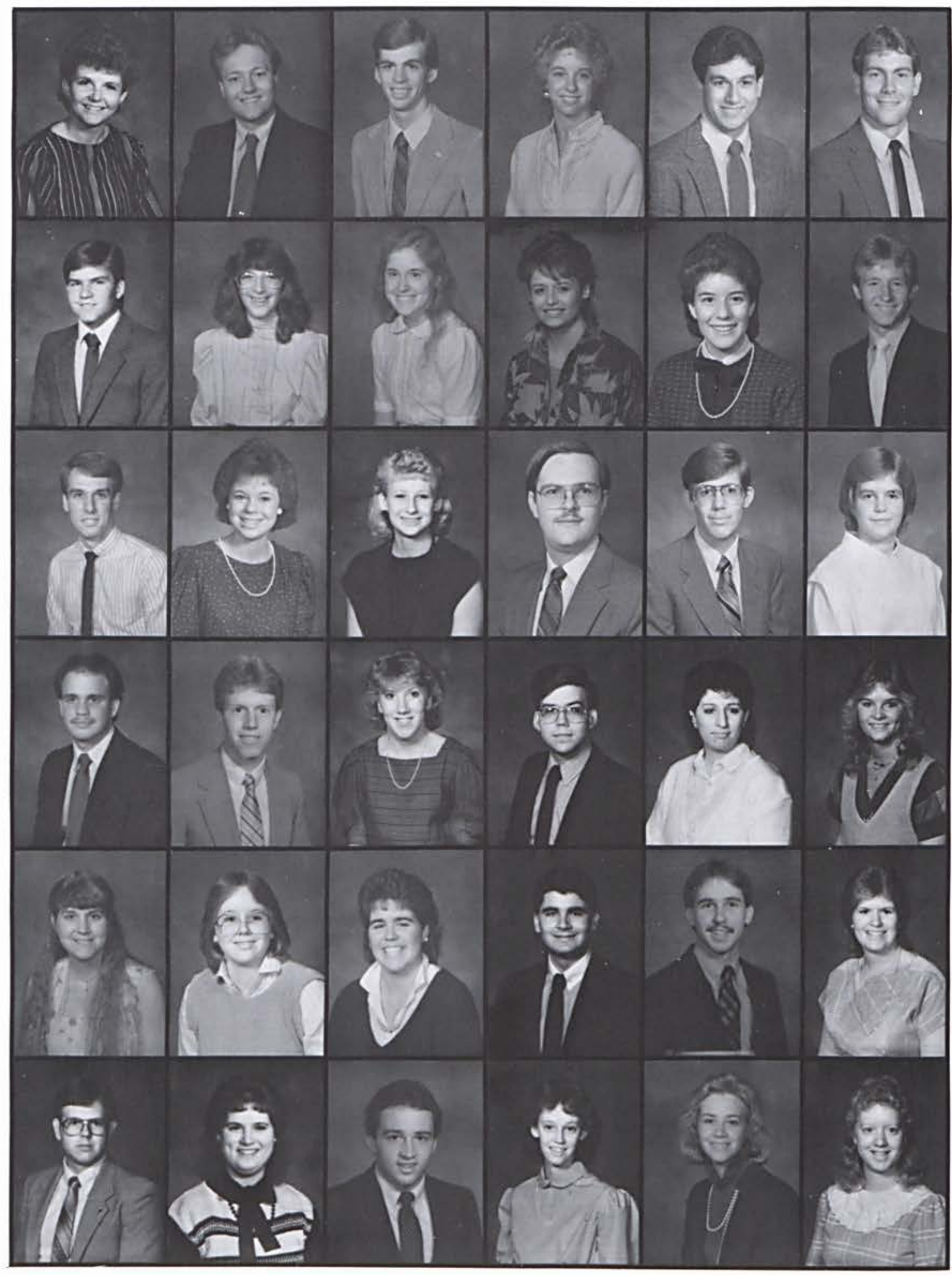




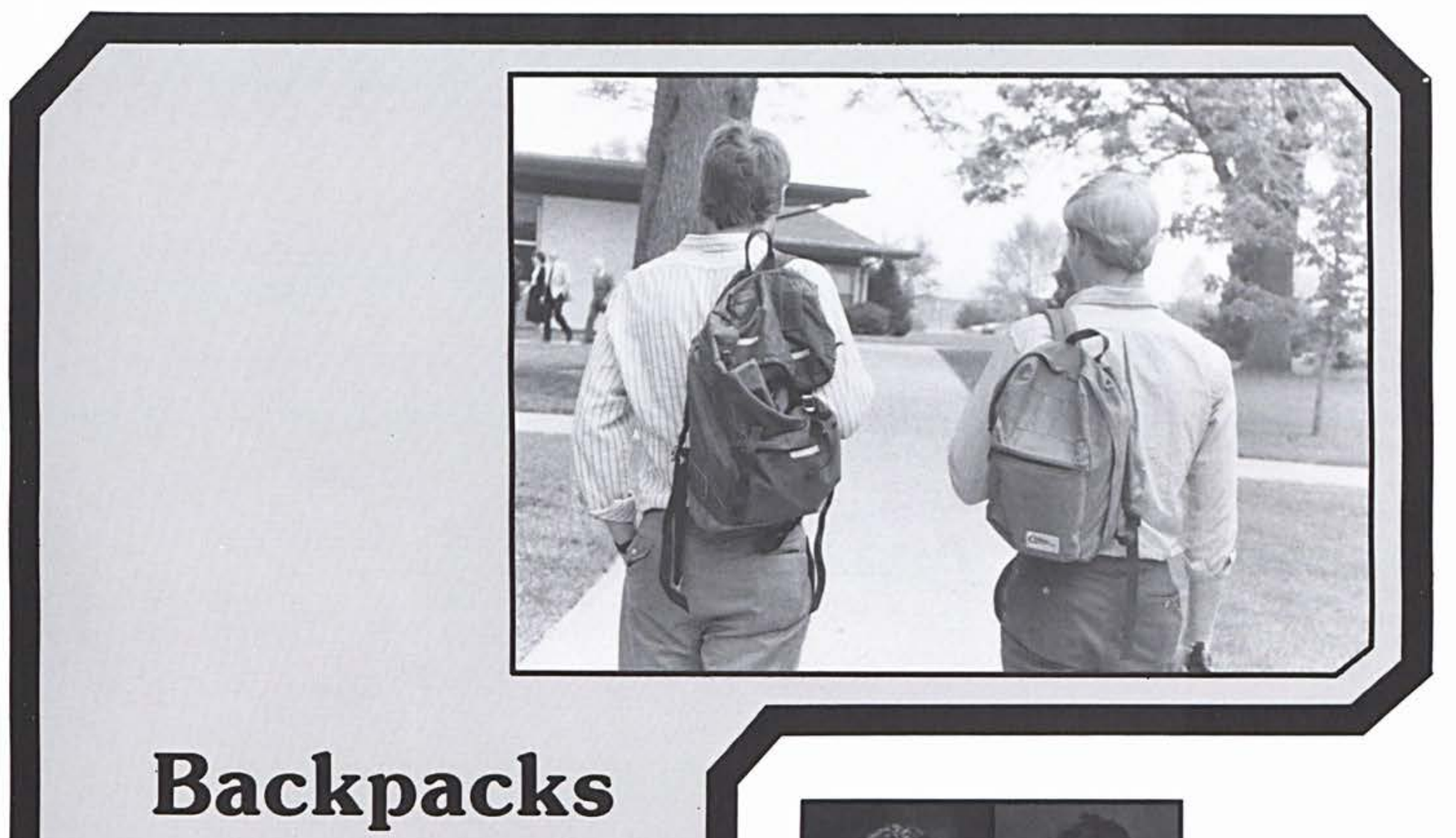

\section{Backpacks}

nly a few brave souls dare to carry their books uncovered at Cedarville College. Among the containers used to tote books to and from classes, backpacks are most popular. Backpacks are as distinct as the individuals who carry them. Colors range from chartruse to wedgewood blue and brand names from L.L. Bean to Sears Roebuck. The backpack, however, will not go far in the corporate sector and should be succeeded by a briefcase in one's senior year.

Jeff Bergandine

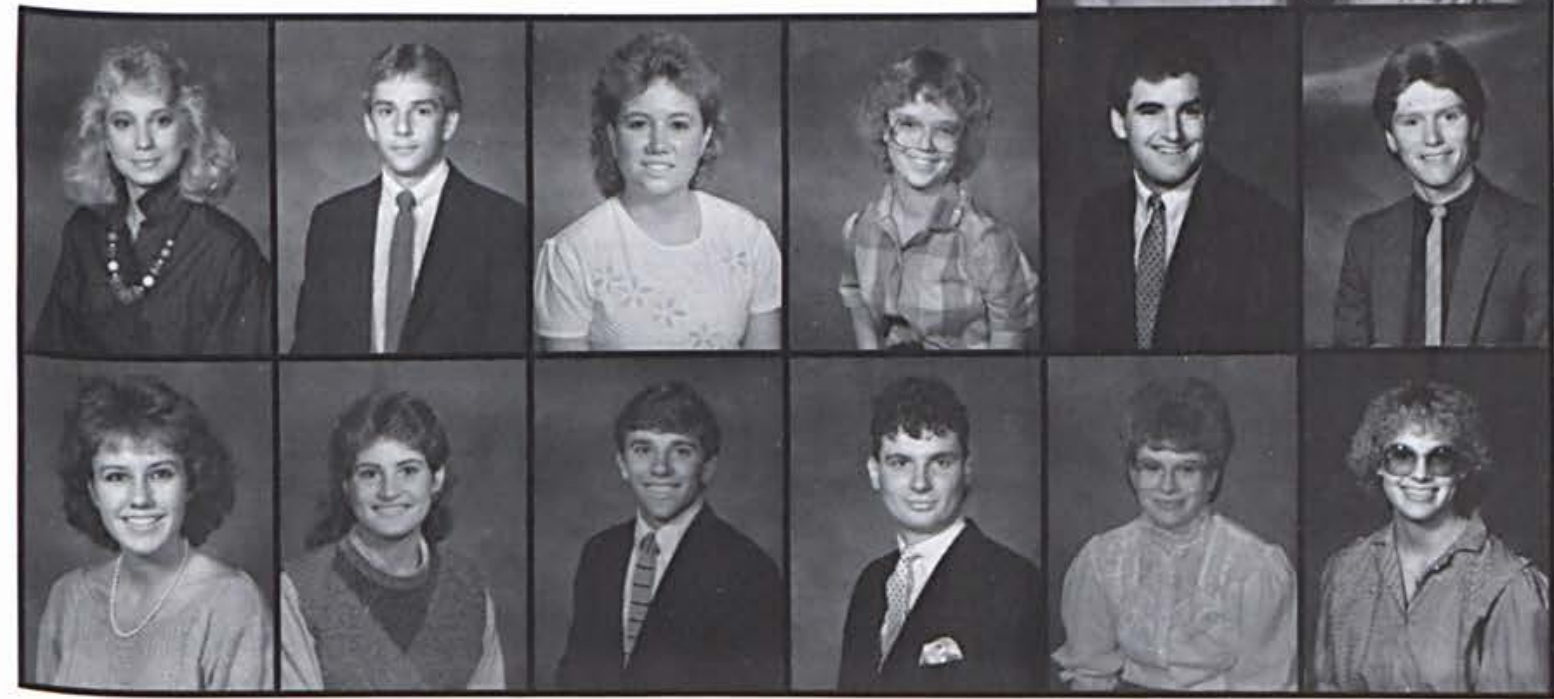

Diane M. Borleis

Krisanne Bartholomew

Talitha Ann Bosworth William Allen Bovey

Martha Sue Bowers Lisa Carol Bowlen

Angela Dawn Bowling Bruce Howard Bowman Debbie Lynn Boyd Mindy Brace

Kristian D. Bradman Kevin Bradshaw

Kim Bradshaw Kimberly K. Bragg Brad Lee Bresson Jeffery P. Brown Lori Lynne Brown Linda G. Browning 
Philip Nathan Brunner Brent Budd

Tonya Jonell Bumpus

Calvin B. Burke

Holly J. Burke

Kimberly Joi Burrell

Jennifer Lee Butler

Daniel K. Byrum

Patrick Ray Cadle

Gayl M. Calkins

Judy R. Calle

Christine M. Carafa

Wendy Elizabeth Carmichael

Renee L. Carr

David R. Carraher

Christine Mary Cheek

Karen Clifford

Cindy Ann Collier

Peggy Ann Collier

Nancy K. Columbo

Lonnie E. Cooper

Lynn Ellen Costley

Matthew Creamer

Sherri Lynn Cruver

oralee M. Cruz

Rhonda Culbert

Kristi Culp

Sue Ann Cunningham

Tina Marie Daley

Kelly Jo Decker

Todd Bryan Dehus

Penny Rae Dellinger

David W. Dennis

Keith A. De Walt

Edward Lyndon Dible

Todd A. Dowden

Sarah Lynn Drake Joy A. Dubois

Debbie Ann Dysert

Kimberly K. Eager

Linda Ann Eberly

Jody Paula Eckert

Ruth Ann Eissens

Eric David Efting

Karen Jane Elliot

Mark Gardner England

Michael C. Engler

Evan English
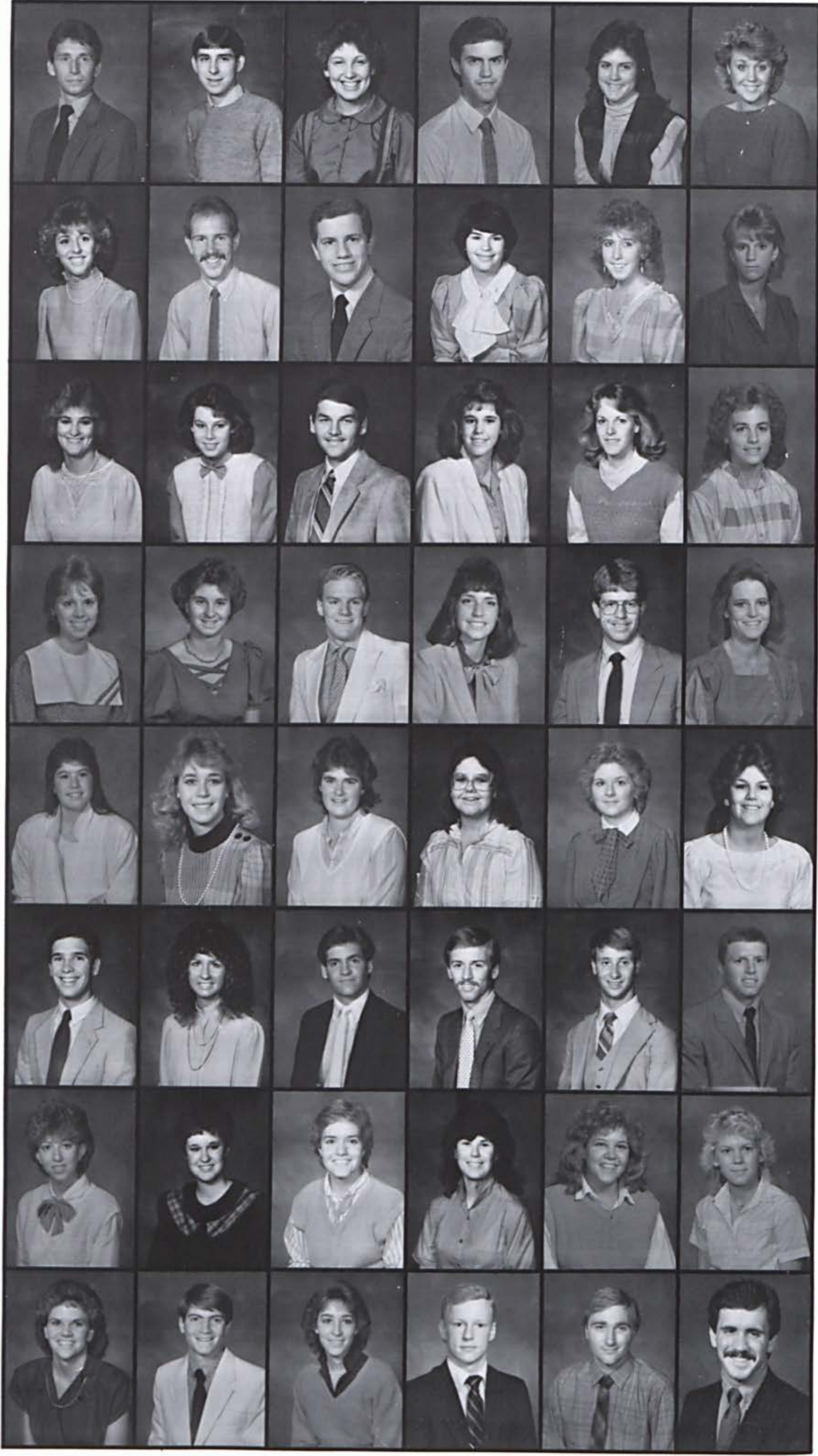


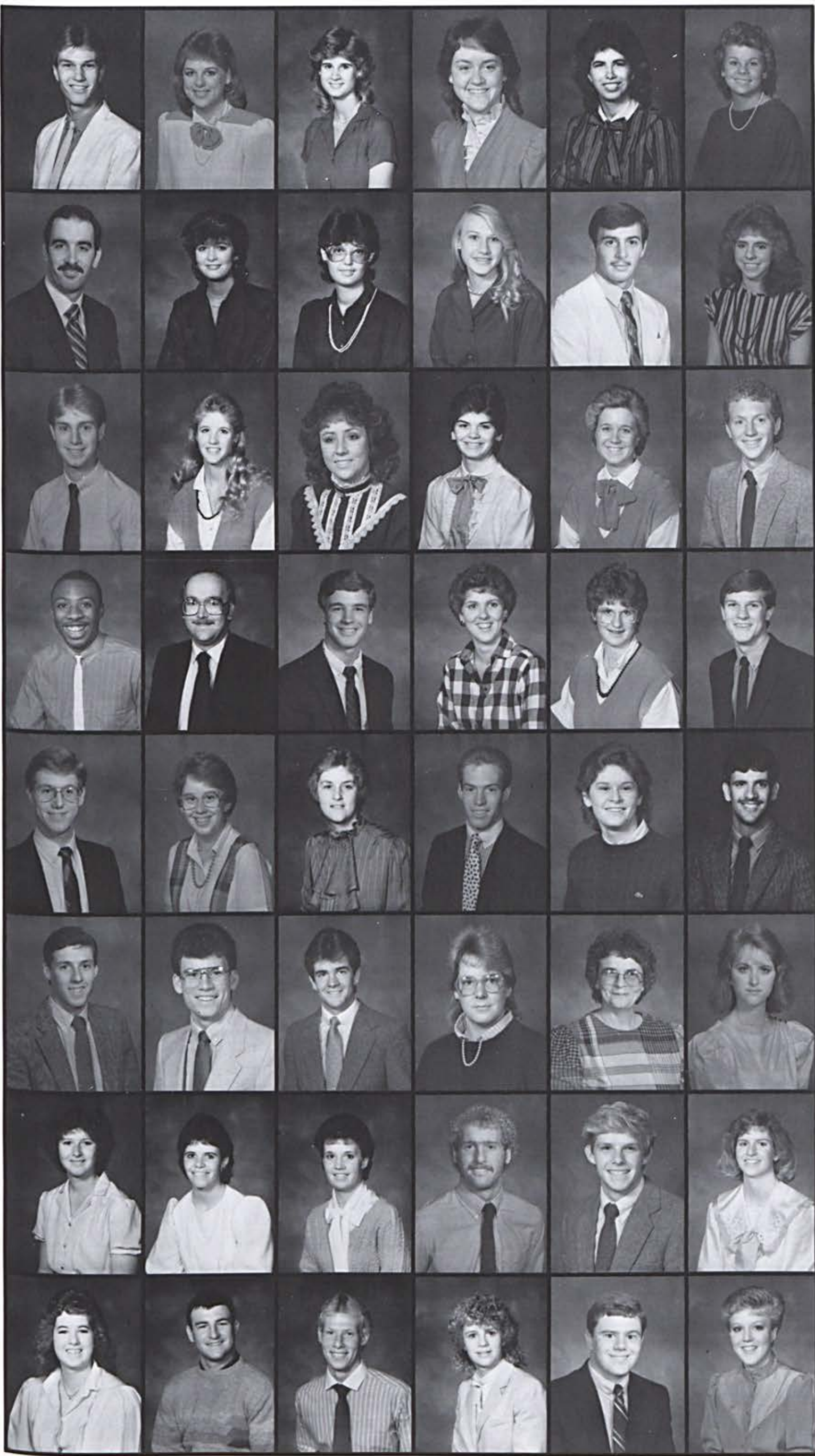

Daniel Bruce Erlandson

Layne E. Etchison

Donna Jean Evans

Tonya Lynne Evans

Jennifer Lynn Everage

Susan Renee Everitt

Mark H. Fairhurst

Melissa E. Felt

Alice L. Fenstermaker

Melody Rose Ferguson

Gary Franklin Fernandez

Laura Jeanne Fetzer

Keith E. Field

Bethany Jayne Flenner

Lisa Ford

Kimberly Ann Fordyce

Debbie Lynne Foster

Greg L. Frank

Michael B. Freeman

Gary Marvin Frew

Dean Alan Frey

Christine Ann Friedkin

Eileen D. Friesen

Chip A. Fullerton

Daniel W. Gaskell

Carol Ann Geese

Julie Ellen Gersema

Alan Leonard Gilstrap

Pauline Marie Ginsberg

Allen D. Gipson

Bradley G. Gregory

Robert William Gresh

Mark Larry Groves

Cindy M. Guido

Margaret Ellen Guido

Rebecca Jo Haga

Heidi Lynn Haist

Melanie G. Hall

Melissa J. Halleck

Paul L. Hamlin

Keith Allen Hammer

Nancy Glynn Hanna

Sherri Lynn Hannay

Joel Scott Harbaugh

Mark Harden

Kathleen J. Hardman

David R. Harper

Jennifer K. Haufler 
Jennifer S. Haupt Joel A. Hayden

Ronda Mae Heise Donna E. Helm

Theresa J. Henry Robert G. Hicks

Cheri A. Hill

Kirsten T. Hoddelmann Kristina Theresa Hoddelmann Mari Jo Hofer

Gretchen Anne Hoffmeyer

Sandra Lee Holbrook

Cheryl Lynn Holland Brenda K. Hollopeter Van B. Holloway Robert Holmes Joanne Renee Hornbeck Kenneth R. Horton

Shellie Kim Horton Deborah Lynne Howard Laura Susan Huggart Beth Ann Hughes Brian Albert Hultz Todd D. Hummel

Lisa Renee Hurst Terri Lynn Husband Norma Hutchison

Kristine Kay Hyatt Barbara Louise Jacobs James W. Jacobs

Vickie Yvonne Jackson Mark D. James Julie Ann Jensen Eric Lynn Johnson Jan Renee Johnson

Kristyn Johnson

Karen Sue Johnston Dean Edward Jones Amy Lee Joslin Kathleen Lynn Kegel Pamela Beth Kenyon Deborah Lee Kettel

Beth A. Keyes Kendra J. King Robert William Kinney Barry L. Kitchen Laurie Anne Knowles John M. Kormash
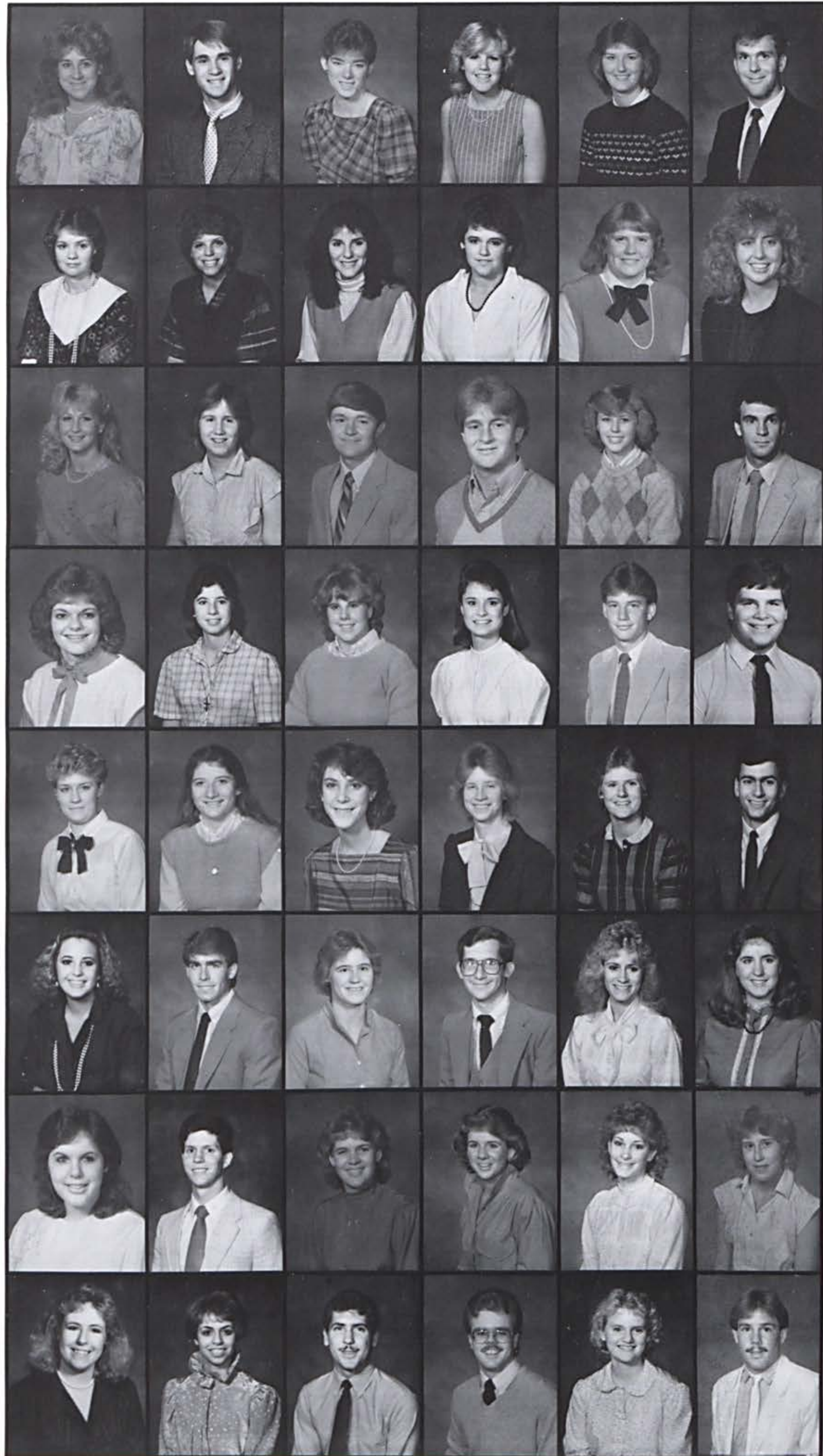


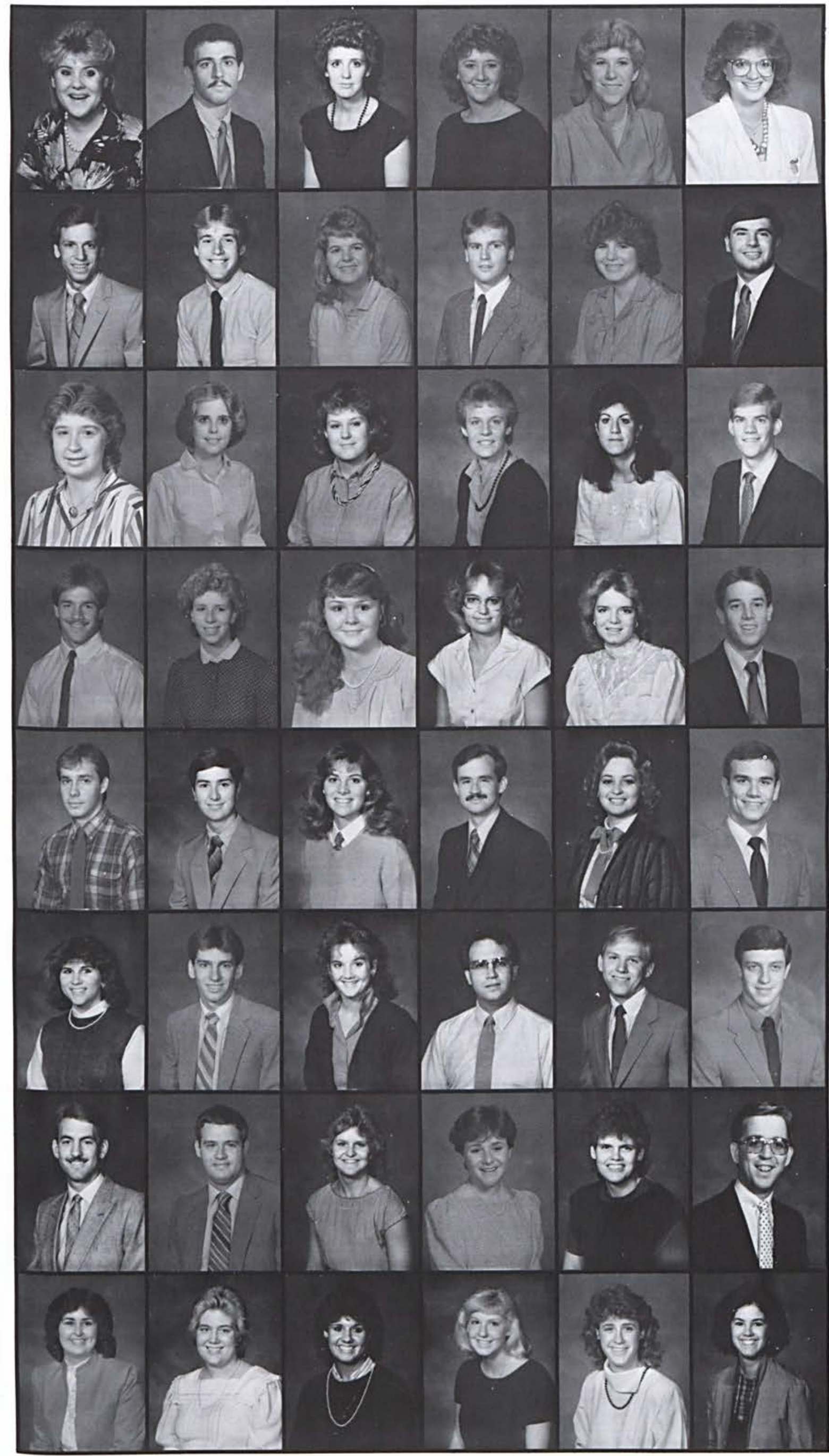

Kara Frances Kozma

Kip F. Kratche

Kathy Ellene Krull

Diane Louise Kruppa

Laura Kay Kuntz

Michele Laird

Stephen Philip Lamb

J. Michael Landis

Rogé Dawn Lash

Terry Edward Lassitter, Jr.

Beth Anne Latorella

Robert L. Latorella

Barbara Lynn LaVancher

Tracy Yvonne Lawrence

Julie Anne Lawson

Shari K. Leach

Michelle Jan Lelah

David Andrew Lindley

Christopher S. Link

Roxann Lee Livengood

Gina Rae Long

Brenda Mae Lynn

Heather Lynna Macfarlane

Thomas Stuart Mach

Kevin Mackenzie

Mark D. Maglott

Laura Lynn Maiers

Jeffrey Donald Main

Stephanie Jo Manning

Karl E. Mansfield

JoAnne L. Mantz

Brian J. Marburger

Ruth Evelyn Margraff

Keith L. Marion

David Lawrence Markison

Scott Alan Marsh

Jeffrey A. Martin

Ronald L. Martin

Syndy Jane McCafferty

Jeanne M. McCarrell

Stacy Marie McCaskill

Gilbert Delano McClanahan, Jr.

Christine Ann McCormick

Michele Lea McGarry

Amy Beth McKibben

Cherry Joy McLaughlin

Deborah Lyn Meriwether

Sharon Lynn Michael 
James D. Mieden

Andrew L. Mininger

Michele D. Moody

Pamela J. Moon

Christopher Dale Moore

Kelly Micheal Moore

Scott David Morgan Ruth Dawn Morris

David Lee Mossman

Gretchen Lynn Mountz

Chad Vincent Moyer

Steven R. Moyer

Paul K. Muckley

Errin G. Mulberry

Glenn Steven Nash

Tammie Sue Nasse

Patrick M. Nesbitt

David J. Netzley
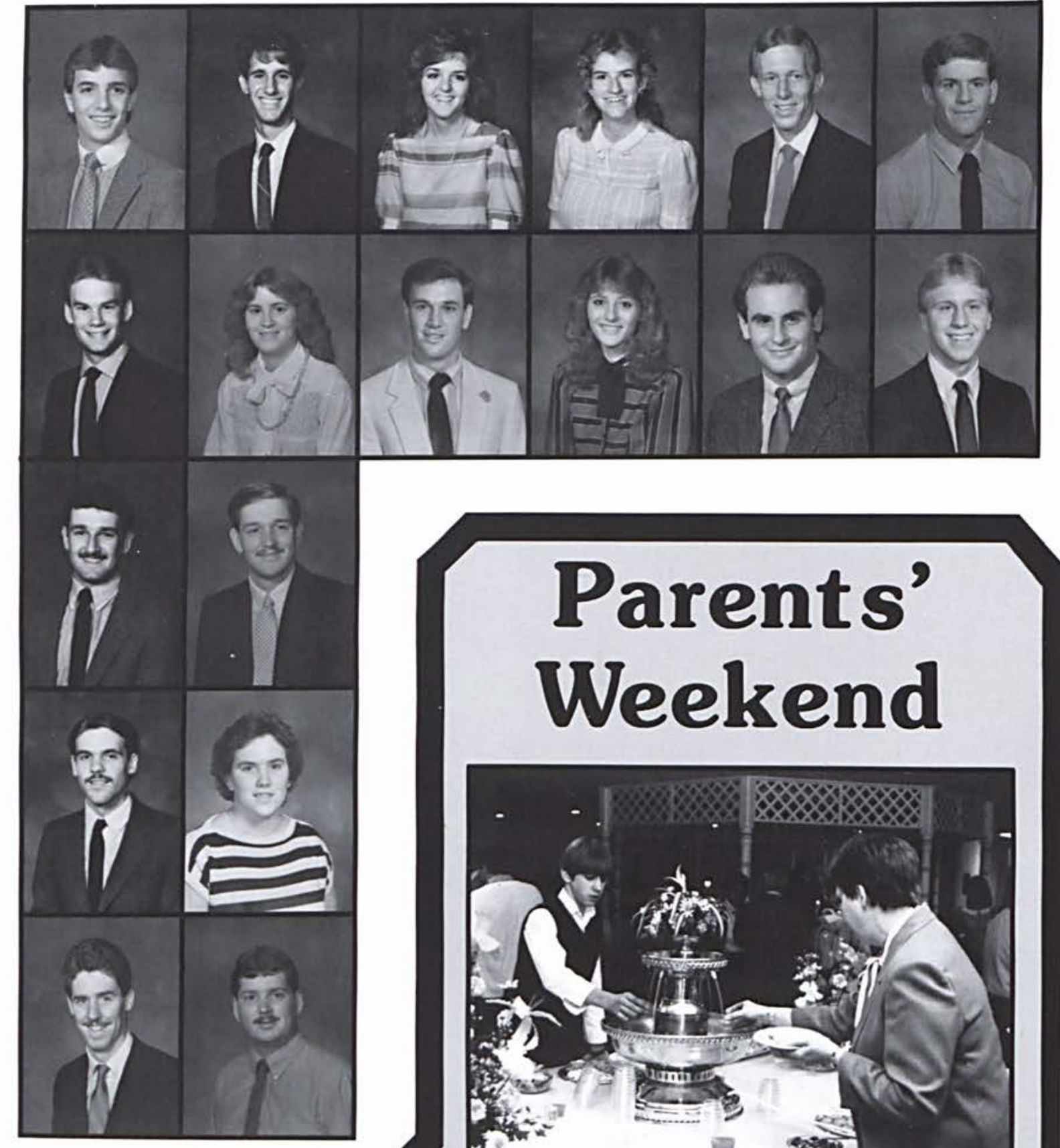

\section{Weekend}
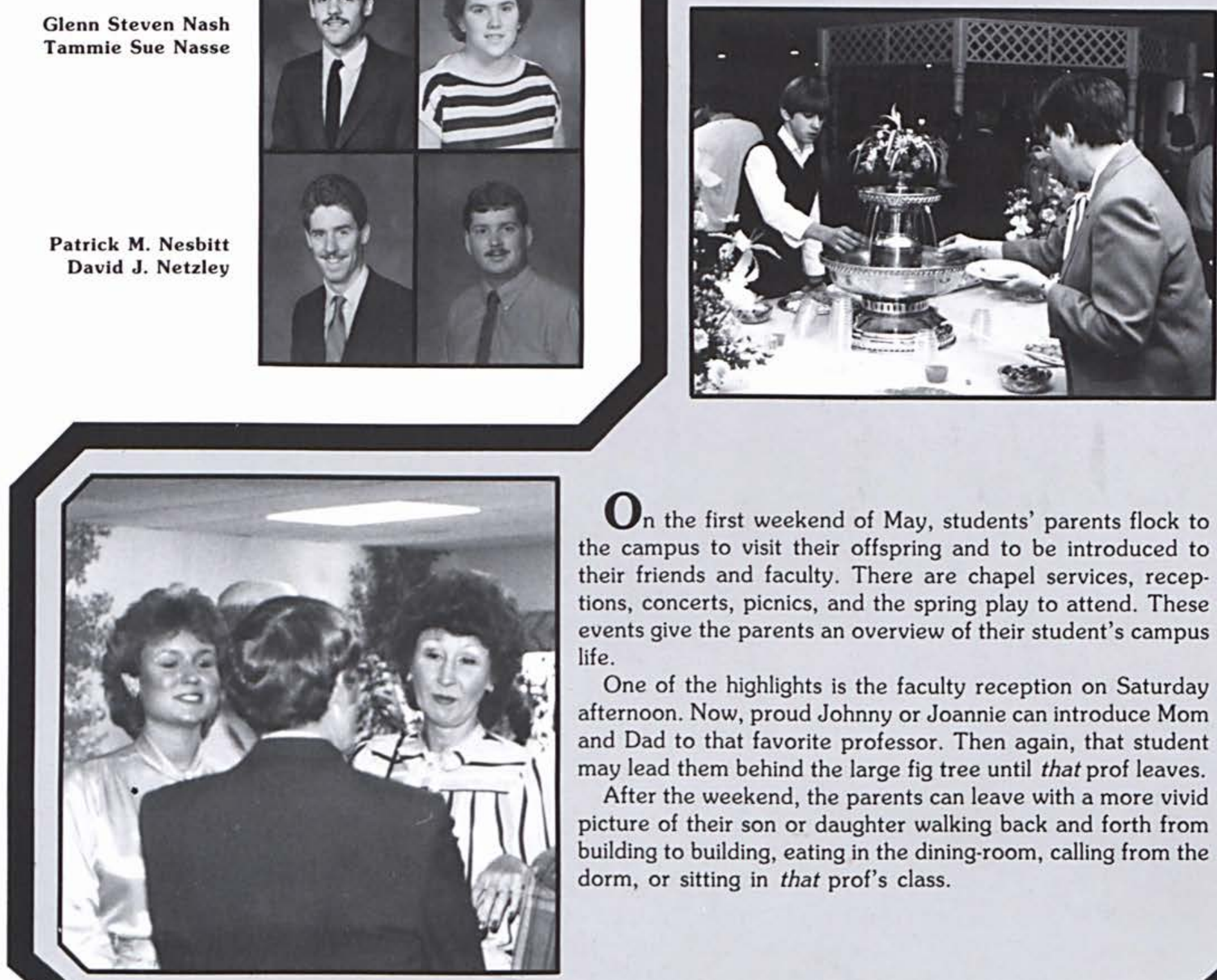

the first weekend of May, students' parents flock to the campus to visit their offspring and to be introduced to their friends and faculty. There are chapel services, receptions, concerts, picnics, and the spring play to attend. These events give the parents an overview of their student's campus life.

One of the highlights is the faculty reception on Saturday afternoon. Now, proud Johnny or Joannie can introduce Mom and Dad to that favorite professor. Then again, that student may lead them behind the large fig tree until that prof leaves.

After the weekend, the parents can leave with a more vivid picture of their son or daughter walking back and forth from building to building, eating in the dining-room, calling from the dorm, or sitting in that prof's class. 


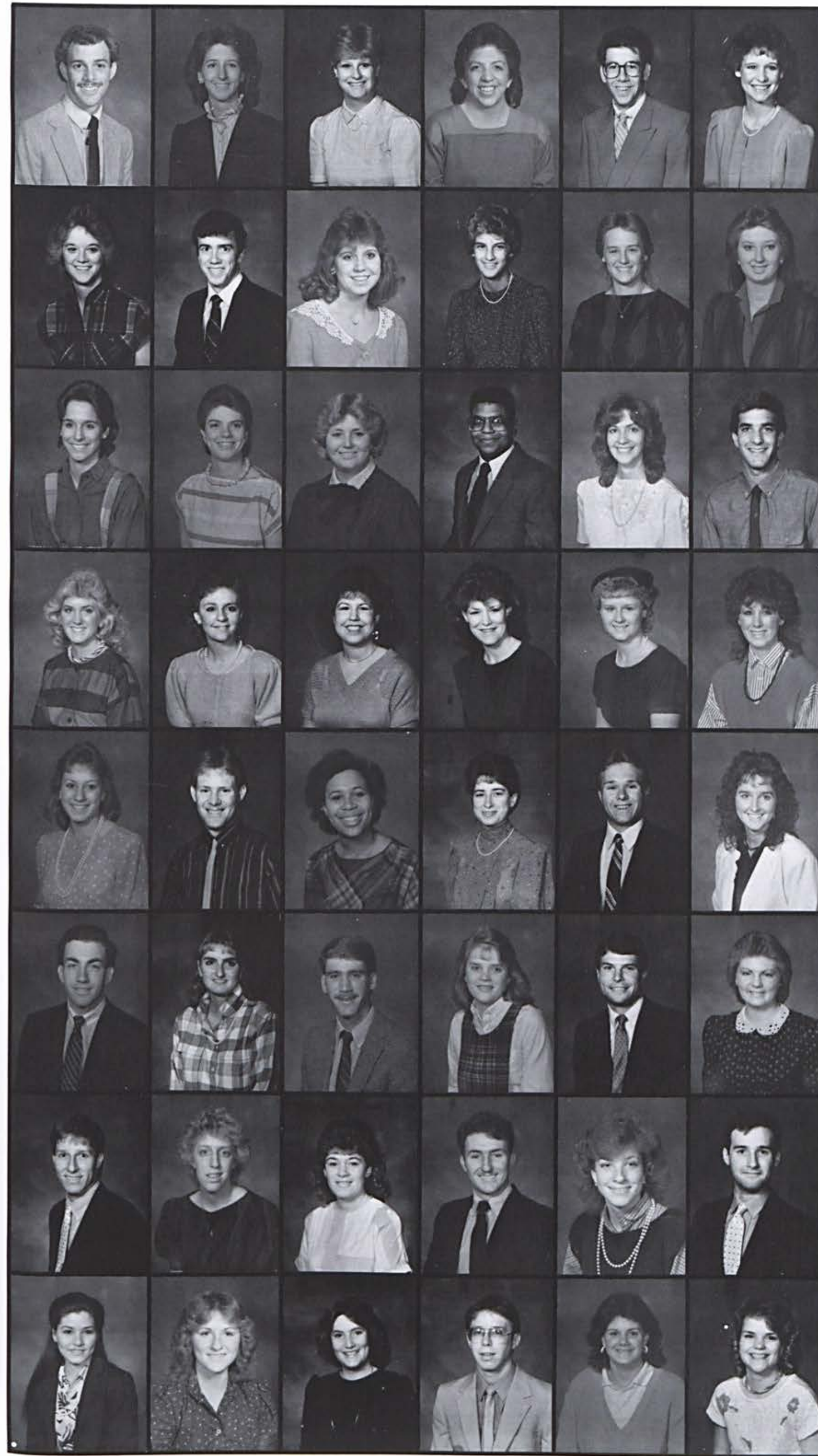

Cory S. Neumann

Dianne M. Noggle

Leslie Lee O'Donnell

Kathy A. O'Kresik

Gordon Gregory Ooms

Lori Diane Osborn

Lori Ottaway

Tim S. Page

Patti J. Parker

Carolyn S. Patrick

Crystal Ann Patrick

Jennifer Lynn Patrick

Jennifer Marie Patry

Cheryl Lynn Paxson

Shelly Rae Payne

Silas Pearson

Suzanne Marie Perott

Rick Charles Petek

Rebecca J. Peters

Diana Sue Phillips

Cheryl Ann Plooy

Marian Denise Presley

Gwen Renee Price

Yvette Printy

Becky Lynn Pruner

Steve Allen Racz

Ebbie Joy Radcliff

Mary Margaret Raisch

Kenneth A. Ramey

Debbie M. Ramaker

Brian Reebel

Krista Gail Reed

Mark Alexander Reed

Michele B. Reed

Chris A. Resse

Lori Lee Reid

Tom Reiter

Debra Ruth Reynolds

Lori A. Rhoden

Hamilton Don Richards

Melissa Riggs

Craig D. Ritchie

Thea Karina Rivera Jennifer Lynne Rogers

Tamara Karen Rogers

David Mark Roggow

Wendy Rose

Gayle Lesley Ruggles 
Melissa Sue Runion Jimmy Rushe

Heidi Marie Ryan

Kerri L. Sadler

Mark Edward Salyer Scot Alan Schieferstein

Kevin James Schleinitz

Fay D. Schonfeld Charles V. Scott

Richard Fulton Sechrist, Jr.

Erick Seefried

Lila M. Seest

Marcia J.A. Sewell

Lorena H. Shaff

Ronette Shank

Phil A. Shaull

Elizabeth Ann Shepherd

Sandra Kaye Shulse

Joy Elizabeth Shuman Lynne Sickau

Don Howard Simerly Karla R. Simpson Jill M. Slayton Robin Kay Sloan

Janae Michelle Smart Allyn N. Smith

Kristine Lynn Smith Rhonda Lynell Smith

Rich R. Smith

Bonnie B. Snyder

Connie Marie Soellinger Keith Duane Soules Kevin Lee Sperry Lori Jan Spiegel Kristen E. Stagg Susan Lynn Stalter

Larry Von Starkey Meredith Ann Steiner John Robert Stephens Jennifer Dawn Stevens

Betsy G. Stoltzfus

Tamara Sue Storm

Lila L. Strause Heather Renee Stretch Brenda J. Sutliff

Mark Alan Swander

Alice Maureen Sweitzer Rebecca Leah Tacket

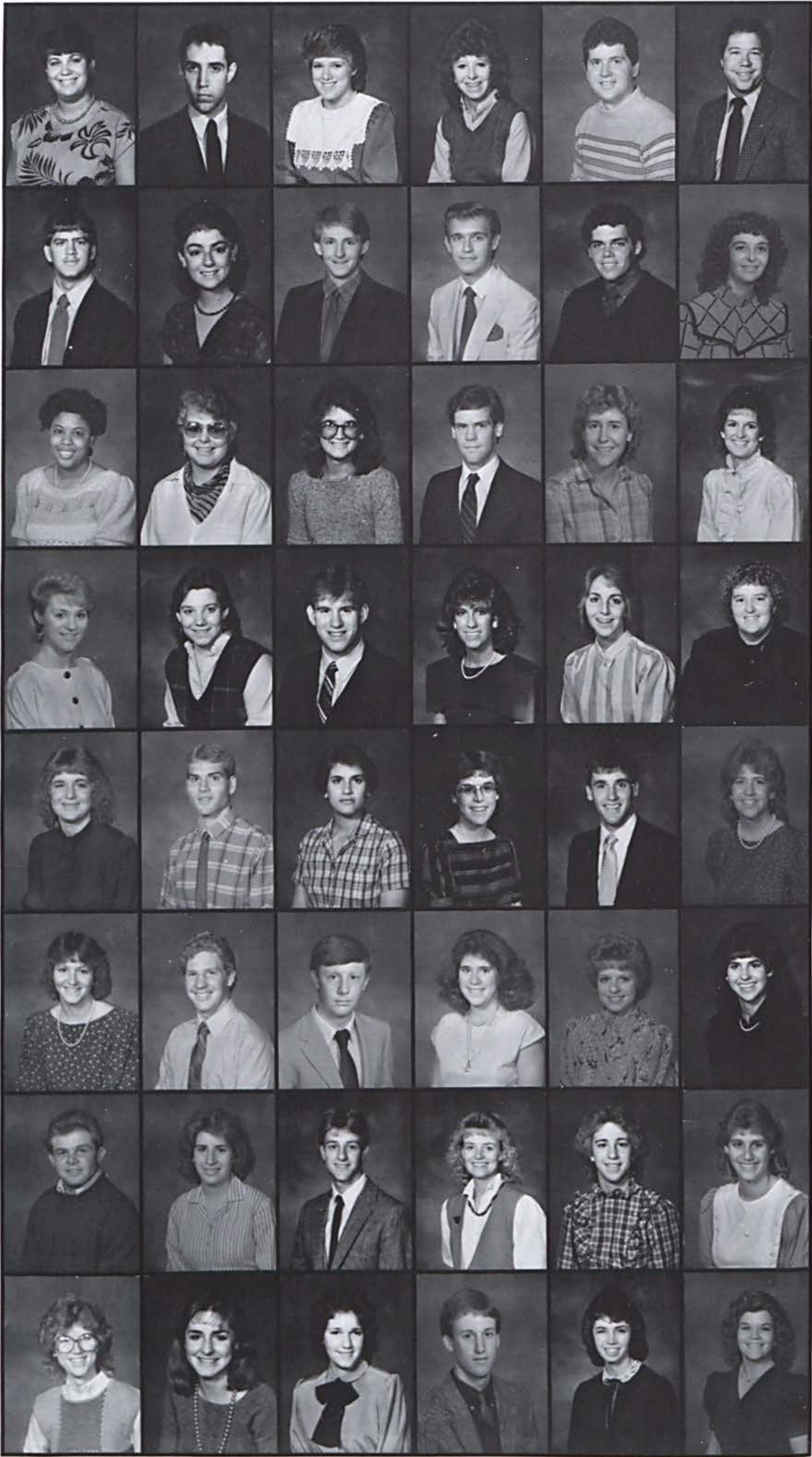



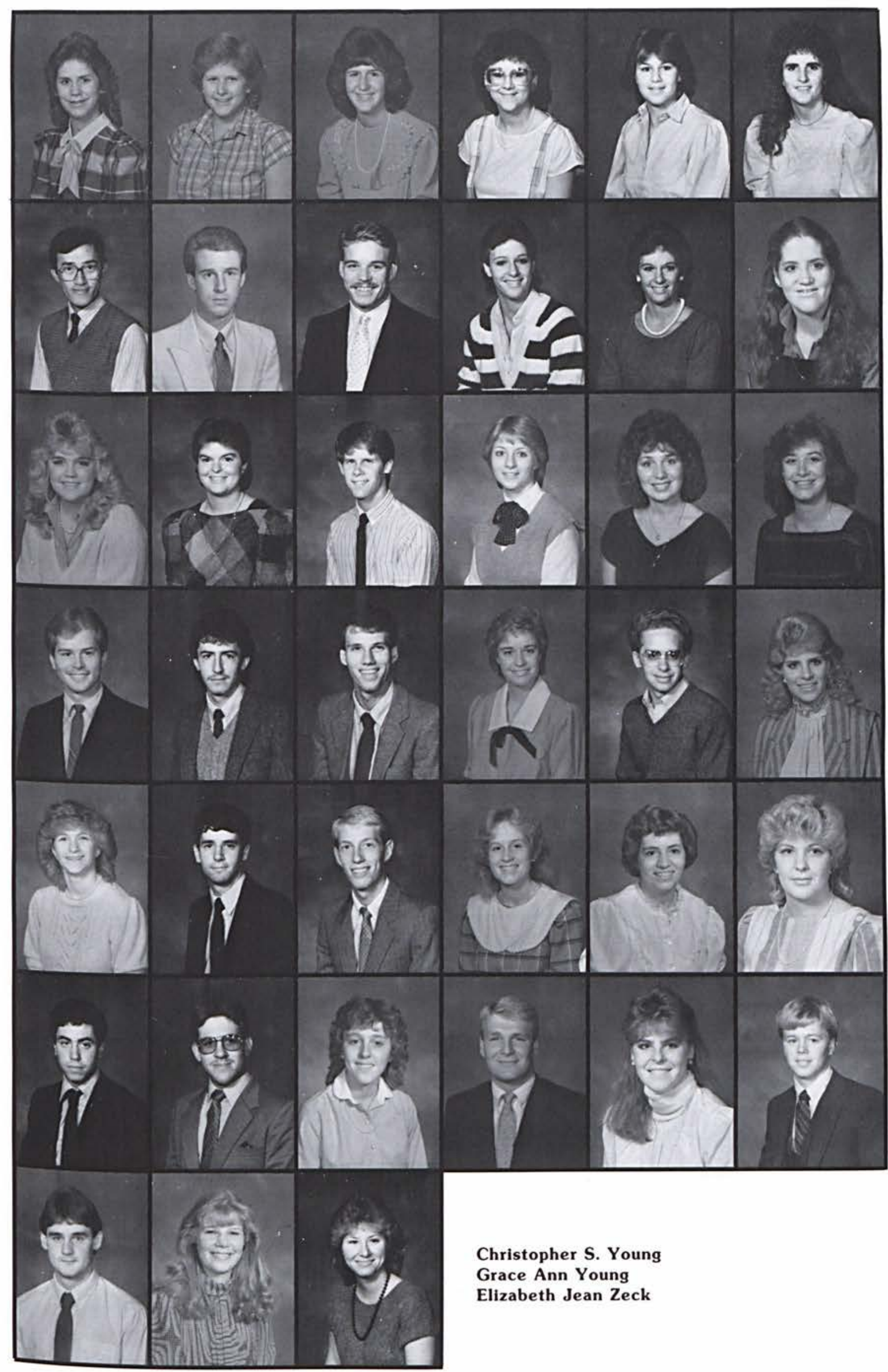

Christopher S. Young

Grace Ann Young

Elizabeth Jean Zeck
Valerie Jean Teed

Susan Vivian Terkelsen Joanne Elizabeth Thompson

Debra Sue Timco

Andrea Lee Torok

Sara M. Triehy

Donald Tung

John Paul Tuttle

David C. Tyler

Terri Lynn VanBeveren

Toni Lynn VanBeveren

Margaret L. Vanderberg

Deborah K. Van Dorf

Lisa Marie Vaughn

James C. Venman

Tamara L. Venman

Cari S. Vucish

Cynthia Jayne Wagner

Timothy M. Walborn

Brett J. Waress

Michael William Warfield

Melissa Sue Way

Conrad R. Weaver

Carla Carol Weitkamp

Loreena G. Westfall

Russell Allen Wight

Tim A. Willms

Rebecca Ann Wilson

Melissa Nadine Windish

Rebecca Ann Wingard

David A. Wolcott

Jeffrey Owen Wolfe

Cathie A. Worthley

Dave Paul Wuestner

Jill Sharysse Wyse

Brian Duane Young 


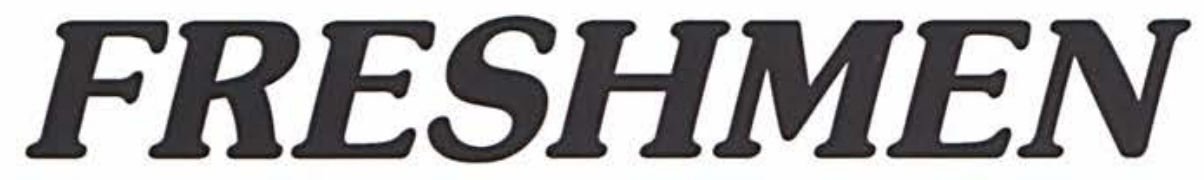

Timothy Wayne Abramowitz Maudetta Kay Adamson Debby Ann Ager Theresa L. Allen Andrew R. Allinson Ronda Lea Altman

Catherine L. Anderson Rachael Lee Angst Matt James Anthony Andrew S. Apple Stephen Leslie Apple Amy Lynn Armstrong

Vince Amor Robert C. Atkinson Cathy Marie Avery Susan R. Avey Michael Edward Ayres Brian David Baab

Brion J. Bachman Teresa Yvonne Bailey Jeffrey Alan Barber Dannah Kay Barker Roberta Lynn Barnhart Troy David Barton

David Anthony Batencourt Sherri Ann Bauer Kerry Eugene Baumgartner Dawn Leona Beach Scott James Beattie Daniel Lincoln Beck

Jacki L. Becker Julia Michelle Beimly Amy Ruth Belgarde Lisa Marie Bengtson

Rachel Mae Bennett Sharon Lynn Betlejewski

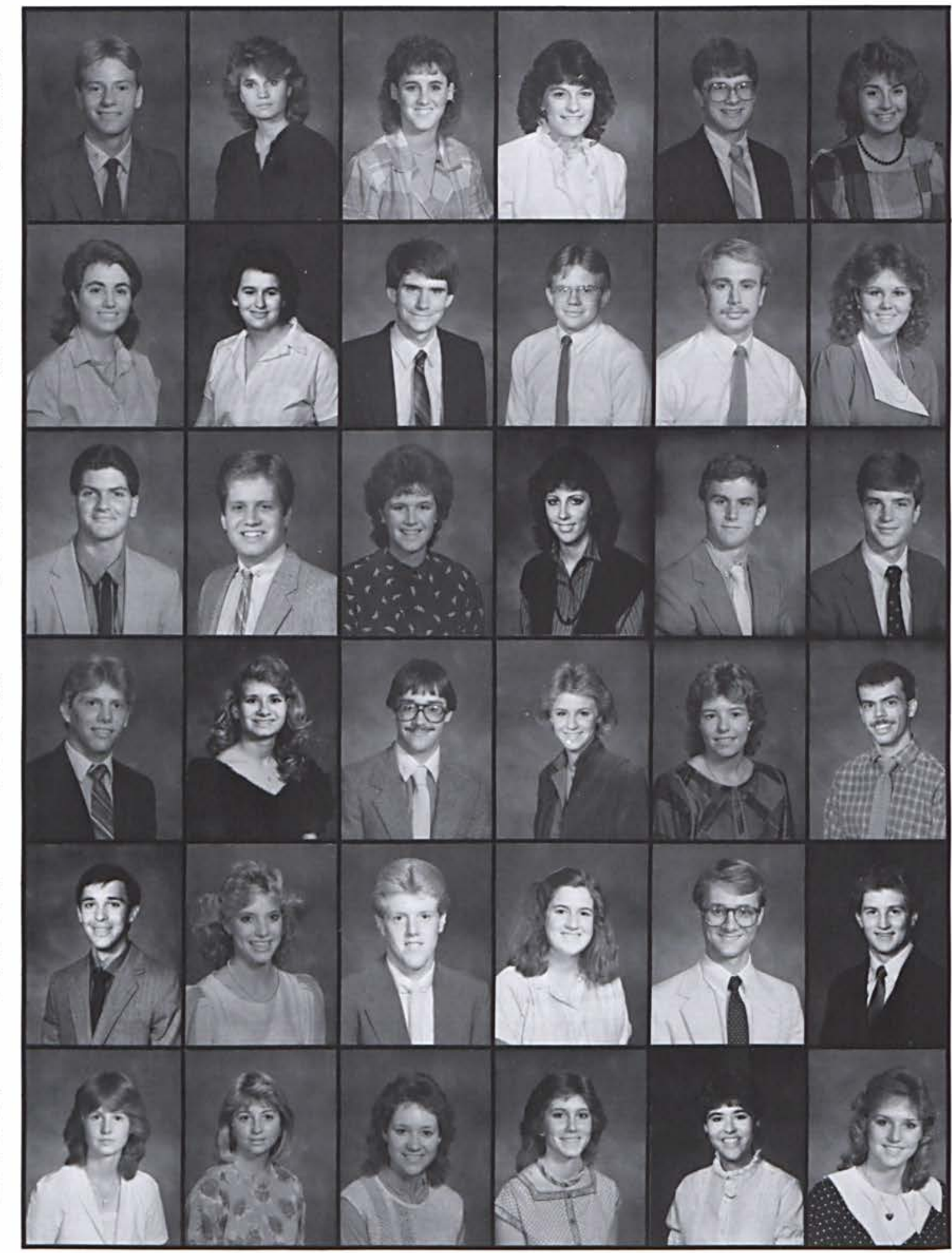




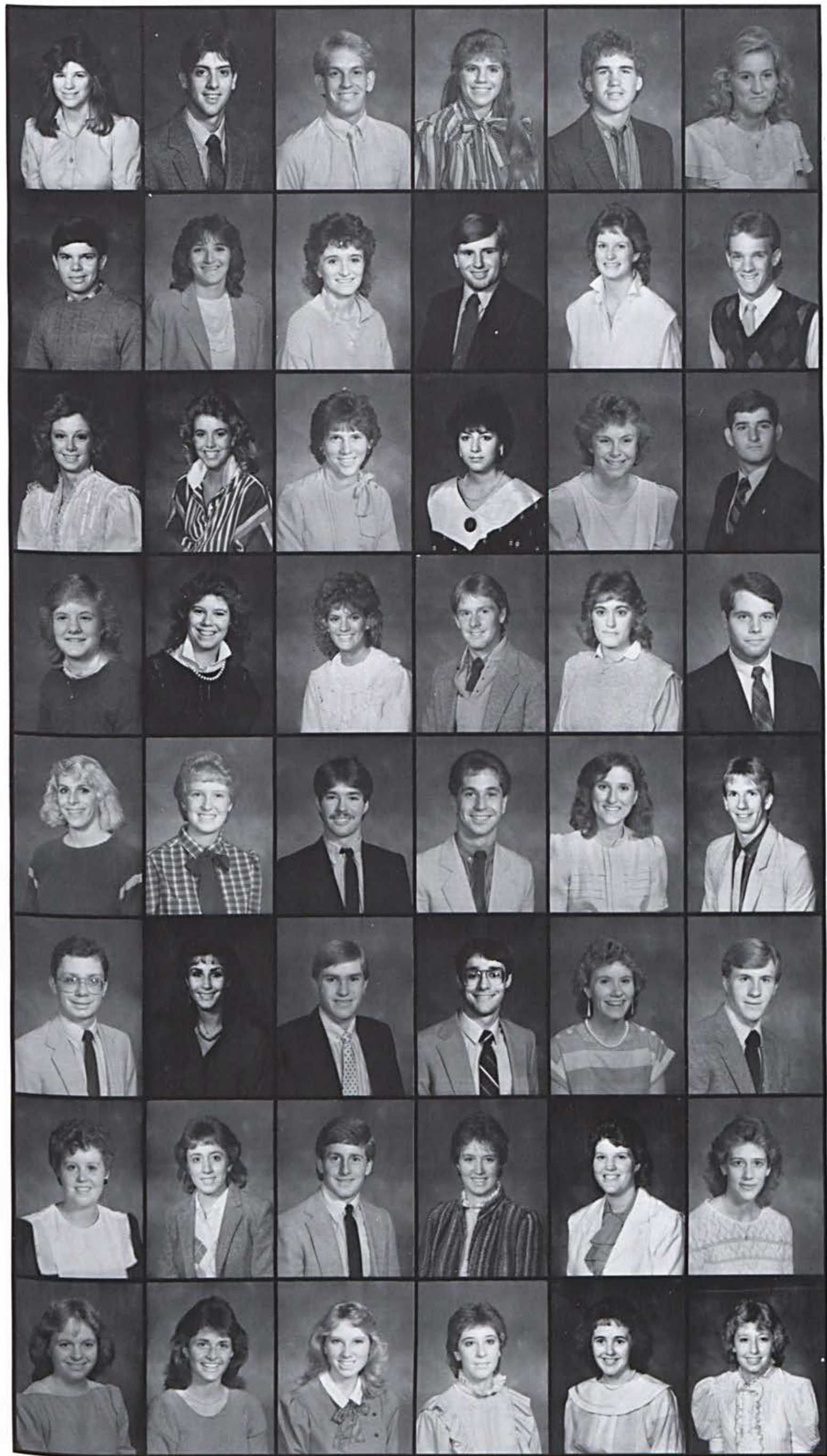

Donna Lynn Blumenstock John G. Bocciardi Jeff Stuart Bolds Lani Sue Borgman Stephen Michael Bovey Brenda Jean Bow

Tod A. Bowen

Tara Lynn Bowling

Toni L. Bowling

Robert James Bowman

Julie Beth Box

Scott A. Boyer

Chris Lori Boyle

Kelli Denise Bradds

Janie M. Bresson

Polly A. Brewer

Marcia R. Britton

Mark Edward Brown

Renee Sharon Brown RoShay Lynn Brown

Lisa Marie Bryant

David Allen Buchanan

Mary Jane Burger

David L. Burk

Julie Anne Burkholder

Kim J. Byrom

R. Bradley Caldwell Lee Calisti

Callie Ann Campbell

Keith Raymond Campbell

Timothy L. Canterbury Donna Eileen Carpenter Glenn Wayne Carpenter Kevin Lee Carpenter Jennifer Lynn Carroll R. Scott Carroll

Julie Christine Carter Lynn M. Case

Tedd Michael Cassidy Amy L. Chandler

Pamela G. Charlton

Patricia S. Cherry

Elizabeth $\mathbf{H}$. Church Melanie Sue Clark Crystal Clarke Cindy Sue Cleaver

Connie S. Cline

Reneé Carmen Clor 
Diane Beth Clymer Robert Stephen Coffman

Trina Louise Collick

Pamela Joy Commons

Sally Ann Compton

Pamela Faye Conrad

David Patrick Cook

Laurie Ann Cooper

Deborah Caryl Crawford

Kim D. Crawford

Cathy Lynn Creech

Louanne M. Cruz

Luis Cruz

Jill Lynne Cunningham

Carla Rhea Curry

Paul Allen Czerniak

Brenda Kaye Dailey

Rochelle Lynn Daniels

Richard H. Danhof

Lana Jo Darling

Lisa Joy Darling

Lori J. Darling

Lisa Faye Davidson

Kimberly Ann Davidson

Nikita Davis

Rebecca L. Davis

Stacey M. Davis

John Paul Dawes

Amy L. DeCook

Carol Joy Delaney

Melissa Lynn Denenberg

Angela Jean Dennis

Richard Timothy Dennis

Joy Christine Detweiler

Shannon O. Dillabough

Robert Marc Donawa

David A. Doud

Melanie Gail Drendall

Dave Alan Driskil

Donald Allen Drozd

Scott A. Duncke

Theresa Reneé Dunlap

Susan Marie Dye Ann Marie Dykes Jennifer Lynn Eads

Nancy A. Ebel

Kimberly Kay Edwards Kimberly S. Eimers

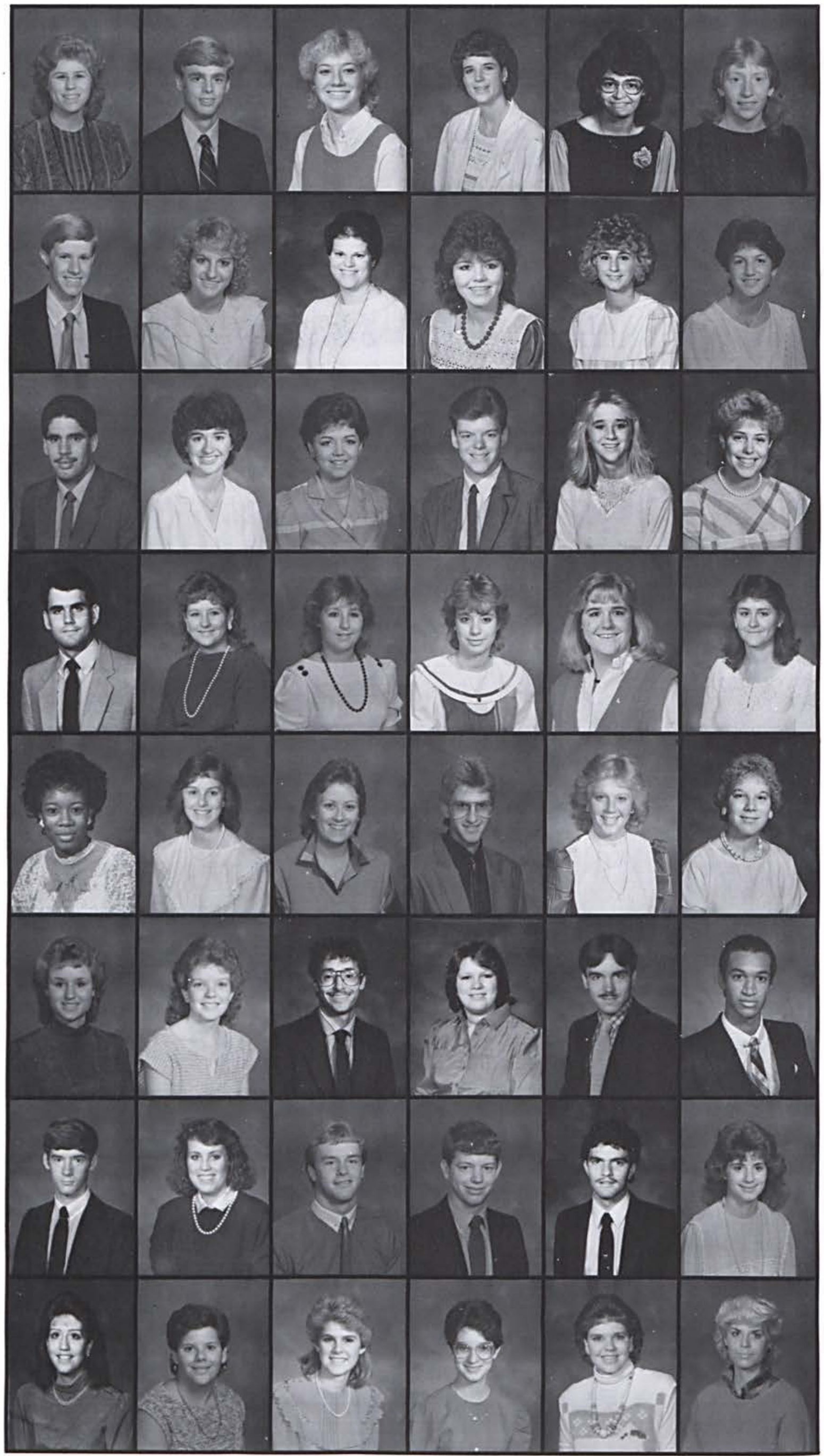




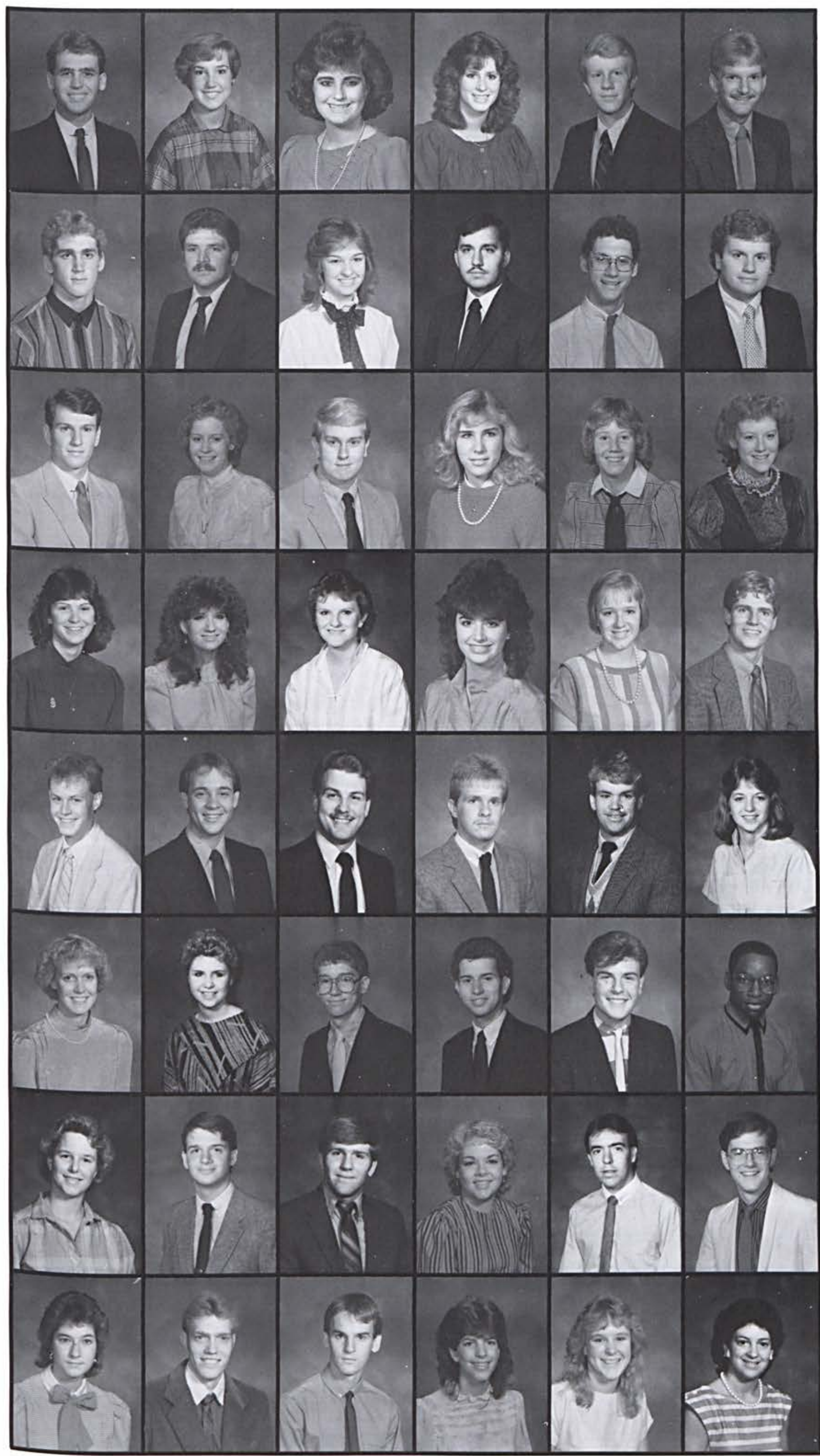

Stephen Forrest Elkins

Wendy Sue Elkins

Laura Elzerman

Cheryl Ann Entingh

Richard D. Ernst, Jr

Brian James Ethridge

James Edward Eutsey

James Lawton Evans

Tracy Ann Evans

Brian K. Fasick

Craig Michael Fee

Ken Patrick Fleetwood

Douglas Scott Flitcraft

Deborah Lynn Fogle

Roger Leslie Foreman

JoAnn M. Freyermuth

Christine Elizabeth Friesen

Shannon Rae Fritz

Julia Rebecca Furiate

Melissa M. Gallagher

Cindy Alice Gamber

Lisa Marie Garabadian

Brenda D. Gard

Benjamin Clayton Garrison

David Andrew Gebhart

Mark E. George

Stephen C. Gerhardt

George William Gibbs

Christian Mark Gifford

Cheryl L. Gilbert

Sandra J. Gilbert

Melissa Lynn Glatz

Eric Jonathan Goldschmitt

Rich F. Goldschmitt

Dan Gonzalez

Kenneth Goodman

Caron Goodemote

Tom E. Gordon

Philip Charles Grafton

Melissa Ann Graham

Michael Alan Green

Richard Daniel Greene

Julia Annette Gregory

Matthew J. Grider

Peter Thomas Grimes

Laurie Jo Gross

Laura Lee Hacker

Joy Ann Hamilton 


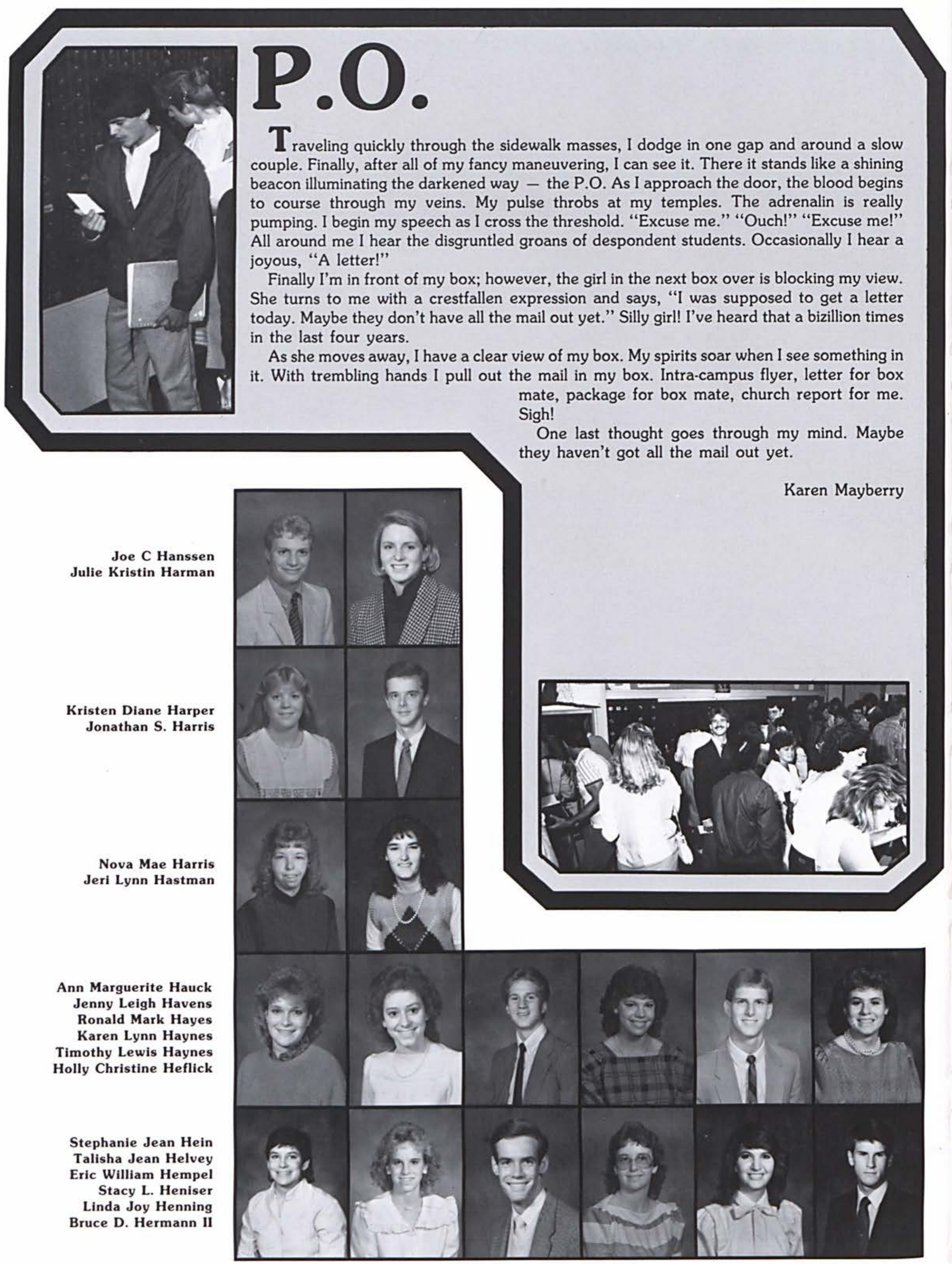




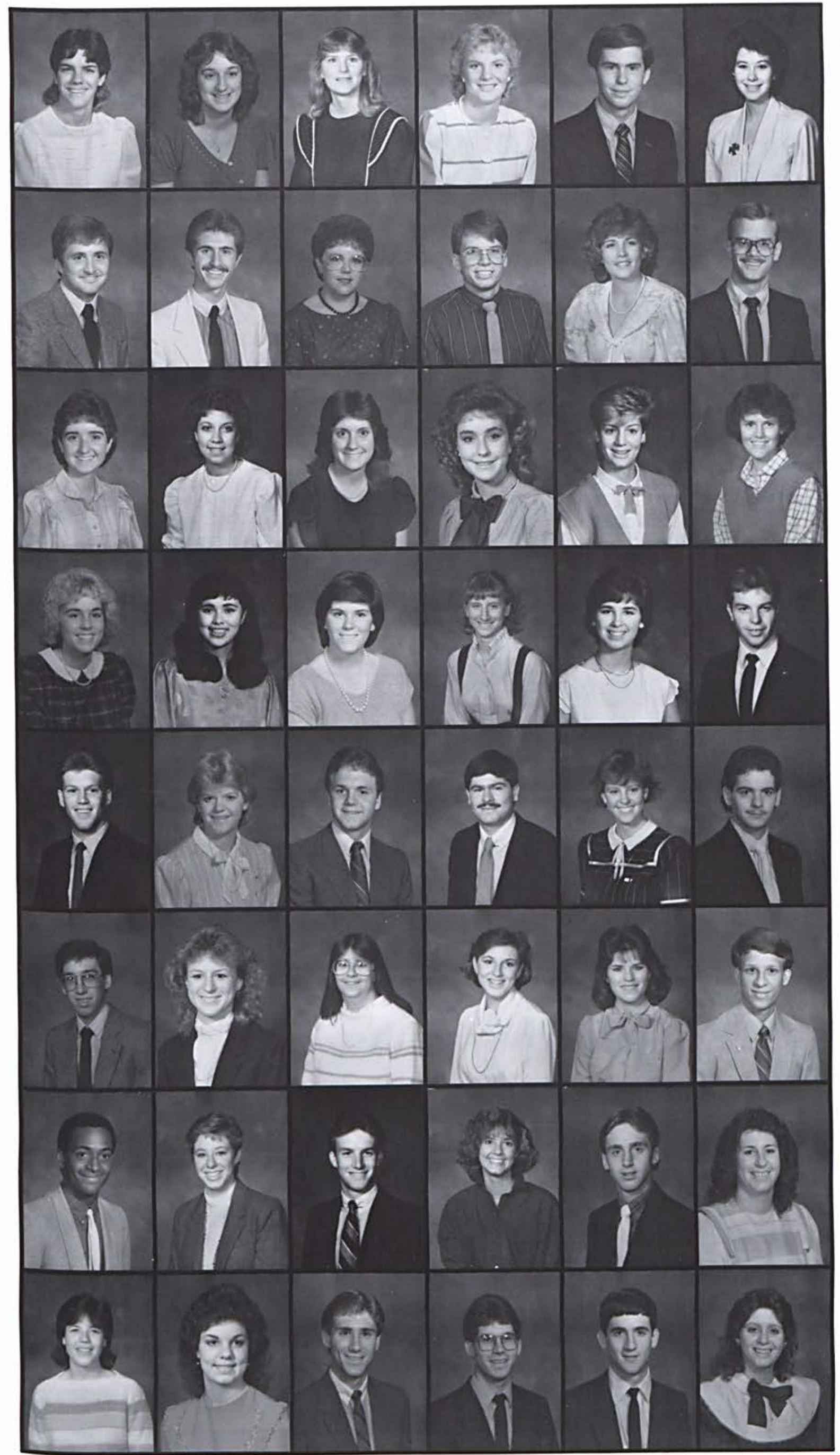

Kendra Joyce Herrold

Lisa Diane Herroon

Jennifer Frances Hess

Keren Ann Hicklin

Robert Joseph Hildebrand

Michelle Christine Hinnergardt

E. Dean Hinshaw

Dwayne Raymond Hoff

Cheryl Ann Holt

Donald J. Holt

Amy Sue Holtmann

Brad M. Hood

Cynthia Dawn Hoover

Corrine Faye Hornbacher

Linda Louise Horton

Tamara K. Houser

Paula J. Howard

Penelope Kay Howder

Rebecca Lynn Howell

Lorena Maria Hoyle

Terri J. Huber

Sandra Marie Hudon

Rebecca A. Hummel

David Alan Humphrey

Donald Stephen Ray Humphreys

Tamara Dawn Humphreys

Jay J. Inman

Ronald Allen Irvin

Margaret Nancy Irving

Bradley Frank Jacobs

Timothy Todd Jeunnette

Tammy Lynn Jenkins

Bonnie Lee Johnson

Dianna L. Johnson

Jill Ann Johnson

Robert Scott Joiner

Daniel Kenneth Jones

Kathleen V. Jones

R. Gene Kaercher

Susan Lynne Kauer

Gerald D. Keller

Kathleen Ann Kenney

Kimberly J. Killian

Melissa Dawn Kimmel

Darrin Alston King

Thomas Edward Kingston

Von A. Kinsey

Danielle Kathleen Kirkpatrick 
Sharyl Lynn Kirkpatrick Jon Mark Kirtland Elici L. Kleinpeter

Danny Kevin Kloha Julie R. Knauff John Mark Kohlmeyer

Alona Kaye Kooyenga John Edwin Krueger Karen Diane Kuntz Dana Sue Lachmiller Mark Richard Lamb Mark Latorella

John P. Law Janet Krishne Lawrence Charles D. Layman Eun Sil Lee

Patricia Beth Leedy Jennifer R. Lenhart

Linda R. Leshan Kelly Jo Link

Kathleen Ann Lippert Beth E. Lockwood Douglas Woodard Loescher Jeri Lynne Long

Tina Lorene Love Timothy Richard Lowing Mark Harold Luce Joel Keith Lum

Kristina Mae Lyden Brent Matthew Lydic

Terri Lyn MacPherson Kimberly Irene Manzi Kristie Michelle Marshall

Bruce Wayne Martin

Tammy Marie Mascari Janelle Lynn Maxwell

Kevin Lain McAlvey Mark David McClain Sharon Elizabeth McClanahan

Cari Ann McFadden

Thomas James McFadden Amanda Dawn McIntyre

David R. McKenney Terry Thomas McNabb

Jolene Beth Merck Jody Lea Merrill

Gladys Irene Merritt Stephen Francis Michonski

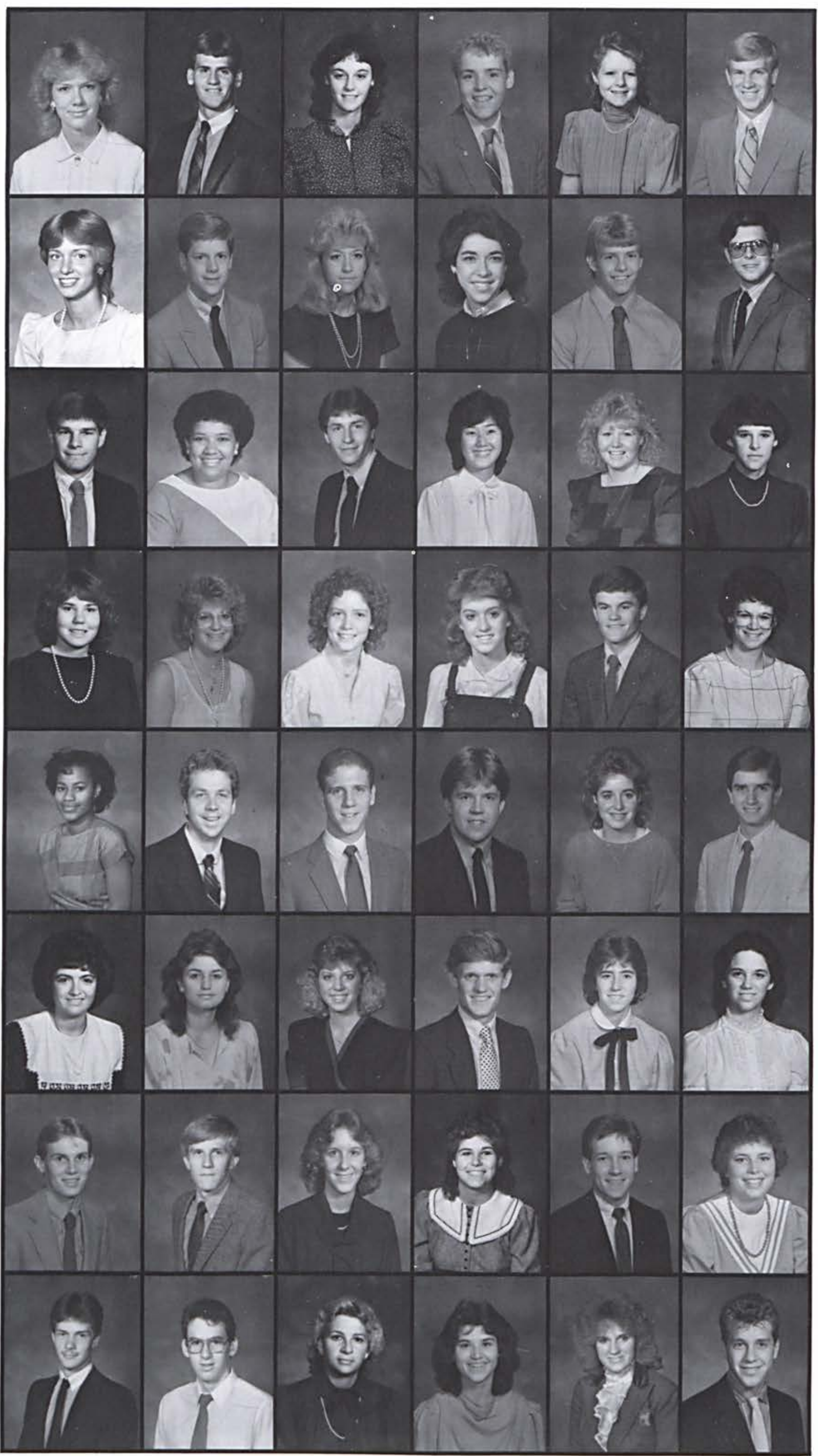




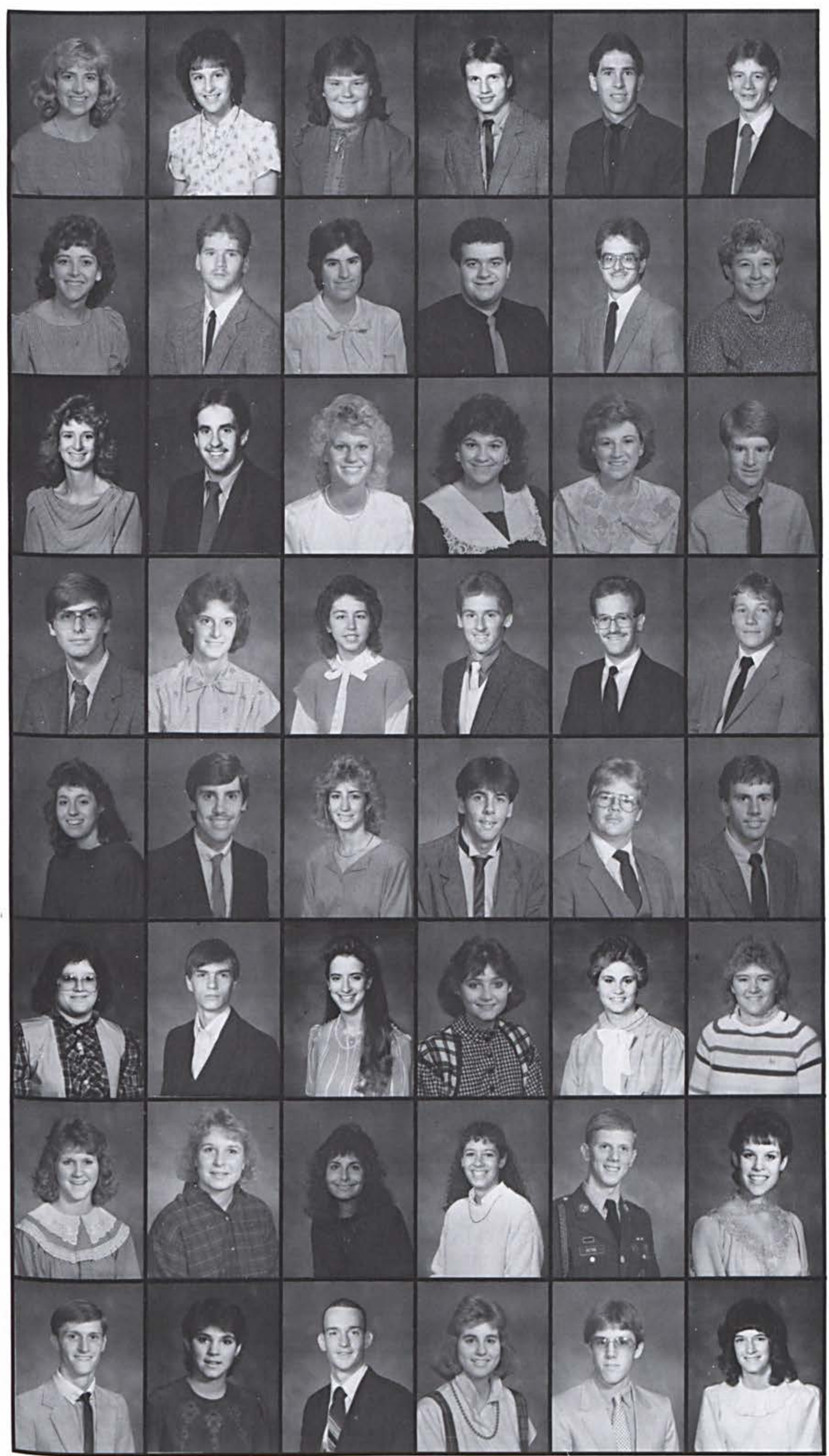

Lori Anne Miesse

Elizabeth Miller

Karen Darlene Miller

Michael Andrew Miller

Robert H. Miller

Howard William Mills, Jr.

Kimberly Kay Mitchell

Russell David Mock

Beth H. Moon

David S. Mooney

Robert Oran Moore

Beth Anne Morse

Bethany R. Most

Dean Scott Mowry

Susan Lynette Moyer

Martha Kelly Murphy

Michelle Denise Nestor

Adam Kent Newell

David Rowell Nichols

Ann Margaret Nicholson

Tammy Sue Noell

Paul A. Norman

Dave W. Norris

Todd Allen Obergfell

Judy M. O'Connor

Gregory Mike O'Dell

Kristin R. Ostrum

Charles David Pack

John D. Parsons

Robert Wayne Paswaters

Holly Lynne Patterson

James Ohmer Pawelski

Alyson Ann Payne

Donna M. Payne

Lisa Lynn Payne

Becky Pearson

Jennifer Lea Pearley

Lisa Ann Peio

Christine Penny

Melissa L. Perkins

Charles David Petrie

Lynne Marie Pitonyak

Bruce Joel Pitsenbarger

Katrina L. Plourde

Jonathan Craig Popa

Laura A. Potter

Brian Ross Purrington

Lisa Beth Raines 
Lynn Ann Ramsey Linda J. Ranger

Paul Brian Reid

Mary Elizabeth Reigle

Becky Lee Reiter

Christine Louise Renberg

Ken Mark Rexilius Debby K. Rinehart

Lisa A. Riopell

Mary L. Ritenour

Amy Ritsema

Joffre E. Robalino

Leah Rae Robbins

Mike J. Roberts

William Allen Rodebaugh

Michelle Lynn Rogers

Susan Goodrich Rogers

Wiatt Douglas Ropp

Michael L. Rose

Stephen C. Ross

Debra Kay Rotramel

Douglas Routh

Norman F. Russell

Theresa Fay Ryder

Sally-Jo M. Sager

Jose L. Sanchez

Peter Joseph Savard

Steve J. Schepers

John Edward Schneider

Lois Jean Schofield

Bryan Carl Schroll

Monica Schuttenberg

Deborah Lynn Schwartz

Gary Brian Shaffer

Kenyon Lyle Shepherd

Mark Harold Shirey

Sharon M. Shook

Denise Ann Simington

Brian Keith Sjoquist

Tina Nadine Skiver

Marjorie Beth Smallman

James D. Smelser

Allison Renee Smiley

Cheryl Kay Smith

Christopher P. Smith

Dan Joel Smith

Andrew Victor Snider

Rusty Alan Snodgrass
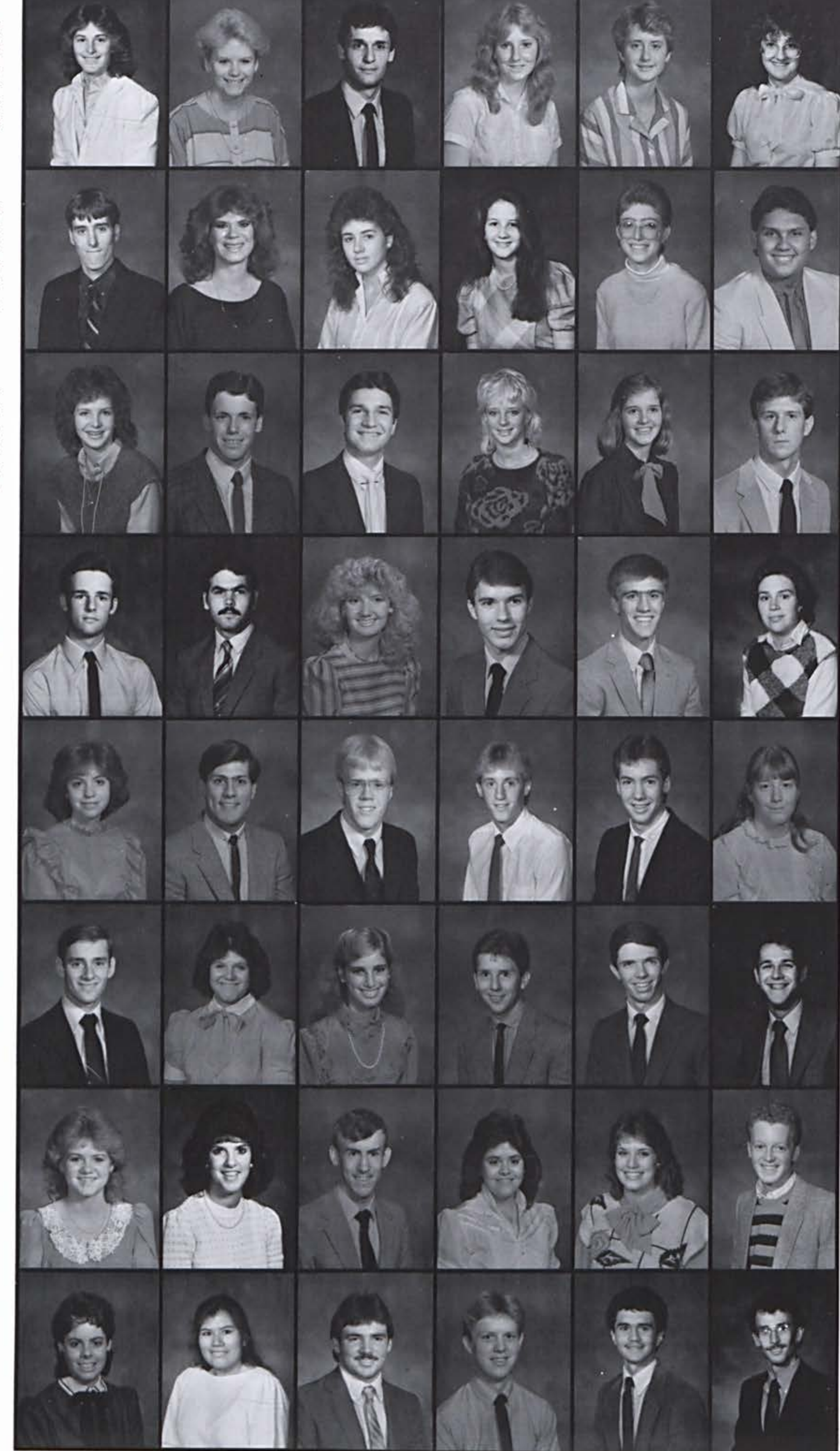

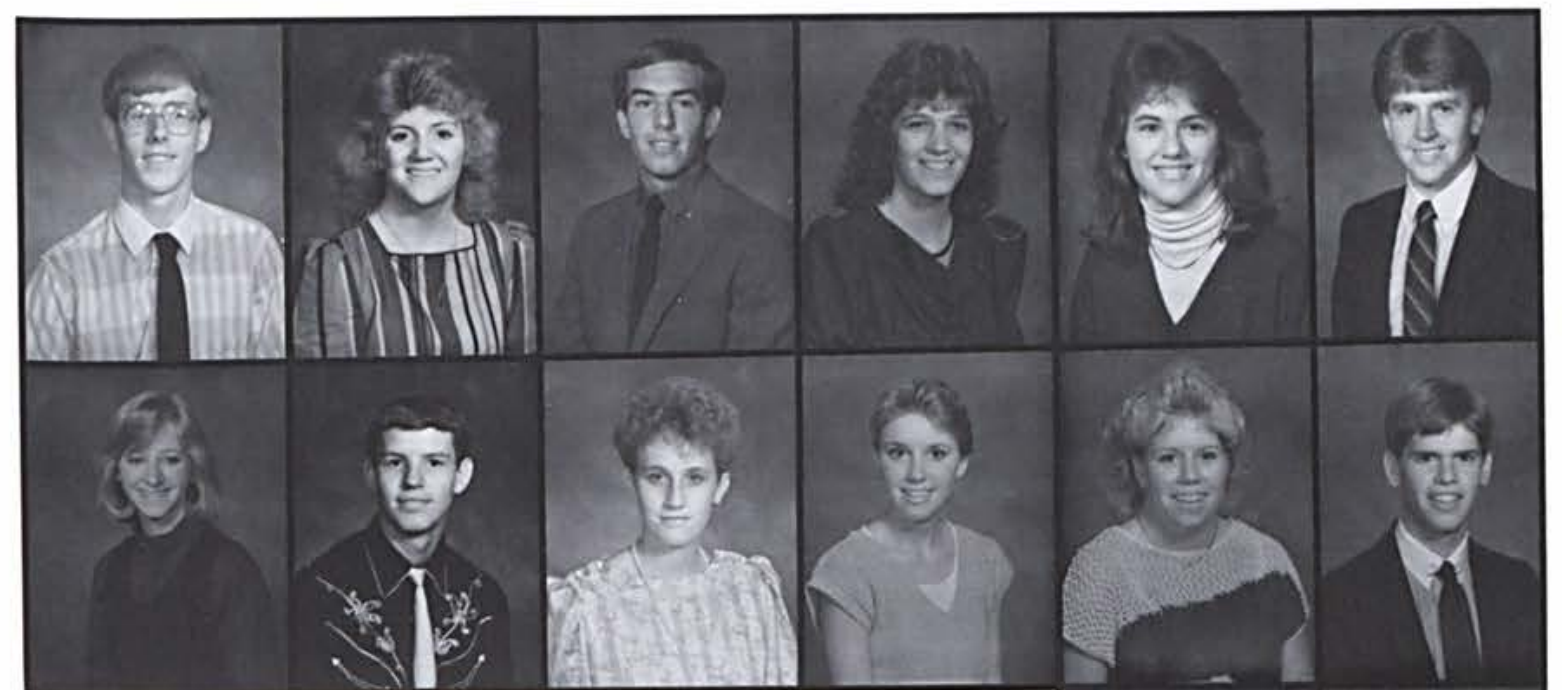

\section{First Phone Bill}

\section{"6 $\mathrm{H}_{\text {ello, Mom? }}$}

Oh, I'm fine.

"Yes, I'm still lost in Foundations of Social Science. But, Mom, I never knew that God was ontological. Well, I just got my first phone bill and it's a little more than I expected. I know I haven't called you all quarter but - Okay, so I haven't written either. Well, do you remember Betty Brown, the one I went to high school with? She's on that student exchange program in Afghanistan and we've been playing cards over the phone all quarter.

"No, Mom, Rook cards. We play only an hour a day between eleven and twelve o'clock. That way I don't miss chapel. Well, uh, I owe $\$ 230$. Alright, I'll start putting signs up in the post office, but do you really think selling my clothes is the best way to pay for it?"

Jeff Bergandine
David Charles Sommers

Diane E. Sorby

Brent David Speas

Heather J. Spicer

Penny Leigh Stackhouse

James Edward Stansbury

Sharon Kay Stephens Andrew William Stevens Damaris Hope Stevens

Stephanie Jo Stevens Tina Renee Stinedurf

Trenton Todd Stokes

Timothy James Stone

David George Stoner, Jr.

Cristine Marie Stowell Deborah Ann Stowers

Glenn E. Streeter

Susan Carolyn Swann

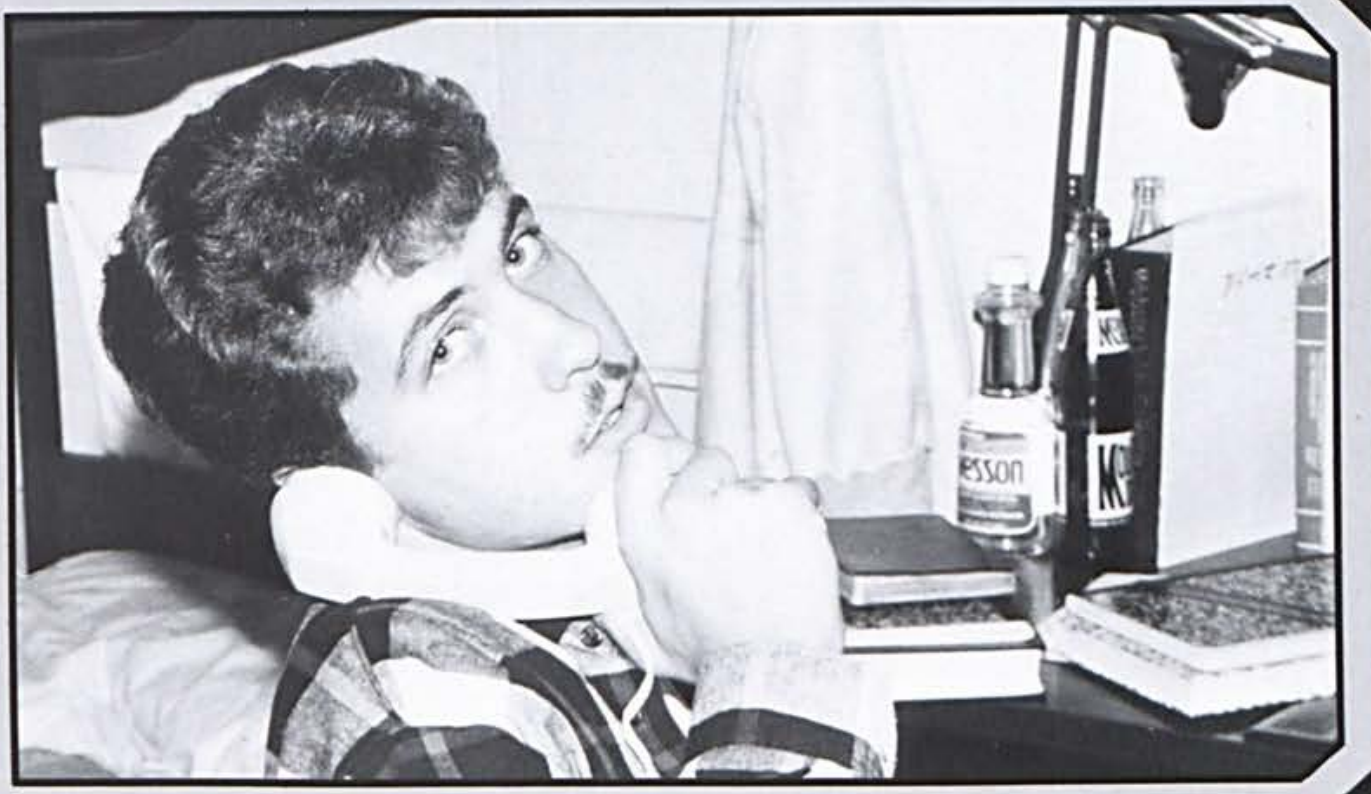


Kimberly B. Sweet

Jennifer Jean Taft

Norman William Tate

Jim Lee Taylor

Kerri Tengesdal

Tamra Sue Terrill

Jon Lynn Terry

Phillip Thornton

Sharon Jean Tinkler

Amy Jo Titus

Eileen M. Thompson

Loren Gregory Tucker

Rebekah Jane Tucker Karin L. Tuckey

Nathan David Tuckey

Kevin Joseph Tupps

Heather L. Tyson

Troy James VanLiere

Sharon G. VanPatten Daniel Jay Wade

Timothy S. Wagner Jonathan David Walborn

Jennifer M. Ward

Deborah Lin Warnshuis

Kevin Robert Warstler Shari Lynn Washburn

Kristine Anne Watson

Michael P. Watson

Noelle M. Watson

Ronda Jean Weaver

Brenda Kay Weber

Brian Paul Weber

Scott W. Wedlake

Dana Louise Weld

Barbara Ann Wells

Mark Halson Wells

Wendy Sue Welty Janet L. Wenger

Gordon E. Wertz

Derek D. Whalen

Wendy Kay Wheeler Jennifer Lynn Whittaker

Paula Dorothy Whitten Suzy M. Widder

Carol Diann Wiggins Kay Lynette Wikstrom Margaret Lynn Wildman John D. Willer

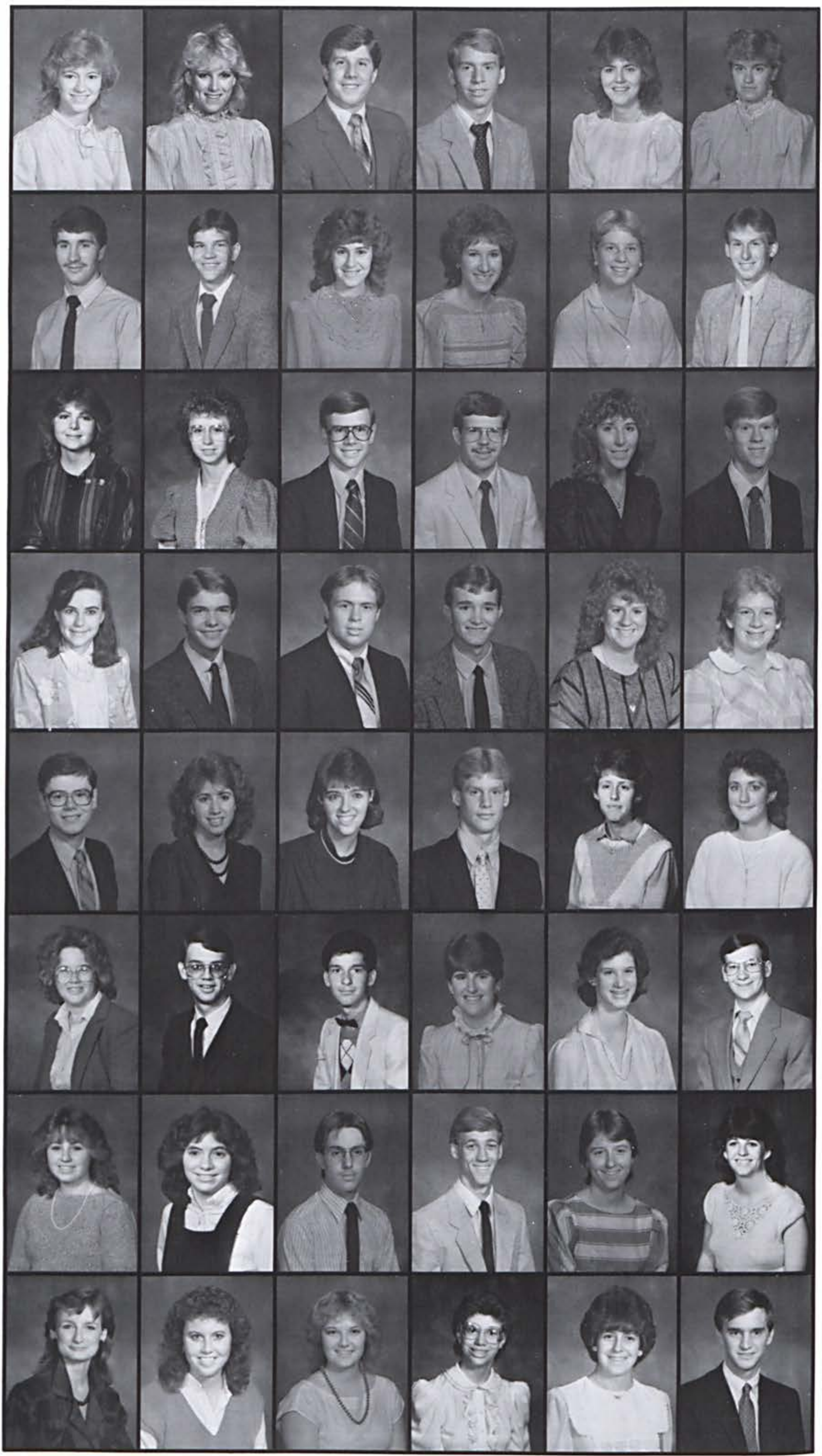




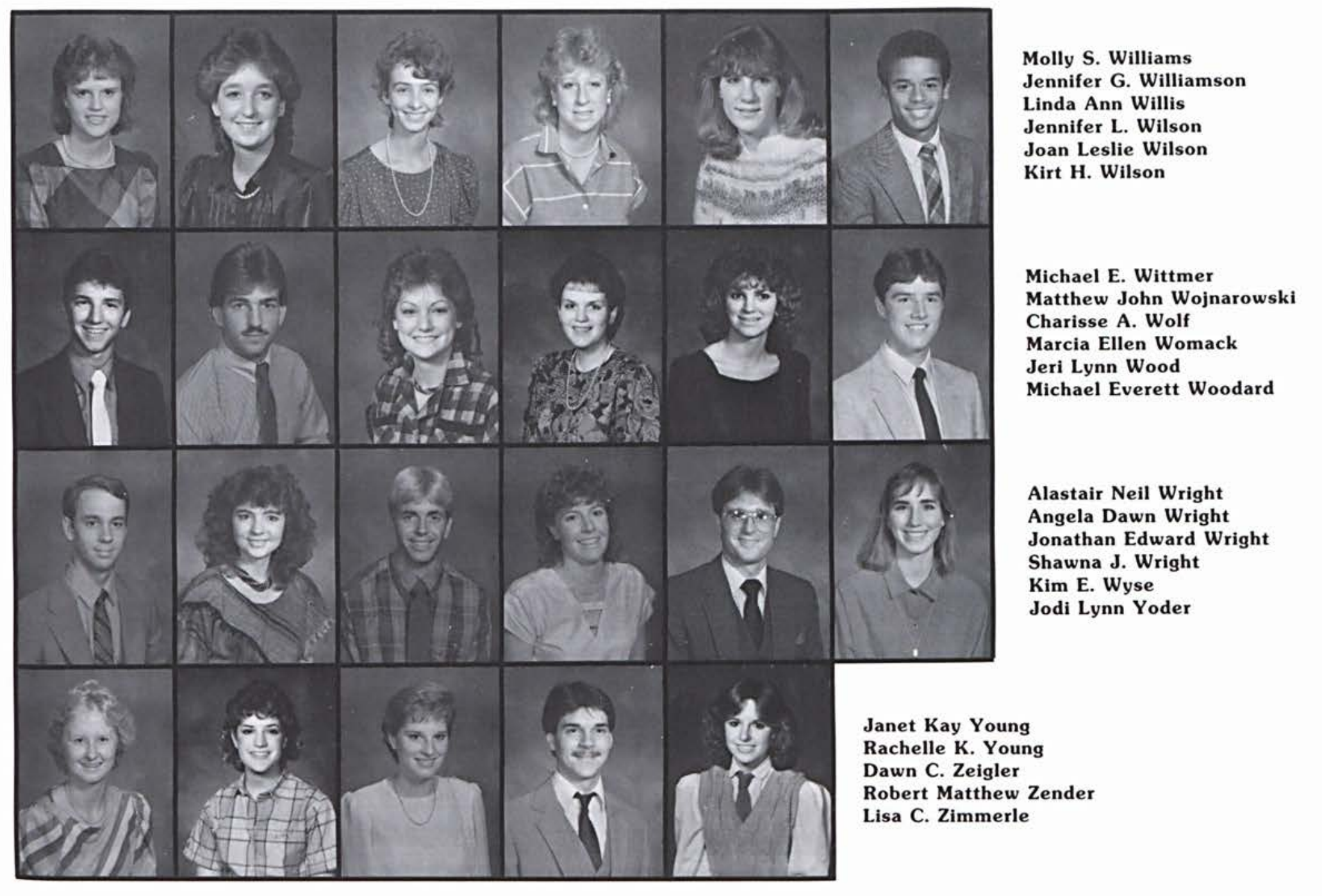

\section{Registration}

$\mathbf{W}_{\text {hat does "section number" mean? }}$ Where do I get an I.D. number? My feet are killing me. Excuse me for living!

Making it through a registration experience should give every student 2 extra points on his GPA. Honestly, these new computer advancements don't exactly speed up the process. There are still lines and more lines.

There are lines for bill payment, lines for classes closed, lines for insurance, lines for blood transfusions, and so on. Students feel like rats in a general psychology experiment.

May I have another form, please? I botched this one. Where is my advisor? He's never in after 3:00 and I need his signature. I've had it; I'm changing my major!

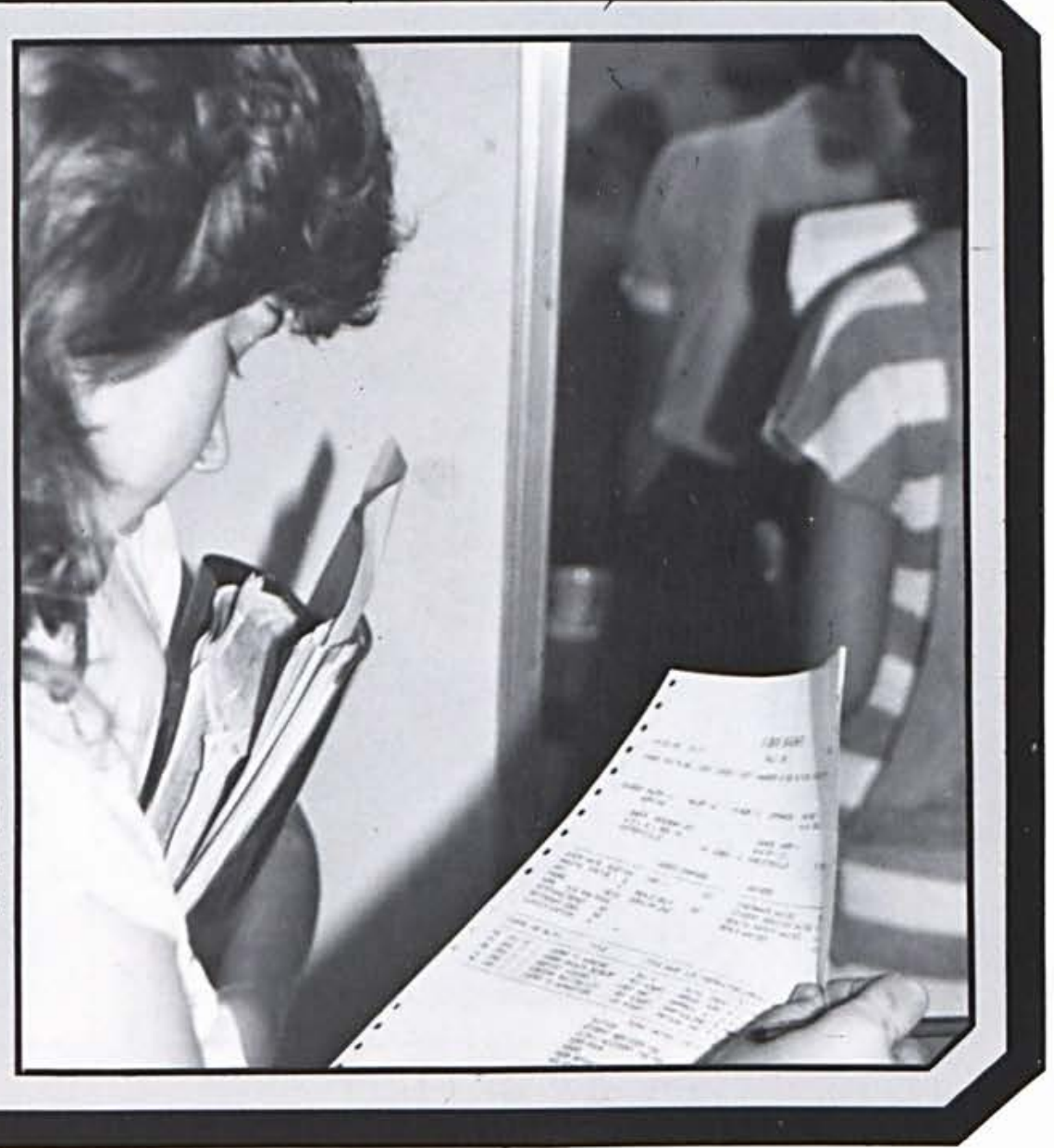




\section{IN MEMORY OF}

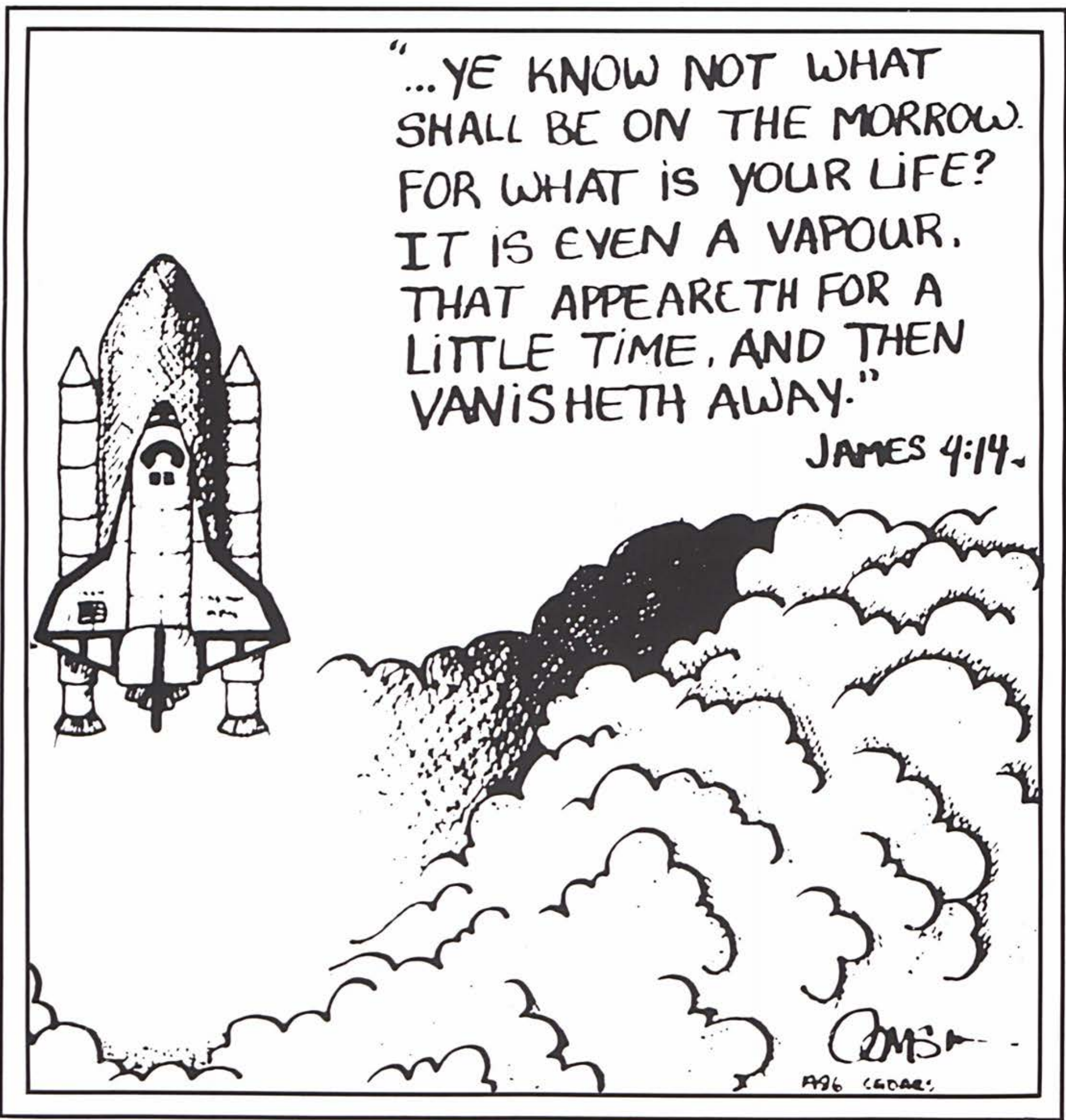




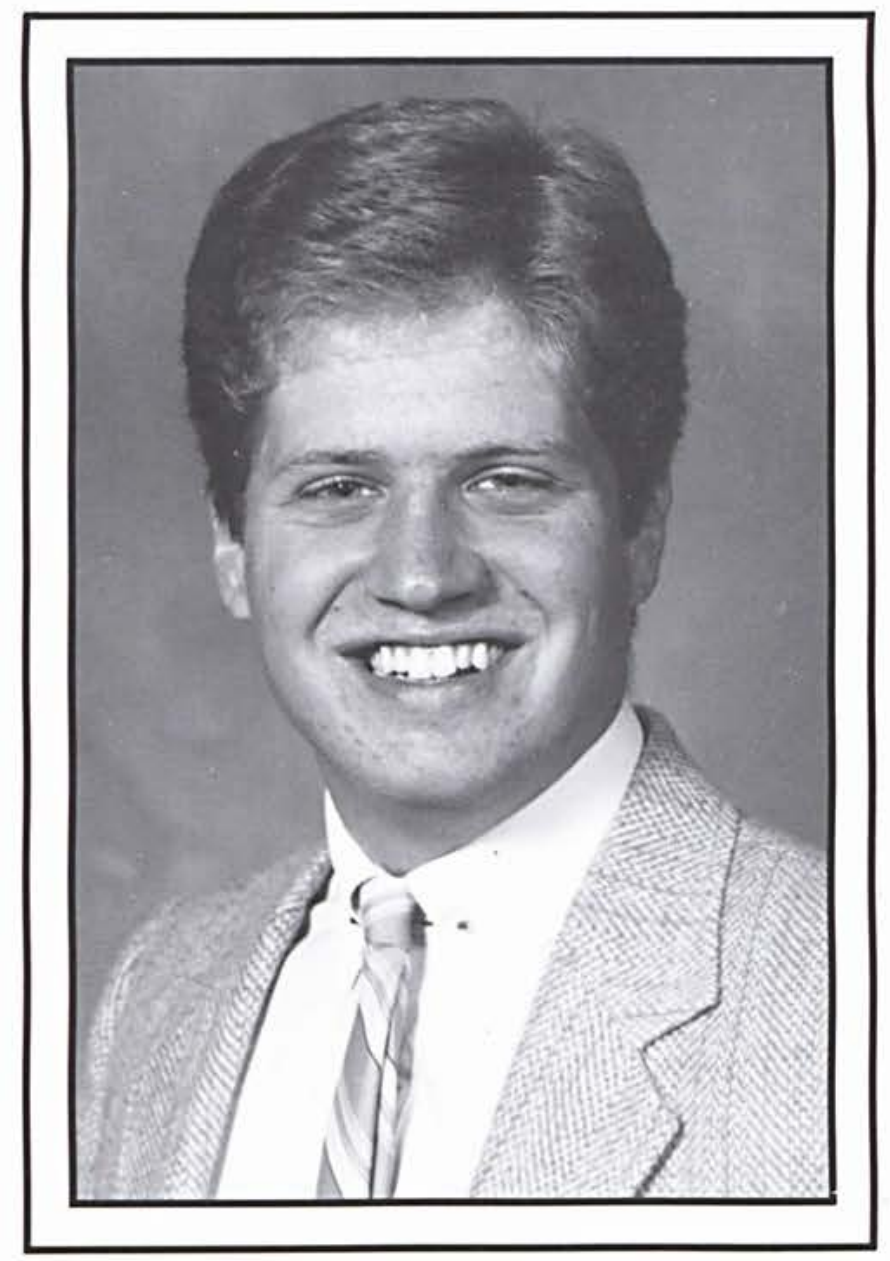

Robert Atkinson

March 7, 1967

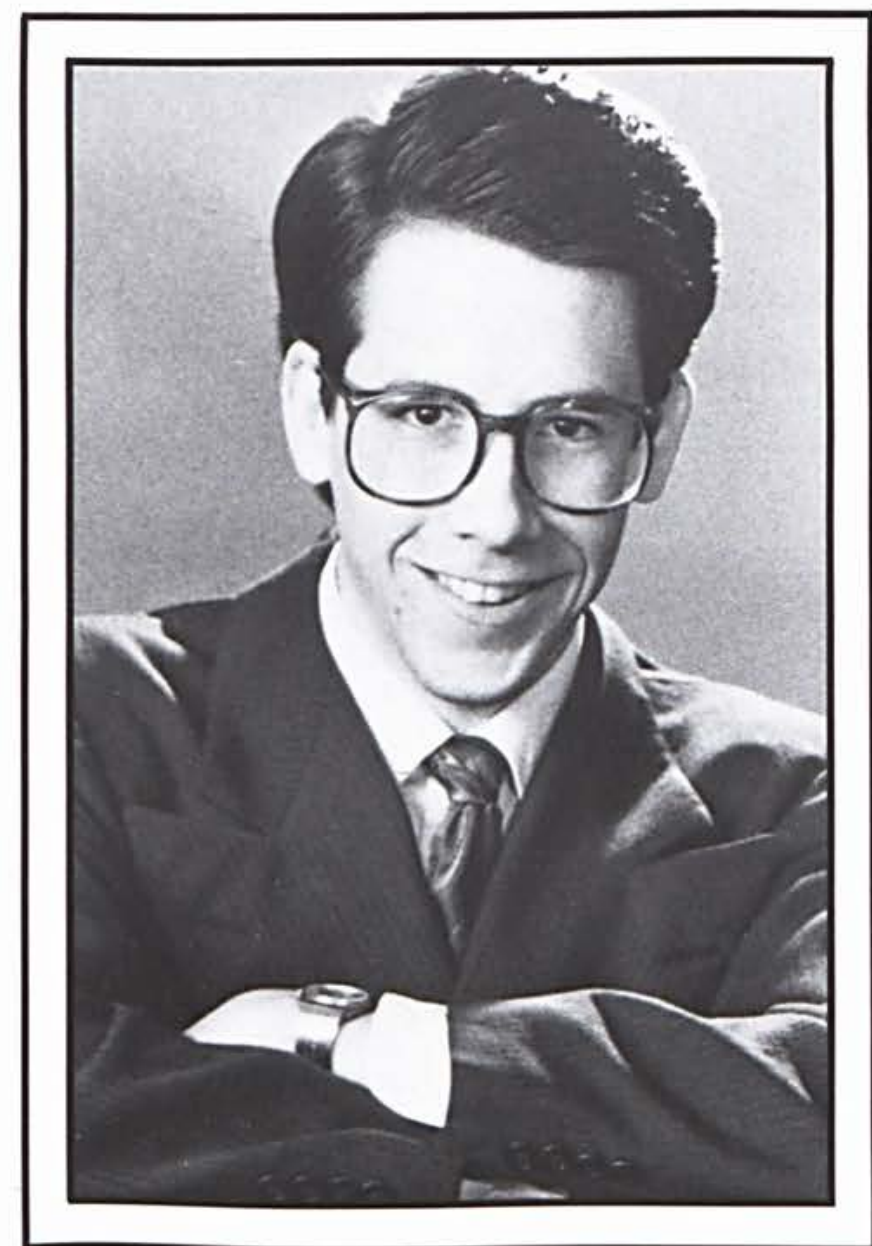

Gordon Ooms

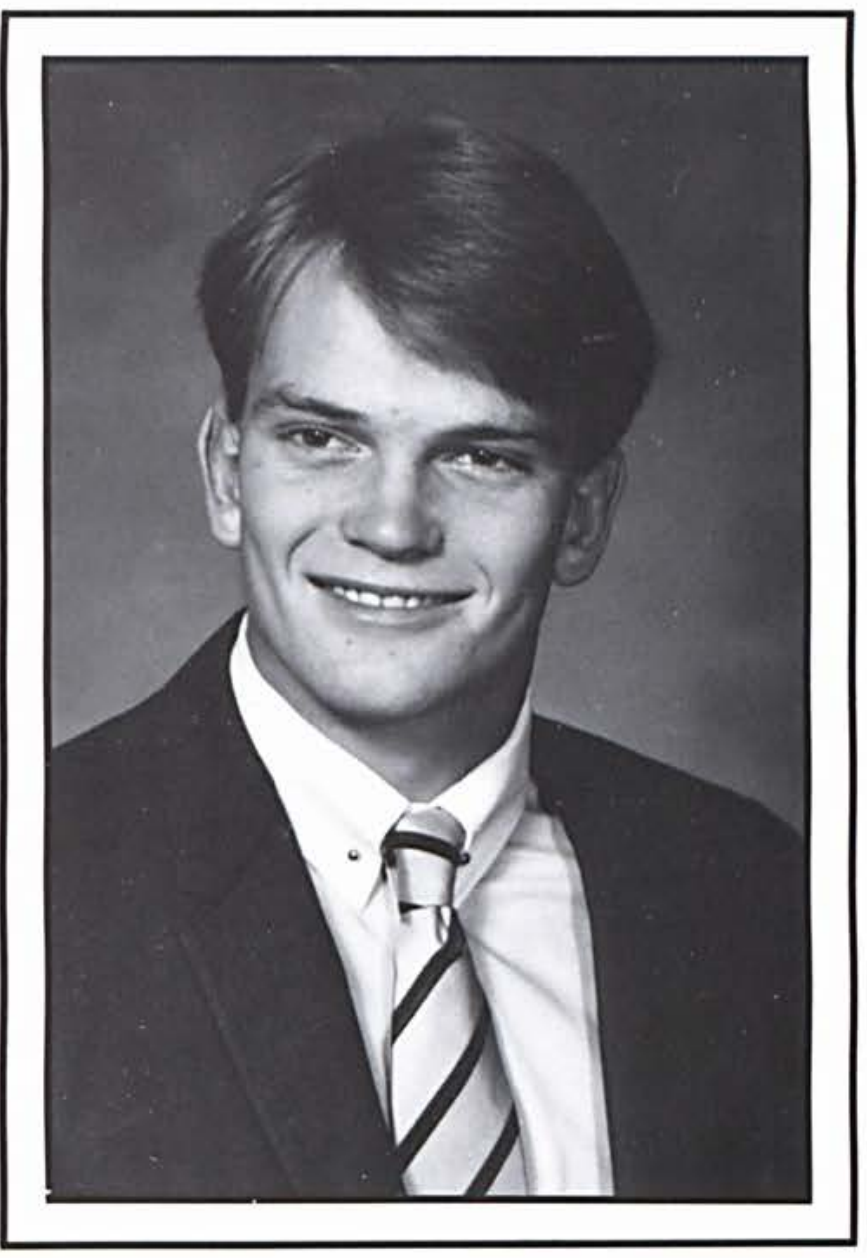

Jay Butcher

July 4, 1964

February 18, 1986

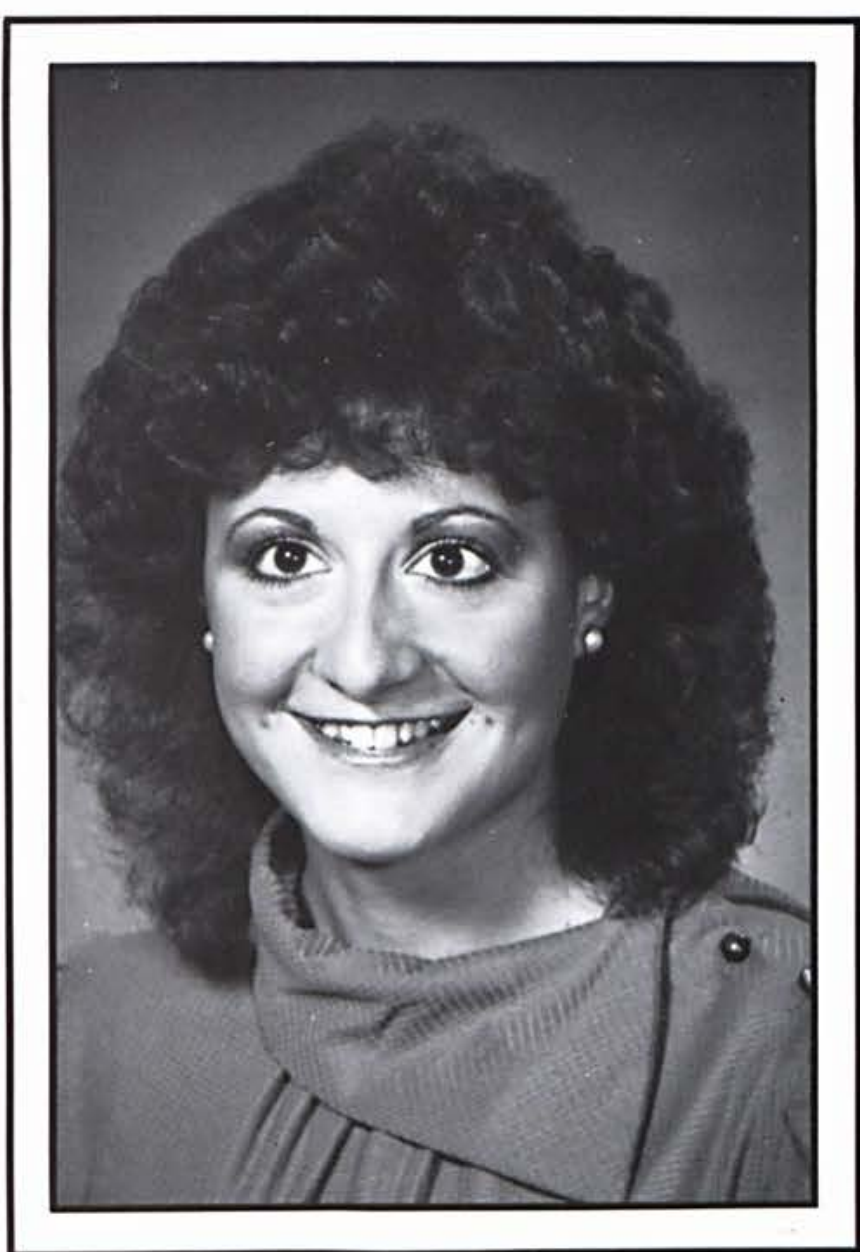

\section{Debbie Henry}

July 9, 1963

April 30, 1986 


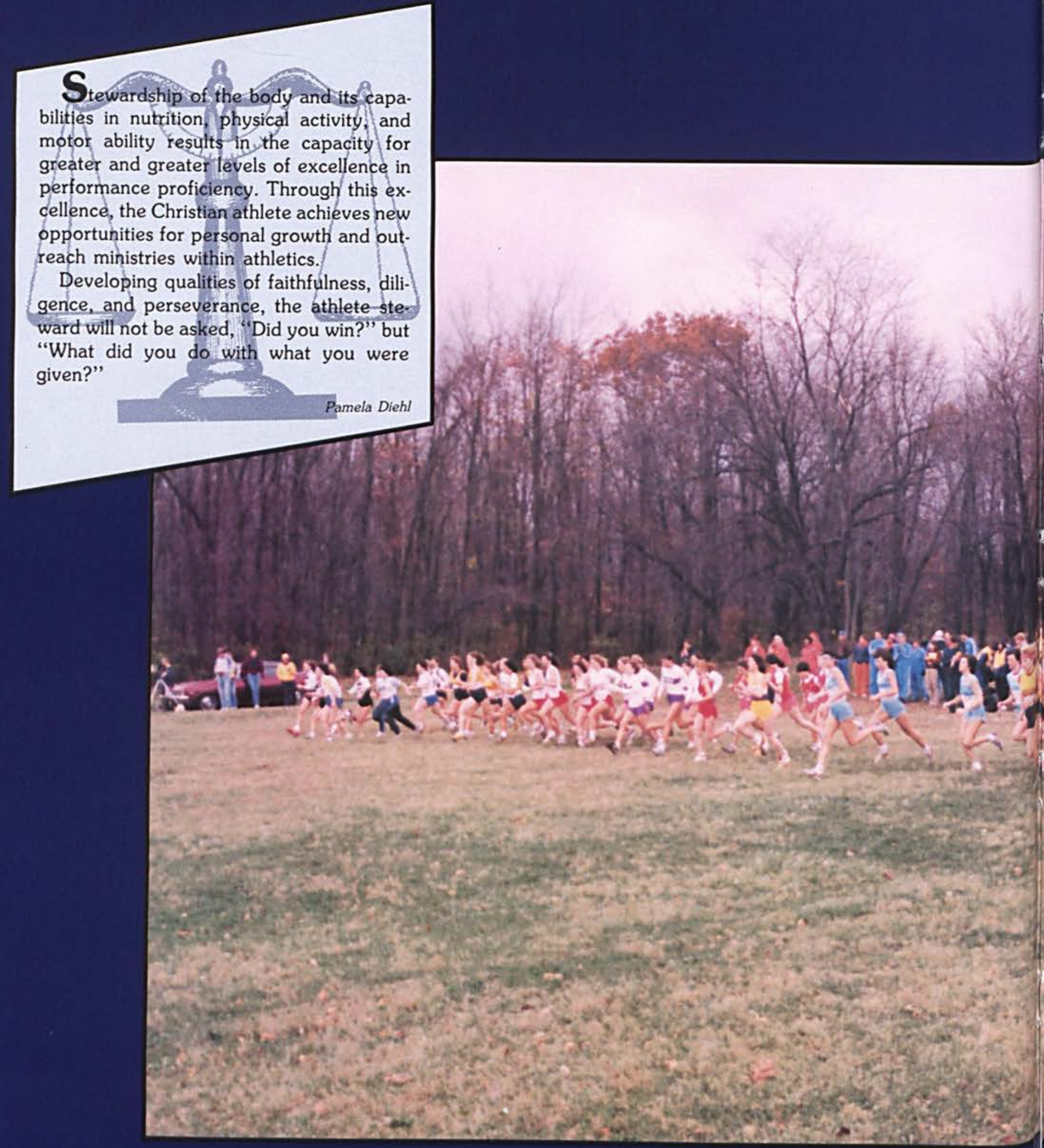
greater and greater levels of excellence in performance proficiency. Through this excellence, the Christian athlete achieves new opportunities for personal growth and outreach ministries within athletics.

Developing qualities of faithfulness, diligence, and perseverance, the athlete ste"Wrd will not be asked, "Did you win?" but "What did you do with what you were given?"

\section{Pamela Dieh}




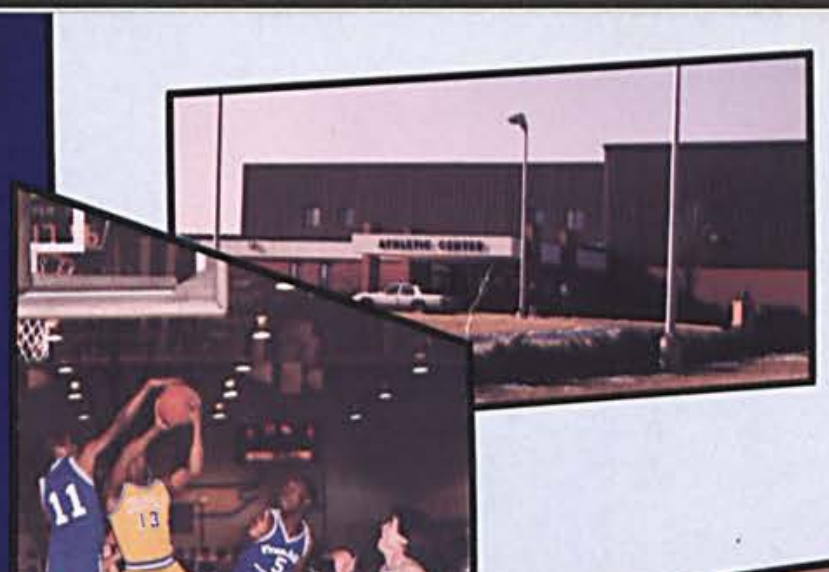
wing Pinetiol 3.Nin 13 (2)
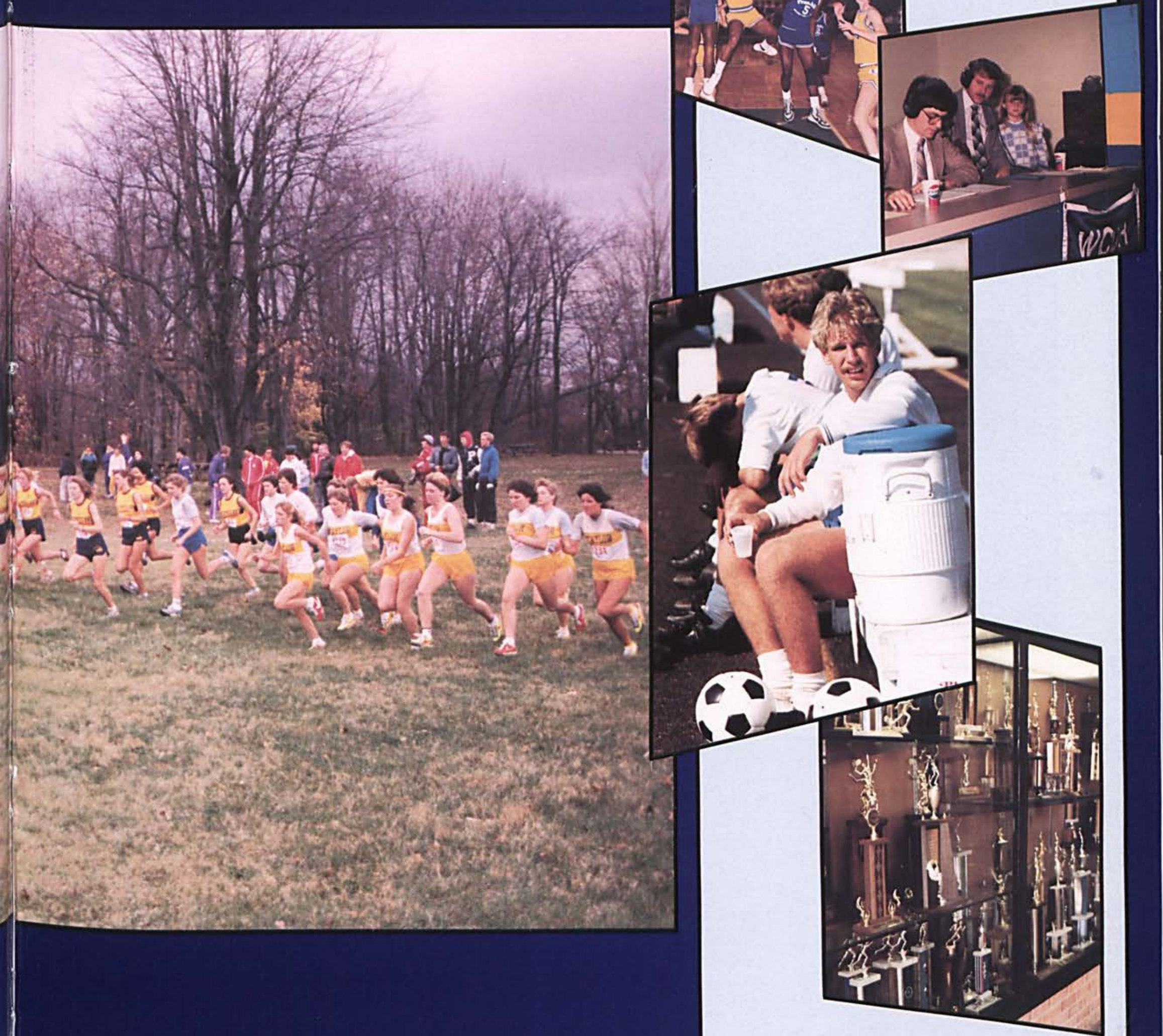

ATHLETICS 
THE

HUDDLE
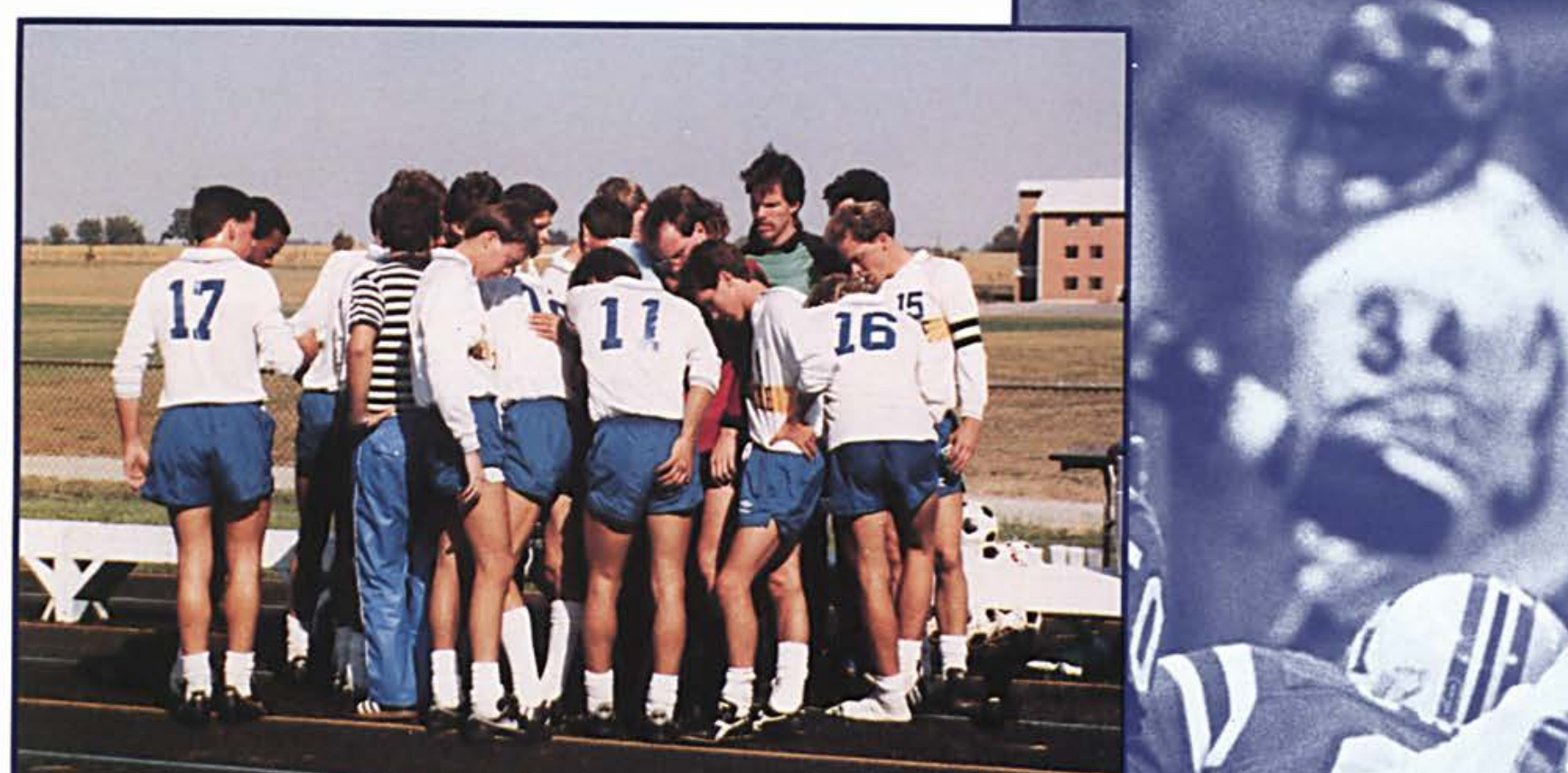

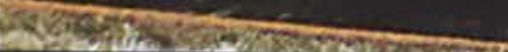




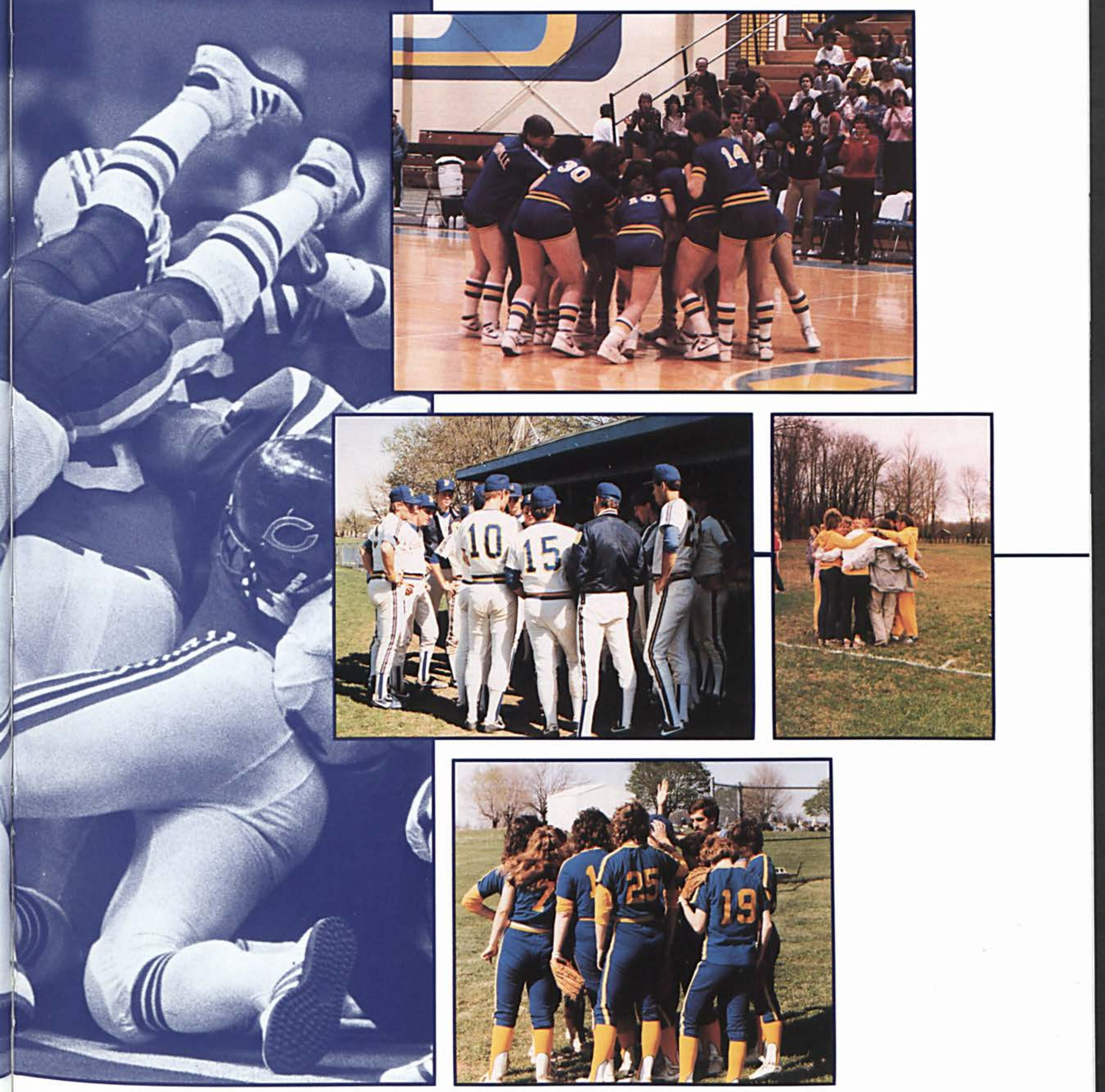



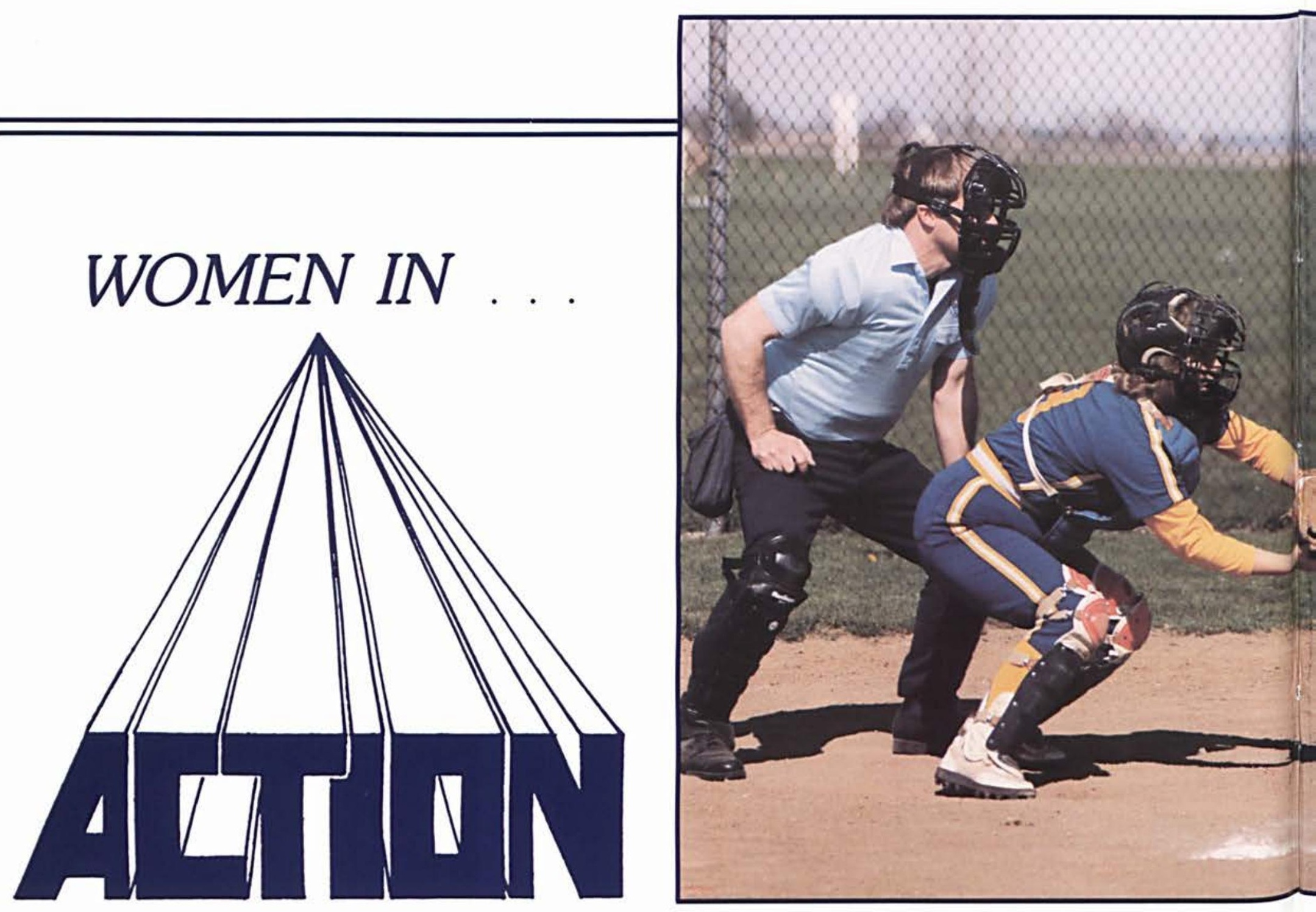

\section{Supporting For 26 Years}

W

What is she supposed to do? What is a marriage like when one partner is a coach? Nedra Callan says that she knew exactly what she was getting into when she married Dr. Don Callan. But the coach surely didn't realize what he was getting when he married her.

Nedra faithfully attends all basketball games, keeps "stats," encourages her husband, shares her insights into particular situations, and acts as a very warm, candid public relations person. The one thing she doesn't do is tell him how to coach.

The MIRACLE thanks you, Mrs. Callan, for all your support to Coach Callan and to the CC sports program. You serve well!

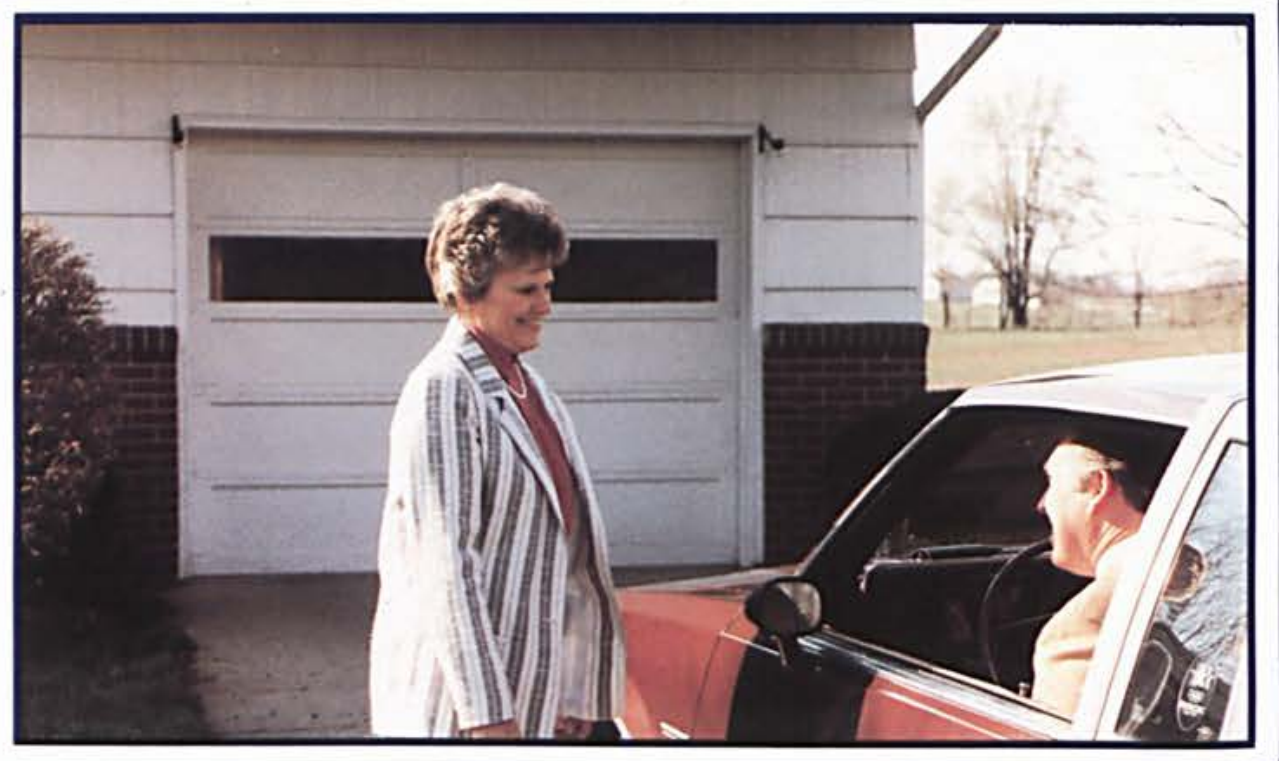



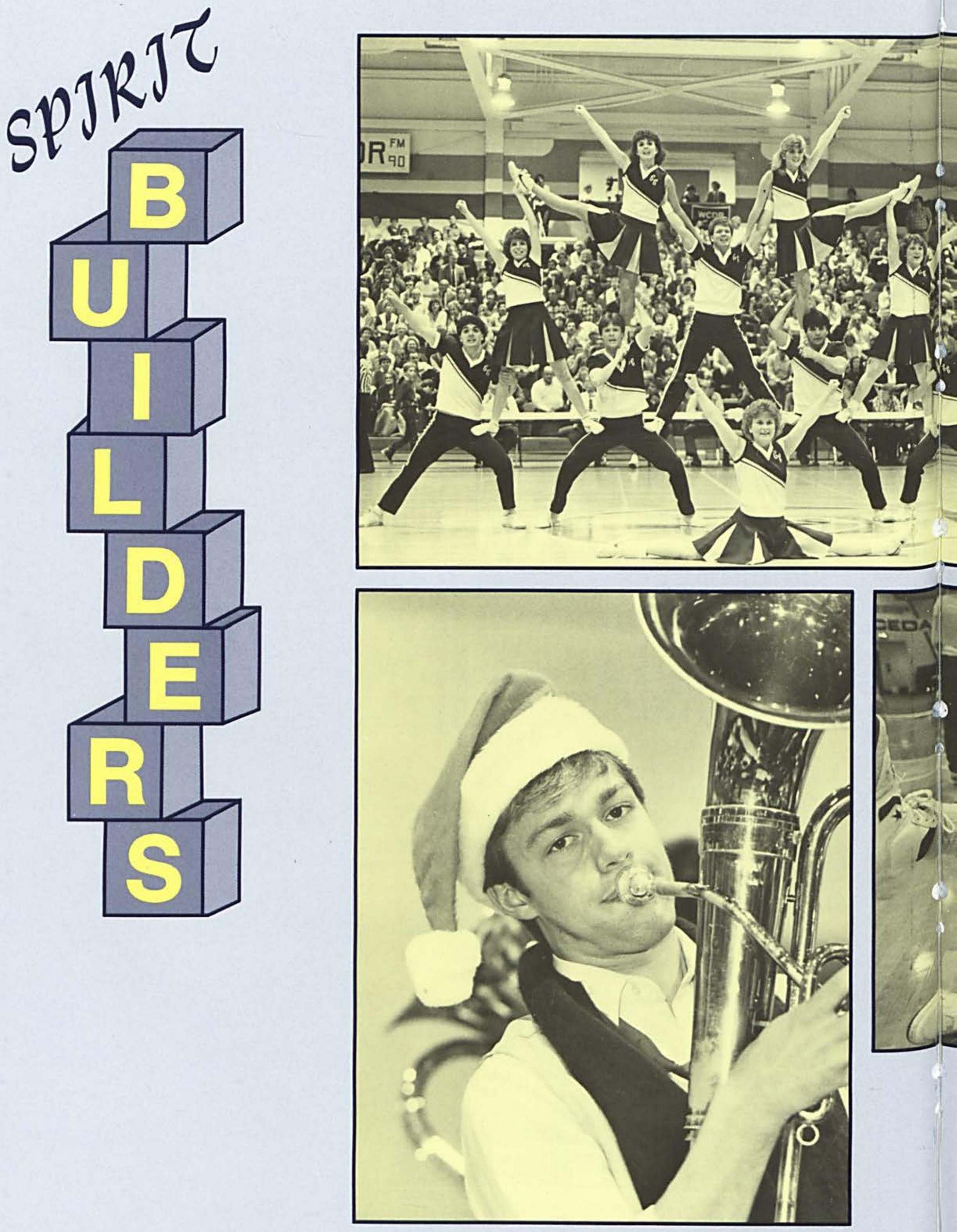


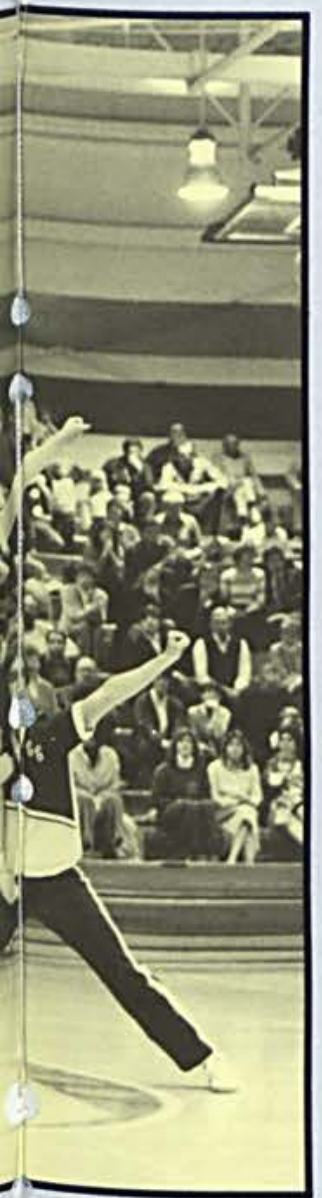

Cedarville College Spirit Builders: Pep Band. Cheerleaders: Tim Trexler, Brian Deffit, Dave Hale, Dave Dooley, Bob Smith, Troy Van Liere, Kirsten Hoddleman, Gwen Price, Becky Peters, Amy McKibben, Mary Wells, Theresa Wilson. Flag Corp: Marcia Womack, Sue Terkedsen, Joy Shuman, Lisa Raines, Julie Knauff, Dianna Johnson, Kathy Reynolds, The Yellow Jacket: Kurt Sum. merville. Buzzy Bee: Chad David Fires
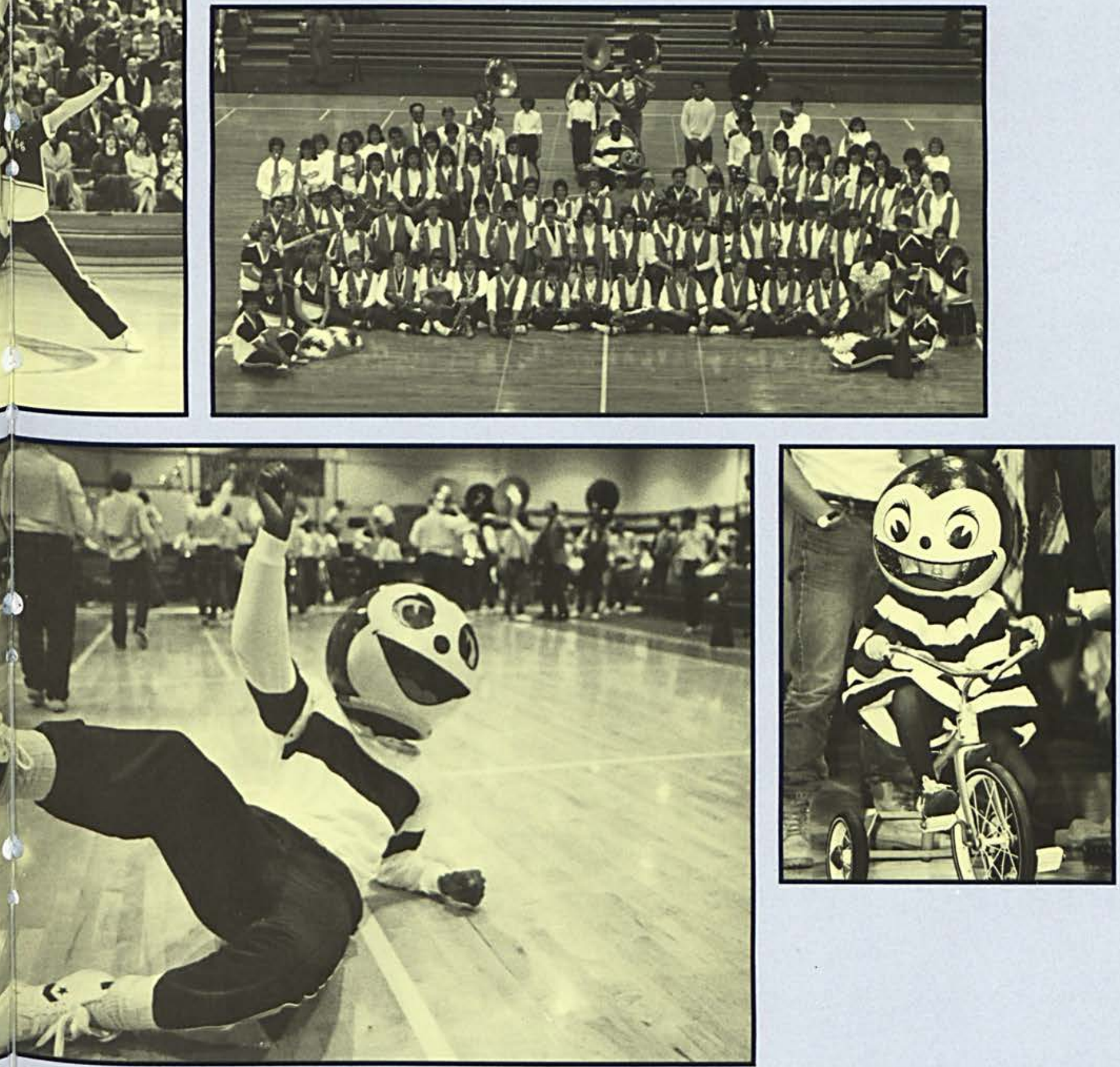


\section{NCCAA Runners-Up}

Front row: Manager Dave Sexton, Brian Hultz, Derek Whalen, Dan Jones, Steve Hanson, Paul Norman, Kirt Wilson, Jim Robinson, Andy Mininger, Brian Singleton, Greg Norden, Tom Peterson, Dan Hawk. Back row: Coach John McGillivray, Dan Collins, Phil Fogle, Mike Green, Dave Burt, Mark Fleetwood, Tim Davis, Jon Reid, Tom Fite, Noel Hack, Rick Seidel, Jeff Baker, Loren Tucker, Dan Byrum, Steve Racz, Assistant Coach Dave Wills.
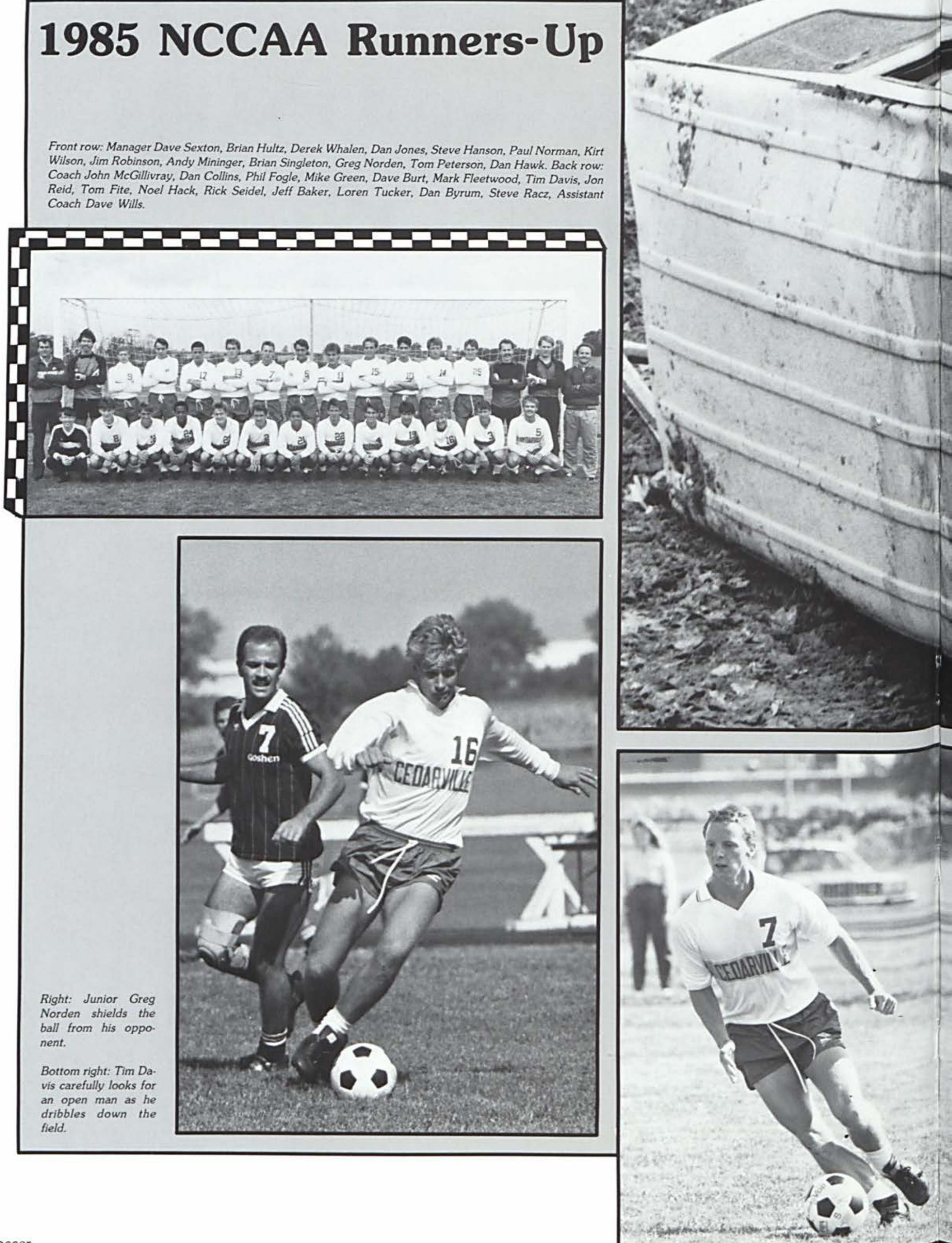


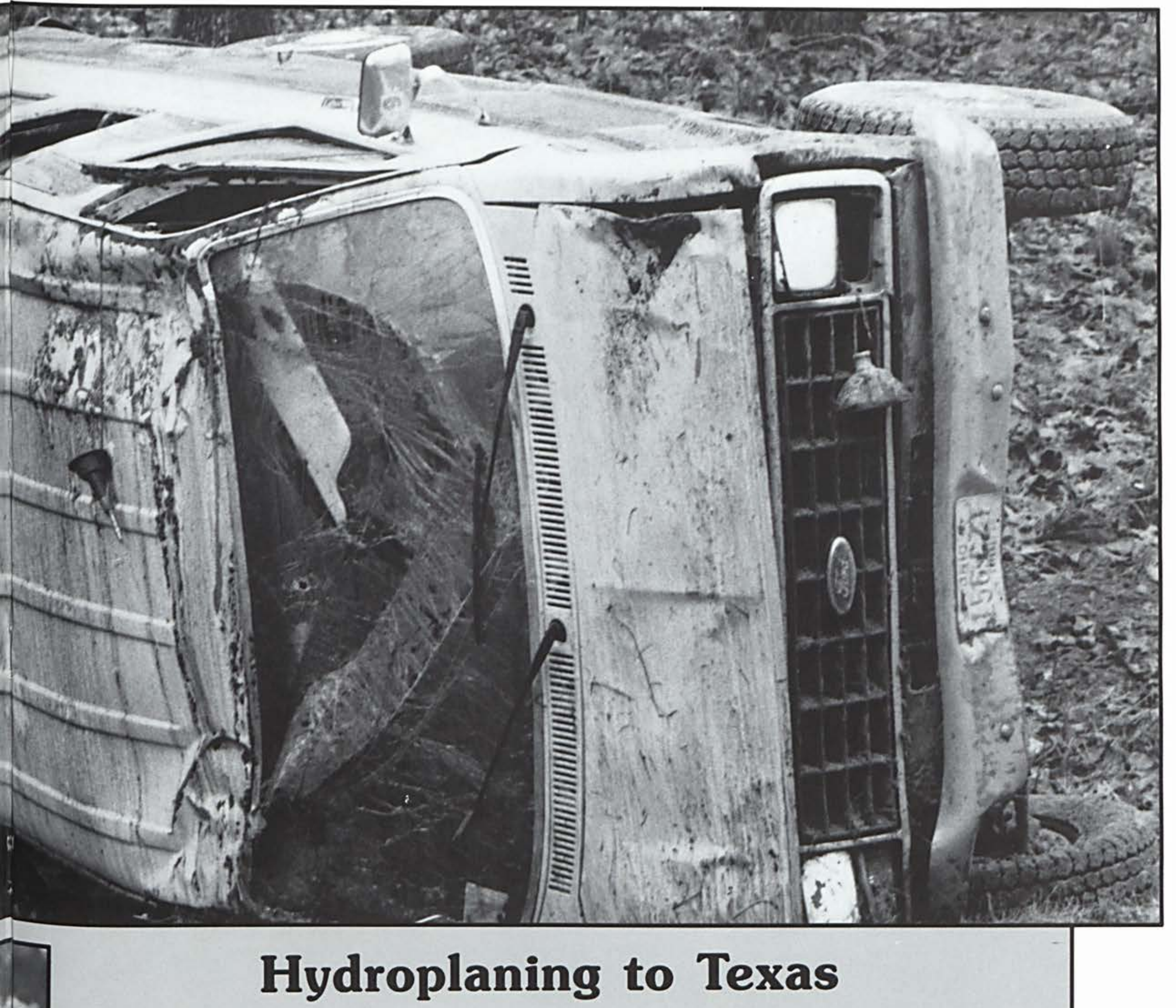

T

his soccer team set the national title as their goal and dream from the beginning of the season. They believed they had the talent and desire to better their previous year's performance. The regular season ended not only with a winning record but also with a few other impressive accomplishments: 15 season victories, 11 shutouts, and an ended 10-match losing streak to Wilmington College. Capping off the season was a trip to Texas for national tournament play.

Twenty miles outside of Longview, Texas, the van carrying eight of the Cedarville soccer players went out of control and rolled completely over as it hit the embankment. At that moment, every team member was afraid. For some, it was fear for their own lives; for others, it was fear for their lives of their teammates and friends. The next few moments were filled with emotion, shock, panic and fearful anticipation. It was an early Thanksgiving as each player was able to walk away from the demolished van with relatively minor injuries. Then, as each player helped comfort and encourage each other, a calmness and affective mood spread throughout the team as the initial fear subsided.

Before the tournament play began, the team had devotions and times of sharing in which players expressed their feelings about the accident and how it affected their lives. The accident had an effect on the entire team and brought a spirit of unity. This inspired unity was demonstrated as the team defeated Letourneau 5-0 in first round action. They then defeated top seated Northwestern 1-0 and headed for a shot at the national title. After a hard fought battle, Cedarville was defeated 2-1 by Kings College in an evenly contested match ending an exciting and eventful season in which each player grew closer to each other and closer to God. 
1985 All Americans: As in any sporting event there were some extraordinary young men who contributed in special ways to lead, enhance and mold the 1985 soccer team. The team took on an air that reflected these strong and intense seniors, Dan Hawk, Noel Hack, and Tom Fite.

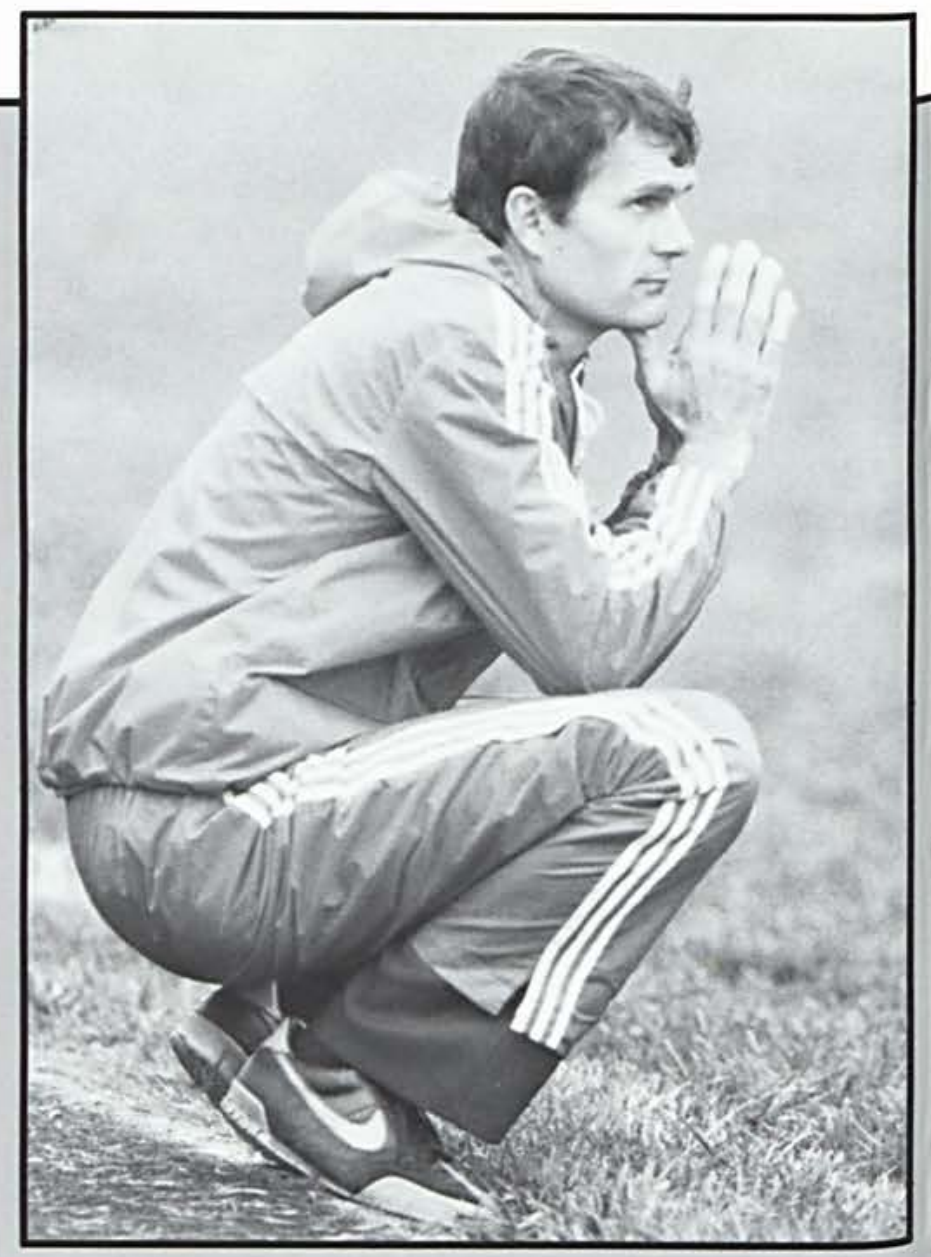

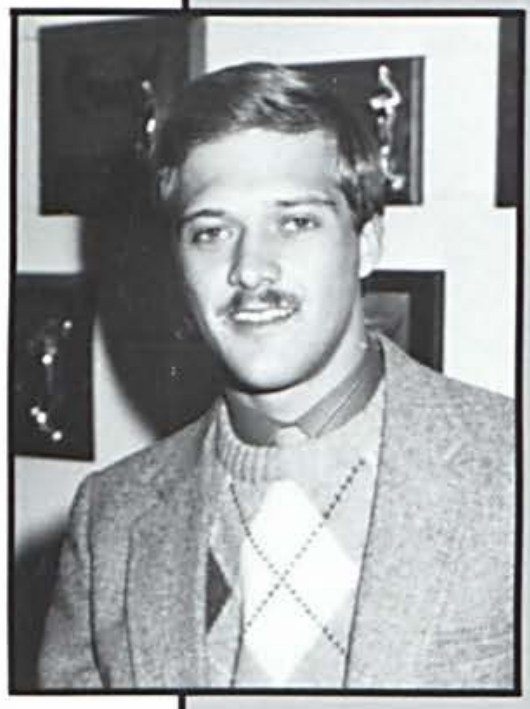
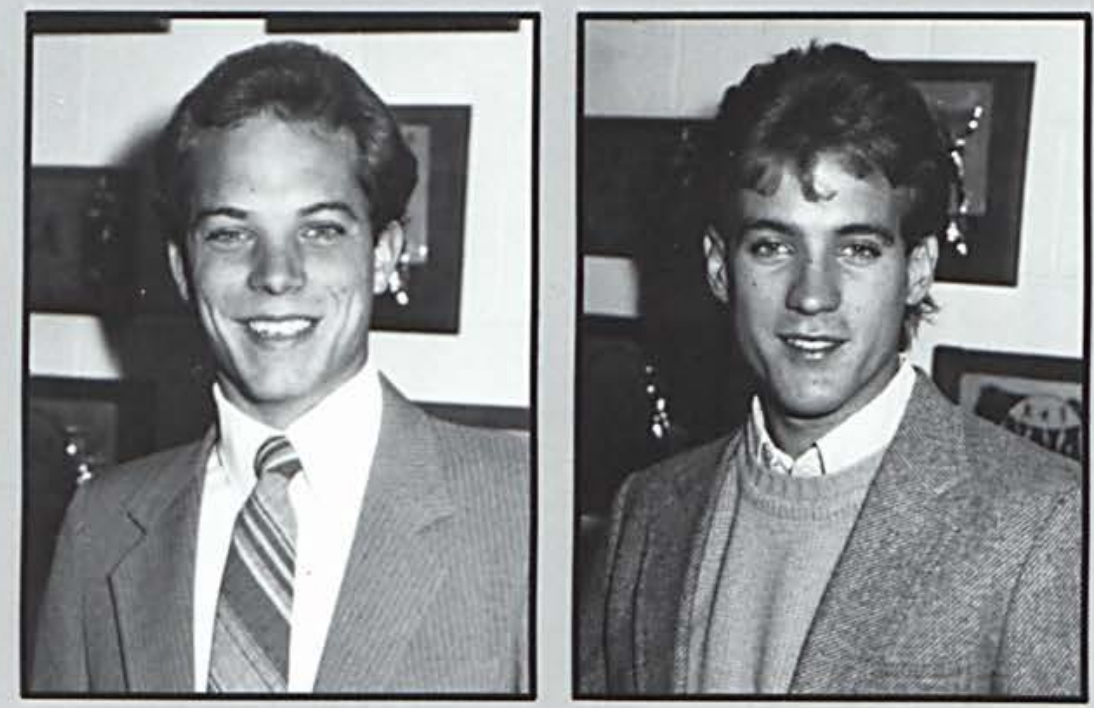

Top Right: Coach John McGillivary analyzes the performance of his team. Right: Freshman Dan Jones showed his skill this fall by netting 6 goals for the

$$
\text { Jackets. }
$$

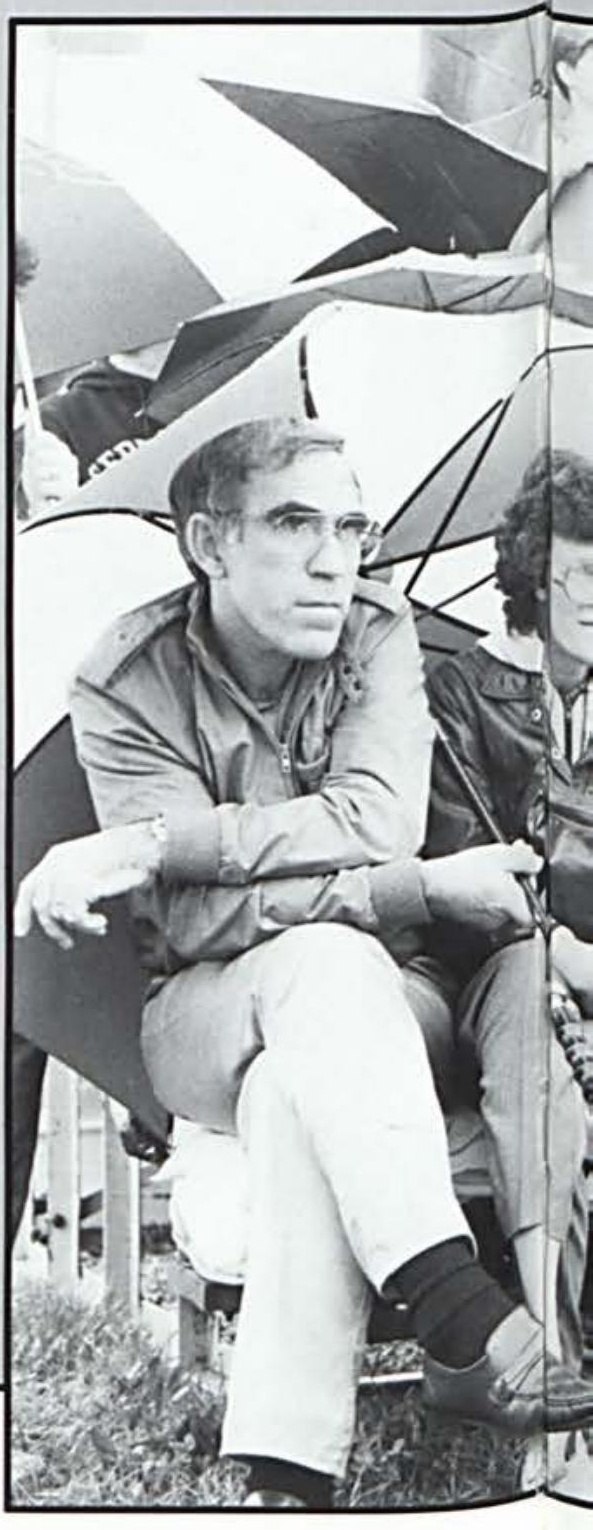




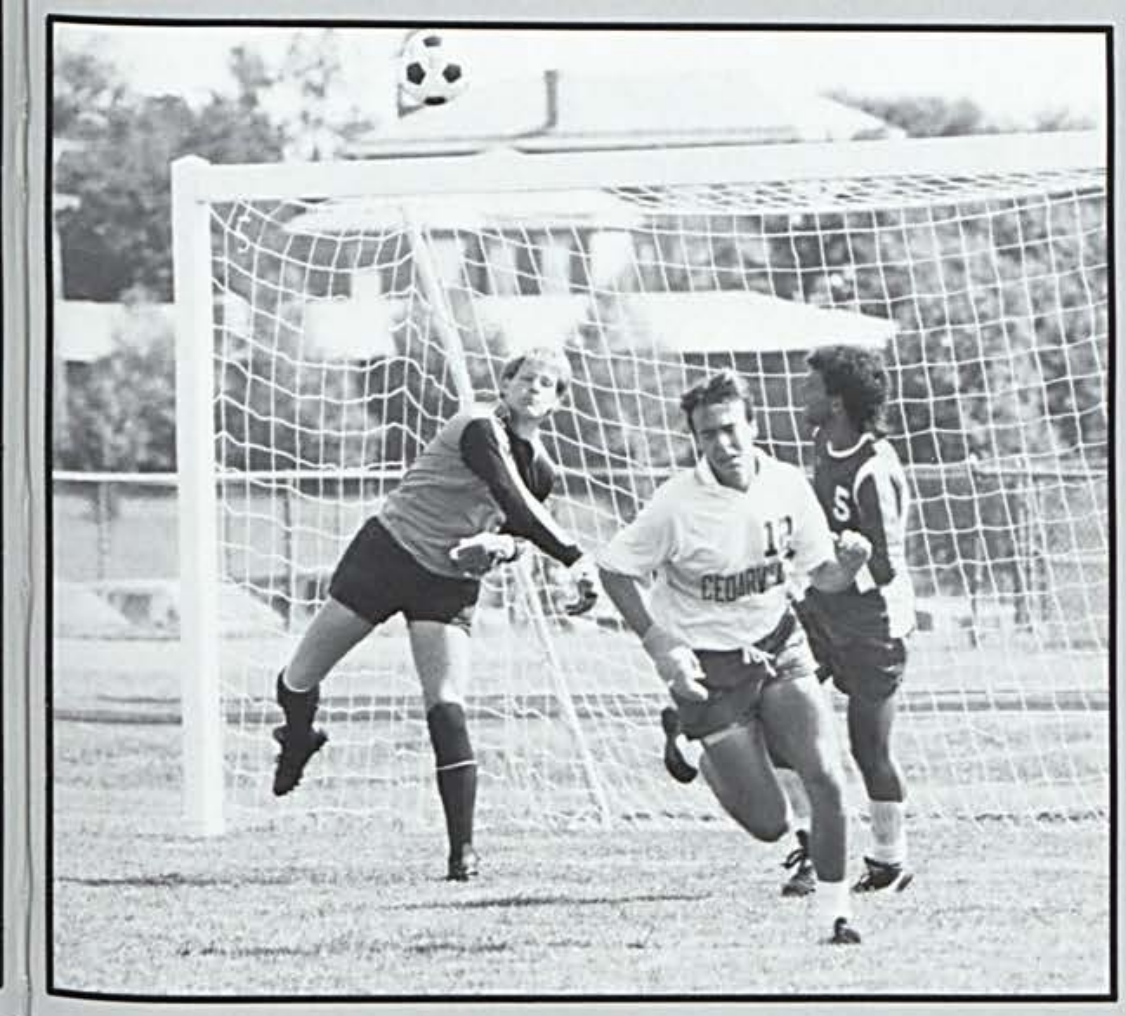

\begin{tabular}{|c|c|c|}
\hline \multicolumn{3}{|c|}{ SCOREBOARD } \\
\hline Jackets & \multicolumn{2}{|c|}{ Opponent } \\
\hline 1 & Denison & 4 \\
\hline 2 & Wittenberg & \\
\hline 6 & Ohio Dominican & 2 \\
\hline 1 & Northern Kentucky & 0 \\
\hline 0 & Asbury & 1 \\
\hline 0 & Goshen & 2 \\
\hline 4 & Mt. Vernon Nazarene & 0 \\
\hline 11 & Rio Grande & 1 \\
\hline 0 & Tiffin & 2 \\
\hline 5 & Urbana - & 0 \\
\hline 3 & Findlay & 0 \\
\hline 2 & Walsh & 0 \\
\hline 3 & Wilmington & 2 \\
\hline 0 & Malone & 0 \\
\hline $\begin{array}{l}4 \\
8\end{array}$ & $\begin{array}{l}\text { Bluffton } \\
\text { Mt Vernon Nazarene }\end{array}$ & \\
\hline 2 & $\begin{array}{l}\text { Mat. Vernon Nazarene } \\
\text { Manchester }\end{array}$ & 0 \\
\hline 0 & Wilmington - & 5 \\
\hline 4 & Marion. & 0 \\
\hline 5 & LeTourneau -- & 0 \\
\hline 1 & Northwestern -. & 0 \\
\hline 1 & The Kings - & \\
\hline & $\begin{array}{l}\text { NCCAA District in } \\
\text { Playoffs }\end{array}$ & \\
\hline & Referee abandoned game & \\
\hline & $\begin{array}{l}\text { at 54:08. } \\
\text { NAIA District } 22\end{array}$ & \\
\hline & Playofis & \\
\hline - & $\begin{array}{l}\text { NCCAA National } \\
\text { Tournament }\end{array}$ & \\
\hline
\end{tabular}

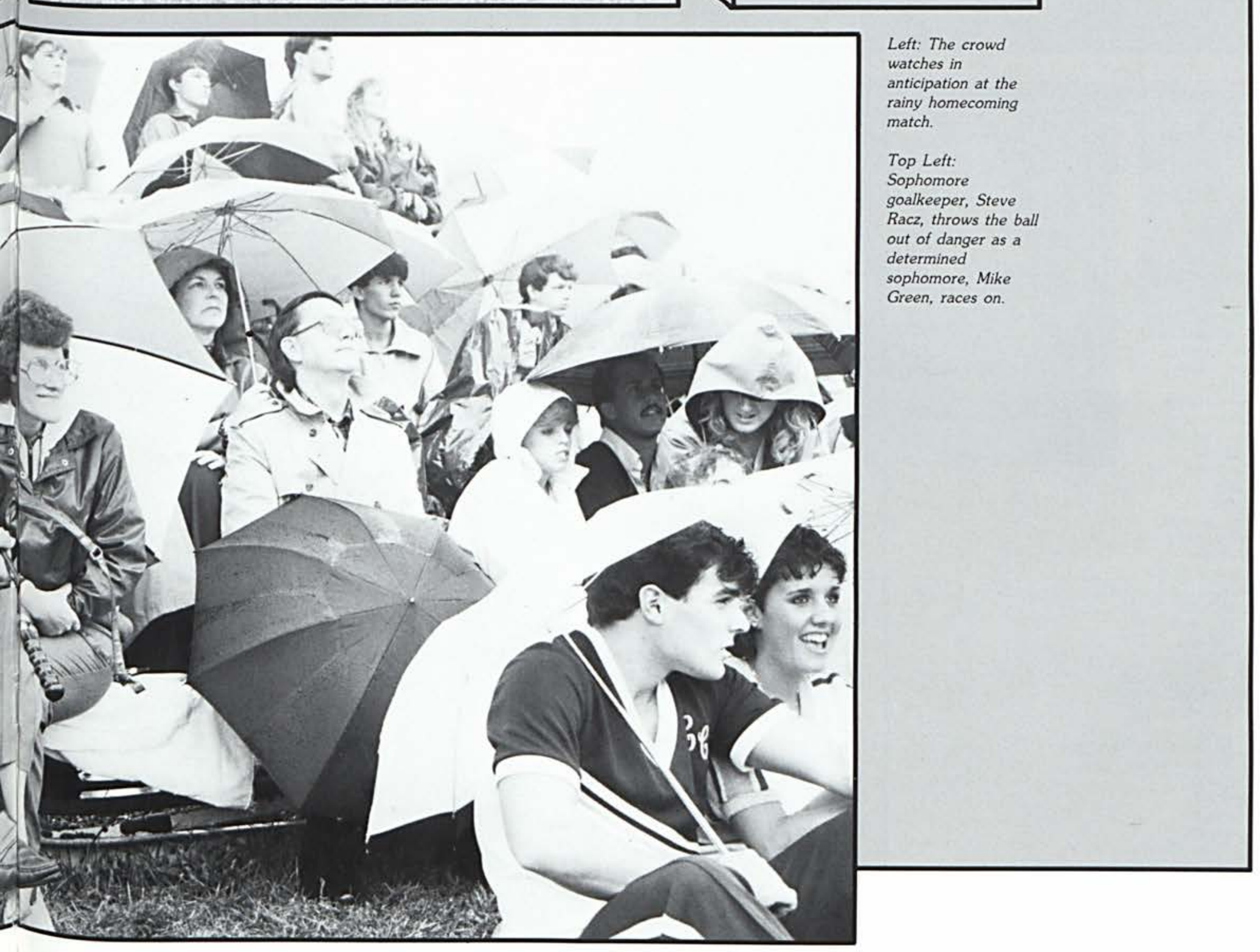




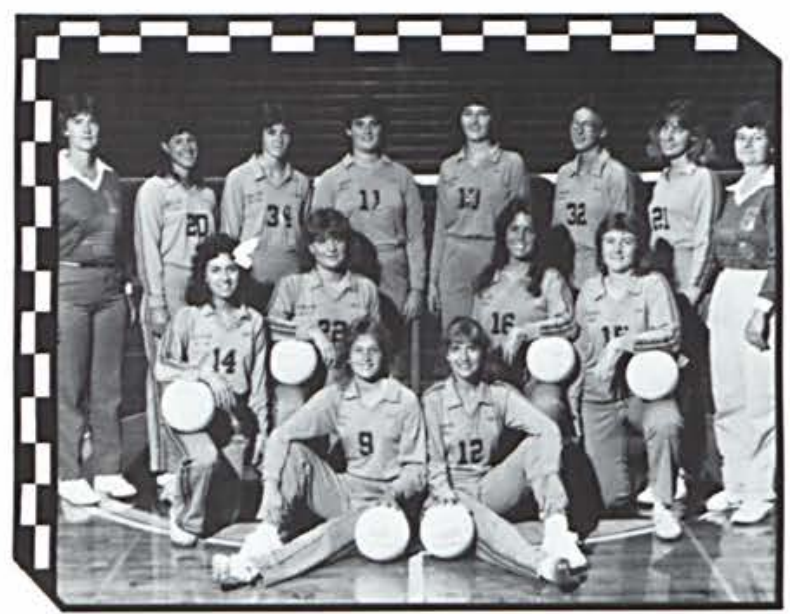

Front row: Judy O'Connor, Lori Miesse. Middle row: Becky Wilson, Janae Smart, Melinda Bradley, Angie Wilcox. Back row: Manager Kelly Helmick, Michelle Lelah, Tammy Mascari, Kristi Culp, Jeri Hastman, Julie Butler, Nancy Ozinga, Coach Elaine Brown.

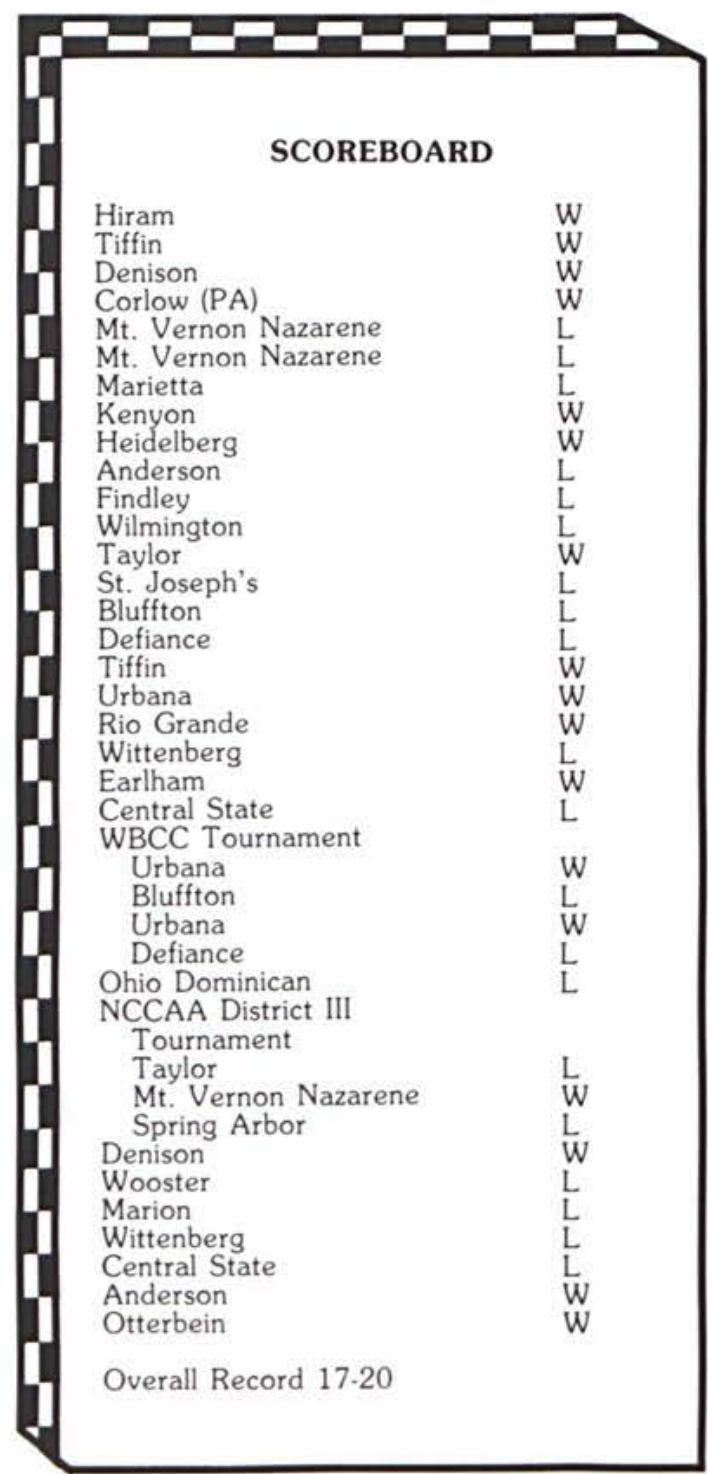

\section{Hoping To Excel}

$\mathbf{L}$

ady Jackets volleyball coach Elaine Brown began last year's season hoping that her team still had the winning desire that it took to have a record season like the year before. Even though their season lingered around the 500 mark before finishing at 17-20, this year's squad displayed much talent. Junior Melinda Bradley (right) hammered 217 kills, accumulated 429 assists and made the All-WBCC first team. Honorable Mention pick Becky Wilson (below) led the team with her 256 digs and 98 percent serve accuracy. Also, contributing much to the team this year was junior Angie Wilcox with 48 serve aces, junior Julie Butler with 26 solo blocks, and freshman Jeri Hastman with 27 blocking assists.

The team will lose two veteran players next year, but coach Elaine Brown has high hopes that her younger players will quickly excel in their skills and fill the empty positions adequately.

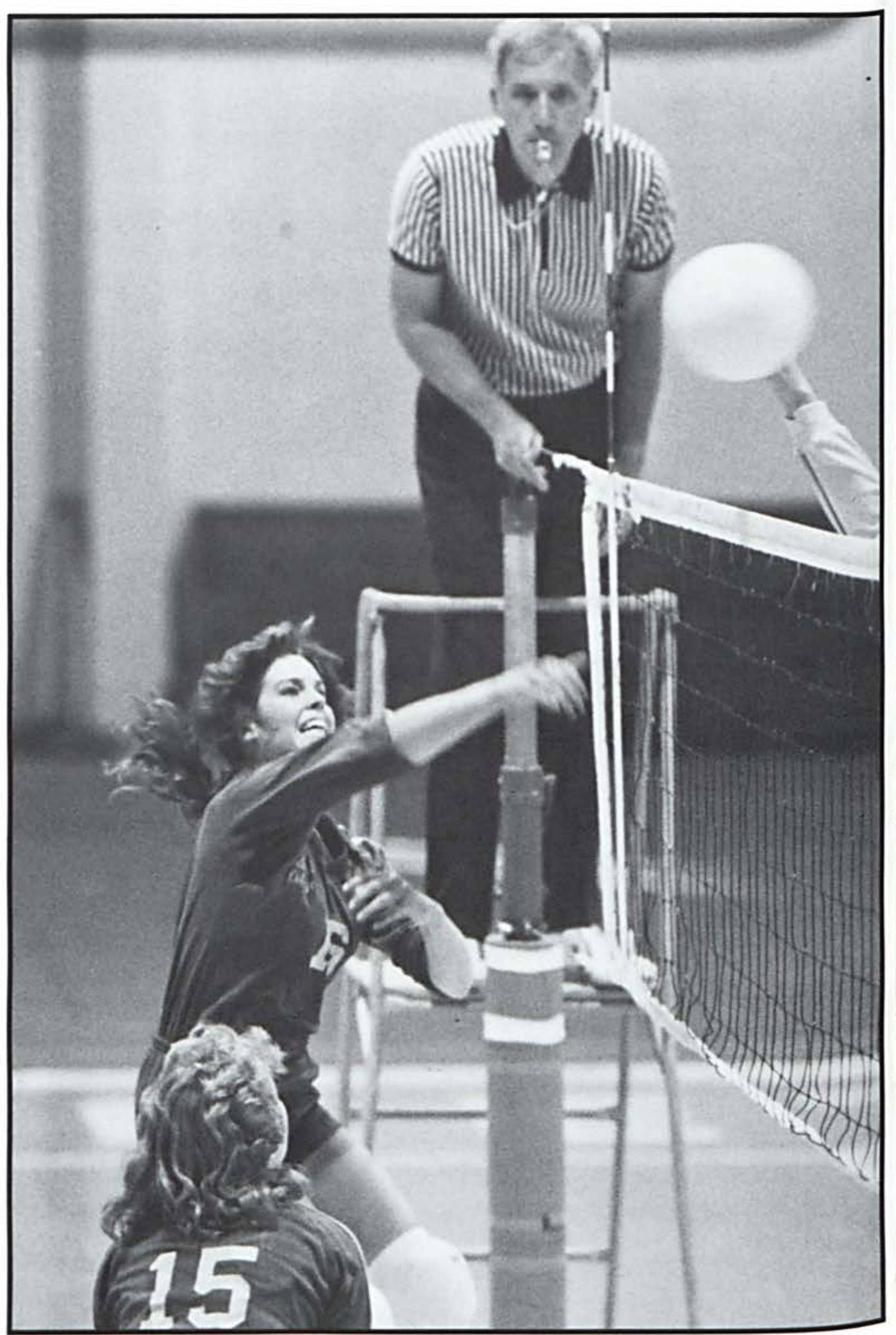




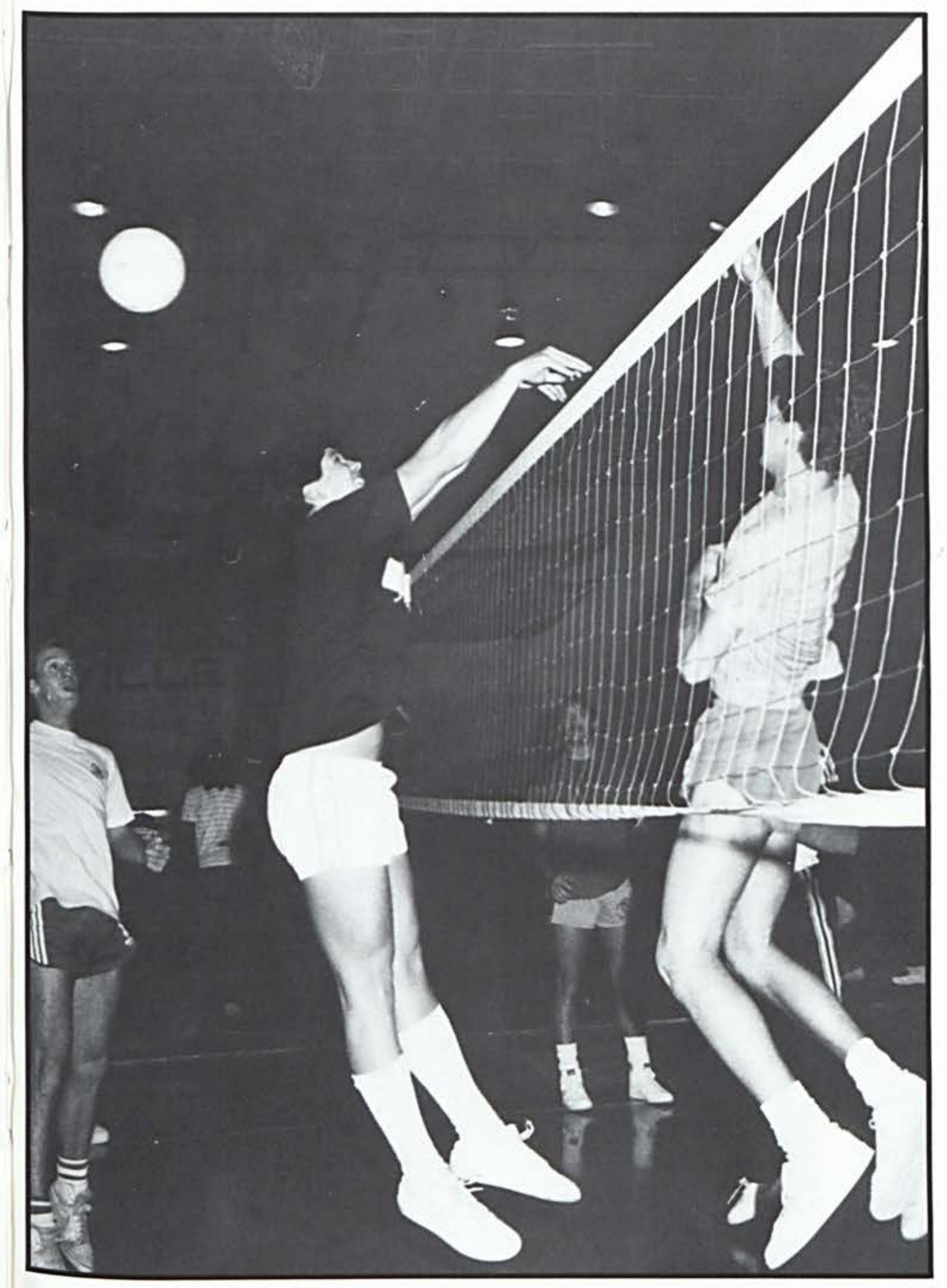

Fall

Intramural

Activity
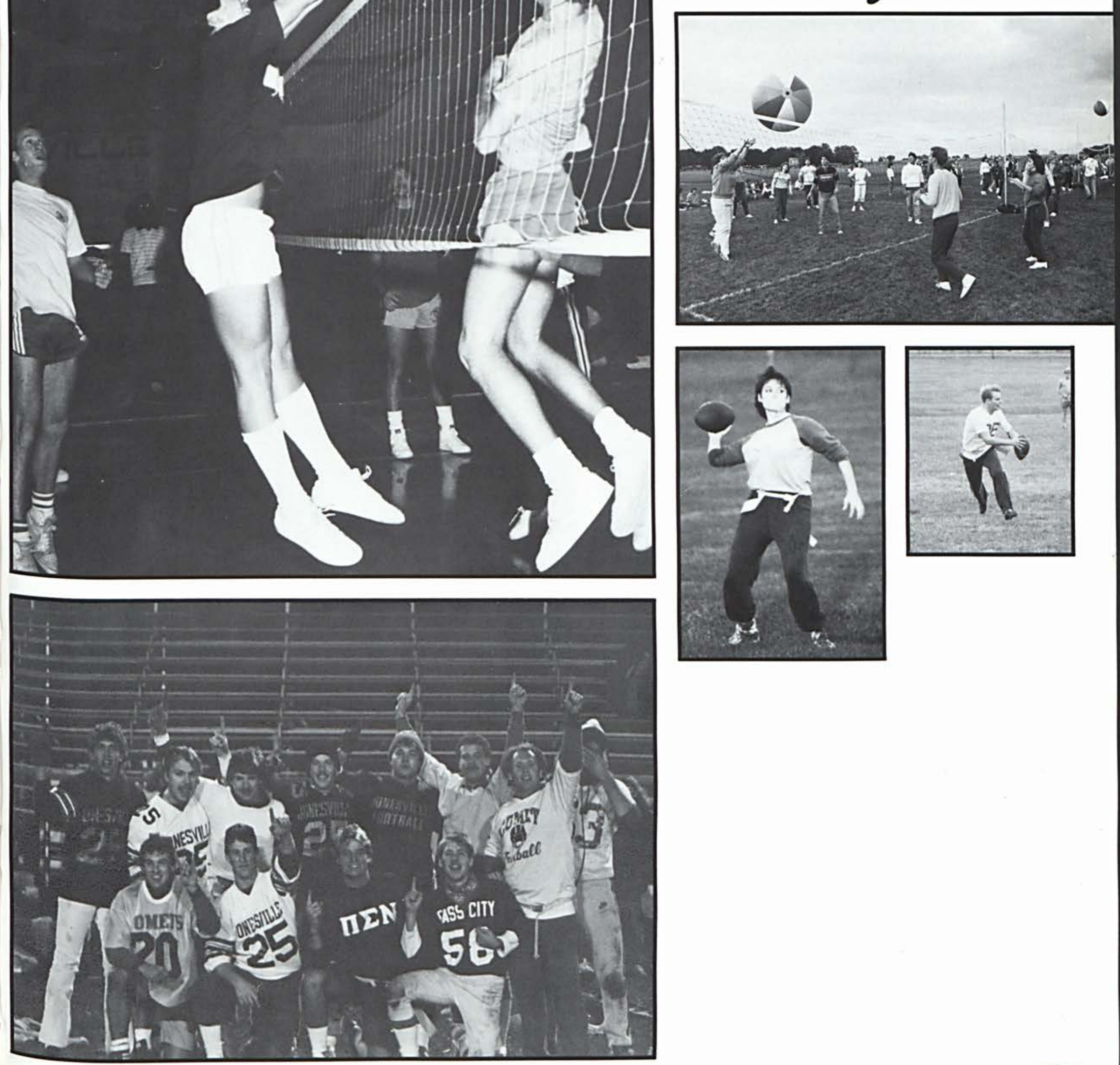


\section{Recapturing the Championship}

I

t all started in early August when the men returned to Cedarville for the 1985 Cross Country camp. Coach Elvin King had high hopes that this would be the best cross country team he had ever assembled at Cedarville

College.

Coach had three main objectives he wanted the team to accomplish: 1) recapture the NCCAA championship title which had been previously held by Anderson College over the past five seasons, 2) qualify as a whole team for the NAIA Championship held in Kenosha, Wisconsin, and 3) defeat Malone College who had been the reigning authority on running in our part of the nation over the past several years.

Much to coach's delight, the team was able to achieve the first two goals by winning the NCCAA crown and strongly qualifying for the NAIA championship meet. The men were unable to defeat Malone College but proved that Cedarville College was now a team not to be taken lightly.

A large part of the success this year can be attributed to the strong leaders the returning Yellow Jackets had: Rob Moore, Tom Hill, Scott Brooker, and Rusty King. In addition to this talent, coach's new recruits: John Oswald, a transfer student from GRBC, and freshmen J.P. Dawes and Steve Schepers provided the depth and balance needed to attain the goals they set.

Tom Hill

1985 NCCAA Champions:

Coach Elvin King, J.P. Dawes, Kevin Wallace, Rusty King, Steve Schepers, John Oswald, Rob Moore, Tom Hill, Scott Brooker, Steve Cox. All American Senior Tom Hill presses on toward the finish line. Coach King encourages senior Scott Brooker to keep up the pace.
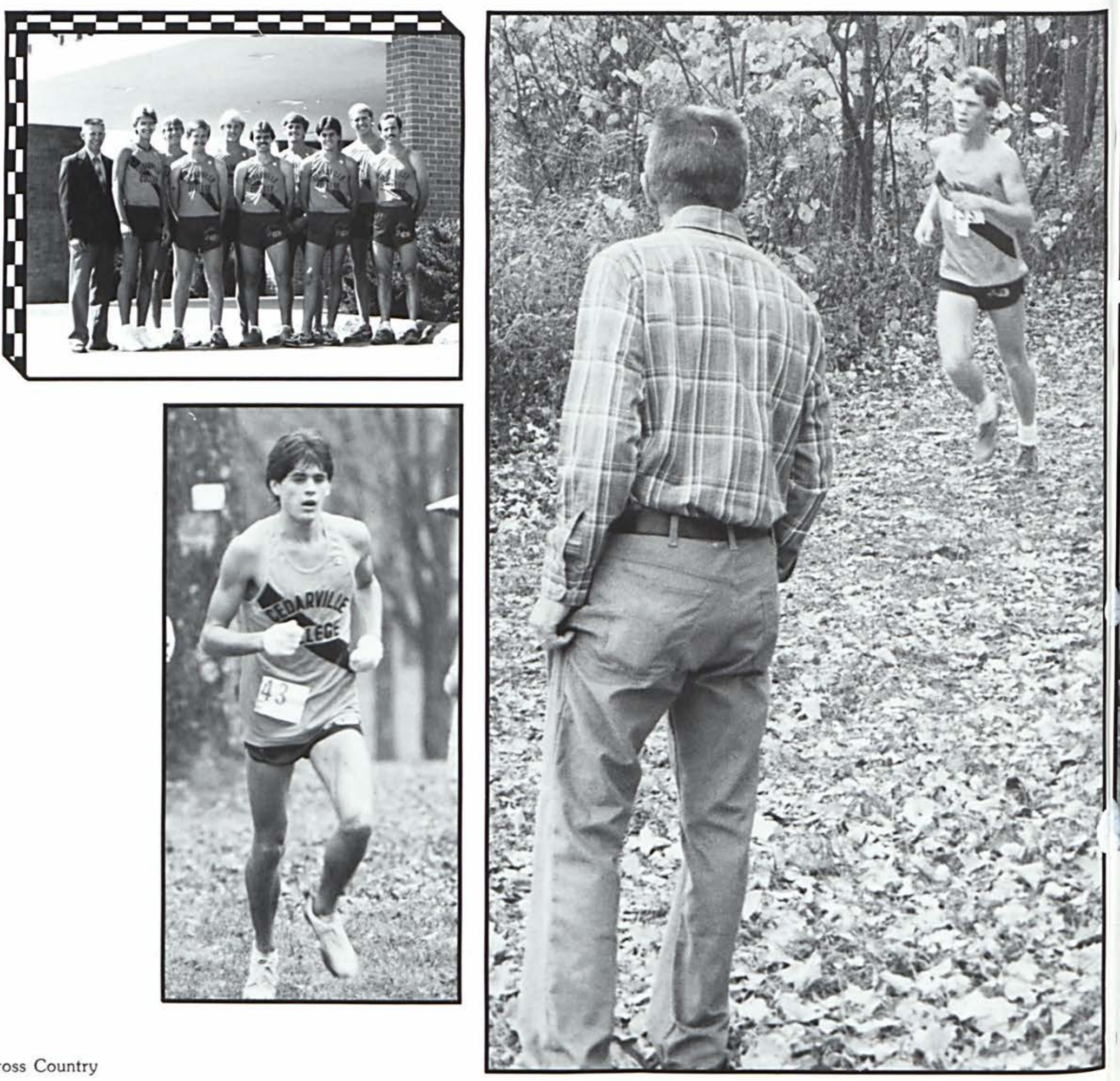

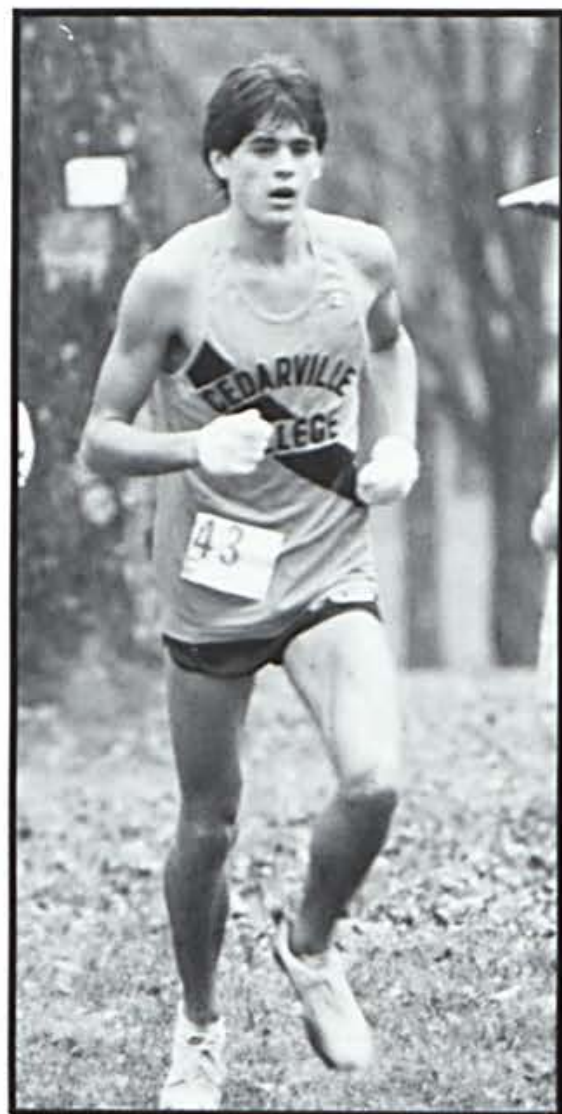

428

Cross Country 

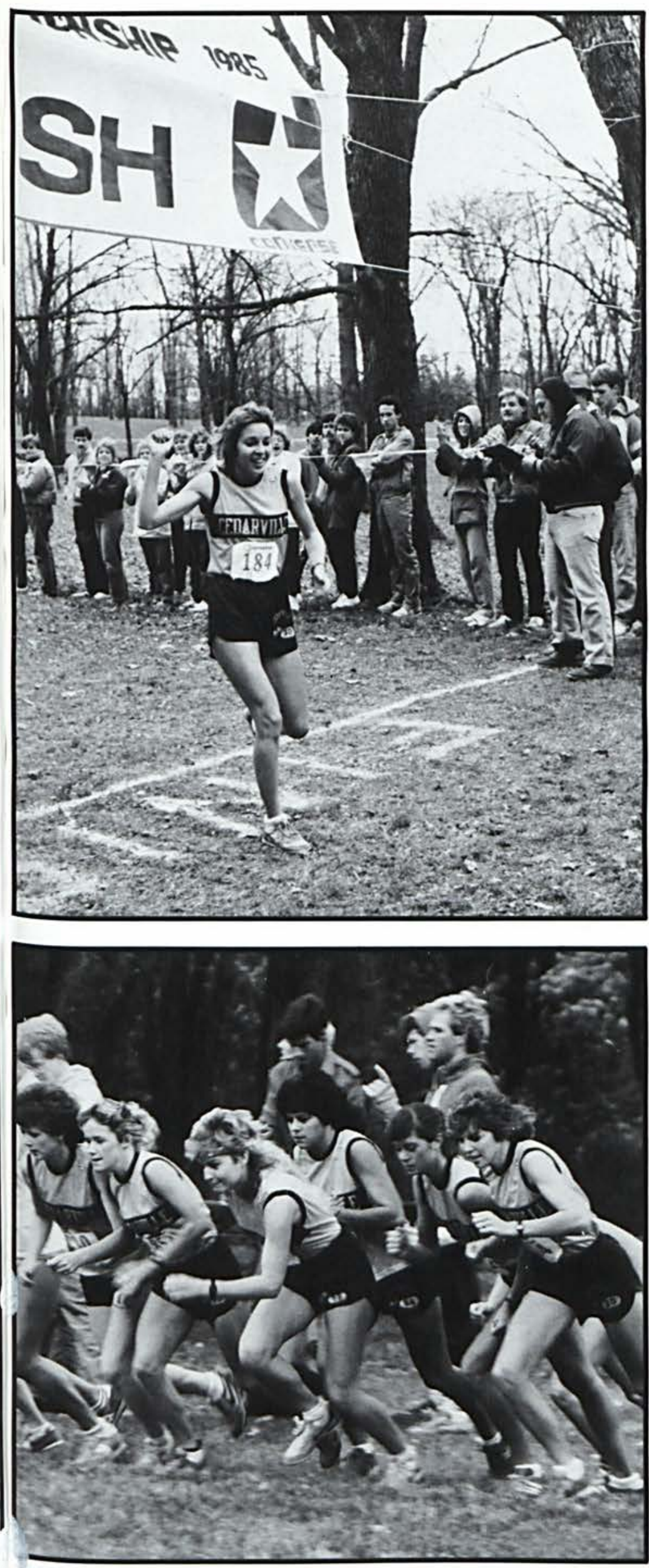

Elvin King. Back row: Becky Averill, Deb Pate, Sherri Norrick.

op left:

With much endurance two-time national champion, Jane Romig victoriously finishes nother race.

Bottom:

\section{Outstanding Female Athlete}

While ability and dedication led Jane Romig Brooker to much athletic recognition, her personality and interest in others led her to many friendships. In the NCCAA, Jane won All-American honors in both track and cross country. She also was a recipient of the Wheeler Award, an award given to an outstanding Christian athlete.

As an NAIA Academic All-American, the senior runner won recognition as an All-American in both indoor and outdoor track. This made her a two-time national indoor track champion. To add to Jane's achievements at CC, she was named Outstanding Female Athlete of the 1986 National Indoor Meet.

Coach King
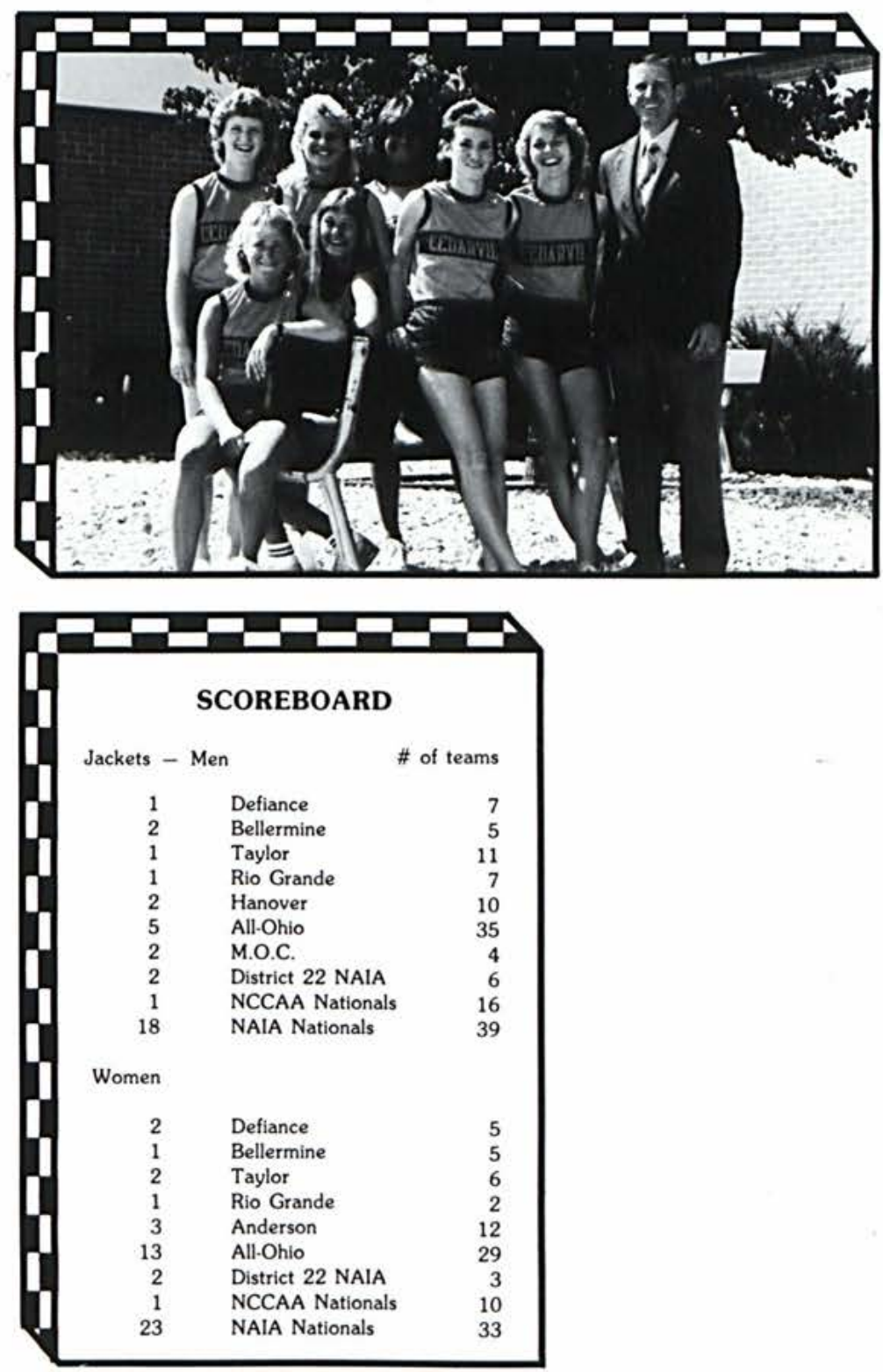


\section{Rolling Ahead}

$\mathbf{T}$

he Lady Jackets of Cedarville had quite a season in 1985-86 under the direction of Coach Bob Fires. The team had a slow start in the beginning of the season, but Coach Fires did an excellent job encouraging and working with them. The second half of the season rolled by with a full head of steam. The Lady Jackets showed a lot of courage and persistence to come as far as they did in a short period of time.

With the leadership of starters and co. captains, Karen Headings and Jewel Shroder, the ladies played strongly at the NCCAA tournament which they hosted. This tournament was the highlight of the season. The improved Jackets upset the No. 1 seed in the first game of the tournament. They battled closely in the second game, but lost the championship game.

The ladies relied heavily on each other. One of their greatest strengths was the encouragements they received from each other and the hard work they put into the season. With an ' 86 record of $11-13$, the Lady Jackets are expecting much more in next year's play.

The returning players are determined to roll forward with a victorious head of steam.

Crystal Patrick

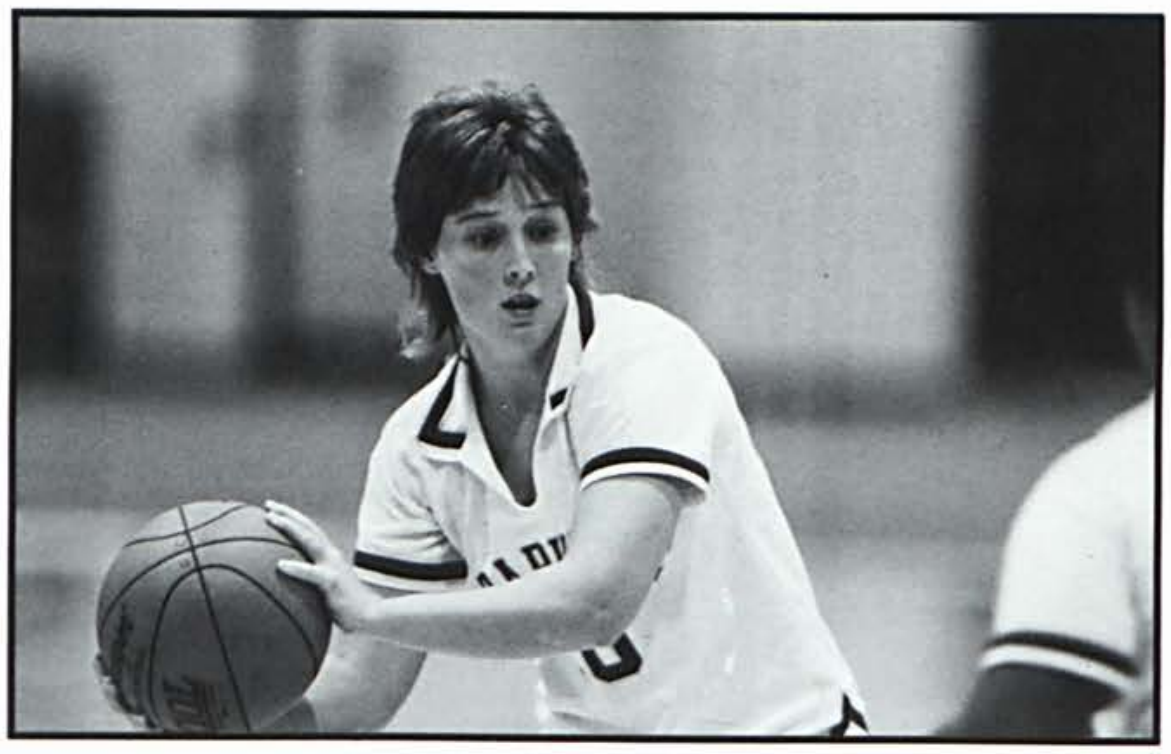

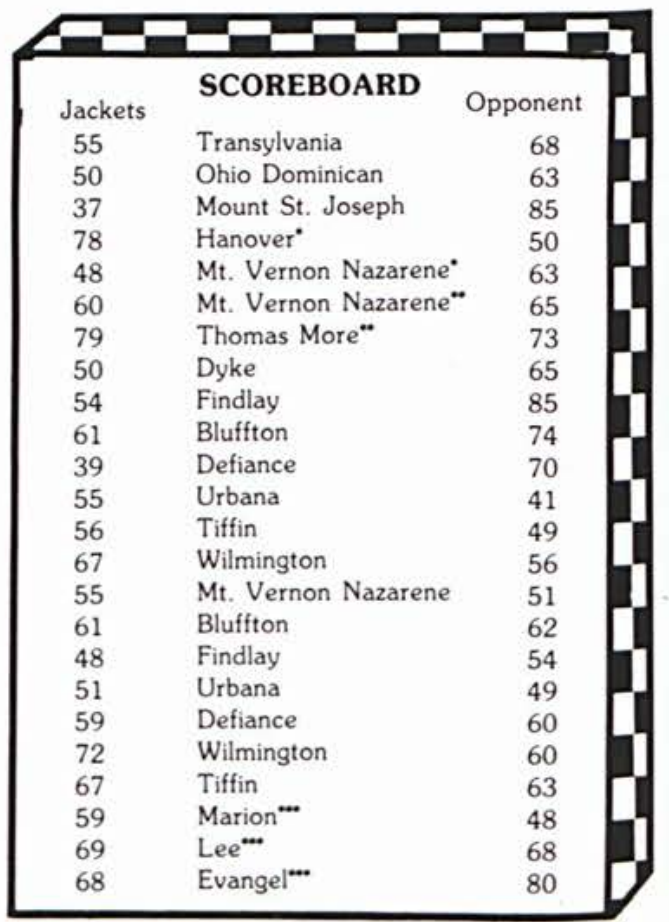

Evangel ${ }^{-*}$ 


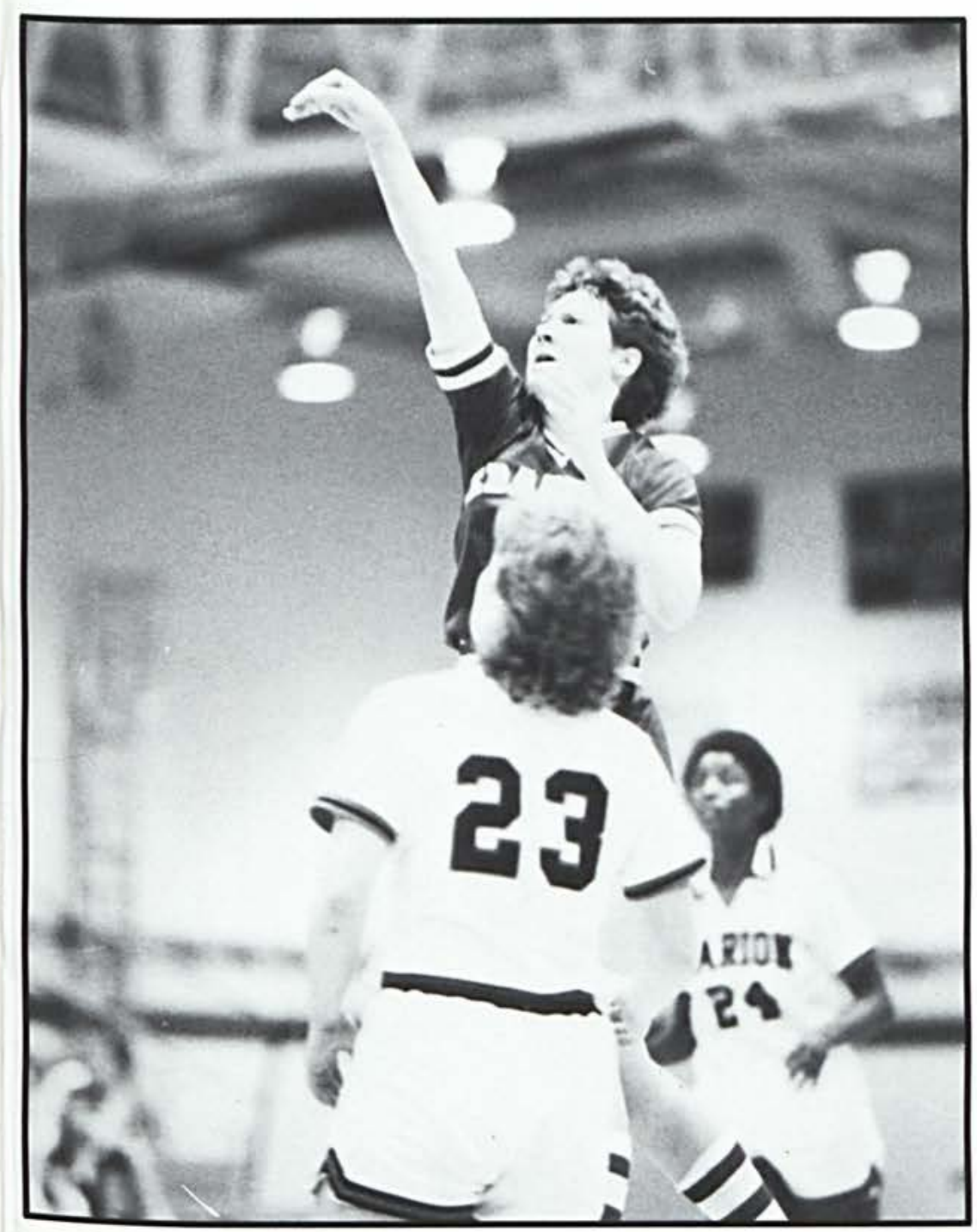

Far left: Freshman Michelle Freeman was high rebounder in the exciting overtime match against Urbana University.

Left: Senior Karen Heddings led the team with the highest percentage of field goals made, free throws made, and rebounds.

Below: Assistant coach Diane Lichtensteiger evaluates the squad as coach Bob Fires calls for a time out in the first game of the Cedarville Invitational.

Bottom far left: Leading the Lady Jackets with 87 assists this season was sophomore Crystal Patrick.

Bottom middle: In the NCCAA National Tournament senior Jewel Schroder contributed greatly to the defeat of Marion College, 59 to 48
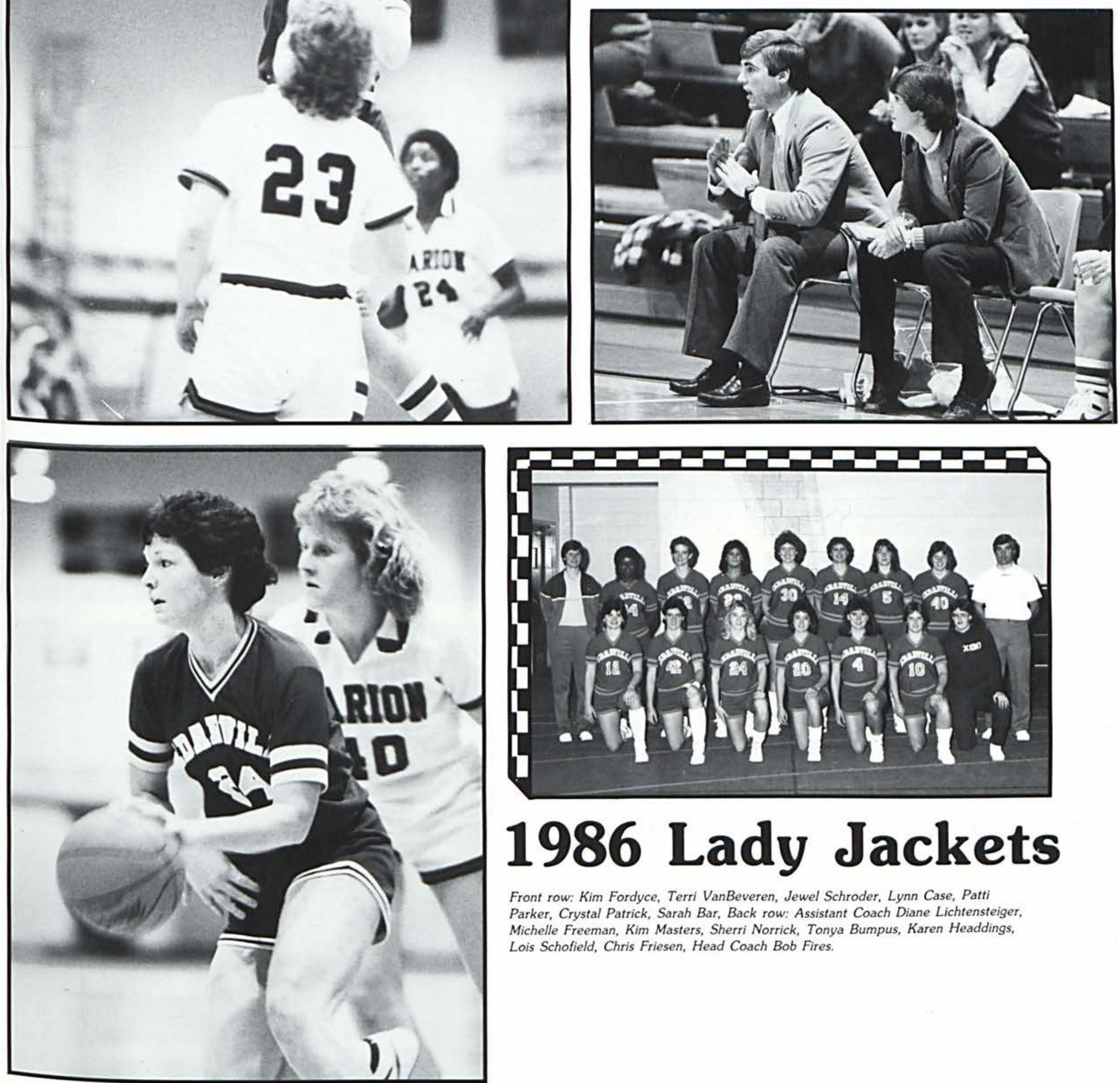

Front row: Kim Fordyce, Terri VanBeveren, Jewel Schroder, Lynn Case, Patti Parker, Crystal Patrick, Sarah Bar, Back row: Assistant Coach Diane Lichtensteiger Michelle Freeman, Kim Masters, Sherri Norrick, Tonya Bumpus, Karen Headdings, Lois Schofield, Chris Friesen, Head Coach Bob Fires. 


\section{NCCAA District III Runners-Up}

Front row: Assistant Coach Mark Kempton, Coach Dr. Don Callan, Assistant Coach Steve Young. Back row: Brent Lydic, Gary Shaffer, Doug Loescher, Doug Pugh, Steve Terpstra, Chris Walter, David Yeager, Don Simerly, Jerry Keller, Kirk Fairhurst, Mike Campbell, Mike Freeman, Chris Reese, George Gorman, Manager Tim Royer.
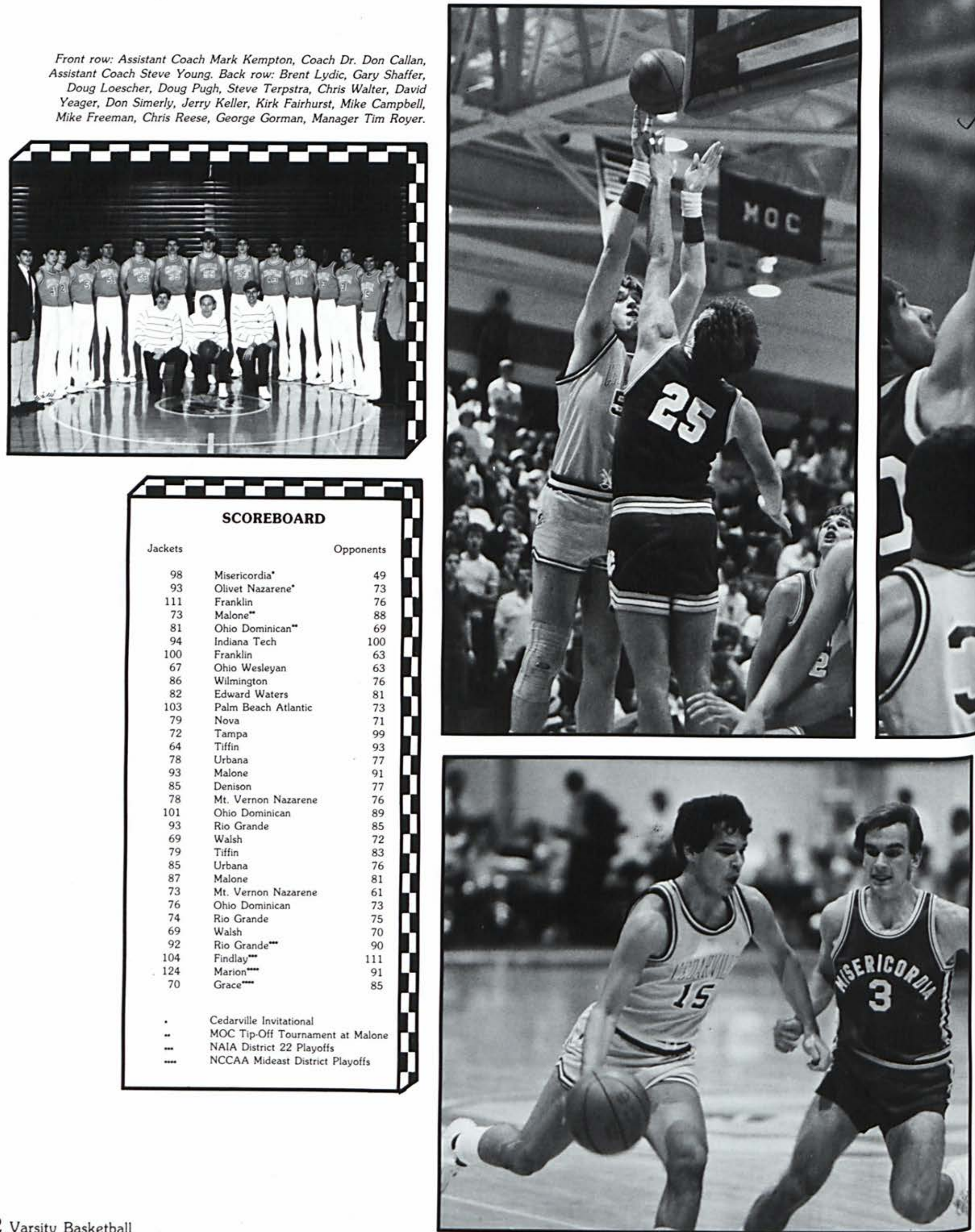

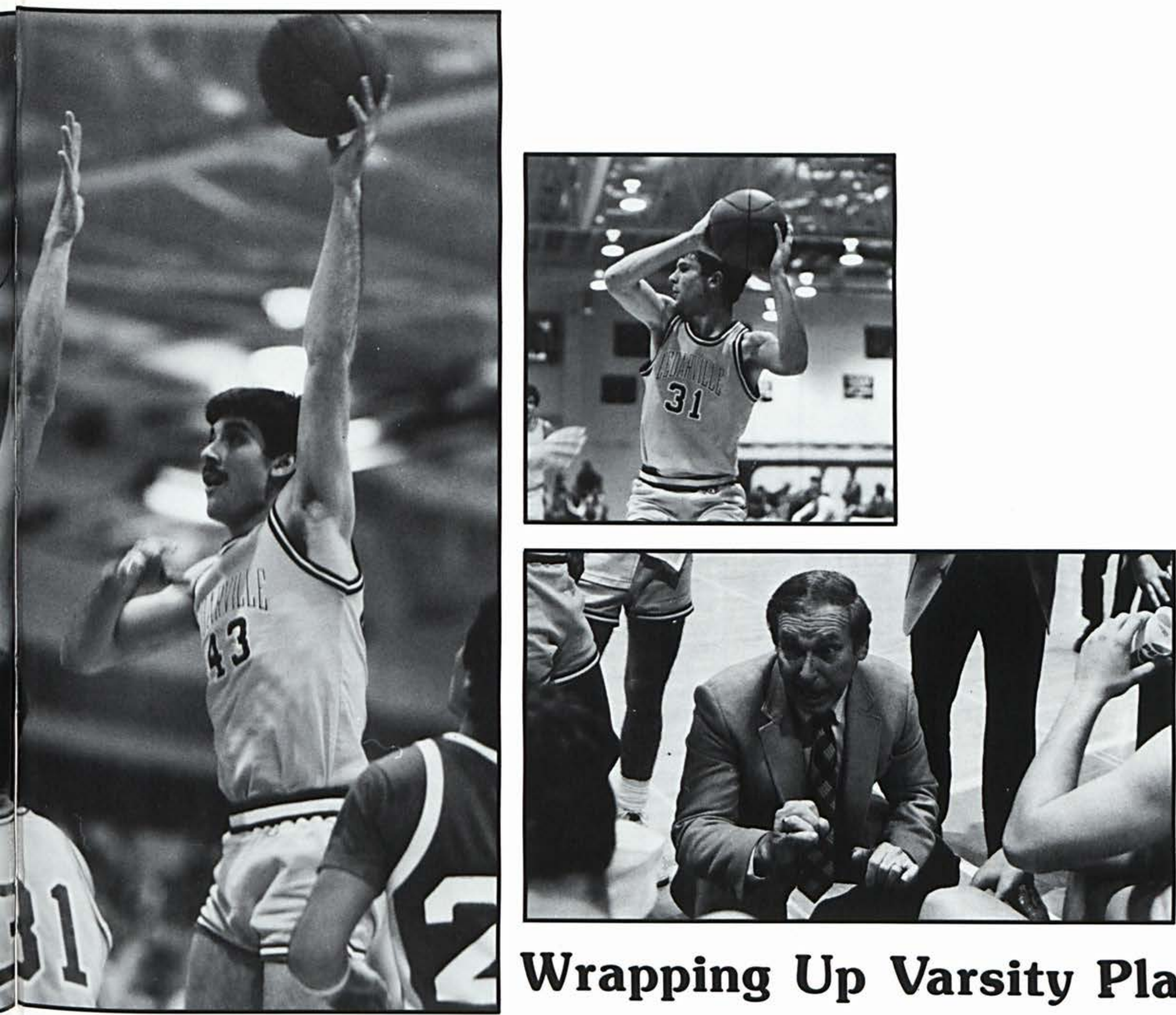

\section{Wrapping Up Varsity Play}

$\mathbf{T}$

he 1985-86 Cedarville College men's varsity basketball program was not given much hope of a winning campaign at season's start. Coach Don Callan (above right) entered his 26th year at the helm with a number of questions and not enough answers. However, the Yellow Jackets pulled together and compiled a 22-10 record which was Callan's first 20-win season in five years.

George Gorman, (left) the "Most Valuable Player," led the club with an 18.5 points per game scoring average and set a school record with 326 assist mark when he dealt out 20 in a win at Franklin. George was named to both the Mid-Ohio Conference and NAIA District 22 first teams. The point guard was selected the MVP of the Cedarville Invitational, twice named the MOC "Player of the Week," and once tabbed the NAIA District 22 "Player of the Week."

Gorman was complimented on the perimeter by sophomores Chris Reese (top right) (16.3 ppf) and Mike Freeman (14.9 ppg). Both players were honorable mention selections in the conference and the district. Senior Chris Wallter (7.9 ppg) and 6-9 sophomore Don Simerly (top, opposite page) (8.2 ppg) started most of the year on the front line. Walter led the team in rebounding at 7.5 per game which included a career-high 22 boards at home against Urbana. Simerly showed tremendous improvement throughout the season and averaged 6.9 rebounds per outing. Callan received plenty of help from his bench in seniors Kirk Fairhurst (above middle) (6.5ppg) and Mike Campbell $(5.9 \mathrm{ppg})$ along with junior David Yeager $(5.3 \mathrm{ppg})$. All three started at one time or another throughout the season and turned in some fine performances.

Cedarville tied for third place in the MOC at 9-5 and was the only team to beat league champ Malone College twice. The Jackets finished as the runner-up in District III of the National Christian College Athletic Association. They also lost to the eventual NAIA District 22 champion in the semifinals of the tournament. Cedarville averaged 85.4 points per game and had a superb $16-12$ record in games it scored 80 or more points. Callan closed the year with a career record of 379 wins and 320 losses. 


\section{Young But Talented}

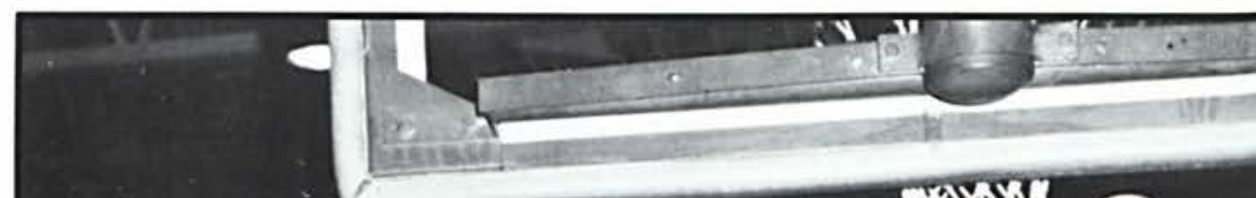

Manager Brent Lydic, Gary Shaffer, Rob Miller, Mike Watson, Dan Morris, Gerry Keller, Mike Woodard, John Bercaw, John Bocciardi, Doug Loescher, Rob Broline, Coach Mark Kempton. Not pictured: Eric Clark.
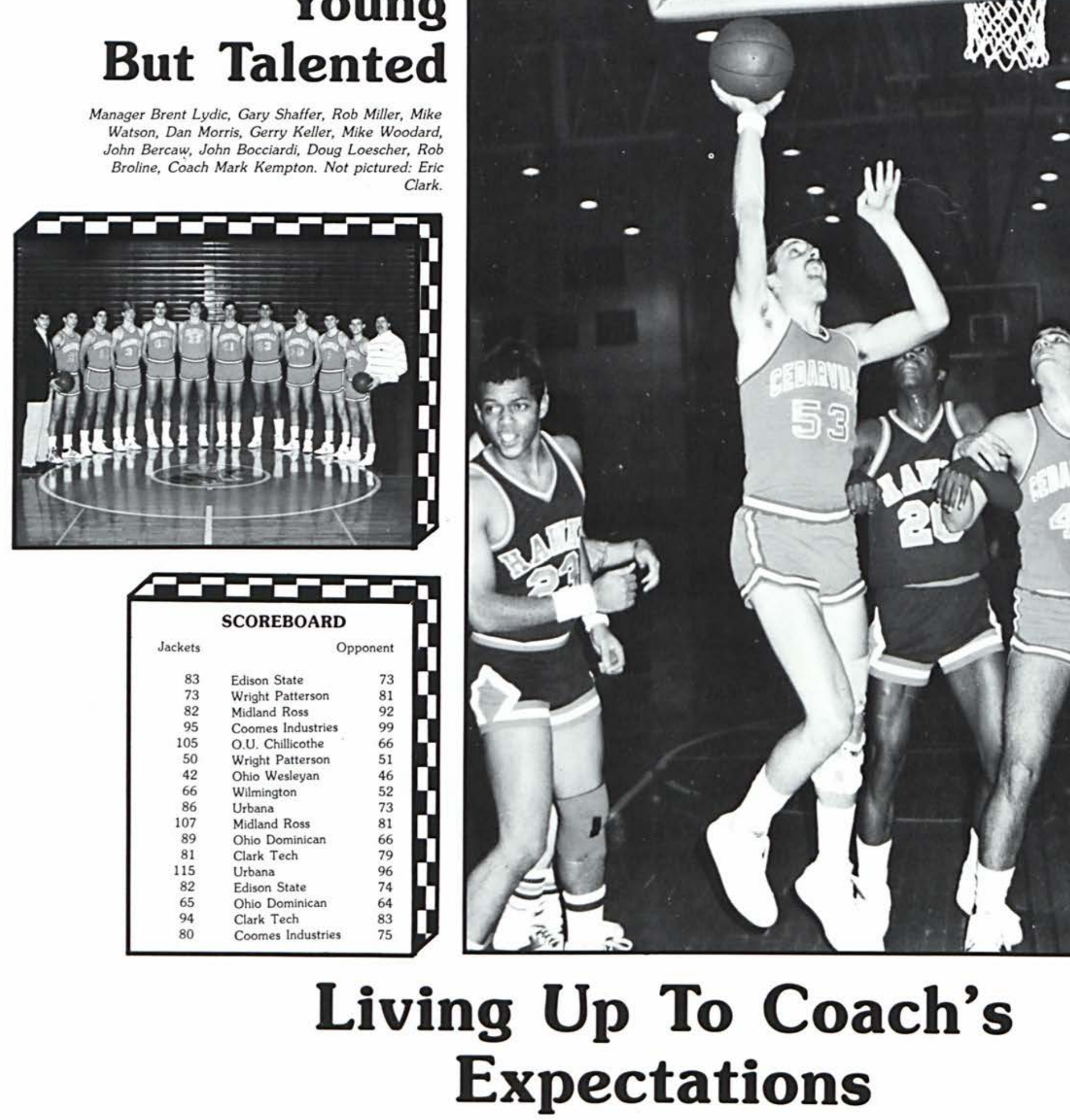

$\mathbf{F}$
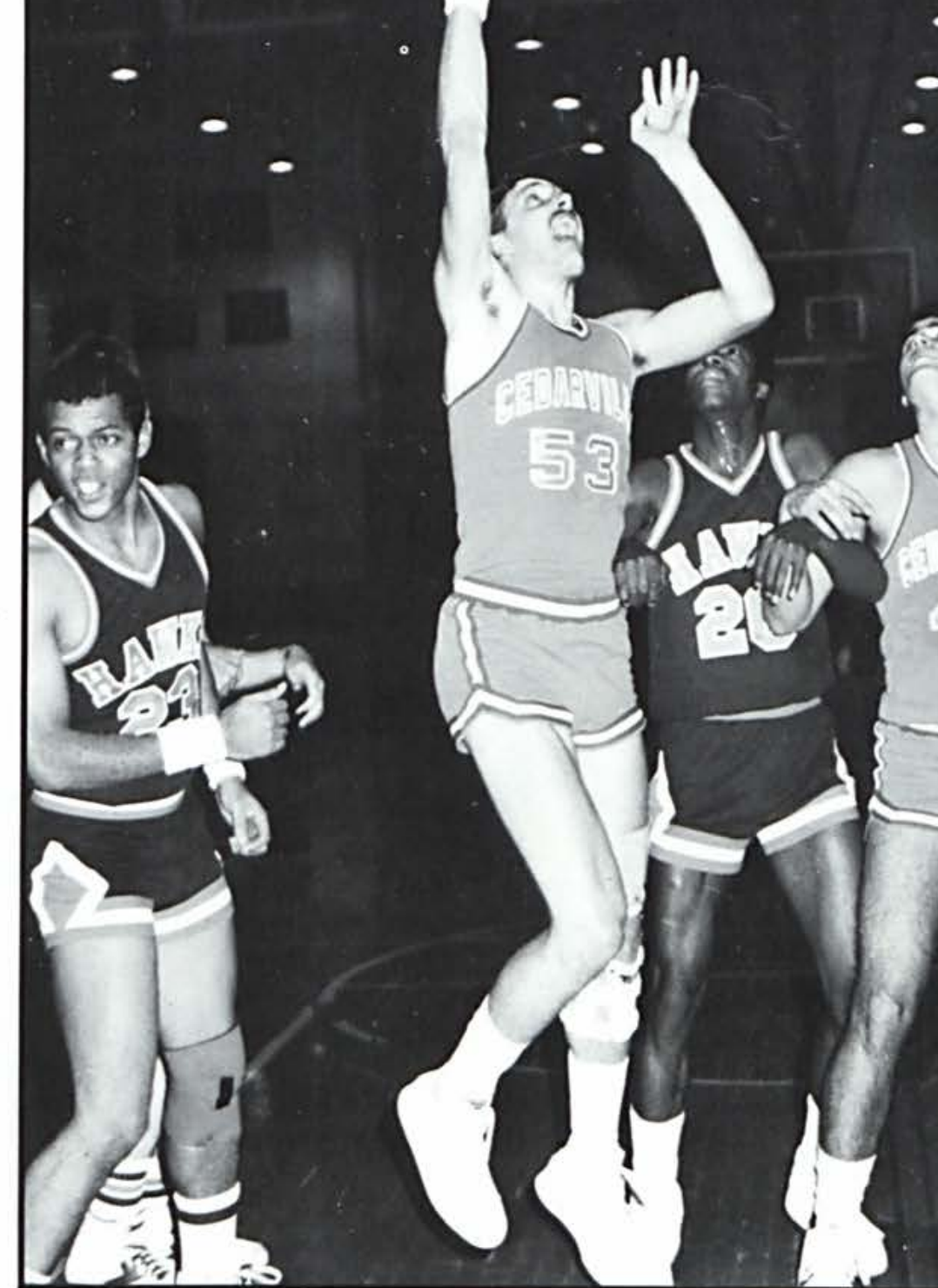
Below: In his freshman year Mike Woodard broke the 100 mark with this jump shot in tournament play asgainst Marion College!
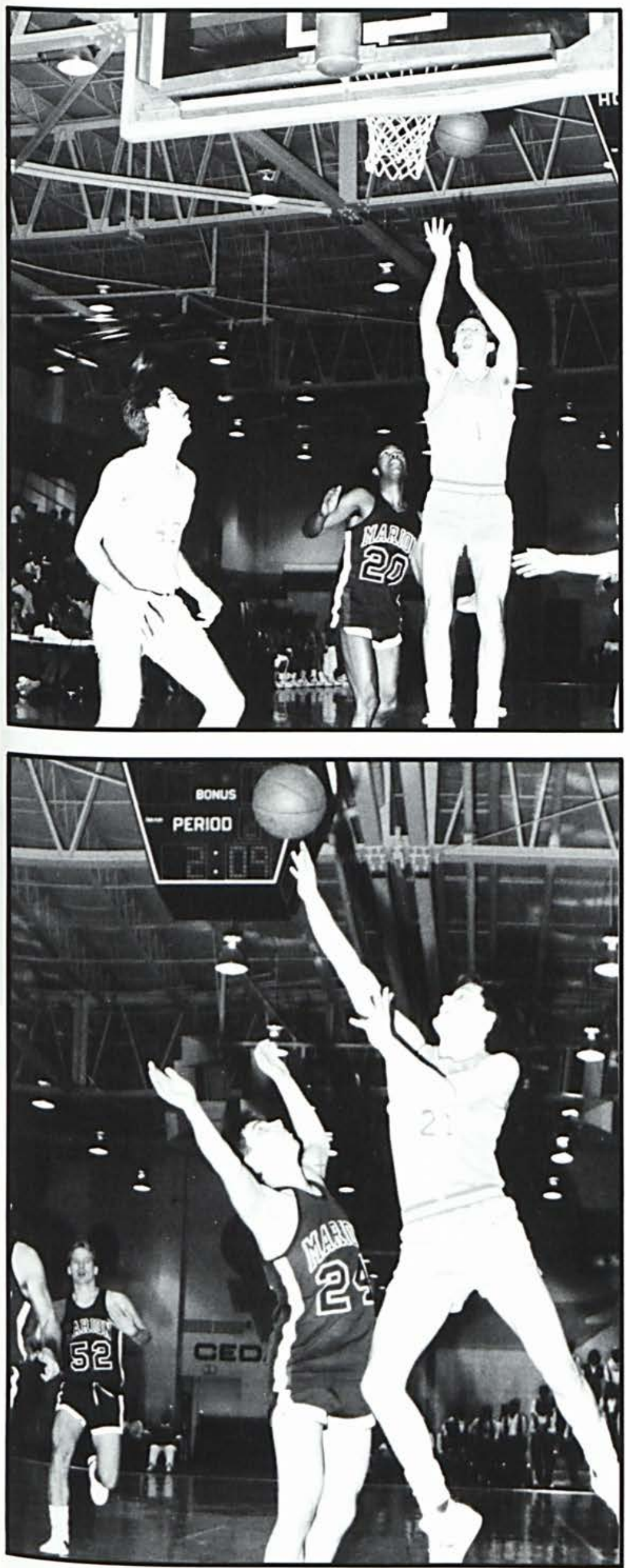

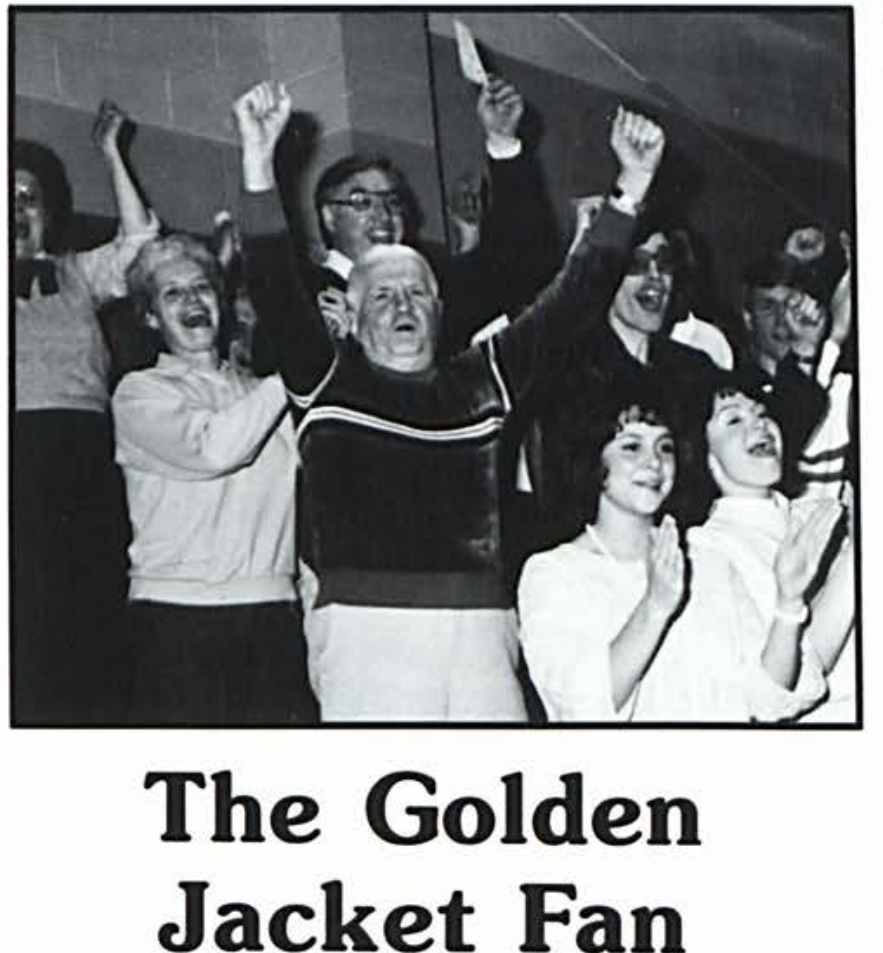

0

ne of the most enthusiastic fans of the Yellow Jacket sports program is Ernie White. This 71 yearyoung lover of sports is easily recognized by his white, shiny "butch" haircut. He loves the college sports program and frequently refers to the A.C. as his "winter playground."

"Gramps," as he is known to the many people who constantly visit his home on Cramer Drive, enjoys seeing sports played in a Christian atmosphere where the emphasis is on sportsmanship and Christian conduct rather than on winning the sports contest.

Bonnie Oliver 


\section{A Game Of Skill and Power}

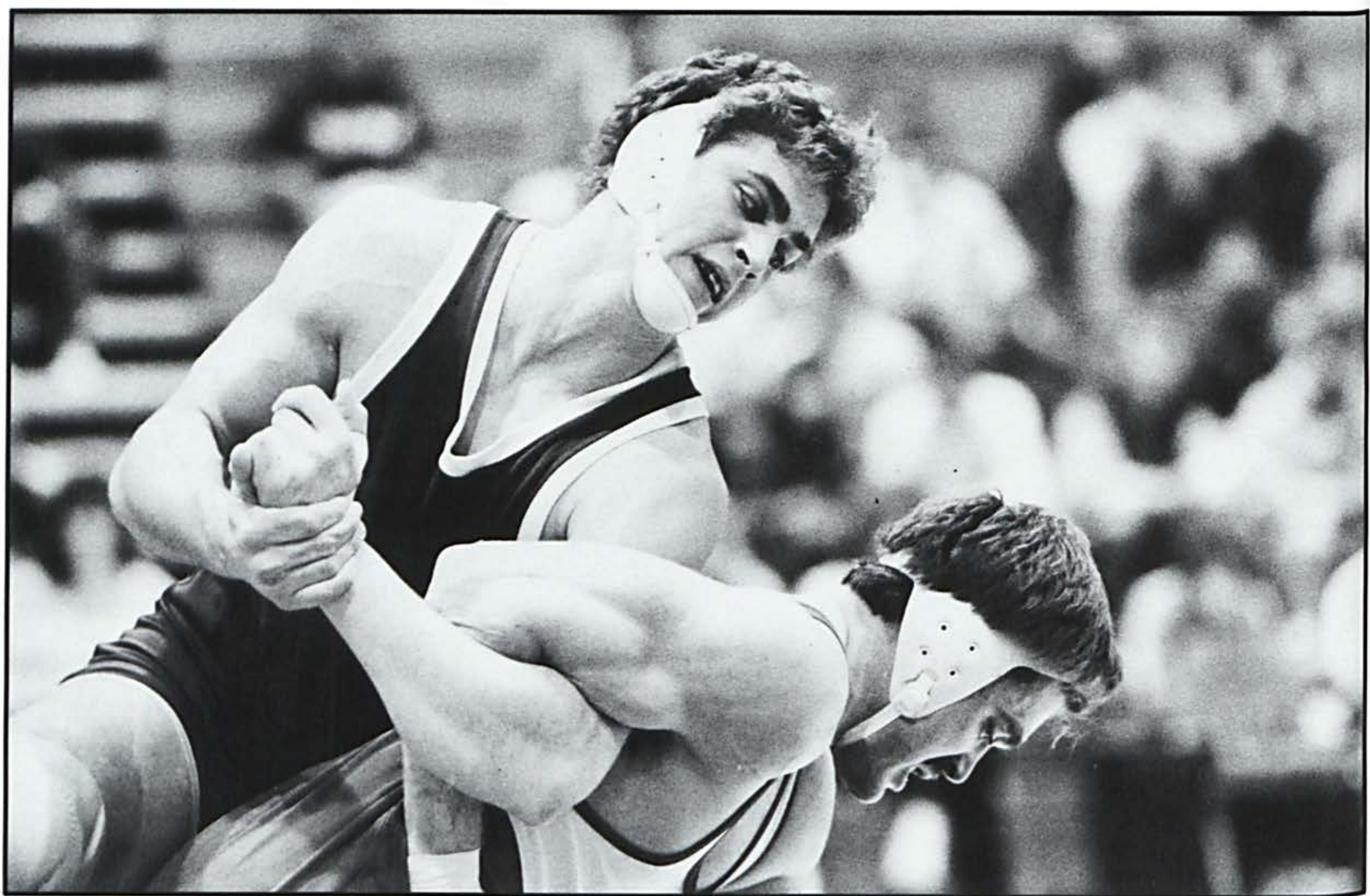

\section{Topping Off the Wrestling Season}

I he 1985-86 Cedarville College wrestling team put on an excellent showing this year. Though still a young team, they were able to compete and do well against much larger schools. Lack of depth was a problem, but

with strong determination that obstacle was overcome by season's end.

The highlight of the season came when the team participated in the

NCCAA national tournament at Olivet Nazarene College in Illinois and finished in 4th place. Two members, Todd Dowden and Chris Link, won

their weight classes for the second year in a row to become repeat AllAmericans. Also contributing to the fourth place finish were Rob English, Evan English and Kelly Moore with third place finishes in their respective weight classes. Rob English was also one of four All-Americans "at large" to be voted by the NCCAA Wrestling Coaches' Association. This topped off a very successful tournament.

From the NCCAA tournament, three wrestlers, Todd Dowden, Chris Link, and Kelly Moore, represented Cedarville at the NAIA national tournament and wrestled well. Based on the successful season this year, the wrestling team shows a great deal of promise for next year.

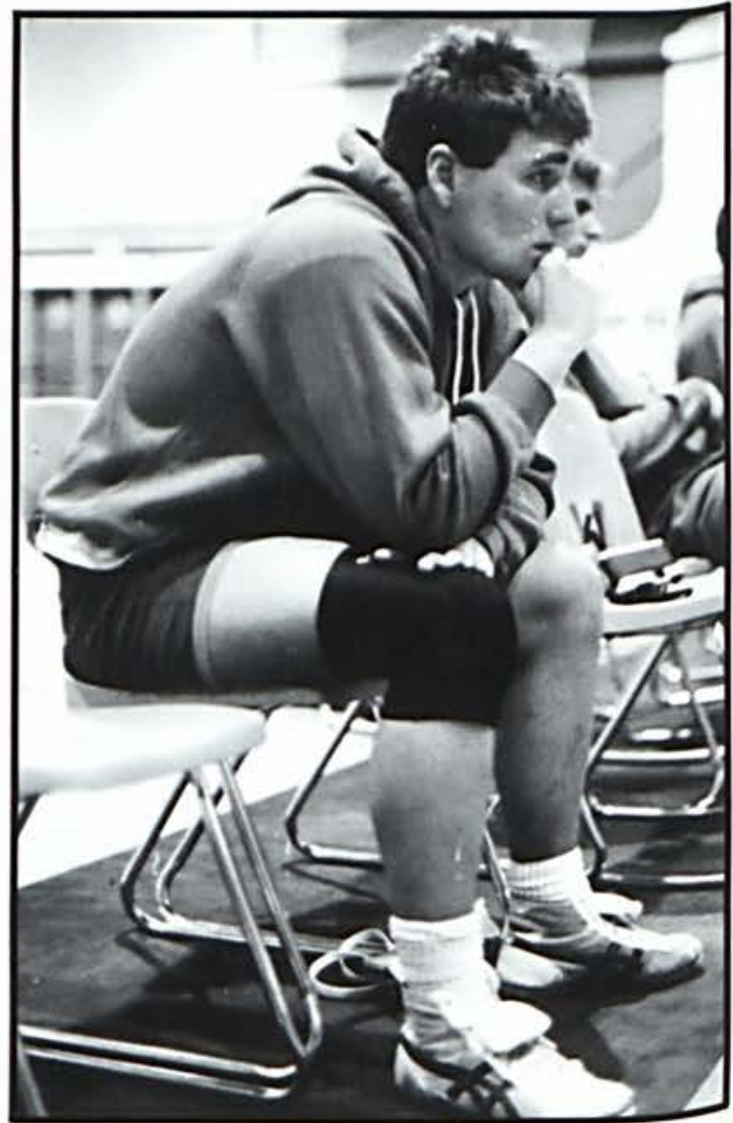




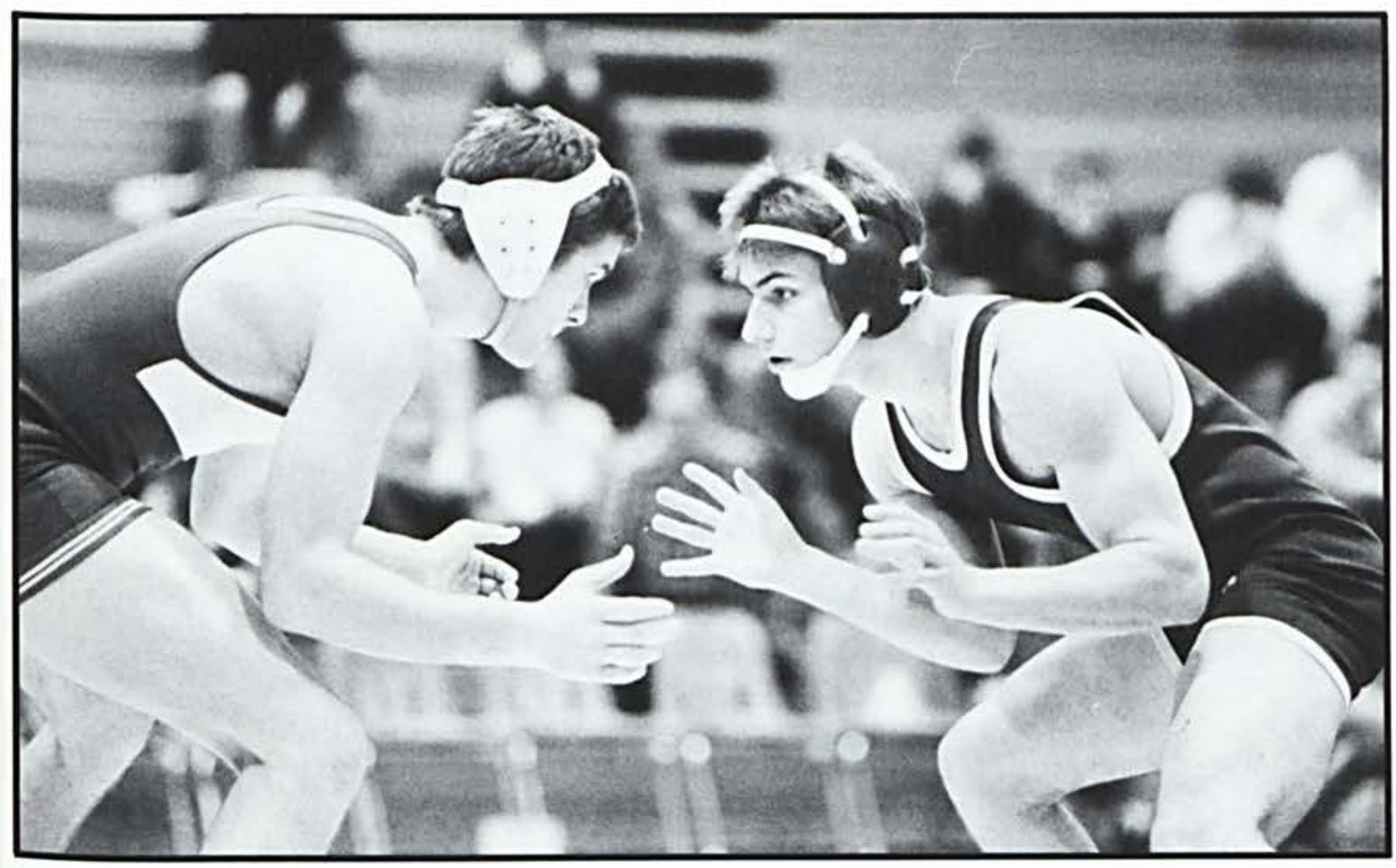

Top opposite page: Freshman Jim Eutsey gives it his all in a tough match against the University of Dayton.

Bottom opposite page: Finishing $3 r d$ in his weight class at the NAIA District 22 Playoffs was sophomore Dave Wuestner, Left: The most improved wrestler this year was freshman Ron Hayes. Below middle: Coach Ron Comfort has big plans for next year's squad.

Below: Most valuable wrestler, sophomore Todd Dowden finished first in his weight class at the NCCAA Nationals.
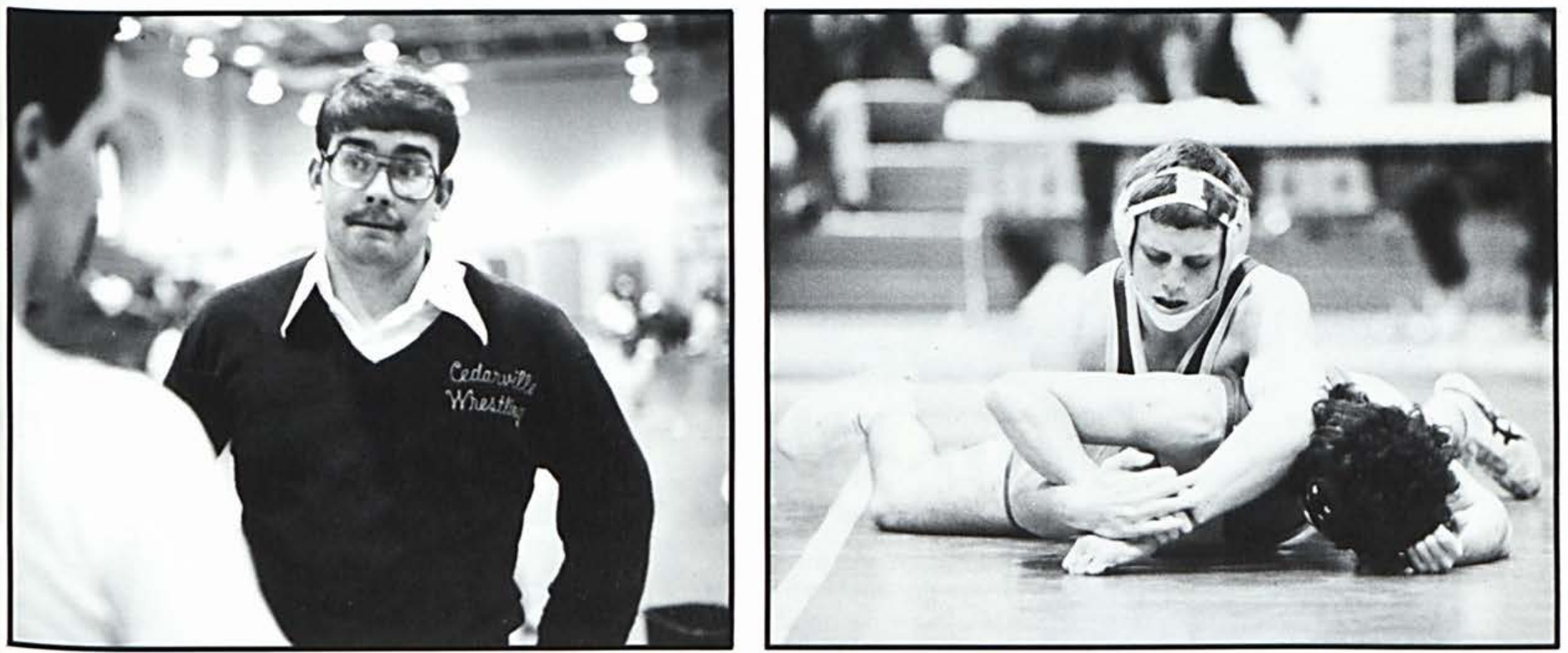

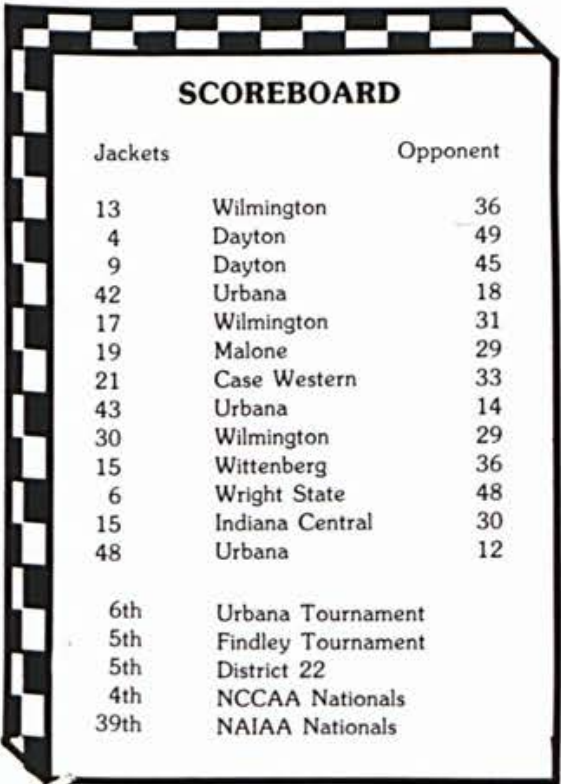
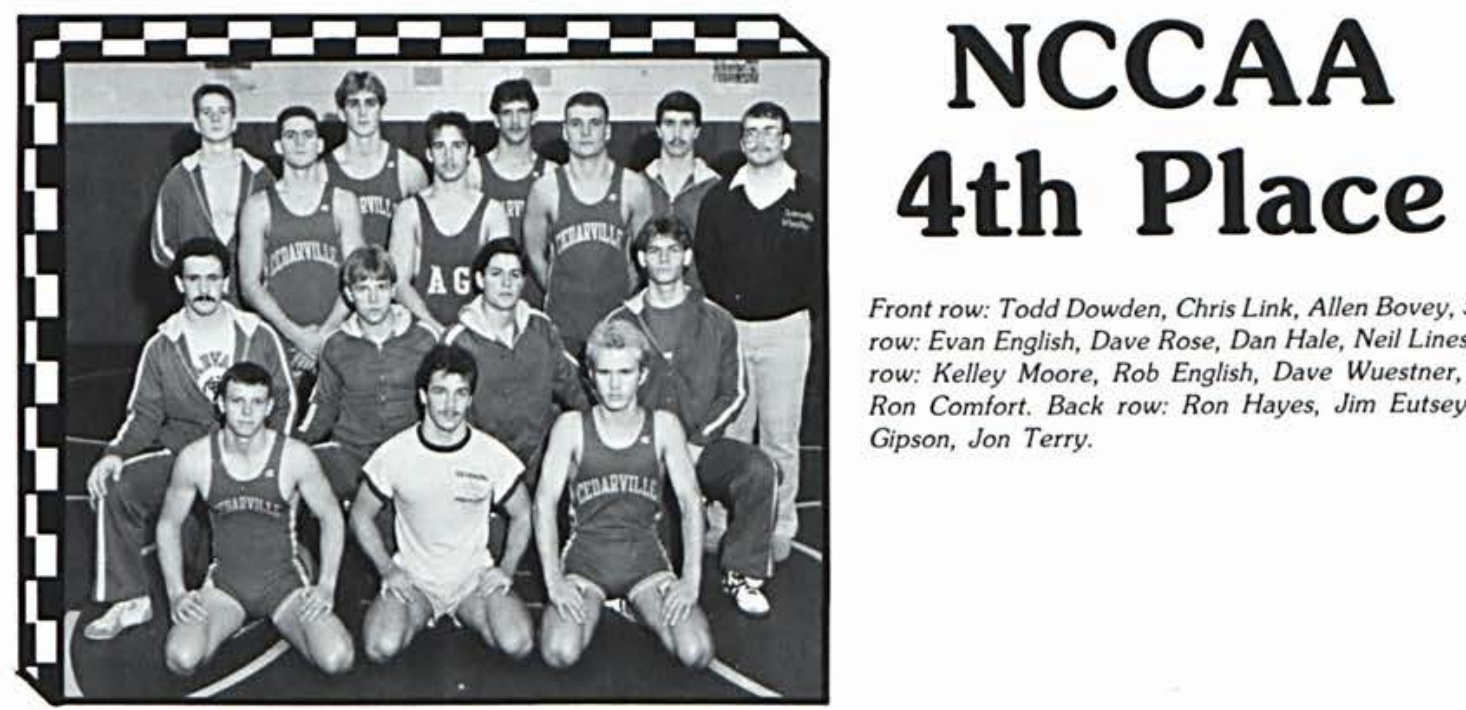

Front row: Todd Dowden, Chris Link, Allen Bovey, Second row: Evan English, Dave Rose, Dan Hale, Neil Lines, Third row: Kelley Moore, Rob English, Dave Wuestner, Coach Ron Comfort. Back row: Ron Hayes, Jim Eutsey, Allen Gipson, Jon Terry. 


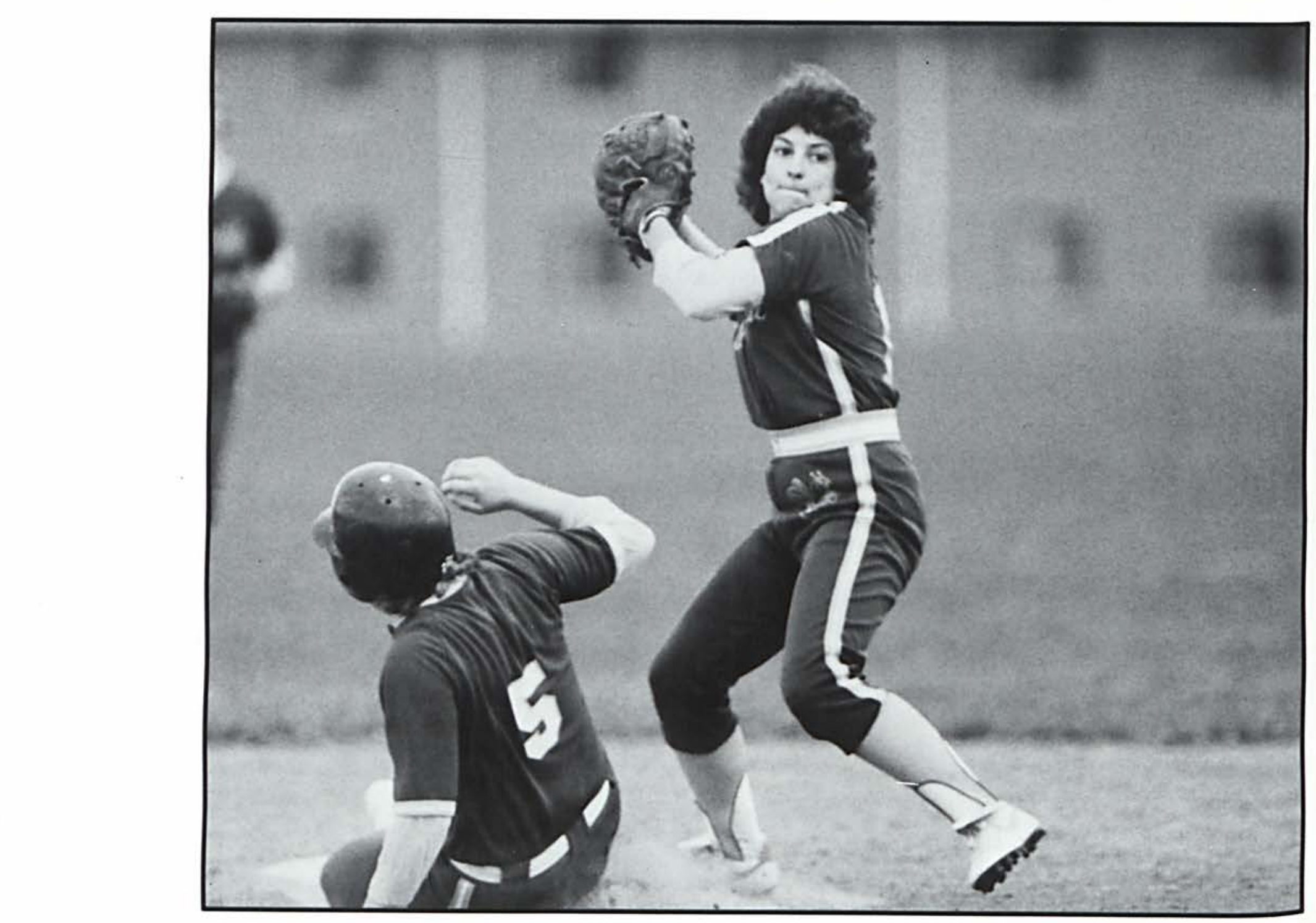

\section{Desiring To Win}

C

edarville's 1986 softball season was marked by transition and adjustments. Under the direction of first year softball coach, Mark Matthews, we focused on fundamentals and strategy. The team also had to adjust to the loss of six key starters, but several new players took their places and played strongly throughout the season.

Although the desire to win was strong, we emphasized unity along with maintaining a Christian testimony to the teams we played.

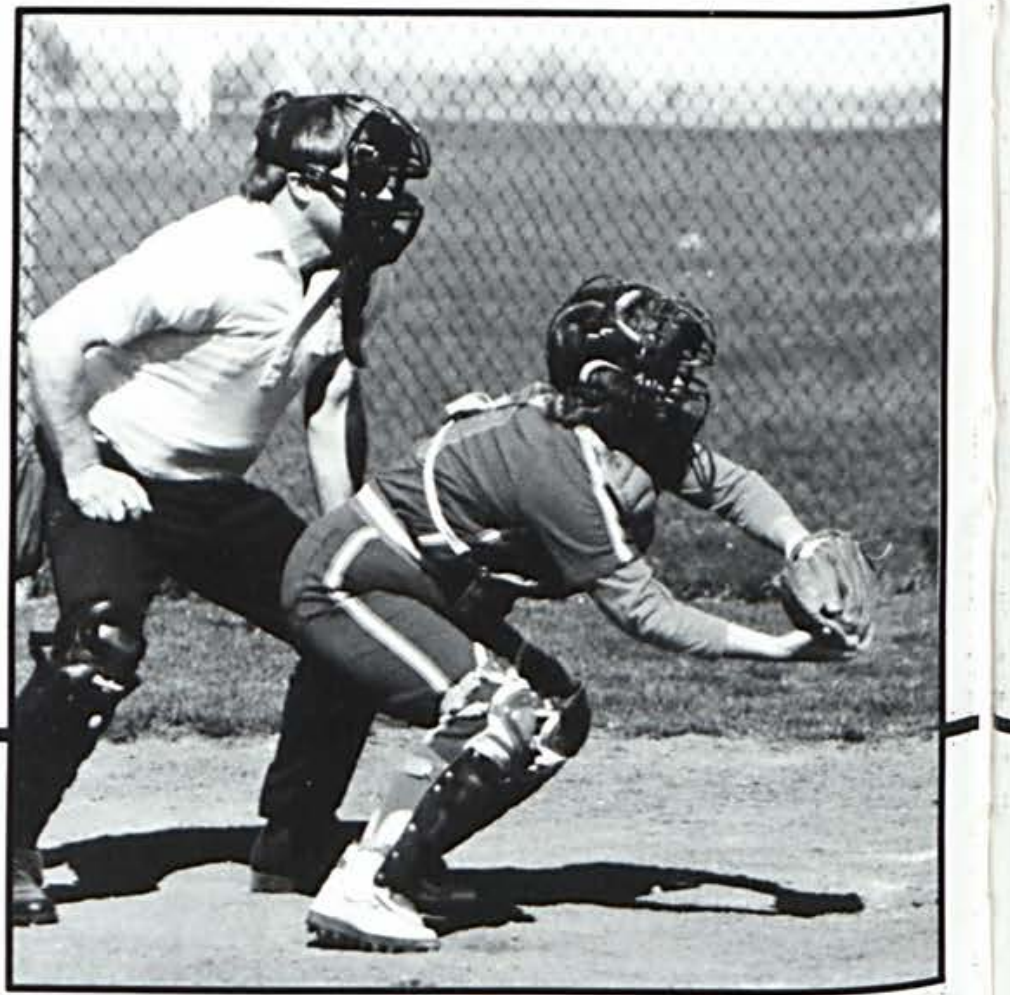




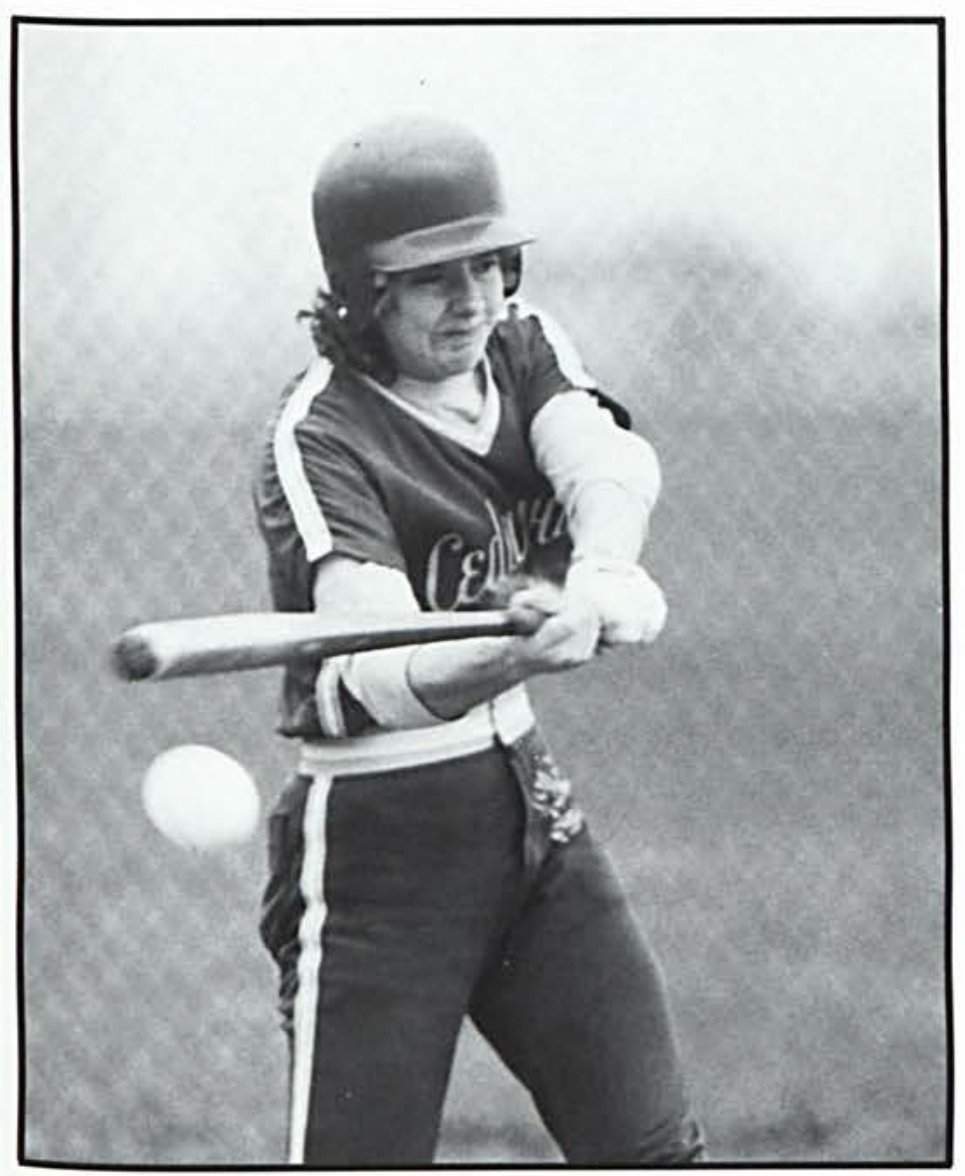

\section{Fundamentals + Determination $=$ Improvement!}

Front Row: Rebecca Clifford, Melanie Clark, Renee Brown, Joy Hamilton, Jenny Haught, Kim Fordyce. Second Row: Coach Mark Matthews, Sue Baldisc, Angela Wilcox, Kristi Culp, Tonya Evans, Angela Cremeans, Julie Butler, Tammy Mascari, Kelly Helmick, manager.
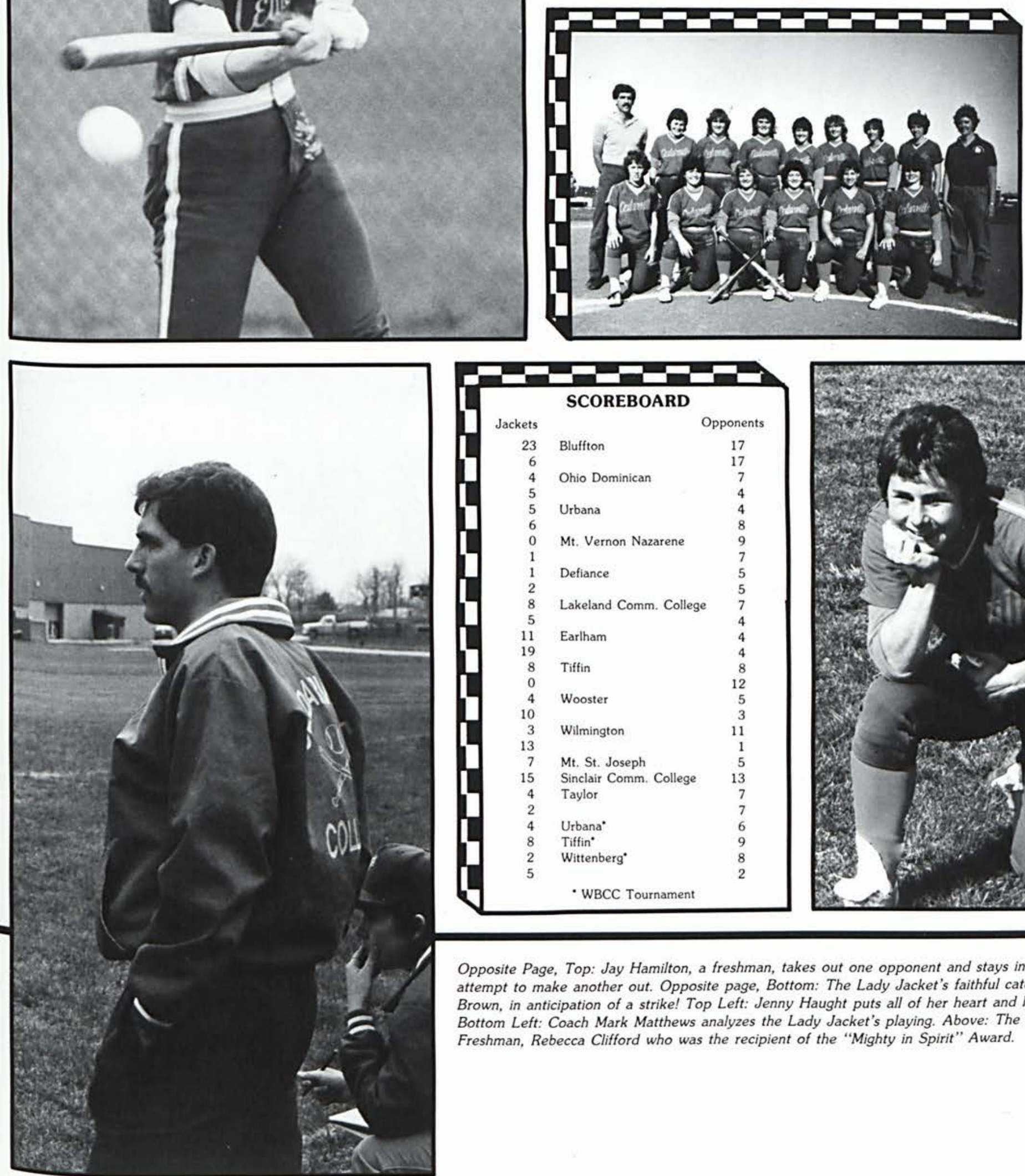

\begin{tabular}{|c|c|c|}
\hline \multicolumn{3}{|c|}{ SCOREBOARD } \\
\hline 23 & Bluffton & 17 \\
\hline 6 & & 17 \\
\hline 4 & Ohio Dominican & 7 \\
\hline 5 & & 4 \\
\hline $\begin{array}{l}5 \\
6\end{array}$ & Urbana & $\begin{array}{l}4 \\
8\end{array}$ \\
\hline 0 & Mt. Vernon Nazarene & 9 \\
\hline 1 & & 7 \\
\hline 1 & Defiance & 5 \\
\hline 2 & & 5 \\
\hline $\begin{array}{l}8 \\
5\end{array}$ & Lakeland Comm. College & 7 \\
\hline 11 & Earlham & 4 \\
\hline 19 & & 4 \\
\hline 8 & Tiffin & 8 \\
\hline 0 & Whares & 12 \\
\hline 10 & Wooster & $\begin{array}{l}5 \\
3\end{array}$ \\
\hline 3 & Wilmington & 11 \\
\hline 13 & & 1 \\
\hline 7 & Mt. St. Joseph & 5 \\
\hline 15 & Sinclair Comm. College & 13 \\
\hline $\begin{array}{l}4 \\
2\end{array}$ & Taylor & 7 \\
\hline 4 & Urbana* & 6 \\
\hline 8 & Tiffin" & 9 \\
\hline $\begin{array}{l}2 \\
5\end{array}$ & Wittenberg" & 8 \\
\hline & $\cdot$ WBCC T & \\
\hline
\end{tabular}

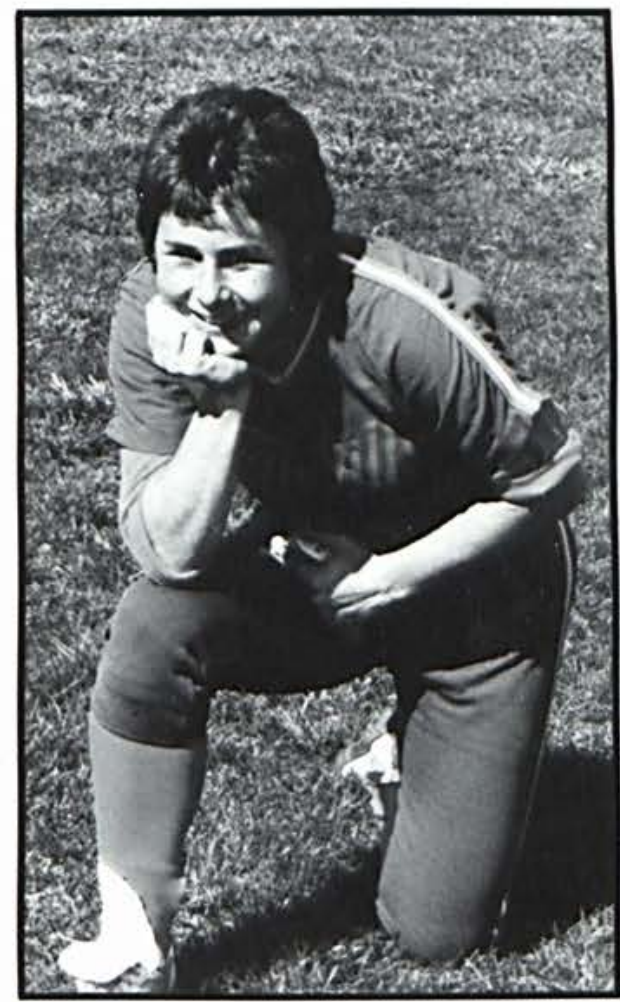

Opposite Page, Top: Jay Hamilton, a freshman, takes out one opponent and stays in action in an attempt to make another out. Opposite page, Bottom: The Lady Jacket's faithful catcher, Renee Brown, in anticipation of a strike! Top Left: Jenny Haught puts all of her heart and head into a hit. Bottom Left: Coach Mark Matthews analyzes the Lady Jacket's playing. Above: The smile of

Freshman, Rebecca Clifford who was the recipient of the "Mighty in Spirit" Award. 


\section{Striving to Do Our Best}

$\mathbf{T}$

he baseball team entered the '86 baseball season with high expectations and with great enthusiasm. The team soon became frustrated because it lost several close games. The final record was 14-18-1.

Despite the disappointments, every player strived to do his best. Danny Olinger was an excellent example. Danny led the team with a .341 batting average and was the MVP. Defensively, Norm Cox sparkled at shortstop, and he was voted "Best Defensive Player."

The team lost five seniors after the '86 season' Norm Cox, Steve Cremean, Finny Rajchel, Roger Luttrel, and Chris Walter. Next year, with the rebuilding process coupled with the past's fine examples of players, our expectations will be reached. It will be a winning season.

Steve Cremean

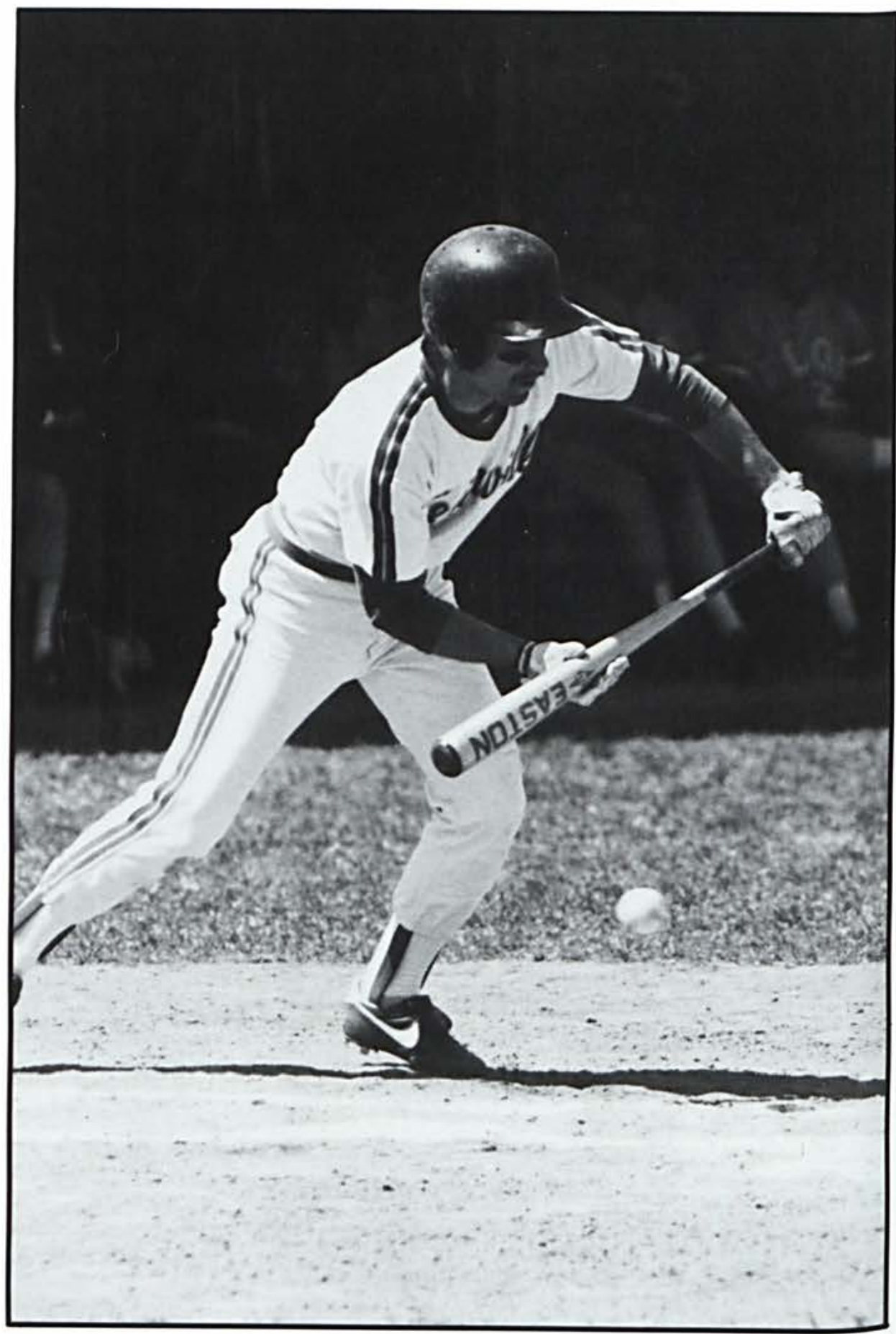

Above: Senior Norm Cox hits a sacrifice bunt in a double header match against Malone. Series below: Freshman Brent Speas' 5 easy steps in striking out the batter. Right: Second year coach Dan Cooms speaks with MVP Danny Olinger. Far right: Glenn Streeter played center field and infield his first season with the Jackets.
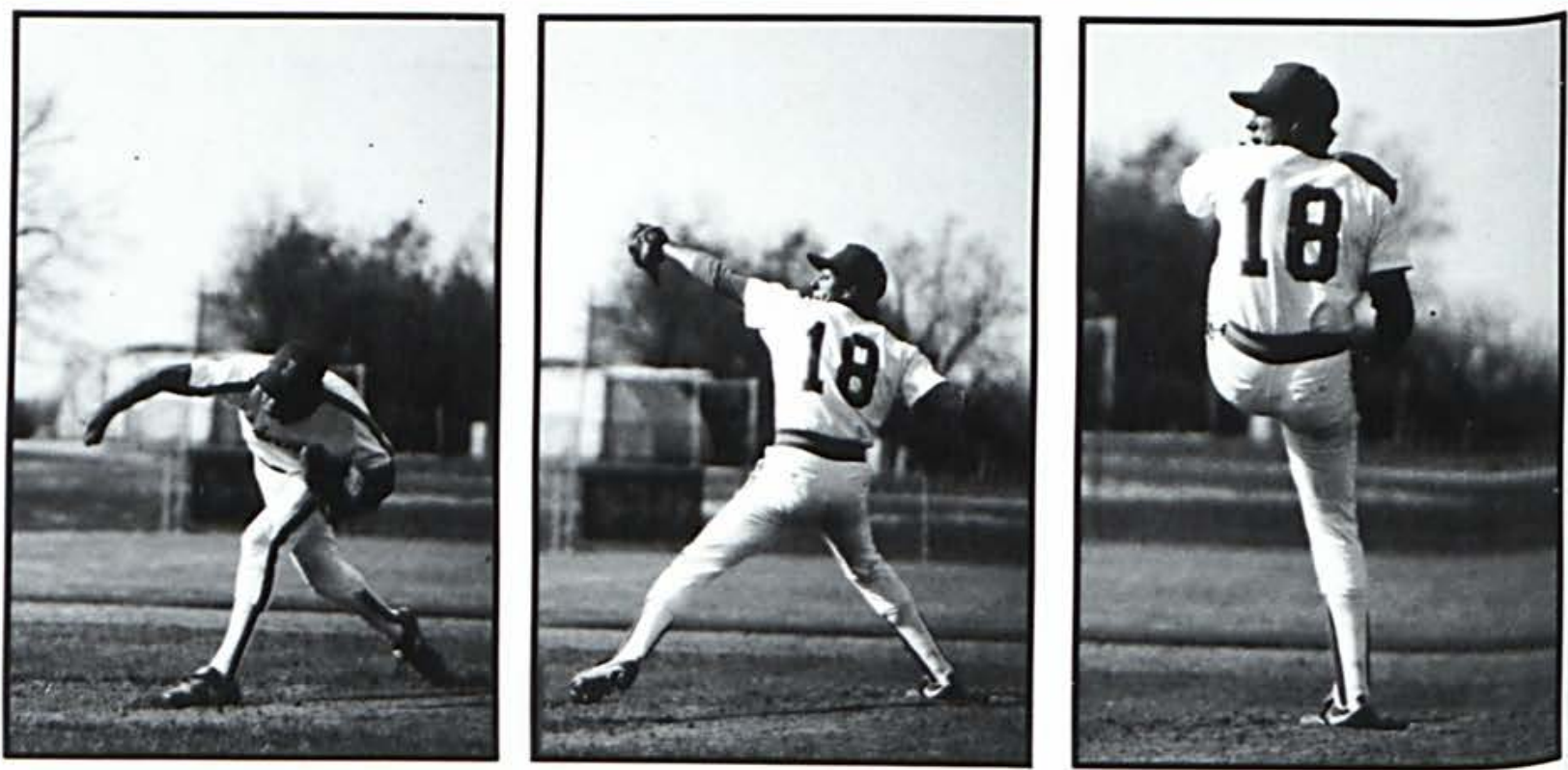


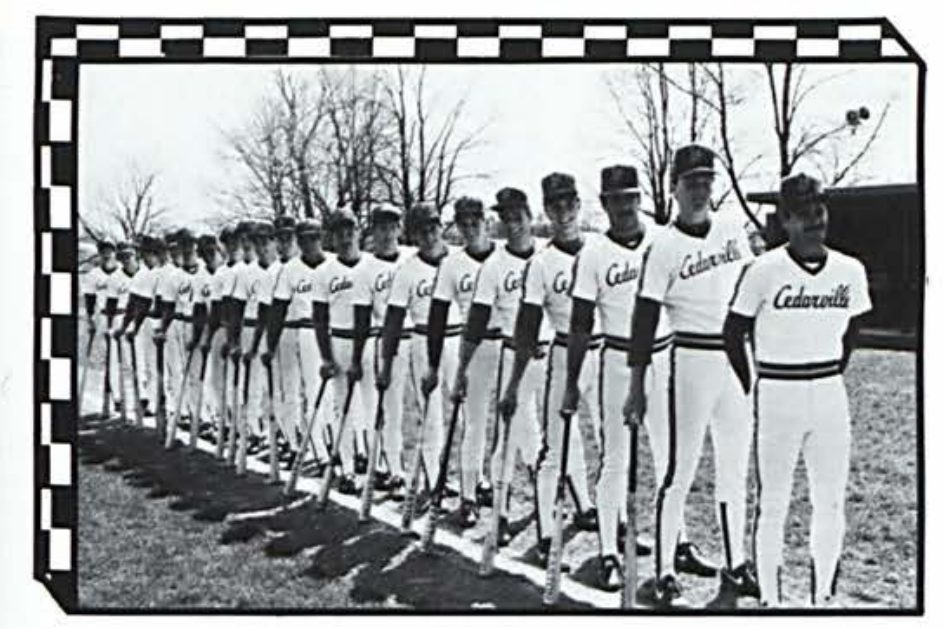

\section{Cedarville Sluggers}

Coach Dan Cooms, Norm Cox, Steve Cremean, Luis Cruz, Dave Dennis, Lamar Eifert, Dan Erlandson, Ken Horton, Roger Luttrell, Brian Marburger, Rusty Mock, Brian Montross, Danny Olinger, Tom Pratt, Captain Finny Rajchel, Mike Rose, Chris Smith, Brent Speas, Sam Springer, Glenn Streeter, Chris Walter.
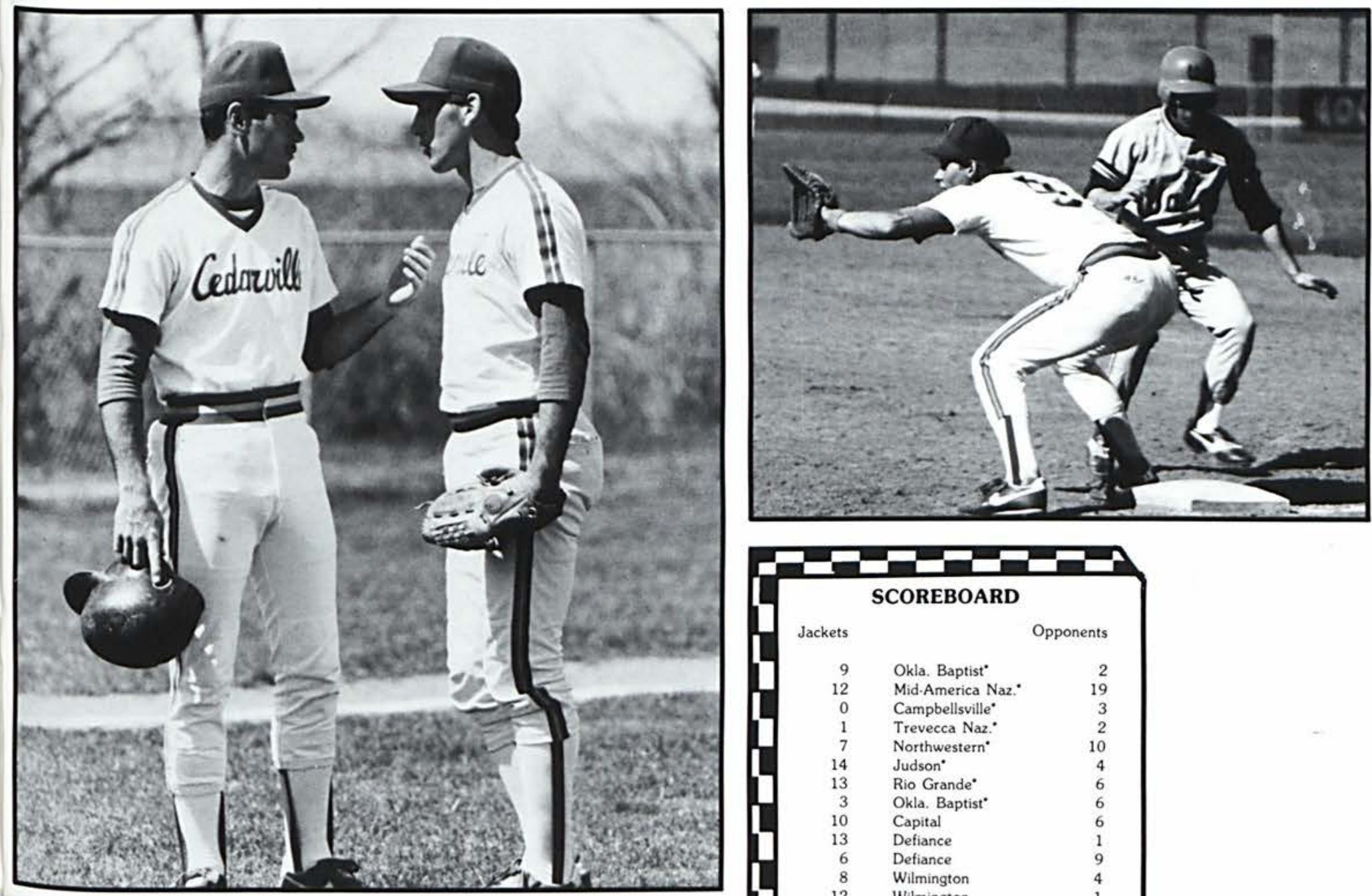

\begin{tabular}{|c|c|c|}
\hline \multicolumn{3}{|c|}{ SCOREBOARD } \\
\hline Jackets & \multicolumn{2}{|c|}{ Opponents } \\
\hline 9 & Okla. Baptist" & 2 \\
\hline 12 & Mid-America Naz." & 19 \\
\hline 0 & Campbellsville & 3 \\
\hline 1 & Trevecca Naz: & 2 \\
\hline 7 & Northwestern & 10 \\
\hline 14 & Judson" & 4 \\
\hline 13 & Rio Grande* & 6 \\
\hline 3 & Okla. Baptist" & 6 \\
\hline 10 & Capital & 6 \\
\hline 13 & Defiance & 1 \\
\hline 6 & Defiance & 9 \\
\hline 8 & Wilmington & 4 \\
\hline 12 & Wilmington & 1 \\
\hline 4 & Rio Grande & 7 \\
\hline 9 & Rio Grande & 8 \\
\hline 11 & Wilmington & 10 \\
\hline 1 & Wilmington & 22 \\
\hline 2 & Malone & 8 \\
\hline 5 & Malone & 8 \\
\hline 8 & Grace & 1 \\
\hline 7 & Grace & 6 \\
\hline 4 & Urbana & 6 \\
\hline 1 & Urbana & 3 \\
\hline 2 & Ohio Dominican & 6 \\
\hline 3 & Ohio Dominican & 8 \\
\hline 4 & Walsh & 10 \\
\hline 5 & Walsh & 4 \\
\hline 6 & Wittenberg & 6 \\
\hline 2 & Mt. Vernon Nazarene & 4 \\
\hline 4 & Mt. Vernon Nazaren & 6 \\
\hline 8 & Tiffin & 6 \\
\hline 4 & Urbana & 3 \\
\hline 5 & Urbana & 3 \\
\hline & ocoa Beach Tournamen & \\
\hline & verall Record 14-18-1 & \\
\hline
\end{tabular}




\section{Being Diligent}

$\mathbf{T}$

his year's track team was not deep, but first place finishers were many. Their feats highlighted the year: Phil Hulbert achieved new records in the shot and discus throws; Rob Moore placed third at the NAIA Nationals;

Tommy Hill set a new school record for the 5000; and Scott Hannay finished his senior year with a new record in the javelin throw.

Illness and injury plagued the team, but they continued to press on and to fight. Diligence pays off. "Seest thou a man diligent in his business? He shall stand before kings" (Proverbs 22:29).

Scott Hannay
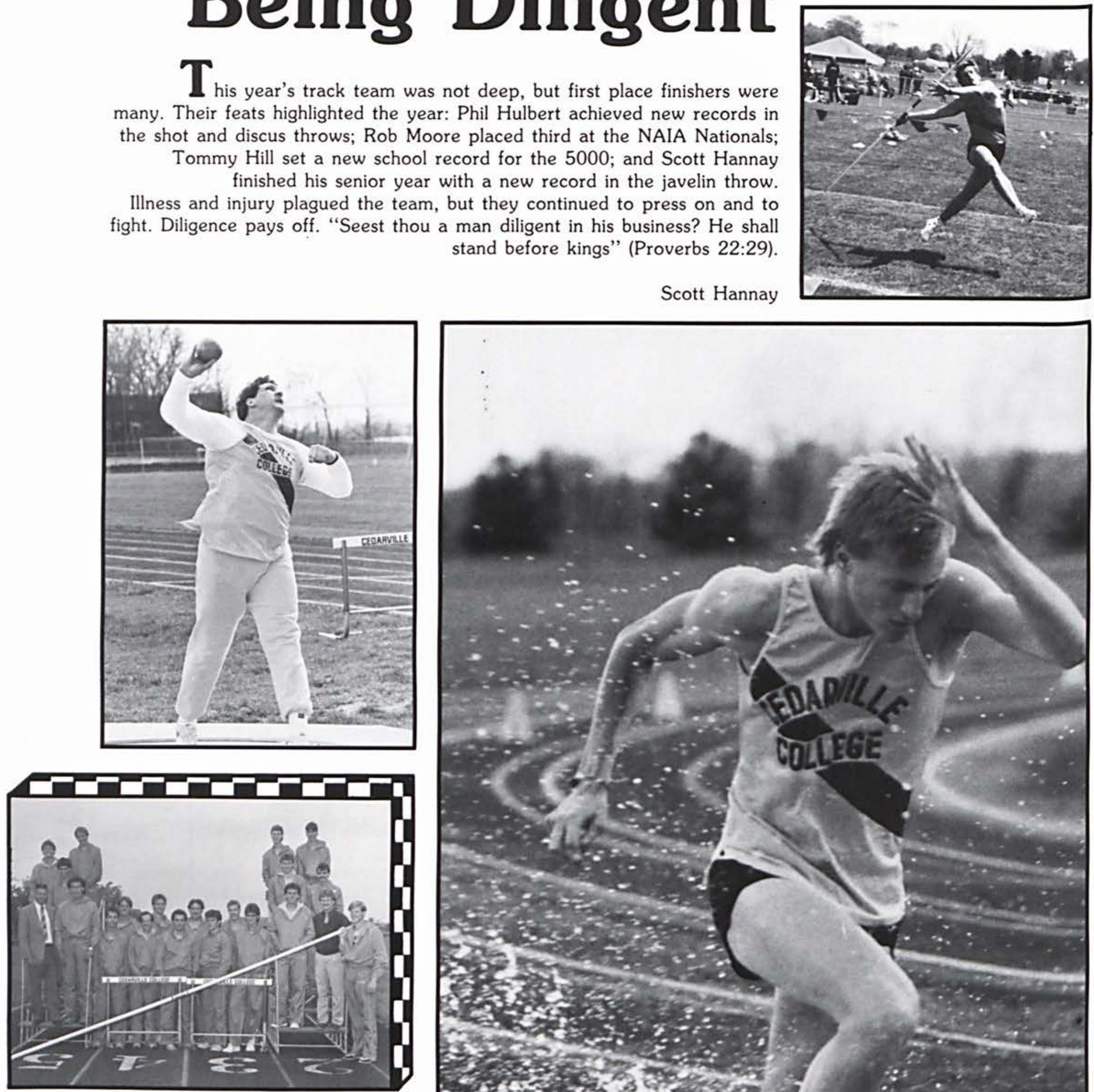

\section{NCCAA 3rd Place}

Front Row: Coach Elvin King. Tim Walters, Lee Calisti, Steve Cox, Steve Billingsley, Kuy Kendall, J.P. Dawes, Rob Paswaters, Brian Ethridge, Eric Shrum. Second Row: Tom Hill, Scott Hannay, Tim Abramowitz, Philip Hulbert, Matt Grider. Loren Tucker, John Oswald. Top: Rob Moore, Scott Brooker, Chris Hoefler, Ken Retlius.

Top: Phil Hulbert shows the form that made him the recipient of the 1986 NCCAA All-American for shot put and discus. Top Right: Senior, Scott Hannay, puts power and speed into his javelin throw. Right: Incoming Freshman, Steven Schepers, pours on the power, proving his abilities.

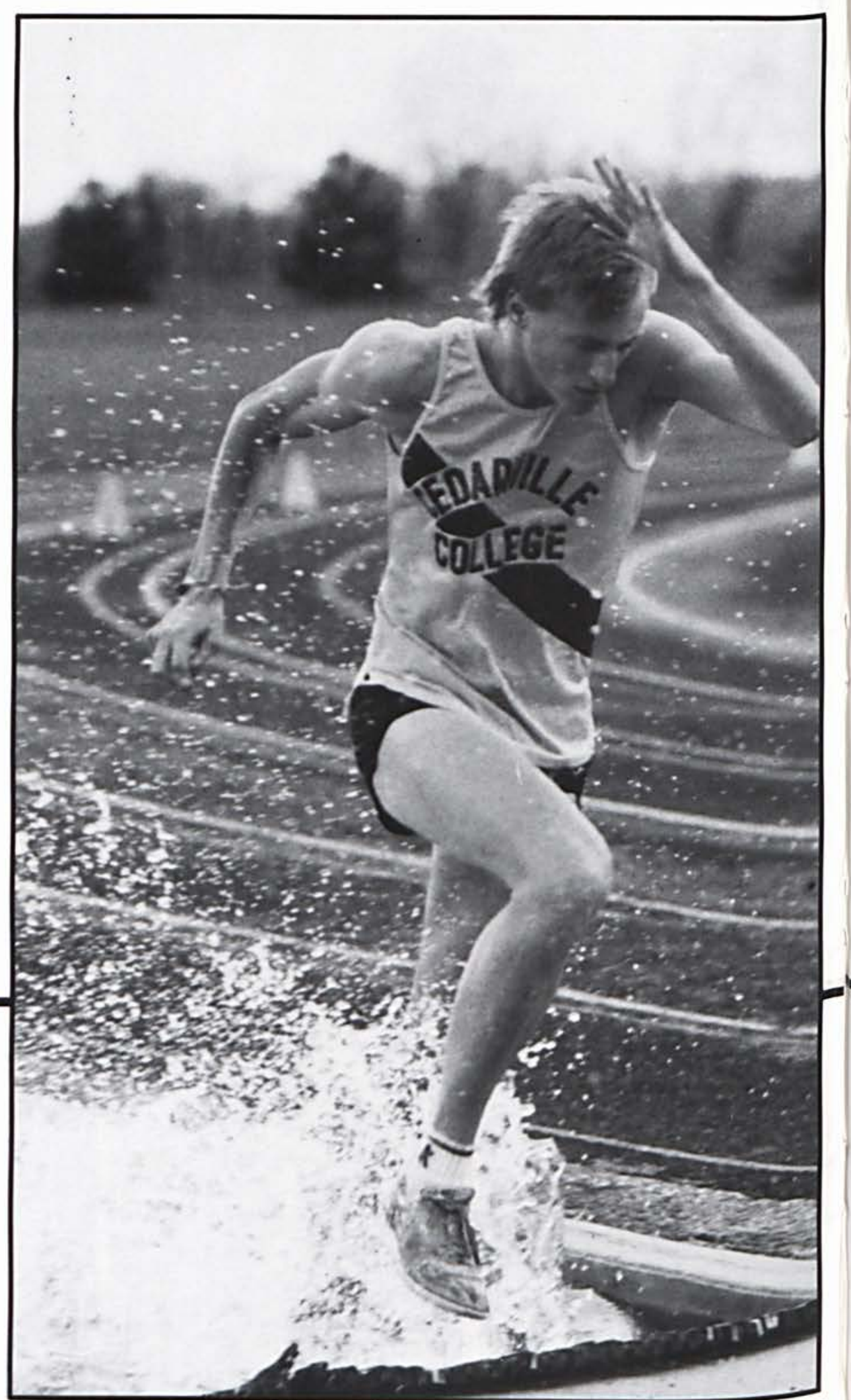




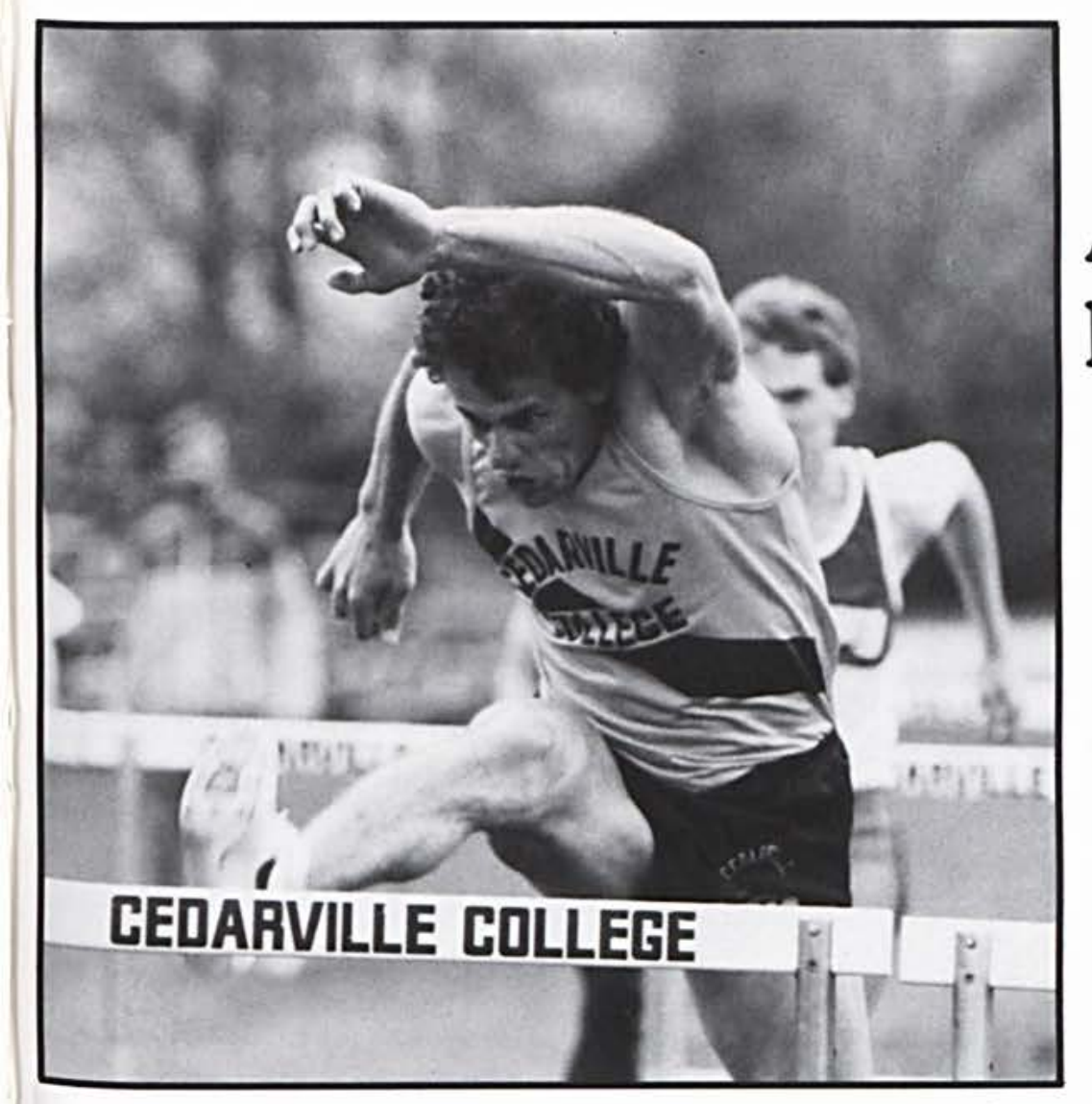

\section{Achieving New Records}
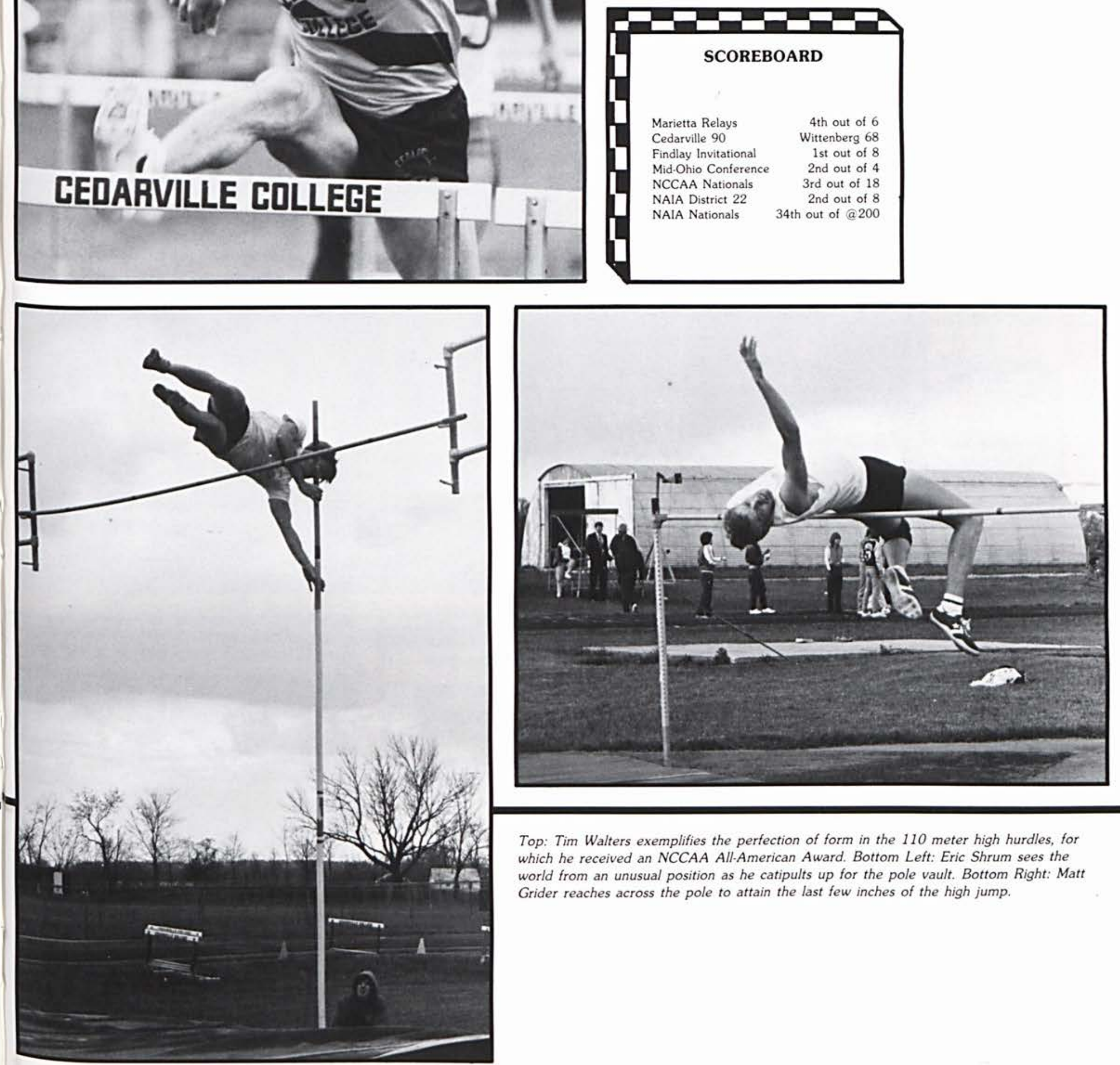

Top: Tim Walters exemplifies the perfection of form in the 110 meter high hurdles, for which he received an NCCAA All-American Award. Bottom Left: Eric Shrum sees the world from an unusual position as he catipults up for the pole vault. Bottom Right: Matt Grider reaches across the pole to attain the last few inches of the high jump. 
Right: Sophomore Jody Eckert gives it her best leap! Below: Sue runs one of her last race's for CC.
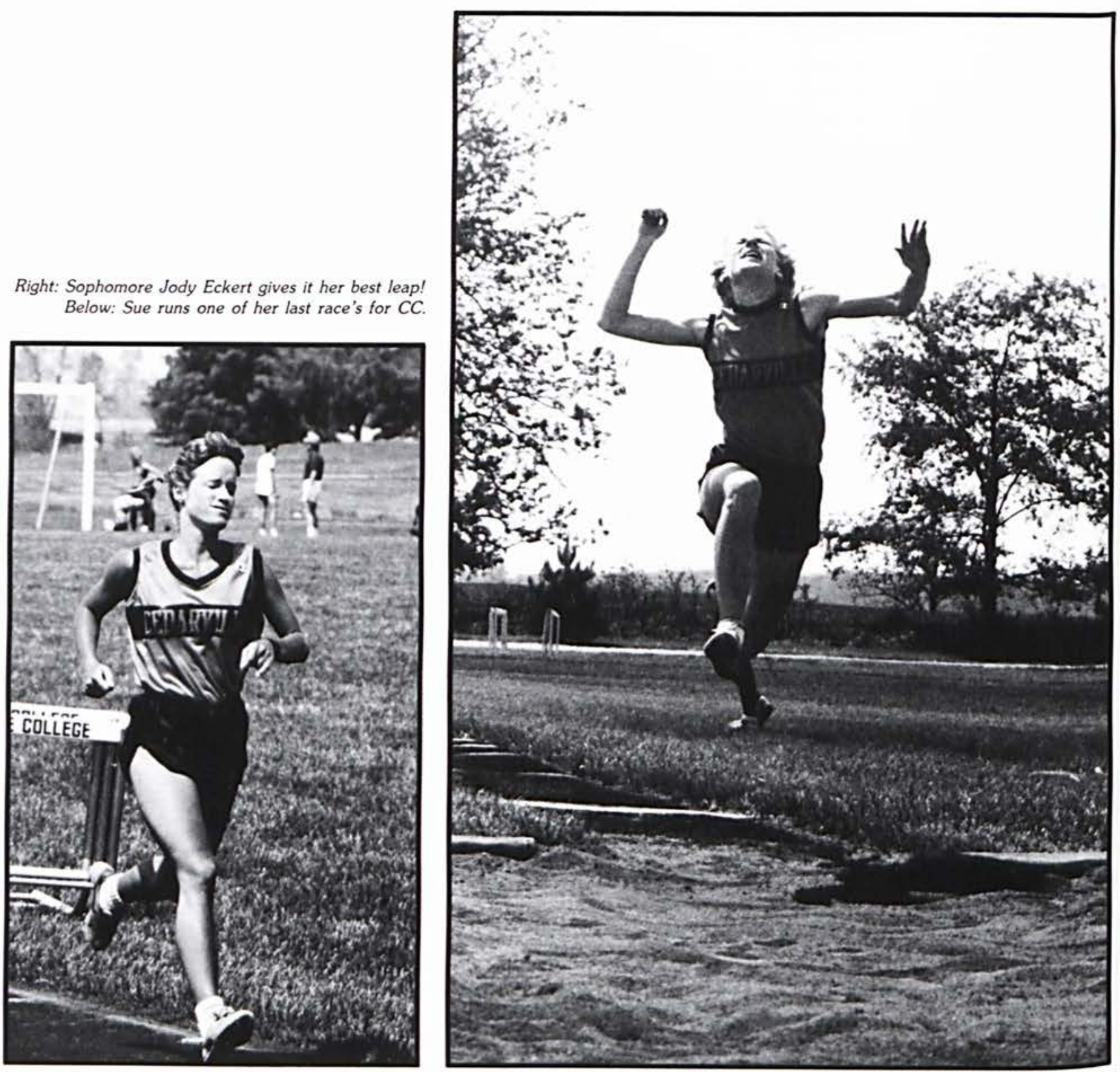

\section{Satisfying and Rewarding Season}

$\mathbf{T}_{\text {his year's track team was the smallest team we have had since the }}$ track program began, but it was also one of the most unified. Although the meets we ran were not as competitive as usual, everyone continued to work hard in both practice and meets. We won the conference meet easily, but the National Christian College meet was a real challenge. Going into the meet, we were not really sure if we even had a chance to win, but everyone did her best. The win was by sixteen points. The meet was very exciting because it caused us to pull together as a team; it also gave us an opportunity to fellowship with our Christian friends from other

teams.

In addition to the teamwork and friendship involved in the meet, three people qualified as All-American by winning their respective events: Jane Brooker, in the 800 , the 1,500 and the 3,000 meter run; Beth McGillivray in the high jump; and Esther Mahr in the 400 meter run. Once again, Jane

Brooker won the Wheeler Award, which is the highest track honor in the NCCAA.

The final highlight of the year was Jane's run at NAIA Nationals in which she placed fifth in finals with a time of 2:09.19, bettering her time from last year's nationals. Overall, the season was a very satisfying and rewarding one.

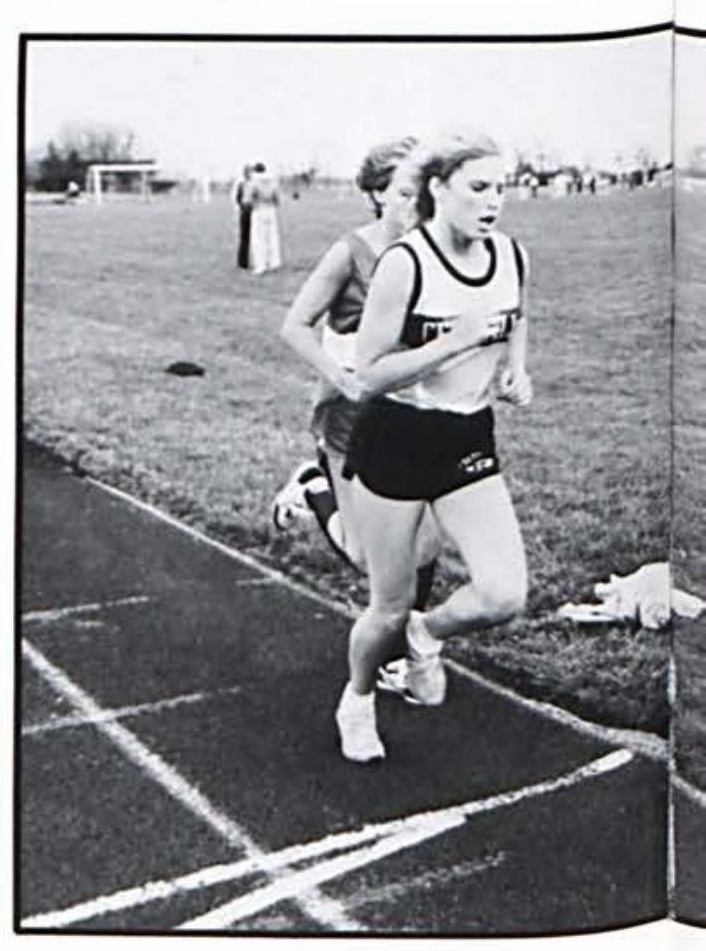


Cindy Collier displayed determination with good form as she ran the hurdles her sophomore year at $C C$.
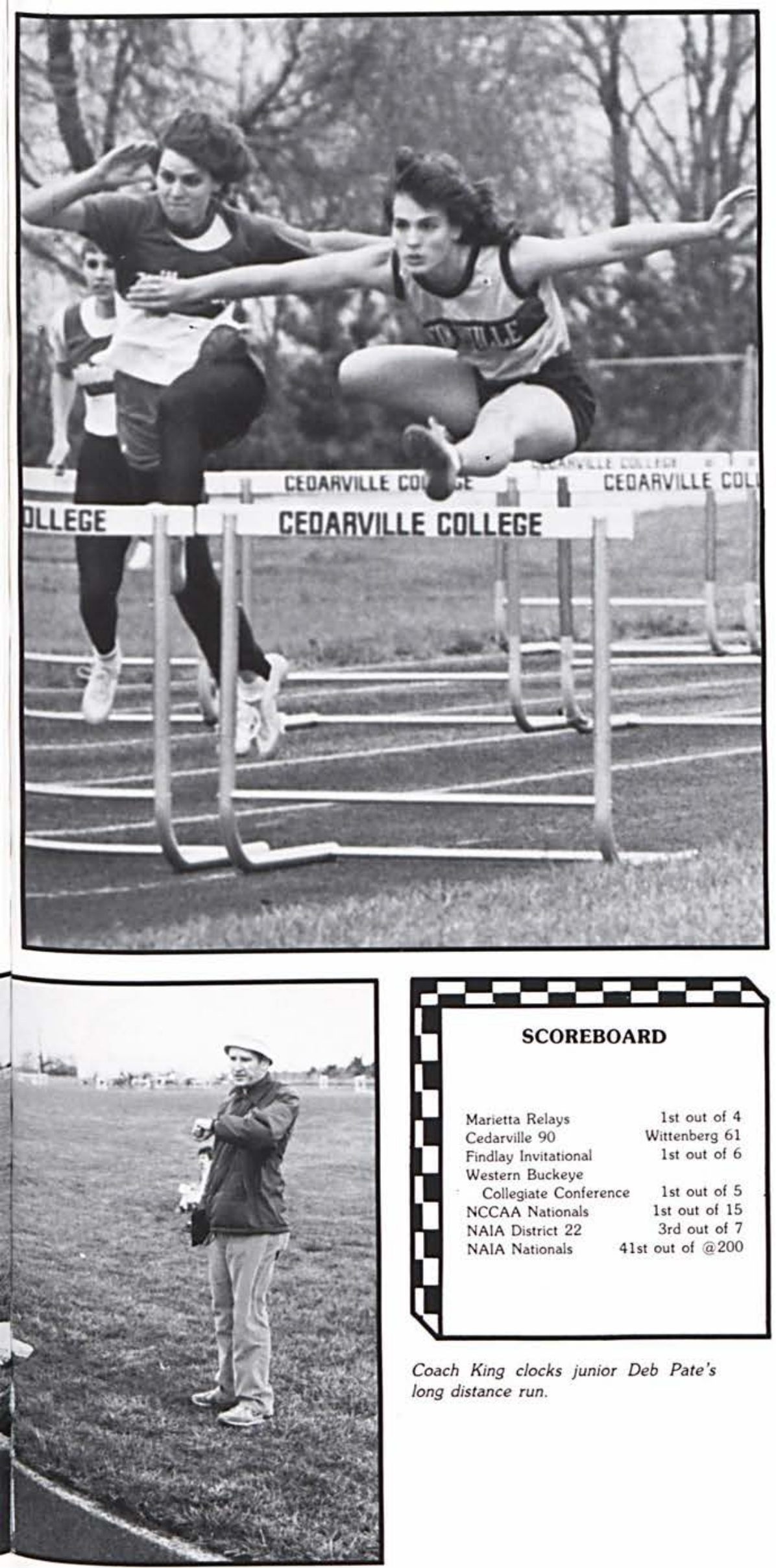

Coach King clocks junior Deb Pate's long distance run.

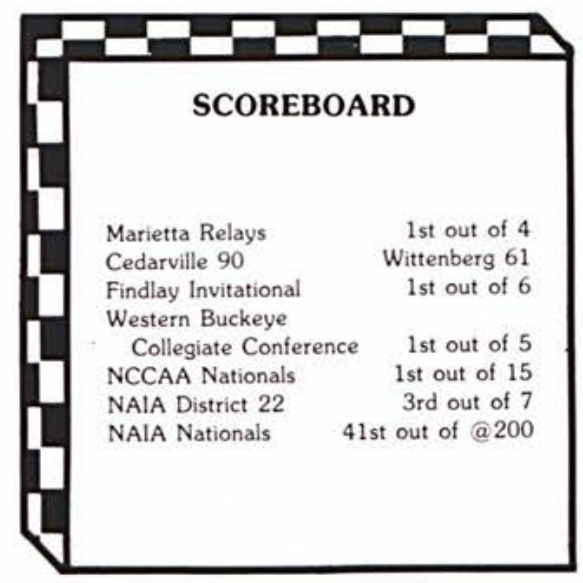

\section{NCCAA National Champs!}

First Row: Sue Vaughan, Kris Parman, Cindy Collier. Second Row: Jody Eckert, Wendy Grady, Coach John McGillivray, Jennifer Stevens. Third Row: Beth McGillivray, Esther Mahr. Fourth Row: Debbie Reynolds, Becky Averill. Fifth Row: Gretchen Moren, Penney Stackhouse. Sixth Row: Jane Brooker, Cathy Watson. Not Pictured: Deb Pate.

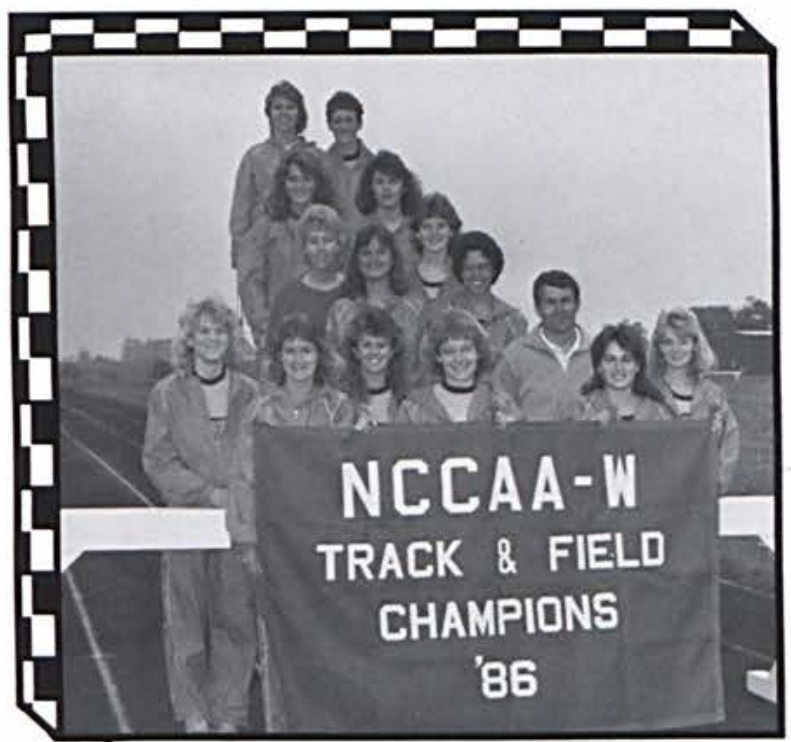




\section{Rebuilding and Recruiting}

$T$

his year's tennis season started with many questions. It was labeled early in the season as a rebuilding year with three freshmen, Dan Jones, Shaun Adair, and Russell "Tank"

McNamara in starting positions. The team suffered two early losses to district rivals Walsh and Bluffton.

After maturing by playing many solid competitors, the team avenged its loss with Walsh by tying for the co-championship of the MOC. Later in the season without the service of Jones and number one player Therm Payton, Cedarville beat rival Bluffton in a 6.3 dual match.

Greg Frank compiled the best individual record. He was closely followed by Jones, McNamara, and senior Frank Terkelson. The season ended with a disappointing finish at the district tournament.

With some fine recruiting, the team will do well next year.
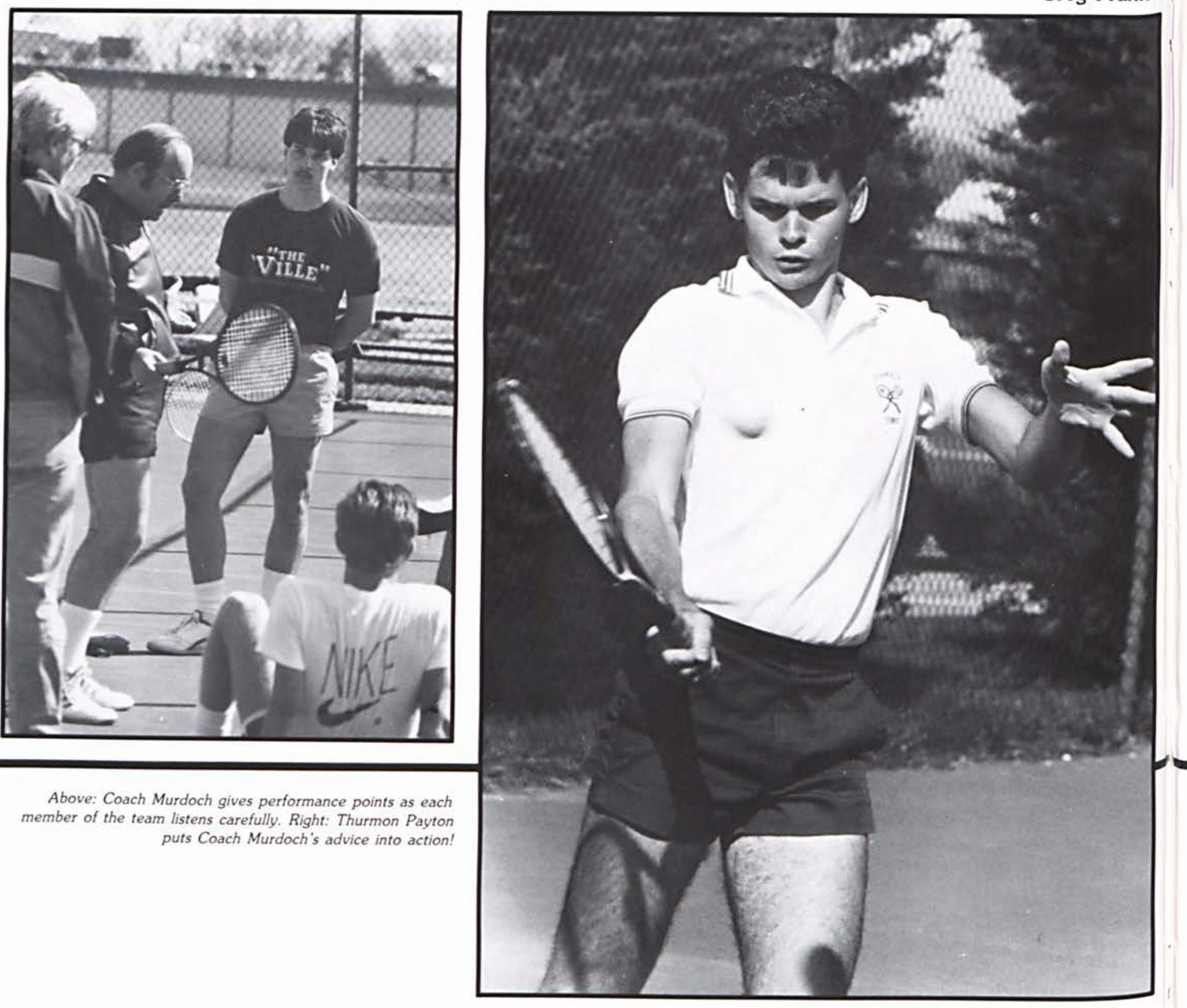

Above: Coach Murdoch gives performance points as each member of the team listens carefully. Right: Thurmon Payton puts Coach Murdoch's advice into action! 

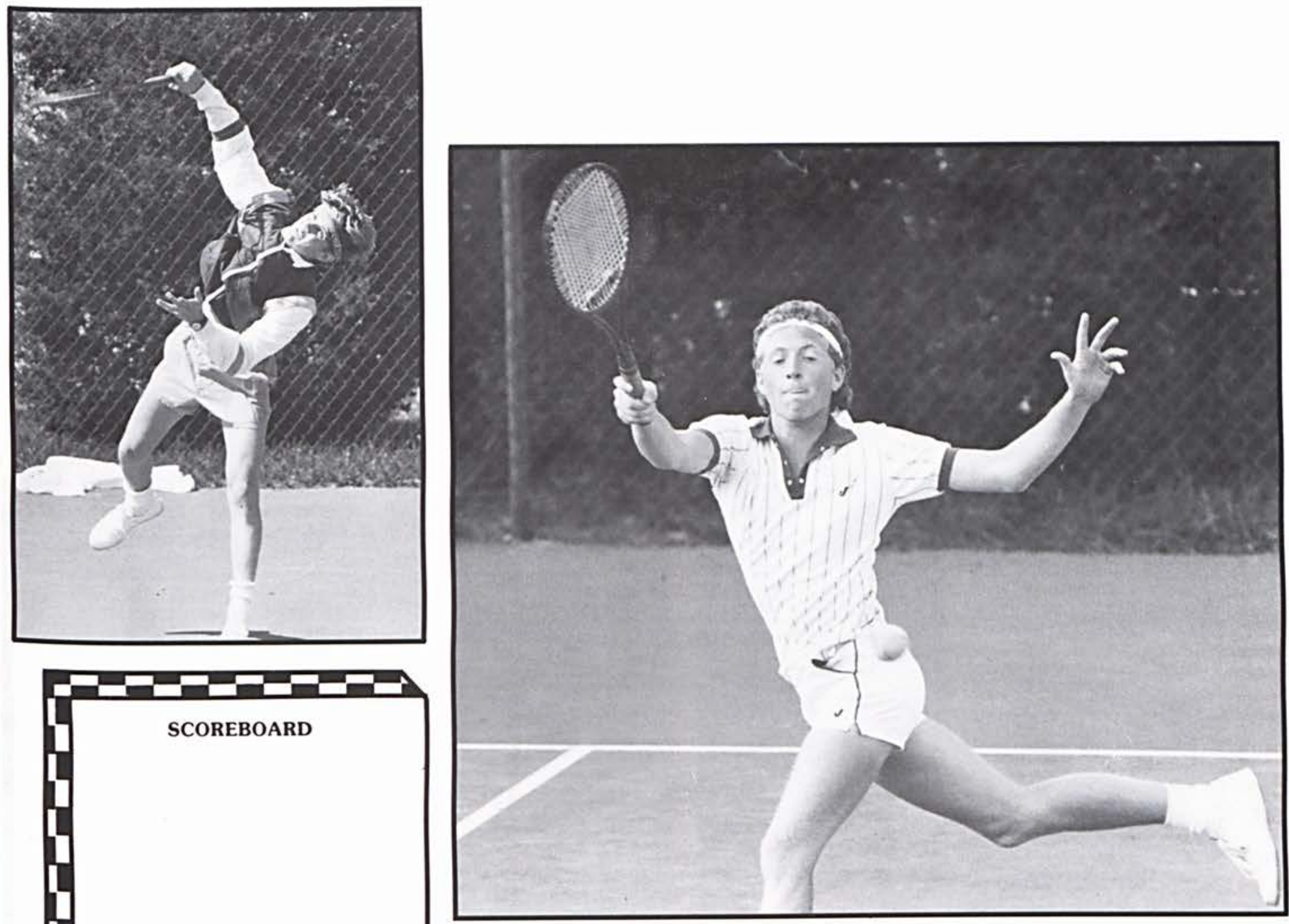

Jackets

Opponent

6 Wright State

0 Denison

Sinclair Invitational

2 nd out of 4

9 Ashland

8 Mt. Vernon Nazarene

Wilmington Invitational

3rd out of 4

4 Bluffton

Walsh

Malone

Otterbein

Earlham

MOC Tournament

1 st out of 4

1 Wittenberg

5 Wilmington

NCCAA Invitational

2nd out of 4

6 Buffton

3 Wright State

NAIA District 22

4th out of 6

Overall Record 11.6

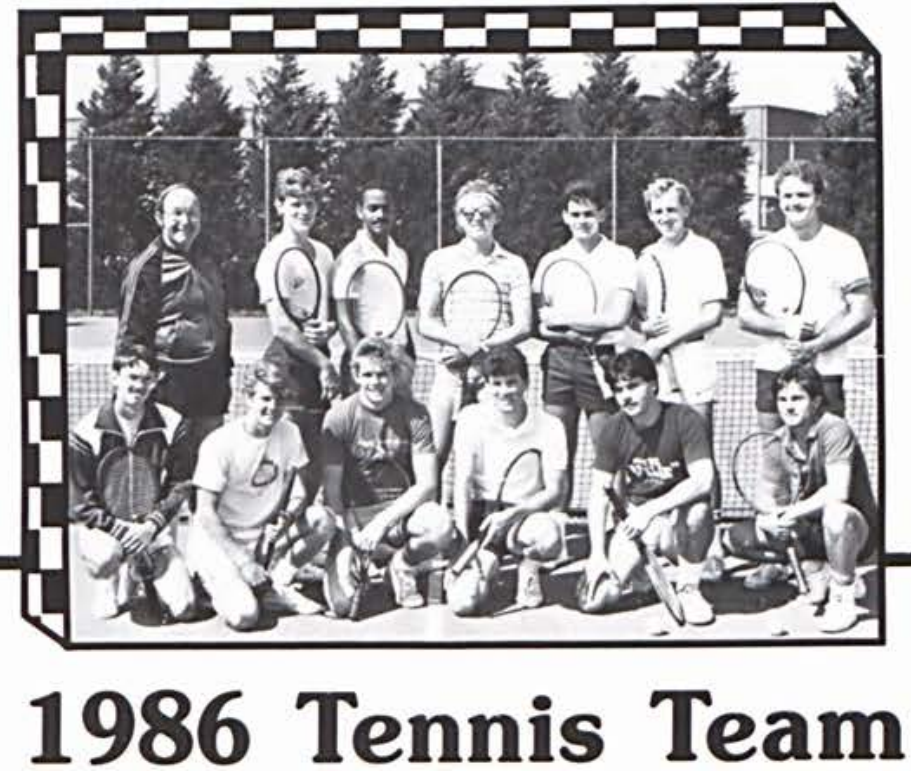

Front Row: Russ McNamara, Shawn Adair, Keith Hammer,

Bob Gresh, Bob Zander, Tim Royer. Back Row: Coach

Murdoch, Bruce Martin, Dan Jones, Greg Frank, Thurmon

Payton, Frank Terkelsen, Jay Inman.

Top Left: Freshman, Shawn Adair, works on the

development of his forehand. Above: Greg Frank shows

bravery by adding a little ballet to his style in his second

year on the tennis team. 


\section{NAIA District 22 Champs!}

1) Cheri Abresch 2) Catherine Anderson 3) Lee Austin 4) Amy DeCook 5) Ann Dykes 6) Judy Happe 7) Rogé Lash 8) Michelle Lelah 9) Beth Nester 10) Dawn Reehl 11) Becky Reiter 12) Becky Tucker 13) Jenny Ward 14) Carla Weitkamp 15) Laura Wuestner 16) Debbie Yacynych 17) Coach Pamela S. Diehl, Ph.D.
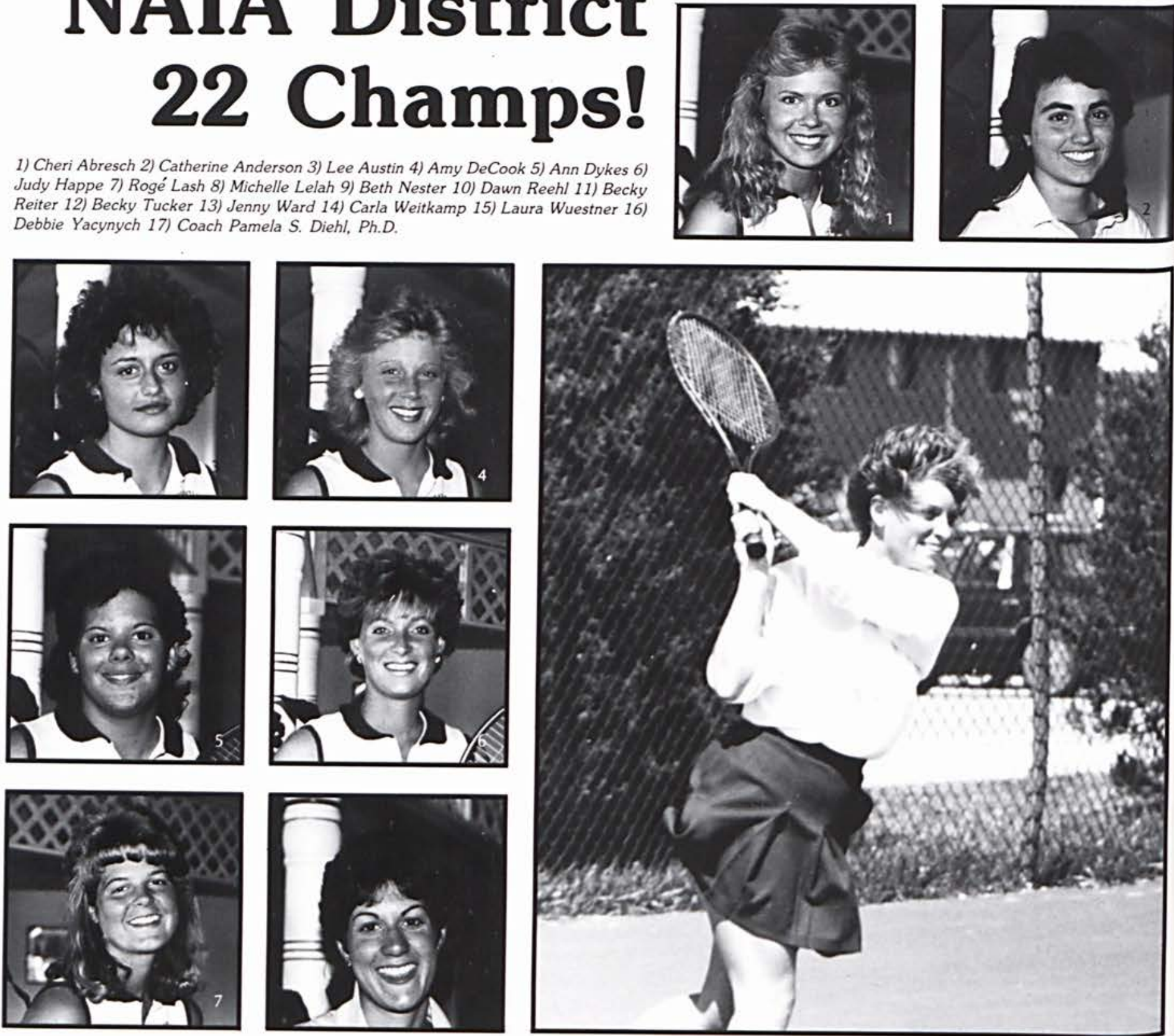

\section{Achieving Achievers}

$\mathrm{T}$

2 o pick out a specific event that highlighted our tennis season this year would be near impossible. From spring training in Florida to rainy weekends on the road, from Districts in Canton to a match in front of our home crowd, from a team spaghetti dinner to an opening banquet at the National NAIA Tennis Tournament, from praying for a fruitful year to reflecting in thanksgiving for the bountiful way God answered our prayer virtually the whole year was a highlight. If I were asked, what was unique about the season this year, I would immediately recite the sixteen names of the individuals on our team, along with coaches Drs. Diehl and Morris, and our favorite "Palooka" Miss Taylor. For the team is not made up of achievements but of achievers. We had a great year together. To God be the glory. 

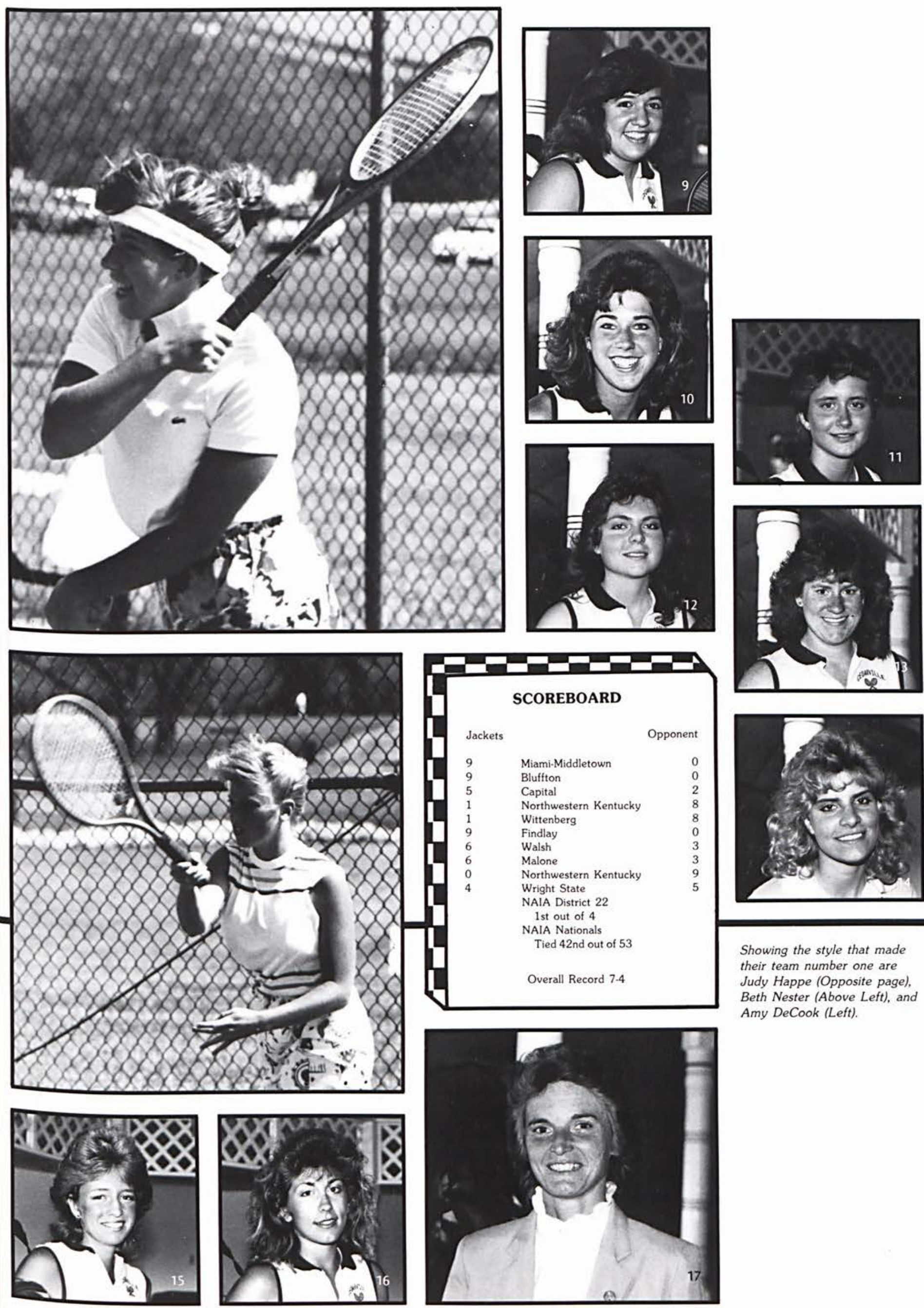

Showing the style that made

their team number one are

Judy Happe (Opposite page),

Beth Nester (Above Left), and

Amy DeCook (Left). 


\section{A Rebuilding Year}

$I_{\mathrm{t}}$ was a definite rebuilding year for Coach

Allen Monroe and his 1986 golf team.

The Yellow Jacket linksters posted an 8.13 dual match record and failed to win a tournament for the first time in several years.

Sophomore Mark Reed was again the squad's top player with an 18-hole stroke average of 78.6. Reed was medalist at the Taylor Invitational with a fine round of 72 .

No other Cedarville player carried an average of less than 86. John Kohlmeyer (86.0), Rich Chasse (86.6), Doug Phillips (86.9), and Bob Armor (89.5) rounded out the varsity line-up.
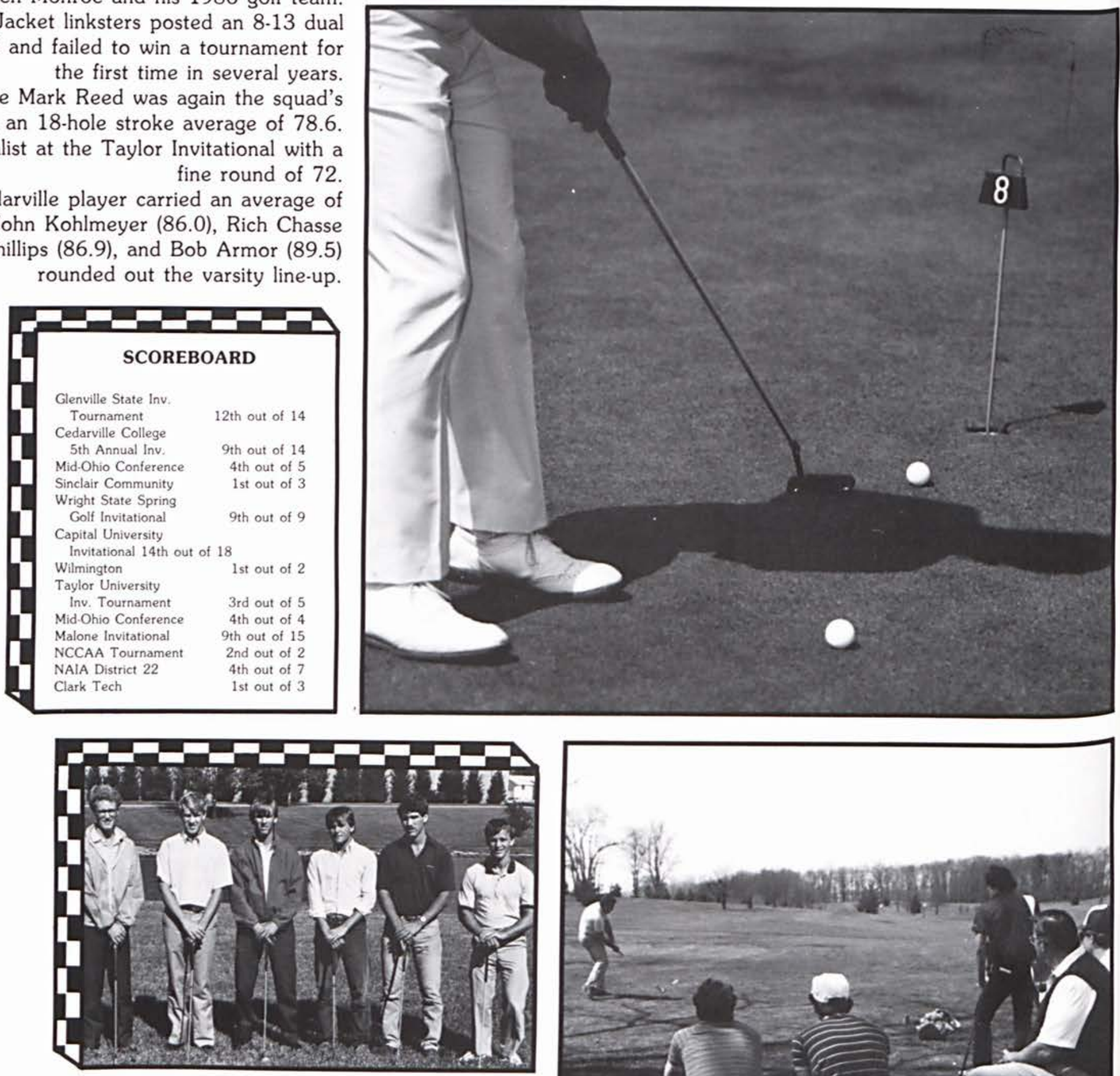

\section{Golf Team}

Bob Armor, Rich Chasse, John Kohlmeyer, Doug Phillips, Mark Reed, COACH: Dr. Allen Monroe (not pictured).

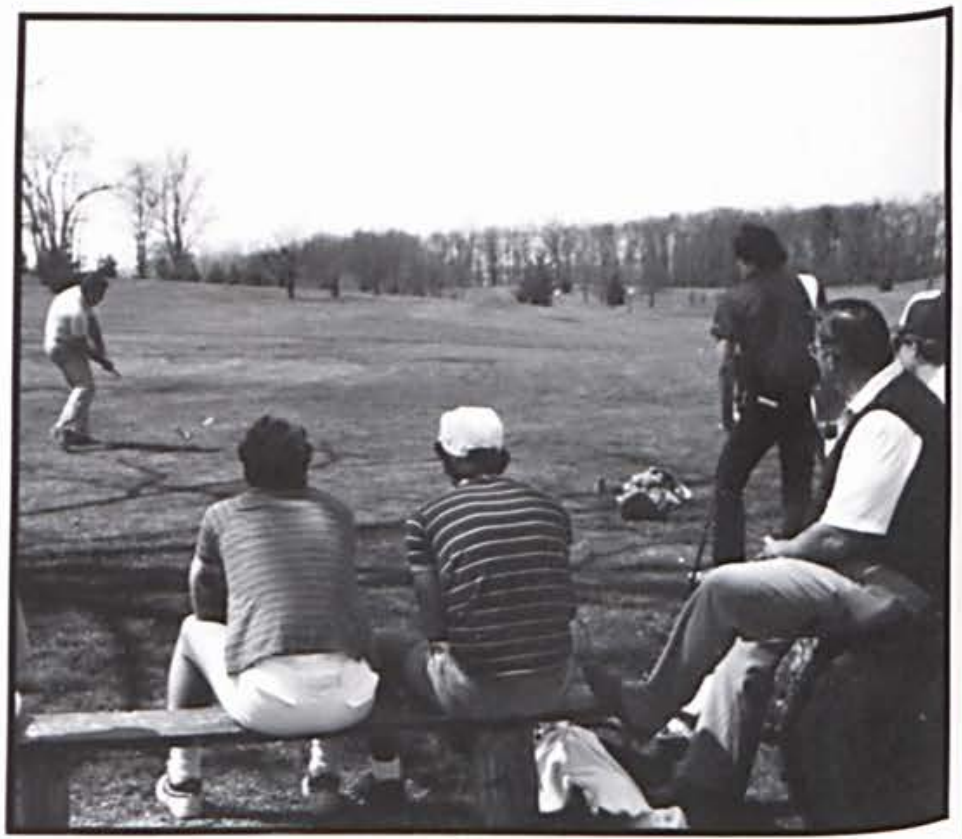




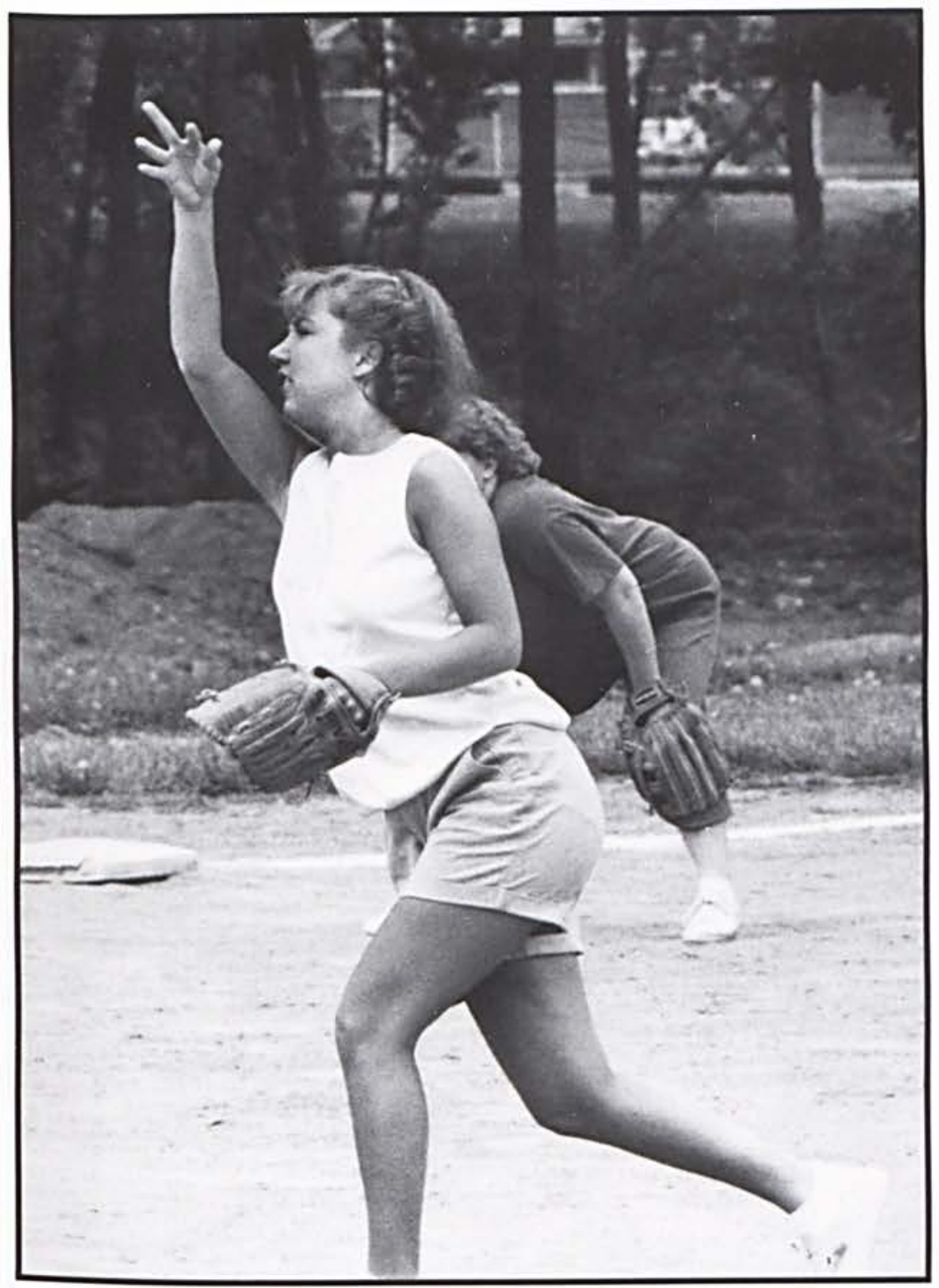

Spring

Intramural

Activity

\section{Varsity C Club}

First Row: Steve Cox, Evan English, Tom Pratt, Brian Marburger, Coach Young. Second Row: Noel Hack, Tim Walters, Todd Hummel, Roger Luttrell,

Norm Cox, Dave Dennis, Chris Walter. Third Row: Dave Yeager, Mike

Freeman, Todd Dowden, Finny Rajchel, Dan Erlandson, Don Simerly, Mark Fleetwood.
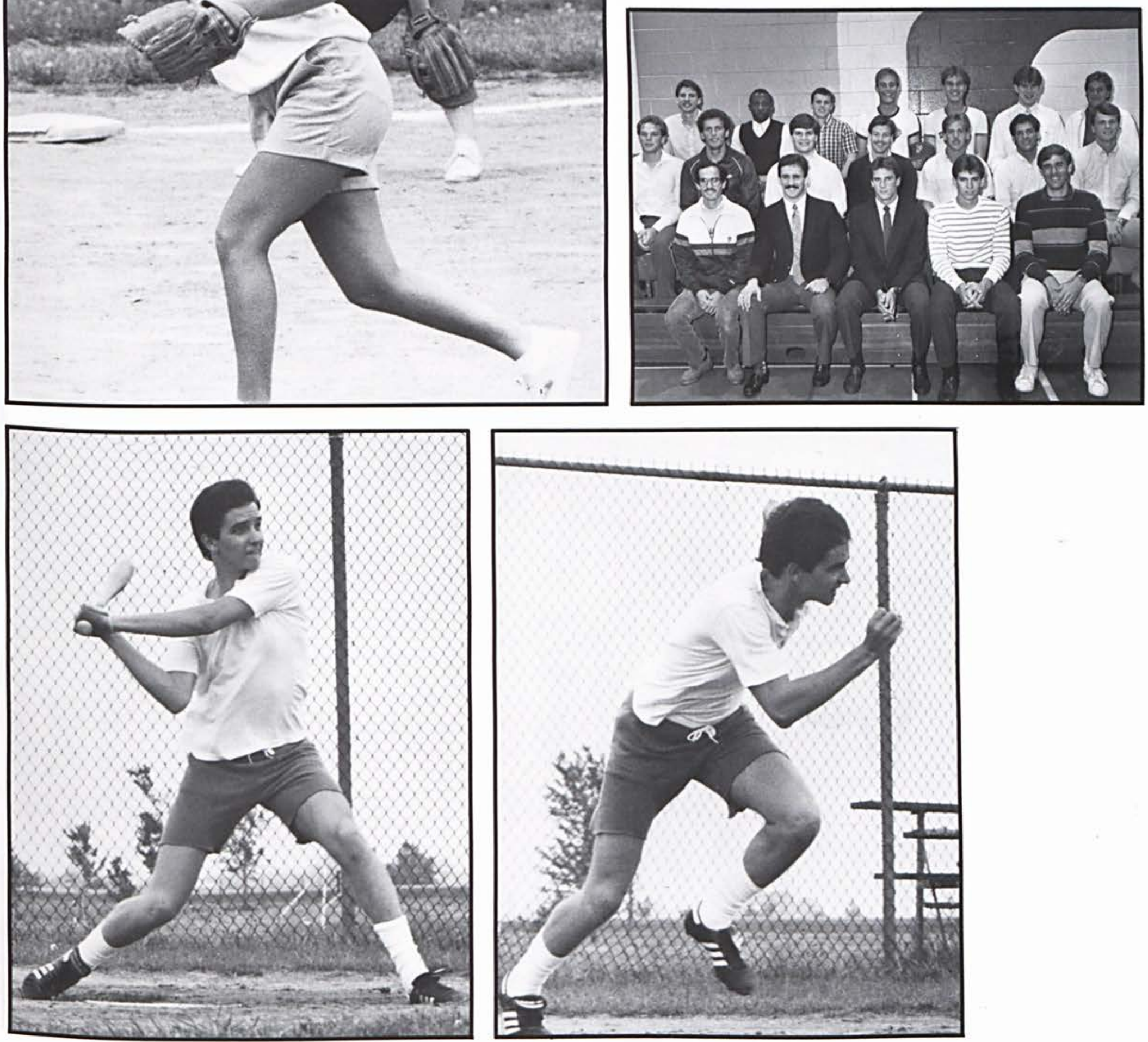


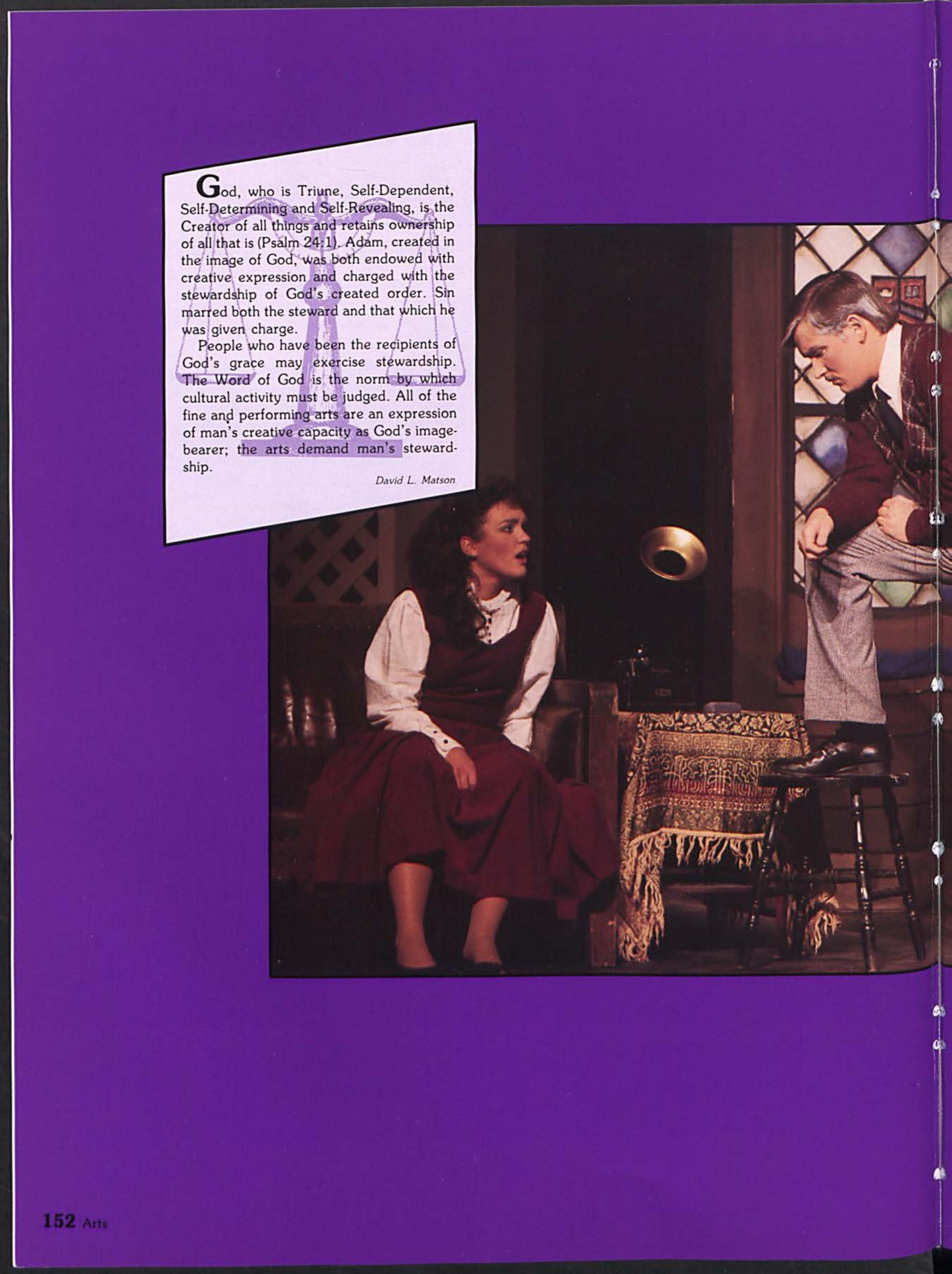




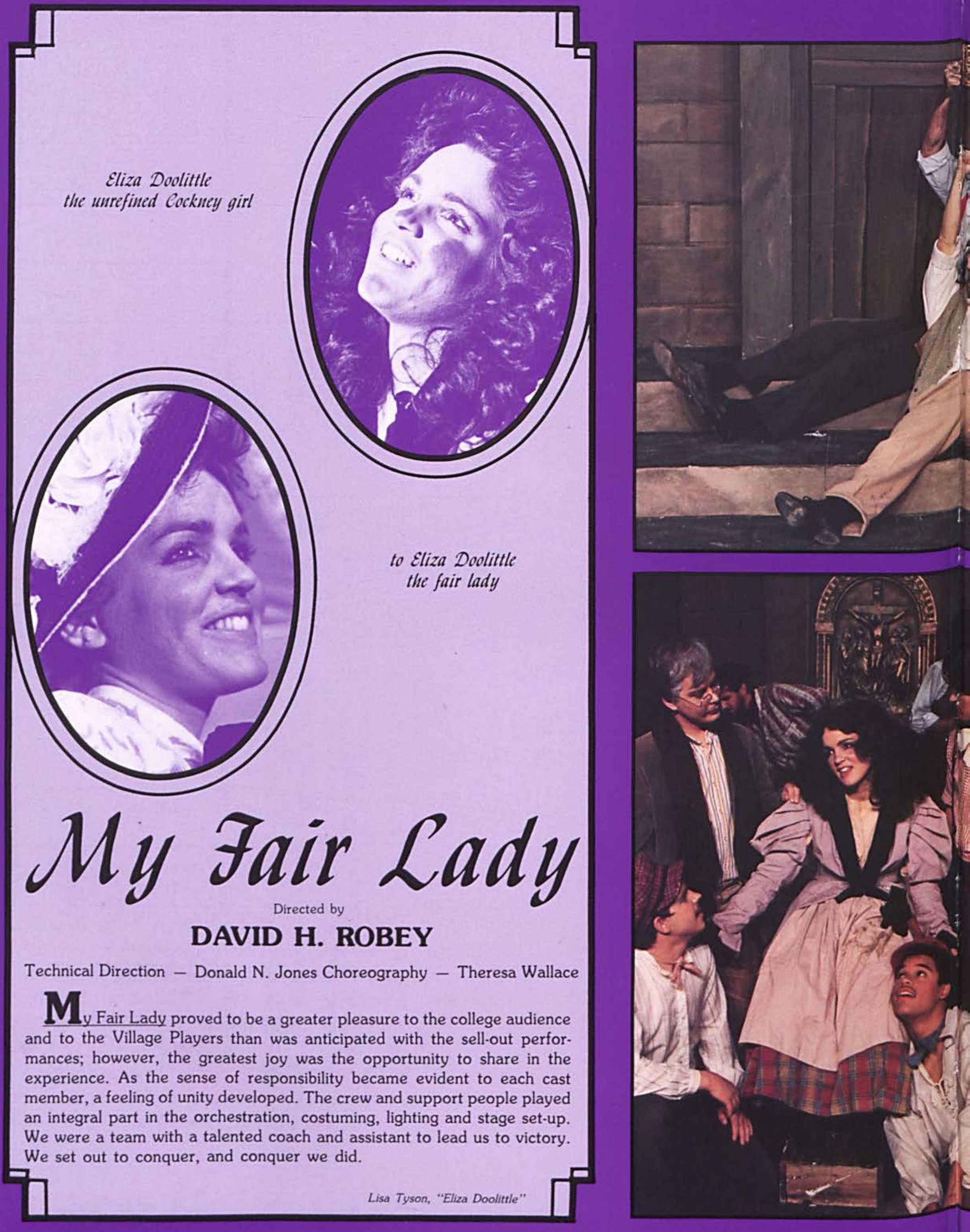



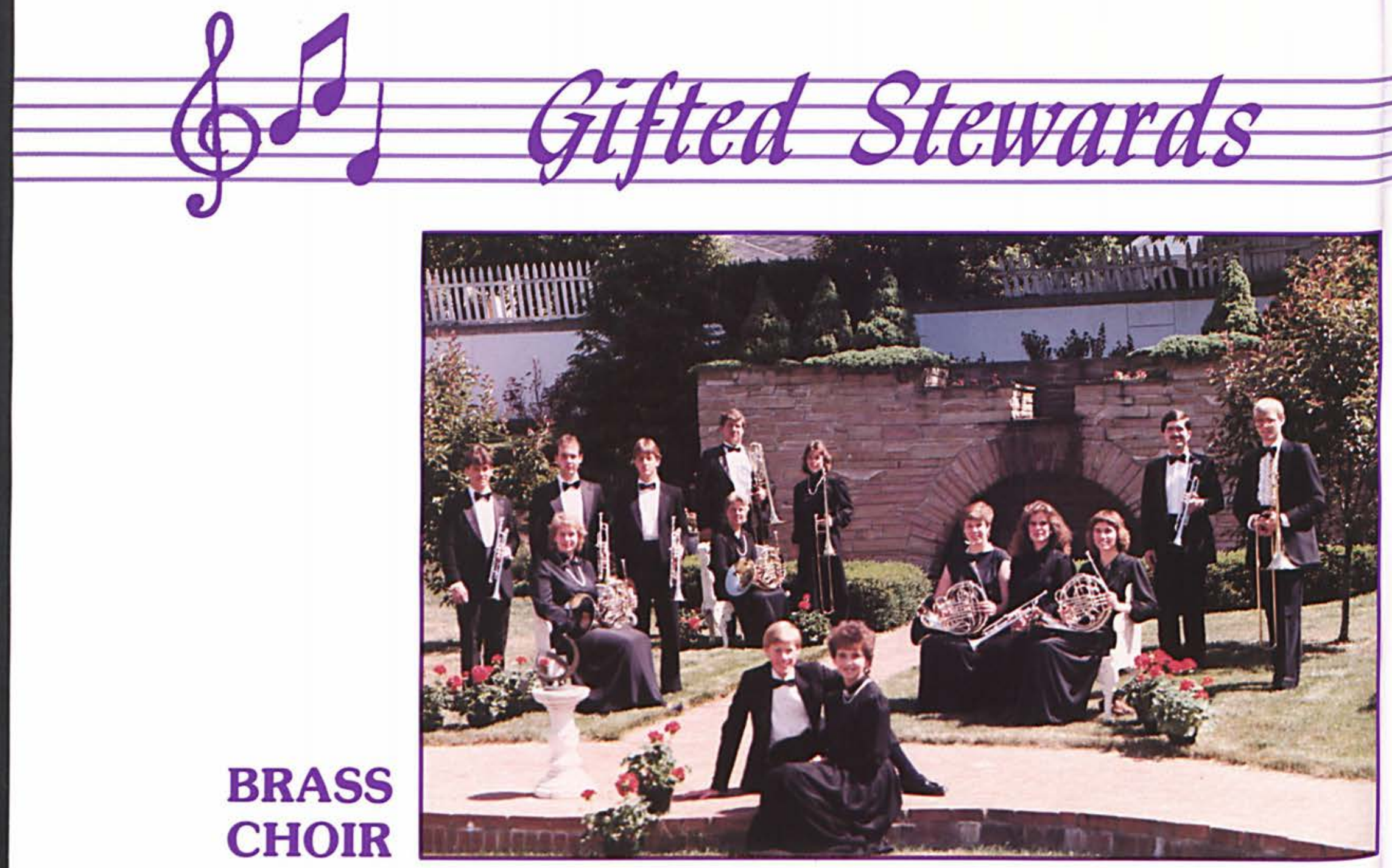

Bill Bany, John Stevens, Mark George, Debbie Rinehart, Gerry Wallace, Richard Carey, Janice Warren, Eileen Tompson, Kathy Jones, Debbie Warnshius, Stephen Wood, Lynell Smith, Bryan Crump, Don Shaffer, Temple Knowles, David Cook, Leah Robbins, Conductor: Charles Pagnard.

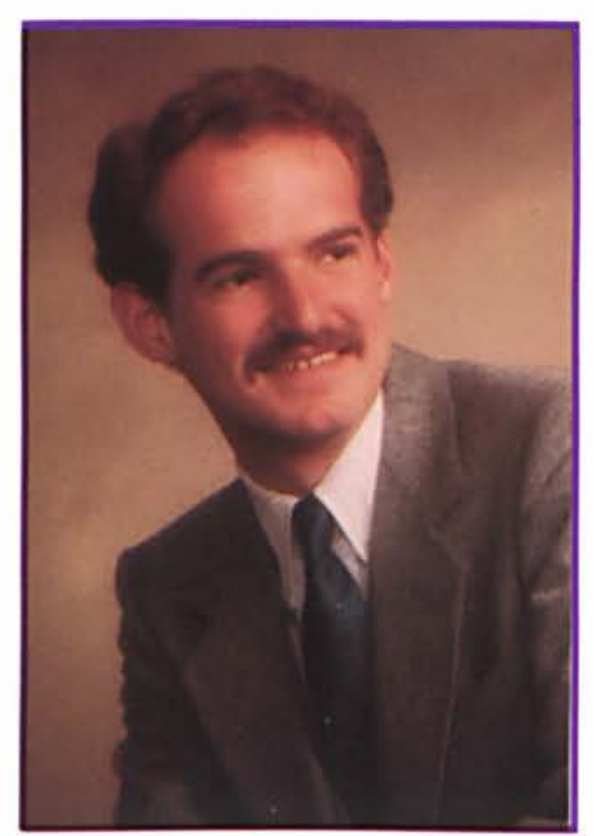

Gary Barker

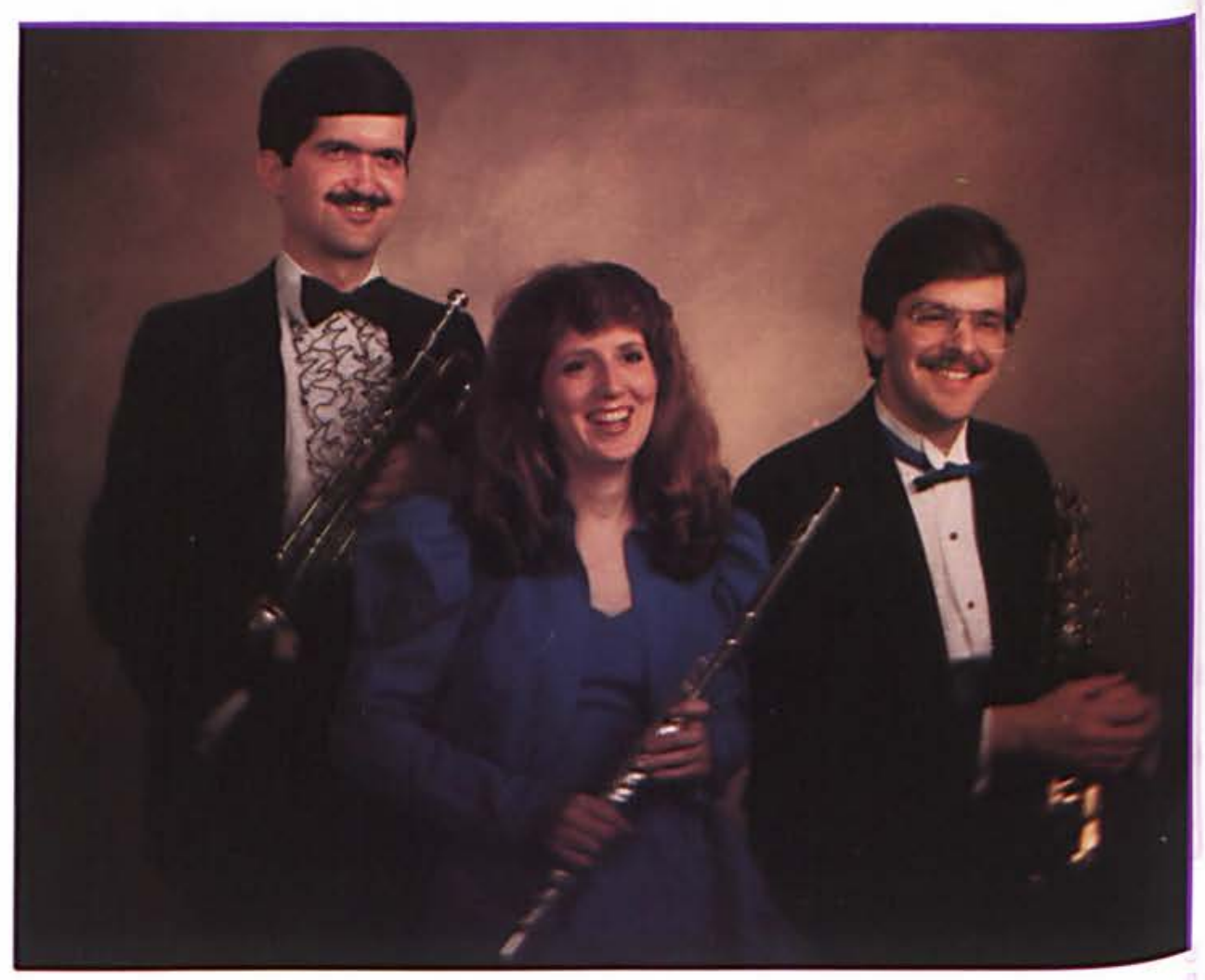

Bill Bany, Joy Burr, and Doug Horne 


\section{The Glass Menagerie}

“. . time is the longest distance between two places."

$\mathbf{T}$

ime is important in this play due to its ability to create memories.

Tennessee Williams termed this play a "memory play," for the events are recollections from Tom Wingfield's memory. Beyond that though, memory is important because the memories of each character influence their action throughout the drama.

Mrs. Wingfield (Elena Michael) and her memories of life on Blue Mountain inhibit her responsibilities of parenting effectively. Laura (Ruth

Margraff), as well, is bound by memories of past failures and

humiliations which keep her from assuming a productive life. In a

different way, memories motivate Tom (Gary Barker) and the

Gentleman Caller (Walter Taylor). For them, memories of disadvantaged

childhoods spur their ambitions on to near selfish proportions. The

passage of time, however, not only creates memories but also affects

their significance.

Since an event's significance and level of emotion may be heightened

in one's memory, this play holds the potential for enormous impact.

The events played out on stage are but Tom's memories and subject to

his sentiment. Even in his memories one can see the pessimism,

bitterness, and regret. Because of their success in capturing the spirit,

Gary, Elena, Ruth, and Walter made their audience feel with them.

The brilliant performance given by this cast and crew evoked a

pathos among those present in Alford as few other productions ever

have. None could help but feel the sorrow and tragedy of this family's

plight. However, time moves forward for all, and the lessons learned are soon forgotten. Yet, perhaps a delicate figurine or a bit of colored glass will bring Laura to mind. Because of the efforts of these individuals, Laura's candles may burn in our memories, too.

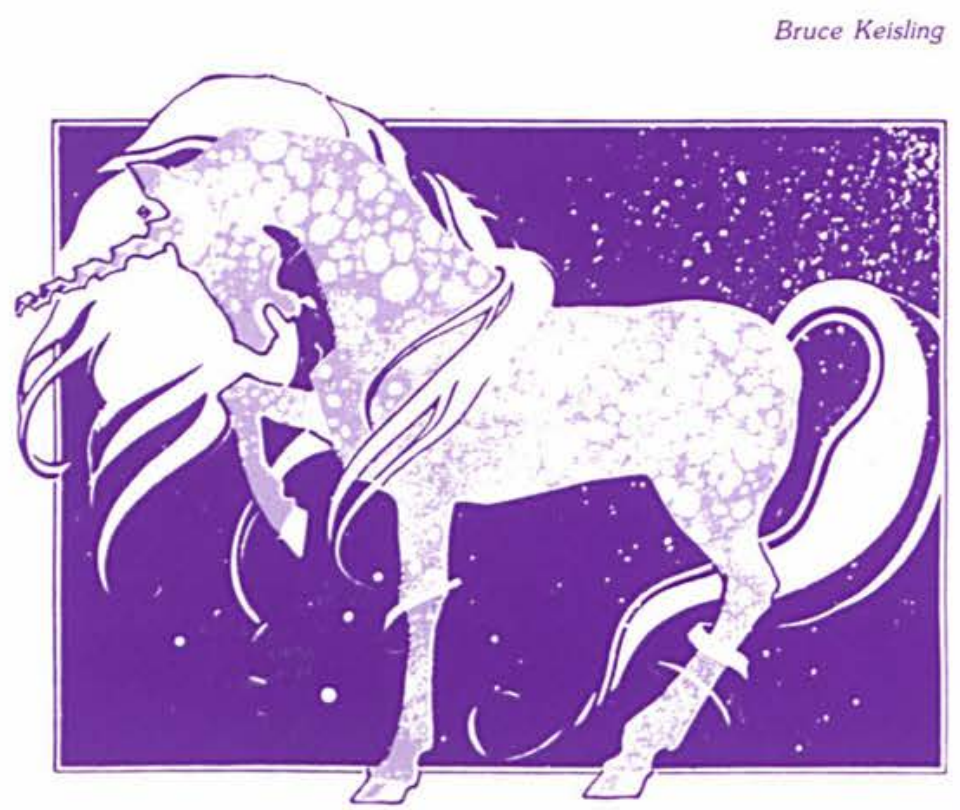

(Tom Wingfield)
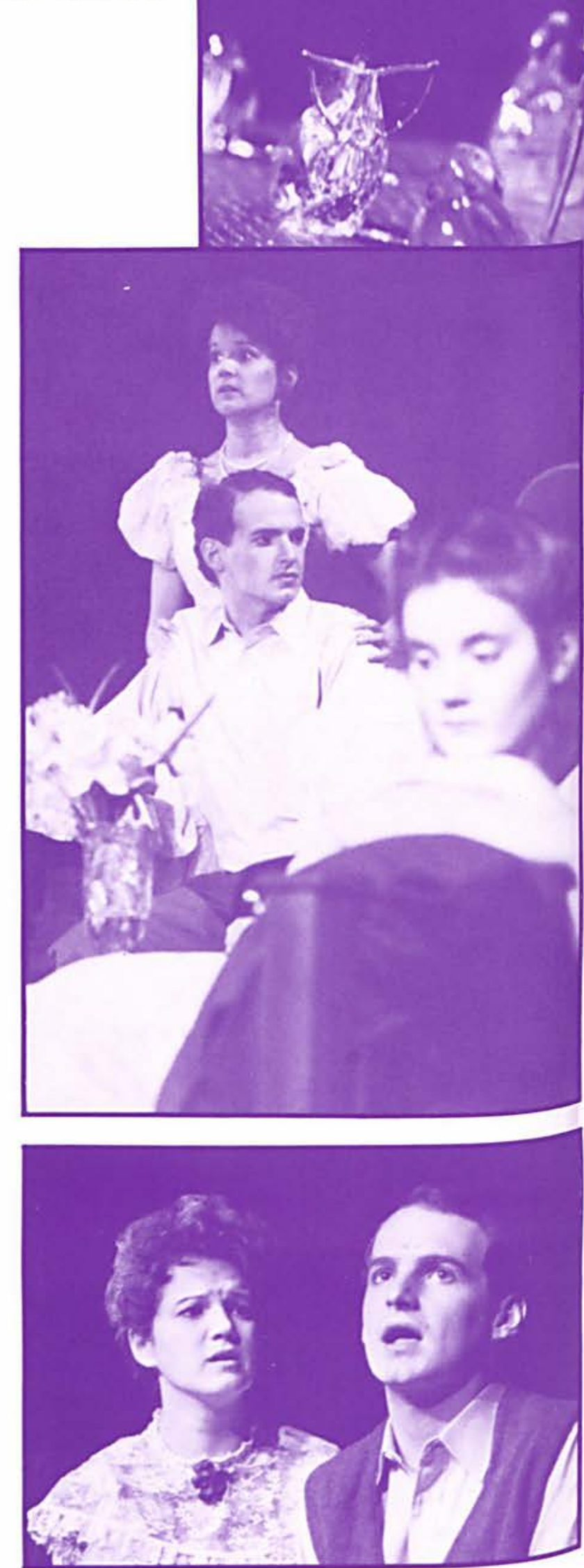

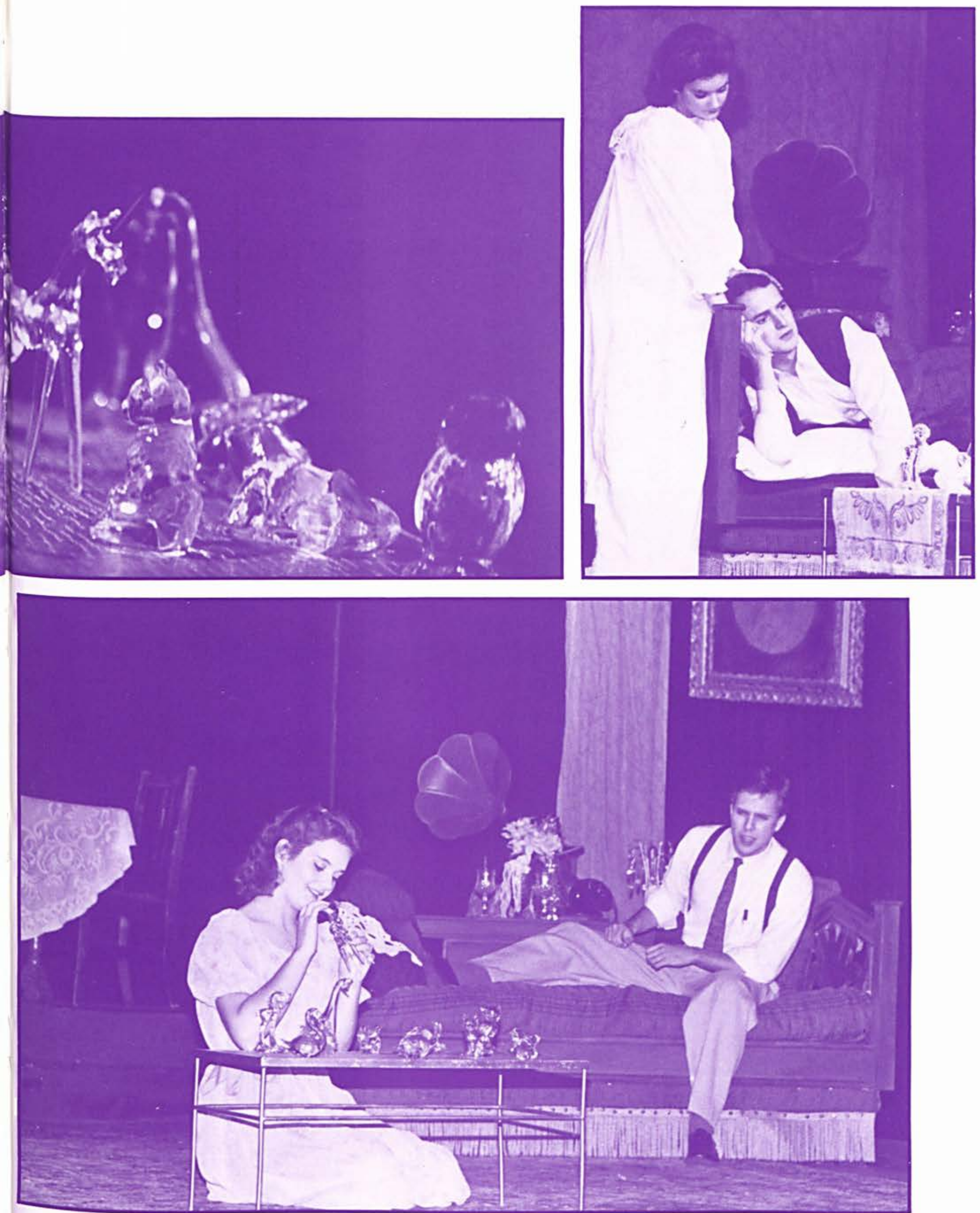

Top left: The glass menagerie that Laura so lovingly cares for. Middle left: Amanda Wingfield, the spoiled southern bell, stands above her children Tom, the rebellious young man, and Laura, the troubled young woman. Left: Amanda worries for her son who leads a questionable life. style. Top right: Laura comforts Tom as he ponders his less than successful life. Above: Laura shows her prized glass menagerie to her gentleman caller. 


\section{耶稣}

The

Village Plaỵers

present

\section{For This Cause: The Ministry and Martyrdom of John and Betty Stam \\ written and directed by David H. Robey}

John Stam and Betty Scott met while attending Moody Bible Institute. As college age young people, they dedicated their lives to Christ and found His approval on their love. One year after their marriage in 1932, Betty gave birth to a baby girl, Helen Priscilla. Two months later, John and Betty were captured and murdered by rebel Communist forces in China.

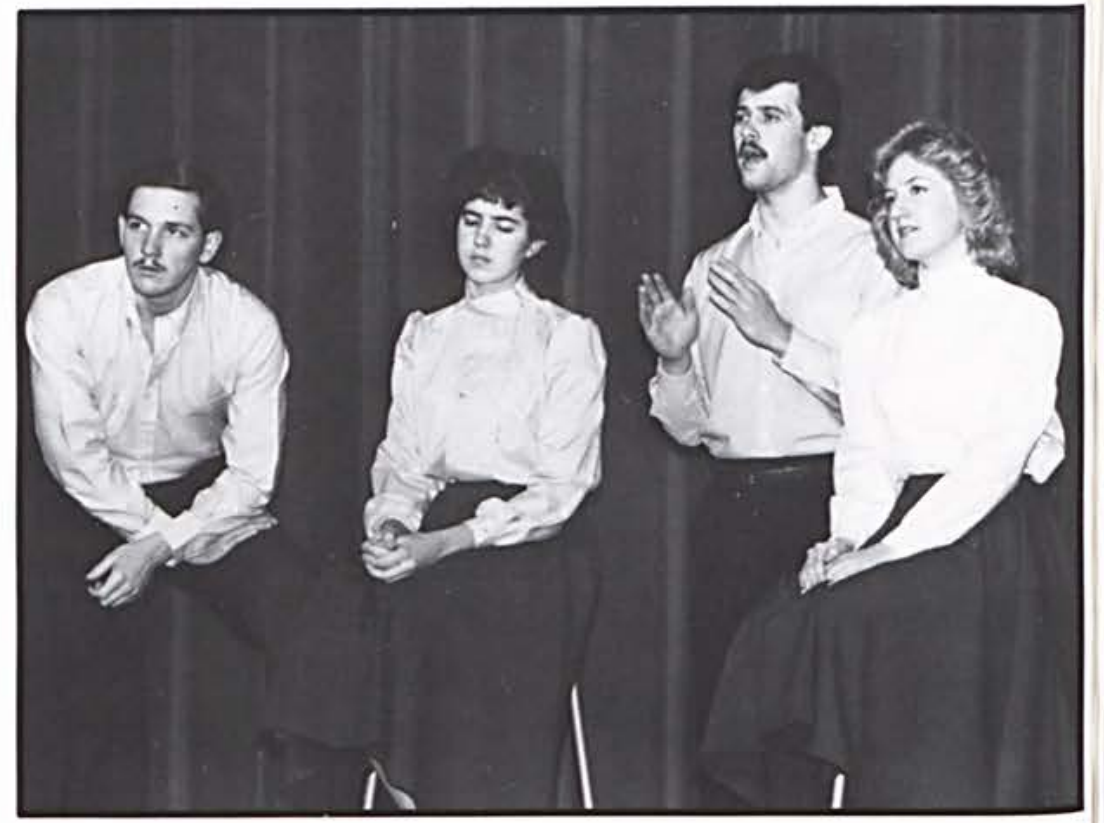

Thomas A. Carr Charles Scott (father of Betty Tammy Evans Barber Clara Scott (mother of Betty

James M. Reiter

Sherry M. Rotramel

Stam)

Mark E. Mathews Radio Announcer, Kenny Scott, Mr. Page, soldier

Errin G. Mulberry Radio Announcer, Laddie Scott, Dr. Hiram, Rev, Torrey, soldier

Nadine L. Terrill Radio Announcer, Helen Scott, Mrs. Page, servant girl

'Except a grain of wheat fall into the ground and die, it abideth alone; but if it die, it bringeth forth much fruit. Christ said, 'For this cause came I unto this hour. Father, glorify thy name.

sermon notation written by John Starn shortly before his martyrdom in China

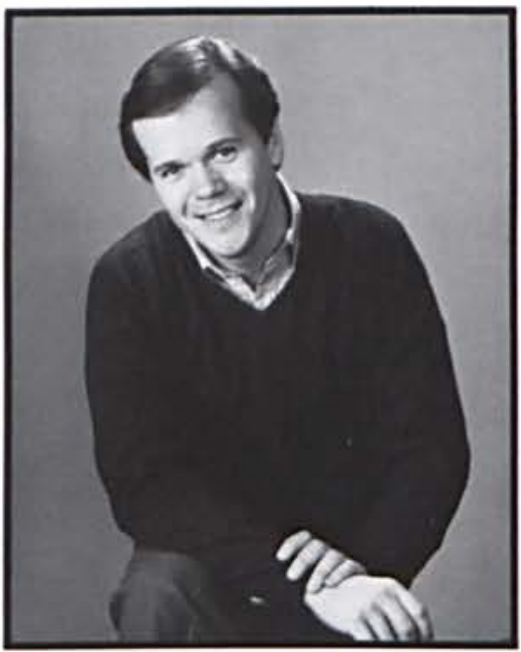

Mr. David H. Robey, author and director of the play

With earnest, Betty Stam (Sherry Rotramel) expresses her desire to serve the true and living God.

Far above: Mr. Page (Mark Matthews), along with his family, dreams of the great opportunities for mission work in China.

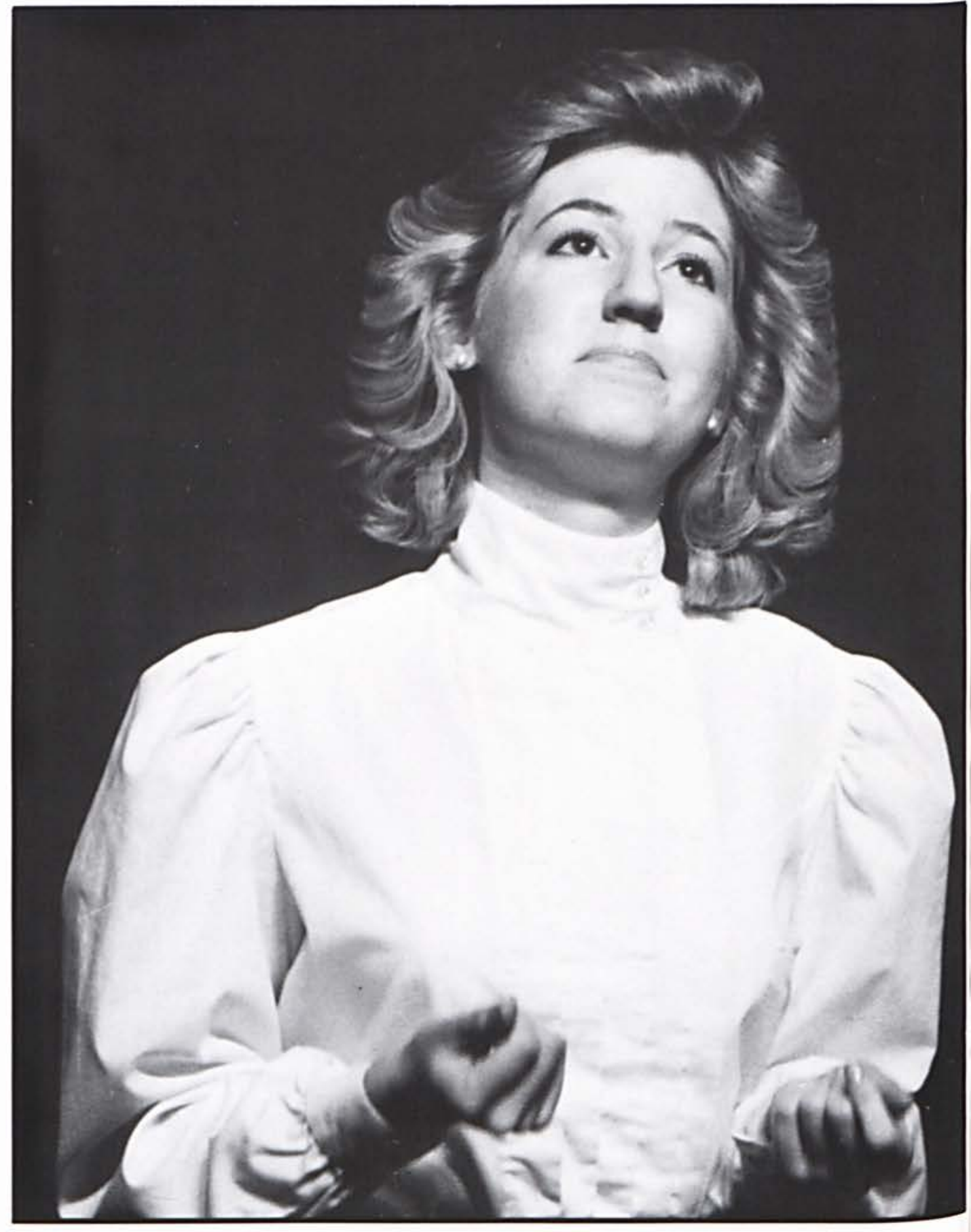



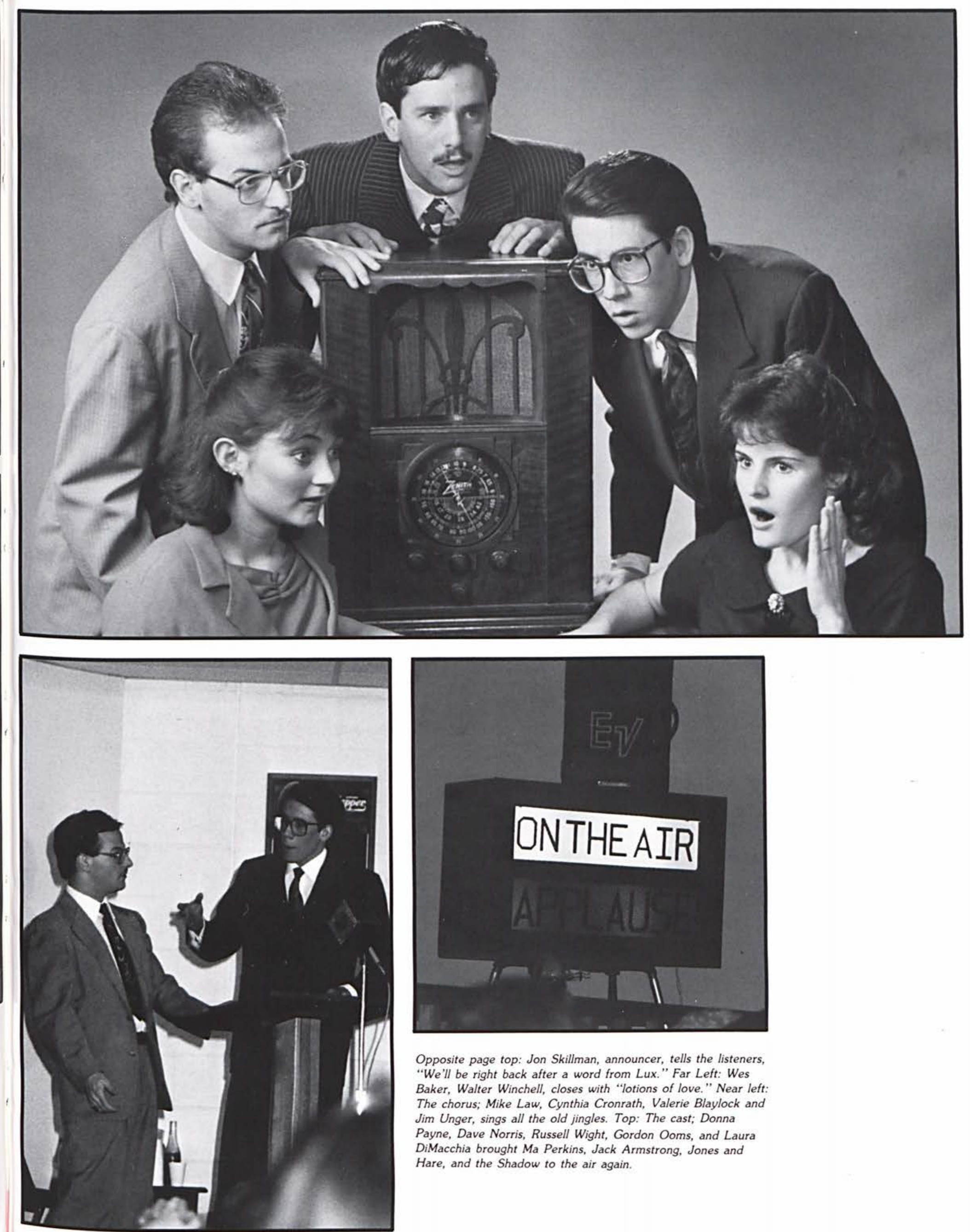

Opposite page top: Jon Skillman, announcer, tells the listeners, "We'll be right back after a word from Lux." Far Left: Wes Baker, Walter Winchell, closes with "lotions of love." Near left: The chorus; Mike Law, Cynthia Cronrath, Valerie Blaylock and Jim Unger, sings all the old jingles. Top: The cast; Donna Payne, Dave Norris, Russell Wight, Gordon Ooms, and Laura DiMacchia brought Ma Perkins, Jack Armstrong, Jones and Hare, and the Shadow to the air again. 


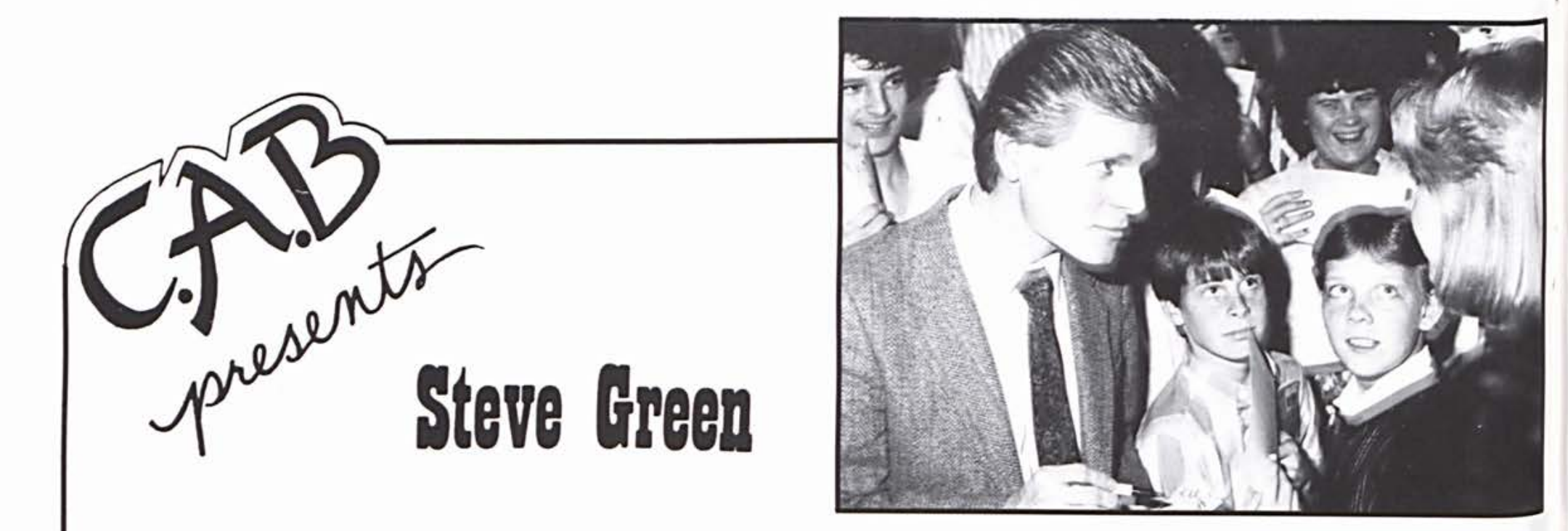

On April 25, 1986, Steve Green, Gospel Music Association's "Dove Artist" of the year, presented a ministry in song to a packed auditorium. He ministered through his candid, piercing testimony and through his heart-felt, edifying music.
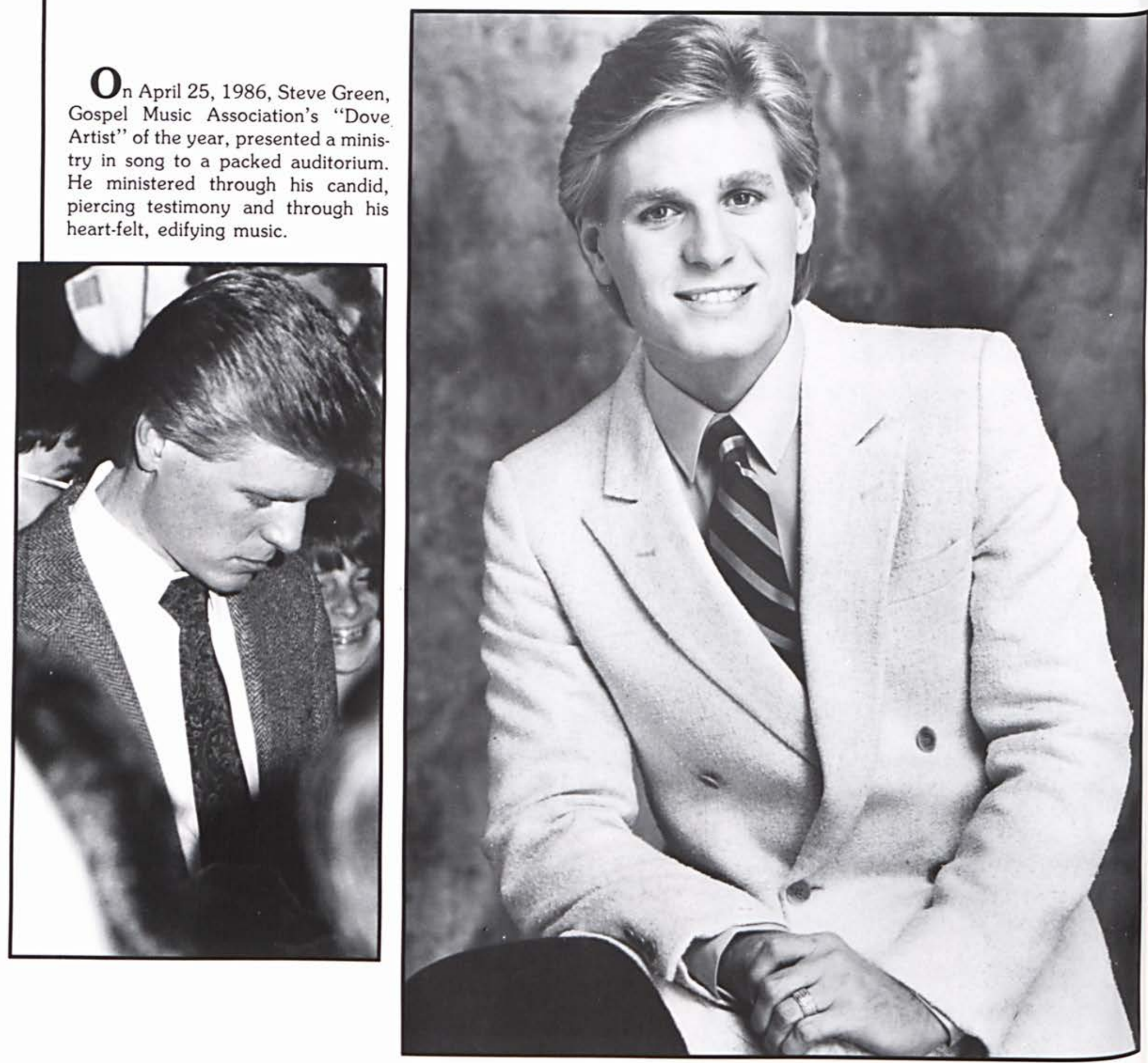

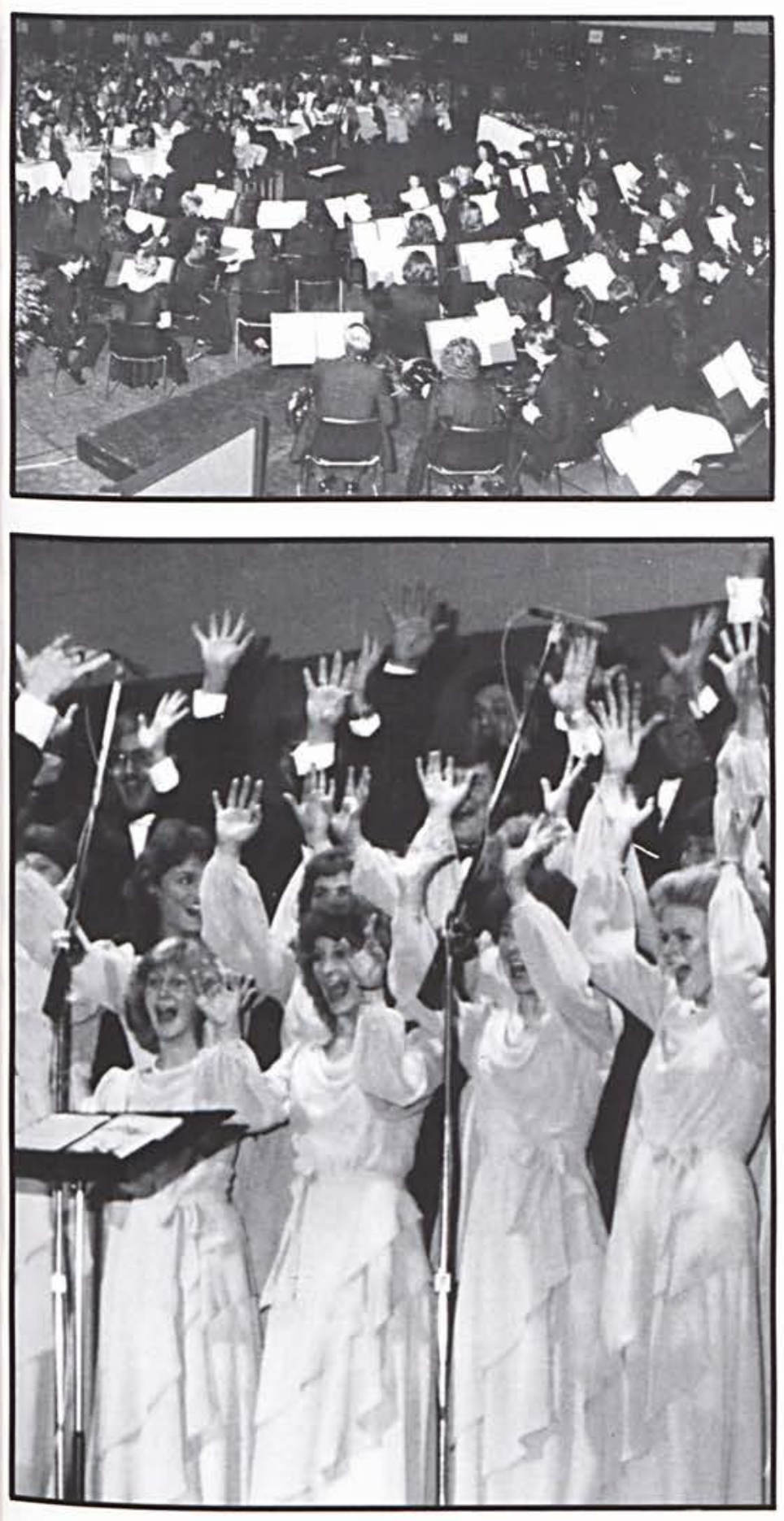

\section{Annual Concerts}

\section{The Pop's Concert}

During Parents' Weekend in May, the Brass Choir, Symphonic Band, and the Chorale combined their musical gifts in a concert for the visiting moms and dads. This second annual, delightful event has grown in popularity each year grown to the point that the audience is getting too large for the present C.C. dining-room setting!

\section{The Oratorio Choir}

667

Io everything there is a season, and a time to every purpose under the heaven" (Ecclesiastes 3:1). The Oratorio Choir, under the direction of Charles Ellington, presented selections from "Contate Doimina," "The Christmas Oratorio," and "Coronation Anthem No. 2." The soloists and choir lifted their praises in song to a great God in "A Time for Greatness."

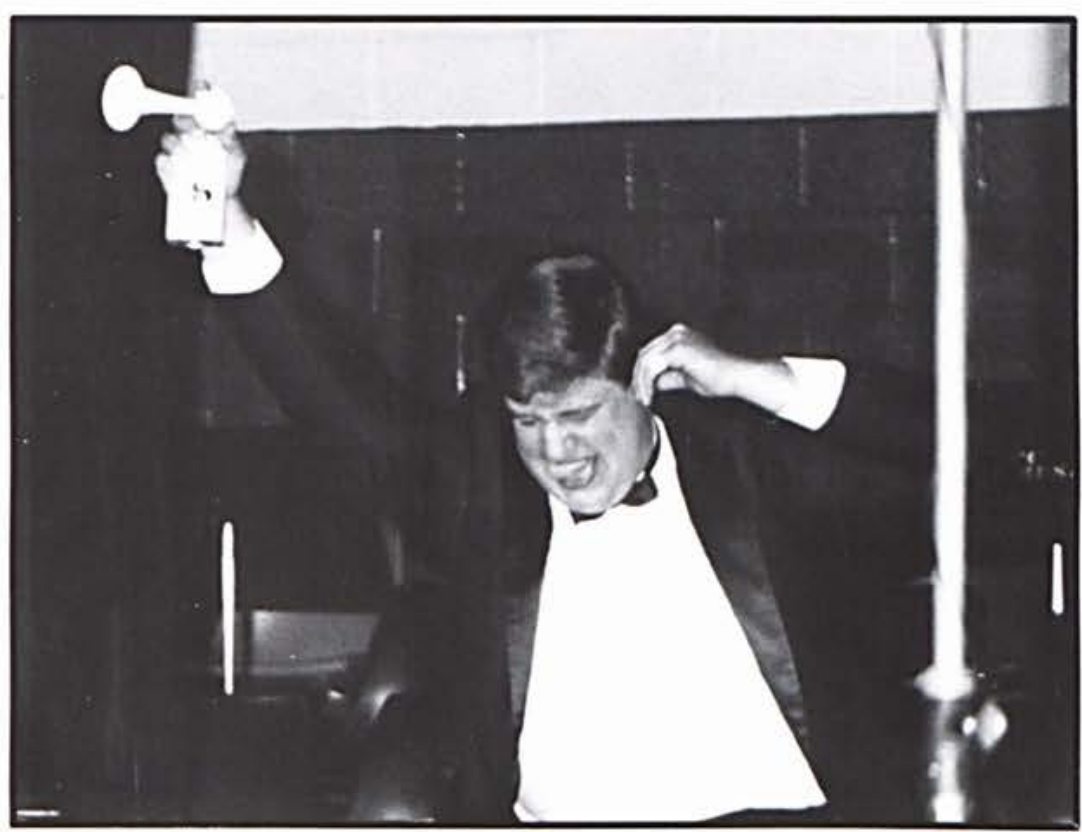

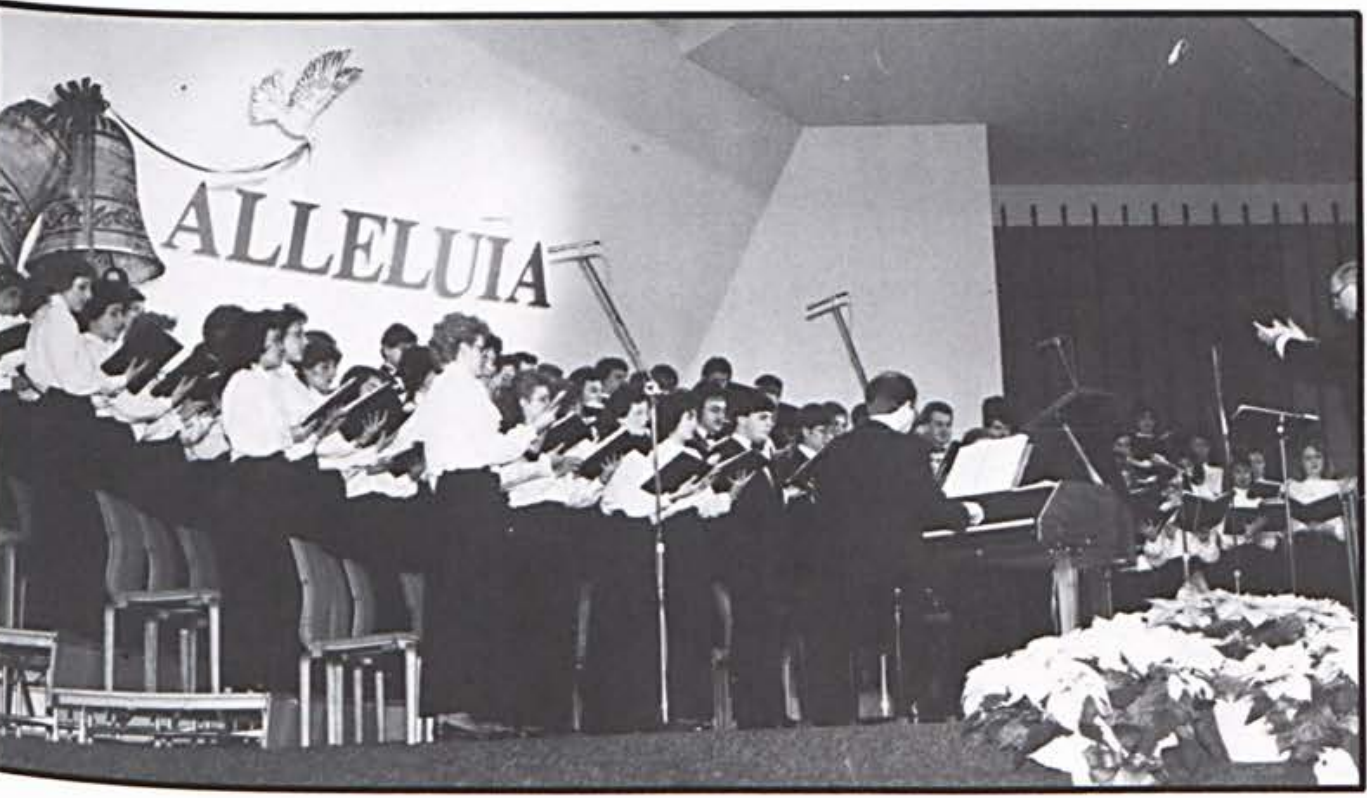

Members of the $1985-86$ Oratorio Choir

Ronda Altman, Mike Anderson, Bauman Rachel, Jeff Beste, Pete Bishop, Bruce Bowman, Warren Brown, Shelly Browne, Lorrie Byrd, Renee Clor, Mary Ruth Cook, Mary Coons, Matthew Creamer, Lisa Davidson, Melissa Denenberg, Angie Dennis, Joy Detweiler, Theres Dunlap, Craig Fee, Melody Ferguson, Roger Foreman, Eileen Friesen, Greg Frye, Stephen Gerhardt, Mark Groves, Karen Haynes, Sand Harner, Mark Hinman, Michelle Minnergardt, Dwayne Hoff, Phil Hohulin Sandra Holbrook, Paula Howard Beth Hughes, Todd Hummel, Don Humphreys, Mary Knicely, Jane Kraner, Karen Kuntz, Michael Law, Doris Lindley. Tern Mackenzie, Laura Maers, Jeftrey Main, Jolene Merck, Stephanie Manning Kim Manzi, Jean Moeser, Man, Jo Murph, Dine Noggle, Gary None Kin Mana, Jean Moeser, Roh Pasurers Sue Perrott, Doug Phillips, Becky Pruner, Lind

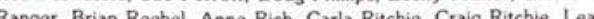
Rober, Brian Reebel, Anne Rich, Carla Rnche, Cralg Rich in Leah Robbins, Judy Runge, Ronette Shank, Jim Smelser, Dorcas Sommers, Wallorn, Cynti Wa Walborn, Cynthia Wagner, Cyndi Walker, Margaret Wildman, Barbara
Yanda 


\section{Arts, Et Cetera}
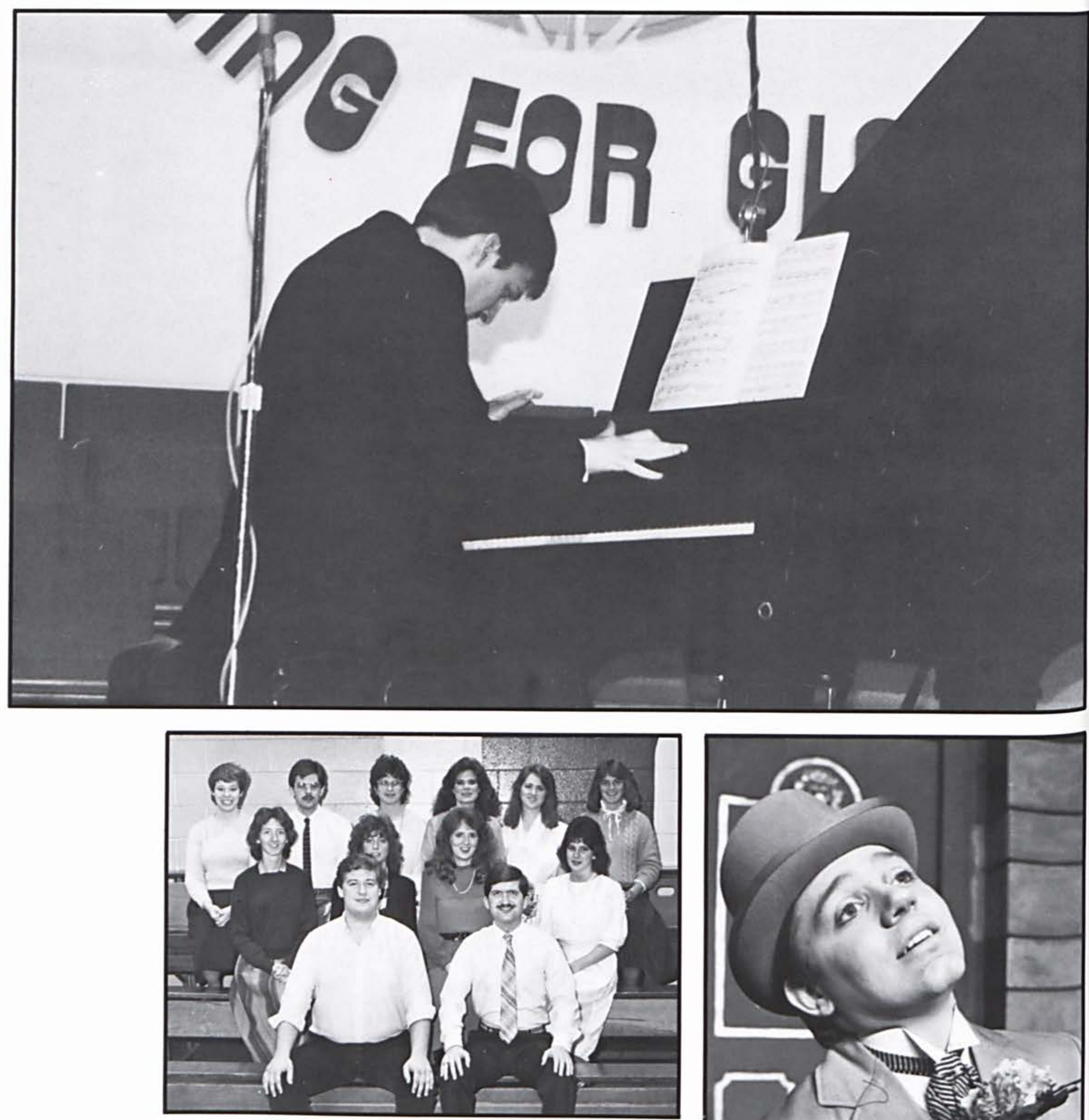

M.E.N.C.: Front: Steve Wood, Bill Bany, Second Row Diane Noggle, Sandra Holbrook, Joy Burr, Terri L. Mackere. Thied Row: Kathy Jones, Douglas Howe, Eleen Friesen, Debby Rinehart, Rebecca Haga, Lynn Ramsey. The club serves God by assisting membes to become quality music education professionals.

Top: Eric Helmuth ministers his music. Right: Mike Law sings "On the Street Where You Live" from My Fair Lady;

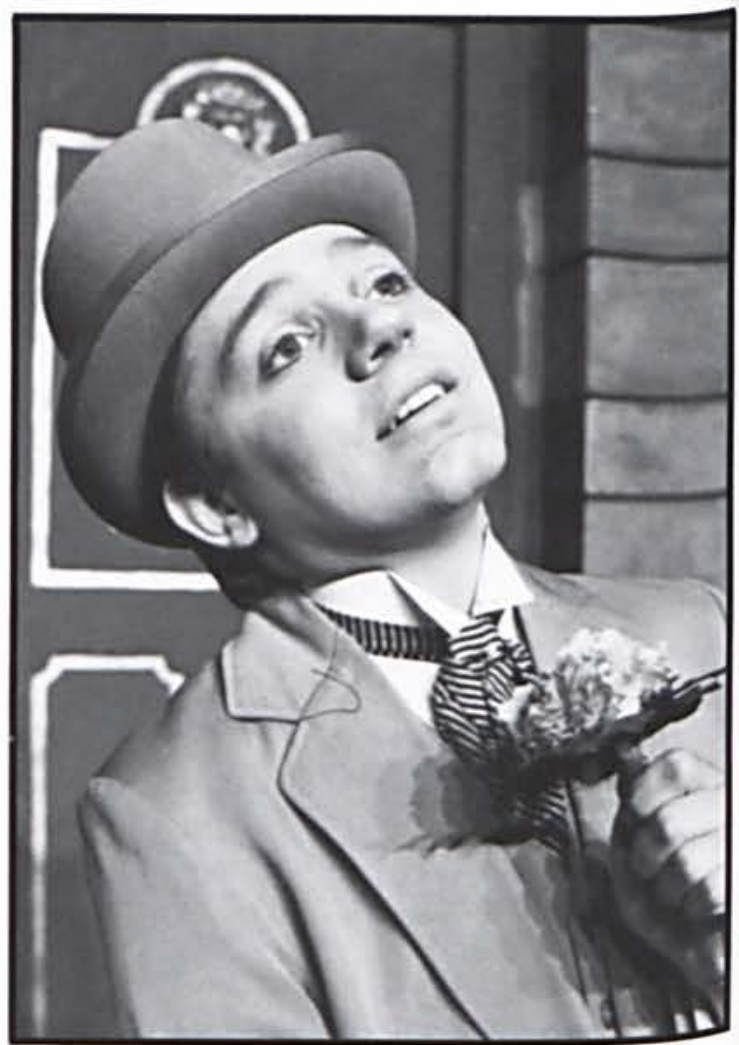




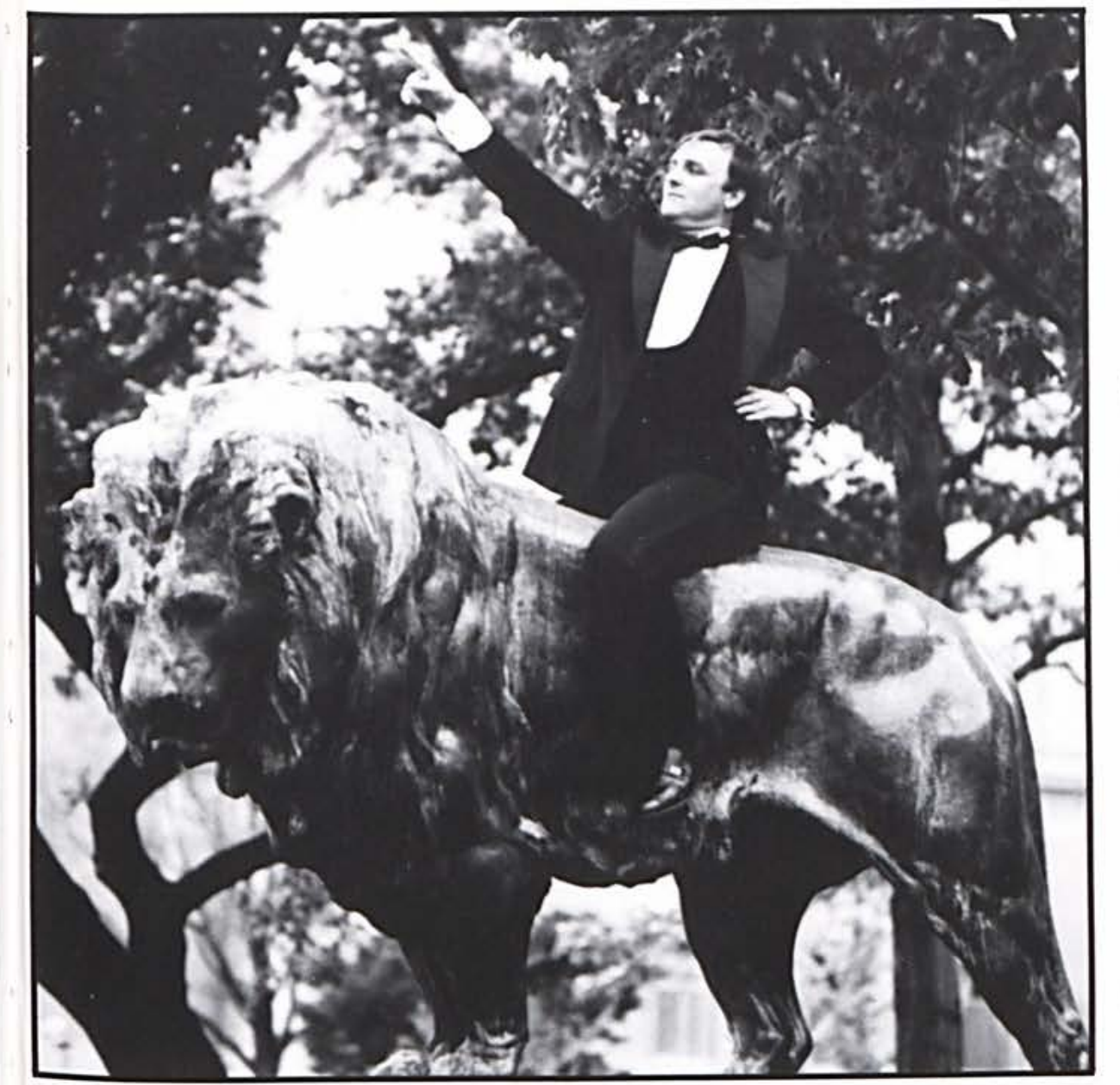

ARTISTIC DESIGN CLUB: Sitting: Diane Borleis, Julia Lee, Gene Evans. Standing: Sally Cochran, Beth Augustine, Mrs. DiCuirci, Advisor, and Debbie Borleis. This club serves God by promo
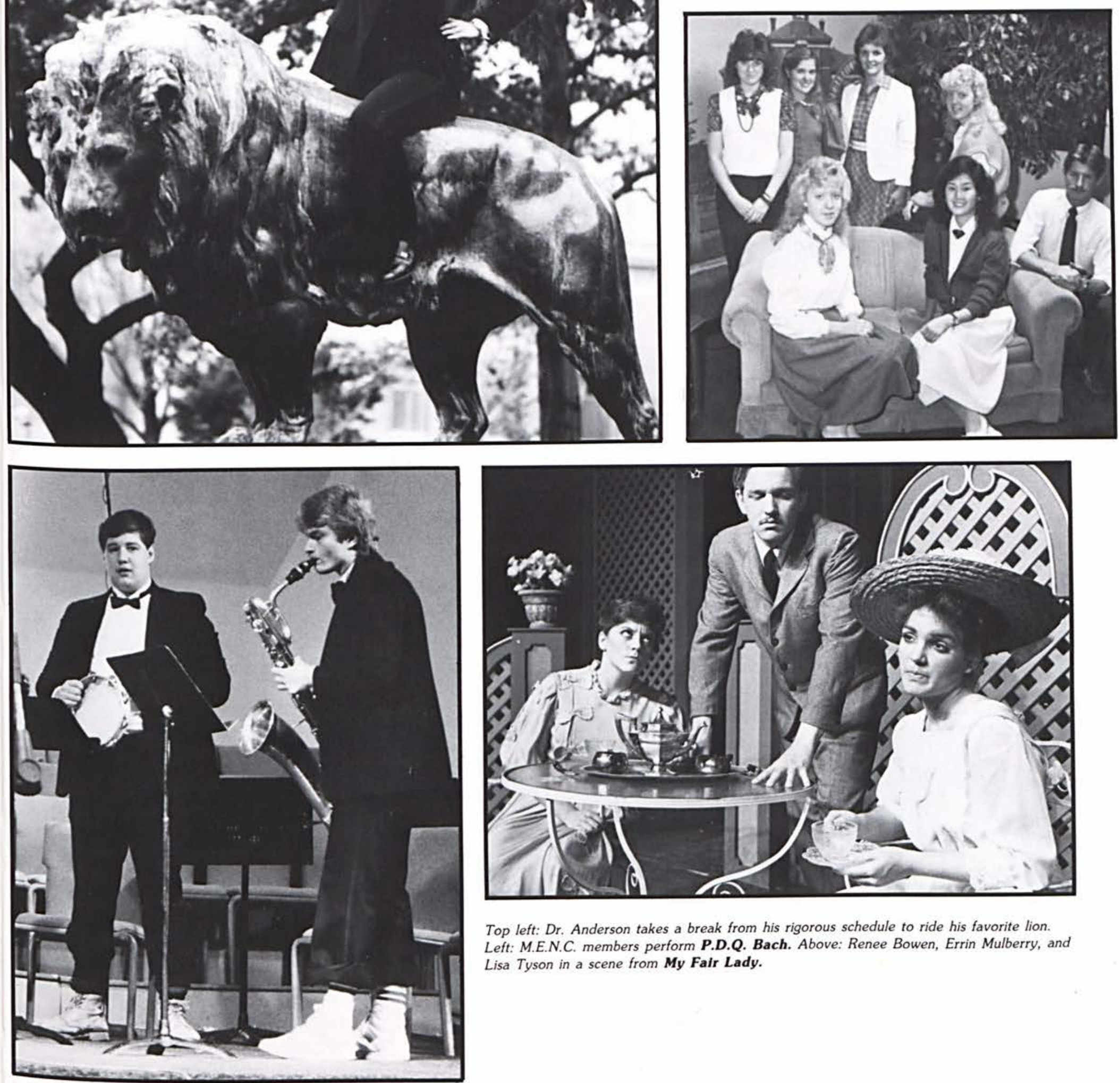

Top left: Dr. Anderson takes a break from his rigorous schedule to ride his favorite lion. Left: M.E.N.C. members perform P.D.Q. Bach. Above: Renee Bowen, Errin Mulberry, and Lisa Tyson in a scene from My Fair Lady. 


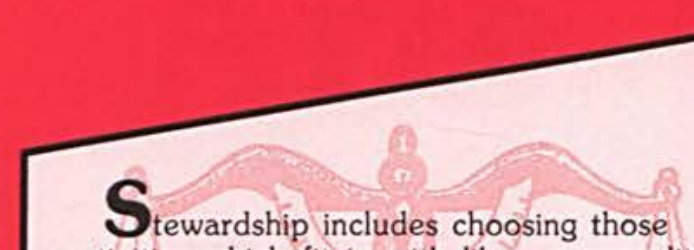

activities which fit in with likes, personalities, and purposes. Although the value of those activities includes fun, relaxation, and entertain ment, it also includes deeper concepts: ministry, fellowship, friendship, and the develop ment of talents.

God has given everyone the capacity to de. light in beautiful music, to enjoy the thrill of drama, to become totally involved in a sporting event, to laugh heartily with friends, and to encourage those around themselves. More than that, $\mathrm{He}$ has given the ability to honor $\mathrm{Him}$ in all that is done, which makes "student life" a part of the whole picture of stewardship.

Sandra Entner

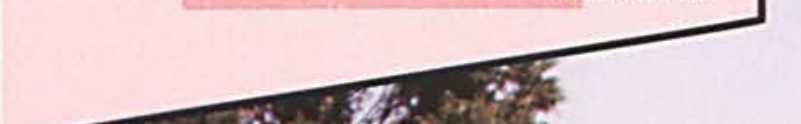



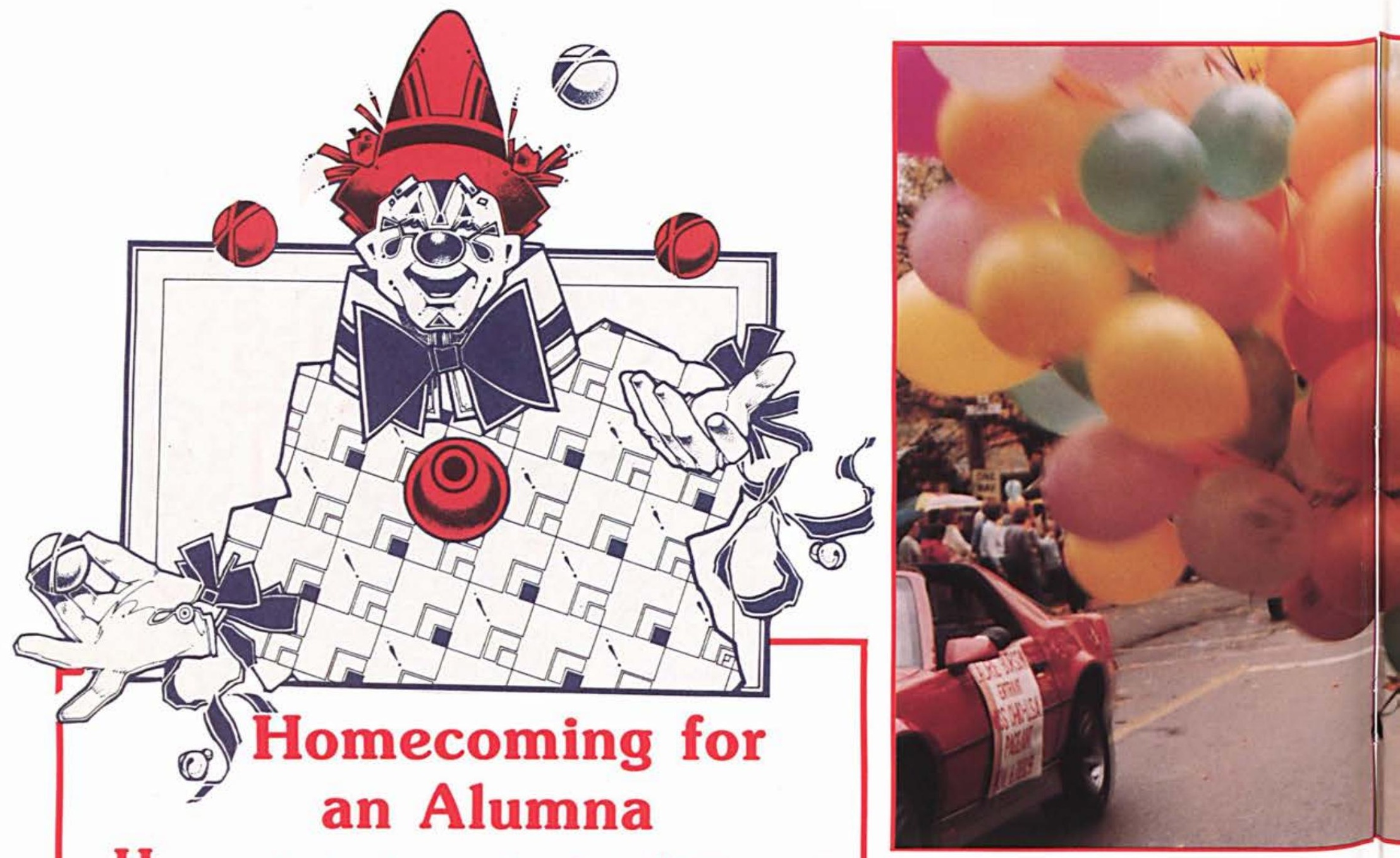

$\mathrm{H}_{\text {omecoming has always been a time for reflection. Whether returning }}$ after five years or twenty-five years, it has a way of bringing back memories. Changes are often startling and invariably evoke comparisons.

Perhaps the biggest change for me was the Athletic Center. Construction began in the spring of my senior year and was completed the following year. As a result, I never saw the finished product until Homecoming. Today, north of Maddox, a modern sports facility can be seen where once stood little more than scaffolding.

While new additions on campus were readily apparent, other buildings seemed only to have changed their function. The health center, for years a landmark, is now housed by Patterson, formerly a women's dorm. Williams Hall, once a men's dorm (and several other things!), now provides office

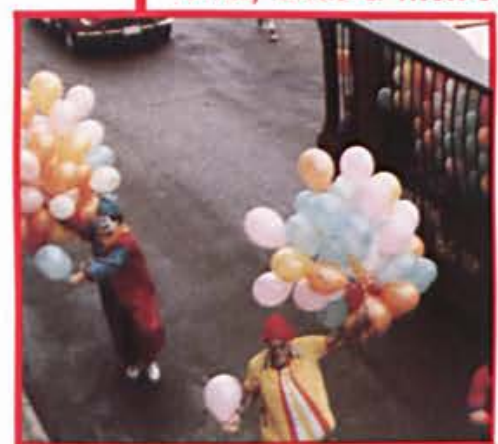
space for faculty and staff. And a funny thing happened on the way to the "G.S."; I accidentally ran into the old gym on the way to the dining hall!

It makes me wonder. In another twenty years, would Rip Van Winkle recognize Heritage Square?

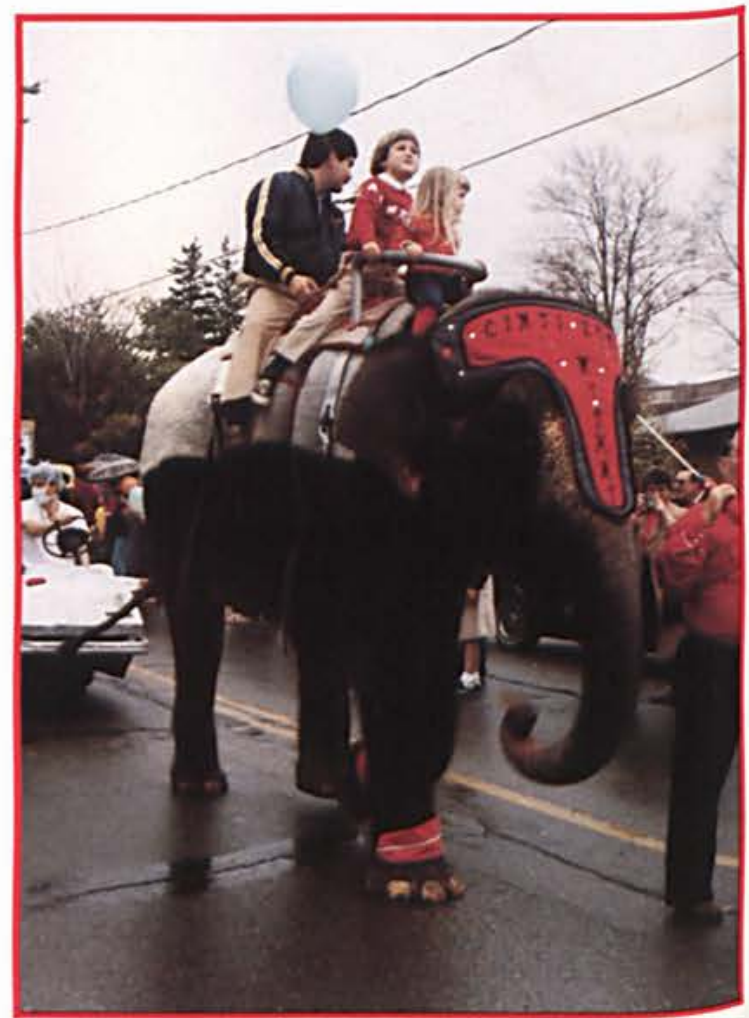




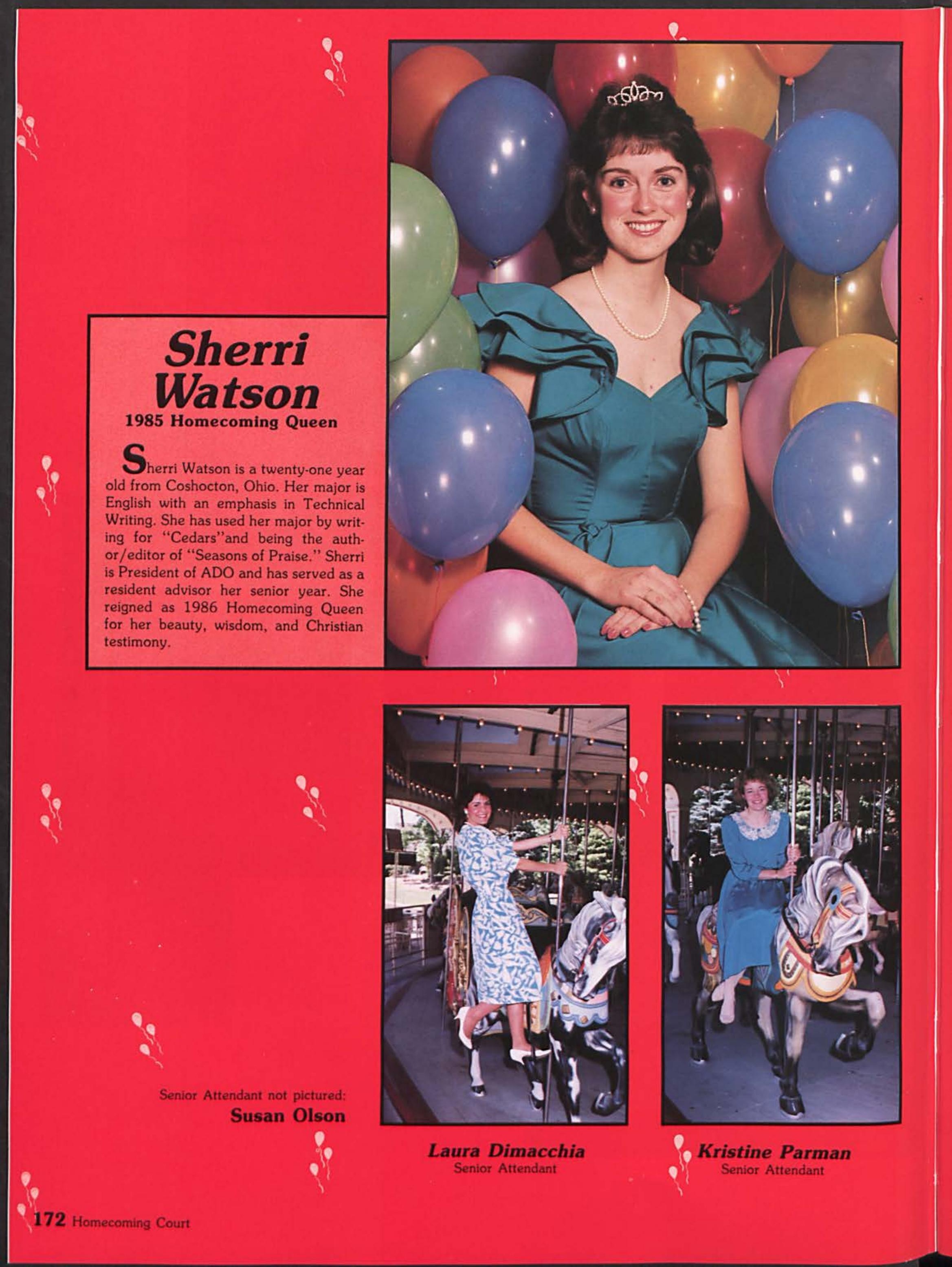


So

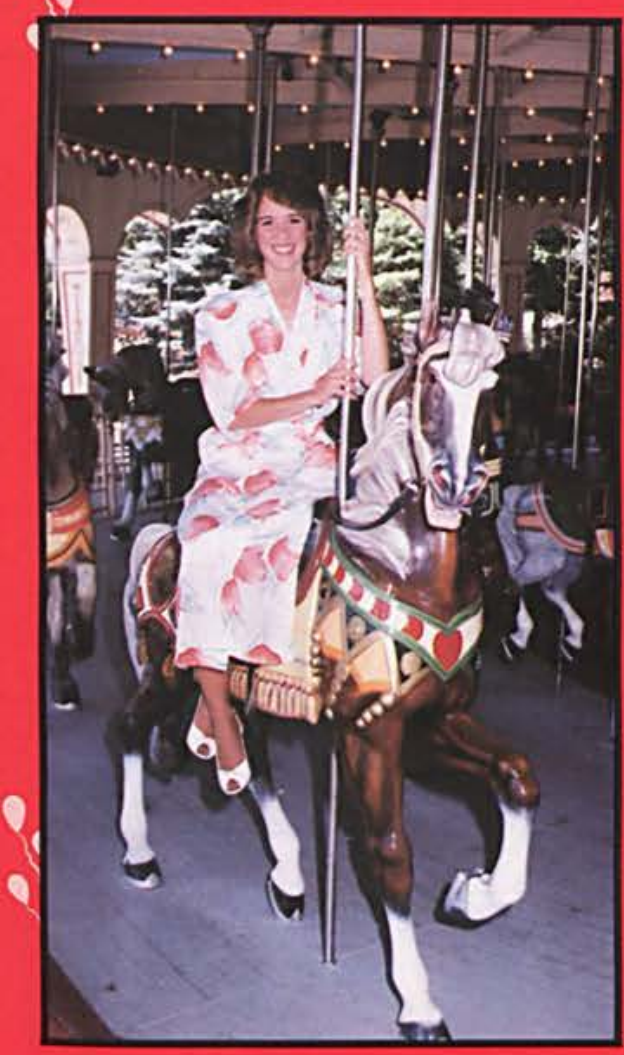

Doris Lindley

Junior Attefdant

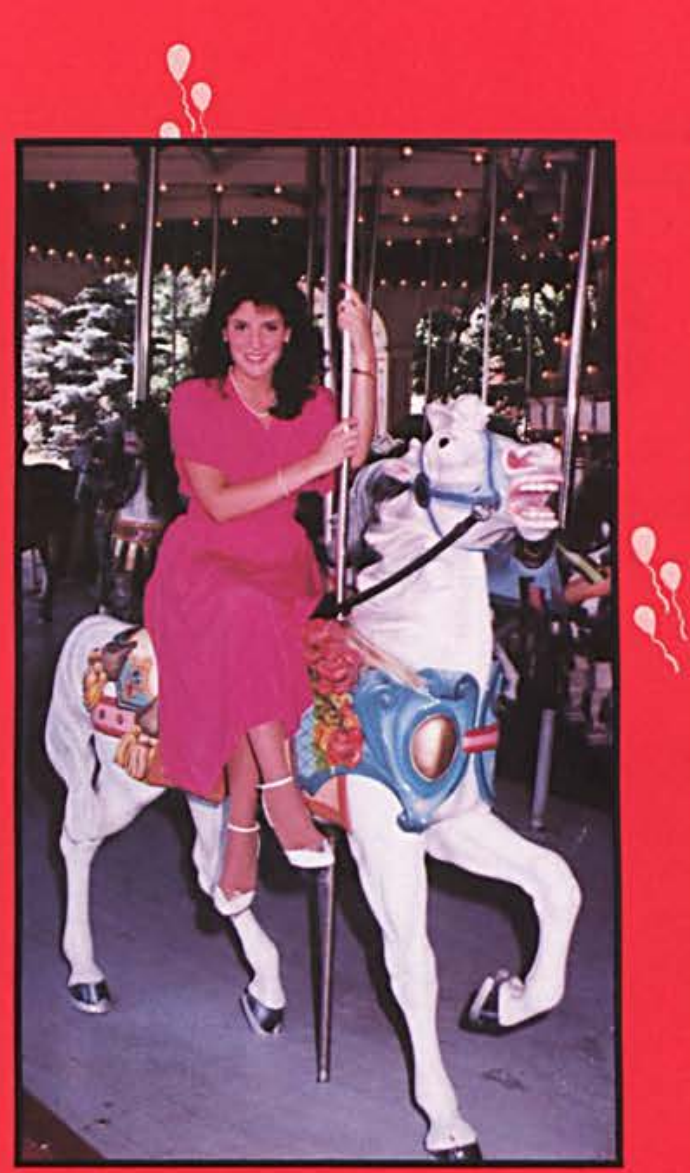

Kristina Hoddelmann

Sophomore Attendant

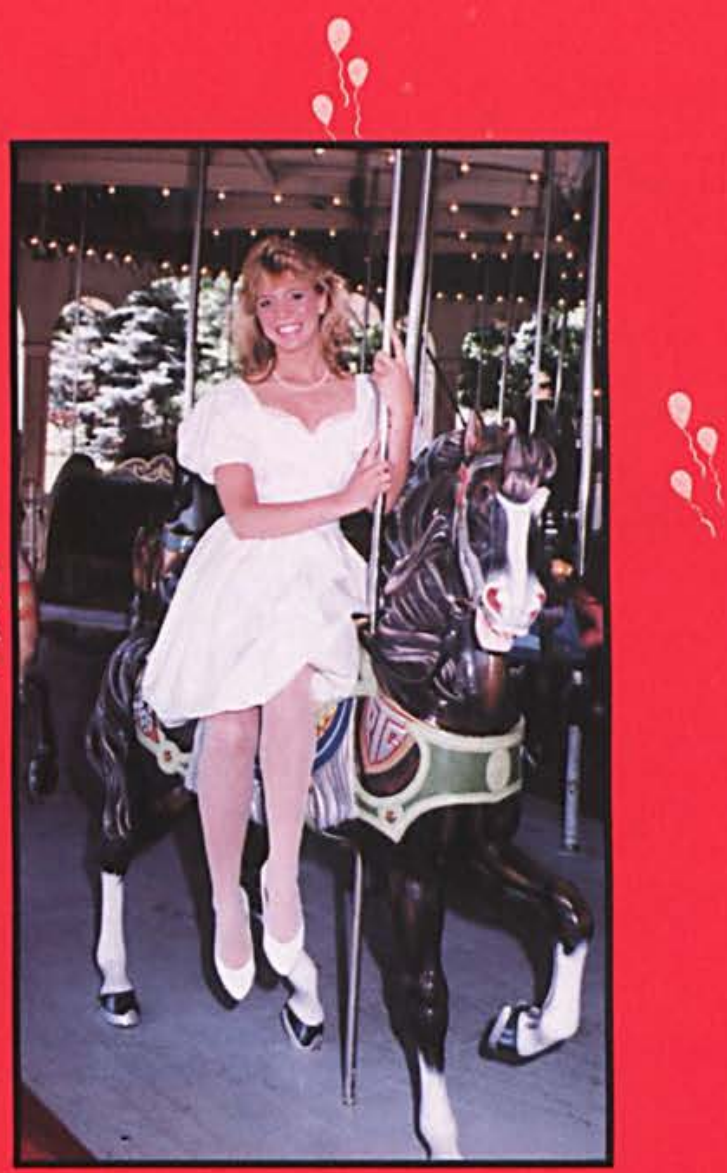

Sherri Bauer

Freshman Attendant
?

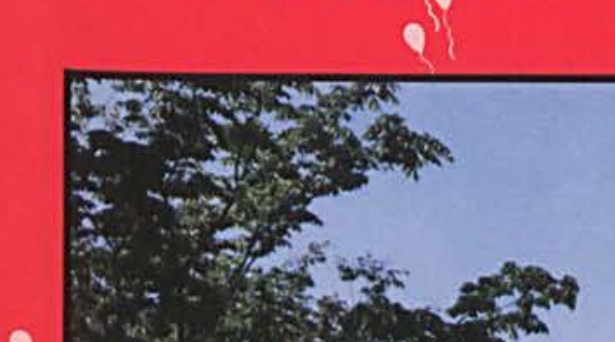

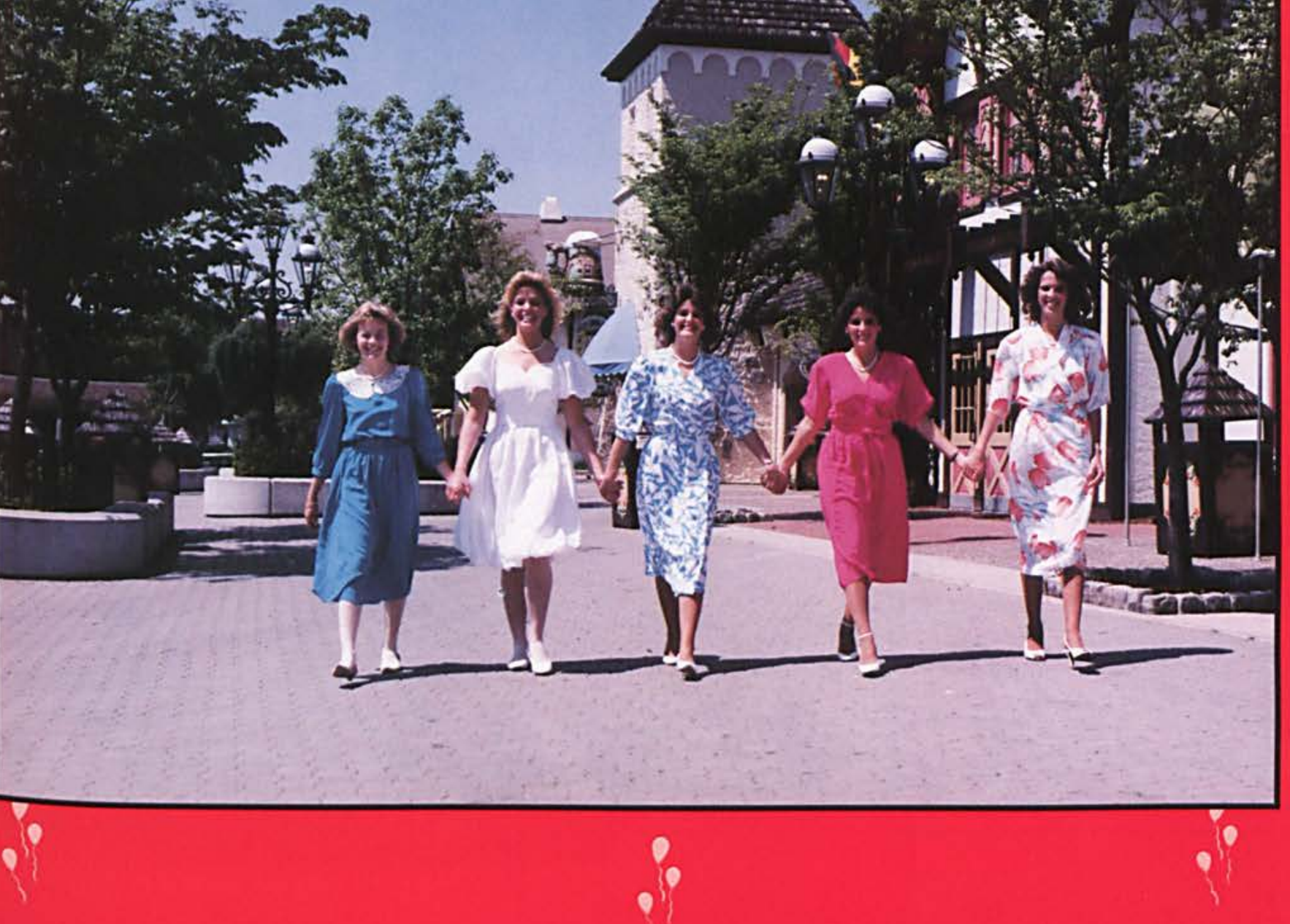

The Court

Pictures taken at

Jings 

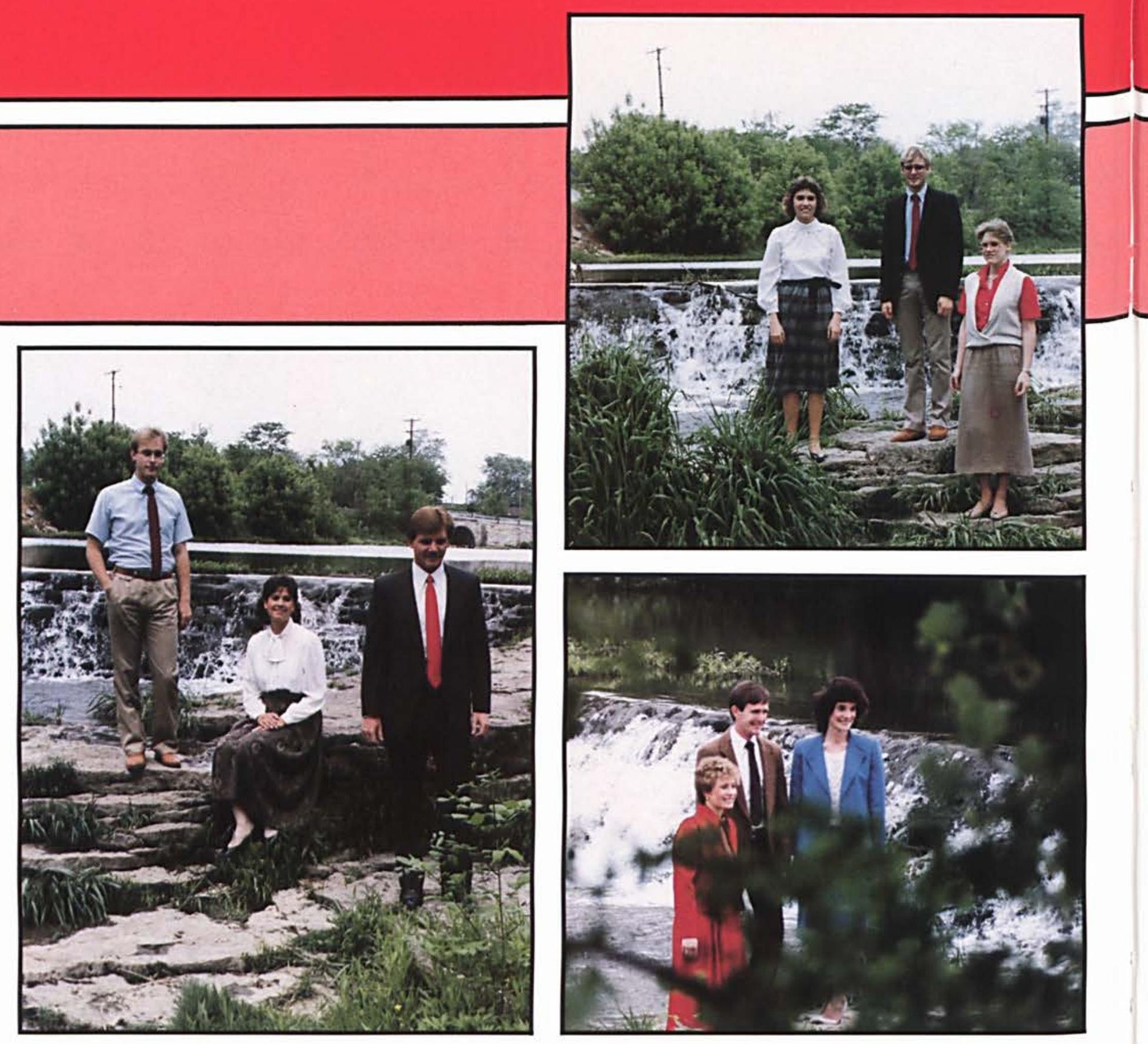

Top Right: Janice Warren, Bryan Crump, Judith Oakes. Middle Right: Shannon Saunders, Rusty King, Heidi Hempel. Right: Amy Guest, Diane Brown. Above: John Williams, Sarah Anderson, Lamar Eifert. Not Pictured: Kenneth Bane, Jill Campbell, Phil Clifford, Steven DeCook, Carey Danielson, Laura Dykstra, Teena Fleetwood, Eric Helmuth, Michelle Longo, James Murdoch, Teresa Palmer, Lisa Prall, James Reiter, Denise Ross, Robert Sand, Richard Sharp, Christine Weidman.

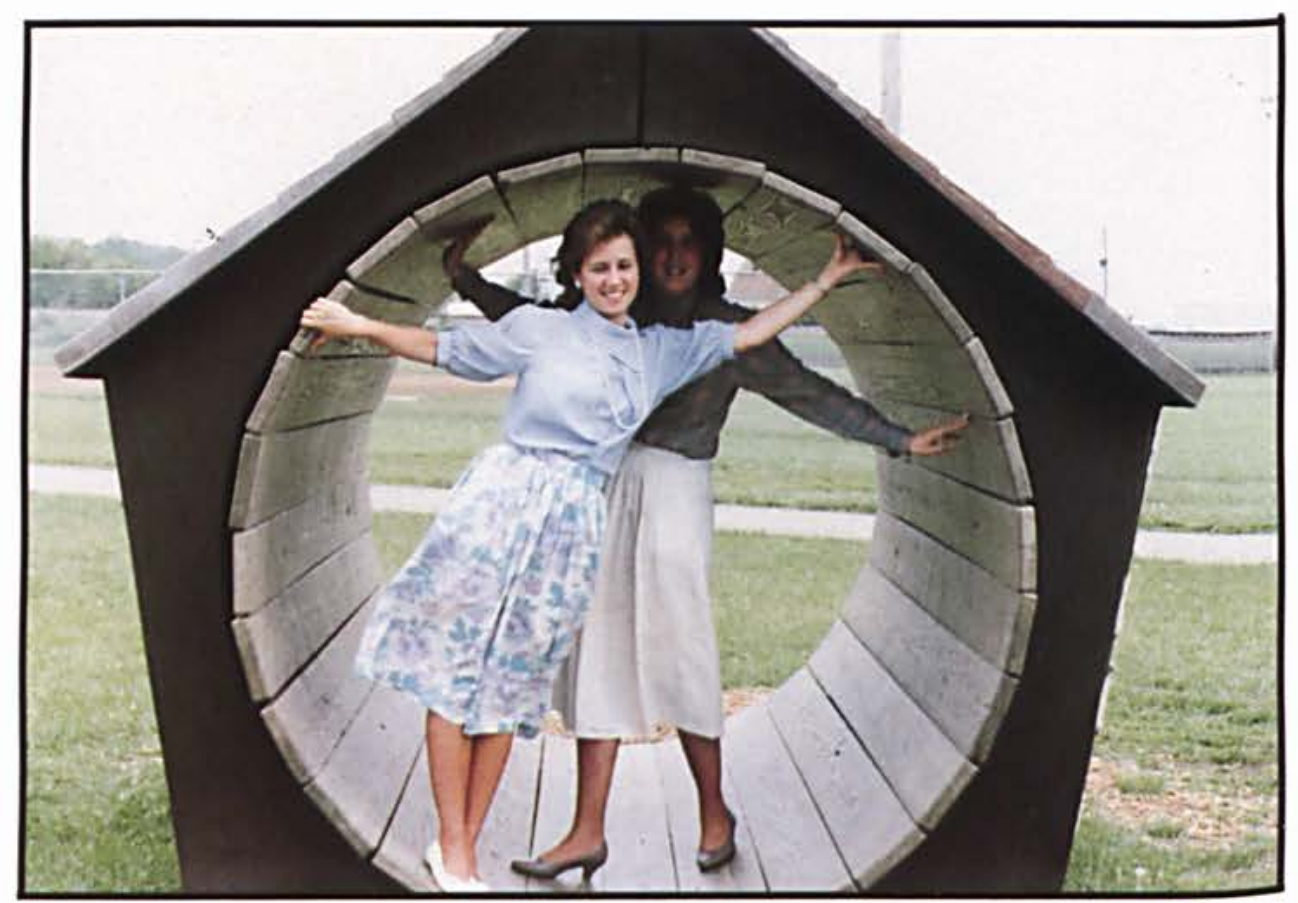




\section{WHO'S WHO 1986}

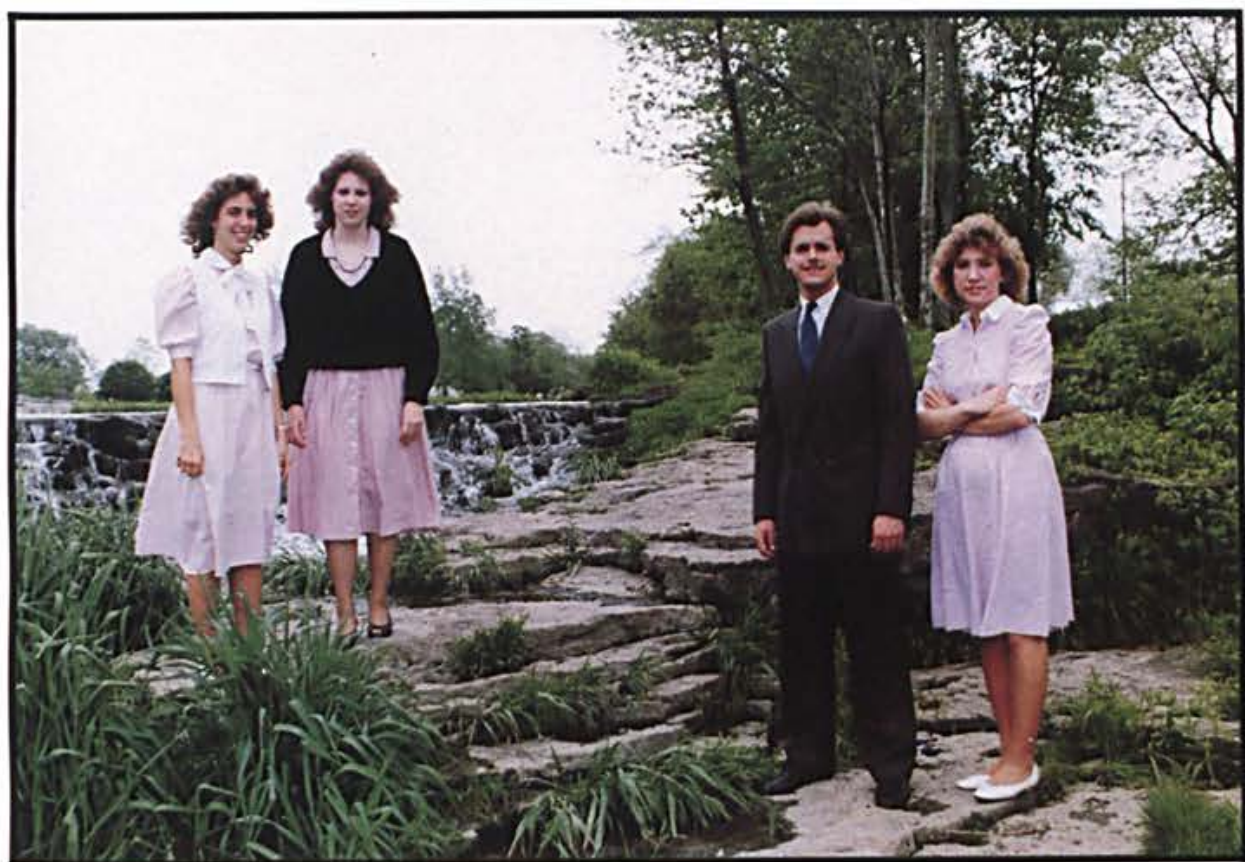

\section{Who's Who Among Students in American Colleges and Universities}

$T_{\text {he selection process for }}$ Who's Who is based upon academic, social and spiritual qualities. Each academic department selects three candidates and the Student Affairs Committee selects several students who they feel meet the criteria for Who's Who. Each candidate must be a junior or senior with a minimum grade point average of 3.0, manifest spiritual qualities and participate in campus organizations. All selections are subject to final approval by the Administrative Council.
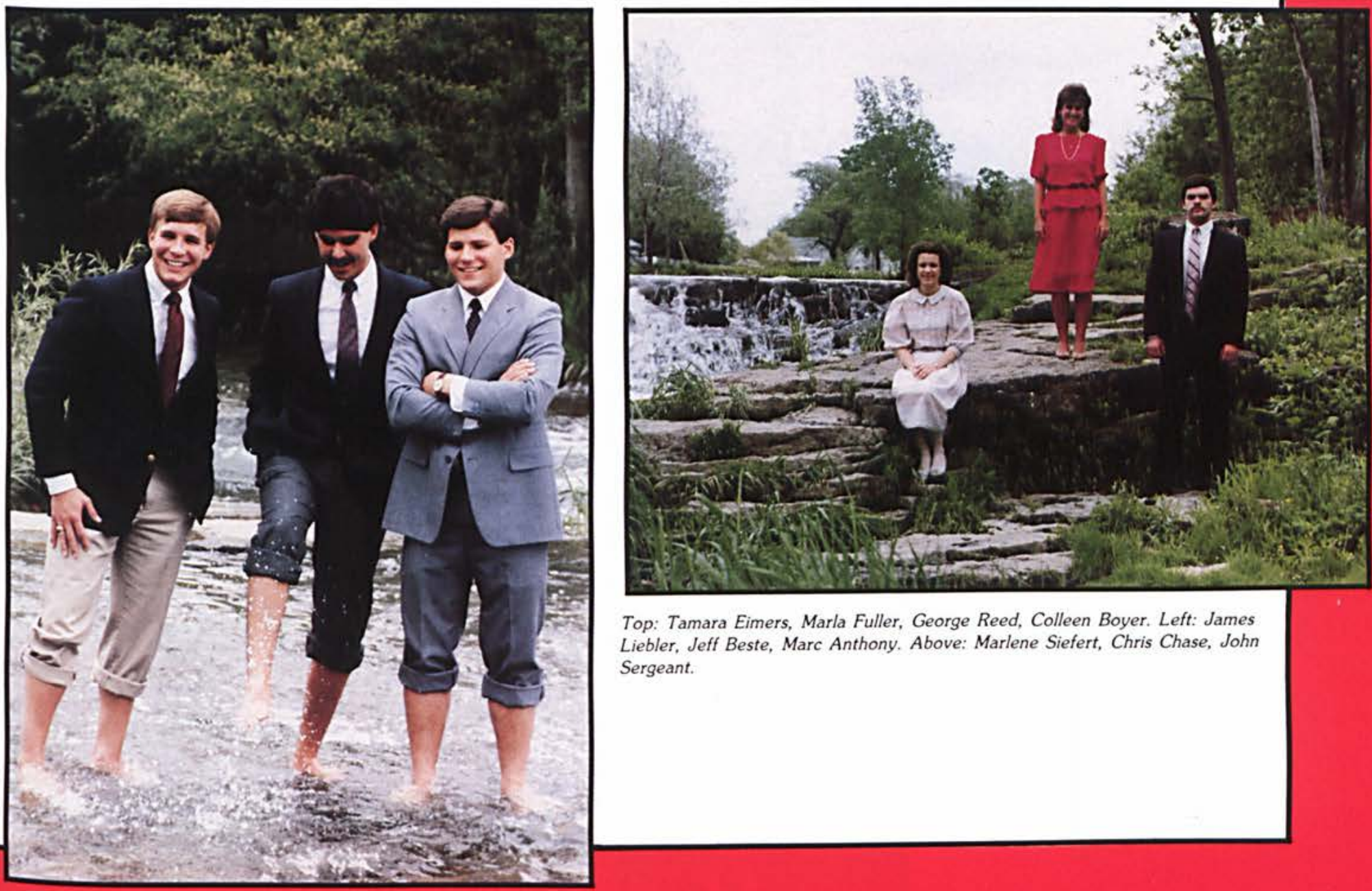

Top: Tamara Eimers, Marla Fuller, George Reed, Colleen Boyer. Left: James Liebler, Jeff Beste, Marc Anthony. Above: Marlene Siefert, Chris Chase, John Sergeant. 


\section{Presenting the Nursing Class of '86}

The Nurses' Convocation was held on June 6 for the 1986 Nursing graduates. During the ceremony which was attended by over 300 parents and friends, each graduate was given a Certificate of Character and the

Department of Nursing pin. The pin is the same for all graduates of all classes. Each graduate's character traits were derived from descriptions of them written by their classmates.

The graduates presented a skit and a slide/tape program reflecting dimensions and highlights of their experience as nursing students. The

Chair of the Department of Nursing, Dr. Irene Alyn, received the class

gifts of money for the Learning Lab and a certificate indicating the establishment of a Nursing Alumni Scholarship and then spoke on the topic "Performance and Production."

The following awards were given: Academic Achievement: Nancy R. LaBonte and Colleen R. Boyer Excellence in Nursing Practice: Nancy R. LaBonte Outstanding Character: Karen Y. Headdings

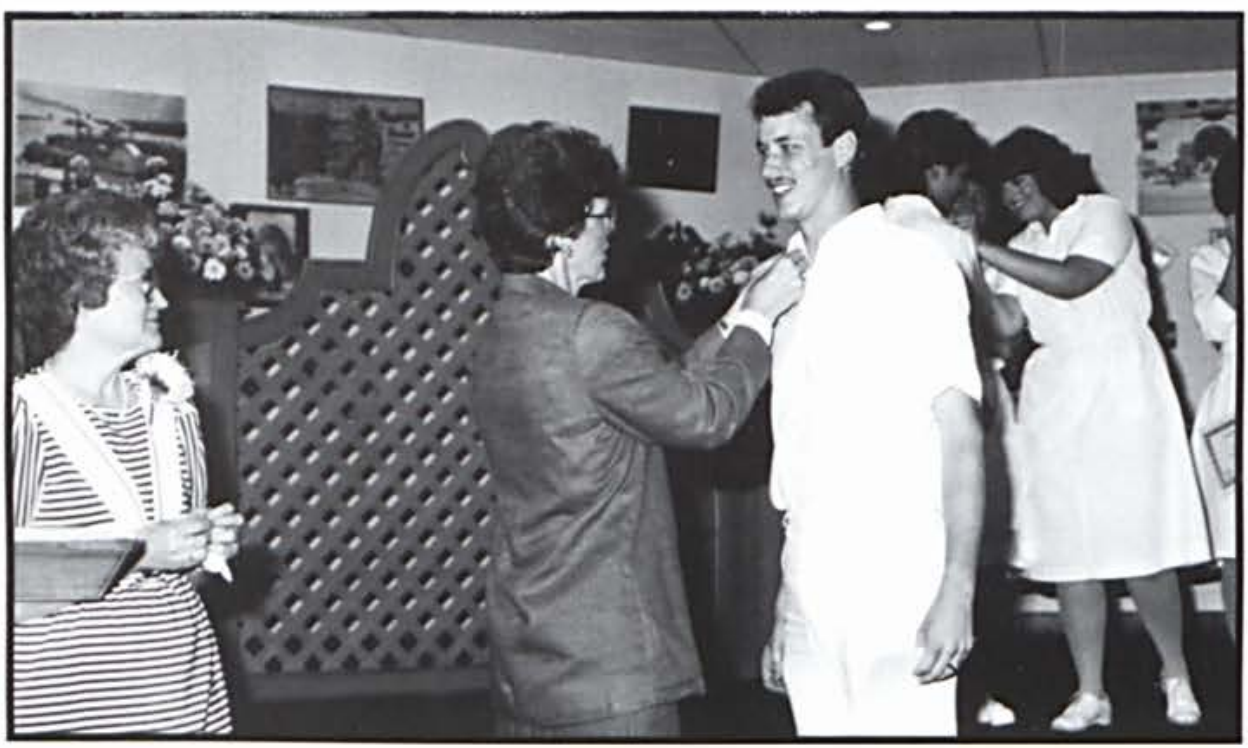

Irene Alyn
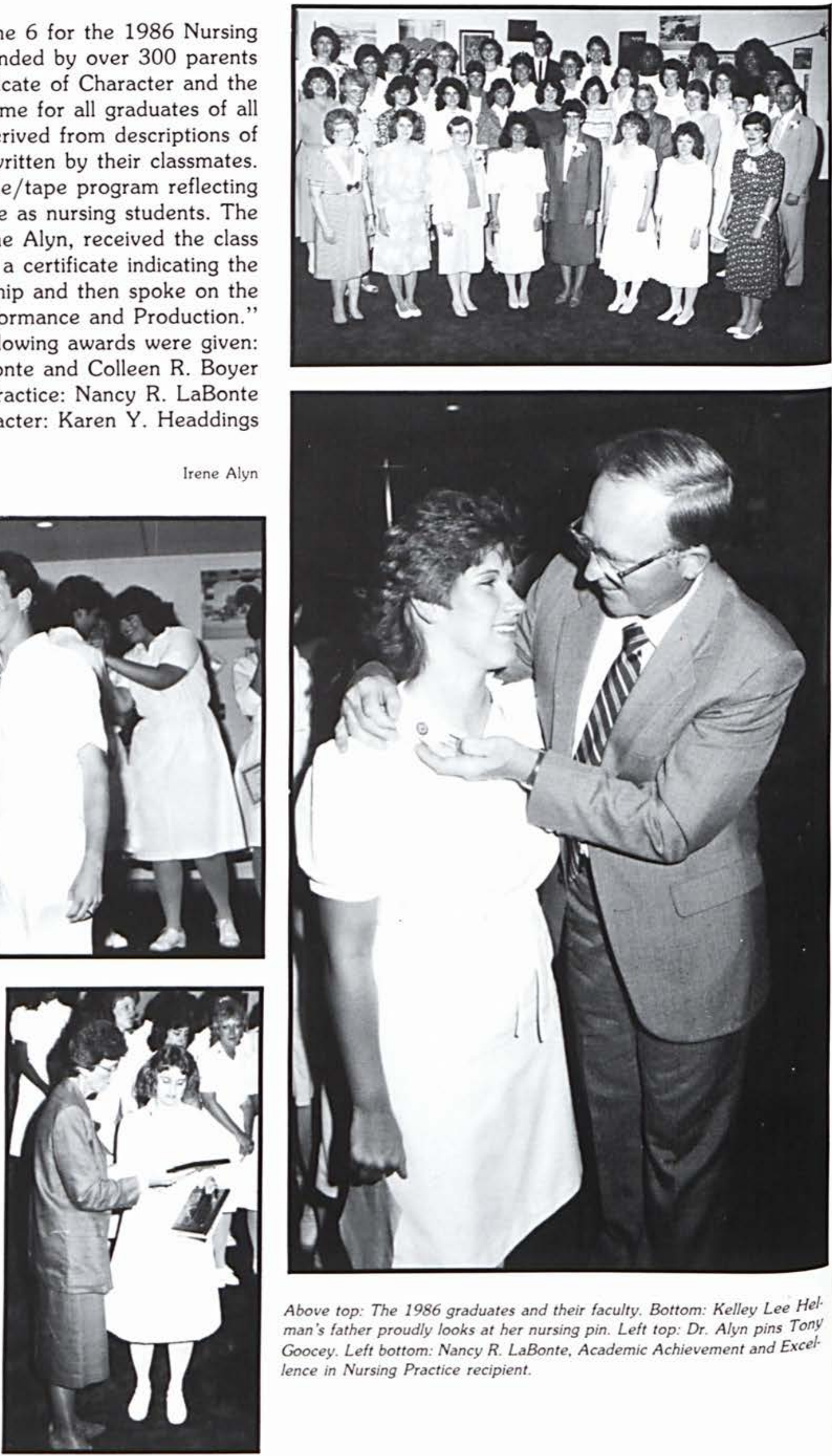

Above top: The 1986 graduates and their faculty. Bottom: Kelley Lee Hel. man's father proudly looks at her nursing pin. Left top: Dr. Alyn pins Tony Goocey. Left bottom: Nancy R. LaBonte, Academic Achievement and Excellence in Nursing Practice recipient. 


\section{Senior Night}
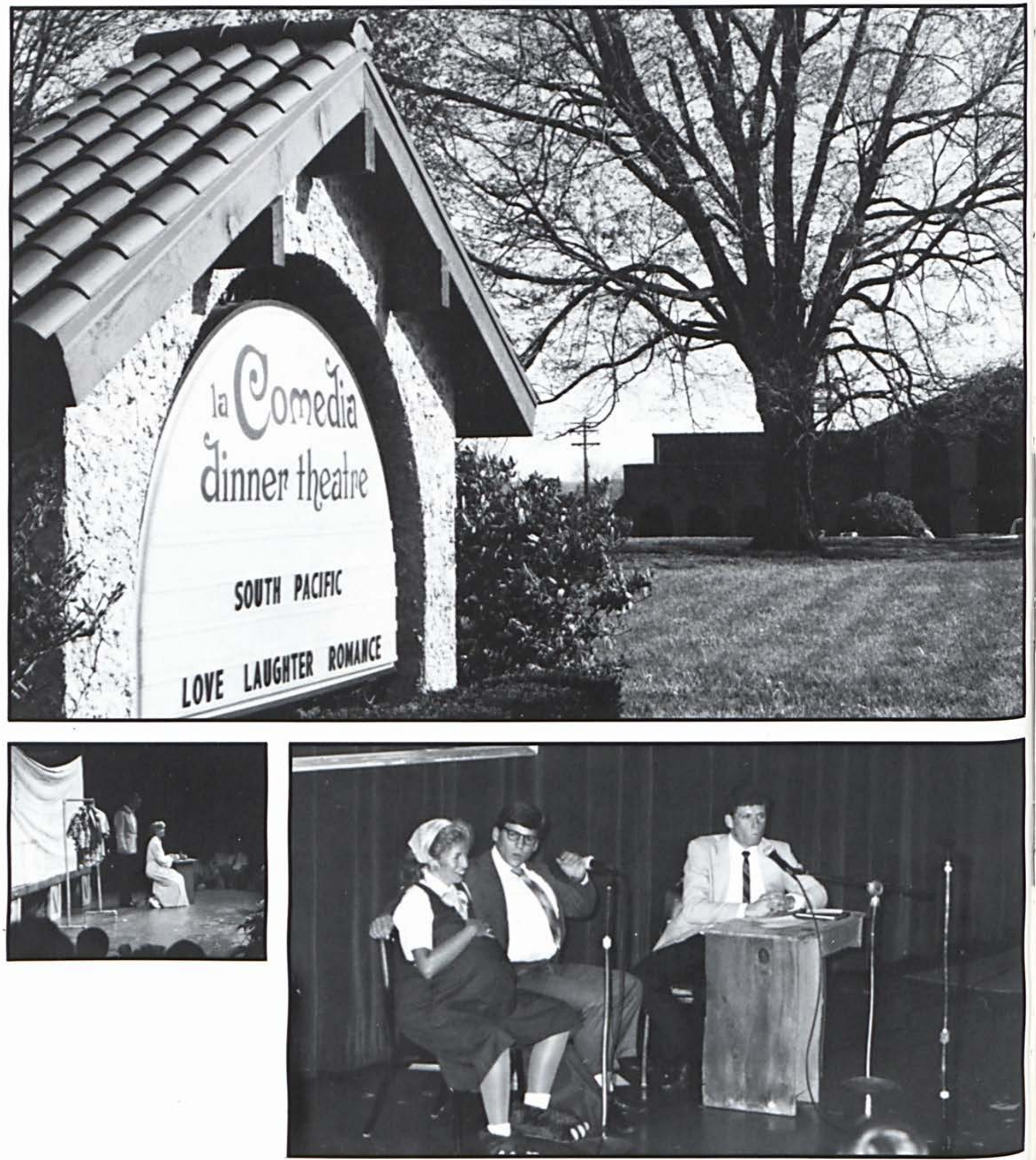

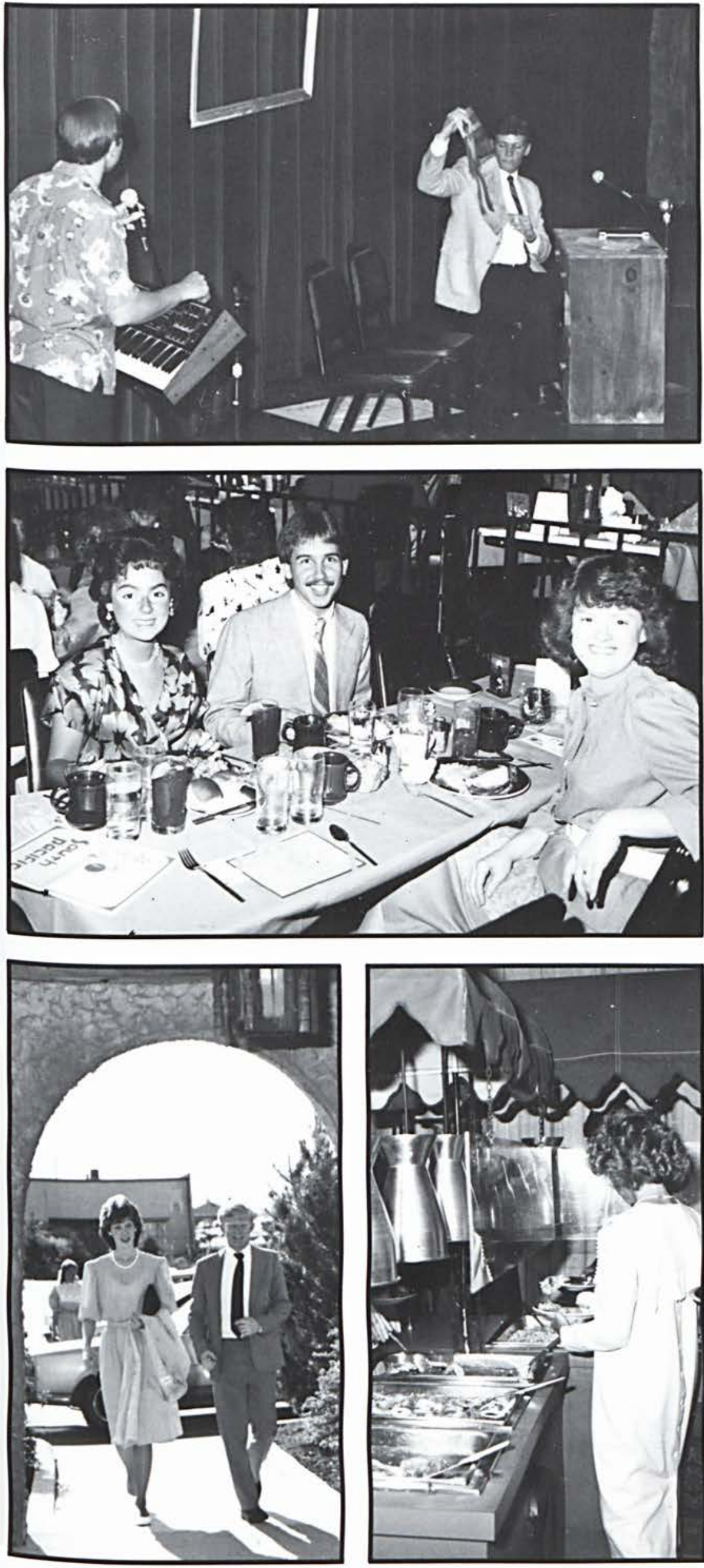

\section{A Dining Pleasure}

$\mathbf{W}$ media Dinner Theater to see South Pacific, we were looking forward to an excellent drama production. Little did we know, however, what drama our own classmates had in store for us. It consisted merely (always a dangerous understatement) of a Mark "Letterman" Horne talk show, featuring the twenty year reunion of the class of 1986.

Among those "alumni" interviewed were Mark and Laura Anthony, now expecting their ninth child and Jerry Robbins celebrating his 25th year as a vending manager of Cedarvile College. Jim Liebler then pro. vided us with a commercial break featuring the newest kids' fling for the year 2006 - toast on a stick.

It was indeed an evening to remember!

Suzanne Her

Opposite page: Top: La Comedia welcomed the seniors and their guests. Far left: A poignant scene from the play. Near left: The Anthonys returned after 20 years. Top left: More of the 'Letterman' show. Middle left: Fay Schonfeld, Faux John Ritter, and Michelle Fouch enjoyed the fellowship. Bottom left: the lucious buffet provided many choices of food. 

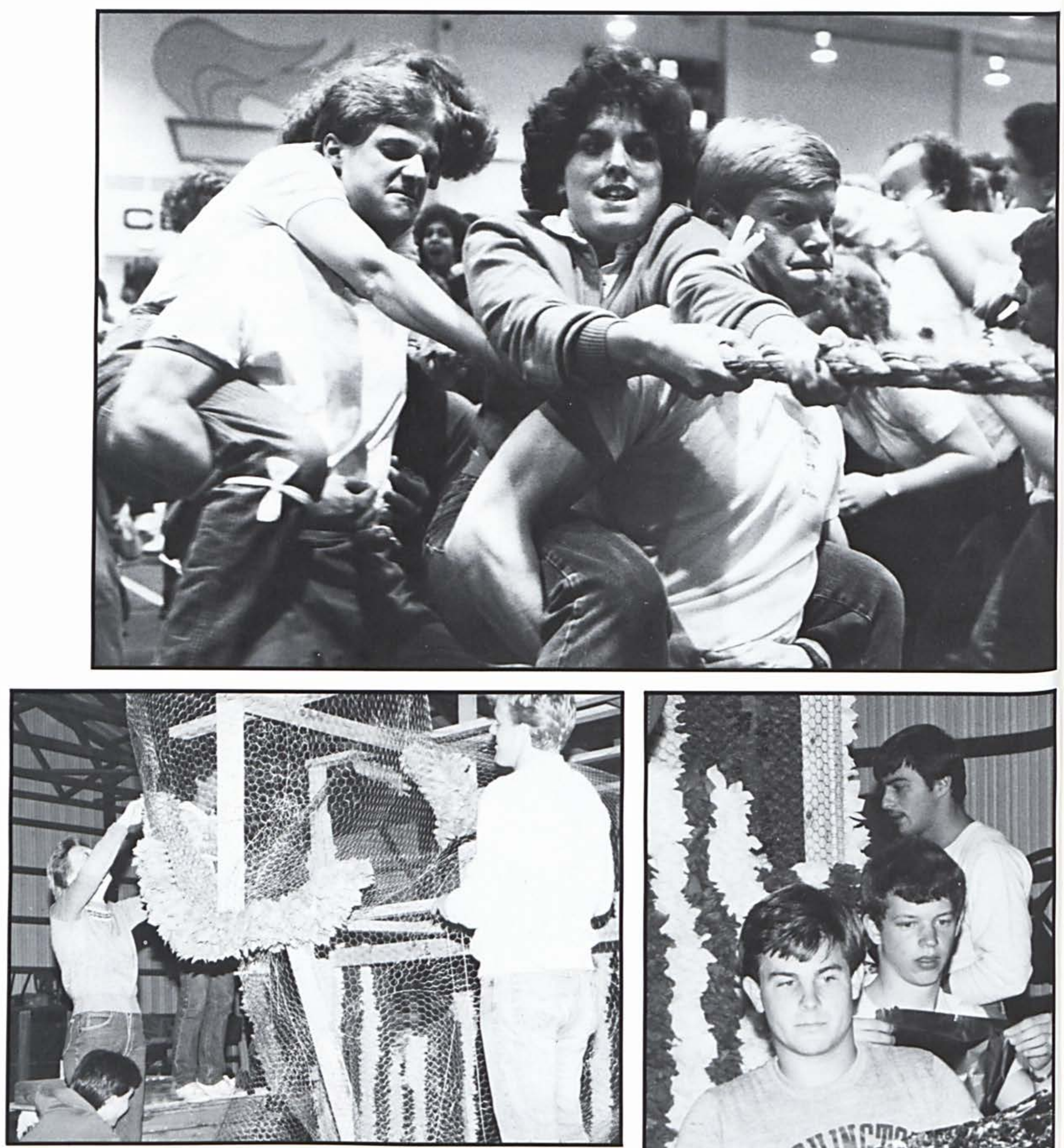

Top left and right page: Sweat, Grunts and Groans accompany the Juniors and Sophomores as they battle it out in an intense game of tug of war! Above Left: The Sophomores work on their prize-winning float of an elephant. Above Right: Tim Royer oversees work on his class' homecoming float entitled "The Circus of the Future." Opposite Right: Another unusual game between classes at Cedarville College.

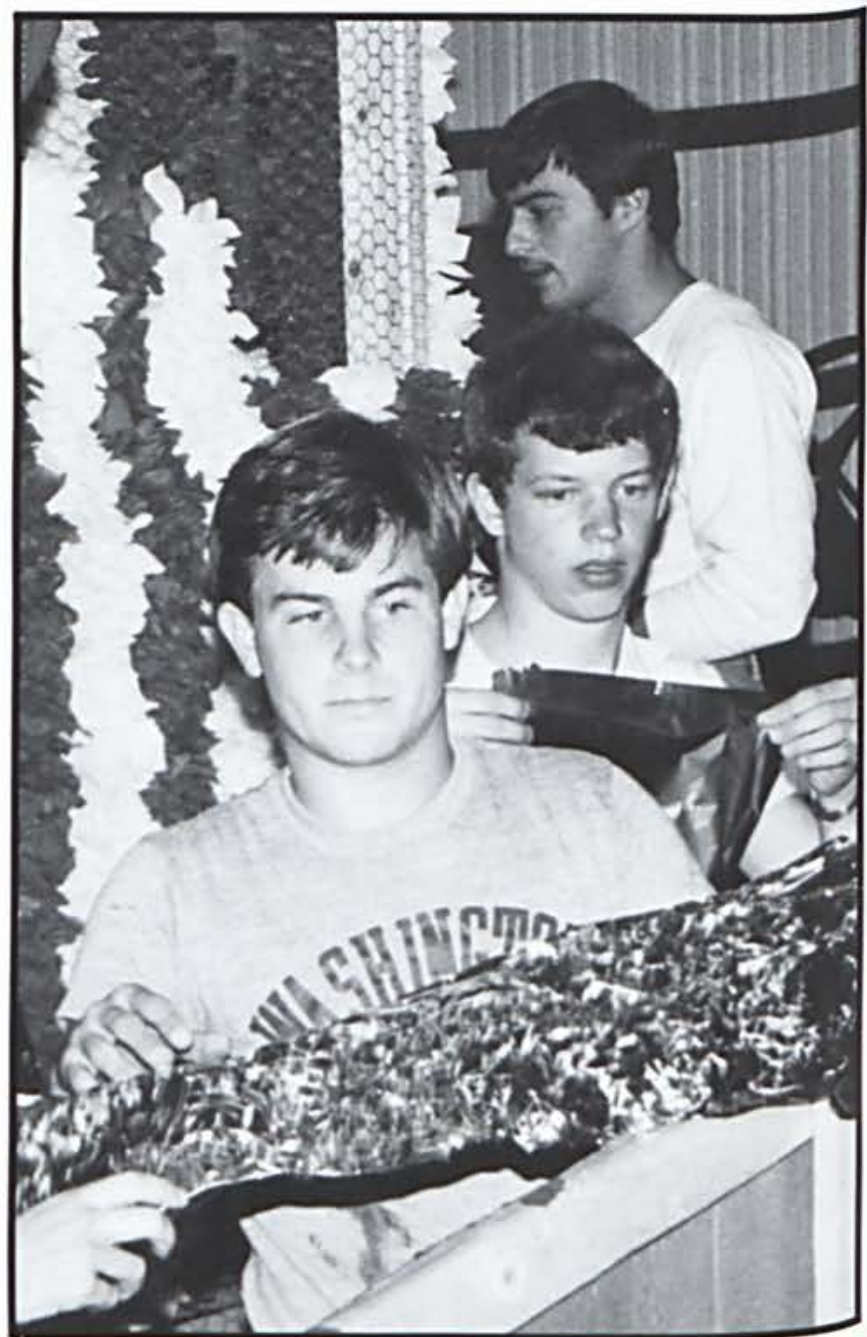




\section{That Competitive Spirit}
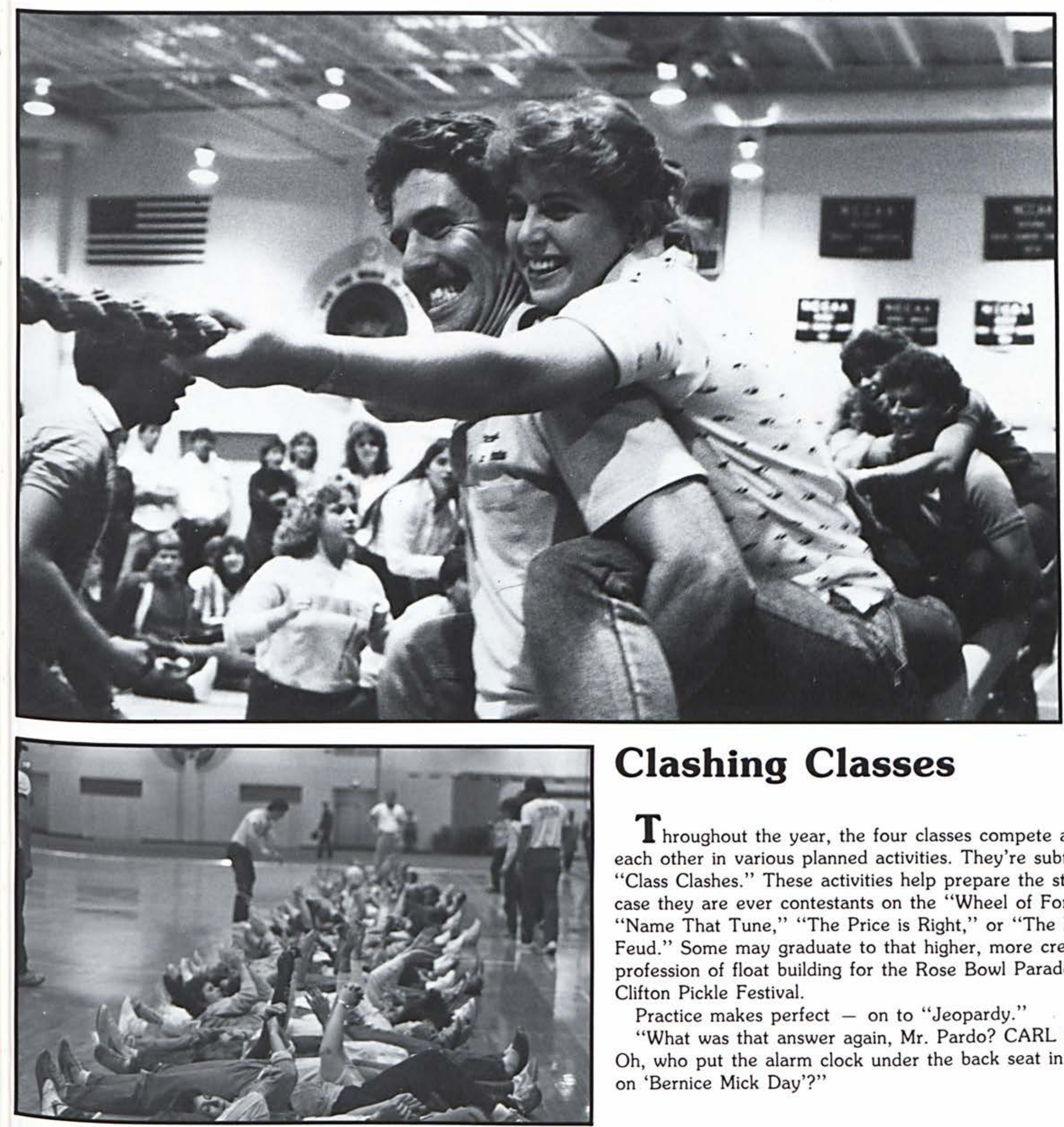

\section{Clashing Classes}

$\mathbf{T}_{\text {hroughout the year, the four classes compete against }}$ each other in various planned activities. They're subtly called "Class Clashes." These activities help prepare the students in case they are ever contestants on the "Wheel of Fortune," "Name That Tune," "The Price is Right," or "The Family Feud." Some may graduate to that higher, more creative profession of float building for the Rose Bowl Parade or the Clifton Pickle Festival.

Practice makes perfect - on to "Jeopardy."

"What was that answer again, Mr. Pardo? CARL RUBY!! Oh, who put the alarm clock under the back seat in chapel on "Bernice Mick Day'?" 


\section{Students In}
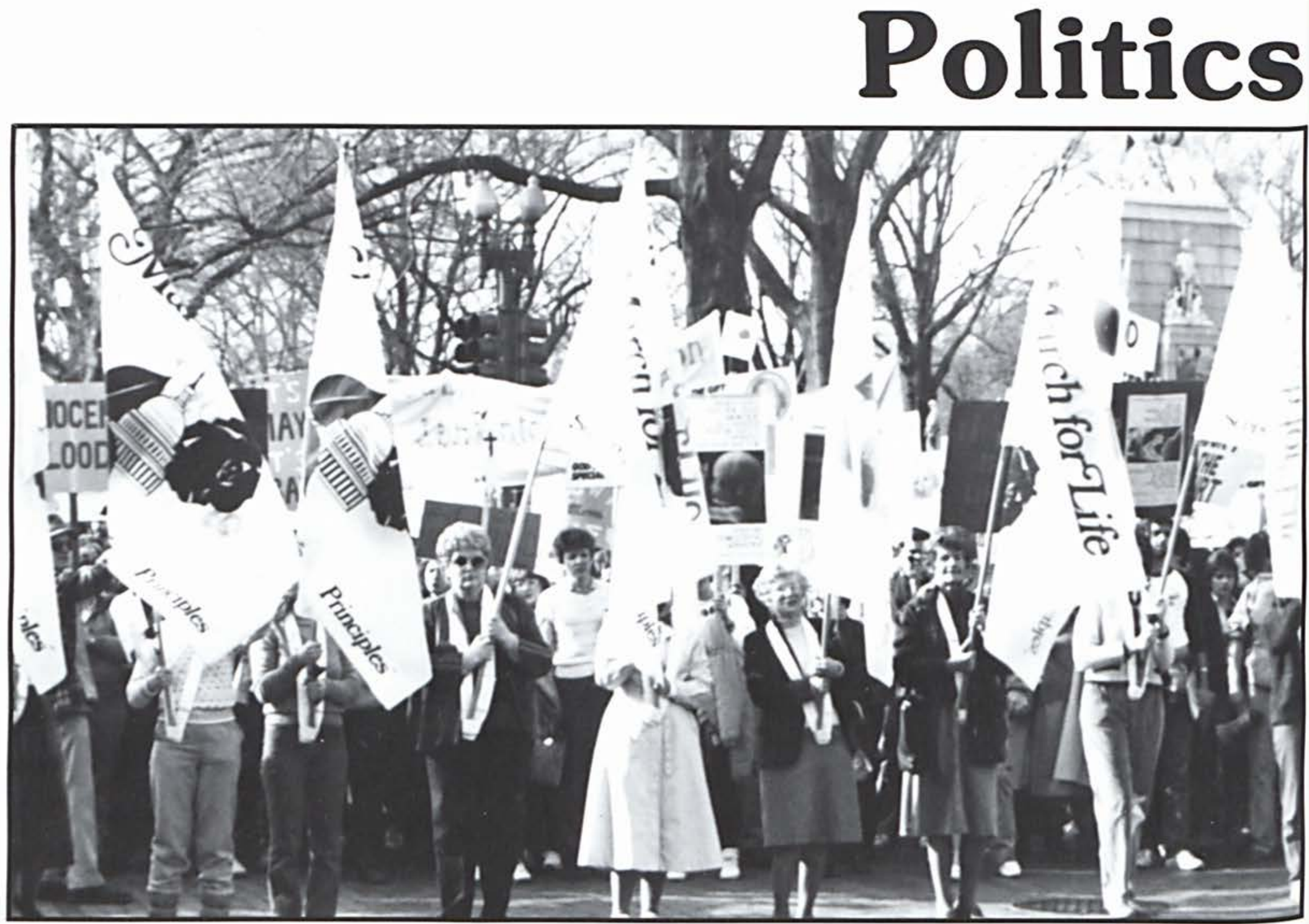

\section{C} involved in the political process. This year the Cedarville College Republicans have been involved in encouraging prayer for our nation's leaders, sponsoring speakers, campaigning, lobbying, and attending statewide political events.

Many CC students attended the annual March for Life rally in

Washington D.C. As Christians, we must seize opportunities to involve ourselves: we must continue to be the salt and the light of the world.

Dave Edwards

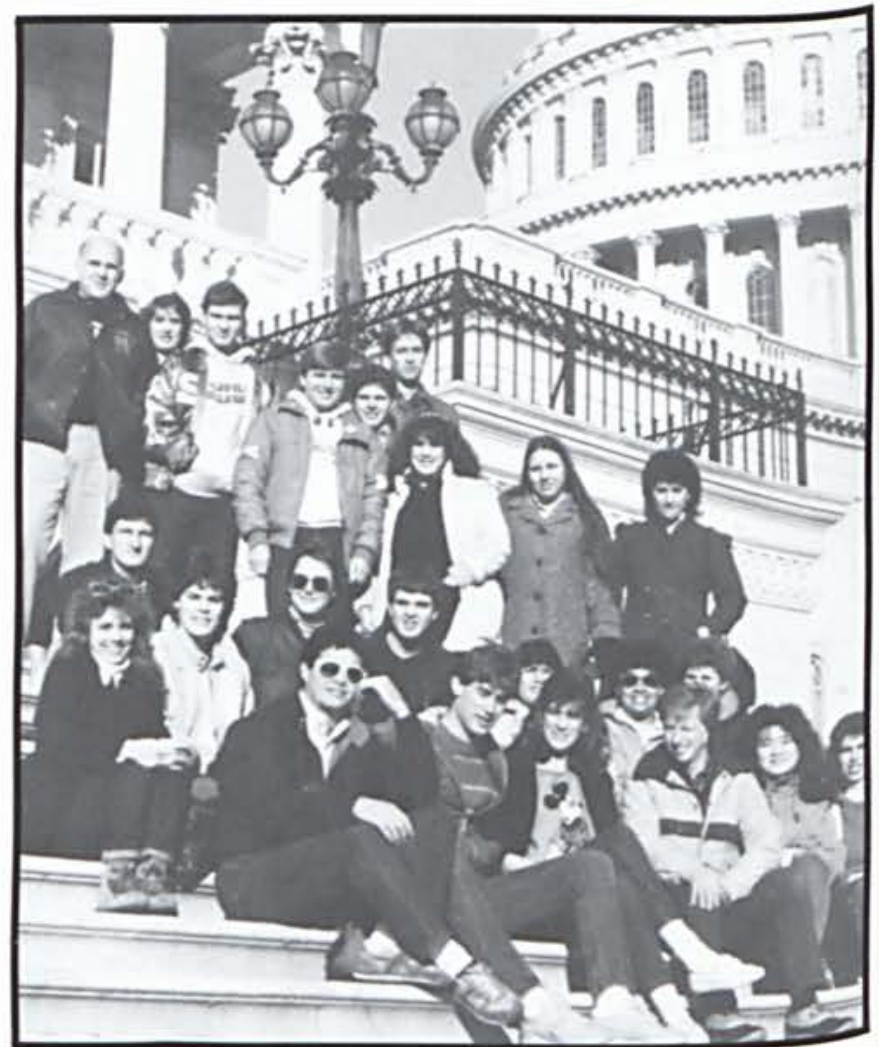



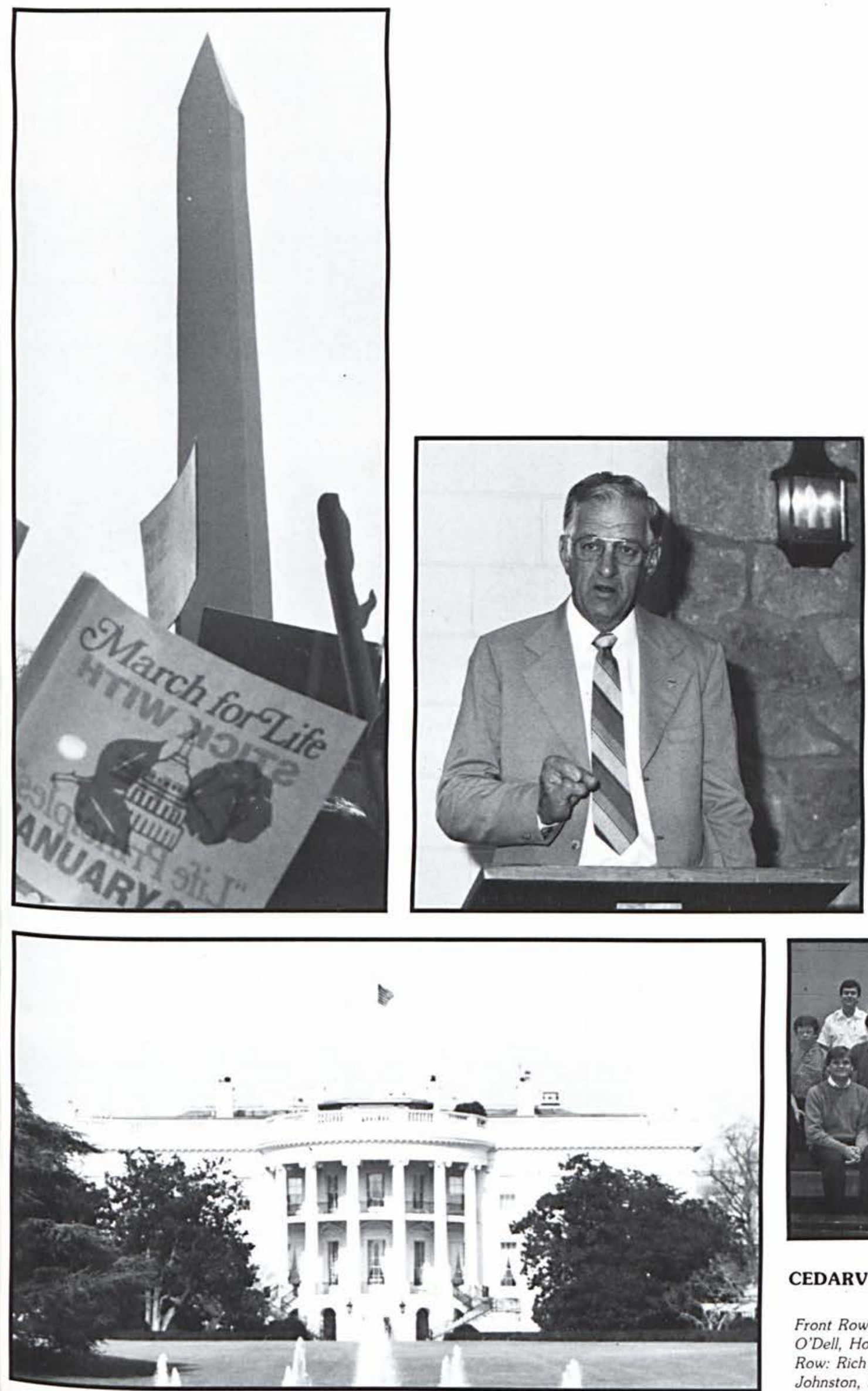

Opposite page top: The flags for March for Life held during winter quarter. The march was supported by Cedarville College as several students attended. Opposite page, bottom: A group of Cedarville College visited the nation's capitol and posed for a picture on the steps of the Capitol Building. Washington Monument stands tall behind persuasive flags from the March for Life. Top right: Senator Haines was the speaker for a political prayer breakfast held at the end of a prayer week in which students were encouraged to pray for their government leaders. Bottom left: Cedarville College students also visited the beautiful White House.

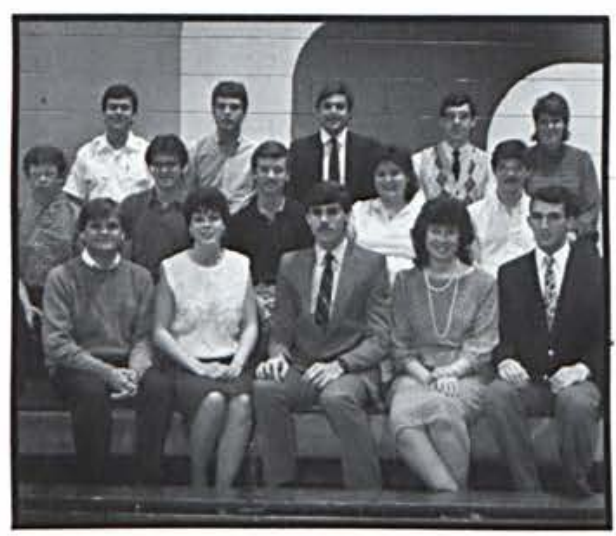

CEDARUILLE COLLEGE REPUBLICANS

Front Row: Scott Zimpfer, Kim Killian, Greg O'Dell, Holly Marshall, Tim Koerber. Second Row: Rich Kester, Matt Biggs, Mark Moses, Amy Johnston, Kurt Anderson. Third Row: James Jacobs, Dave Edwards, Bill Marshall, Bruce McNabb, Heather Healey. 


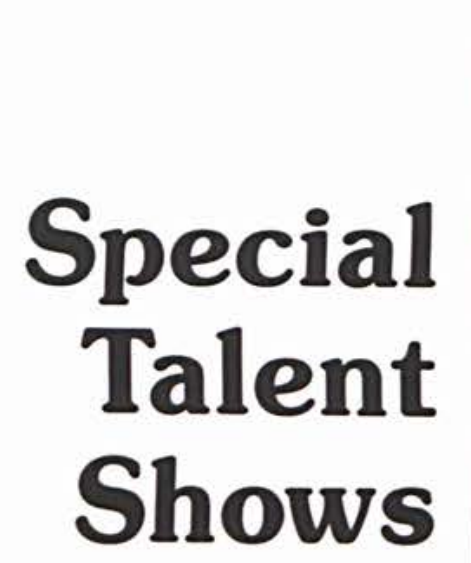

Each year two student talent shows occur: New Student Talent Night and Alpha Chi Talent Show. The lively balance of humorous and serious performances made each show a rewarding display of

C.C. students' creative gifts.
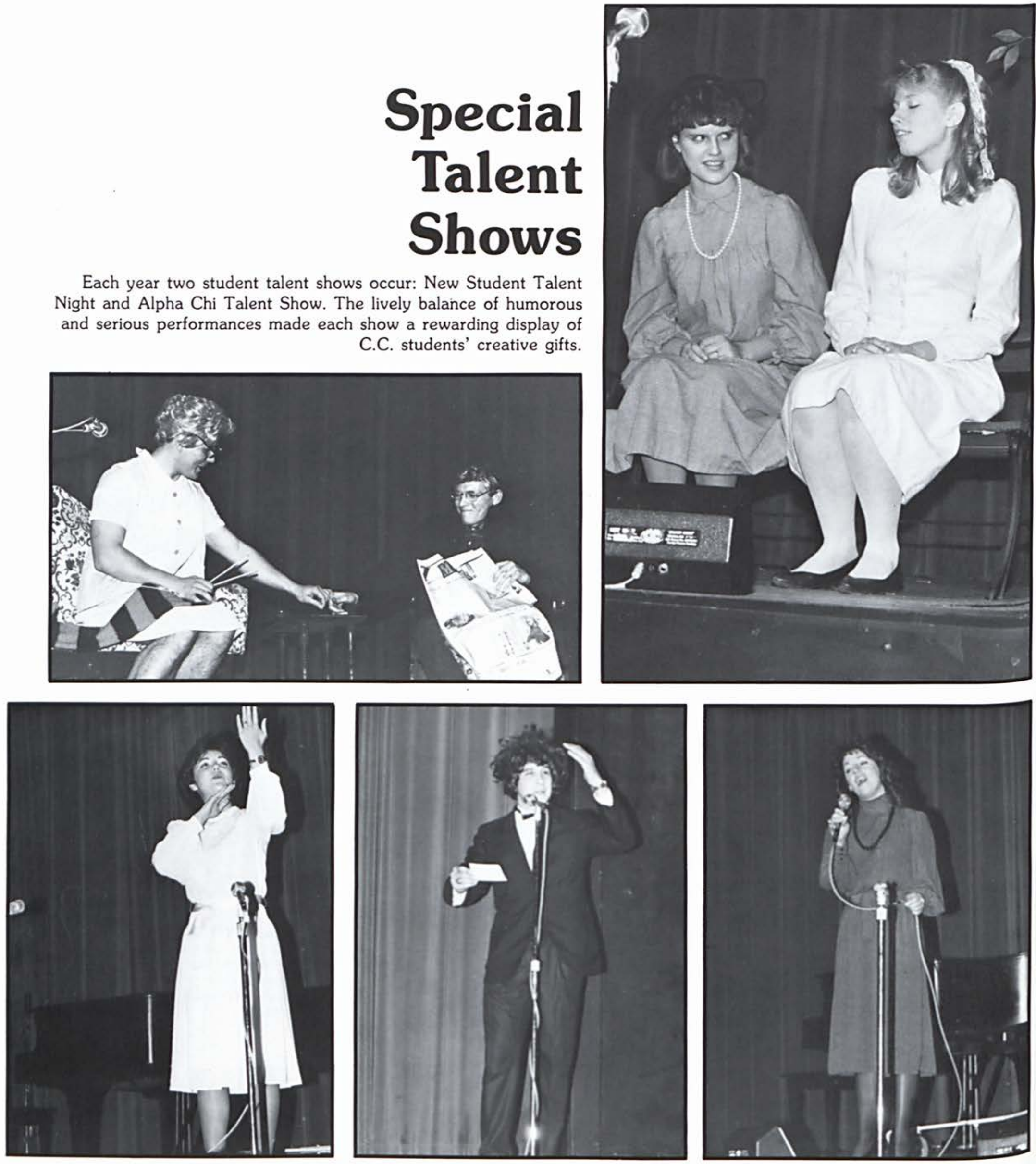

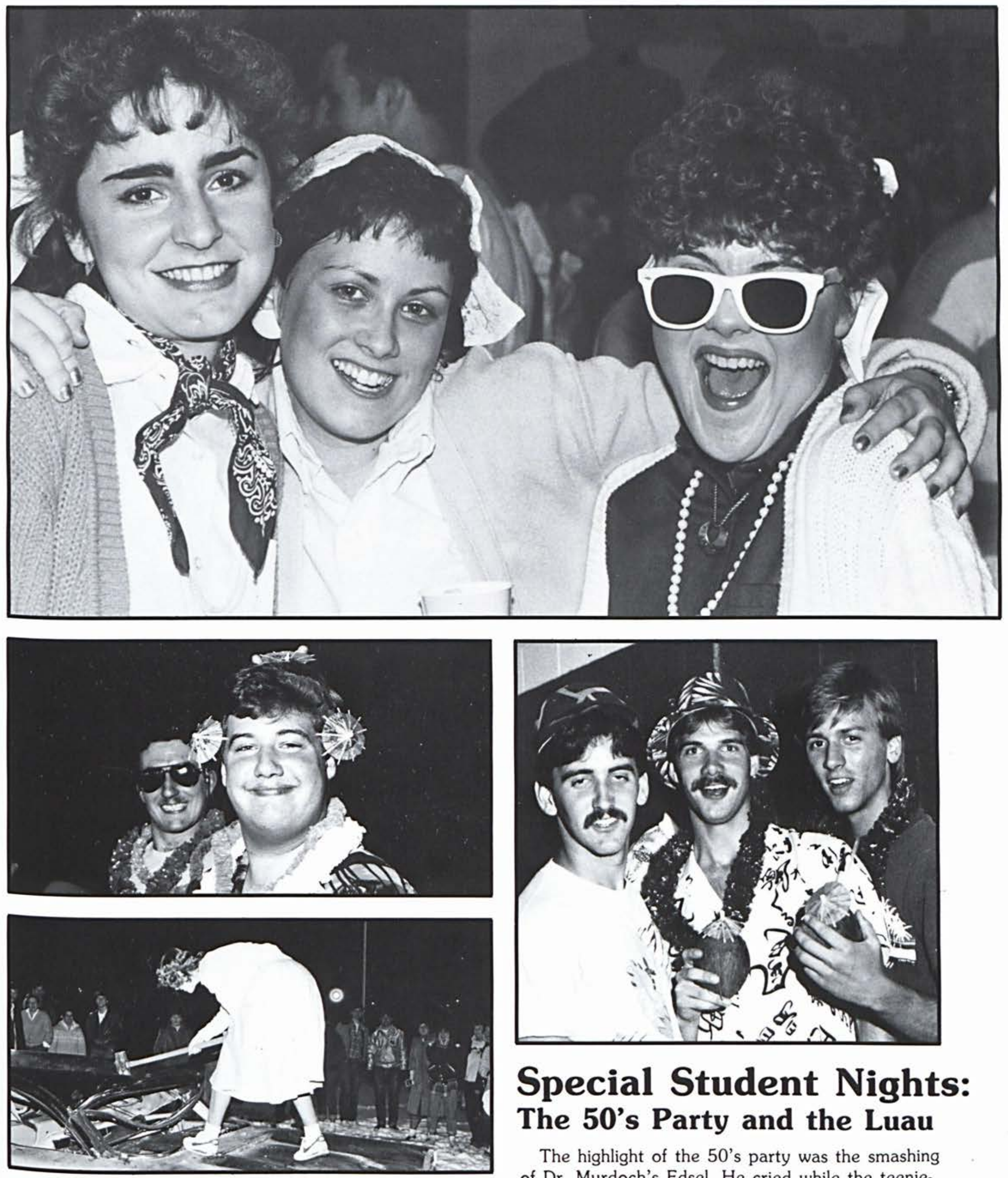

\section{Special Student Nights: The 50's Party and the Luau}

The highlight of the 50's party was the smashing of Dr. Murdoch's Edsel. He cried while the teenieboppers smiled, drank their cherry coke, and donned their hula hoops.

Chuck McKinney's crew truly captured the Hawaiian spirit with a beautifully decorated dining room filled with palm trees, leis, coconuts, and hula girls. Students came in jams, Hawaiian shirts, and bare feet to eat the delicacies. Maloha, Pioneer. 


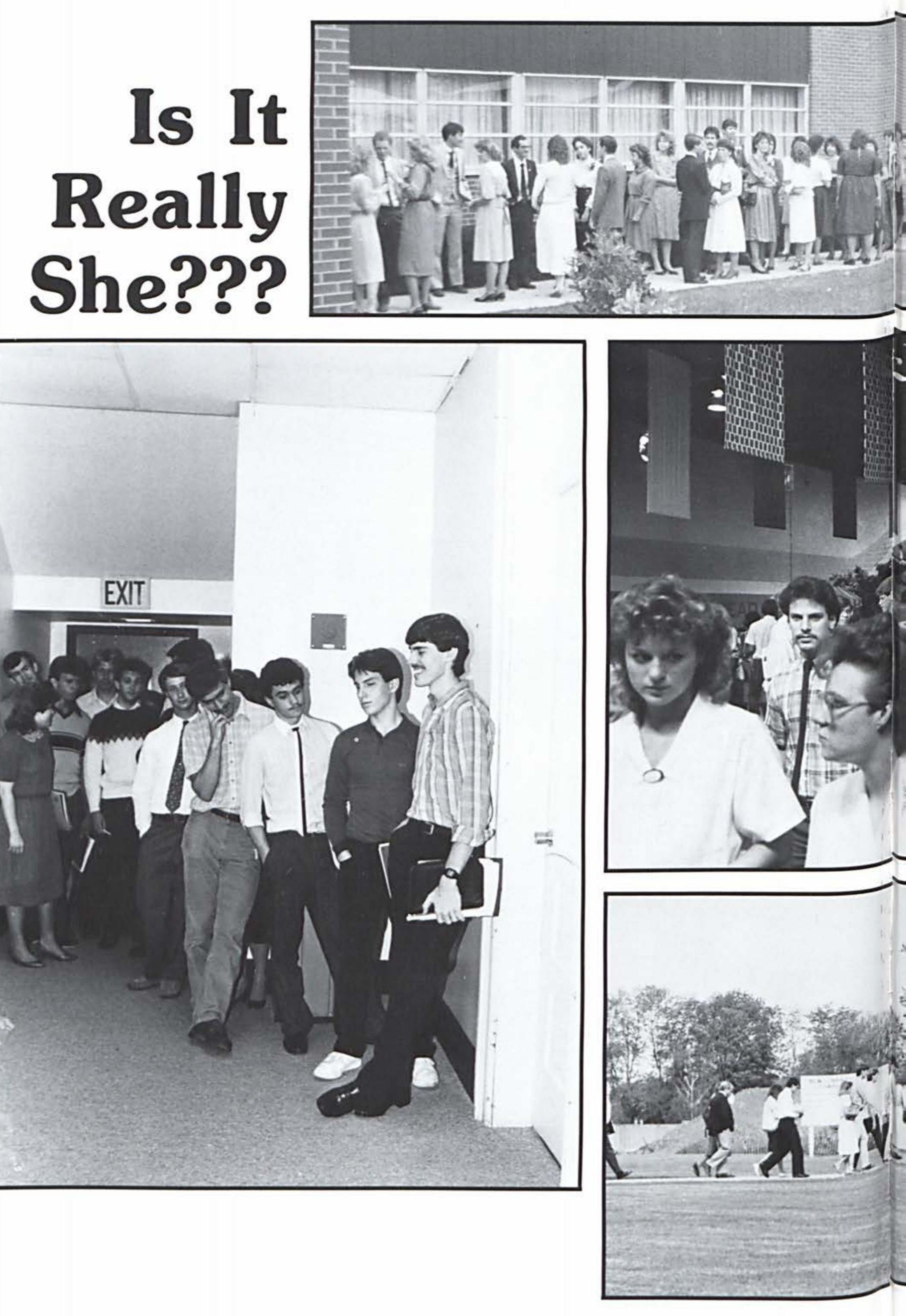




\section{Dating in the 'Ville circa '86}

1. Will he perceive me to be a fluzzie for wearing "Come-hither Mauve"? Or should I stay with a simple "Root Beer" gloss?

2. I always say the choice of a man's tie sets him apart from the average wimp.

3. May I offer you a rose? (Maybe I should have bought the silk one instead of the plastic).

4. Isn't there a certain romantic sound to the word weltanschauung?

5. Well, I did say I'd pick you up on a Honda, not in a Honda. 6. May I hold your hands as we pray?

7. This can't be for real. I'm an erudite, sophisticated woman of the ' 80 's dating a moped-maniac twit!!! 8. A little lower, please! (Oh, I hope he misses that zit!)
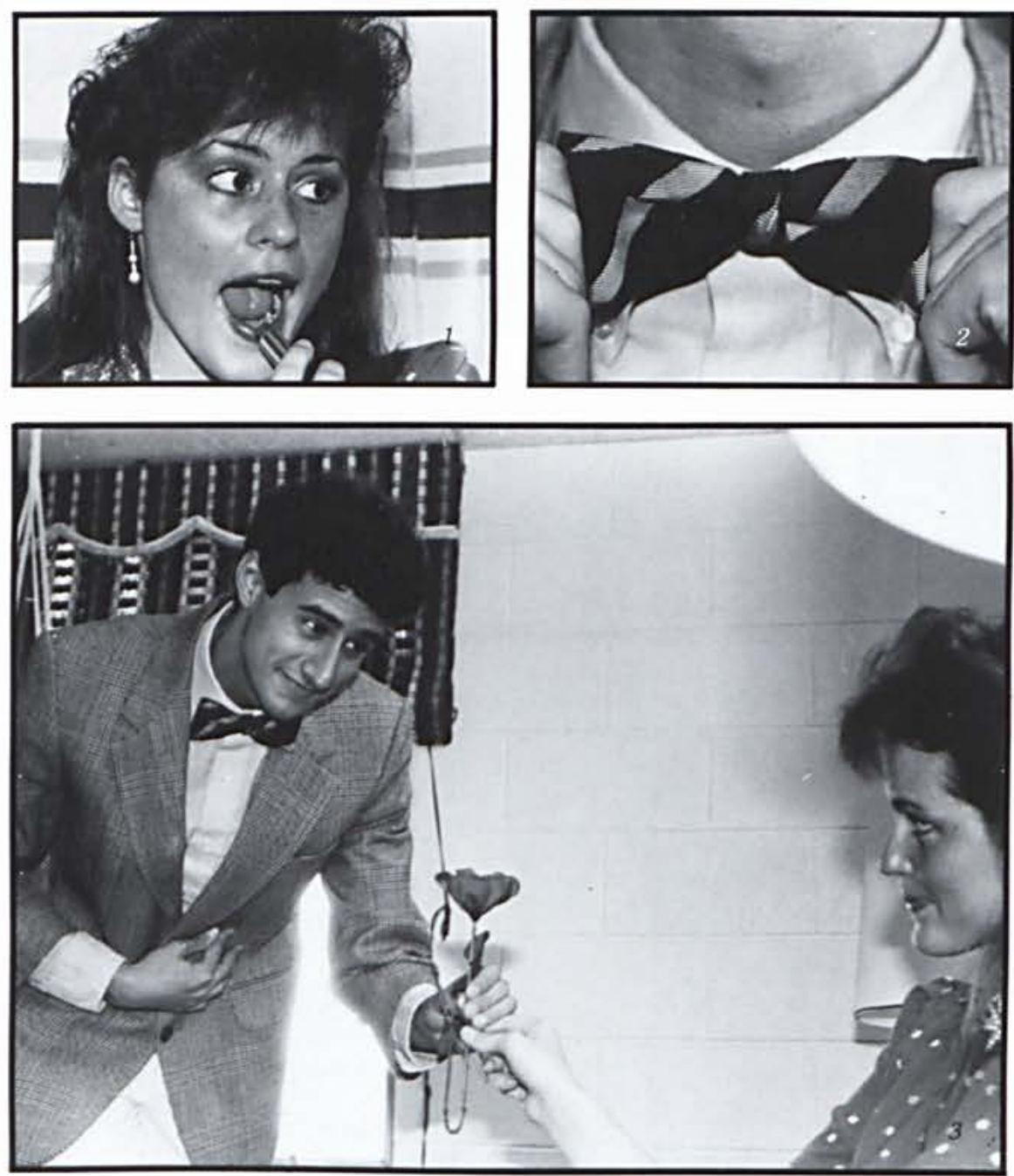

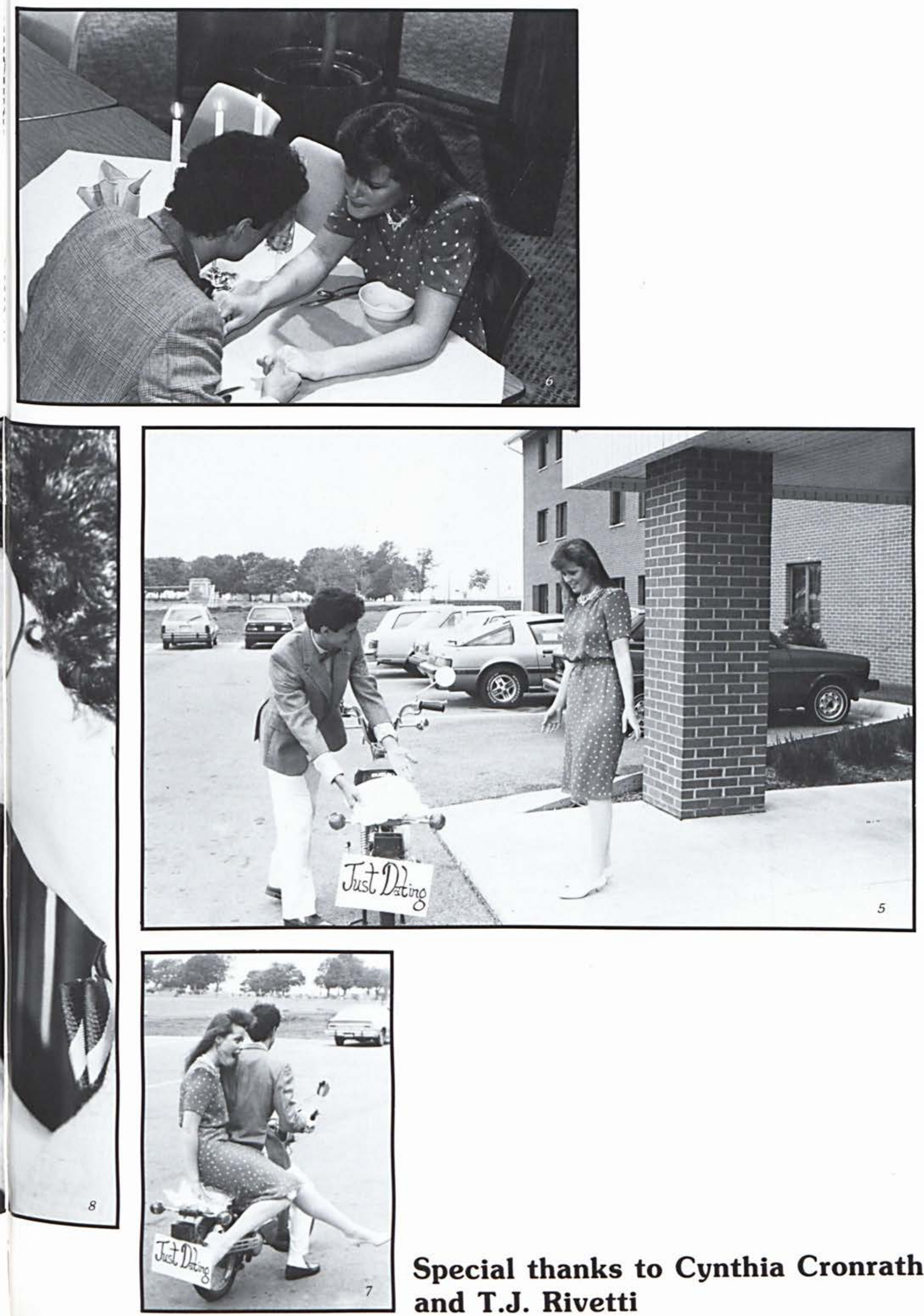

Special thanks to Cynthia Cronrath and T.J. Rivetti 


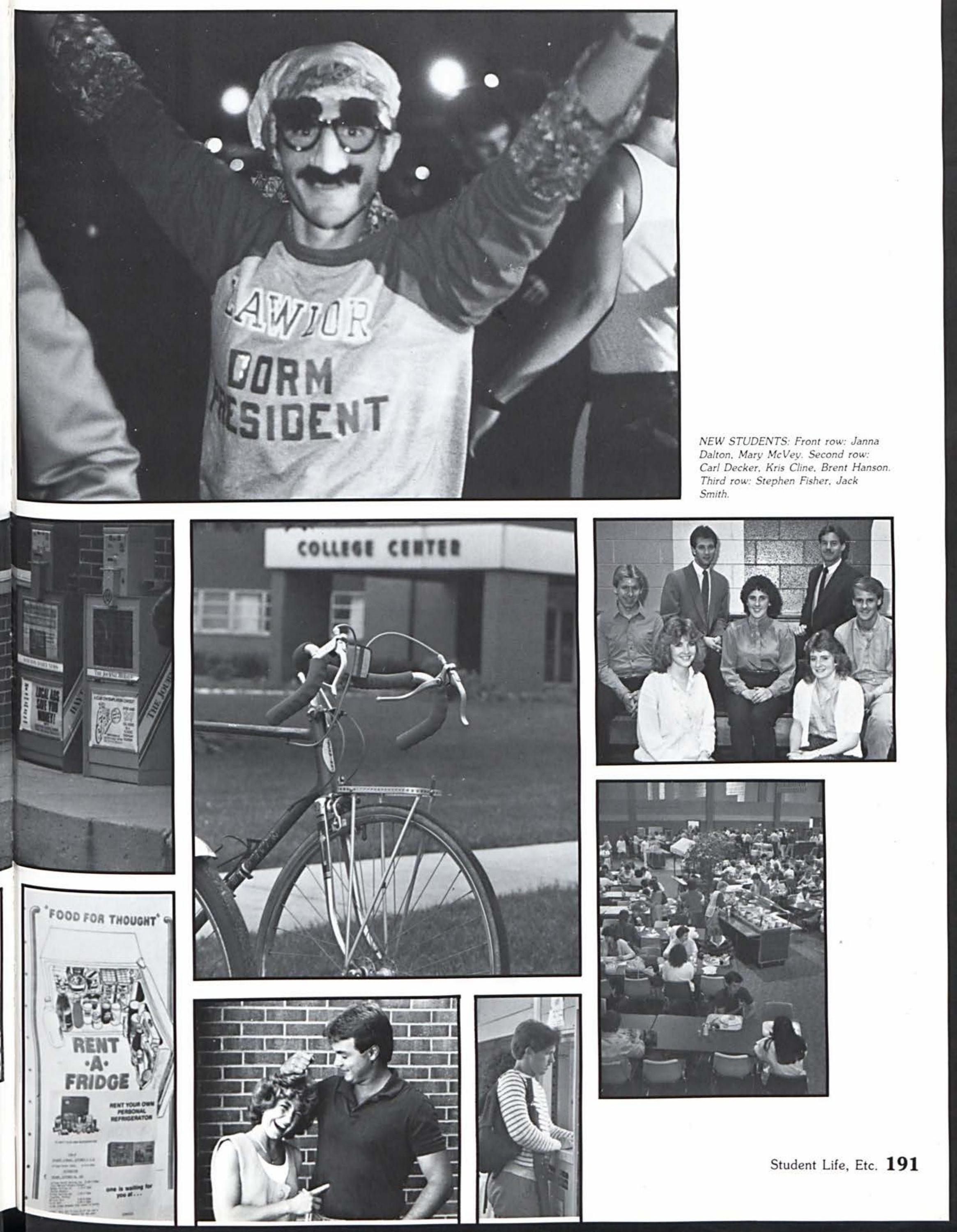



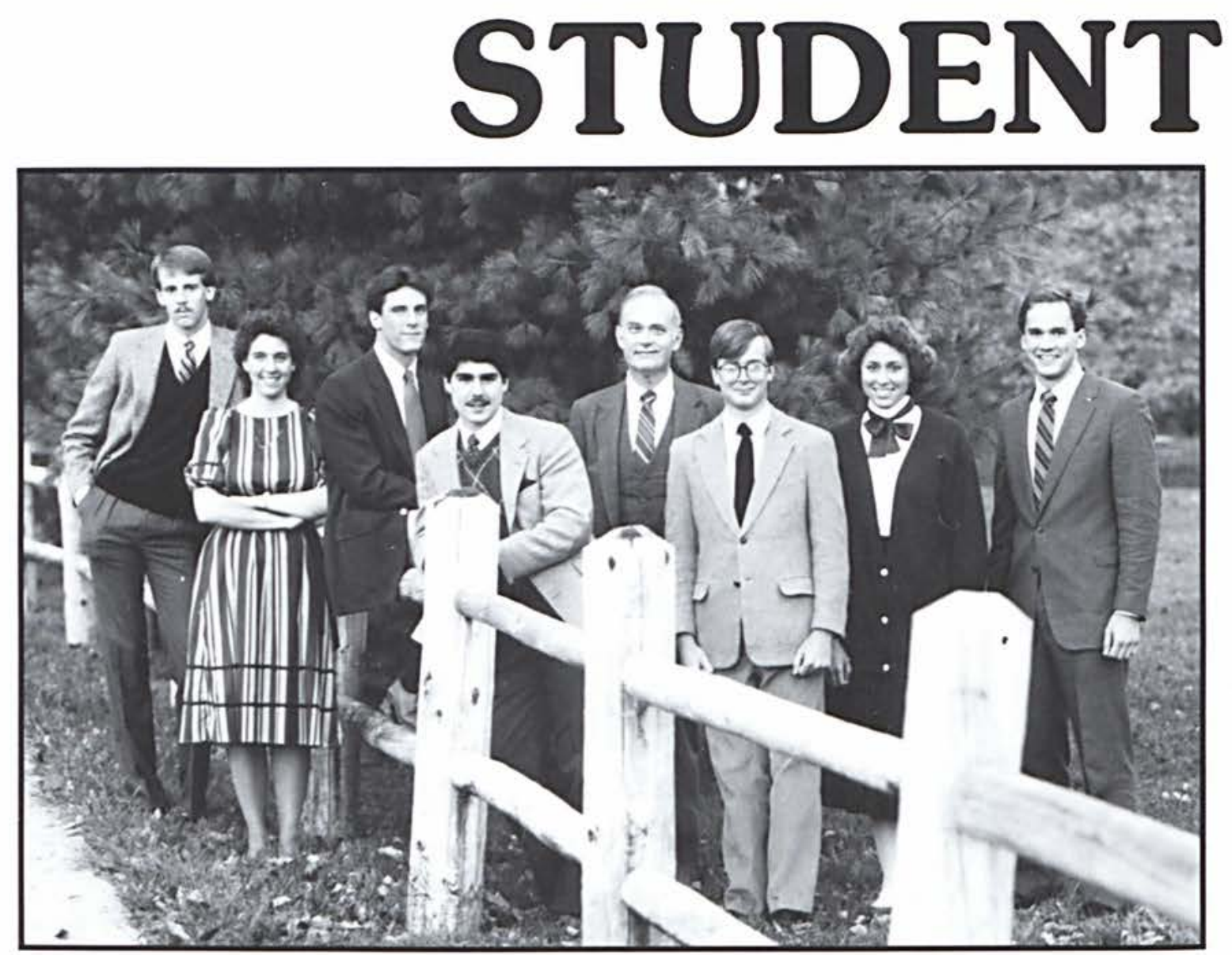

SENIOR CLASS OFFICERS: Rob Loy, Melissa Beach, Tom Pratt, Jeff Beste, Dr. Charles Ellington, Advisor; Gary Nonnemacher, Karen Beattie, Jim Reiter.

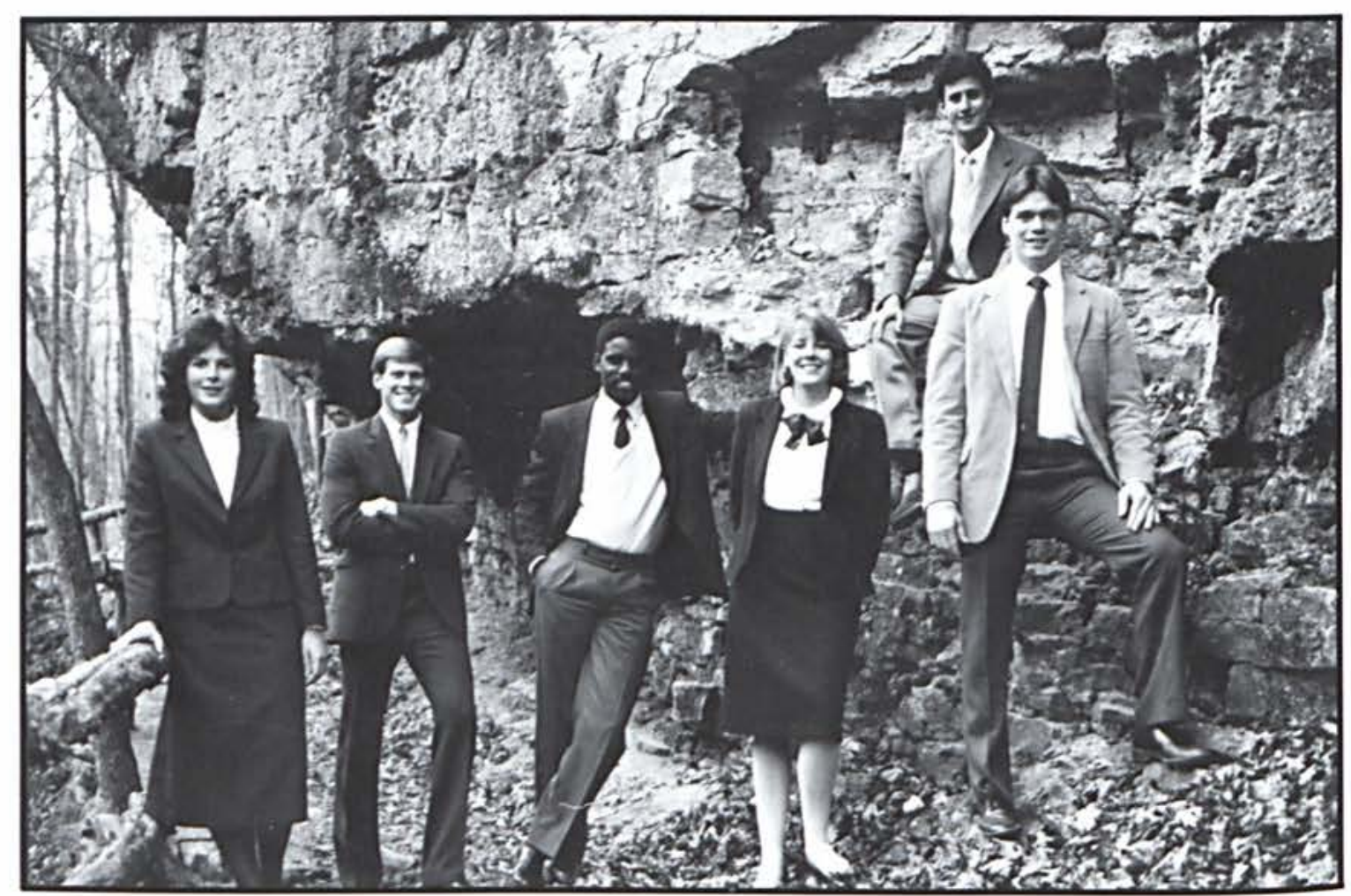

JUNIOR CLASS OFFICERS: Linda Lons, Eric Shrum, Kurtis Summerville, Rhonda Perkins, Timothy Rivetti, Clancy Cruise, (Not pictured: Mr. DiCuirci, Advisor). 


\section{GOVERNMENT}

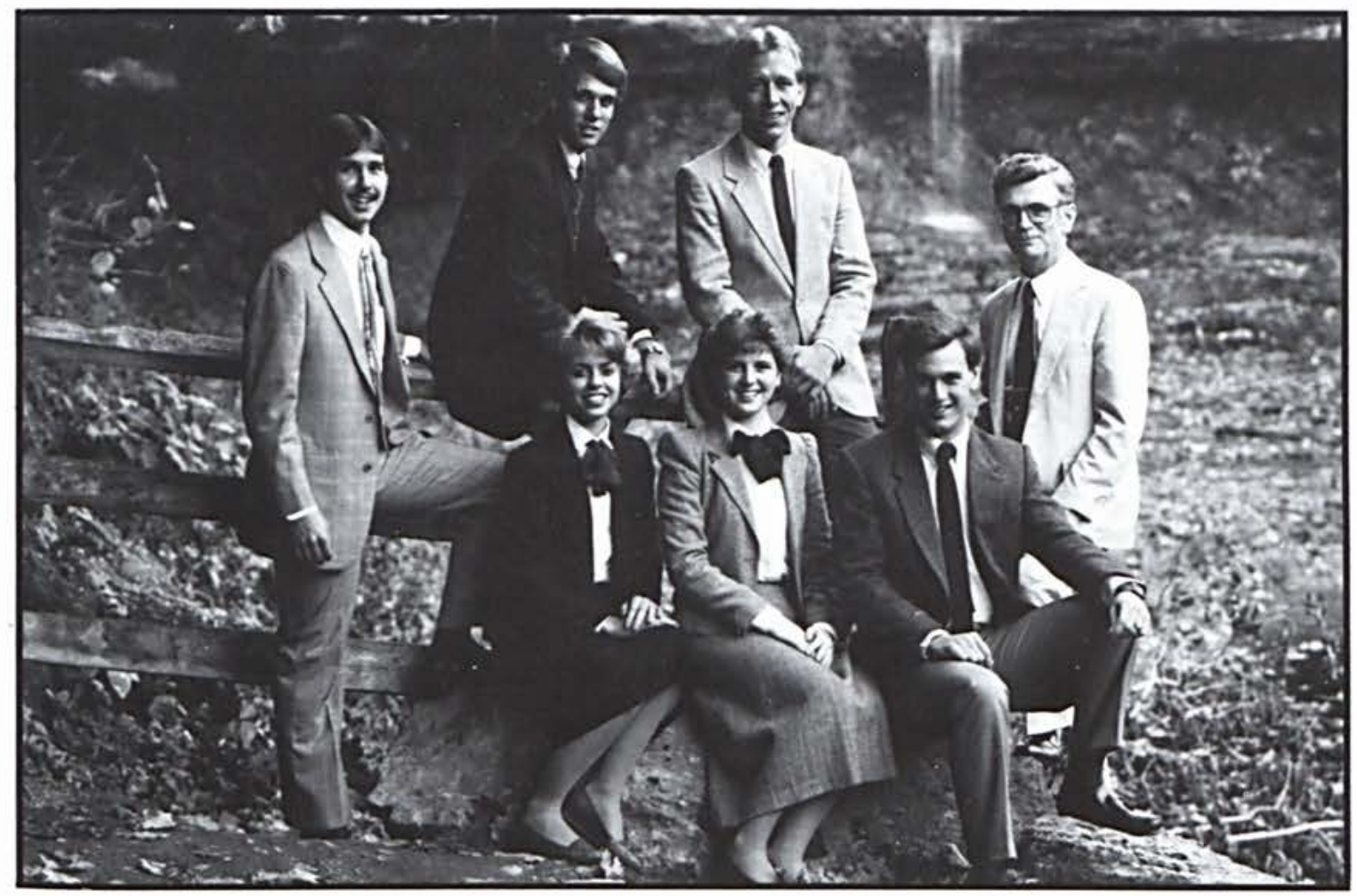

SOPHOMORE CLASS OFFICERS: Jeff Bergandine, Douglas Baldwin, Christopher Moore, Harmon Bergen, Advisor. Seated: Kendra King, Becky Carter, David Mossman.

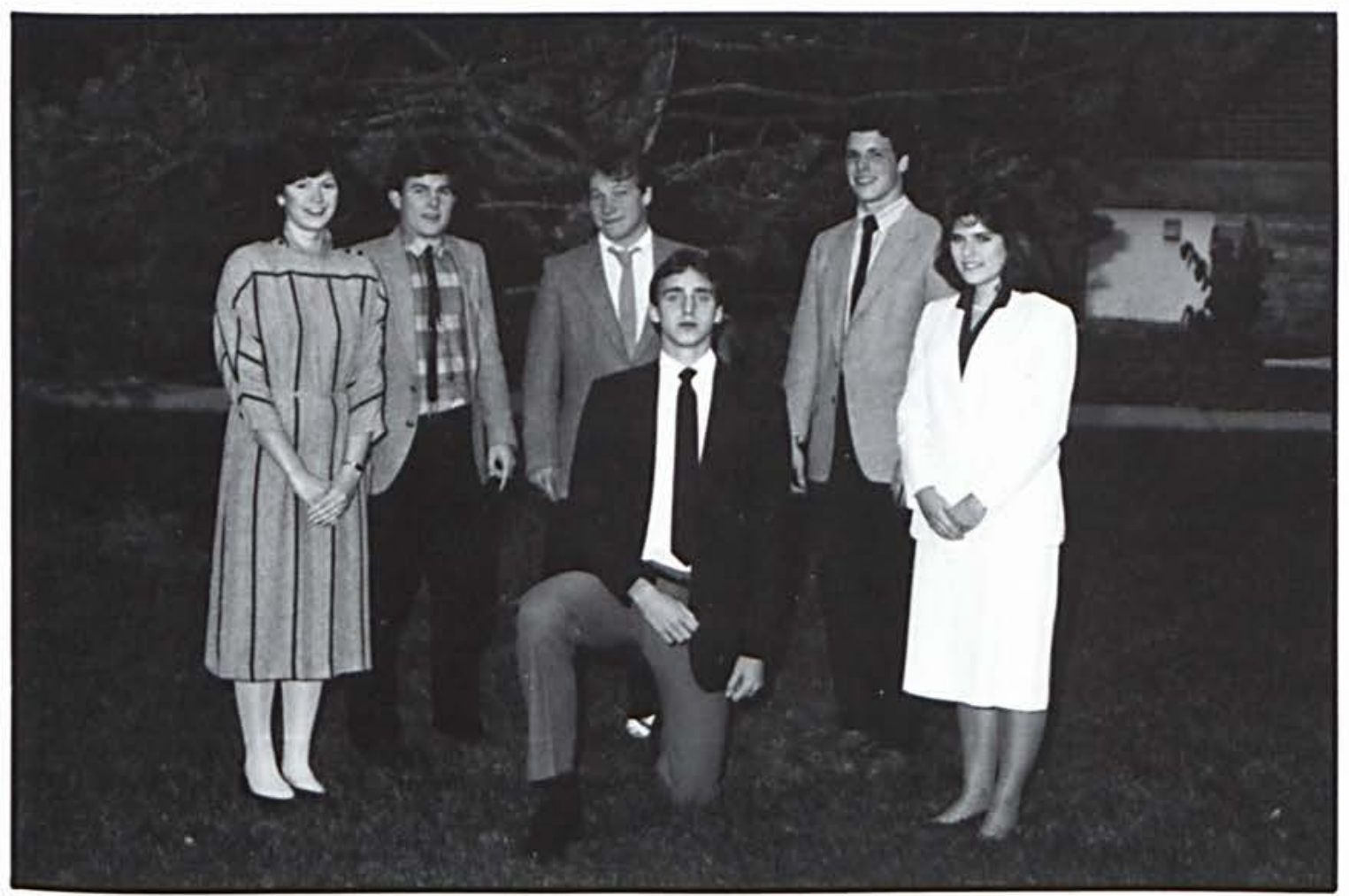

FRESHMEN CLASS OFFICERS: Julia Furiate, Tim Royer, Todd Obergfell, Gerald Keller, Mike Roberts, Jill Johnson, (Not pictured: Dr. Lopez, Advisor.) 


\section{Campus Organizations}

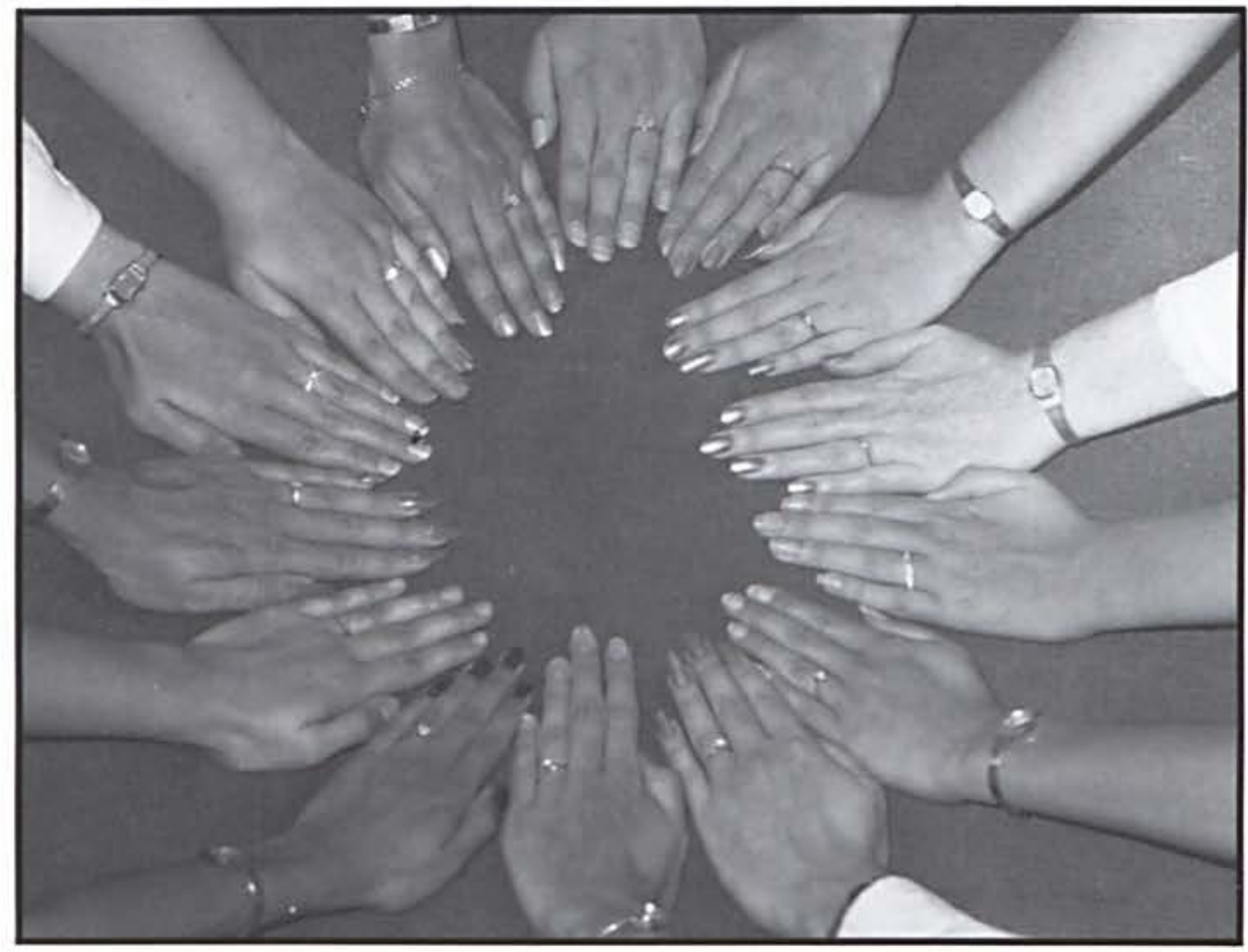

Above: Alpha Mu Chi serves God by preparing engaged women for their future God-honoring weddings and marriages. Right: Alpha Chi serves God by performing volunteer services for the college family and community.

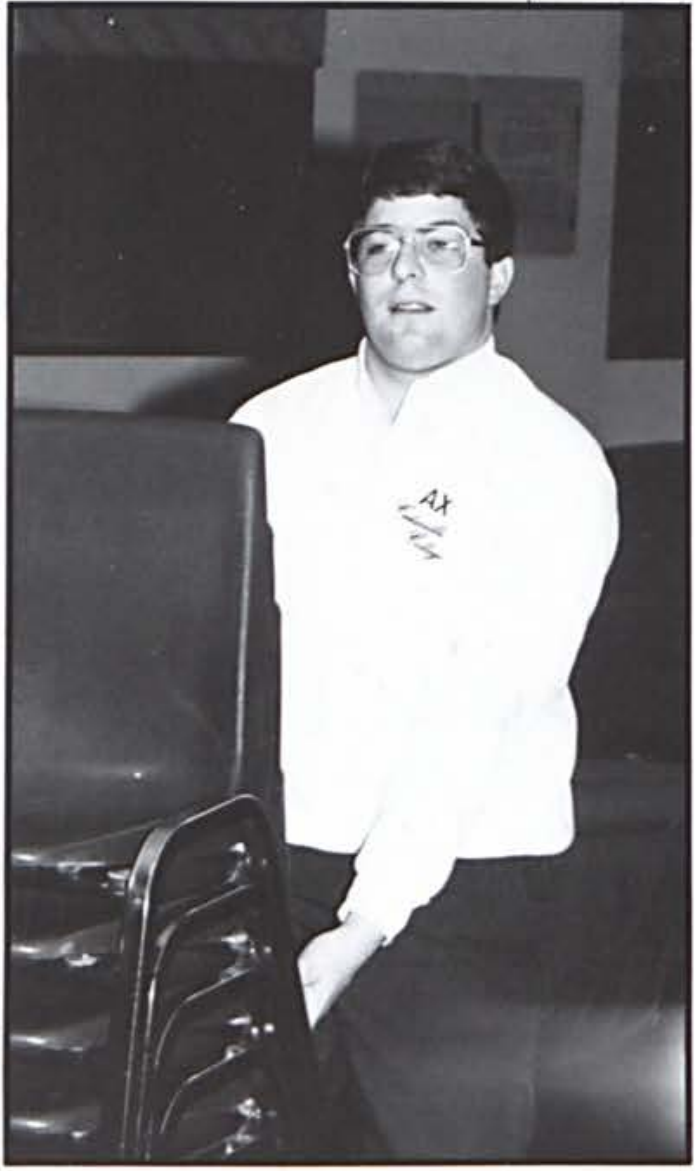

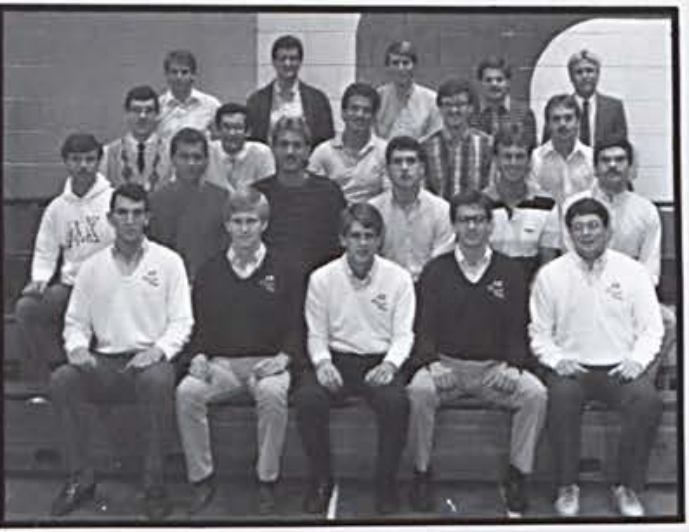

ALPHA CHI:

Front: Jim Koerber, Mark McClain, Joel Hoskinson, Brent Lydic, Perry Chiar elli. Second: Mark Walter, Don Tom, Jeff Martin, Bob Kinney, Scott Moyer, John Seargent. Third: Bruce McNabb, Eric Johnson, Dave Beverly, Doug Suby, Fourth: Chuck Scott, Ken Oliver, Scott Howder, Tom Redding, Jim Murdoch.

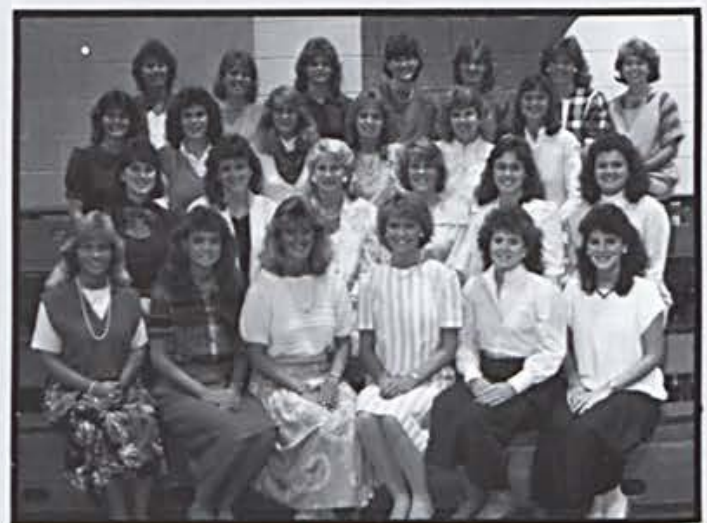

\section{ALPHA DELTA OMEGA}

Front: Amy Allen, Mary Wells, Nancy Huddleston, Kendra Wittenbach, Denise Auckland, Tina Hoddlemann. Second: Sherri Watson, Renee Bowen, Cary Barber, Shelle Perkins, Beth Bucklew, Tammy Barton. Third: Laura Dimac chia, Linda Lons, Melissa Marshall, Beth Hoecke, Joy Harden, Beth McGili vray. Fourth: Becky Klopp, Lyn Hackenbery, Sandy O'Boyle, Donna Snyder. Becky Reid, Sonya Nickols, Kendra King.

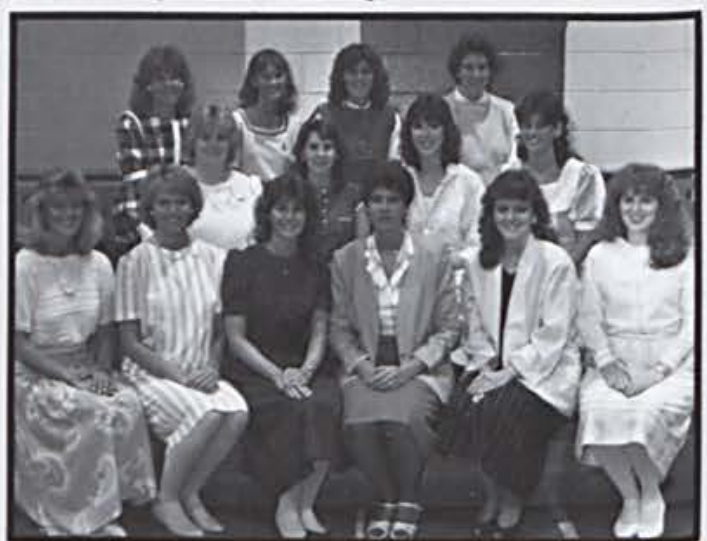

\section{ALPHA MU CHI:}

Front, Nancy Huddleston, Kendra Wittenback, Laura Dimacchia, Laura Waik Gezen, Kim Potts. Thirr Burr. Second: Shelly Payne, Amy Snook, Debbie Beach.

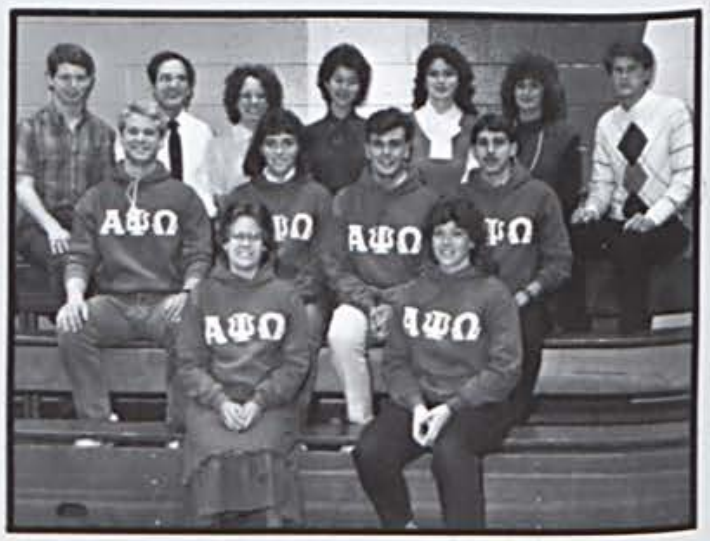

\section{ALPHA PSI OMEGA:}

Front Dana Messinger, Mary Welch, Second: Stuart Rammes, Kristine Watson, Dan Gonzalez, Brent Budd Thind, Don Drozd, Tim Dysert, Teena Coronato, Michelle Hinnergardt, April Augustus, Theresa Dunlap, Bruce Herman. 


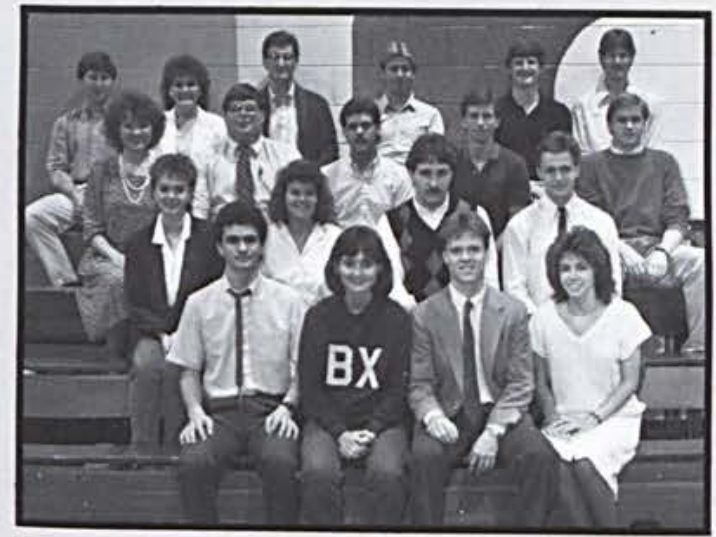

BETA CHI:

Front: Andy Snider, Donna Payne, Troy VanLlere, Alice Sweitzer. Second: Jennifer Robinson, Becki Tacket, Jim Leightenheimer, Steve Hansen. Third: Ann Gruneisen, Mark Tinner, Phil Shaull, Chad Bresson, Glenn Carpenter.
Fourth: Todd Rhoades, Judy Denning, Ken Oliver, Carl Decker, Pete Wright, Paul Wenz.

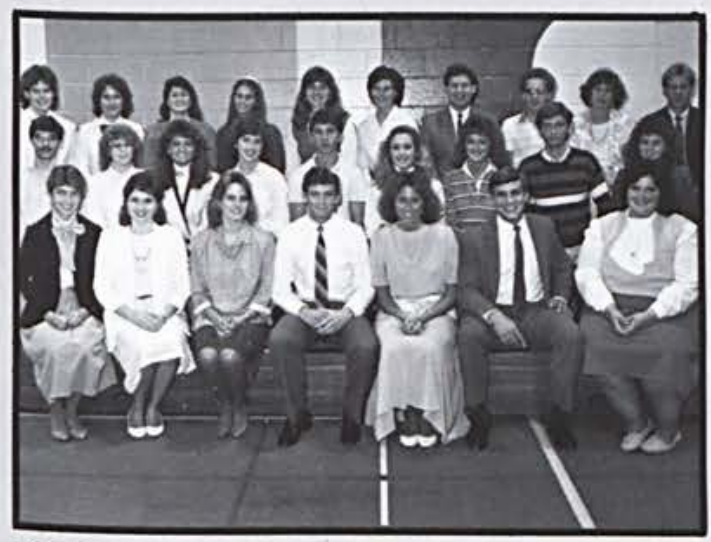

\section{CEDARS STAFF:}

Front: Tami Eimers, Christina Hart, Sherri Cruver, Mark Horne, Karen Beattie, Jim Liebler, Stacy Gunther. Second: Kurt Anderson, Lisa Faucett, Mary Wells, Becky Hummel, Mike Wittmer, Vickie Jackson, Kristin Weber, Greg Crawford, Robin Johnston. Third: Ruth Murtoff, Brenda Sutliff, Sue Blake, Suzanne Hers, Kevin Shaw.

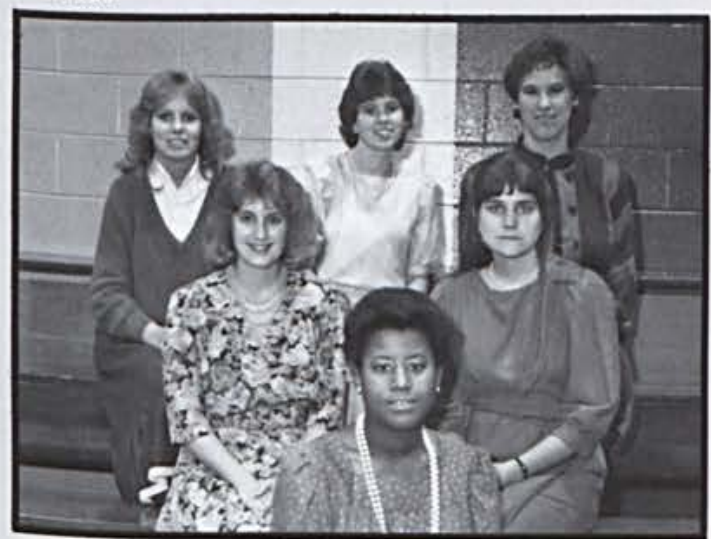

\section{C.C.S.N.A.}

Front: Shelley Brown Second: Nancy LaBonte, Wendy Bell. Third: Beth Hoecke, Debbi Berdy, Keclley Helman

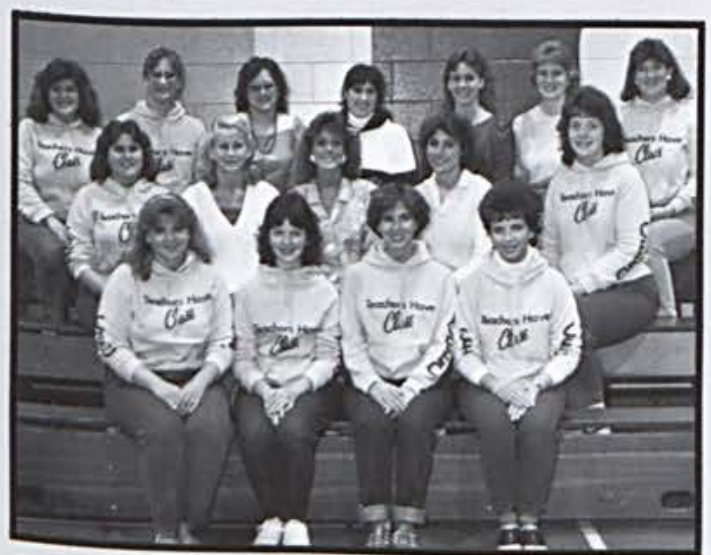

\section{C.E.E.C}

Front: Theresa Bonning, Rachael Cook, Donna Thomas, Leah Robbins. Sec. Third: Pari Casteel, Caryn Barber, Shawna Denney, Chris Dail, Amy Johnson. veren, Kam Woods, Kendra Doctor, Holly Patterson, Beth Moon, Terri VanBe
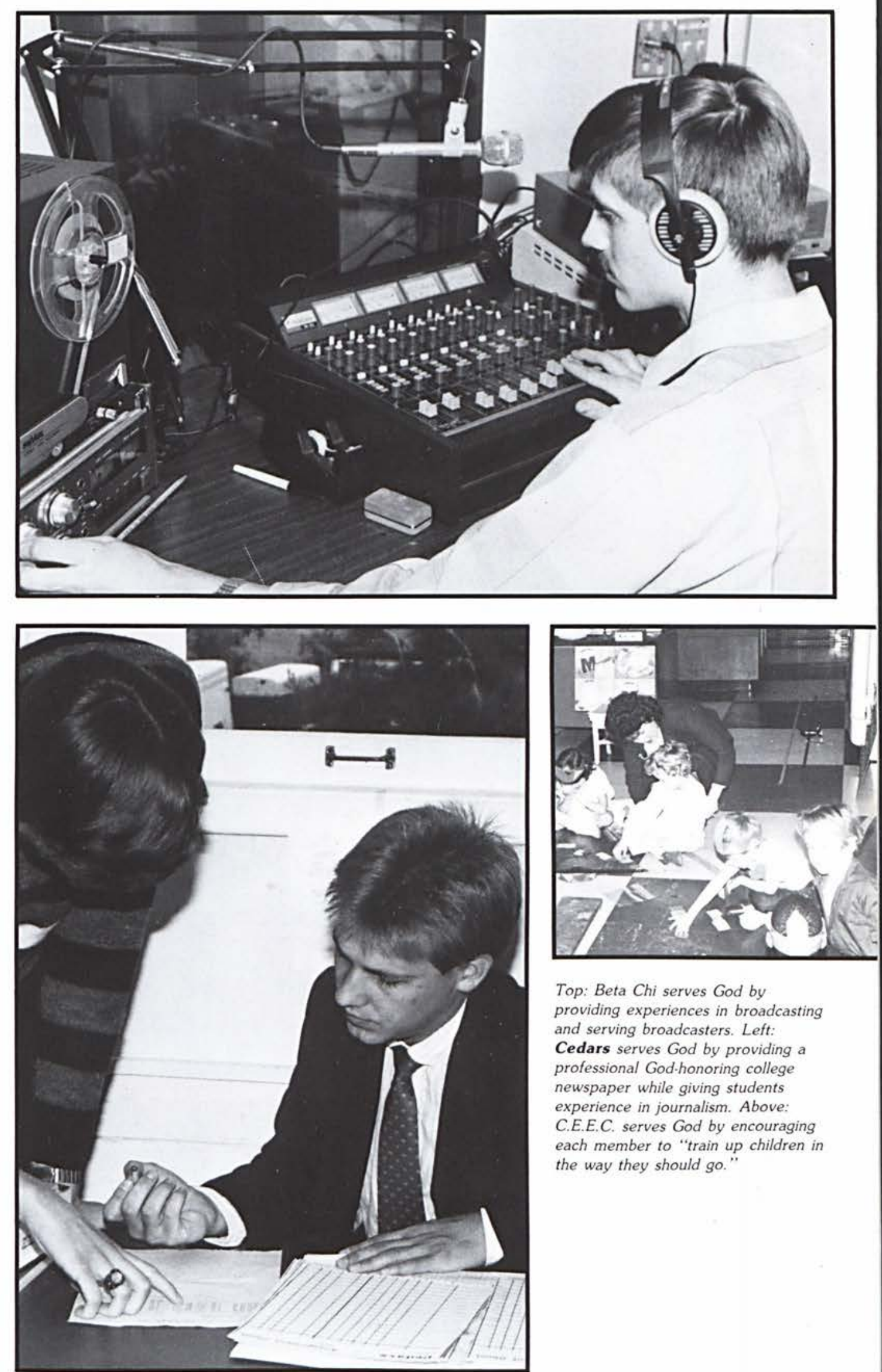

Top: Beta Chi serves God by providing experiences in broadcasting and serving broadcasters. Left:

Cedars serves God by providing a professional God-honoring college newspaper while giving students experience in journalism. Above:

C.E.E.C. serves God by encouraging each member to "train up children in the way they should go. 


\section{Campus Organizations}
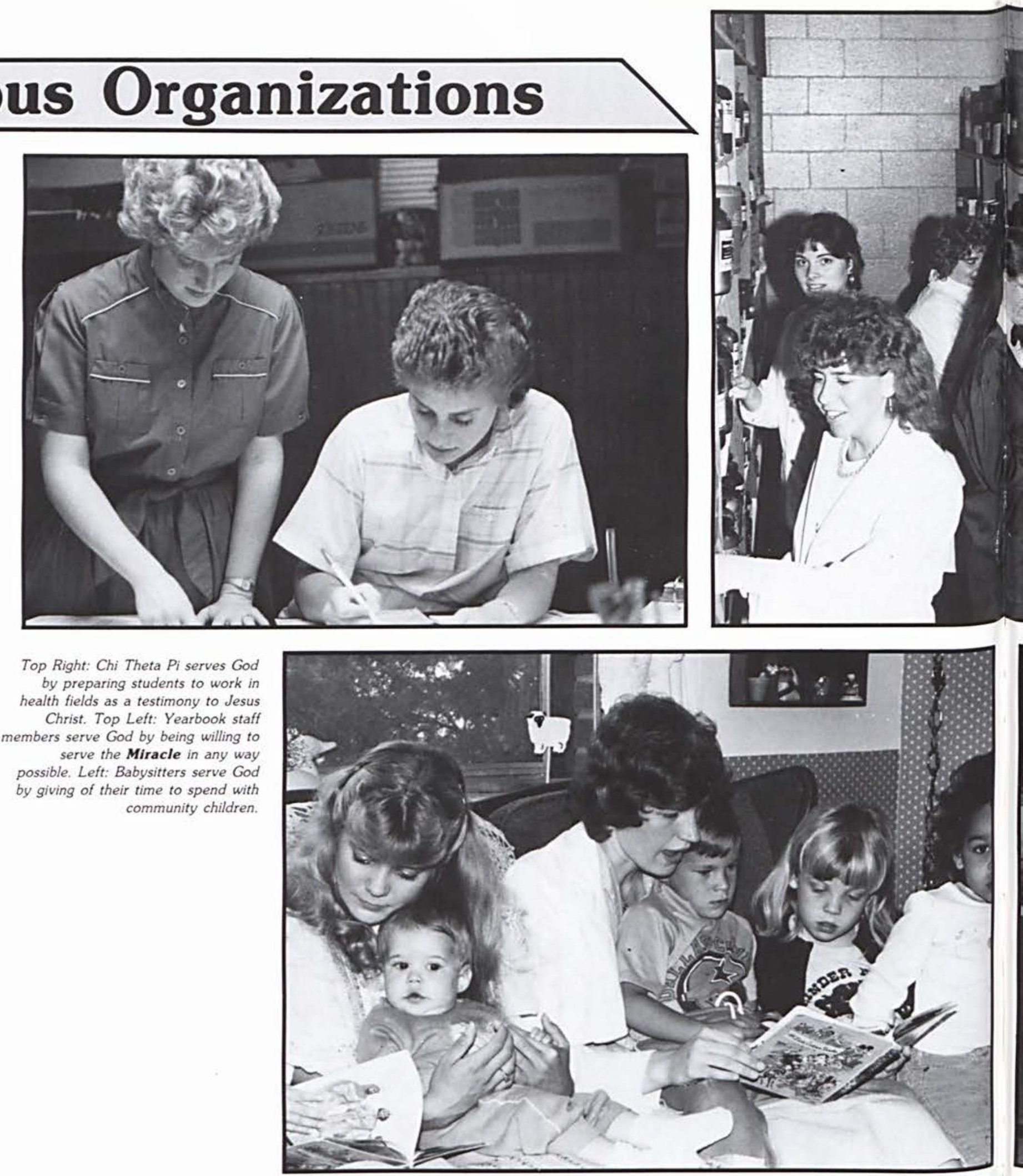

CHI THETA PI:

Front Jean Moeser, David Sommers, Christie Renberg. Second: Laura Maiers, Meredith Steiner, Cory Neuman, Lorena Hoyle, Lila Seest. Third: Sarah Barr, Sherri
EMS:

Pore Savard Cheri Abresch, Laura Maiers, John Willer Sec ond Bill Marshall, James Jacobs, Ken Geisman.
FORENSICS:

Front: Gary Barker, Loni Cooper, Jim Liebler Second. Ruth Margreffit Nadine Terrlll, Cindy Helmick, Kristyn Johnson. Third: Mr. Robey

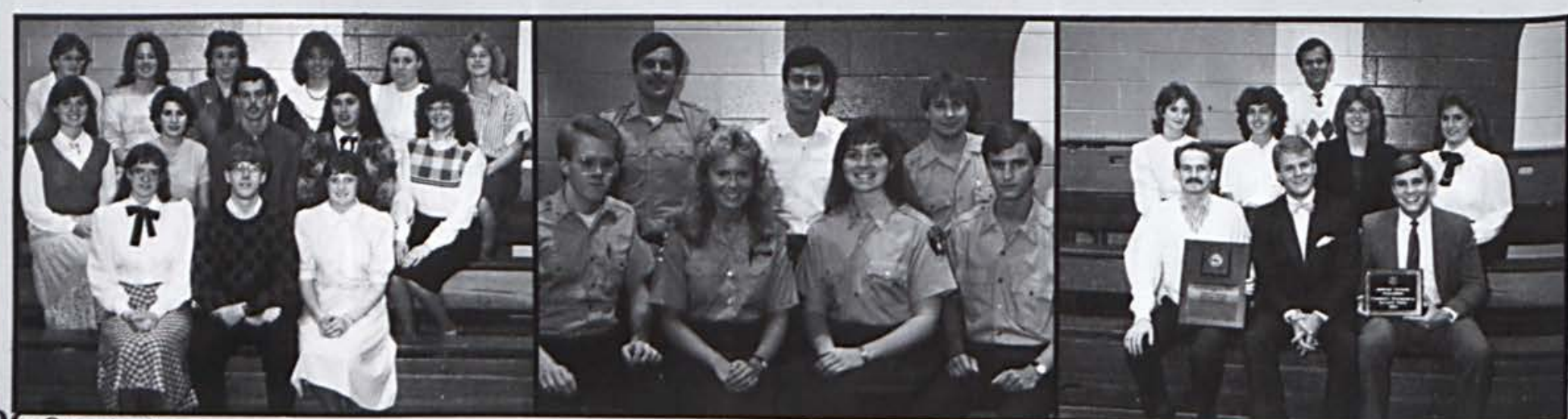




\section{Campus Organizations}

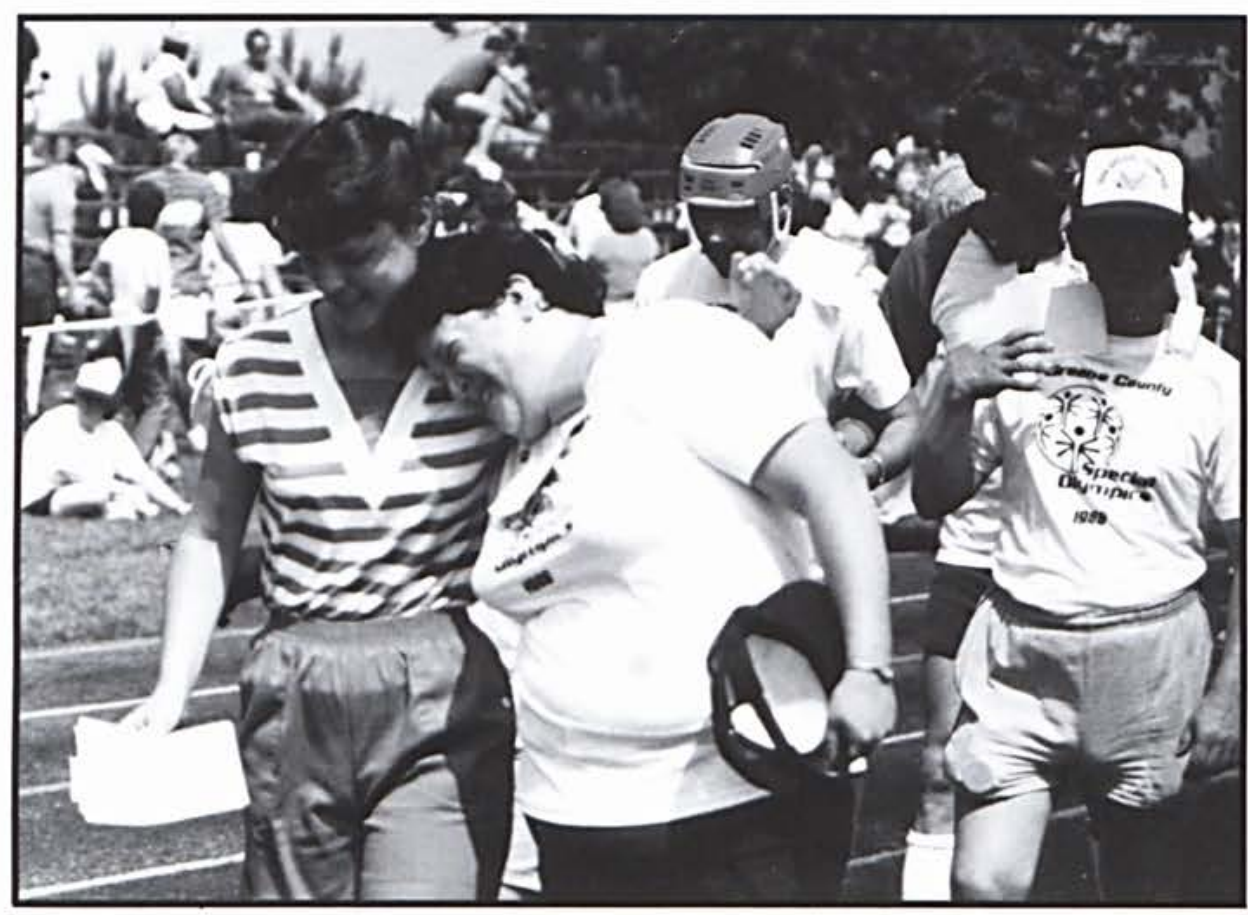

Above: P.M.M Club members serve God by being the hosts for S.W.A.T youth rally in the fall and special olympics in the spring. Right: Pi Delta Tour Club serves God by showing hospitality and serving as guides to $\mathrm{cc}$ visitors.

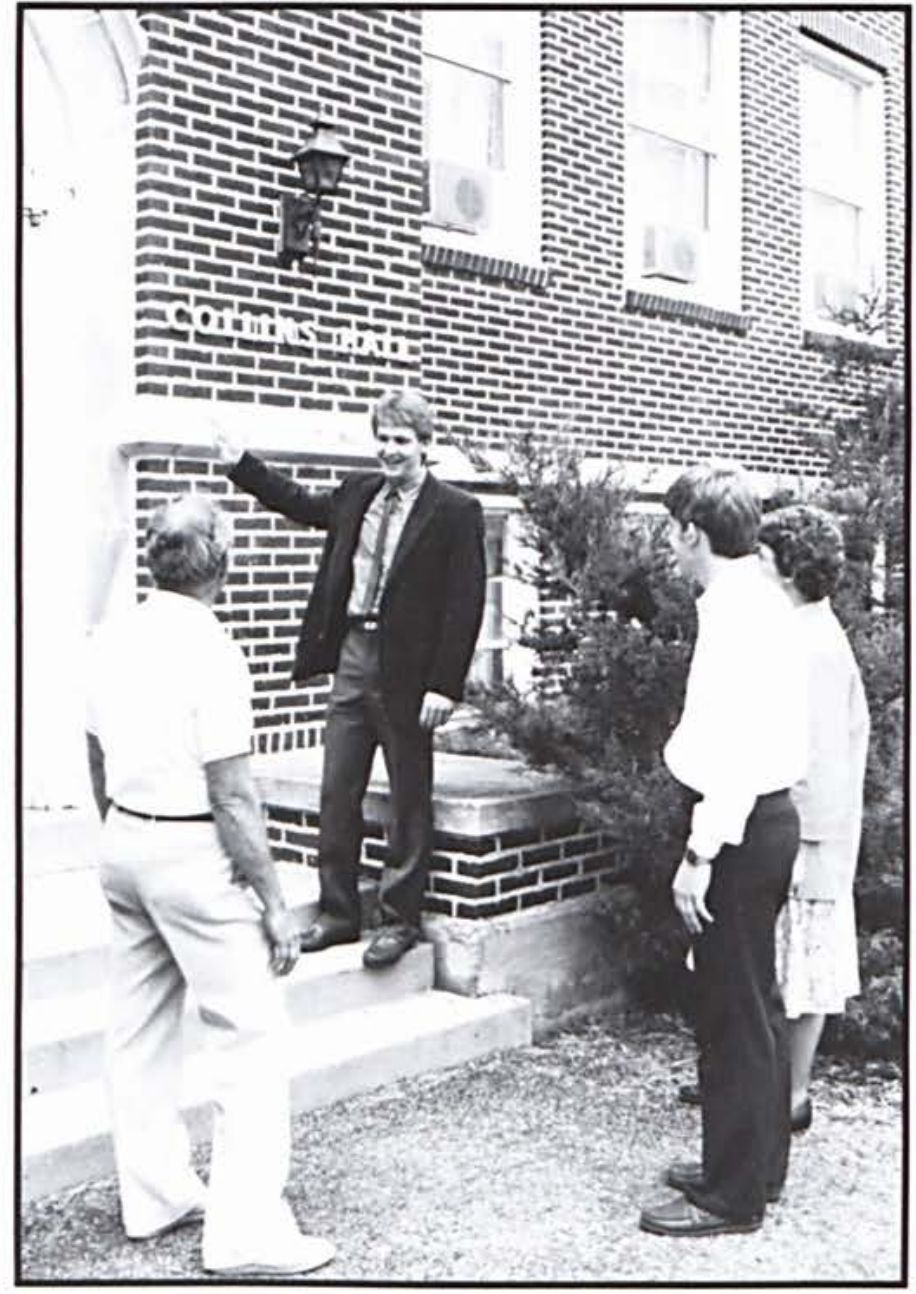

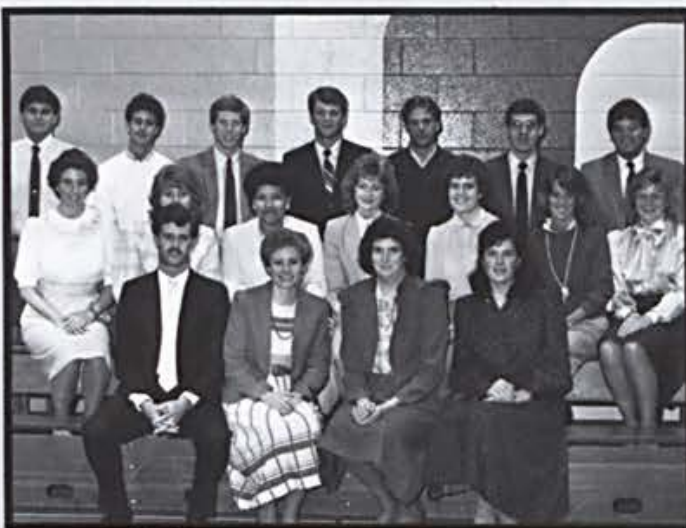

KAPPA EPSILON ALPHA:

Front: Mark Matthews, Shannon Saunders, Marsha Jones, Linda Lons Second Melissa Beach, Sue Edwards, Janet Lawrence, Teresa Carter, Linda Wood gate, Doris Lindley, Chris Stowell. Third: John Bercaw, T.J. Rivetti, Temple Knowles, Chris Walter, Steven Campbell, Bruce McNabb, Alan Titus.

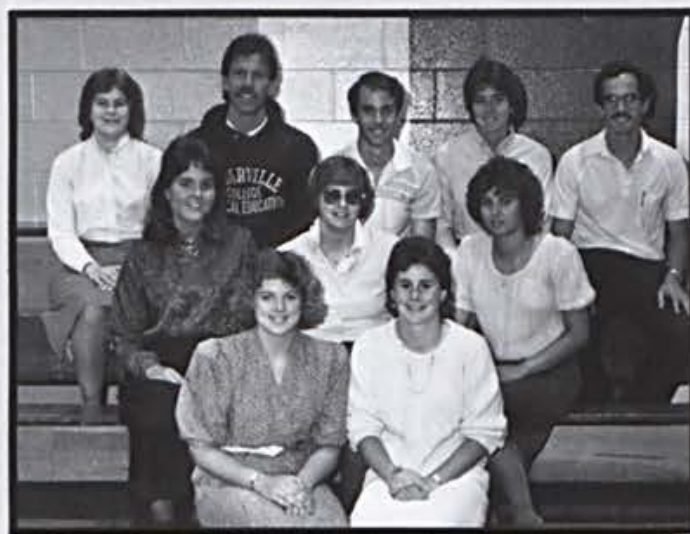

\section{PEMM CLUB:}

Front: Layne Etchison, Sue Baldis. Second: Suzanne Laub, Joy Boersma, Mascari, Steve Cox.

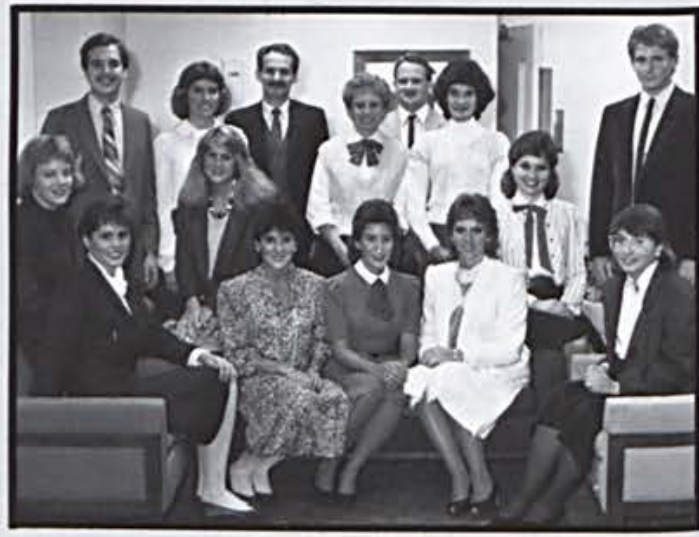

\section{PI DELTA TOUR:}

Front: Cynthia Cronrath, Kristina Hoddelmann, Debbie Jo Baker, Toni VanBe veren, Beth King. Second: Kris Parman, Melissa Marshall, Christina Hart, Chuck Scott. Third. Eric Helmuth Janice Warren, Gary Barker. Shannon Saunders, Dave Robinette, Heidi Hempel.

용

리 2 क्ष A. TIEN MEN MIN 숭

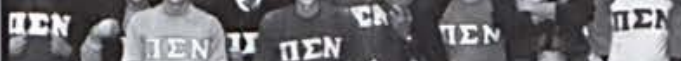

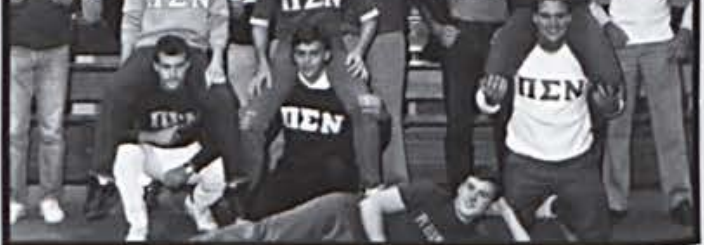
PI SIGMA NU:

Front: Paul Hughes, Second: "Notso" Smart, "Weed" Reld, Ric Zehr, Third" "Gumby" Robinson. Second: "Notso" Smart, "Weed" Reid, Ric Zehr, Third" Mathis, "Squirrel" Fite, Shawsby, Jaymo Martin, Clem. "Hole bait" Cooke. Fifth: Mark Swander, Mike Donahoe, Andy Mininger, "Mugsy" DeWalt, Rick Seidel, Drew Fraser. 


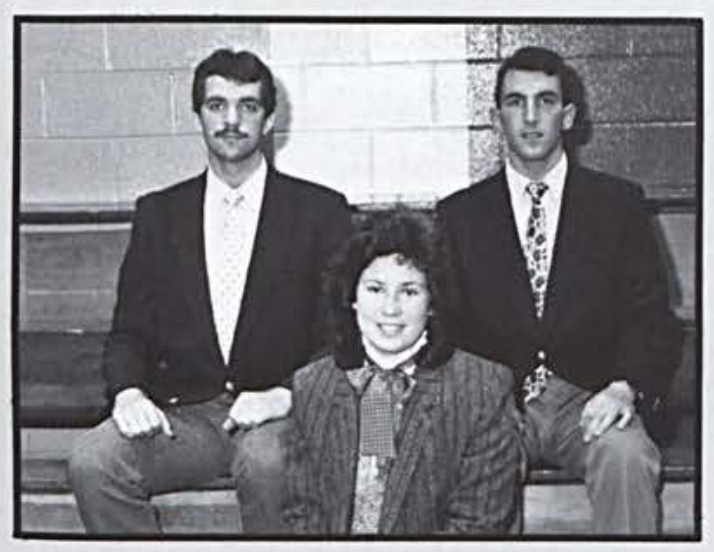

PRE-LAW SOCIETY:

Front: Holly Marshall. Second: Mark Baker, Jim Koerber.

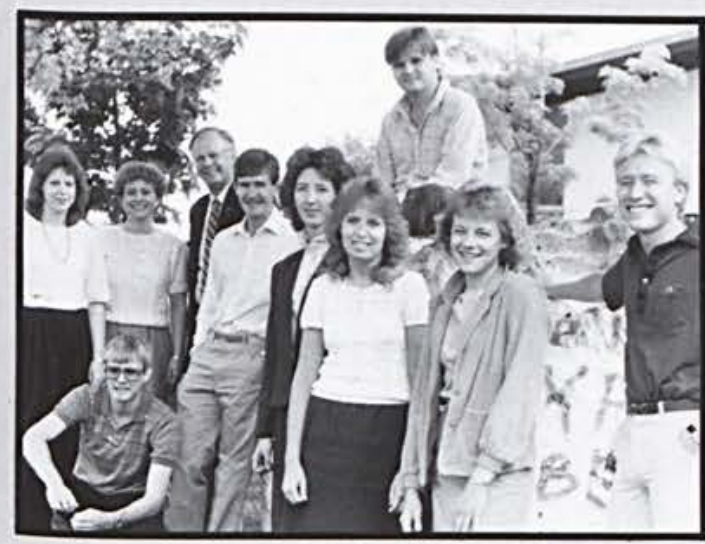

STUDENT ACADEMIC ADVISORY BOARD: L to R: Colleen Boyer, Shannon Saunders, Bryan Crump, Dr. Johnson, Rusty
King, Diane Noggle, Beth Hoecke, Scott Zimpfer, Kris Parman, Jim Murdoch.

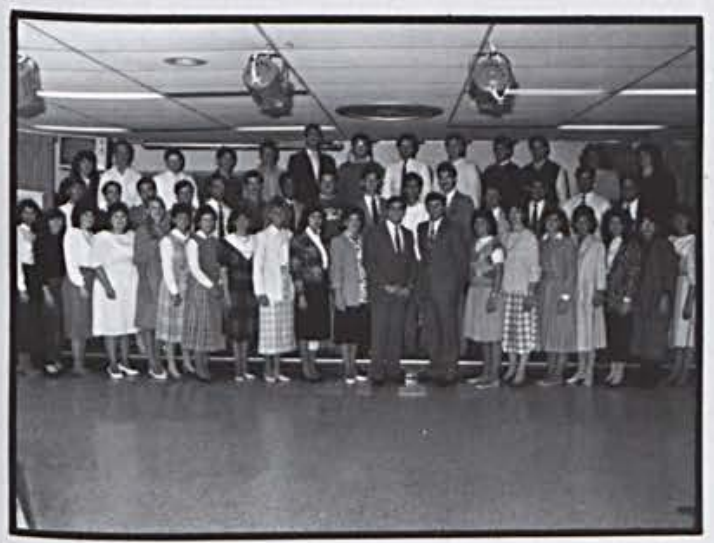

STUDENT SENATE:

Front: Laura Dimacchia, Wendy Norton, Amy Guest, Amy Johnston, Melody Ferguson, Rhonda Trueman, Julie Stackhouse, Bonnie Snyder, Susan Moyer. Lorena Hoyle, Elizabeth Hansen, Jim Liebler, Mark Horne, Janie Bresson, Eileen Friesen, Betty Smith, Jenny Dean, RoseAnn Nemecek, Beth King, Kathy Harris.

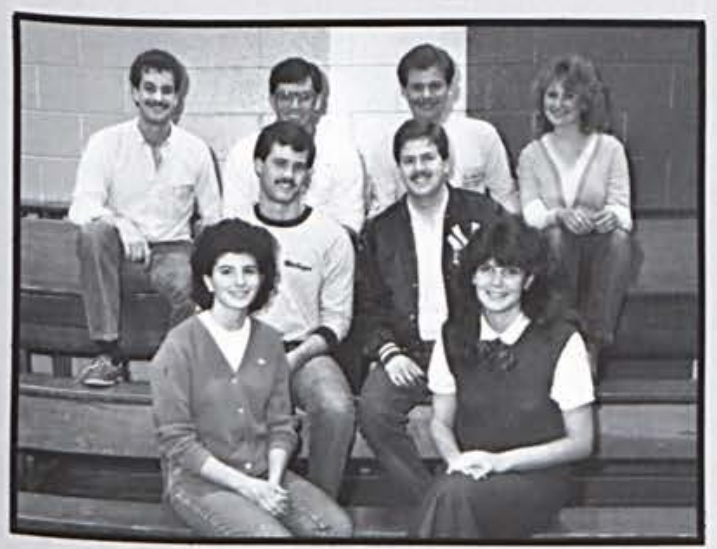

TIMALATHIANS:

Font: Catherine Romano, Jennifer Raught, Second: Mark Matthews, Dave Shulse. Third: Charles Jackson, Danny Olinget, Bill Taft, Brenda Fisher.
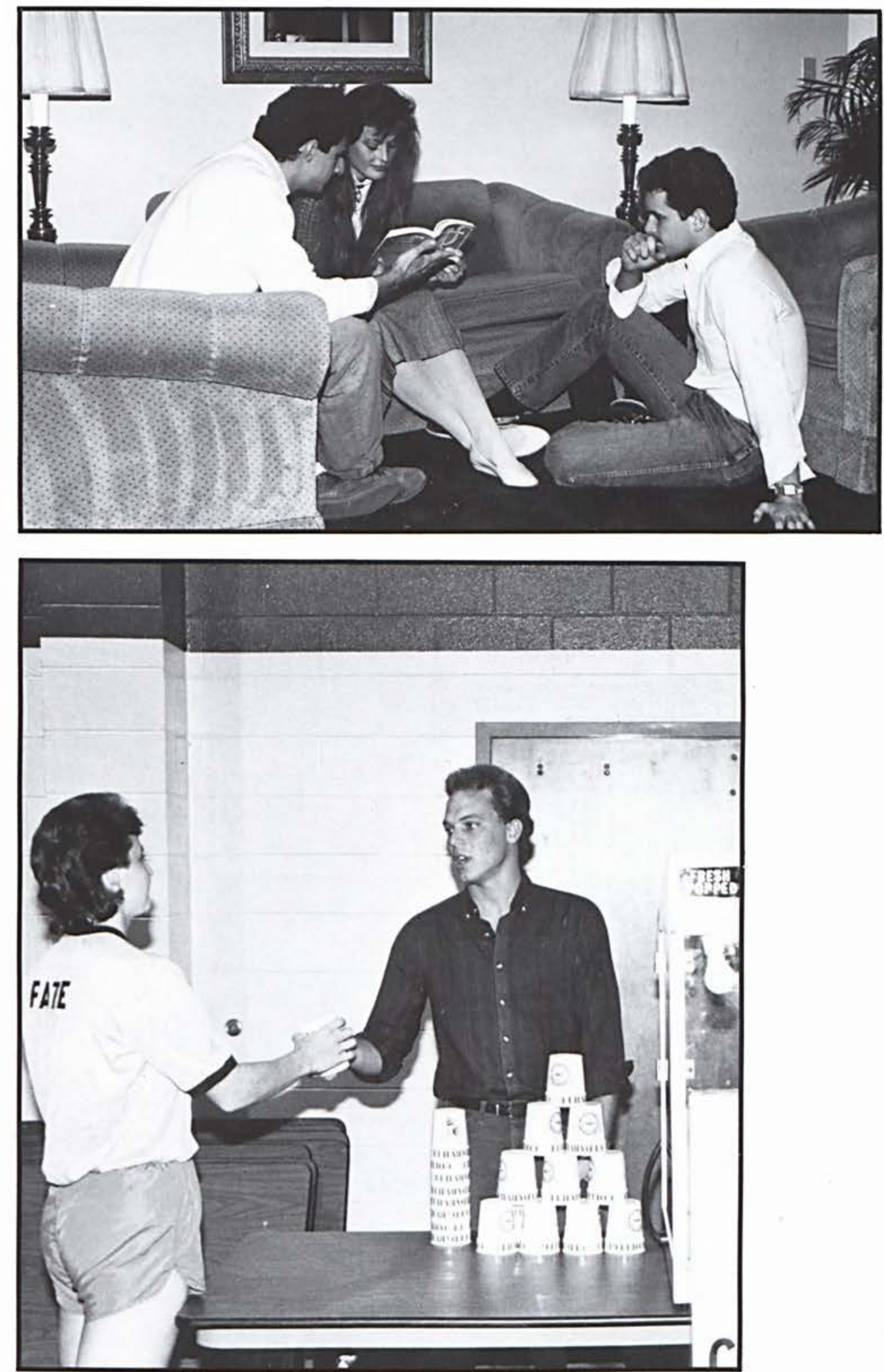

Top: Timalathians serve God by providing opportunities for students to develop a Christian world-and-life view and stimulating the student to present Christ in the 20th century.

Bottom: Varsity " $C$ " serves God by donating money to missionaries and M.I.S. program volunteers.

STUDENT SENATE CONTINUED:

Second: Keith DeWalt, Alastair Wright, Craig Ritchie, Scott Zimpfer, Scott Beattie, Cory Neumann, Marc Donawa, Jay Martin, Bruce Keisling. Timothy J. Rivetti, Andy Wilson, Brian Deffet, Doug Pugh, Jeff Beste, Jim Reiter. Third: Debbie

Ramaker, Chris Moore, Perry Chiareli, Jeff Imhoff, Todd Obergfell, Mark Baker, Rich Greene, George Reede, Loni Cooper, Steve Rockwell, Steve Campbell, Karen Beartie, Cindy Helmick. 


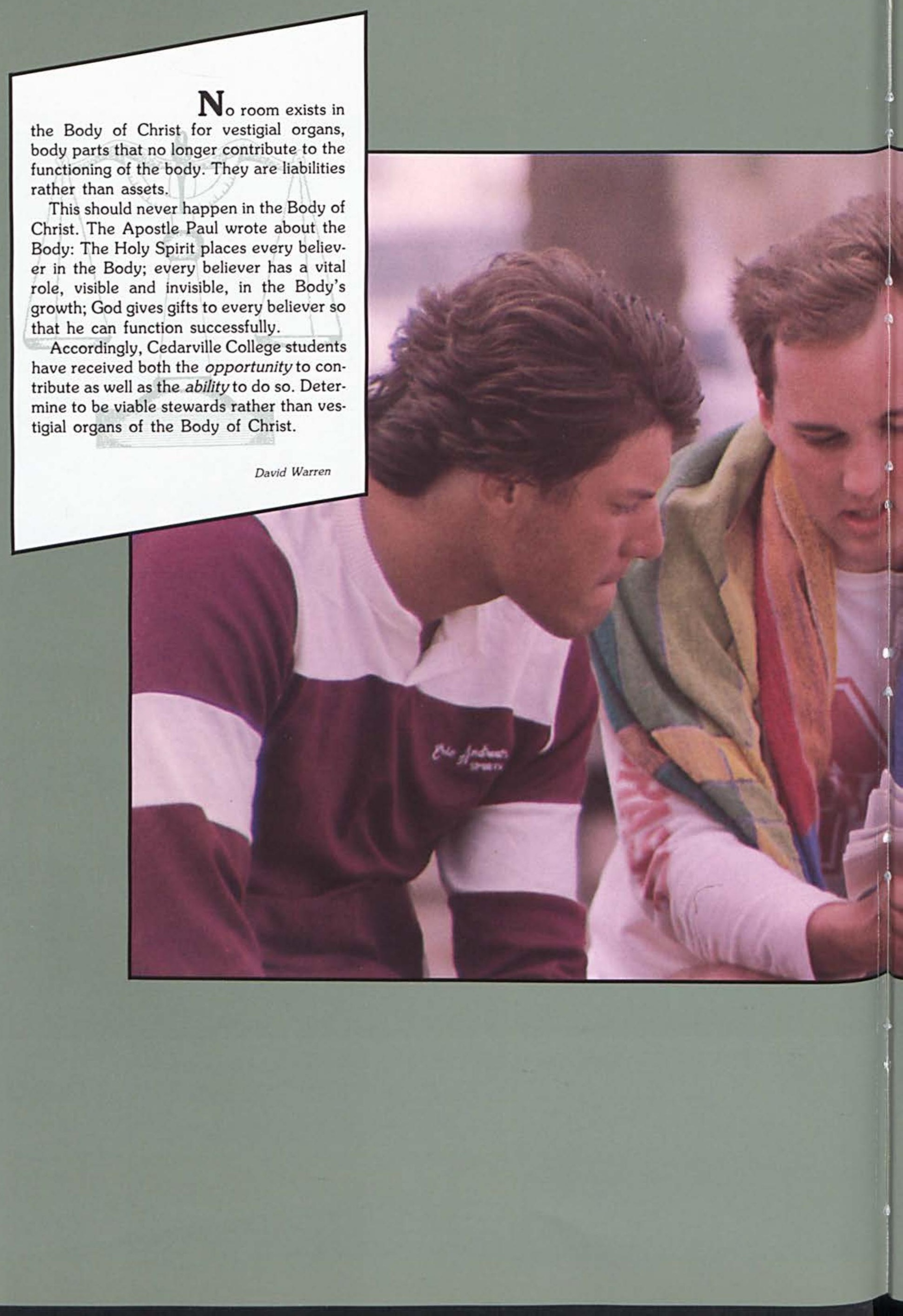




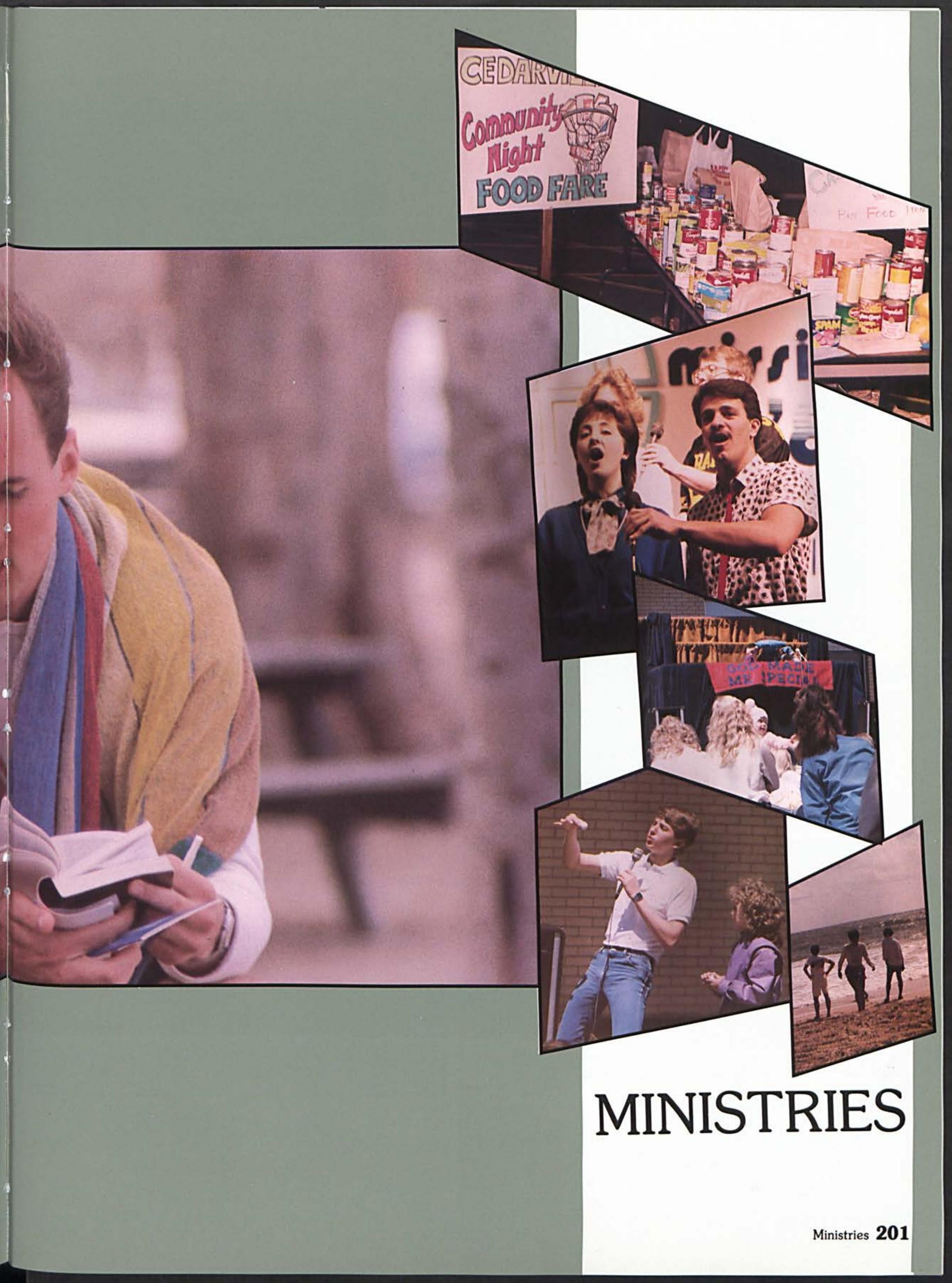




\section{SPECJAL CHAPELS}

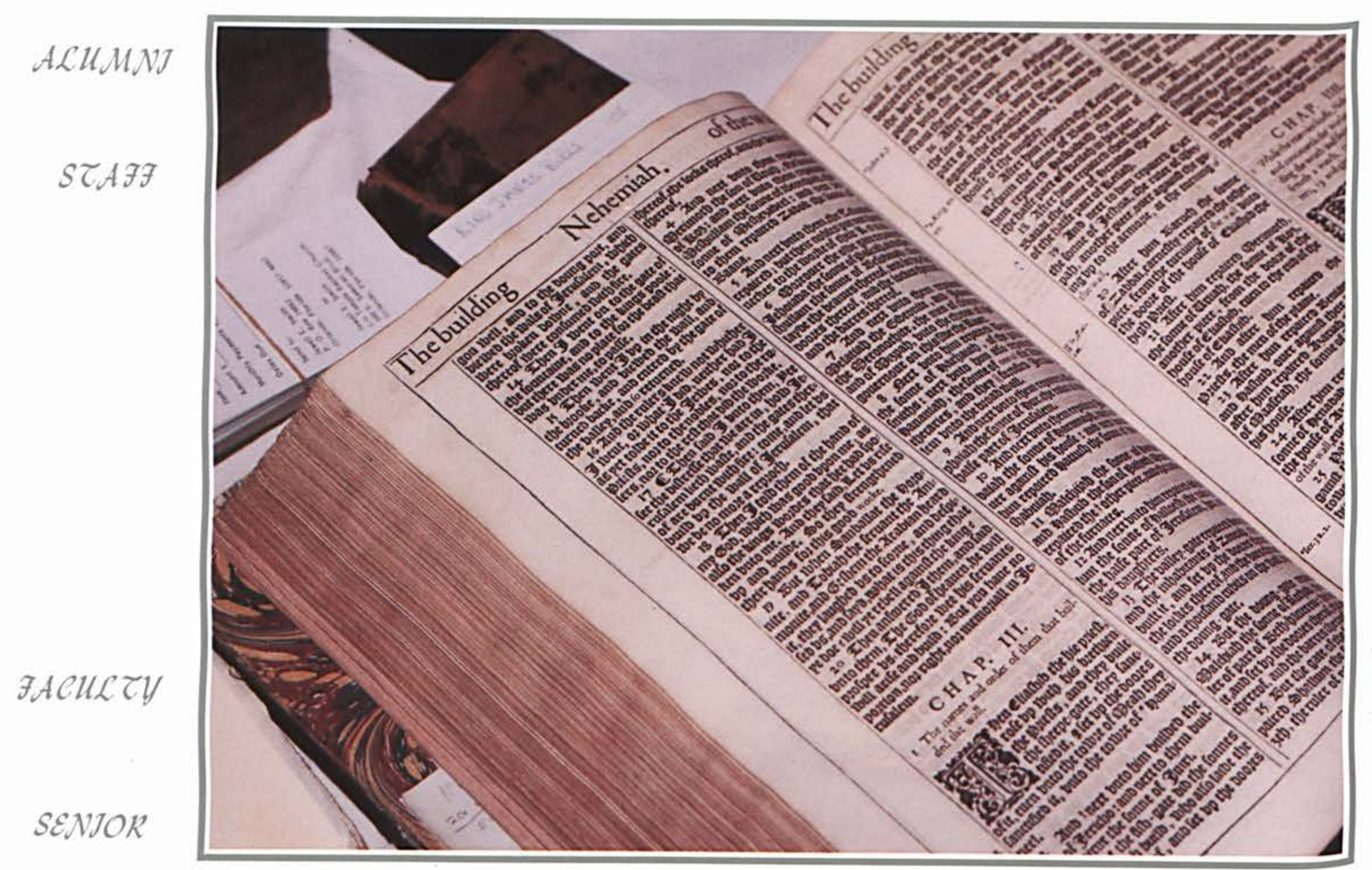

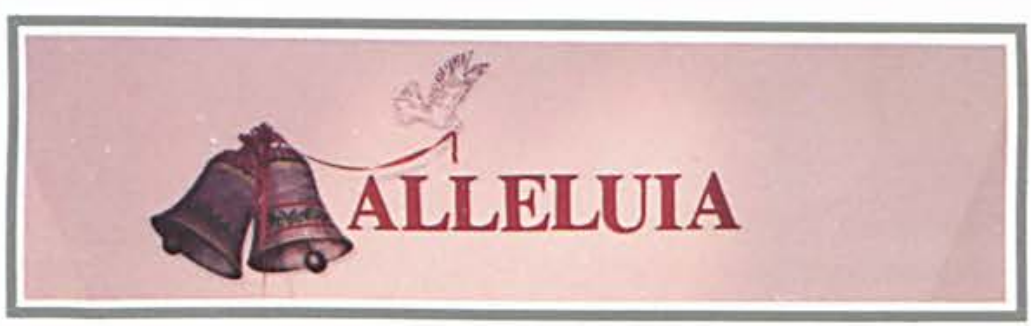

CHKJST MAS CHAPEL LOGO

SENA $\tau \mathcal{E}$

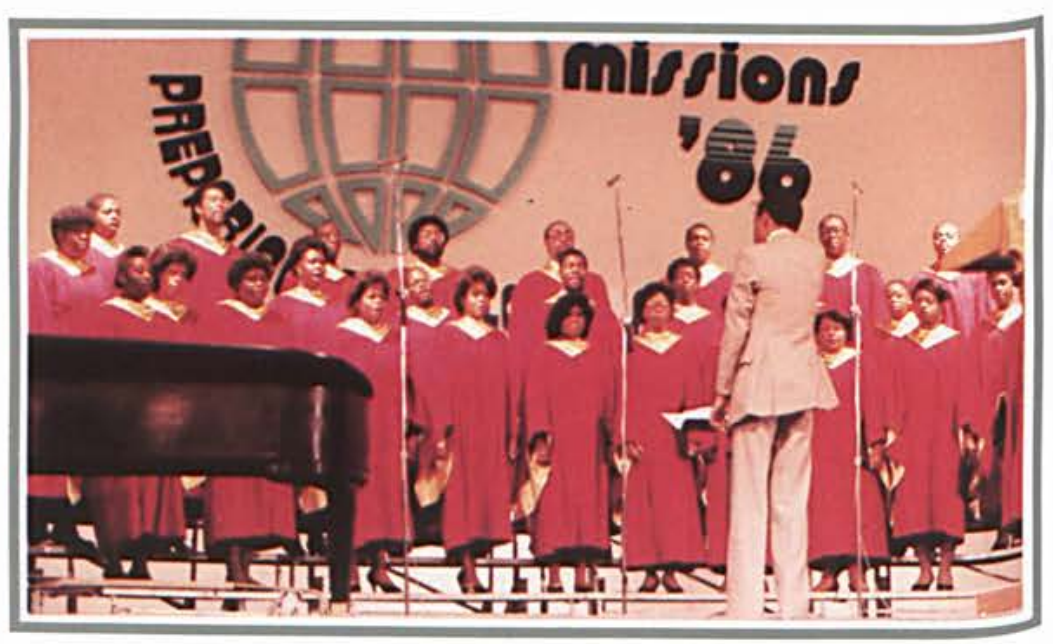

CENTKAL STATE DAY

\section{THANKSGJVJNG}




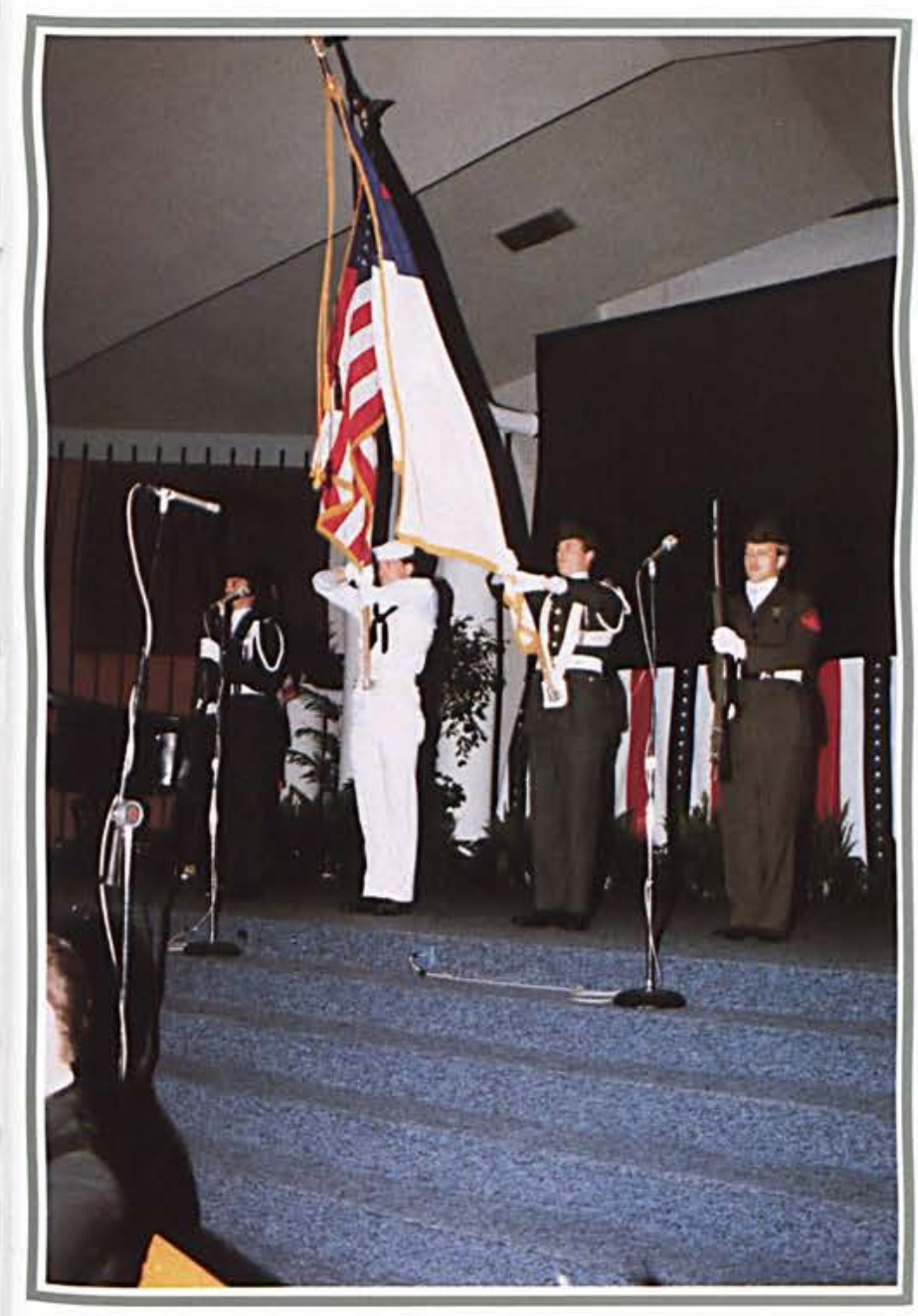

SPRJNG TEAMS DEDJCATJON

pJ SJGMA $\mathcal{N U}$

TEACHEK RECKUJTMENT CONFERENCE

MEMORJAL DAY

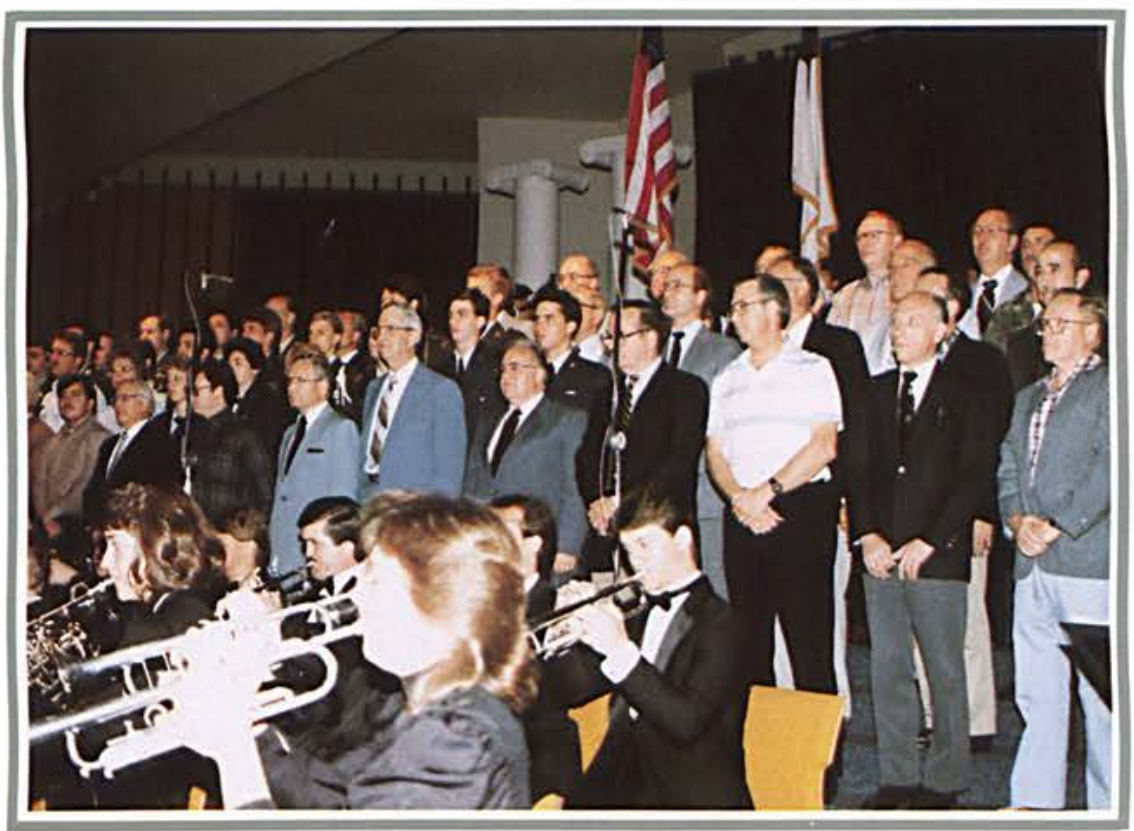

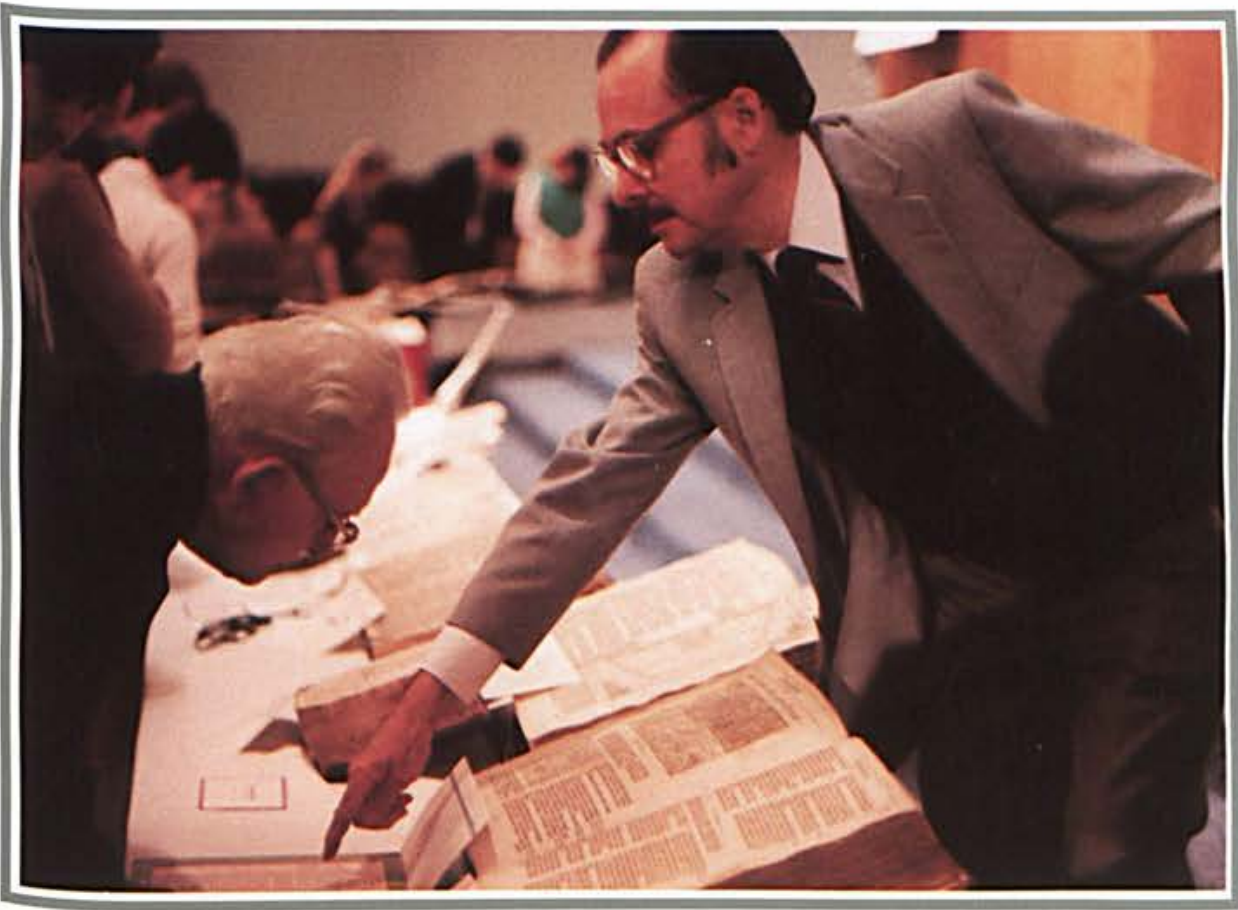

YOUR BJBLJCAL HERJTAGE

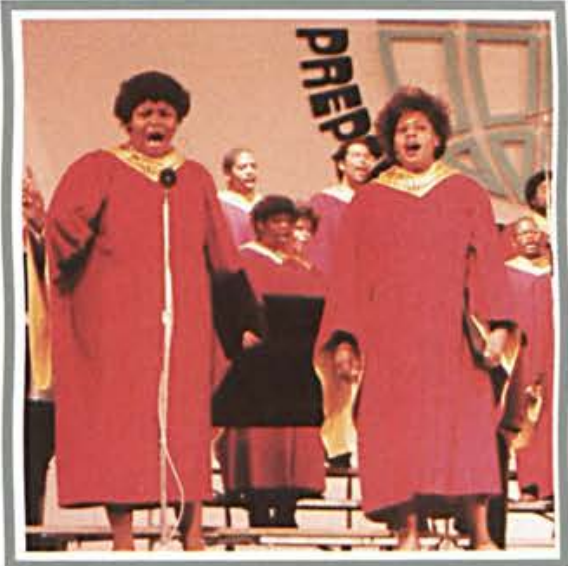

IKEE $\mathcal{E N} \tau \mathcal{E} R P \mathcal{R} J \mathcal{E}$

CHRJSTJAN LAYPERSONS

SENJOK SAJNTS

DEPAK $\widetilde{M} \mathcal{E N} \tau \mathcal{S}$

gewel Smith

ONE JS A WHOLE NUMBER 


\section{0}

Fing is

watey

1. 1 (t)

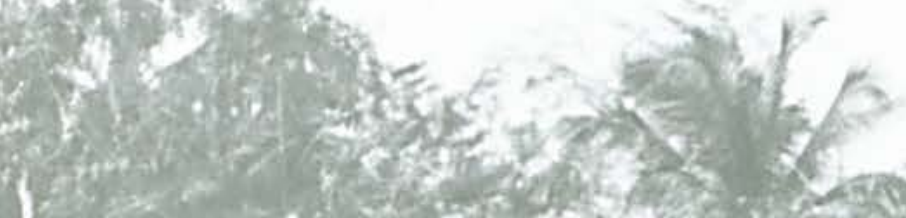

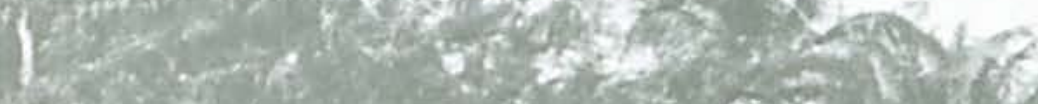

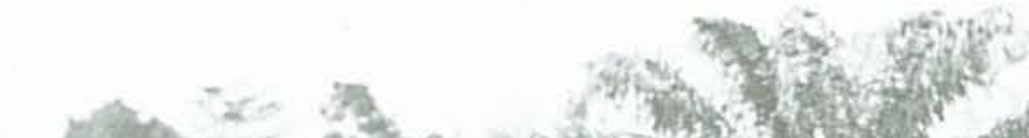

काओं

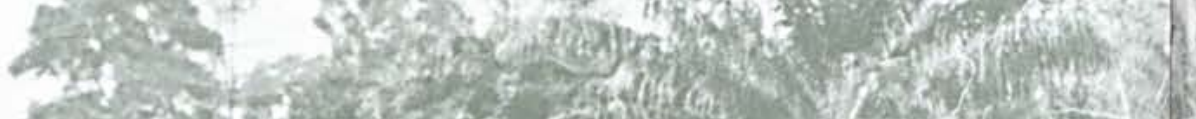

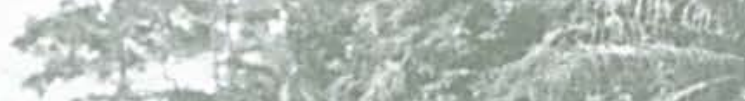

1.

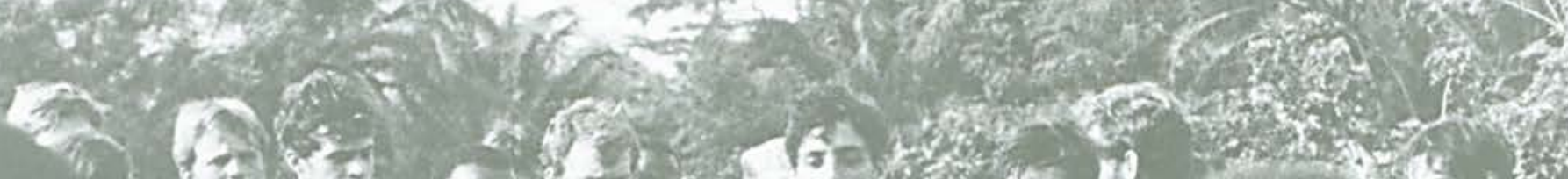

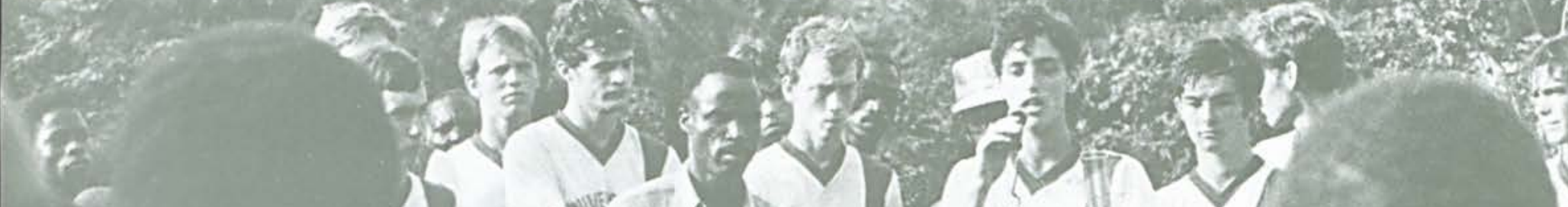

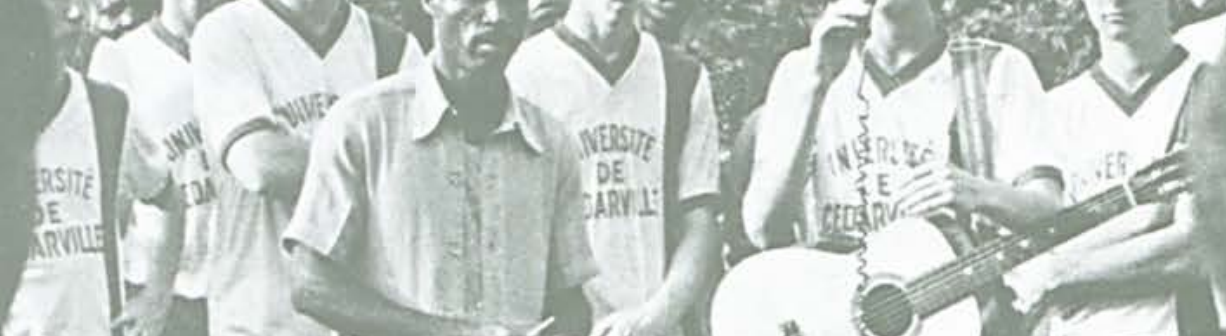
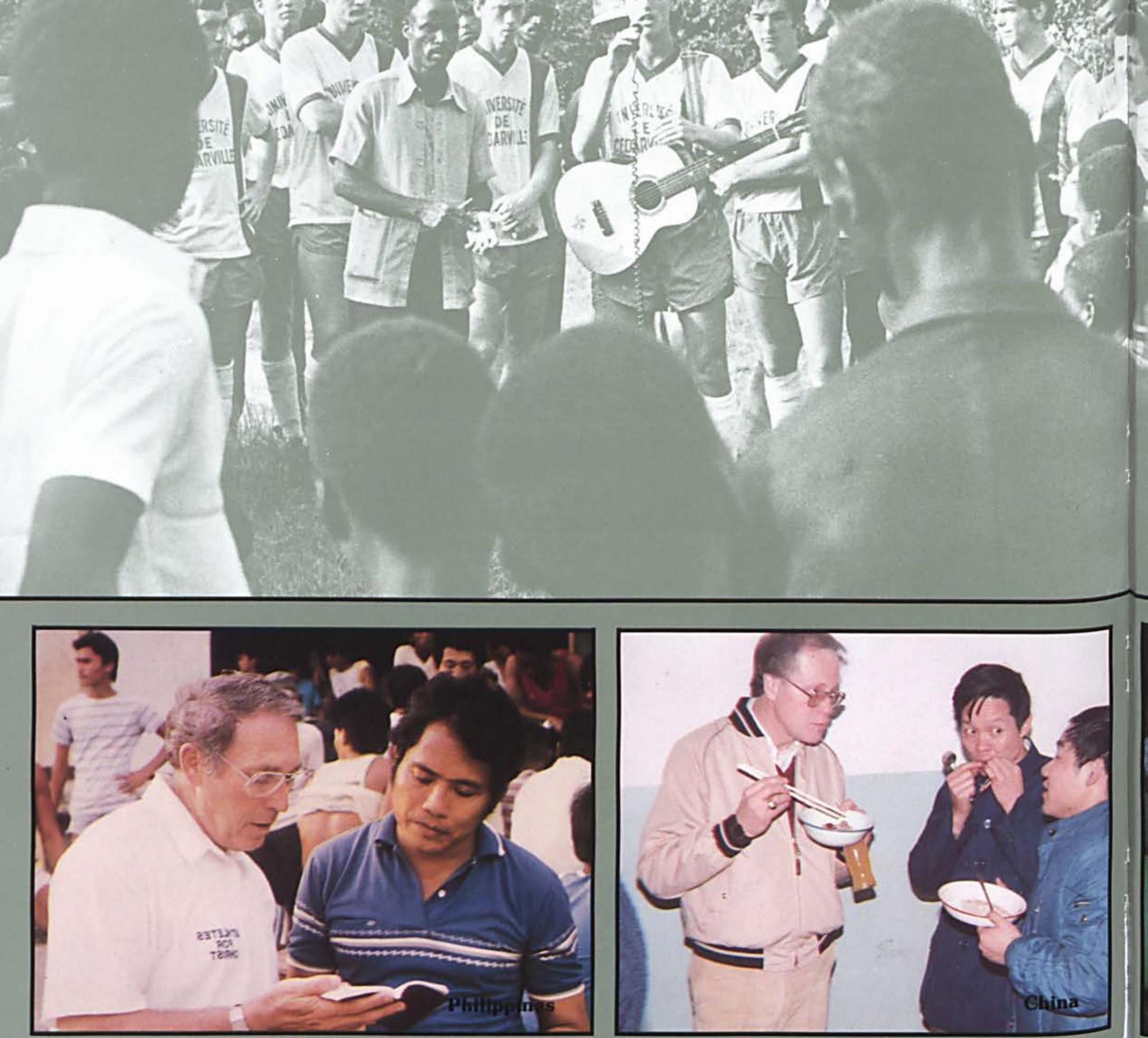


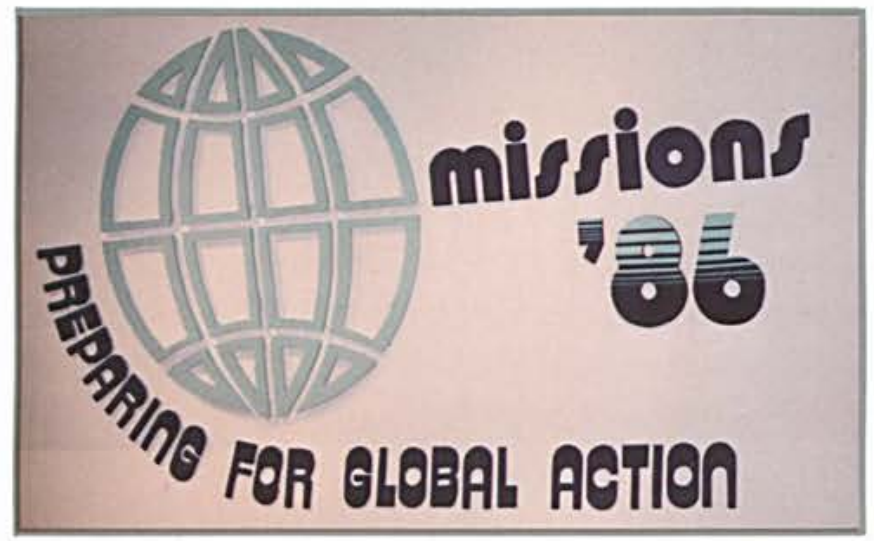

Starting

Off Right

Quarter

Conferences:

\section{Fall}

Who's that giant on the platform? Looks like he could be a Roman centurion caught in a time warp. Speak. ing with a rate like a machine gun, Dave Breese expounded upon the significance of a single individual who is determined to do nothing but the will of God and who is determined to be a pillar of Christian wisdom.

\section{Winter}

"Preparing for Global Action" was the central focus of the winter quarter's missionary conference. Roy Watkins encouraged us to consider missions with the thought that the need is great and so are the rewards. Bill Smallman, in his message to "the rest of us at home," said that our commitment to Christ should be evident in everything we do, even if we are not called to a foreign field. Dan Gelatt, with his enthusiasm in message and song, called for us to use every opportunity to further the cause of Christ.

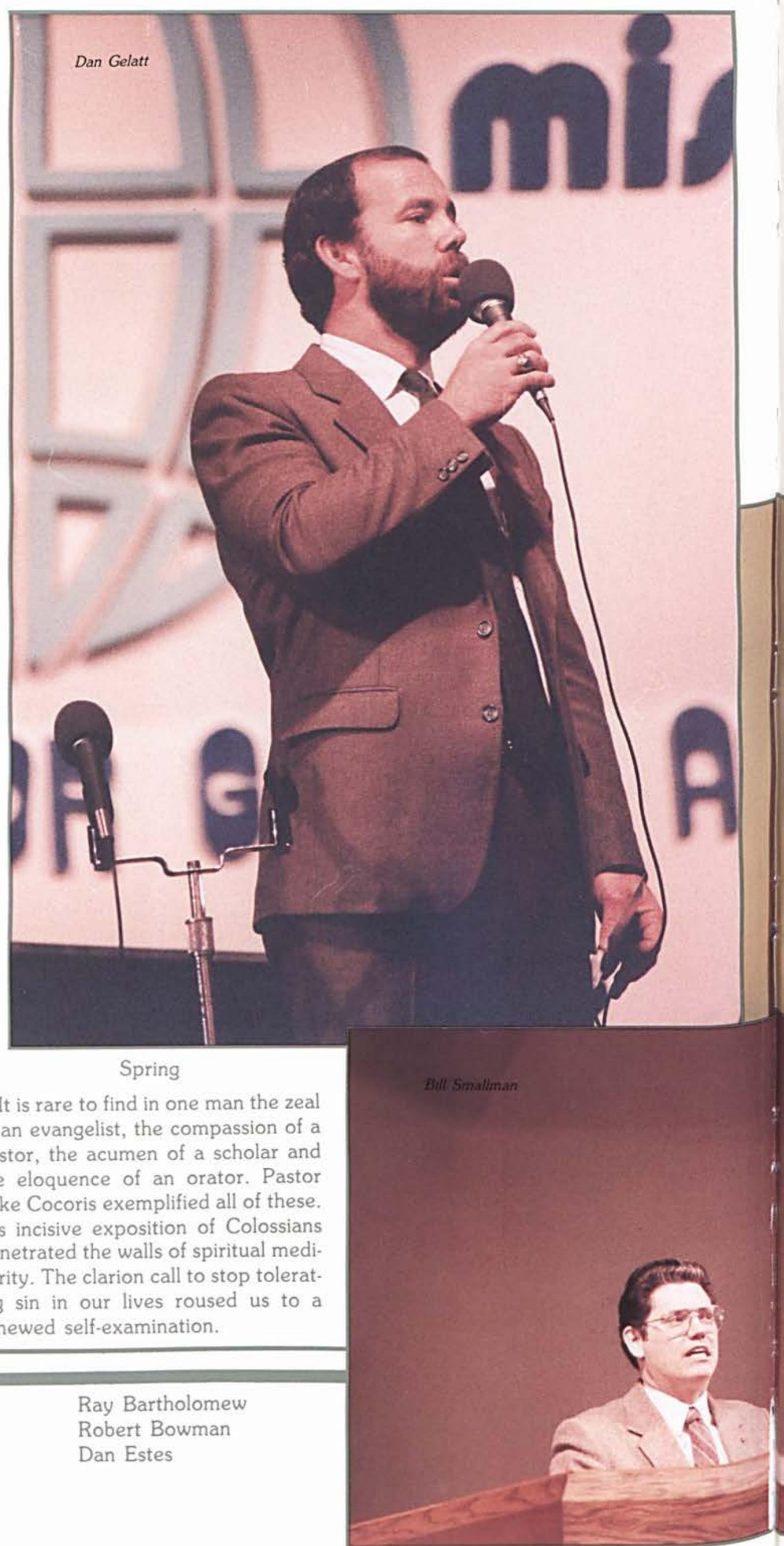




\section{CHAPEL MINISTRY}

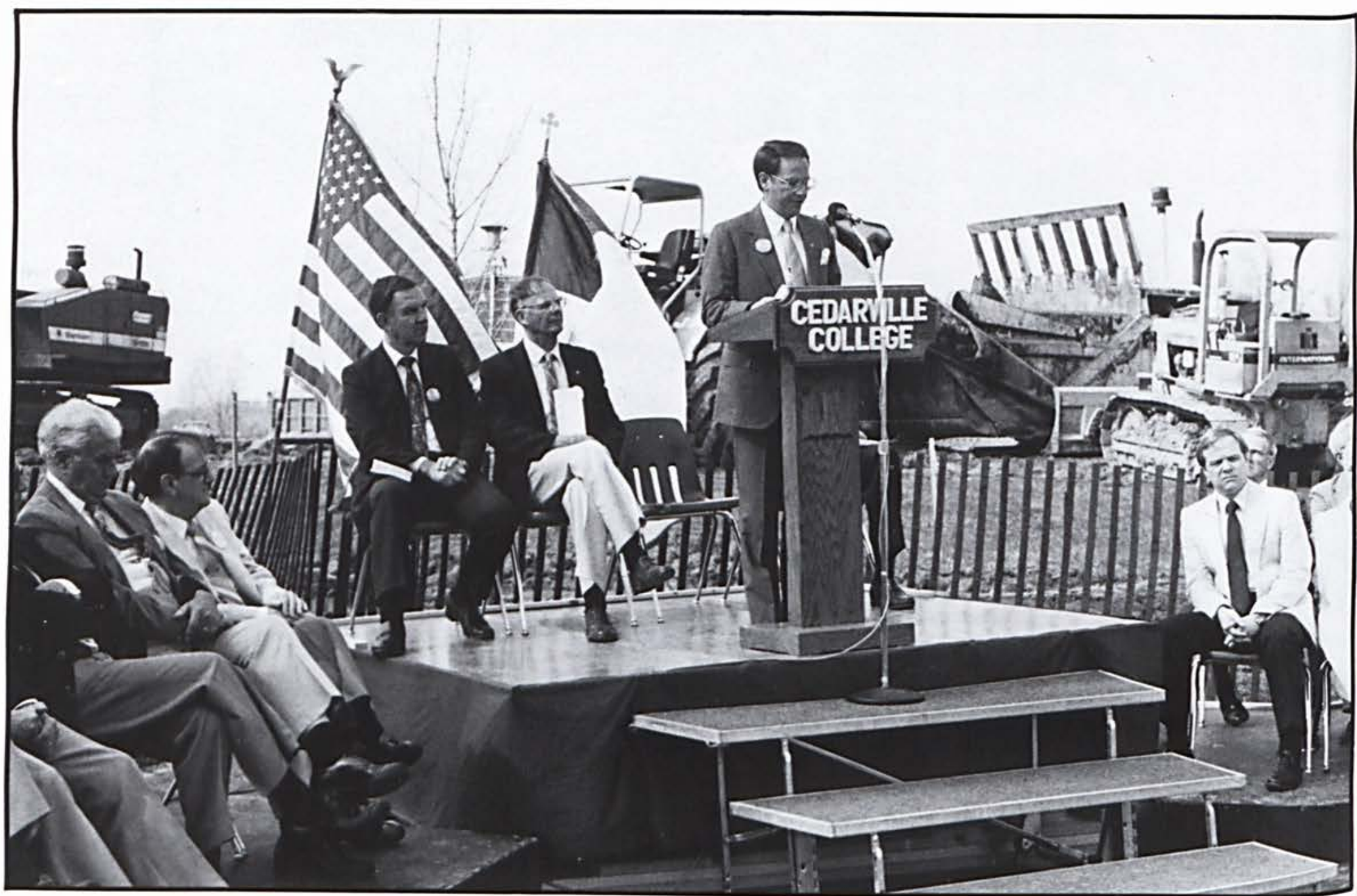

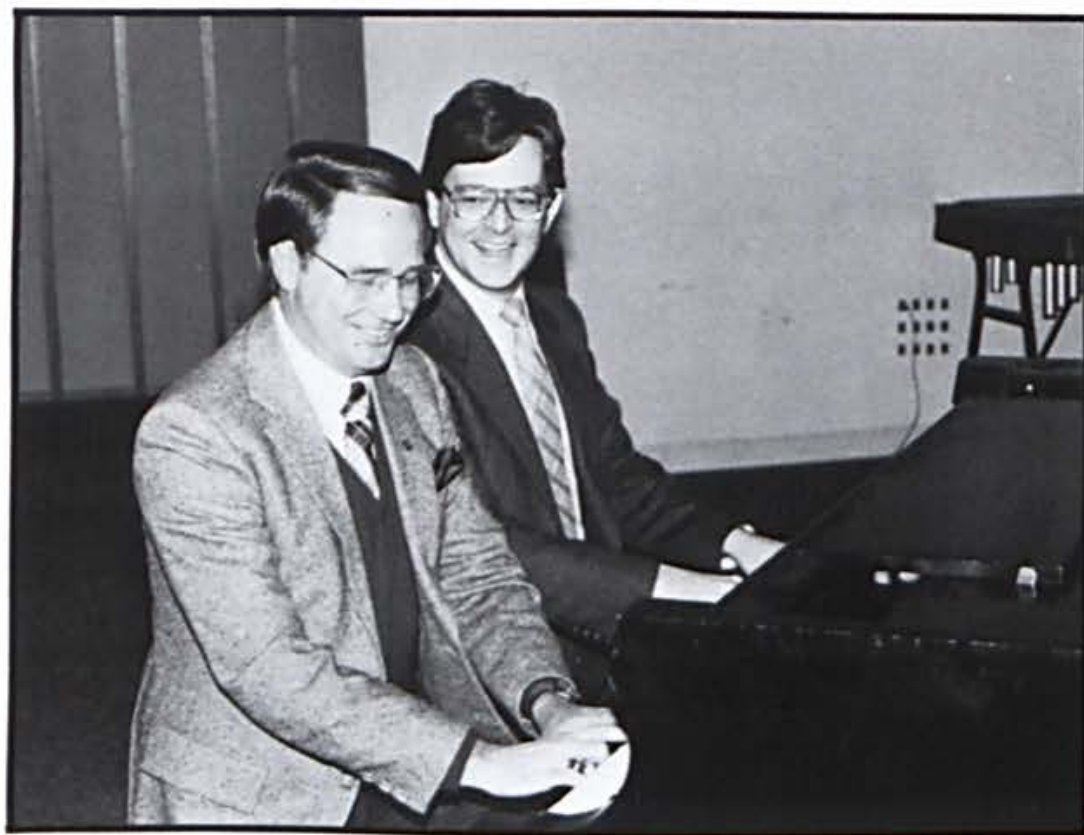

Top: $A$ very unique chapel service occurred in the spring quarter: the ground breaking of the new library. Above left: President Dixon made his piano debut with the help of Dr. Clevenger The President played to demonstrate and illus trate how the Master can enable. Right: Scott Schieferstein and Tina Skiver listened attentive. ly to the chapel message.

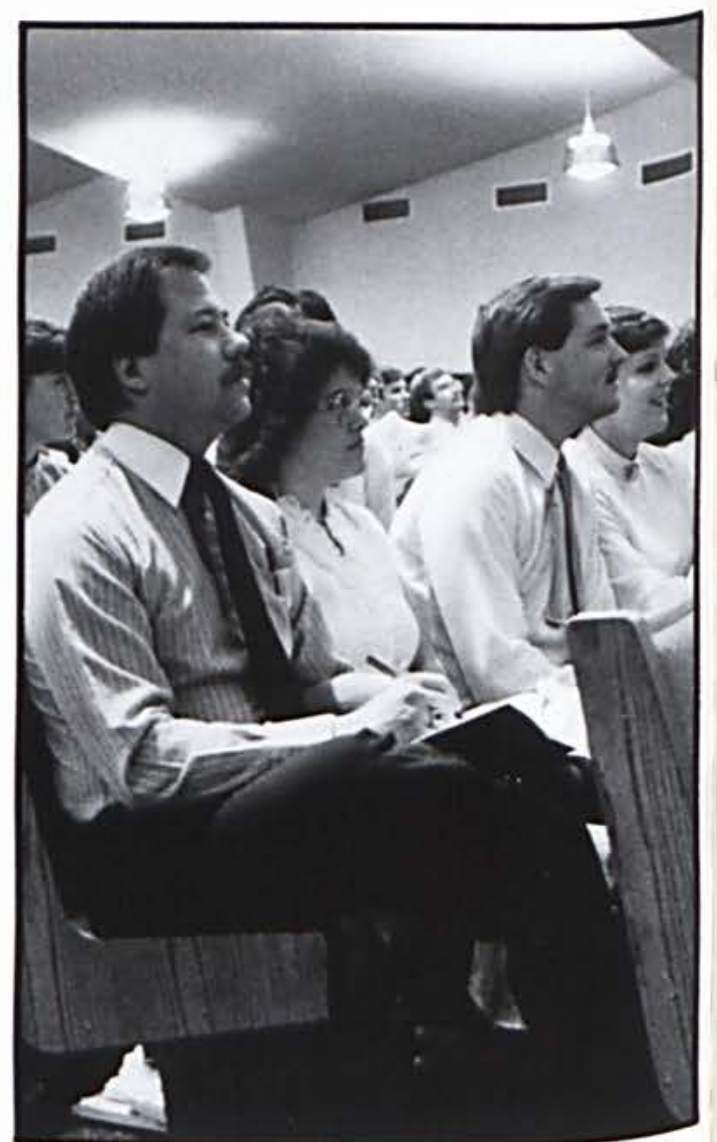




\section{Guest Speakers}
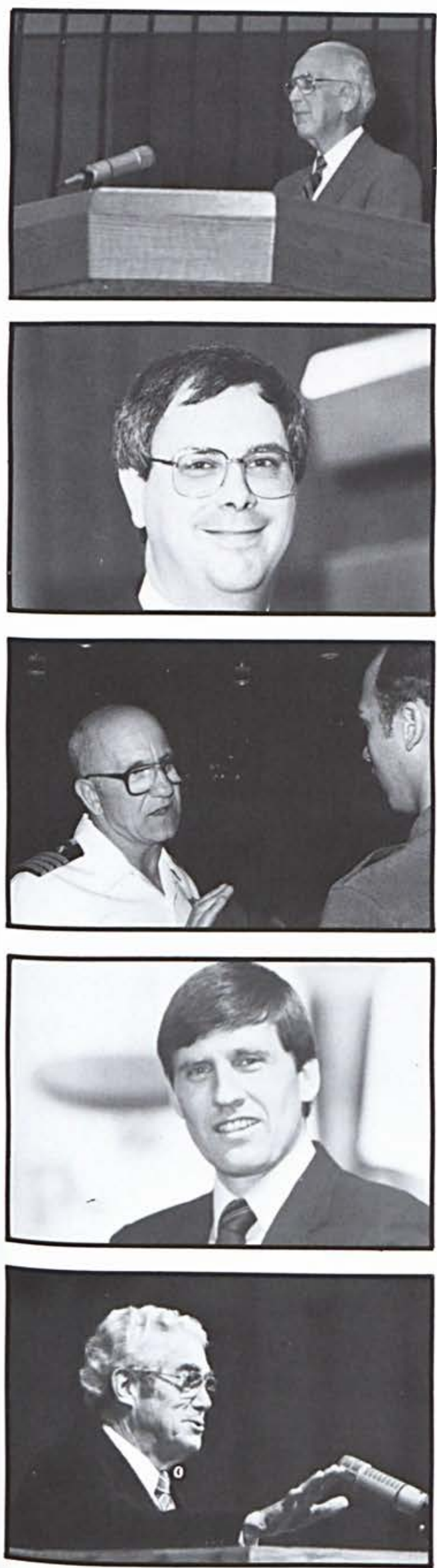

From top to bottom

Chancellor James T. Jeremiah

Mr. Ted Oakley. Principal and Alumnus

Capt. Jerry D. Moritz, Chaplain Corp, US Navy

Pastor Bruce McDonald, Alumnus

Mr. Jack Wyrtzen, Director of Word Life
0 than 300 songs were sung.

And a multitude of amens were given.

Chapel is the "heartbeat" of CC. Along with the students' favorite speaker, President Dixon, They heard a myriad of other expositors and motivators during their four years.

Long after June 7, ' 86 , has passed, many kernels of truth will continue to sprout, grow, and promote good works among obedient believers.

"Be done with lesser things ... serve the King of Kings." (Dave Breese)

"The only platform for our ministry is holiness." (Pastor Bruce Bickel)

"A person who chooses not to glorify God lives a life of insignificance, not significance." (President Dixon)

"Applied knowledge is power." (Dr. Hensley)

"Be patient and like it." (Pastor Mike Cocoris)

"Paul prayed that we'd be filled with the knowledge of God and that we'd walk worthy ... Pray this for one another." (Cocoris)

"People can change if they know the strength of redemption. (Pastor Wilbur Ellsworth)
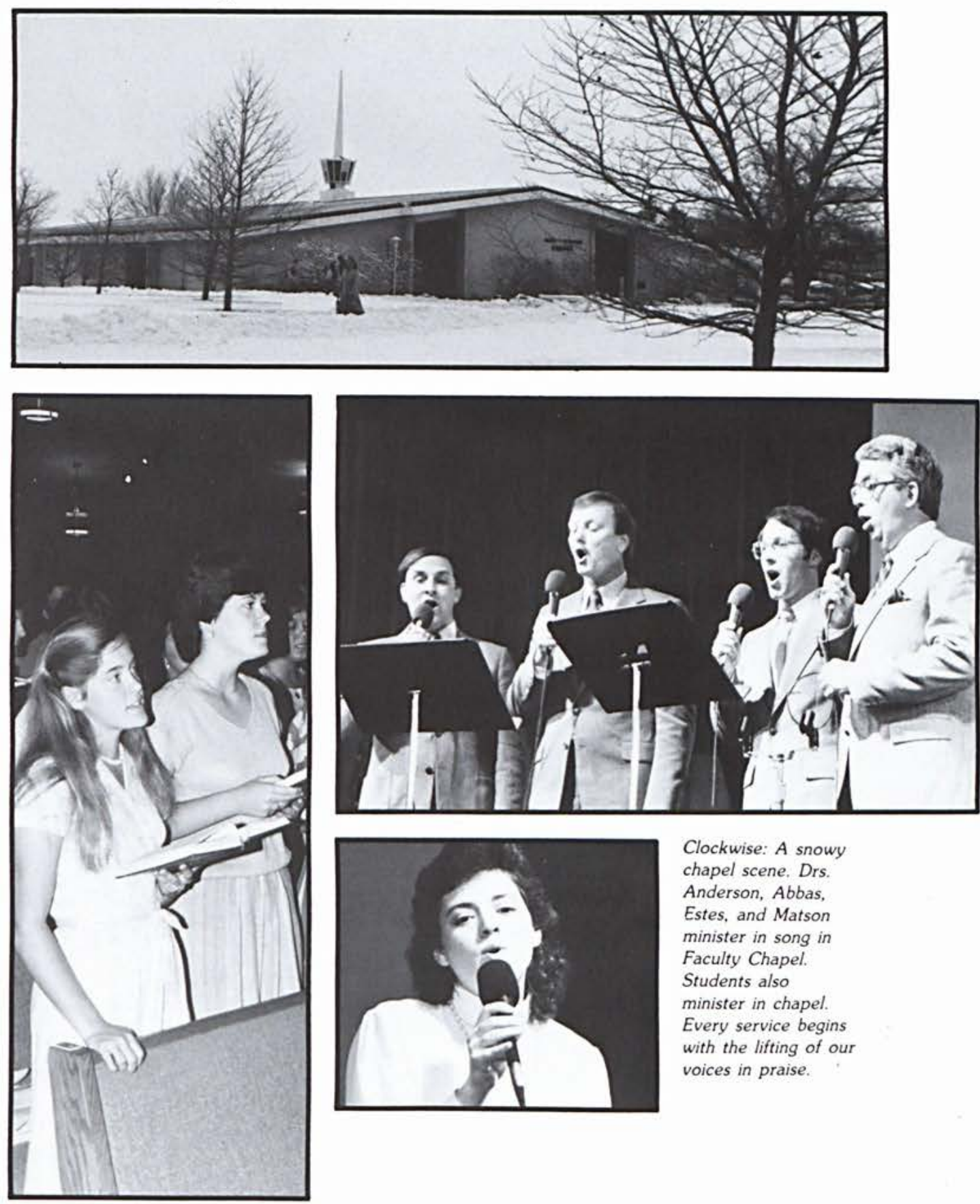

Clockwise: A snowy chapel scene. Drs. Anderson, Abbas, Estes, and Matson minister in song in Faculty Chapel.

Students also minister in chapel. Every service begins with the lifting of our voices in praise. 


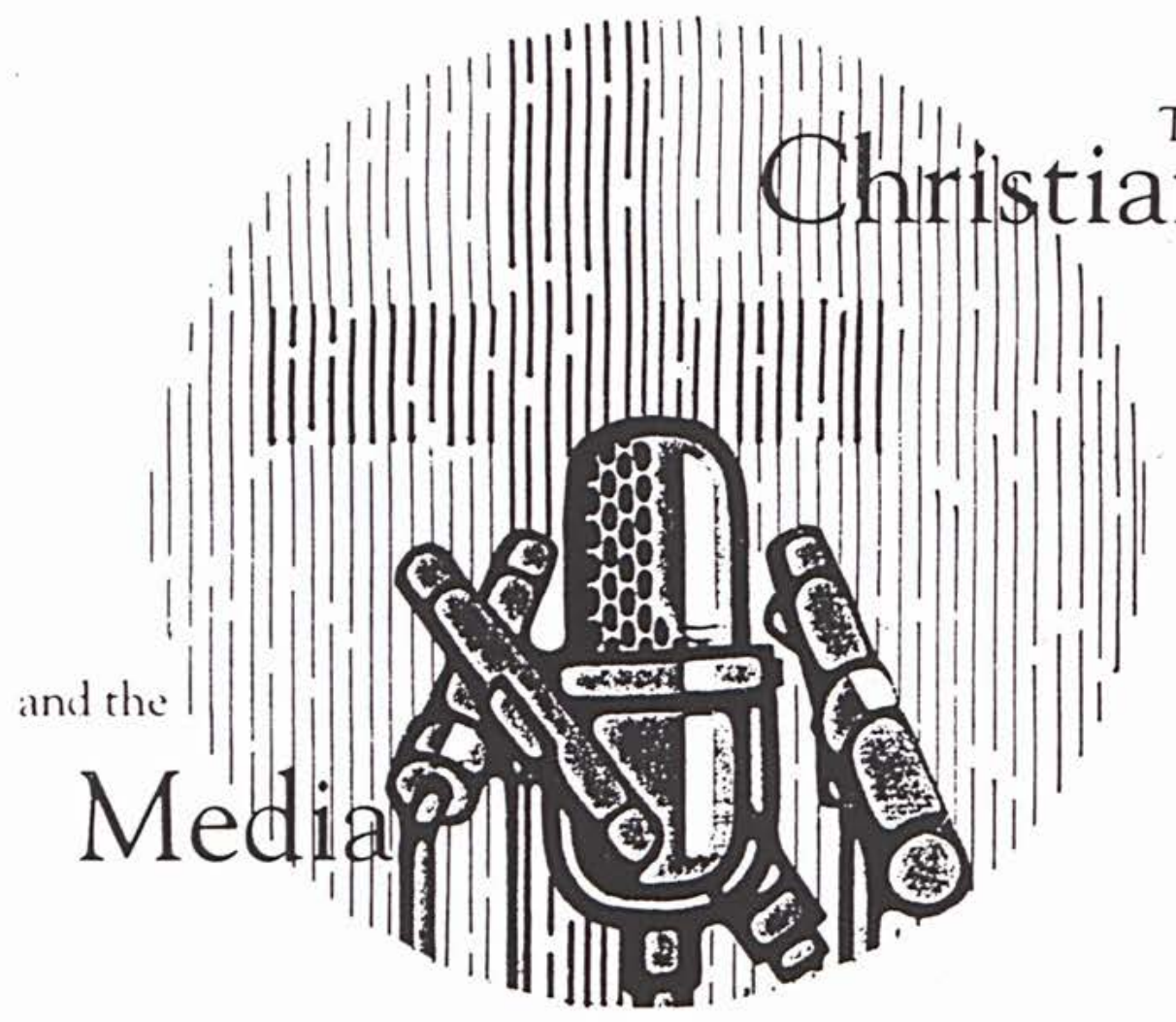

The

\section{From the Real to the Unreal World}

O

ne of the highlights of my presidency this year was organizing the Student Senate Inforum Series: "The Christian and the Media." Wes Baker, Assistant Professor of Communication Arts, opened the week by looking at the Christian media consumer. He was followed by John Rodman, a radio journalist from Boston's WEEI, who gave us a very practical look at a Christian involved in the media.

Cal Thomas, a syndicated columnist, wrapped up the week by challenging us. His impressive credentials and unique sense of humor allowed him to reinforce his message: Students should be salt in the "unreal world" as they leave the "Christian Ghetto."
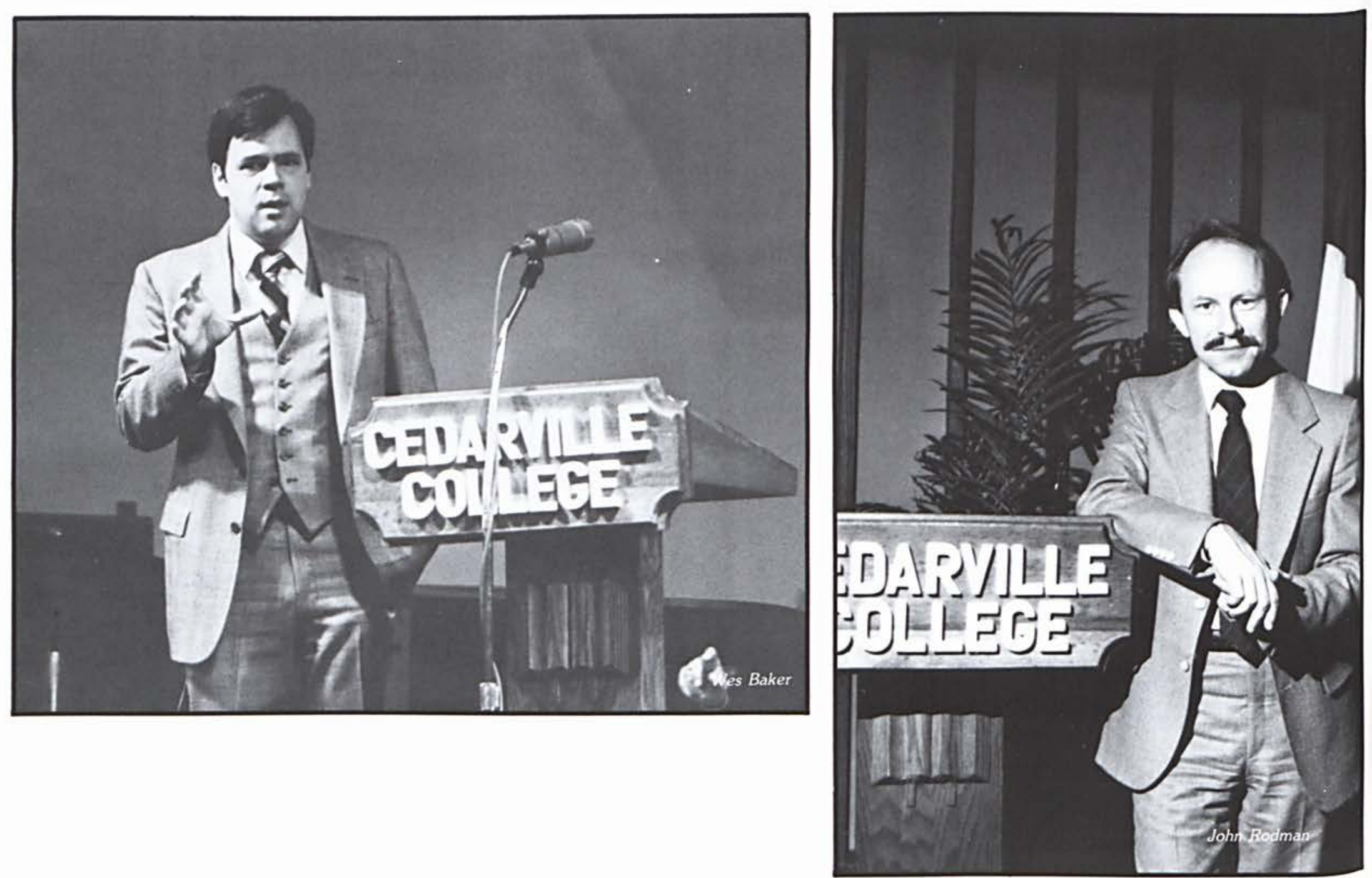

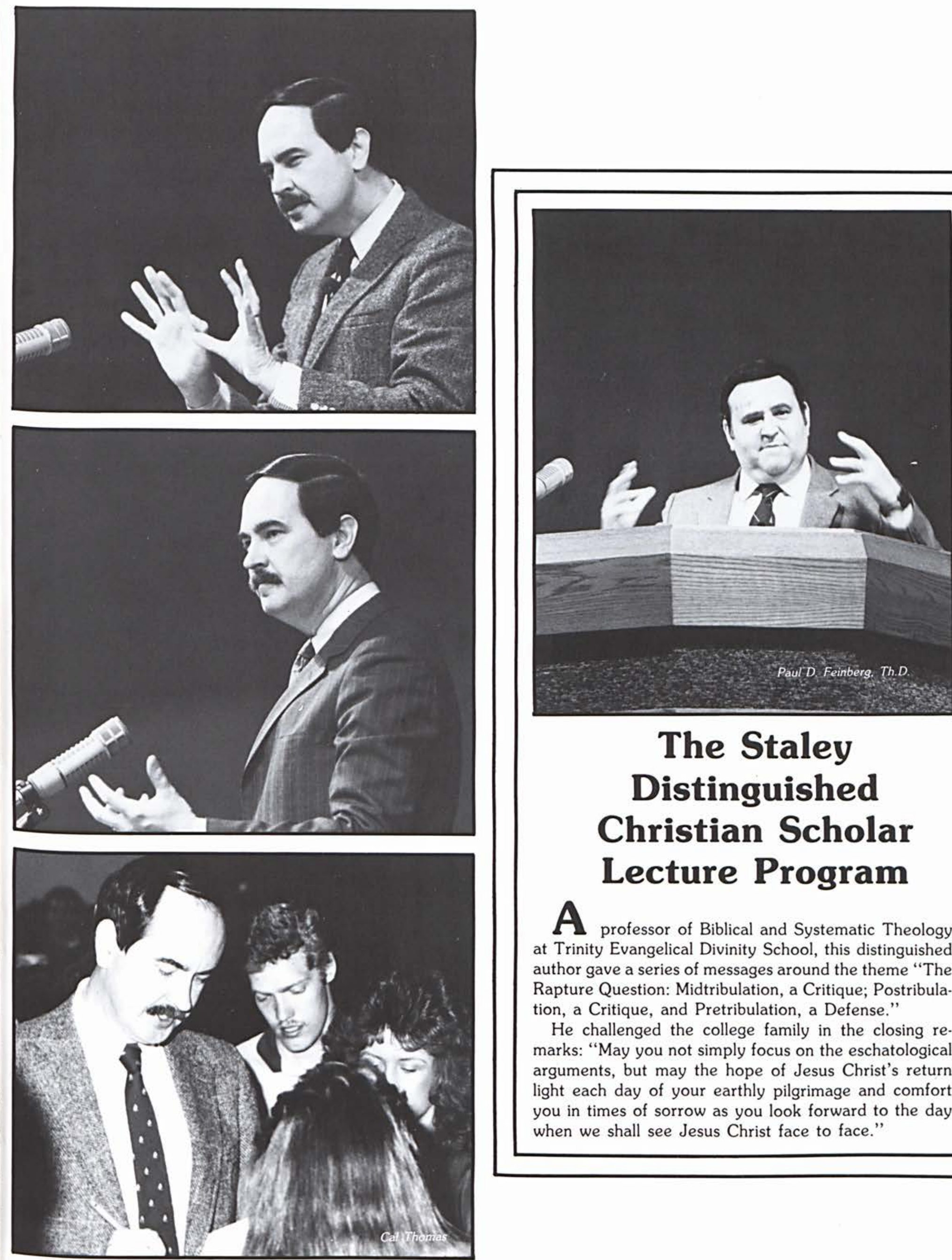

The Staley Distinguished Christian Scholar Lecture Program

A

professor of Biblical and Systematic Theology at Trinity Evangelical Divinity School, this distinguished author gave a series of messages around the theme "The Rapture Question: Midtribulation, a Critique; Postribula. tion, a Critique, and Pretribulation, a Defense."

He challenged the college family in the closing remarks: "May you not simply focus on the eschatological arguments, but may the hope of Jesus Christ's return light each day of your earthly pilgrimage and comfort you in times of sorrow as you look forward to the day when we shall see Jesus Christ face to face." 


\section{Christian Ministry Teams}
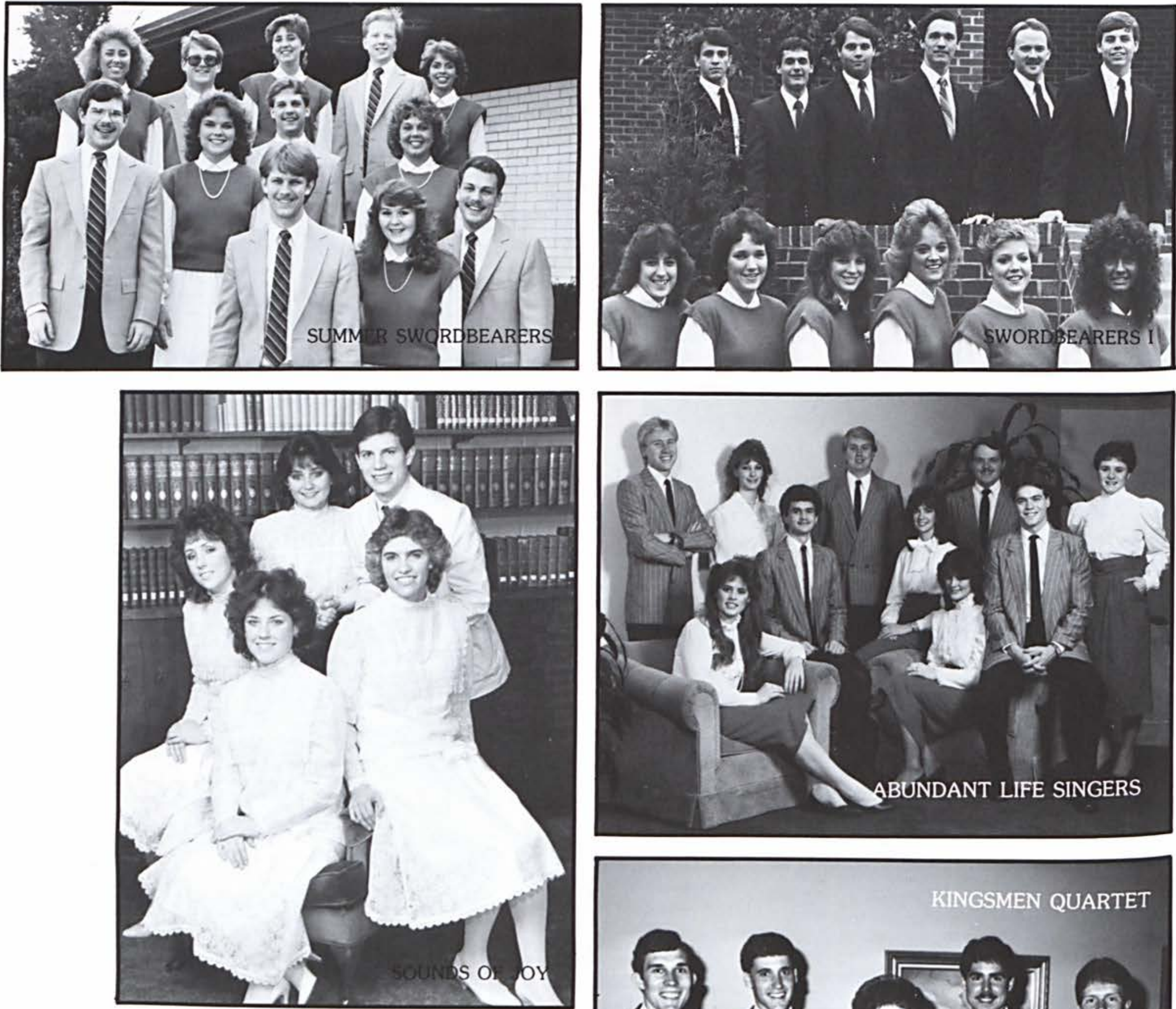

Summer Swordbearers: Karen Beattie, Steve Camp. bell, Stephen Gerhardt, Mark Hinman, Kendra King. Gina Long, Pat O'Donnell, Jody Peters, Renee Rolfe, Gayle Ruggles, Ron Smith, Kevin Tupps. The Sounds of Joy: Lisa Ford, Donna Ford, Janice Warren, Donna Payne, Will Marling. Swordbearers I: Diane Weaver, Brenda Sutliff, Donna Blumenstock, Lori Ottaway, Jen. nifer Haufler, Penny Dellinger, Jeff Vestrand, Paul Reid,
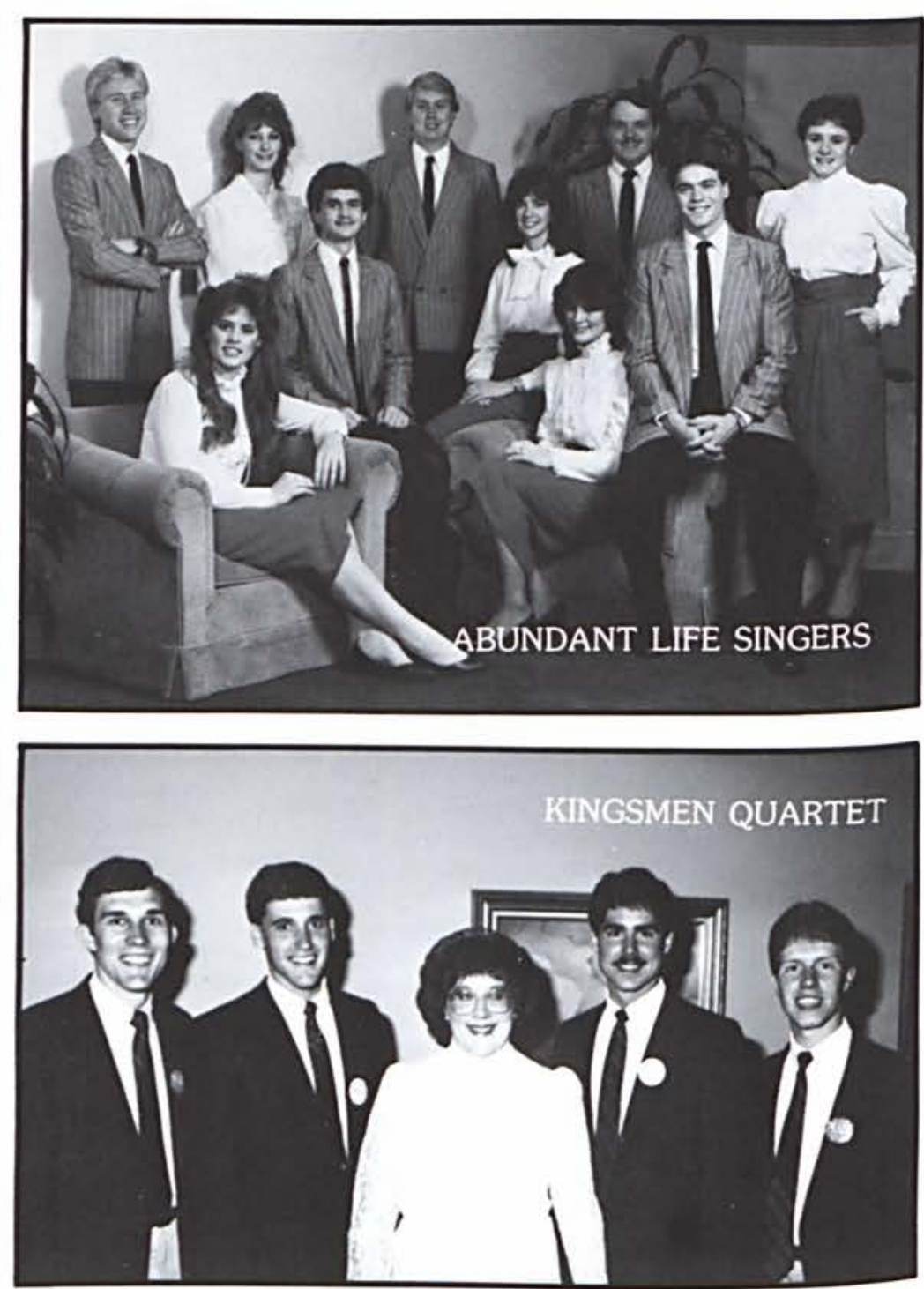
Danve Burk, Dave Frey, Dave Robinette, Keven Has.

kins. Kingsmen Quartet: Rich Smith, Alan McCain, Jeff Beste, Tim Beach, Judy Walter, Abundant Life: Cynthia Conrath, Clancy Cruise, Roger Foreman, Greg Frye, Pam Kenyon, Jeanne McCarrell, Jim Murdoch, Sheri Shuler, Andy Snider. 


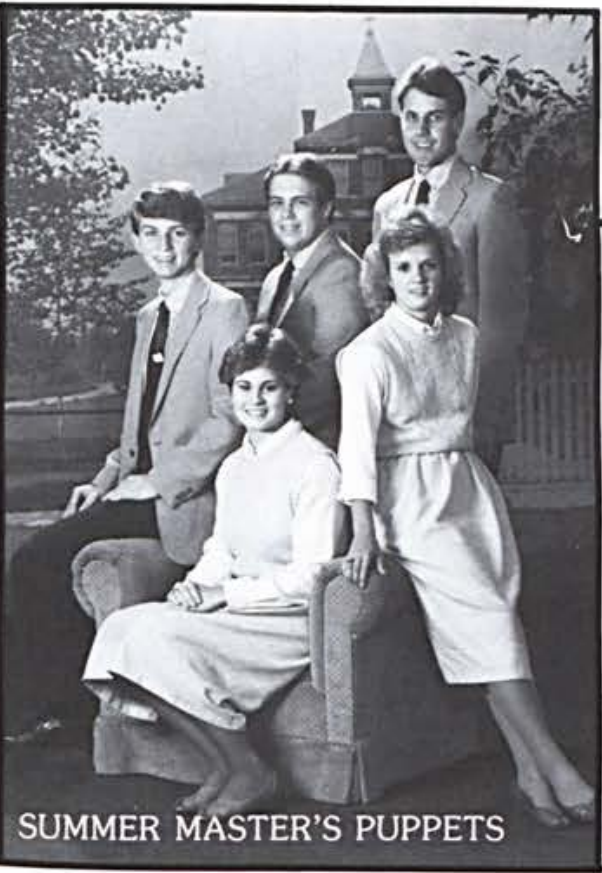

$\mathbf{E}$ dification of the local church is the chief purpose of the traveling teams at Cedarville College. The students involved also gain hands-on experience for when they leave Cedarville College campus and continue in the Lord's work in their own church.
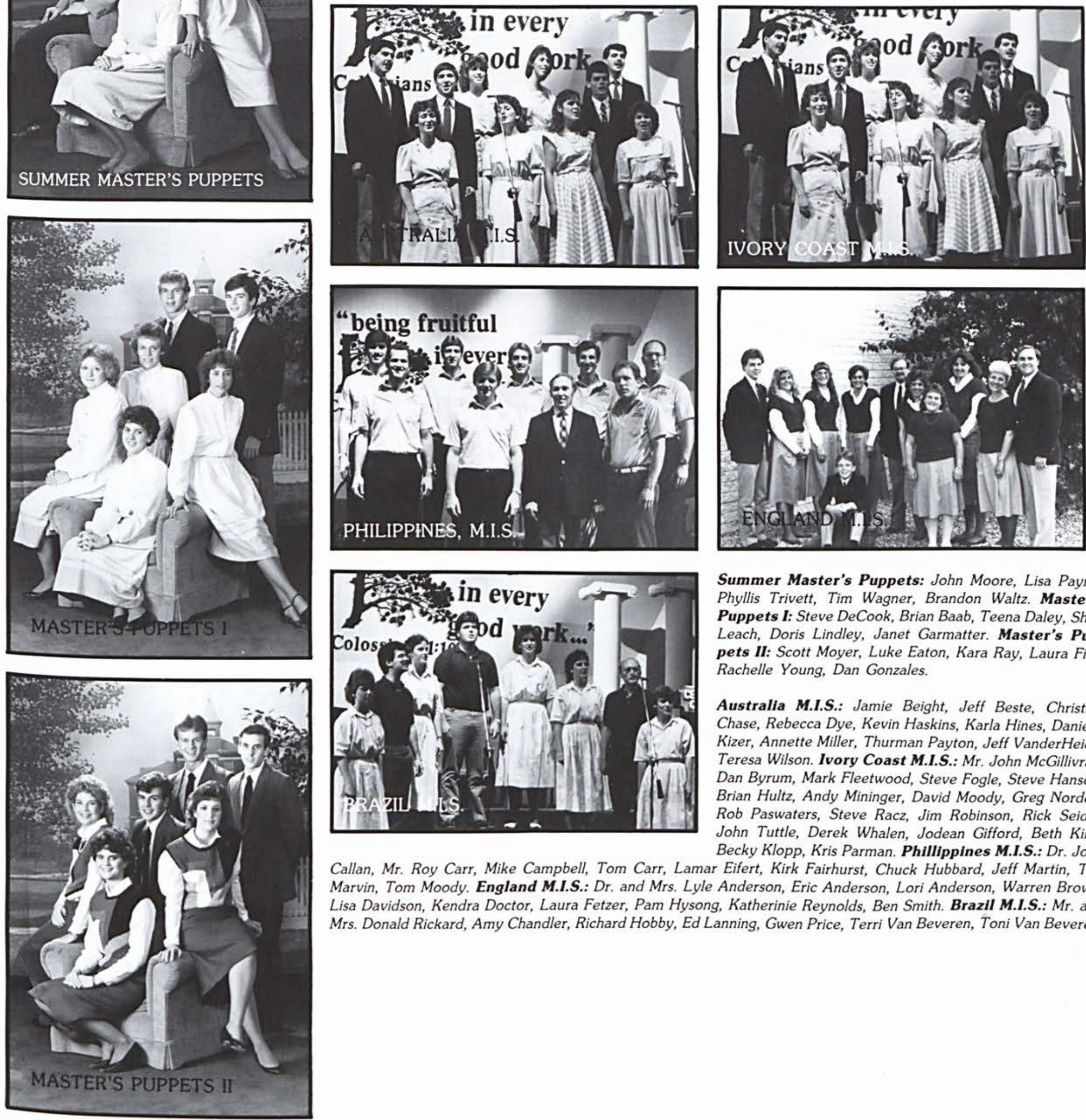

Summer Master's Puppets: John Moore, Lisa Payne, Phyllis Trivett, Tim Wagner, Brandon Waltz. Master's Puppets I: Steve DeCook, Brian Baab, Teena Daley, Shari Leach, Doris Lindley, Janet Garmatter. Master's Puppets II: Scott Moyer, Luke Eaton, Kara Ray, Laura Fish, Rachelle Young, Dan Gonzales.

Australla M.I.S.: Jamie Beight, Jeff Beste, Christina Chase, Rebecca Dye, Kevin Haskins, Karla Hines, Danielle Kizer, Annette Miller, Thurman Payton, Jeff VanderHeide, Teresa Wilson. Ivory Coast M.I.S.: Mr. John McGillivray, Dan Byrum, Mark Fleetwood, Steve Fogle, Steve Hanson, Brian Hultz, Andy Mininger, David Moody, Greg Norden, Rob Paswaters, Steve Racz, Jim Robinson, Rick Seidel, John Tuttle, Derek Whalen, Jodean Gifford, Beth King, Becky Klopp, Kris Parman. Phillippines M.I.S.: Dr. John Callan, Mr. Roy Carr, Mike Campbell, Tom Carr, Lamar Eifert, Kirk Fairhurst, Chuck Hubbard, Jeff Martin, Tod Marvin, Tom Moody. England M.I.S.: Dr. and Mrs. Lyle Anderson, Eric Anderson, Lori Anderson, Warren Brown, Lisa Davidson, Kendra Doctor, Laura Fetzer, Pam Hysong, Katherinie Reynolds, Ben Smith. Brazil M.I.S.: Mr. and Mrs. Donald Rickard, Amy Chandler, Richard Hobby, Ed Lanning, Gwen Price, Terri Van Beveren, Toni Van Beveren. 


\section{Christian Ministries}

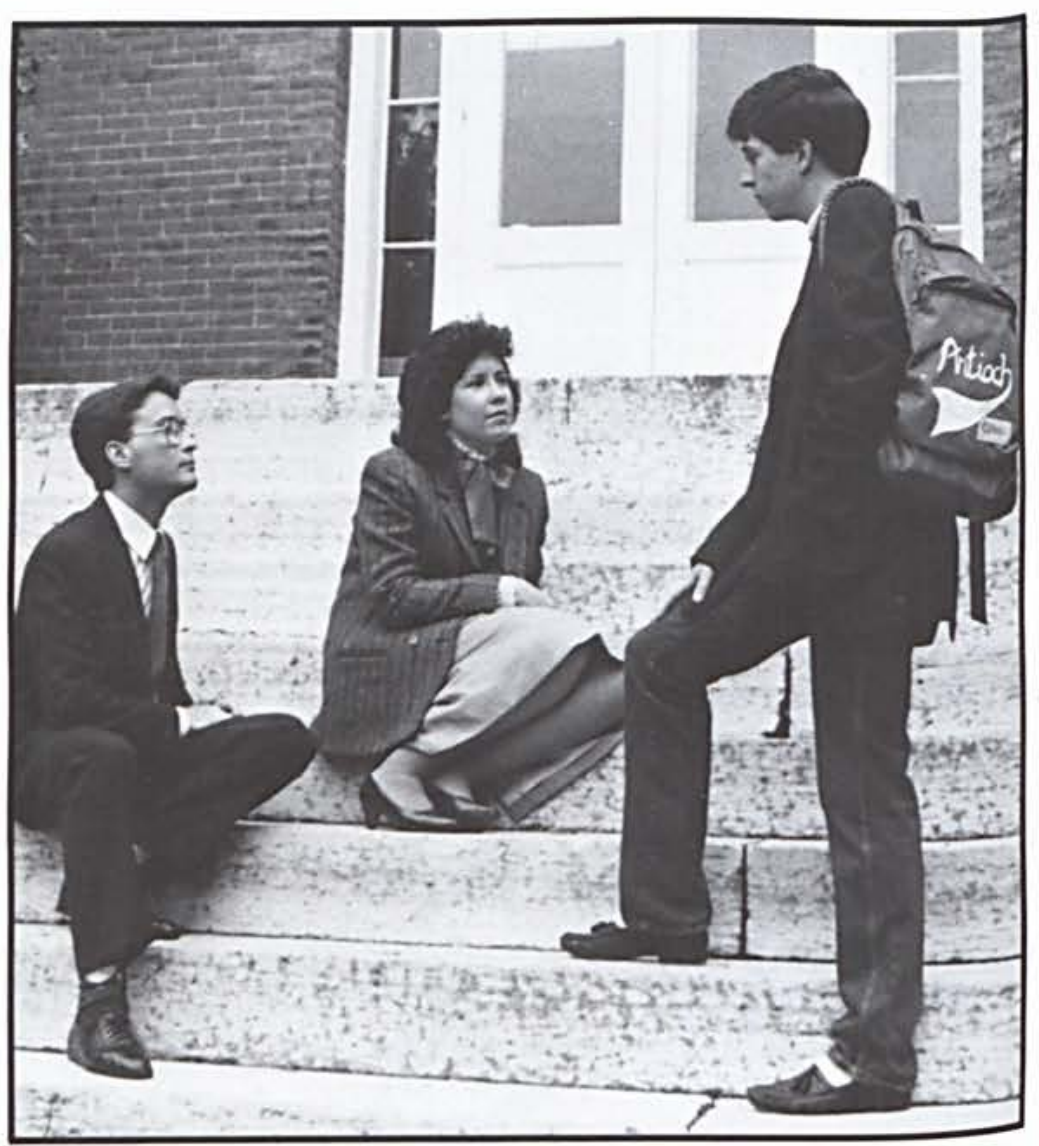

Antioch Interaction serves God by establishing friendships with college students from Antioch College thru discussions, forums, and activities in the hope that both representative groups from the colleges will learn more about Him. Cedar Cliff Elderly Housing serves God by investing time in the lives of the elderly through visitation and Bible study.

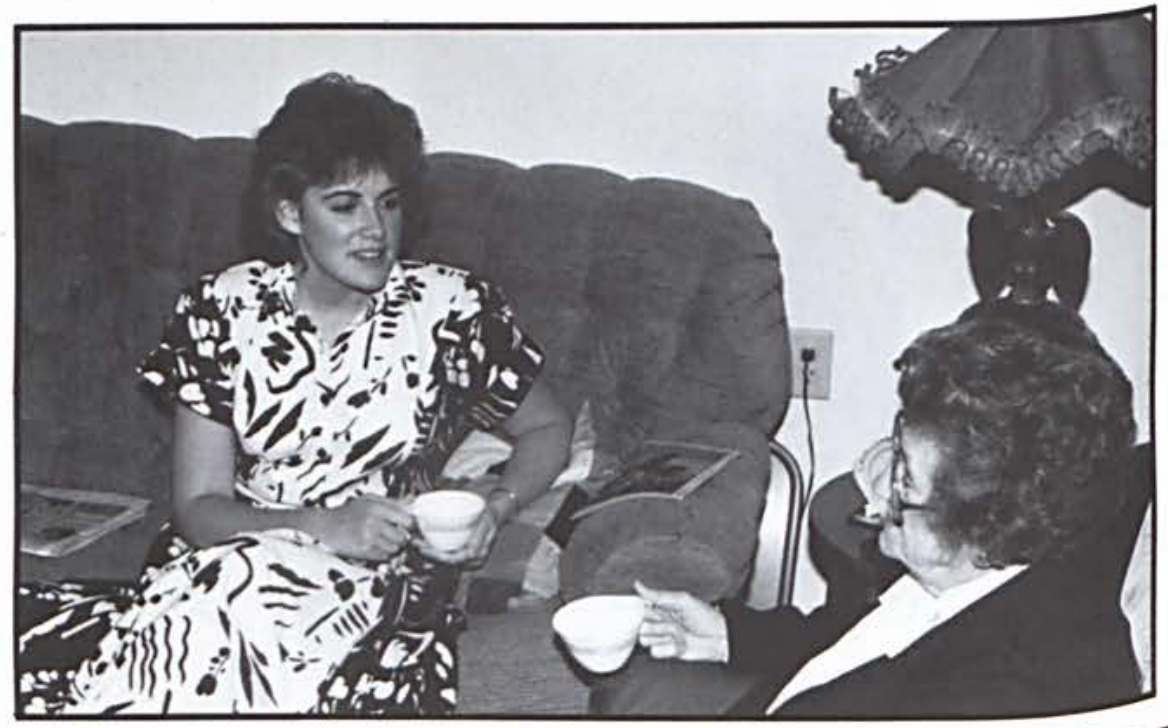

ANTIOCH COLLEGE INTERACTION:

Front: Liana Smith, Becky Sinclair, Lynne Bartlett. Second: Holly Mar

Front: Liana Smith, Becky Sinclair, Lynne Bartlett.
shall, Rachel Wilson, Karen Clifford, Scott Margan.

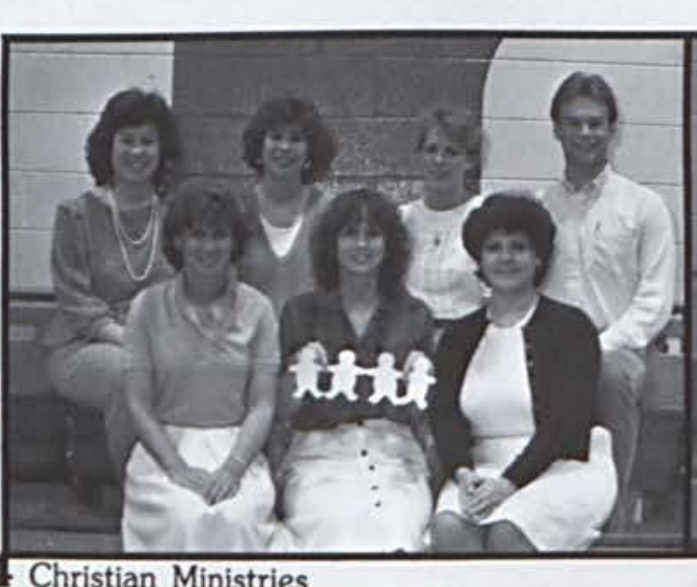

BETHESDA REHABILITATION CENTER:

Front: Linda Curtis, Second: Rob Broline, Tom Fite. Third: Molly Williams.

Rick Seidel, Andy Mininger, Diane Noggle.
CEDAR CLIFF ELDERLY HOUSING:

Front: Noel Hack Kimberly Moroan, Doren Tucker Second: Derek Whalen.

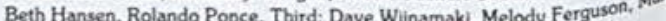
Chitwood.

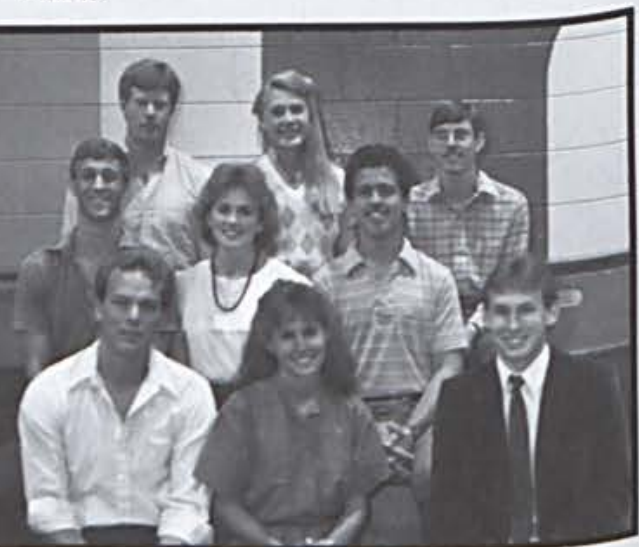



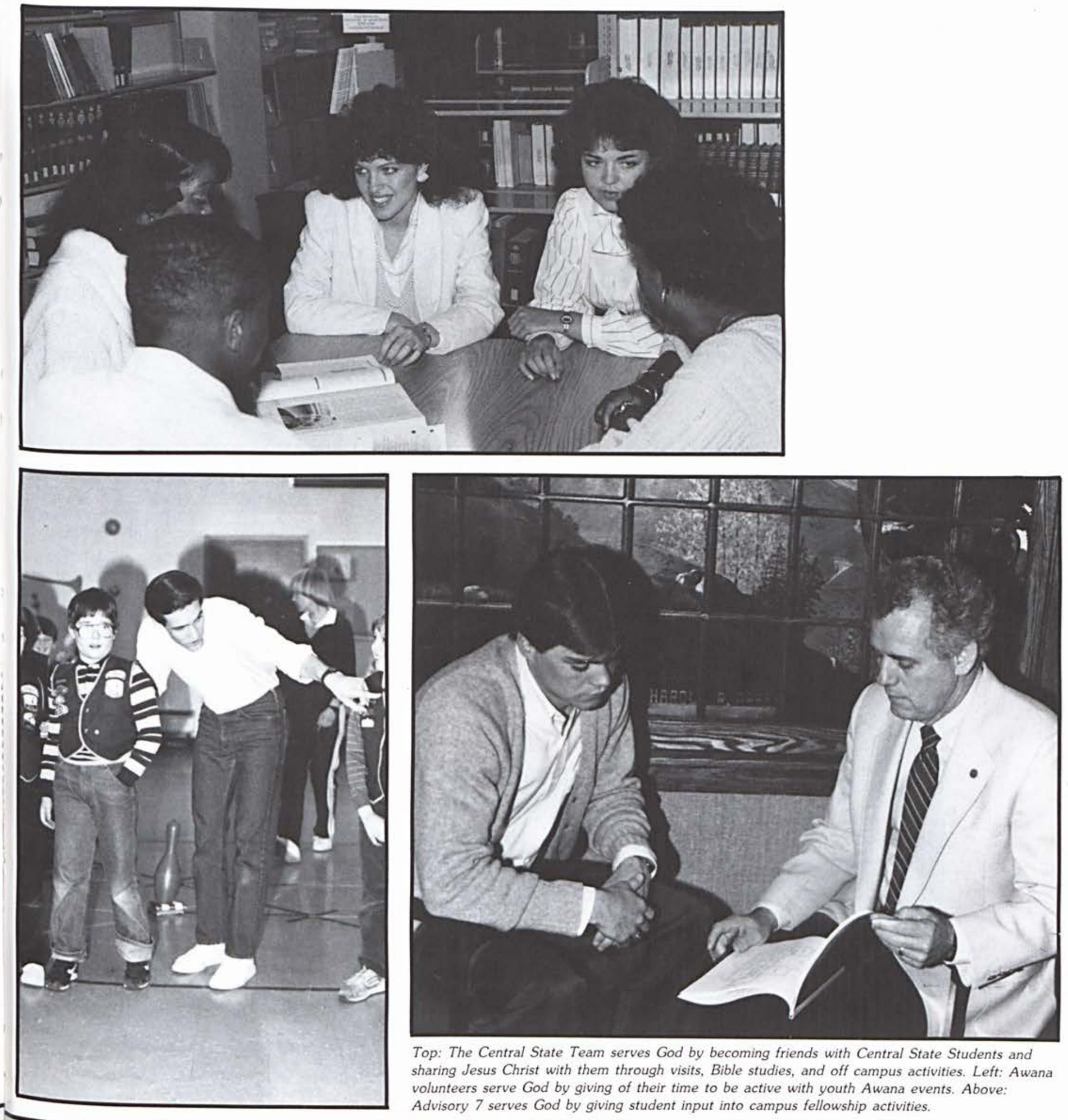

Top: The Central State Team serves God by becoming friends with Central State Students and sharing Jesus Christ with them through visits, Bible studies, and off campus activities. Left: Awana volunteers serve God by giving of their time to be active with youth Awana events. Above: Advisory 7 serves God by giving student input into campus fellowship activities.

CENTRAL STATE CAMPUS EVANGELISM:

Front: Tracy McCoy, Ebbie Radcliff, Joan Rattew, Debra Mowrey.

Second: Shelley Tarke, Carla Curry, Van Holloway, Chris Hoefler.
CINCINNATI RESCUE MISSION:

Front: Mary McVey, Sandra Kennedy, Second: Mark Fairhurst

\section{DAYTON DETENTION HOME:}

Front: Lorrie Byrd, Laurie Knowles, Matt Dickinson, Gayle Ruggles, Erin Coffman, Second: James Beight, Patrick O'donnell, Lamar Elfert, Paul

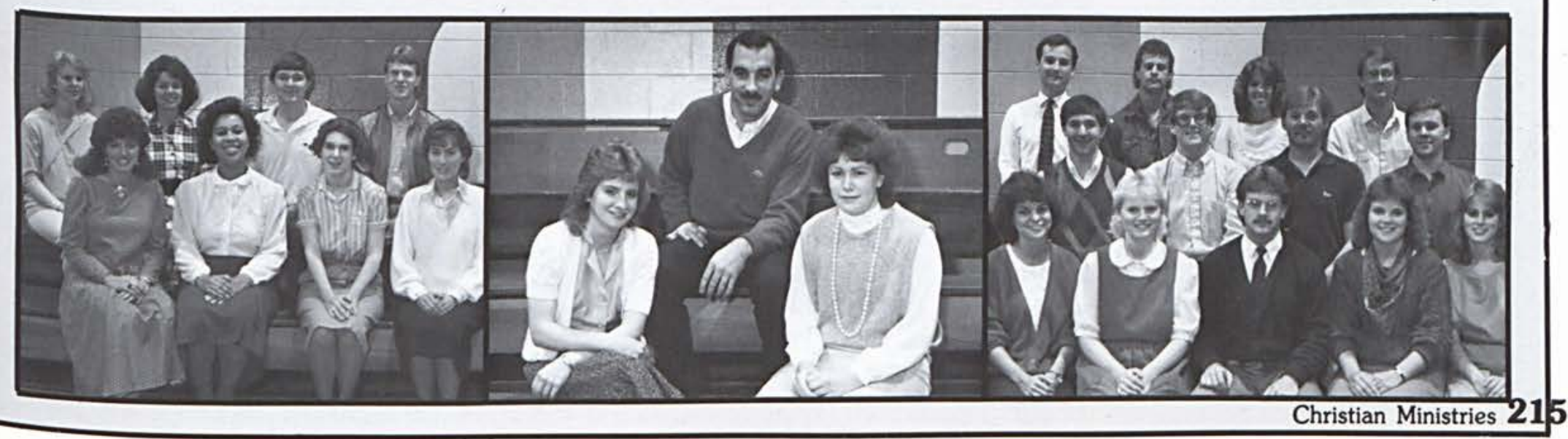




\section{Christian Ministries}

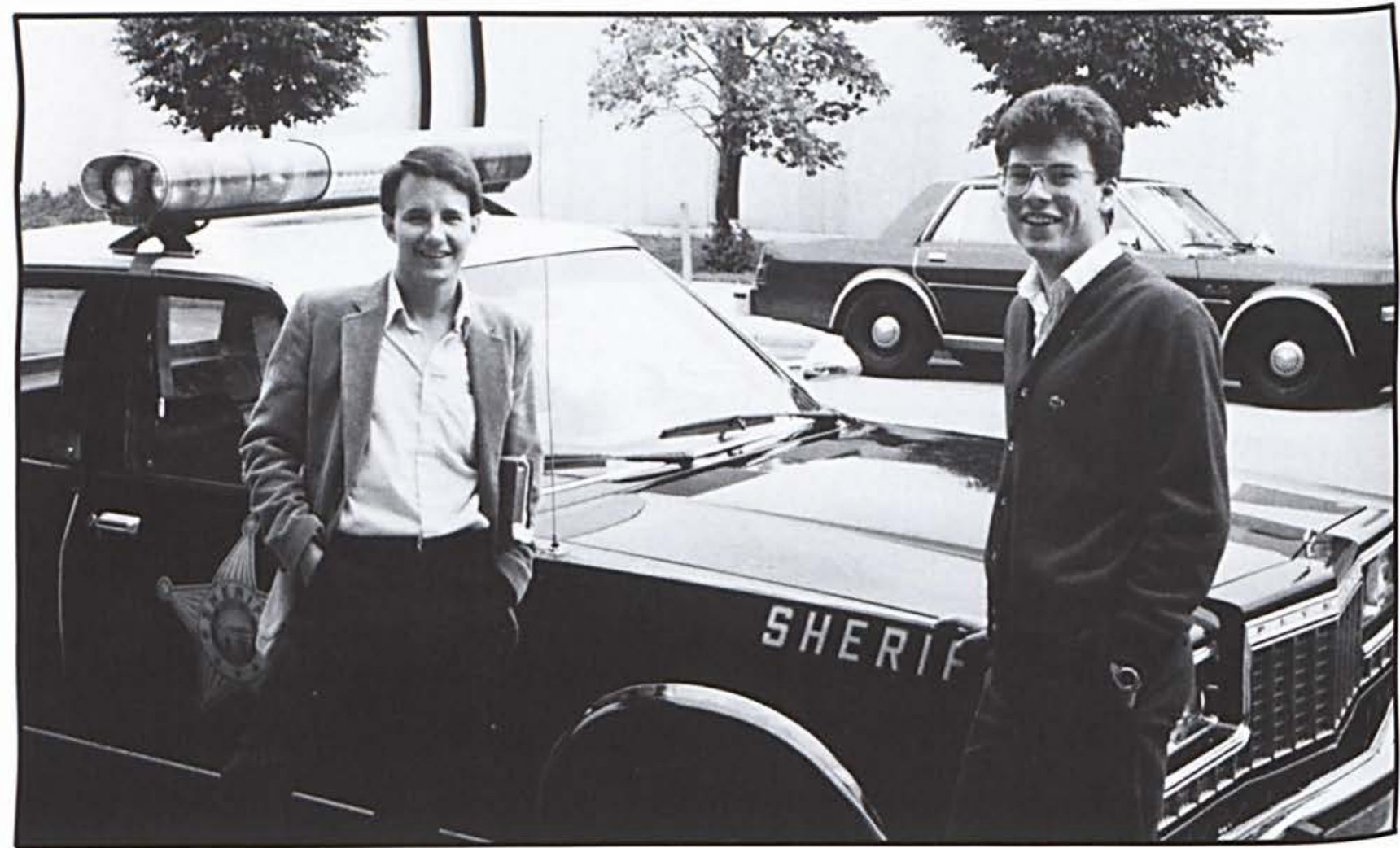

Above: Members of the Greene County Jail team serve God by building friendships and witnessing to inmates through visitation and correspondence. Right: F.W.M. (Fellowship of World Missions) serves God' by increasing awareness of world wide missions by promoting student involvement and supporting missionaries in prayer.
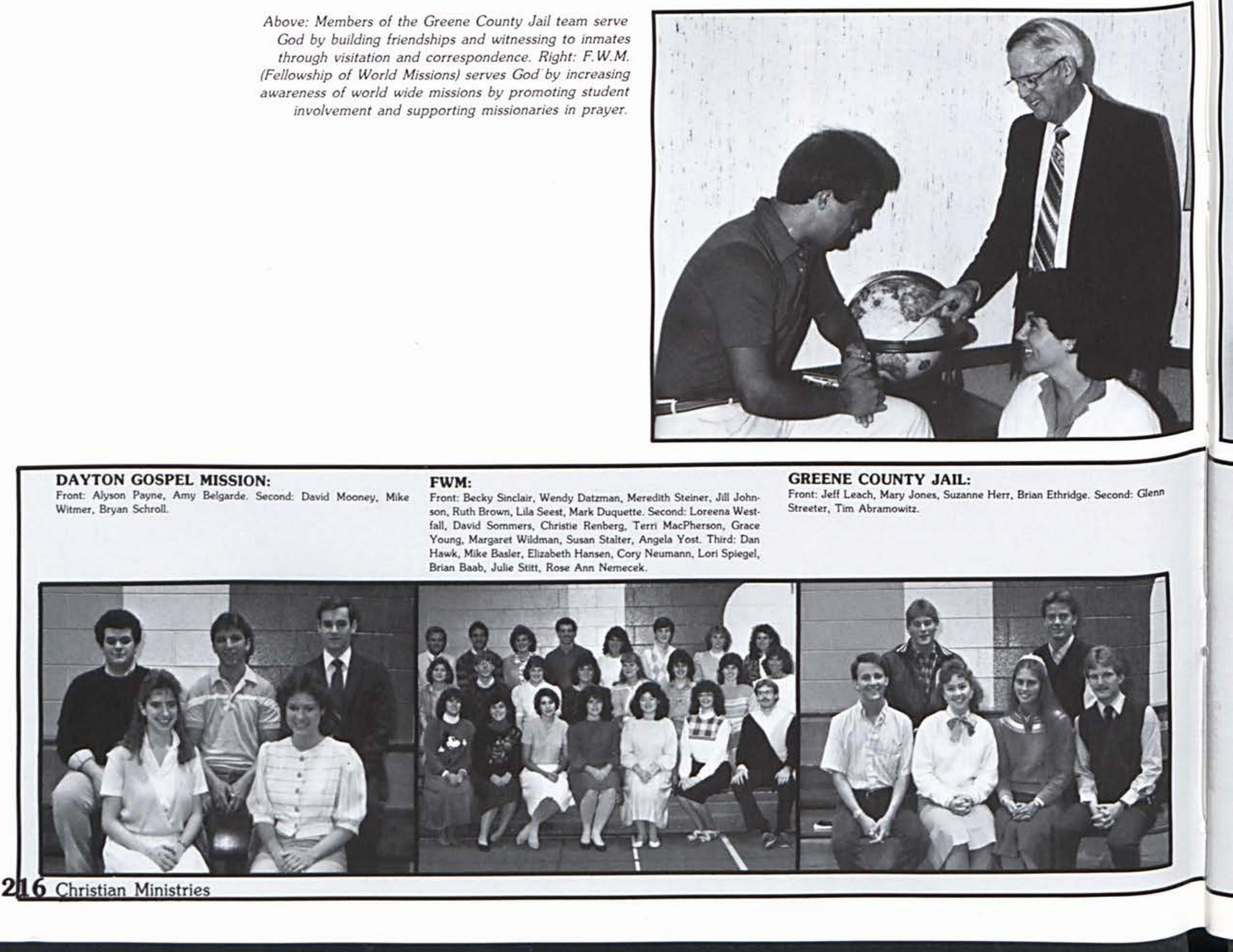

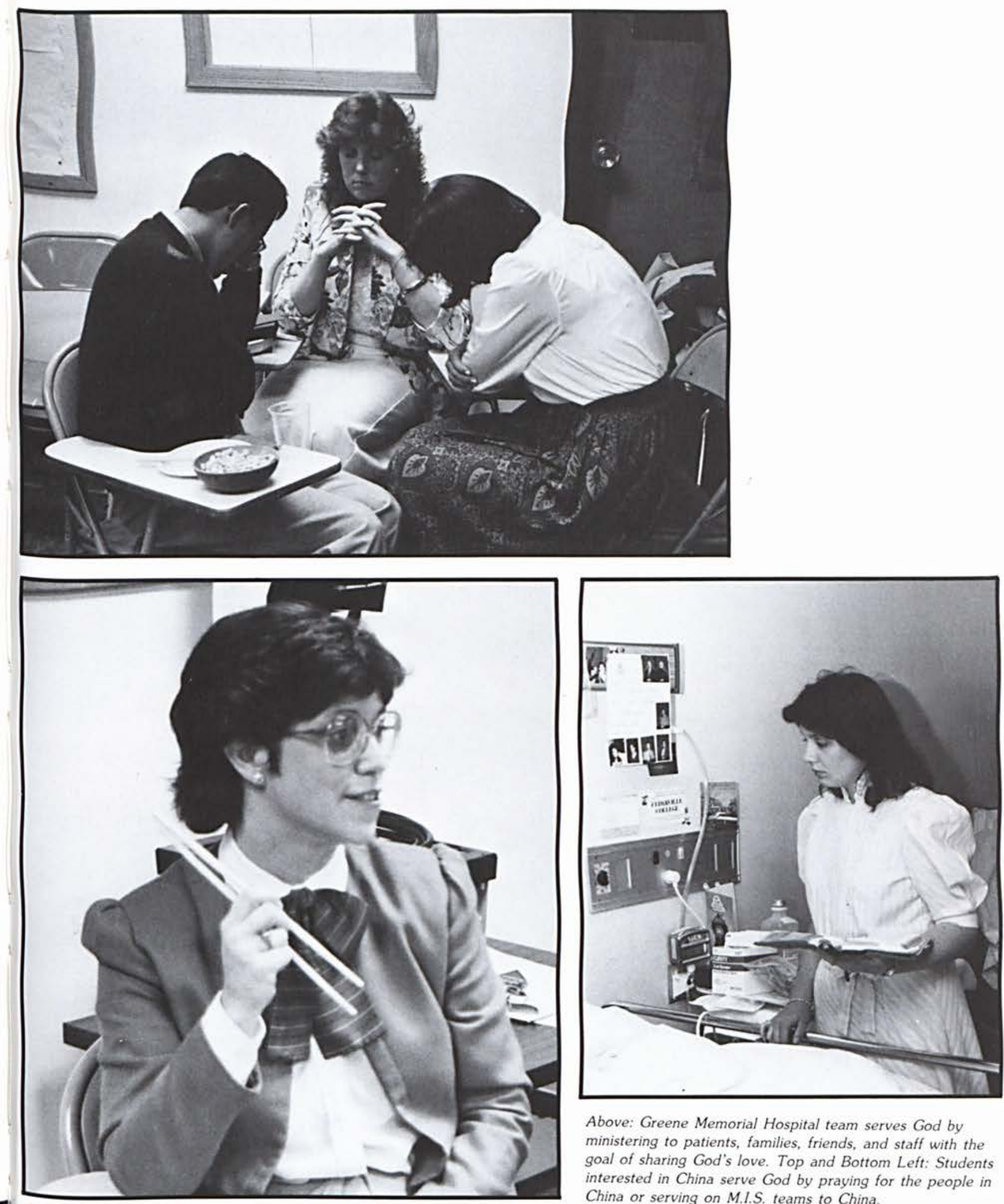

Above: Greene Memorial Hospital team serves God by

ministering to patients, families, friends, and staff with the goal of sharing God's love. Top and Bottom Left: Students interested in China serve God by praying for the people in China or serving on M.I.S. teams to China.

\section{GREENE MEMORIAL HOSPITAL:}

Front: Shelly Payne, Ruth Morris, Tammy Noell, Lisa Herroon. Second: Christie Renberg, Mitzi Vanderberg. Sherri Hannay, Teena Schneider. Tedd Cassidy. Marc Donawa, Paul Hamlin, Pamela Conrad.
GREENEWOOD MANOR NURSING HOME:

Front: Bruce McNabb, Judi Bianco, Bill Bianco, Sally Cochran. Sec-

field, Gretchen Hoffmeyer, Doug Phillips, Cliff Mast.

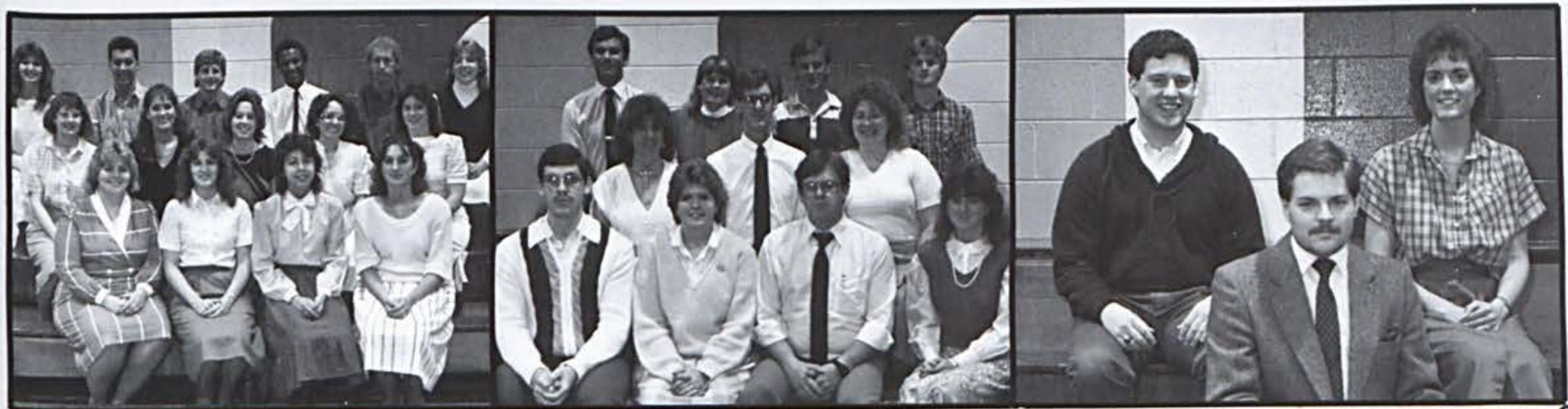




\section{Christian Ministries}

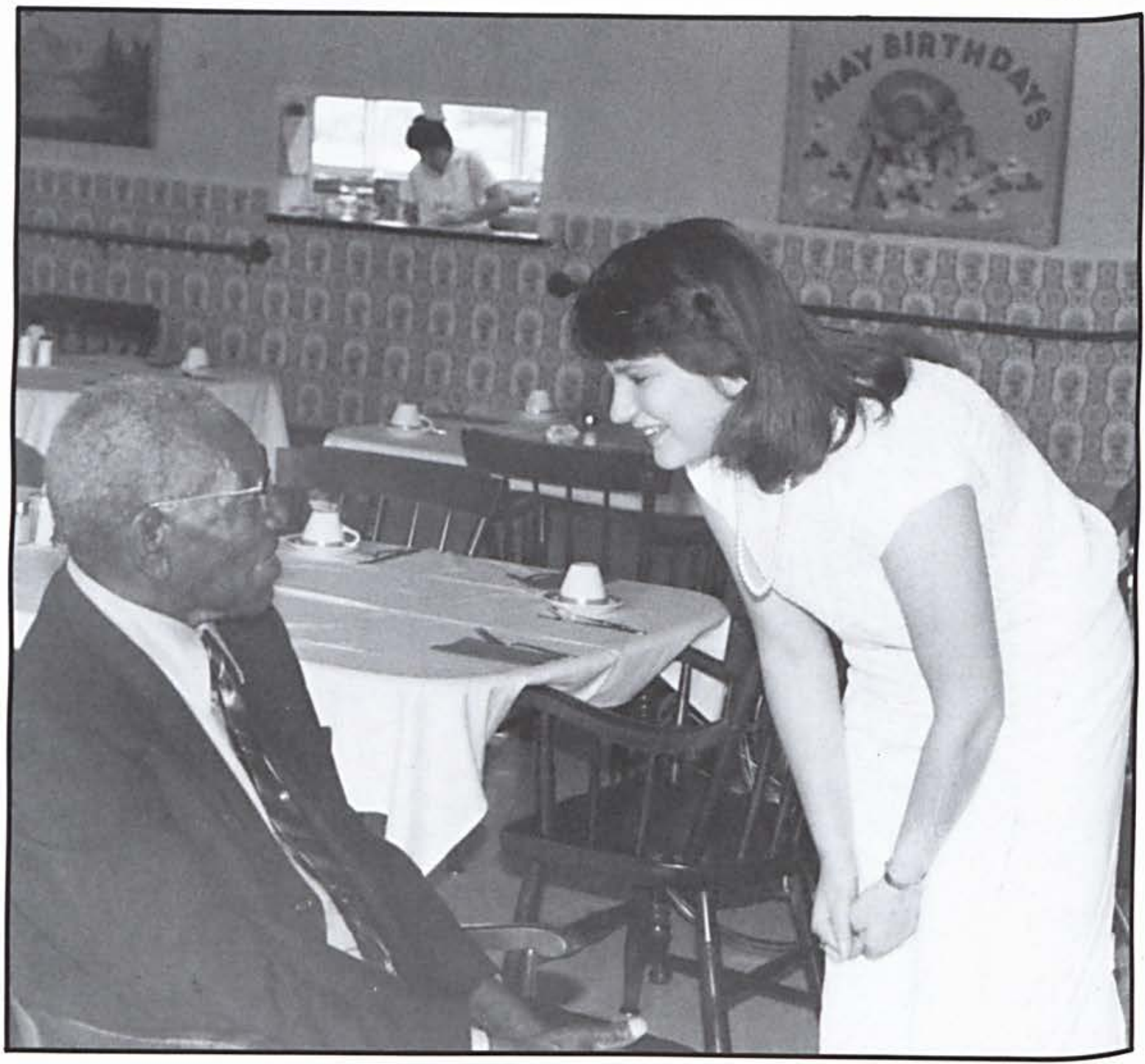

HEATHERGREENE I:

Front: Terri Husband, Corrine Hornbacher. Second: Dave Douglas, Brian

Popenfoose,
HEATHERGREENE II:

Front: Chad Bressen, Shannon Saunders, Angela Wright, Debble Clem, Ann Hauck. Second: Melissa Windish, Kristin Stagg. Angie Ledford, Kristine Watson, Kendra Doctor, Laura Walker. Sharon Tinkler. Third: Lynne Sickau, Brad Bressen, Steve Moyer, Susan Moyer, Janie Bressen, Mark Mitchell,
HOSPITALITY HOMES EAST AND WEST:

Front: Sandra Hudon, Martha Buck, Beth Zeck, Julie Box, Second: Brian Roget, Kirt Wilson, Joanie Hull, Liss Chandler, Jill Swayze. Third: Dan Byrum, Tim Brock, Jeff Marble, Mark McClain.

\section{(2)}

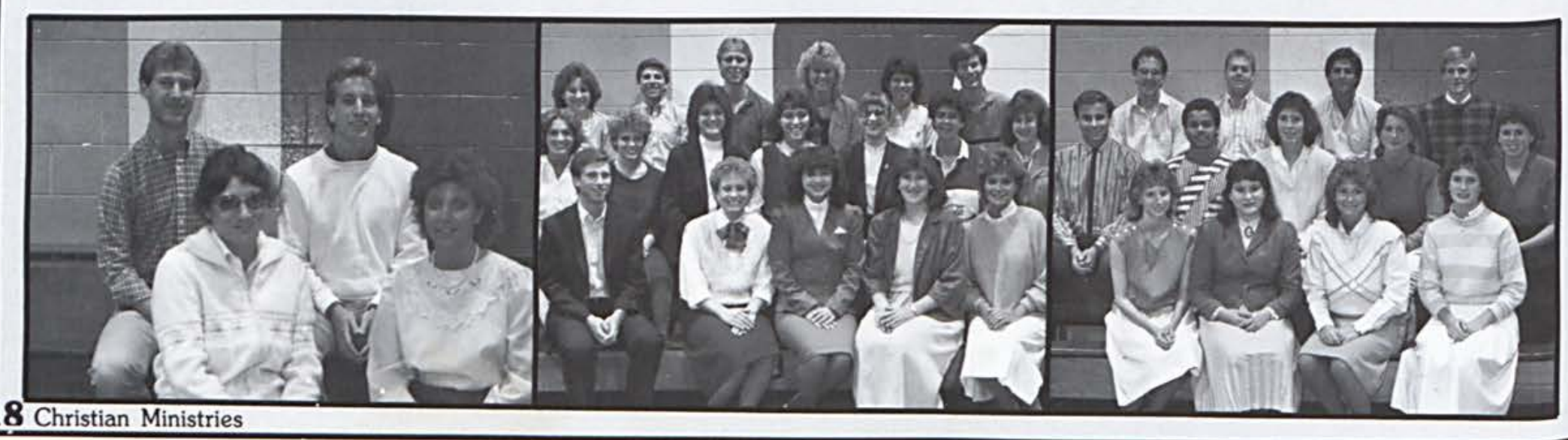




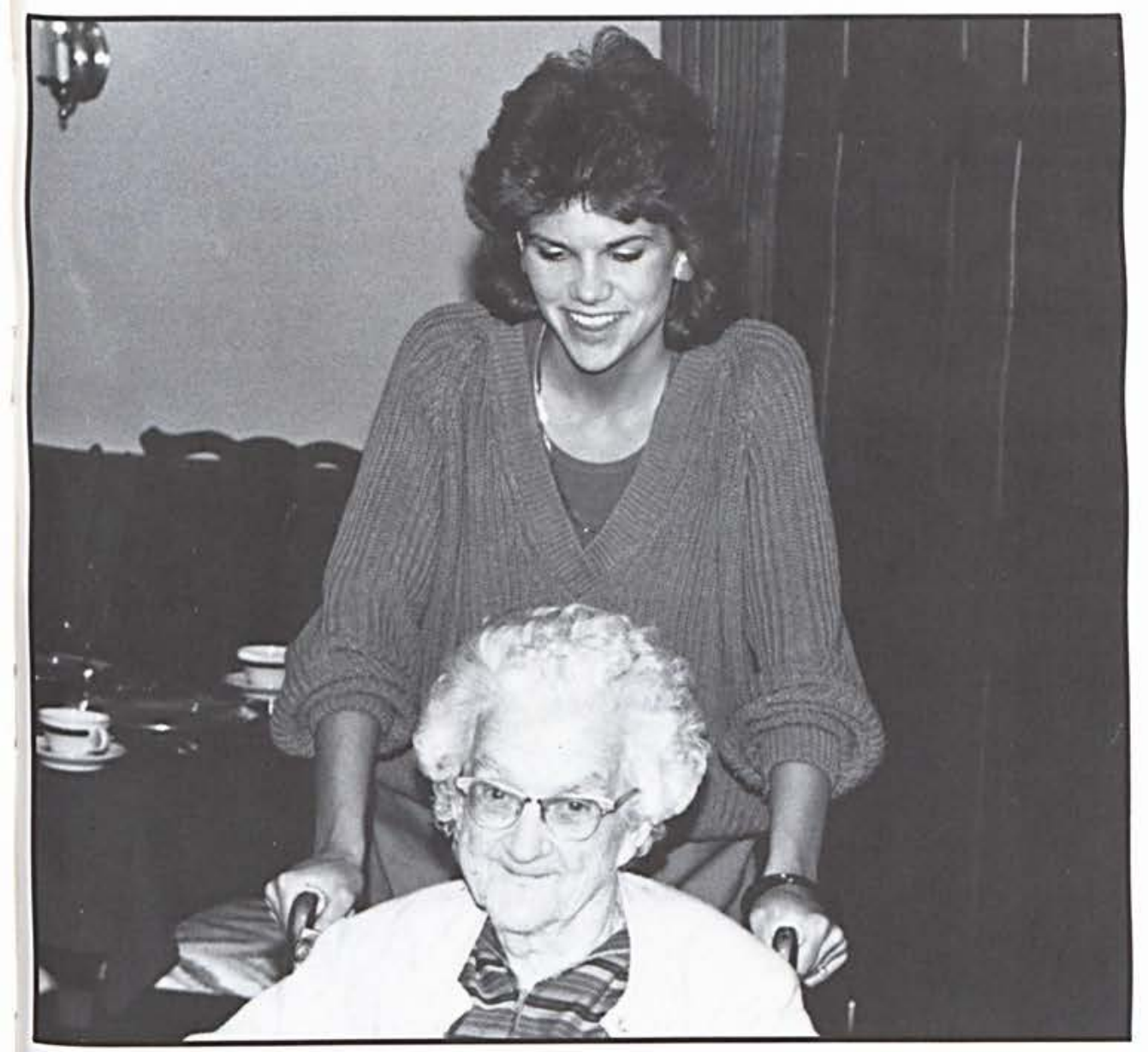

Below and Left: Knight of Pythias team serves God by teaching and preaching God's Word to help the elderly know God.

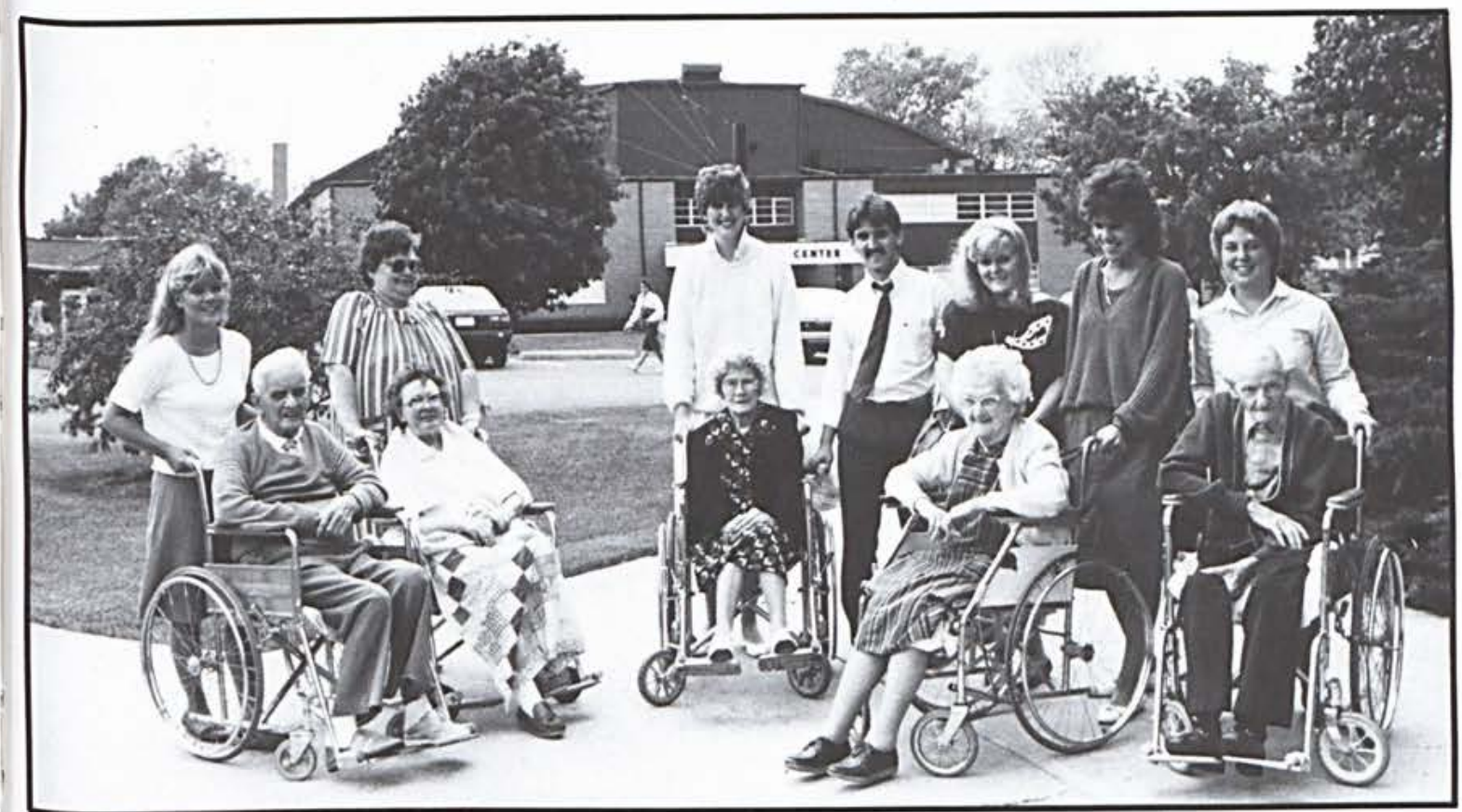

KNIGHTS

OF PYTHIAS

Front: Kristen Harper, Eileen Thompson, Theresa Dunlap. Second Ruth Eissens, Jeff Imhoff.
MERCY HOSPITAL:

Front: Thea Rivera, Tammy Jenkins, Pam Commons, Jolene Merck. Second: Joann Freyermuth, Susan Swann, Trina Collick, Cind Cleaver. Thind Jenny Zebrun, Sue Jessop. Beth Moon, Lynn Cost-

\section{MUELLER RESIDENTIAL CENTER:}

Denney, Debi Firman, Mandy Melntyre. Second: Jennifer Rogers, Lisa Vaughn, Wendy Bell, Kendra Herrold, Shawn Joel Acker.

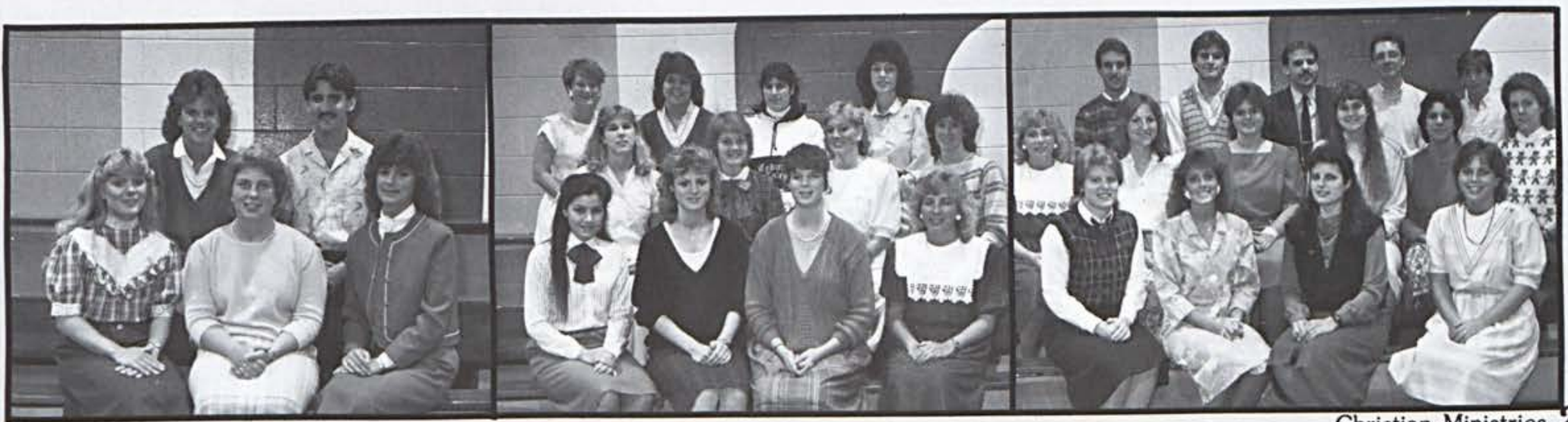




\section{Christian Ministries}
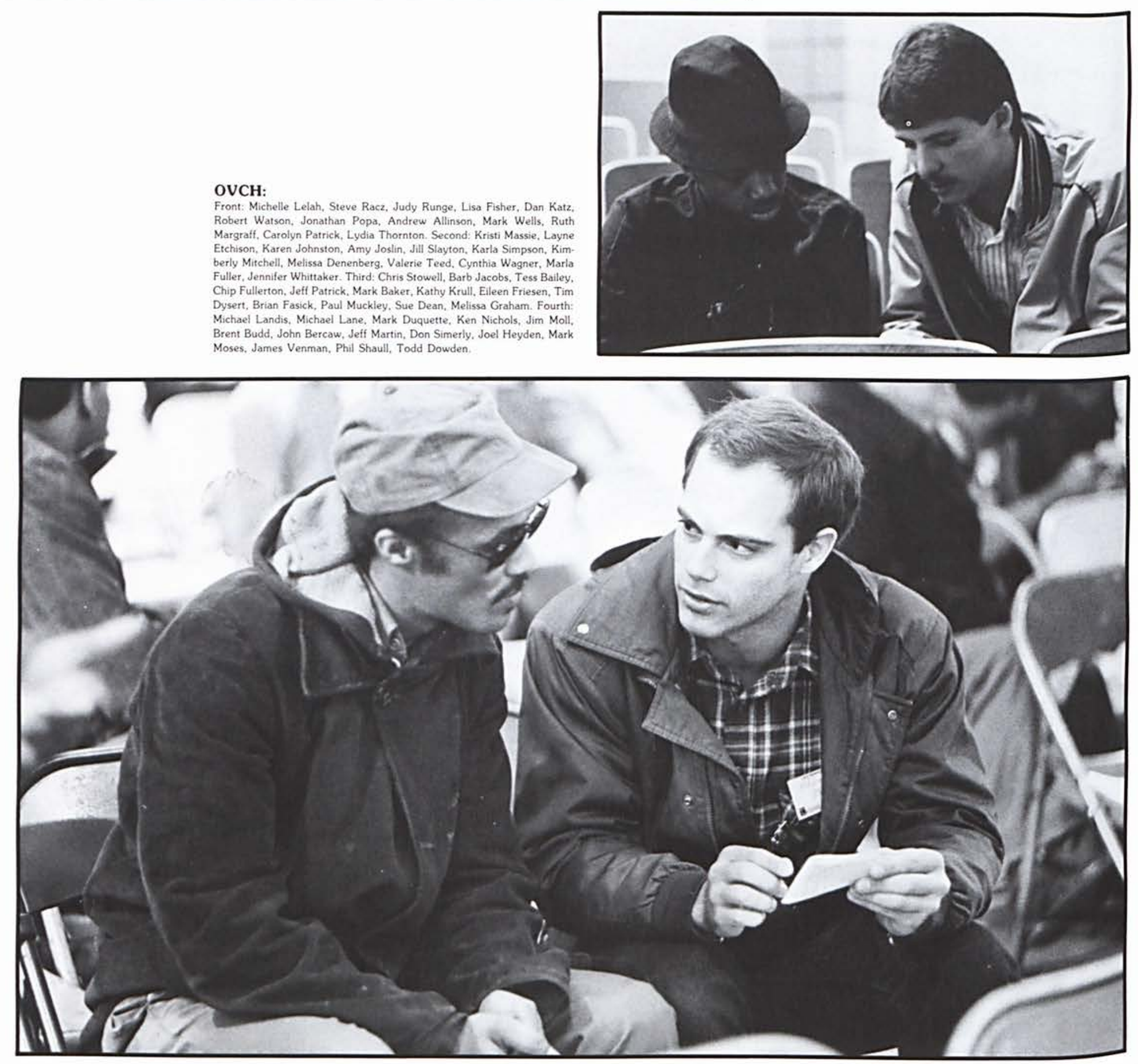

NURSING HOME I.O.O.F.:

ton, Renee Carr. Third: Brian Baab, William Tate
OPERATION REBIRTH:

Front: Richrd Woughter, Ron Stowell Second: Sherri Cruver, Kurt Ander

son, Mark Walter, Rhonda Trueman. Third: Mary Welch, Steve Walter.

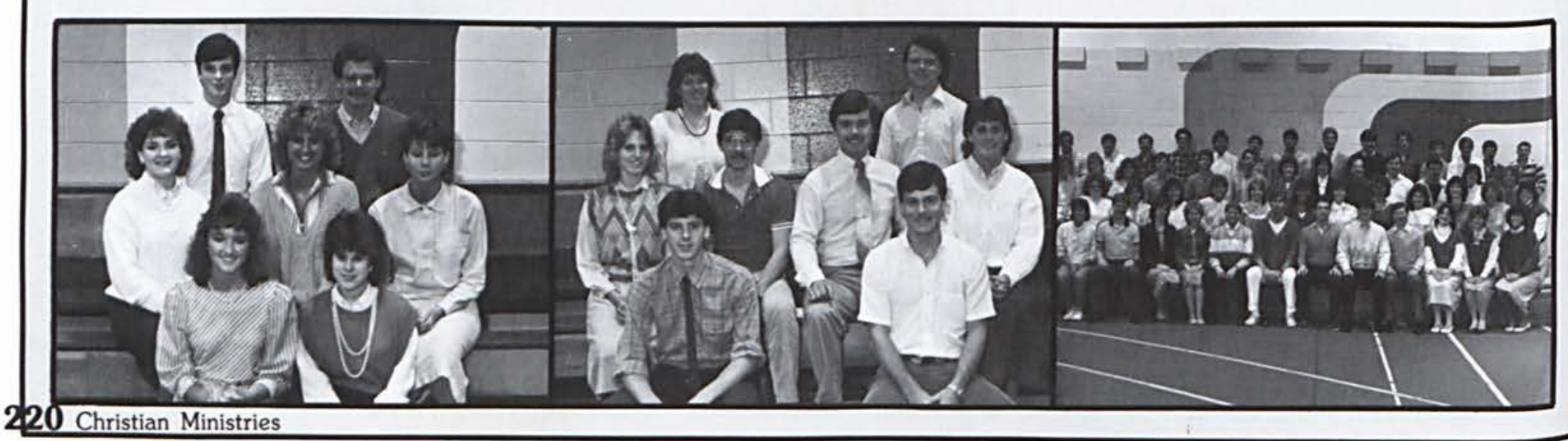




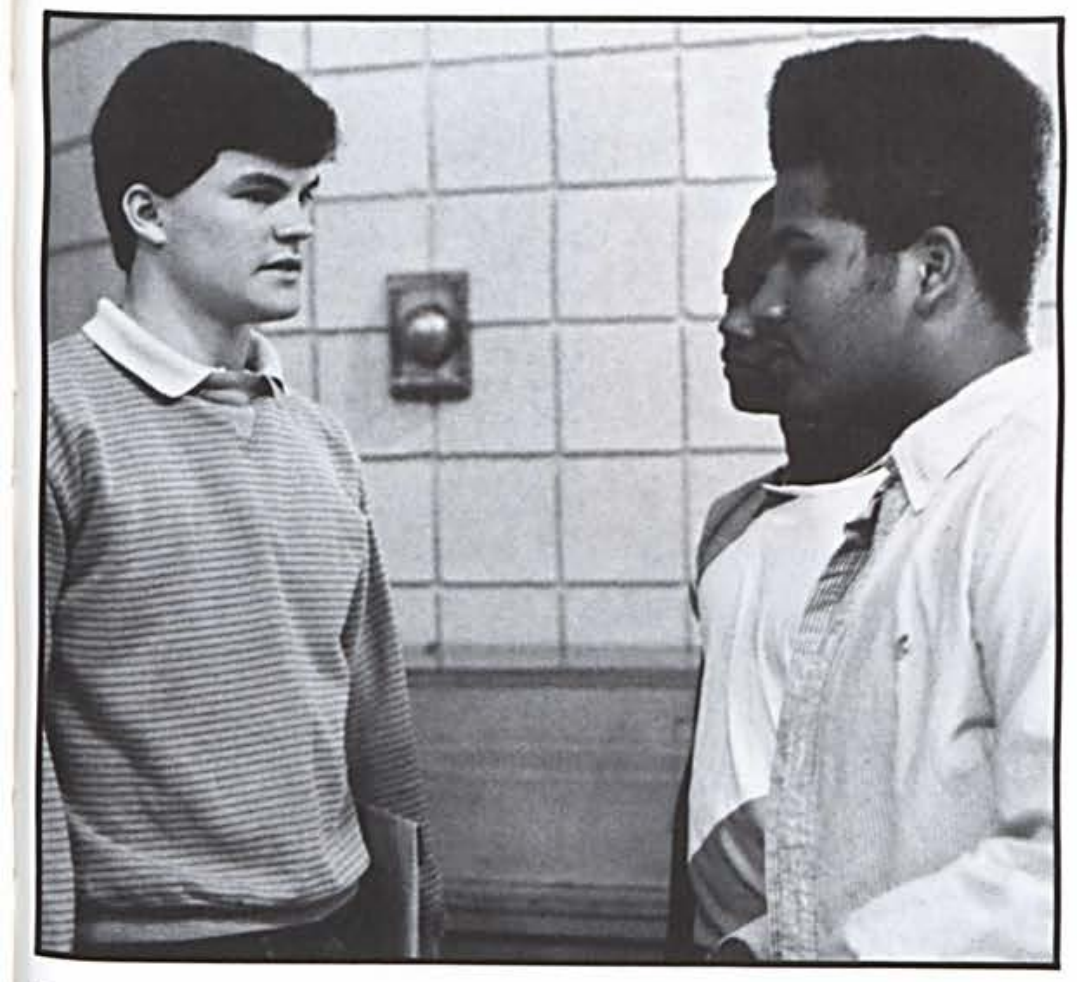

All Pictures: CC students traveled to Philadelphia to serve as counselors in a prison ministry. Photography by Ron Kuntz

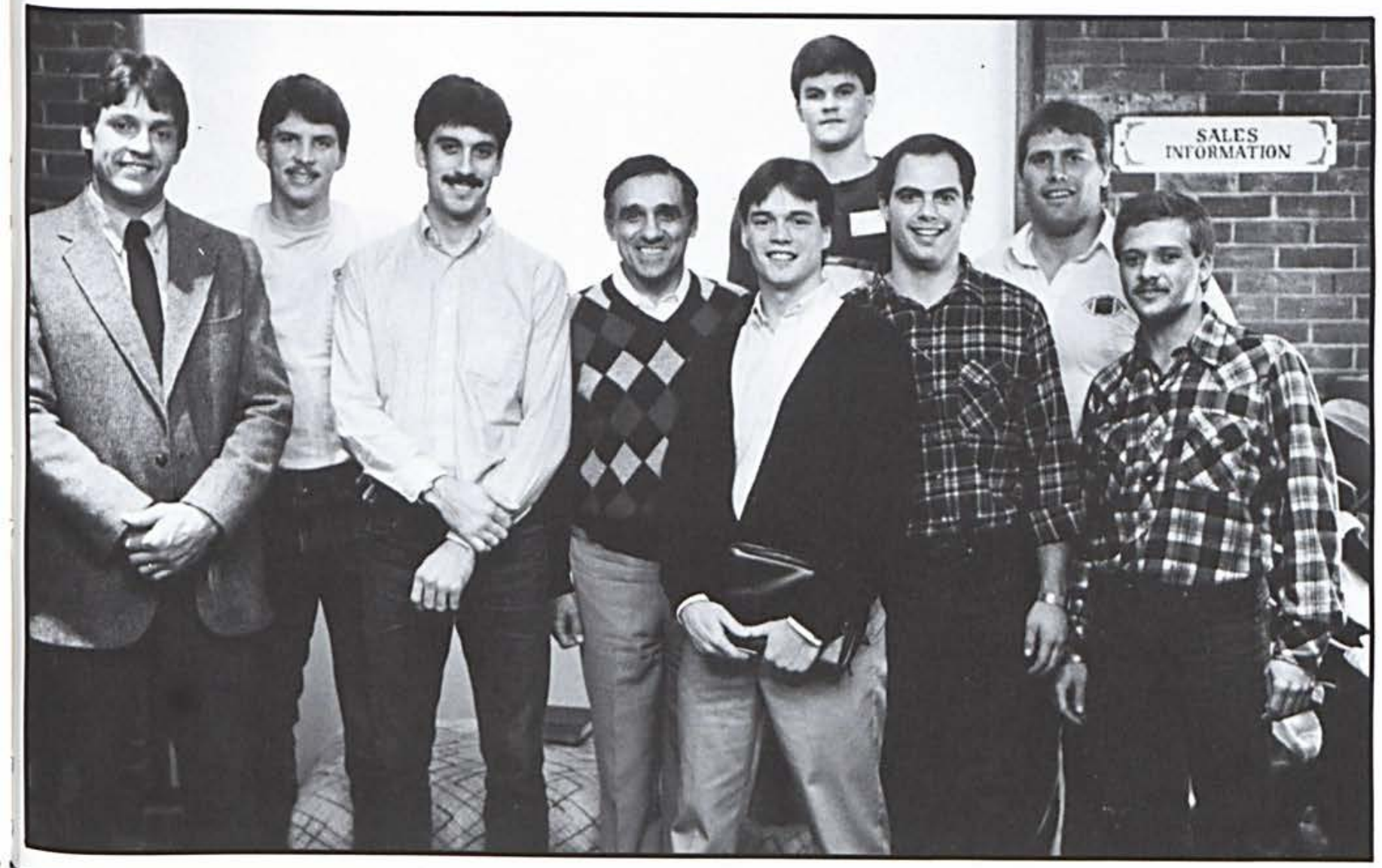

RONALD MCDONALD HOME:

SPRINGFIELD DETENTION:

Front: Kim Sweet. Becki Tackett. Second: Dorothy Howdyshell,

Front Deb Pate, Steve Hansen, Susan Blake.

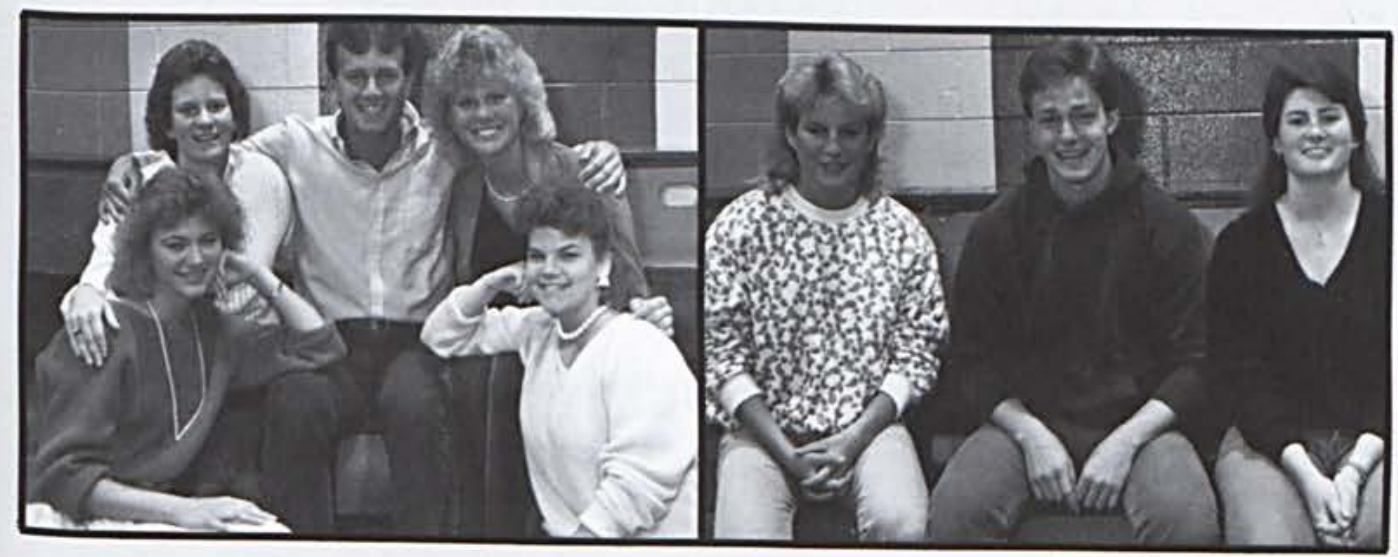




\section{Christian Ministries}

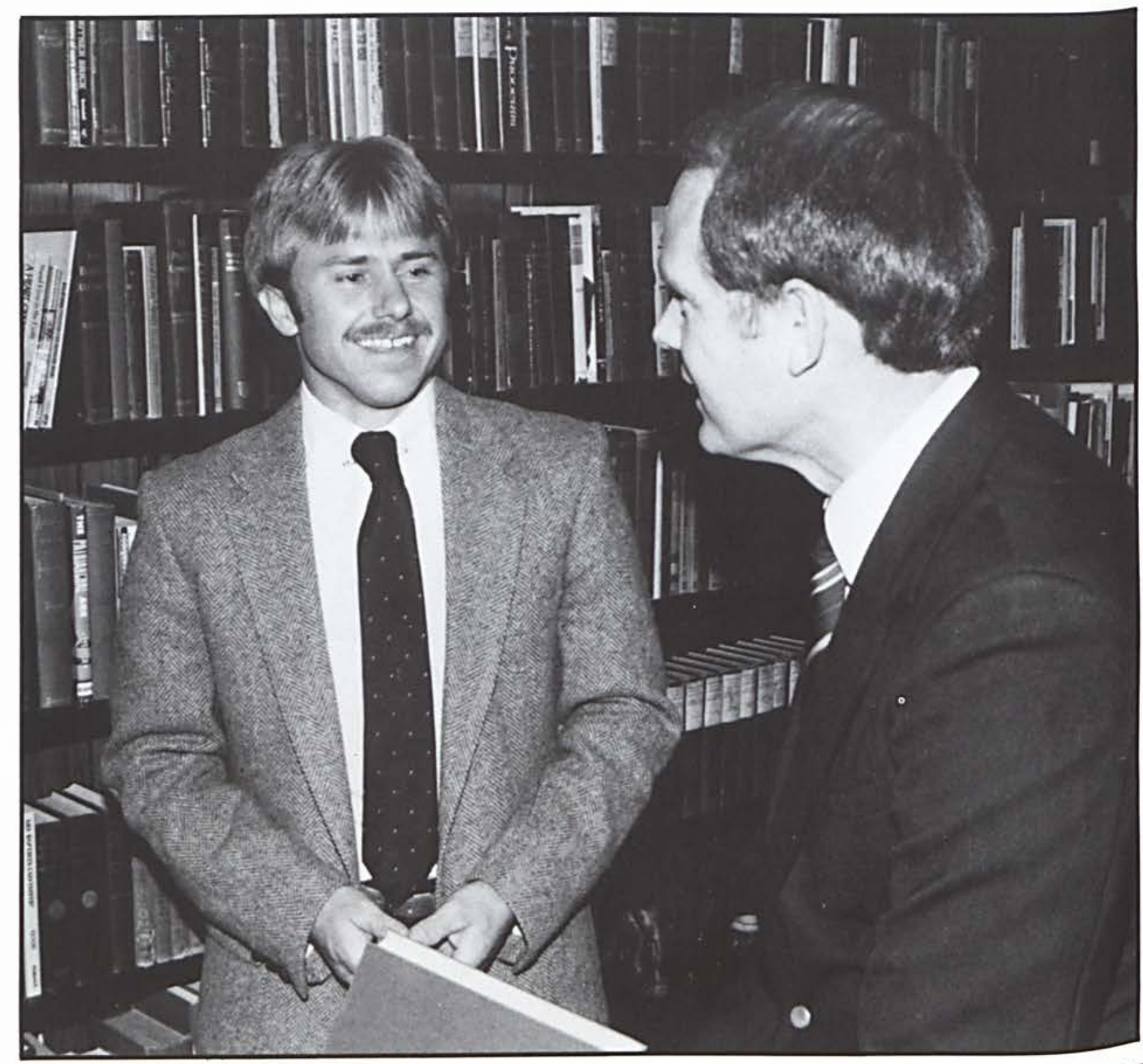

Pastoral internships allow Bible majors preparing for the ministry to gain a "hands on" experience. Gary Bragg participated in this "Paul-Timothy" experience with Pastor Paul Jackson of Grace Baptist Church.
SUNNYLAND VILLA NURSING HOME: Front: Bob Latorella, Debbie Reynolds, Debble Borleis, Loreen Westiall, Valerie Jones, Lori Brown, Dave Driskill. Second: Greg O'Dell, Beth Keyes, Beth Latorella.
WITTENBERG CAMPUS EVANGELISM: Front: Lisa Garabadian, Jill Johnson, Lisa Tyson, Betsy Stoltzius. Second: Susan Dye, Dave Bevely, Joan Hull.

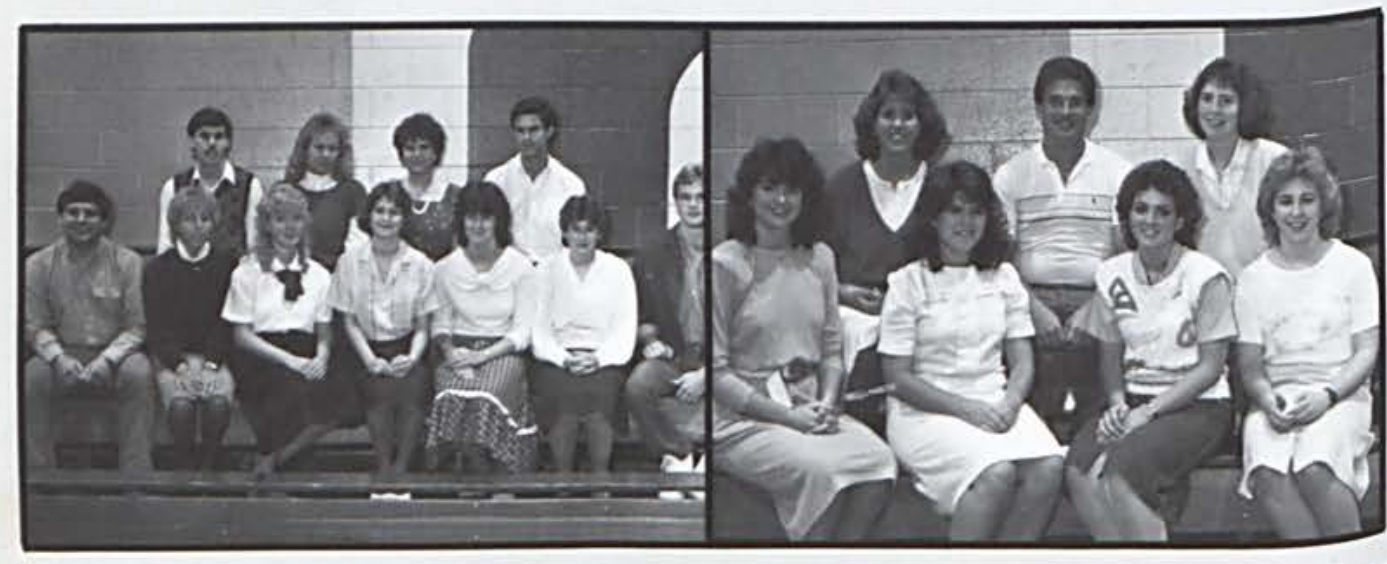




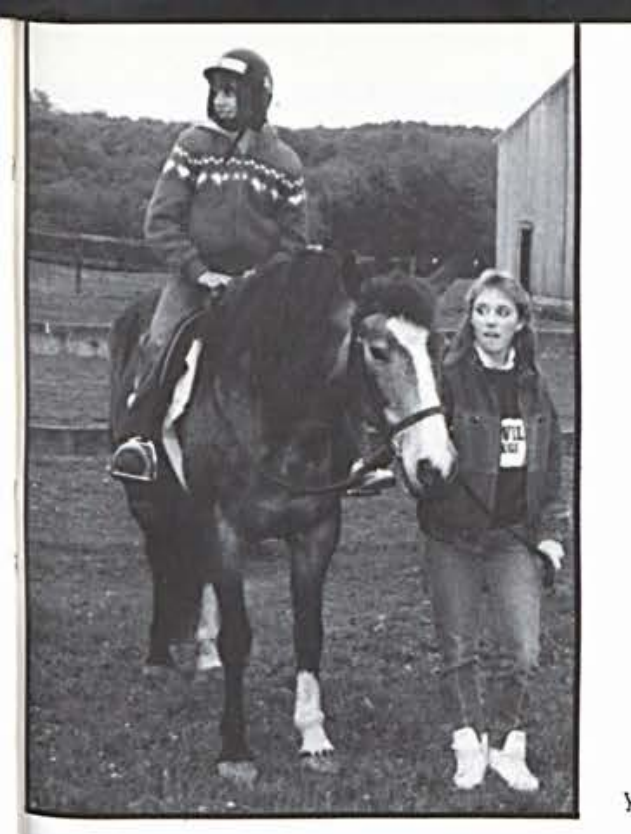

Yellow Springs Riding Center members serve God by assisting the handicapped with riding skills.

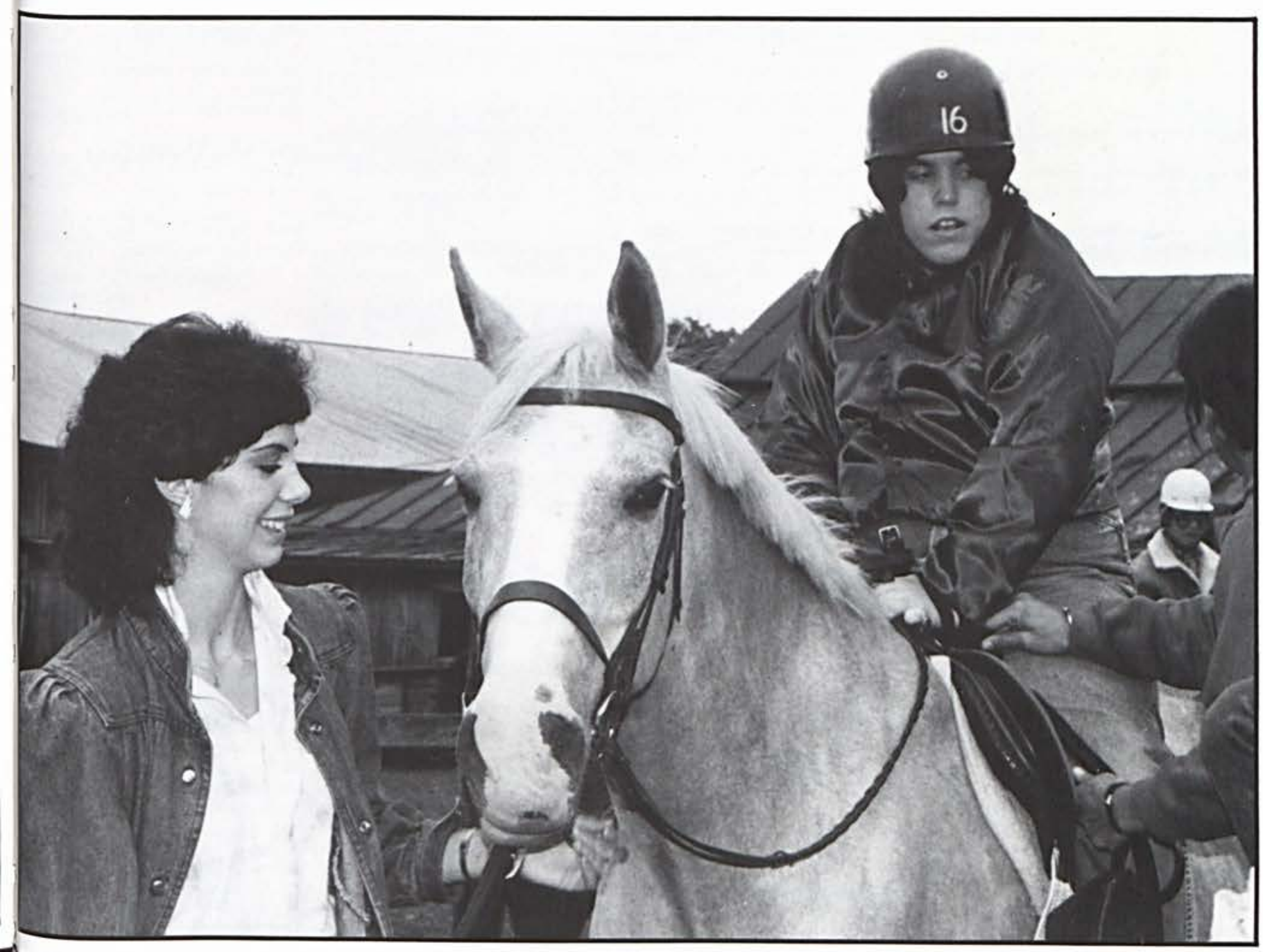

WRIGHT STATE CAMPUS EVANGELISM:

YELLOW SPRINGS RIDING CENTER:

Front: Amy Belgarde, Amy Titus. Second: Susan Rogers, Janet

Young, Noelle Watson, Nathan Tuckey. Third: Penni Howder, Thea

Rivera, Theresa Bonning. Ann Blessing.

Heacox, Eric Shrum, Brian Fasick

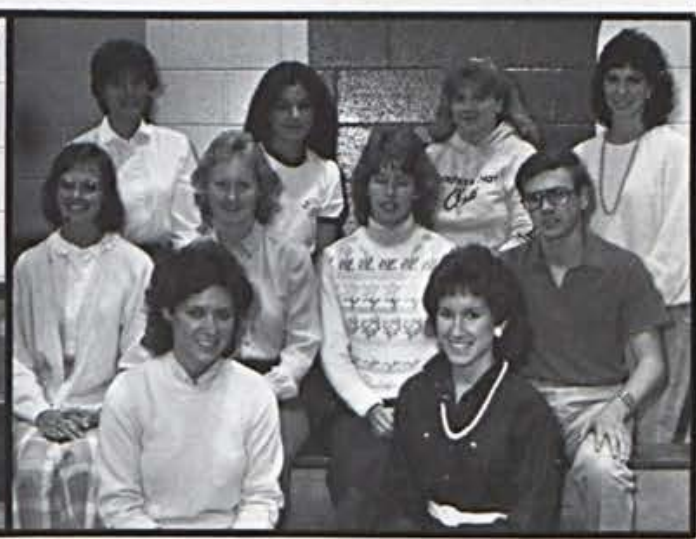




\section{CHURCH PATRONS}

Ankeny Baptist Church Norman Hoag, Pastor

Bailey Road Baptist Church Lester R. Webster, Pastor

Berea Baptist Church

Kenneth J. Spink, Pastor

Berean Baptist Church

Berean Baptist Church Kenneth Eisentrager, Pastor

Bethel Baptist Church Dr. Loren R. Anderson, Pastor

Bible Baptist Church John B. Murdoch, Pastor

Calvary Baptist Church William L. Moser, Pastor

Calvary Baptist Church Larry L. Chute, Pastor

Calvary Baptist Church Everett L. Kier, Pastor

Calvary Baptist Church Albert S. Yost, Pastor

Calvary Baptist Church Dick Sumner, Pastor

Calvary Baptist, Church Frank M. Kisner, Pastor

Central Fellowship Baptist Church

Community Bible Presbyterian Church

Philip Futoran, Pastor Wayne M. Frasier, Pastor

Dr. S.L. Sherrill, Pastor

Coral Ridge Baptist Donald Sanders, Pastor

Daniels Road Baptist Church Willard Benedict. Pastor

Eastbrook Baptist Church Robert W. Belt, Pastor

El-Bethel Baptist Church Robert M. Hooten, Pastor

Emmanuel Baptist Church No pastor at the present time

Emmanuel Baptist Church $R$. William Wheeler, Pastor

Evendale Community Church Earl O'Neal, Pastor

Faith Baptist

R. Dean Cooper, Pastor

Faith Baptist Church Lewis W. Newkirk, Pastor

Faith Baptist Church Fred D. Jensen, Pastor

Faith Baptist Church Glen E. Crabb, Pastor

Findlay Grace Brethren Church No pastor at the present time

First Baptist

William A. Ditty, Pastor

First Baptist Church Dr. Howard Longcore, Pastor

First Baptist Church Ronald D Schrock, Pastor Paul Matthiesen, Assoc. Pastor

\section{PARENT PATRONS}

Dr. and Mrs. William H

Anderson, $J r$.

West Springfield, PA

Mr. and Mrs. Delmar Augustus South Charleston, $\mathrm{OH}$

Mr. and Mrs. Jerry Avey

Lynchburg, VA

Mr. and Mrs. Ray Baker Quincy, IL

Mr. and Mrs. Charles Baldis Simsbury, CT

Barbara and George Baldwin Lakeland, FL

William W. and Linda K. Bany, Sr.

Montpelier, $\mathrm{OH}$

Mr. and Mrs. Walter D. Barker State College, PA

John Bartus, Sr.

Toledo, $\mathrm{OH}$

Mr. and Mrs. Dick Bauer Akron, $\mathrm{OH}$

Mr. and Mrs. Lee Beach Elizabethtown, PA

Rev, and Mrs. Alan Beal Fayette, $\mathrm{OH}$
First Baptist Church Joseph Godwin, Pastor

First Baptist Church

First Baptist Church David Miller, Pastor

First Baptist Church

First Baptist Church G. Ben Reed, Pastor

First Baptist Church W.E. Alexander

First Baptist Church Jack Wiltheiss, Pastor

First Baptist Church Tom Younger, Pastor

First Baptist Church David L. Birch

First Baptist Church Donald Leitch, Pastor

First Baptist Church of Enfield George H. Heiland, Pastor

First Baptist Church of

Massapequa

Frederick Thomas, Pastor

First Baptist Church of Strongsville

Wilbur Parrish, Pastor

First Baptist Church, University Place

Phil Williams, Pastor

First Baptist Church of Walteria Robert D. Hayden, Pastor Greg Boyle, Pastor
Robert E. Currier, Pastor

First Church of God David Fields, Jr., Pastor

First United Methodist Jim Christensen, Pastor

Grace Bible Church Jerry R. Nash, Pastor

Grace Baptist Church W. Paul Jackson, Pastor

Grace Bible Presbyterian

Church

Rev. Albert W. Cook, Pastor

Hessville Baptist

Richard P. Beck, Pastor

Huntsburg Baptist Church Ben H. Garlich, Pastor

Immanuel Baptist Church Roger Copas, Pastor

Johnstown Independent Baptist Church

R. Drew Baker, Pastor

Lagrange First Baptist Church Dennis Gilbert, Pastor

Lebanon Valley Bible Church

James A. Ober, Pastor

Milan Baptist Church

Blake Hunt, Pastor

New Boston Baptist Church

Tom W. Shelton, Sr., Pastor

New Harmony Baptist Church Eric P. Cuenin, Pastor
Dale and Cathy Bennett Lakewood, $\mathrm{OH}$

Earl and Sandy Bennett Zanesville, $\mathrm{OH}$

Mr. and Mrs. Robert J. Bercaw Troy, $\mathrm{OH}$

Susan K. Bergandine Decatur, IL

Mr. and Mrs. John R. Bigolow Fairbanks, $A L$

Mr. and Mrs. Bob Blaylock

Mr. and Mrs. Merlin B. Bliss Belding, MI

Mr. and Mrs. C. Donald Borleis Harleysuille, PA

Judith and Douglas Bradman DeWitt, MI

Mr. and Mrs. Ivins Brewin Cherry Hill, NJ

Mr. and Mrs. David H. Brown Sylvania, $\mathrm{OH}$

Doris A. Browne

Washington, DC

Mr. and Mrs. Gerald A Buckholz Chattanooga, TN
Vermilion, $\mathrm{OH}$

The Burger-Deglmann Family Euclid, $\mathrm{OH}$

Mr. and Mrs. Ray Burk

Fostoria, $\mathrm{OH}$

Dr. and Mrs, James K. Burt

Marshall and Liz Butcher Othello, WA

Mr. and Mrs. Ronald Calle Limerick, PA

Mr. and Mrs. James B.

Carraher

Toledo, $\mathrm{OH}$

Wayne and Donna Carpenter Normal, IL

Dr. and Mrs. W.E. Cherry Sterling, IL

Mr. and Mrs. James Church III Parma, $\mathrm{OH}$

Mr. and Mrs. William Clarkson Manassas, VA

Mr. and Mrs. Larry C. Clemens and Todd

Limerick, PA

Bill and Sharon Commons Worthington, $\mathrm{OH}$
Cherry Hill, NJ

John and Carol Cooper New Braintree, MA

Mr. and Mrs. Ron Cox Margate, FL

Mr. and Mrs. David L.

Dachenbach

Chariton, IA

Jim and Lois Day

Belle Center, $\mathrm{OH}$

George and Rose Deffet Columbus, $\mathrm{OH}$

Donald L. and Bonnie J.

Denney

Hebron, KY

Mr. and Mrs. Enos L.

Detweiler, Jr.

Gardenville, PA

Mr. and Mrs. W. Dimacchia, $J_{r}$. Lorain, $\mathrm{OH}$

David and Janet Dye

Mutual, $\mathrm{OH}$

Waneta Dye

Ravenna, OH

Henry and Ann Dykstra

Hobart, IN

Nottingham Baptist Church Donald E. McClintick, Pastor

Oak Grove Baptist Church James R. Gray, Pastor

Ossipee Mt. Baptist Paul E. Williams, Pastor

Perry Baptist Church Kenneth E. Floyd, Pastor

Southgate Baptist Church John R. Greening, Pastor

Southside Baptist Church Russell E. Lethbridge, Jr., Pastor

Temple Baptist Church John Hippard, Pastor

Vandalia Grace Brethren Church

No pastor at the present time

Washington Heights Baptist Church

Larry Fetzer, Pastor

York Baptist

David Grinnell, Pastor

Letter H. Edelin

Washington, DC

Kenneth and Lillian Eisentrager Manitowoc, WI

Mr. and Mrs. Robert Elzerman Sterling Heights, MI

Mr. and Mrs. Robert Fread Loveland, $\mathrm{OH}$

Mr. and Mrs. Ken Free Coshocton, $\mathrm{OH}$

Mr. and Mrs. Charles

Freyermuth

lowa City, IA

Dr. and Mrs. Charles

Garabadian

Pickens, SC

Mr. and Mrs. Willard L. Gard Griffith, IN

Tom and Maxine Geese Fresno, $\mathrm{OH}$

Rev. and Mrs. Fred G.

Gerhard

Lansing, MI

Dr. and Mrs. Dean Gifford Urbana, IN

The Gilbert Family Haddon Heights, NJ 
Shax Gorman

San Juan, Puerto Rico

Mr. and Mrs. Thomas S

Graham

Ridley Park, PA

Mr. and Mrs. Gene Greene

Columbus, $\mathrm{OH}$

Mr. and Mrs. Fred B. Greetham

Wellington, $\mathrm{OH}$

Carole Bartlett Groth

Rochester, NY

Mr. and Mrs. Jeffrey Grumbeck

Burlington, WI

Bruce and Eileen Gruneisen

Mansfield, $\mathrm{OH}$

Mr. and Mrs. Noel F. Hack

LaGrange, $\mathrm{OH}$

Mr. and Mrs. David S. Hallman

Pottstown, PA

Lois Van Dorf Halvorsen

Milwaukee, WI

Royce and Janice Hammer

Rockford, $M$

Robert and Marilyn Hannay

Westerlo, NY

Roger and Dianne Hansen

Rockford, M

Rev, and Mrs. Elvin Harden

Hart, MI

Dick and Helen Harper

Rochester, NY

Mr, and Mrs. F.H. Haufler

Reading, PA

Mr. and Mrs. Rodney E.

Haynes

Perry, NY

Harvey and Joan Helm

Fairfield, CT

Mr, and Mrs, Tom C. Hill

St. Marys, WV

Mr. and Mrs. Floyd Hofer

Milwaukee, WI

Mr. and Mrs. Roger Hood

Gallipolis, $\mathrm{OH}$

Mr. and Mrs. Paul Howard

Mount Vision, NY

Mr. and Mrs, Wilfred Hudon

Manchester, $\mathrm{NH}$

Mr. and Mrs. David Huebscher

Cleveland, $\mathrm{OH}$

Mr. and Mrs. Albert A. Hultz

Pottstown, PA

Hosea and Marion Humphrey

Middleville, MI

Russell and Claudine Jenkins

McLean, VA

Mary E, Jones

Ohlman, IL

Mr. and Mrs. Robert E. Jones

Wellman, IA

Mr. and Mrs. Francis T. Joslin

Wisc. Rapids, WI

Rev. and Mrs. Wayne Keisling

Prattsburg, NY
Charles and Sally Kempf

Lakeland, FL

Mr. and Mrs. Hugh Kennedy Cambridge, Ontario

Mr. and Mrs. James Kettel Grafton, $\mathrm{OH}$

Mr. and Mrs. Harold E. Kimmel Greenville, $\mathrm{OH}$

Ralph and Joyce Knowles Brunswick, ME

Mr. and Mrs. Robert J.

Koerber

Colchester, CT

Thomas O. and Joy E. Kraner Cheyeene, WY

Mr. and Mrs. James W.

Krueger

Franklin, WI

Dr. and Mrs. J. Russell Kruppa Trenton, $N J$

Mr. and Mrs. Ralph P. Kuivinen (parents of Thomas S. Mach)

Fairview Park, $\mathrm{OH}$

Ray and Priscilla LaBonte Rochester, NY

Mr. and Mrs. Robert W. Laird Vincentown, $N J$

John and Charlotte Lambert Dale City, VA

Mr. and Mrs. Roger Lash Brownsburg, IN

Mr. and Mrs. Raymond Latini Boca Raton, FL

Mr. and Mrs. Robert Latorella Amherst, NH

Kenneth and Trudy Laub Huntington, $N Y$

David and Virginia Law Norwich, NY

Mr. and Mrs. Donald D. Leach Kettering, $\mathrm{OH}$

David and Eleanor Lelah

Stony Point, NY

Mr. and Mrs. Orville Liebler Findlay, $\mathrm{OH}$

Jim and Jean Limmerie

Medinah, IL

Rev, and Mrs. Fred R. Mackey Canton, $\mathrm{OH}$

James and Grace Marihugh Delphos, $\mathrm{OH}$

Mr. and Mrs. James $H$.

\section{Markison}

Brookfield, IL

Mr. and Mrs. Franklin S

Marshall

Phoenixville, PA

Mr. and Mrs. Billy C. McCain Dallas, TX

Mr. and Mrs. James McCarrell Colts Neck, NJ

Bob and Janet McCaskill North Jackson, $\mathrm{OH}$

Mr. and Mrs. William $H$.

McKibben

Florence, $K Y$
Mr. and Mrs. Gleen

Merriwether

Barnstead, NH

Mr. and Mrs. F. Michonsk

West Simsbury, CT

Mr. and Mrs. Sal Mignogna (parents of Lee and Lynne

Calisti)

Greensburg, PA

Mr. and Mrs. Larry E. Miller Gallipolis, $\mathrm{OH}$

Howard and Caroline Mills, Sr. Sandy Creek, NY

Mr. and Mrs. Charles S.

Monroe

Springfield, $\mathrm{OH}$

Mr. and Mrs. Ted Montrose

Centermoreland, PA

Walter and Freda Moon

Haymarket, VA

The William D. Moon Family

Erie, PA

Mr. and Mrs. David S. Mooney,

Sr.

Greensburg, PA

Mr. and Mrs. W. Eugene Morris and Family

Marietta, $\mathrm{OH}$

Mr. and Mrs. James W. Morton Great Valley, NY

Pastor and Judy Moser

Ashland, $\mathrm{OH}$

Mr. and Mrs. Arthur Motzer

Hamilton, $\mathrm{OH}$

Carl and Iva Jean Nasse

Canajoharie, NY

Mr. and Mrs. Raymond A.

Nemecek

Hollywood, FL

Mr. and Mrs. Ralph Nickoson

Dayton, $\mathrm{OH}$

Mrs. Vera Oakes

Binghamton, NY

Judge and Mrs. Garvin Lee

Oliver

Alexandria, VA

Jud and Roger Ottaway

Corry, PA

Hugh and Jean Parker

Bigfordk, MO

Mr. and Mrs. Phil Parman

Epworth, IA

Ford and Becky Patrick

Columbus, $\mathrm{OH}$

Alf $B$. Pedersen

Monterey, MA

Mr. and Mrs. Tom Perrott

Horseheads, NY

Rev. and Mrs. Douglas Peters Troy, $\mathrm{OH}$

Mr. and Mrs. Clarence A.

Phillips, Sr.

Sebring, FL

Mr. and Mrs. Thomas J. Phipps III

Coatesville, $P A$

Mr. and Mrs. Samuel L. Peirce
Dublin, $\mathrm{OH}$

Mr. and Mrs. Ronald Plooy

Waukesha, WI

Mr. and Mrs. Edwin J. Pratt Ann Arbor, MI

Bob and Bonnie Printy

Holtville, MI

Mr. and Mrs. Edward S. Pugh Louisville, $\mathrm{OH}$

Mr. and Mrs. William B. Price Columbus, $\mathrm{OH}$

Mr. and Mrs. John Racz

Hoffman Estates, IL

Rev. and Mrs. Howard

Rainwater, $J r$.

Palmyra, PA

Mr. and Mrs. Howard Rase

Portsmouth, $\mathrm{OH}$

Mr. and Mrs. Ralph Reed

Mt. Sidney, VA

Mr. and Mrs. George E. Reede Geigertown, PA

Mr. and Mrs. Pete Reese

Saugus, $C A$

Mr. and Mrs. Leonard Reeves Derry, PA

David and June Roarabaugh

Bellwood, PA

Mr. and Mrs. Paul Robbins LuVerne, IA

Dr. and Mrs. Richard

Rodebaugh

Ayden, NC

Mr. and Mrs. Thomas G.

Rogers

Hudson, $\mathrm{OH}$

Mr. and Mrs. Charles Ross

East Providence, $R I$

Mr. and Mrs. Melvin L. Ruby Elizabethtown, PA

Lee and Donna Ryan

Almond, NY

Norman and Jane Sand

Franklin Lakes, NJ

Mr. and Mrs. Stan Schonfeld Oyster Bay, NY

Mrs. Caroll A. Shovelton

Canajoharie, NY

Don and Julianne Smith Akron, $\mathrm{OH}$

Mr. and Mrs. Lowell O. Smith Cedar Falls, IA

Roscoe F. Smith

Binghamton, NY

Bernard Southwell Familhy

Hudson, M

Mr. and Mrs. Irvin L. Sperry Frostburg, MD

Reuben and Eileen Stoltzfus Souderton, PA

Eugene and Carol Stone

Reinbeck, IA

Ted and Joanne Strait

Runnells, IA

Mr. and Mrs. Williams Swann Highland, MD

Jim and Marcia Swanson Cuyahoga Falls, $\mathrm{OH}$

Mr. and Mrs. James R. Triehy Pepperell, MA

Anna Jane Titus

(mother of Alan Titus)

Bowling Green, $\mathrm{OH}$

Mr. and Mrs. H.C. Trautman

Toledo, $\mathrm{OH}$

Mr. and Mrs. Merwyn L.

Trexler

Altoona, $P A$

Mr. and Mrs. Richard A. Tyler Portage, MI

Mr. and Mrs. Ellis Vanness Stickney, IL

Mr. and Mrs. Allen VeStrand Westfield, NY

Mr. and Mrs. Albert M. Wagner West Long Branch, NJ

Mr. and Mrs. Frank G. Walker Cornwall-on-Hudson, $N Y$

Mr. and Mrs. Gerald C. Wallace Elk Grove, $C A$

Mr. and Mrs. Donald Walter Findlay, $\mathrm{OH}$ 


\section{Jaithful}

\section{FAITHFUL STEWARDSHIP IS:}

rising at 4:00 AM on a below zero, frosty morning to shovel snow off the sidewalks

checking and cataloging scores of overdue books at the end of a very busy quarter putting those much expected letters, postcards, parcels, returned papers, and gifts into small, square tubby holes before 10:00 AM

wearing grubby overalls to chapel and sitting next to a squeaking clean 18 year old preppie after just unplugging 10 toilets in Maddox

planting, one by one, flower, tree, or grass seed. lings only to have 3600 feet stomp on them in a mad rush for the PO

picking a dandelion before the President sees it answering the phone and saying. "Hello, this is Cedarville College" thirty zentrillion times a day hurrving to Faith Hall to answer an emergency to

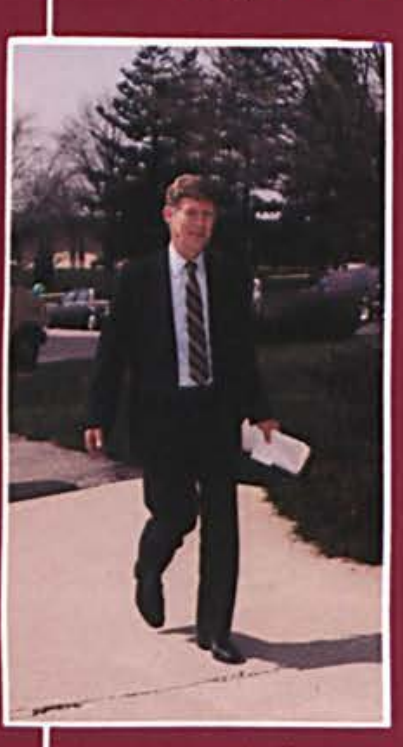
find that Susie only got

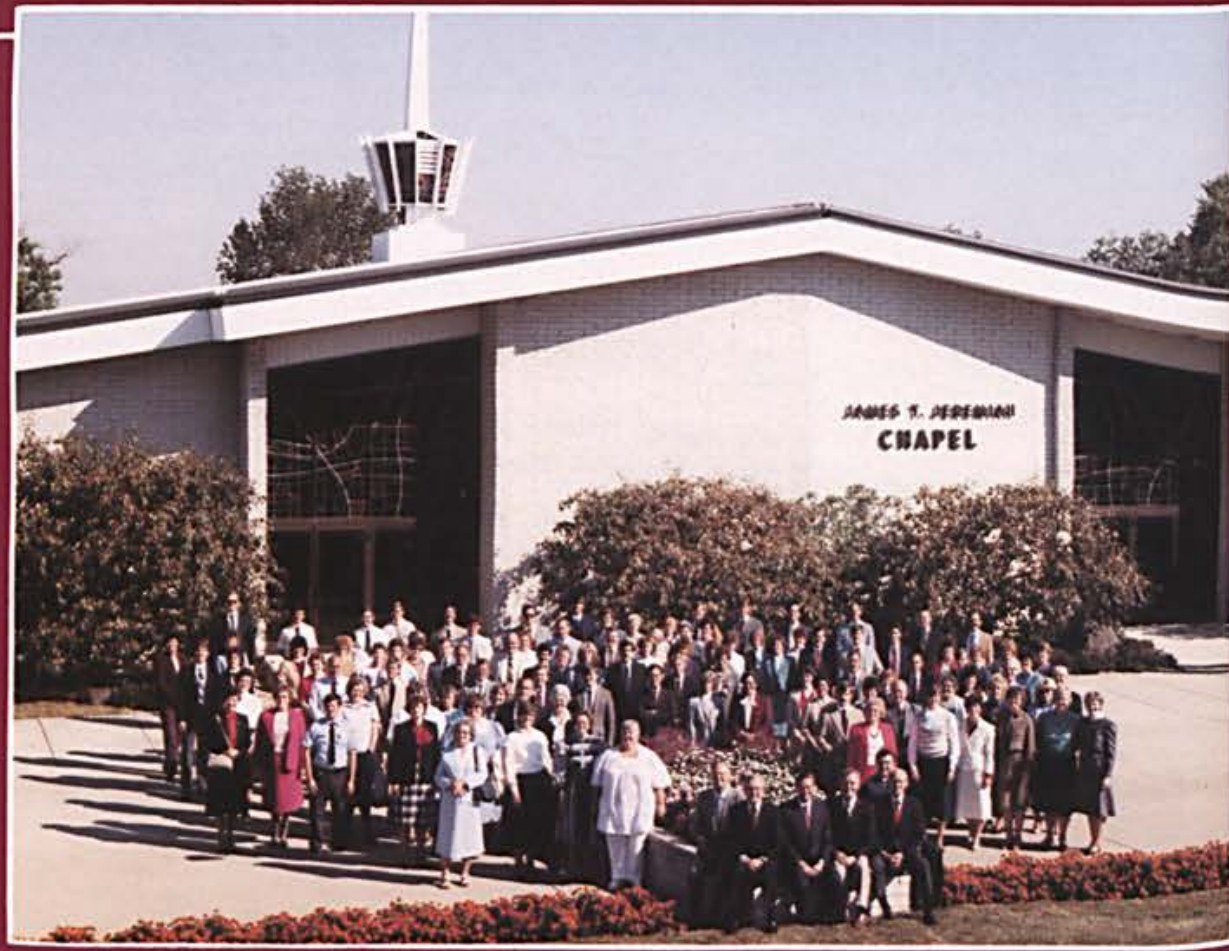
dent who's waiting to see the Dean

"creamed" in the stomach during a Powder Puff Football game

replacing the door, hinges and all, to a "Hill" dorm room after a night of a "buck-buck" marathon keeping an absent-minded prof aware of impending engagements: a visit to the Links and Bunkers taking down, putting up, taking down, putting up the chapel risers

picking up trash behind Printy after the Christmas open house and not finding one useful Christmas tree

- sweeping up after frenzied basketball fans have seen a game with 3 overtimes

- whipping up the potatoes for the CC family favorite: Shepherd's Pie

- backordering 13 course textbooks for Dr. McGol. drick's class

- giving a warm, soothing smile to the trembling stu-

- responding to a frantic sophomore's pleas for Security to open the locked car door so the Old Testament notes can be used for the next day's exam

- giving the "sackcloth and ashes-dressed student" the good news that some anonymous donor has paid off his school bill

- assuring the burdened student who comes for counseling of God's love and constant strength during the perfecting process of becoming more like His dear Son.
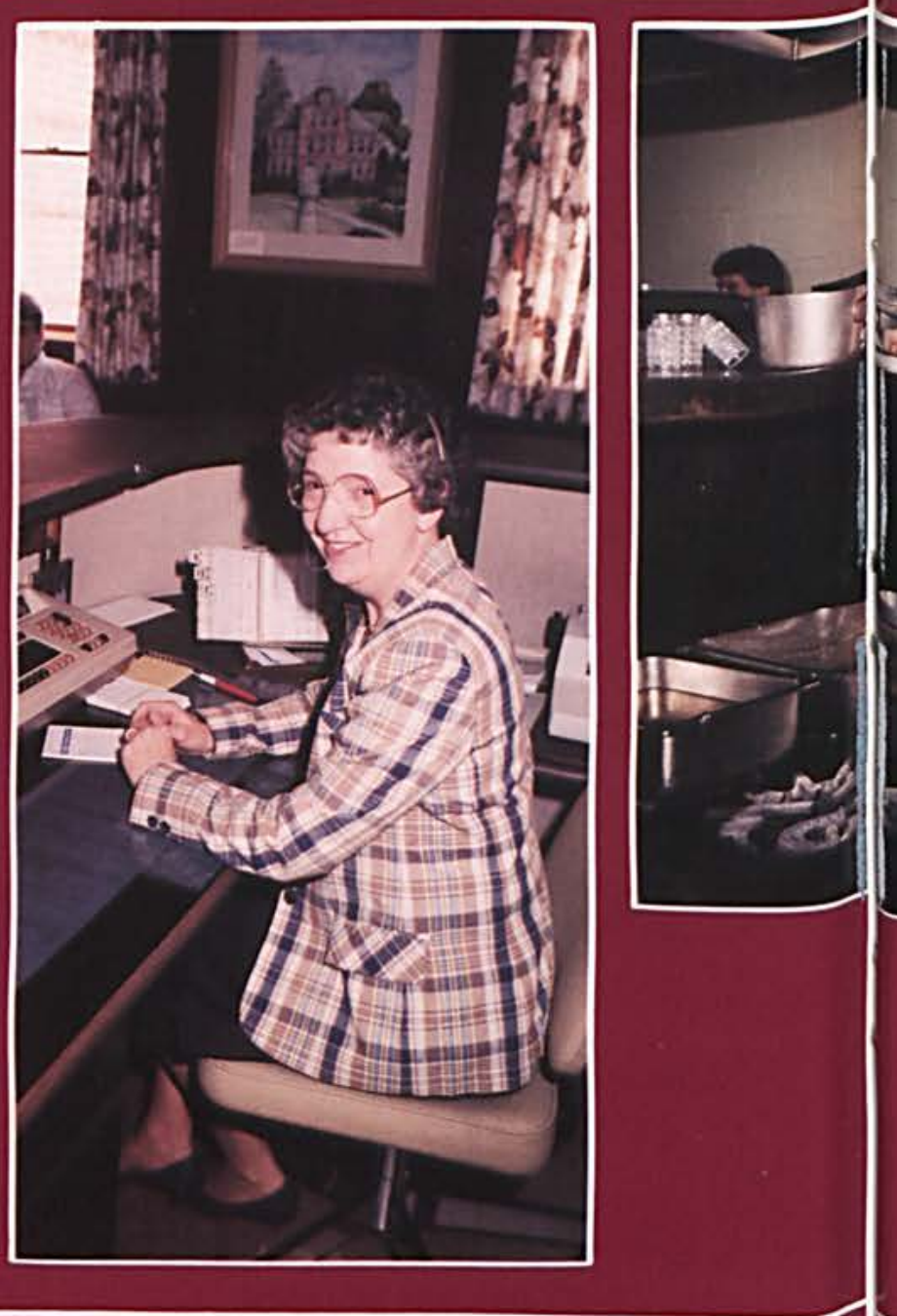


\section{Stewards}

"His Lord said to him. 'Well done, good and faithful servant; you were faithful over a few things I will make you ruler over many things. Enter into the joy of your Lord.' "

Matthew 25:21

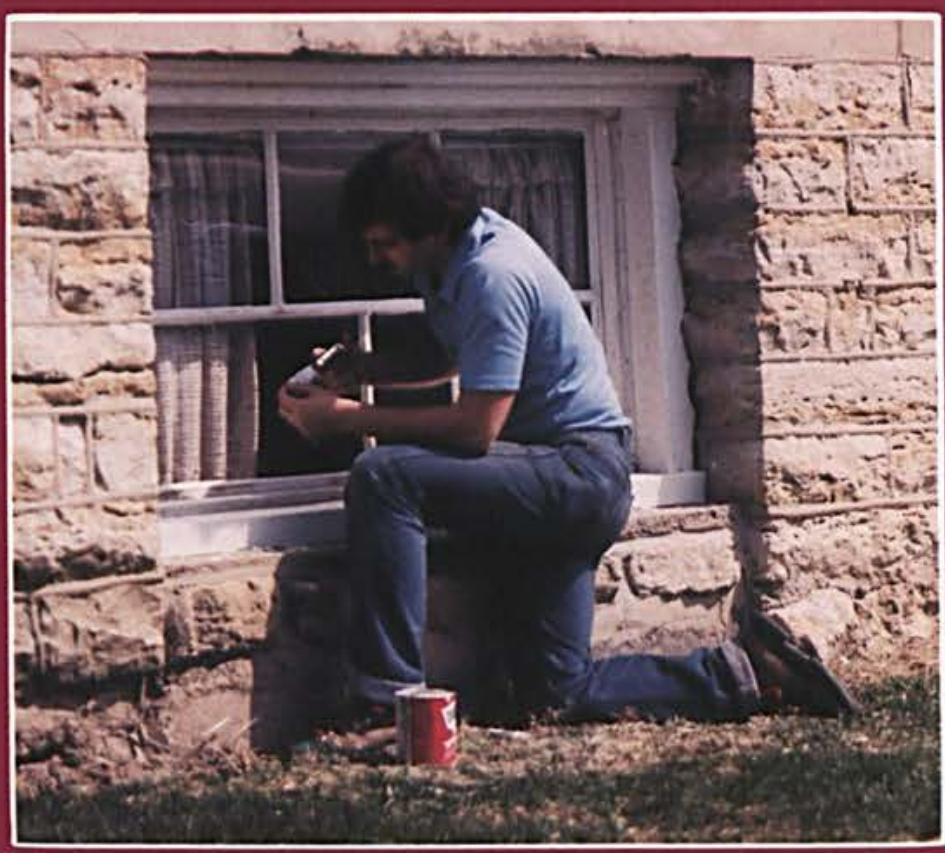

To you Cedarville College's faithful stewards - THE STAFF, the 1986 Miracle is dedicated. You have been a pattern of good works. 


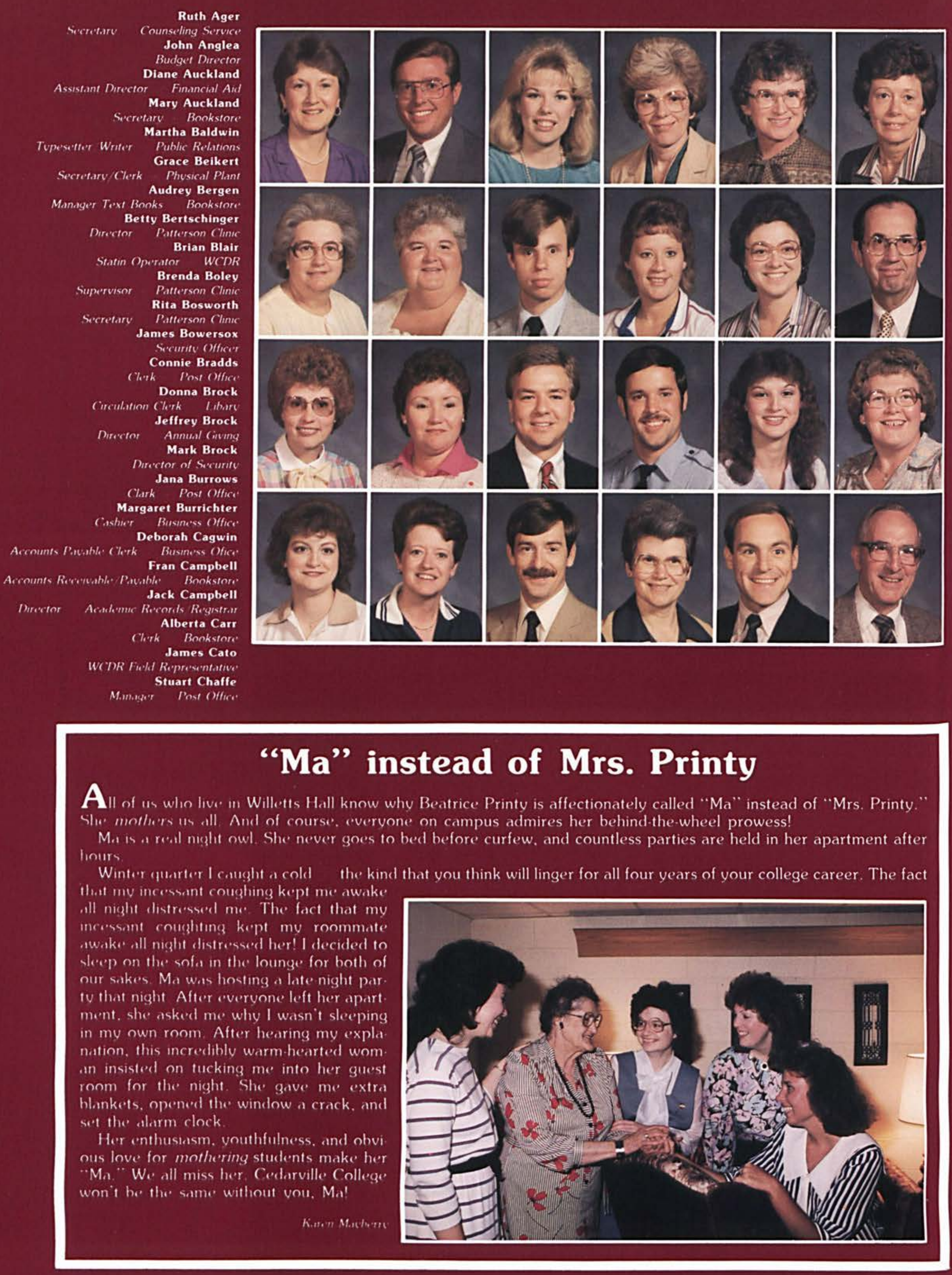




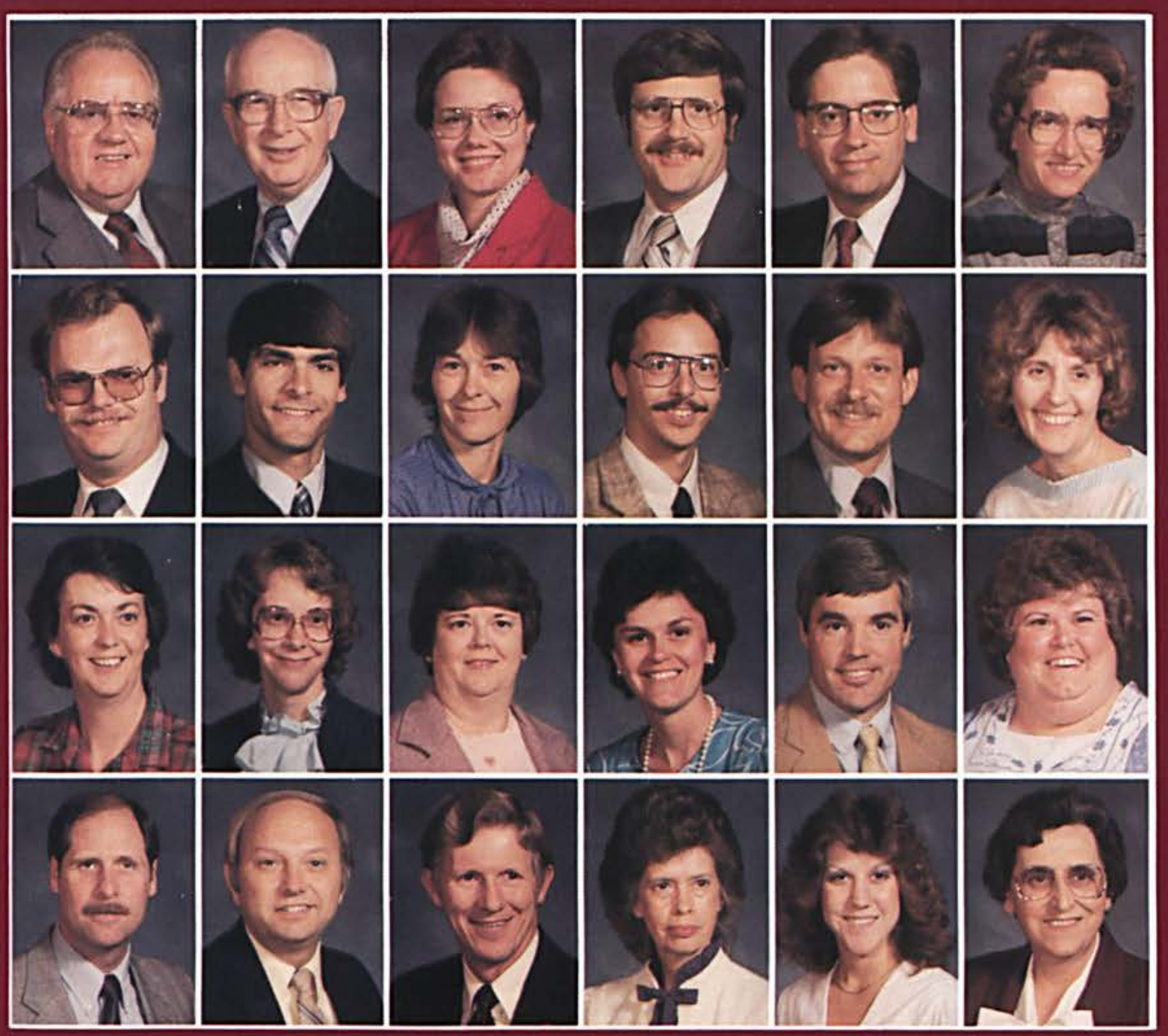

Edward Clark

Director - Staff Personnel

Harry Cole

Assistant Manager - Bookstore

Deborah Compton

Records Clerk - Academic Records

Paul Cope

Repairman - Physical Plant

Ronald Coriell

Director - Public Relations

Sherry Coy

Secretary - Student Services

Jeffrey Cunningham

Electronic Technician - Physical Plant

Timothy Danube

Head Resident

Jeannie Day

Clerk - Bookstore

John DeMeester

Head Resident

Steven DePenning

Director Compassion \& Puppet Ministries Norma Deranek

Secretary - Financial Aid

Margaret Dillon

Otfice Co.ordinator - Patterson Clinic

Linda Divan

Audio. Visual Services Co.ordinator = Library

Virginia Fields

Cashier/Purchasing Clerk Business Office

Judith Fires

Secretary - Development

Robert Fires

Head Residen,

Nancy Fissel

Head Cashier = Business Office

David Gaffner

Director - Placemen

Paul Gathany

General Manager - WCDR

David Gidley

Director Financial Aid

Irene Gidley

Secretary - Presiden

Linda Giesel

Clerk Academic Records

May Greenwood

Secretary Academic Vice President

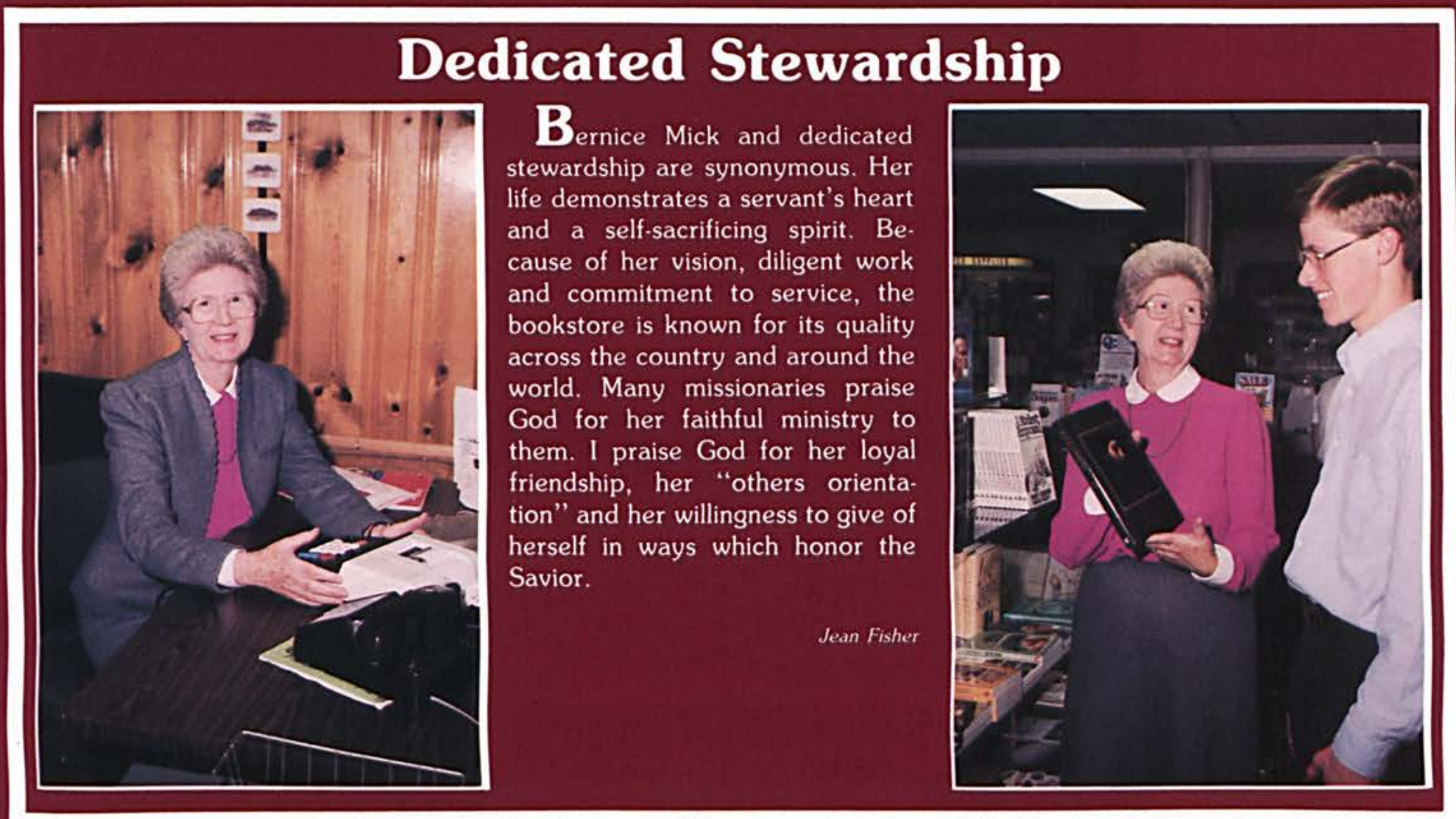




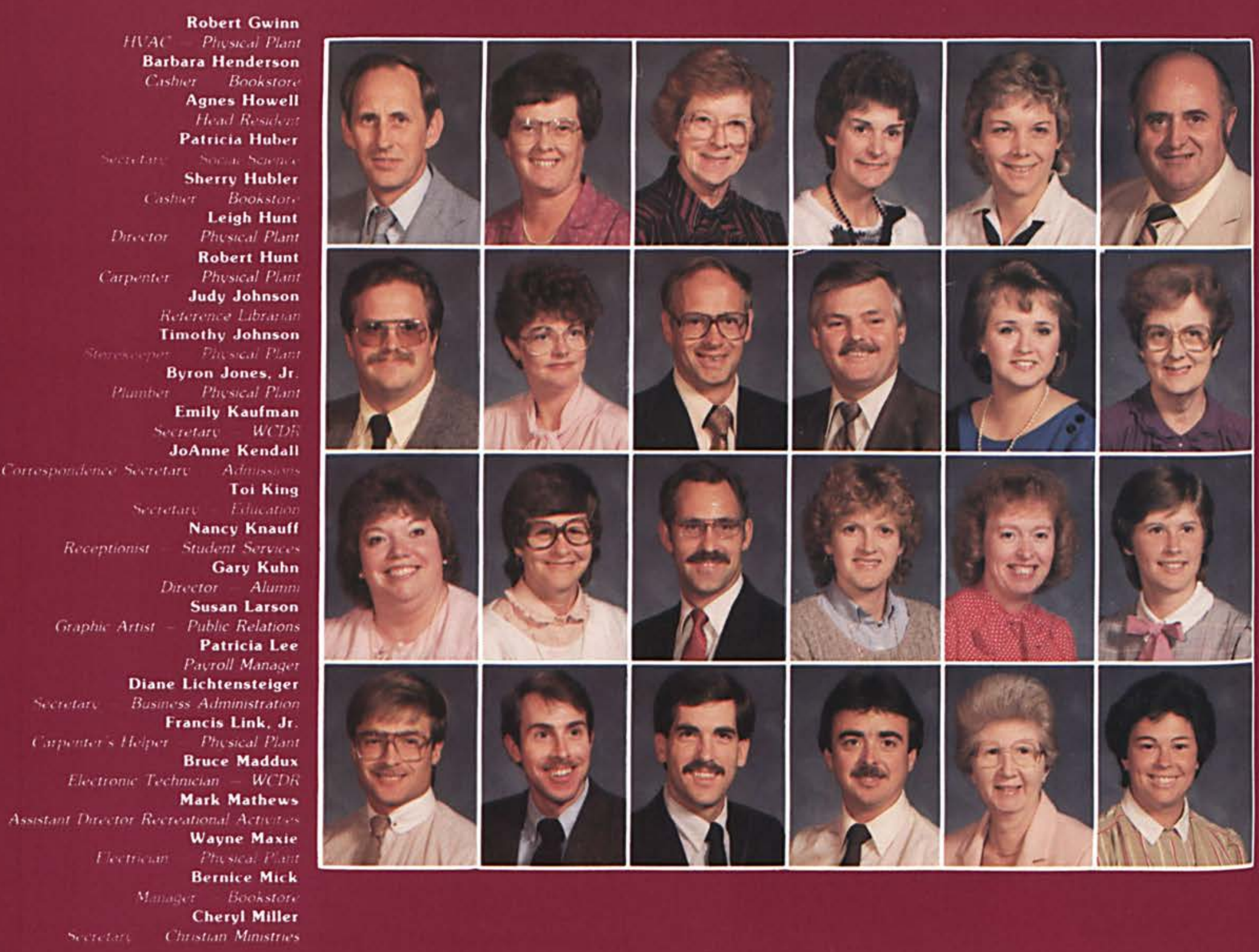

\section{Staff Member Of The Year}

$\mathbf{T}$

1986 "Staff Member of the Year" lives in Cedarville. (Ohio, and is in her 27th year of service to the College Keeping long hours and working diligently is typical of this faithful steward. She's not too busy though to stop and give wise words of counsel to her adopted children. CC stu dents

Her husband Charlie began working at the college in 1959. Ten months after he started, he asked her if she would come and help out for three weeks as a dining hall cook. That was some 26 years and 49 weeks ago, and she is still helping out.

For 42 years, she has been a member of Emmanuel Baptist Church serving as church secretary, clerk, and a Sunday School teacher. For her testimony and her hard work, cleaning every building on campus for the last 15 years as Head of Housekeeping. Cedarville College, in praise to God for His work of grace in her life, recognized Mrs. Betty Tarter as the "1986 Staff Member of the Year."

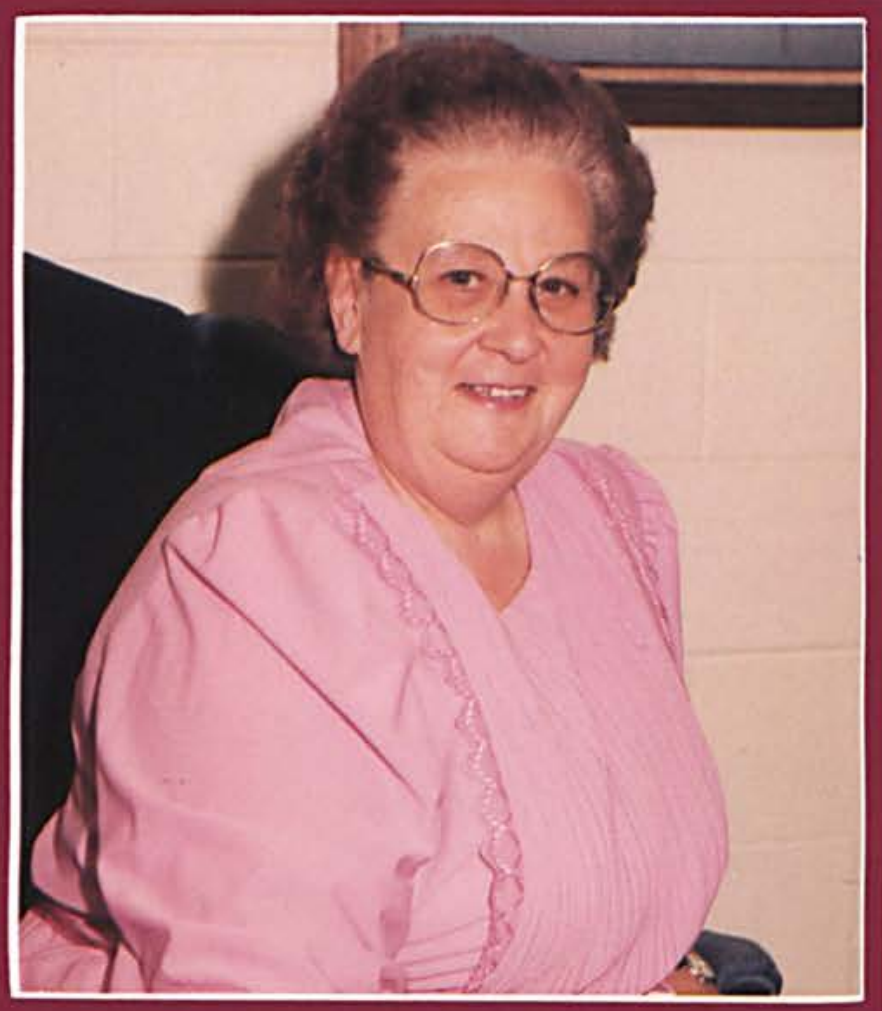




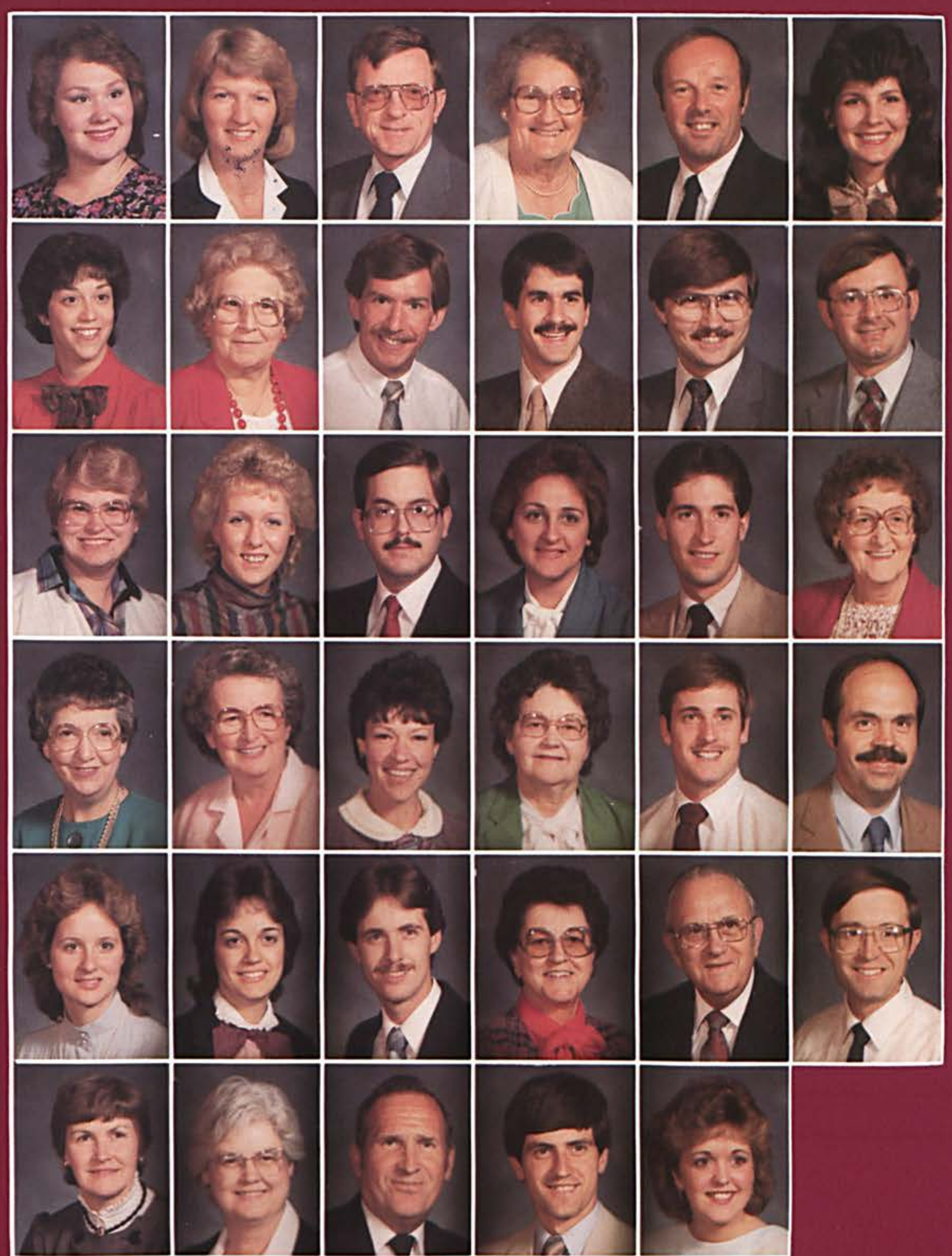

Laurie Miller

Mary Mitchell

Secretare Puble Revintome

Edmond Phillips

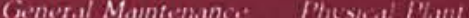

Beatrice Printy

Head Re'sident

David Purrington

Mavmuger New Construten Phoved plant

Jennifer Raught

MPC Superusor tibrare

Sharon Rawson

Head Resident

Ethel Rayburn

secretars Librars

Allen Rees

Photographor Artist Public Rolation

David Samuel

Audio Engineer WCDR

Douglas Sjoquist

Ditector Adminstratis. Computer

Jon Skillman

Program Operations Director WCDR

Sylvia Skillman

Statf Nurse - Patterson Climic

Valerie Smallman

Secretary Financial Aid

John R. Smith

Manager Inst L oams \& Eimploument

Financial Aid

Michele Smith

Serrals Co.ord Acquistions Choth Librat

Roscoe Smith

Visitor Coordinator Admissions

Dorothy Spencer

secretare Busmess Offici

Ida St. Clair

Switchooard Operator Houd Recuptionts

Joan Street

Head Risident

Kathleen Sturgis

Assistant Director of Muvk cimpure

Mimistries

Virginia Taylor

Prearcher Dewopment

Stephen Thompson

First Assistant Disectiog Finumiat An.

John Tocknel

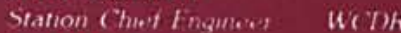

Lori Trautman

(thice Yariaget:

Bonnie Vickman

Mandiger cope cinter

Jeffrey Vickman

Kitty Vine

Allan Vine

(it.

Paul Ware

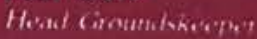

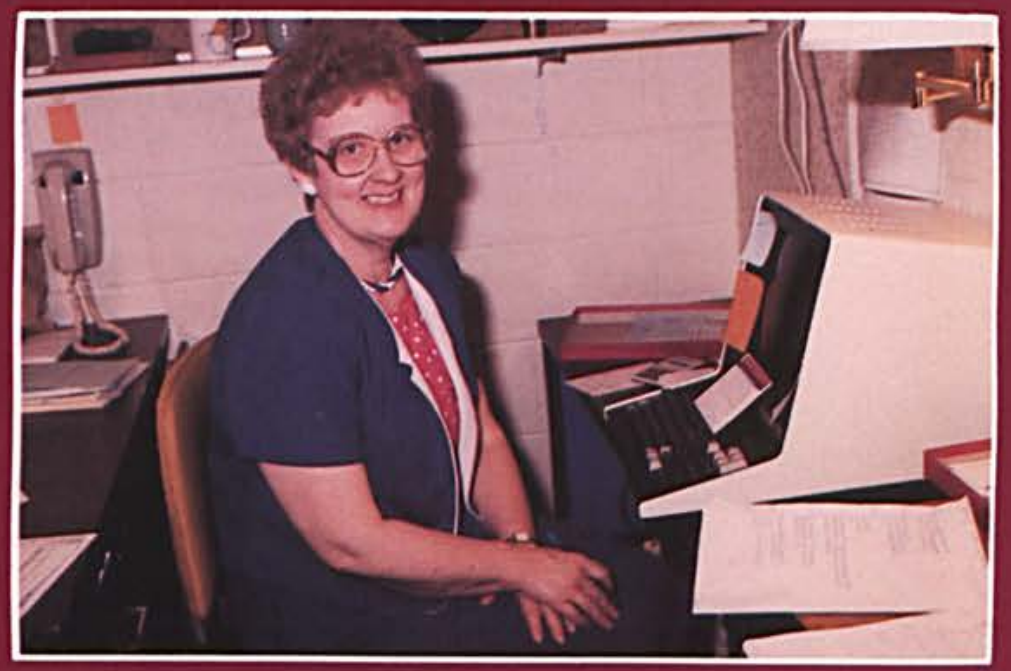

Phyllis Wetzel

Stcretion: Plannet cine

Glenda Womack

Jay Womack

Auto Mecham

Mark Womack

Sports Intormation Puretrot

Kimberly Worosher

Secretary Nursing 


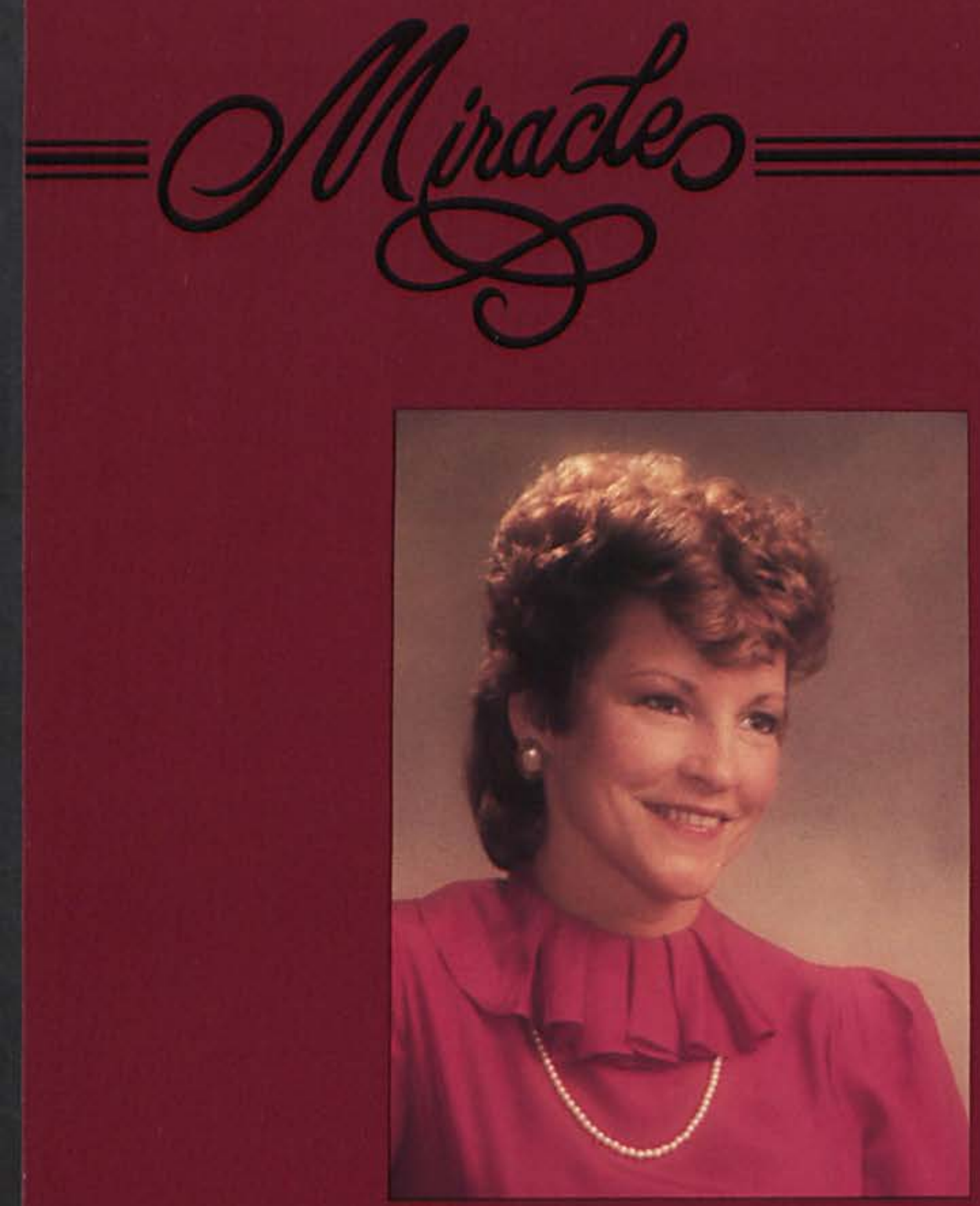

MRS. PAT DIXON

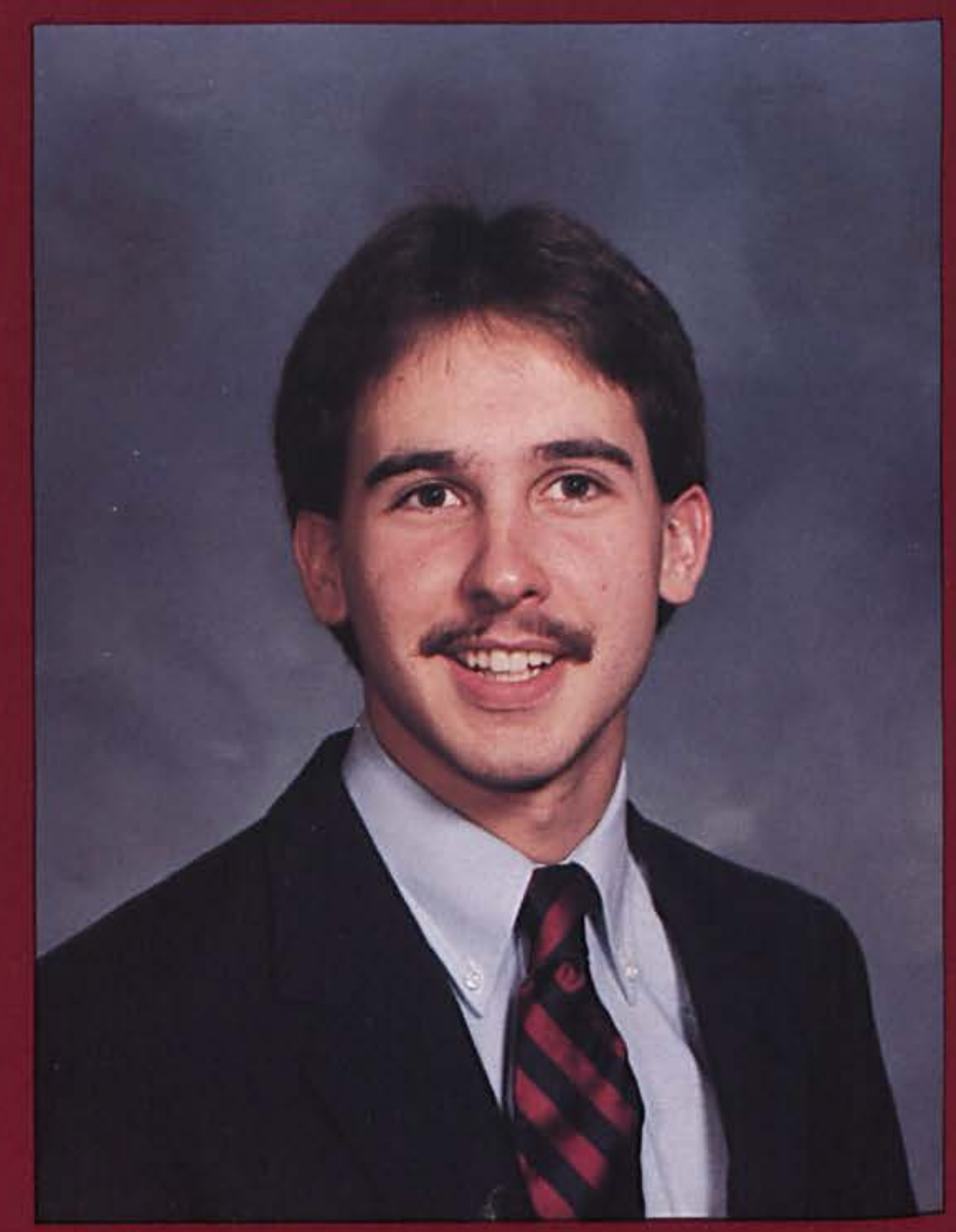

JEFFREY BERGANDINE

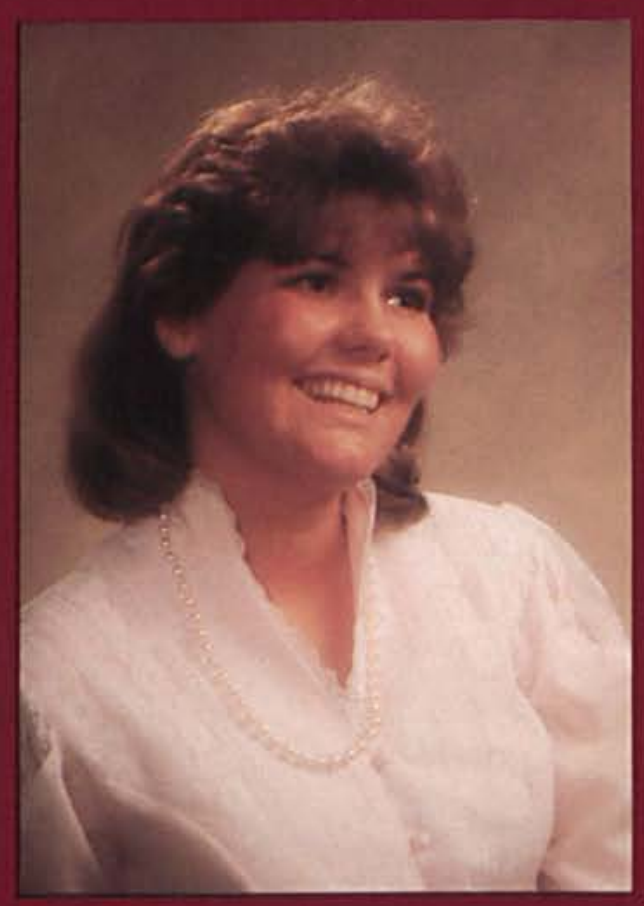

PATRICIA MARIHUGH

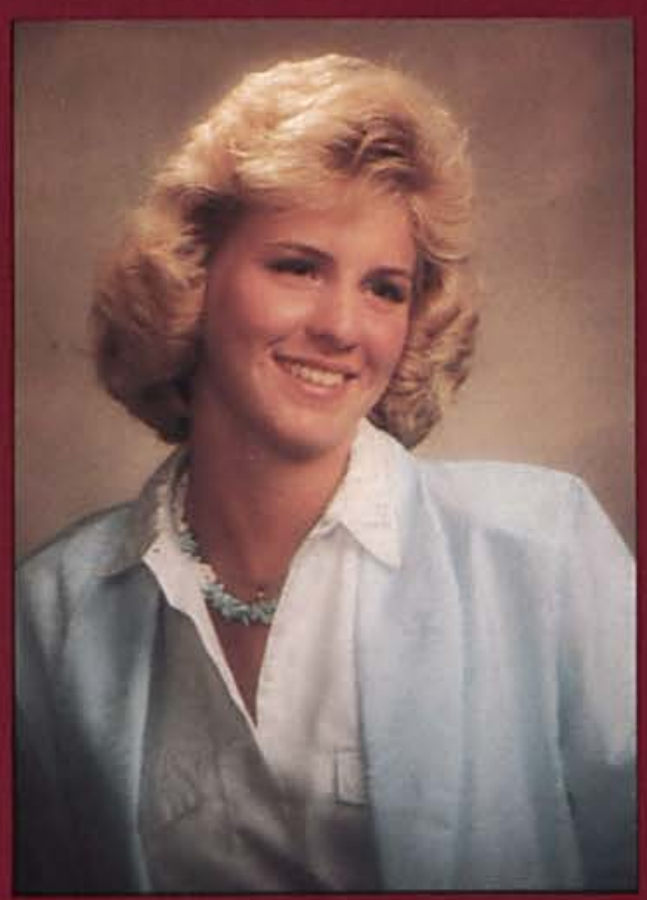

DANNAH BARKER

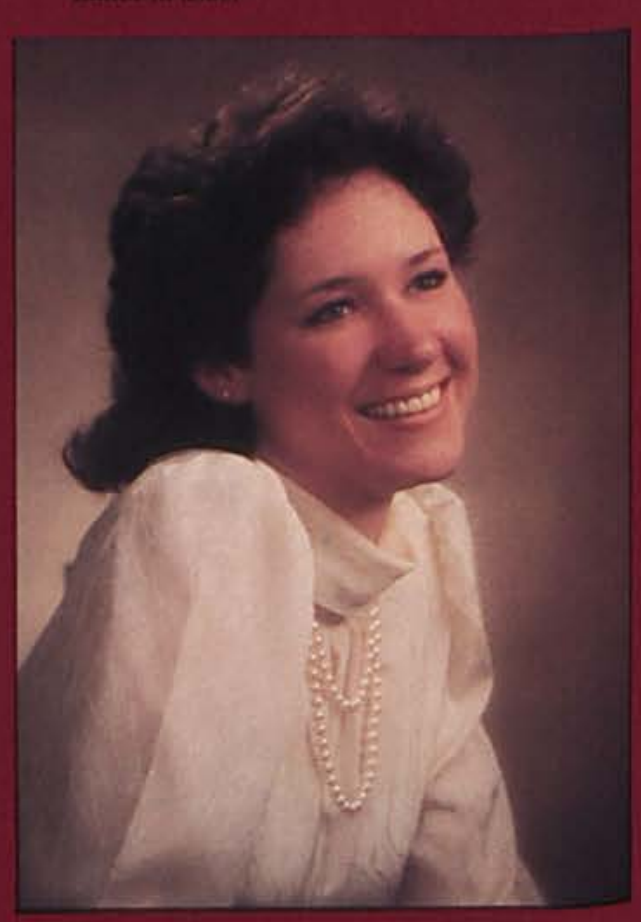

AMY BELGARDE 


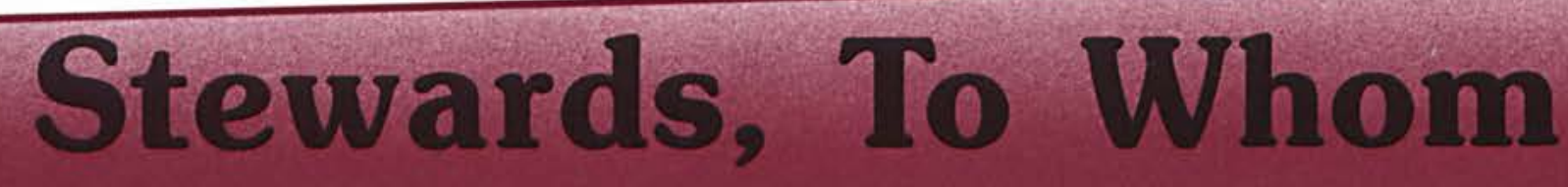

"I urge you therefore, brethren, by the mercies of God, to present your bodies a living and holy sacrifice, acceptable to God, which is your spiritual service of worship. And do not be conformed to this world, but be transformed by the renewing of your mind, that you may prove what the will of God is, that which is good and acceptable and perfect. For through the grace given to me I say to every man among you not to think more highly of himself than he ought to think; but to think so as to have sound judgement, as God has allotted to each a measure of faith."

Romans 12: 1-3

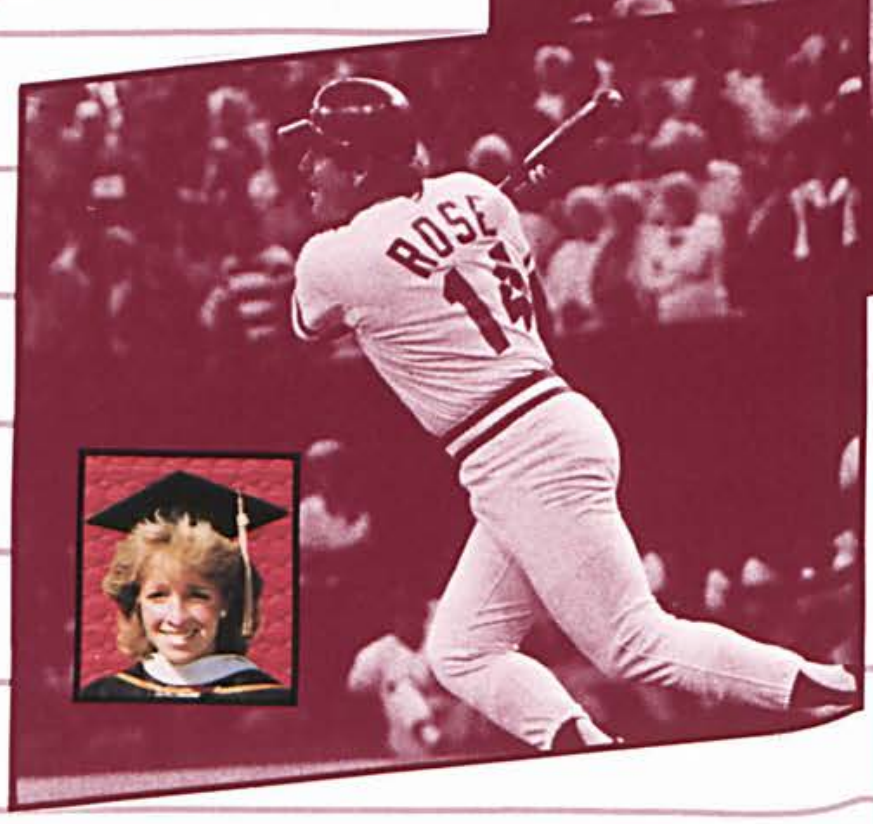




\section{Much Is Given,}

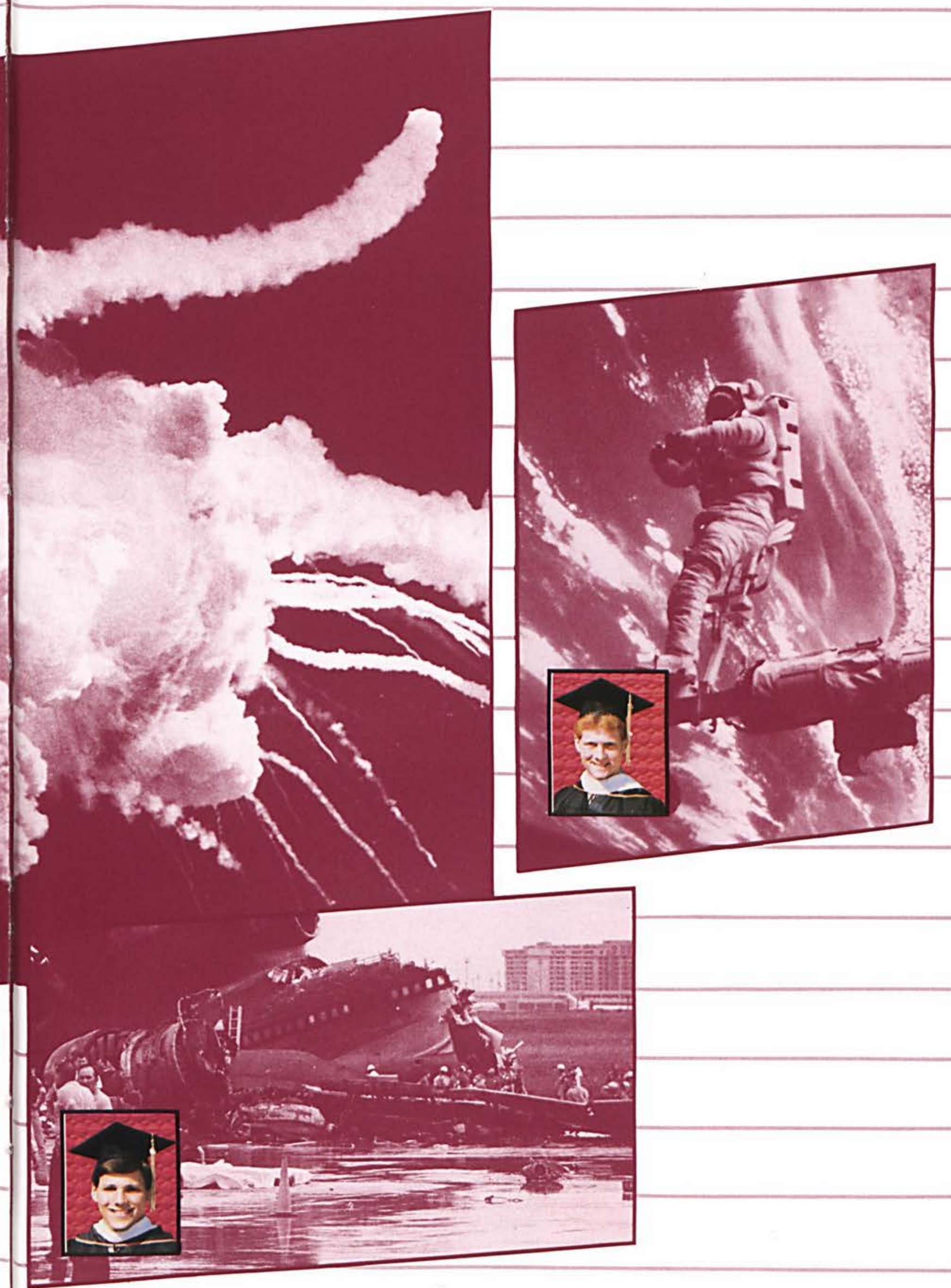




\section{Much Is Required;}




\section{Be Faithful.}

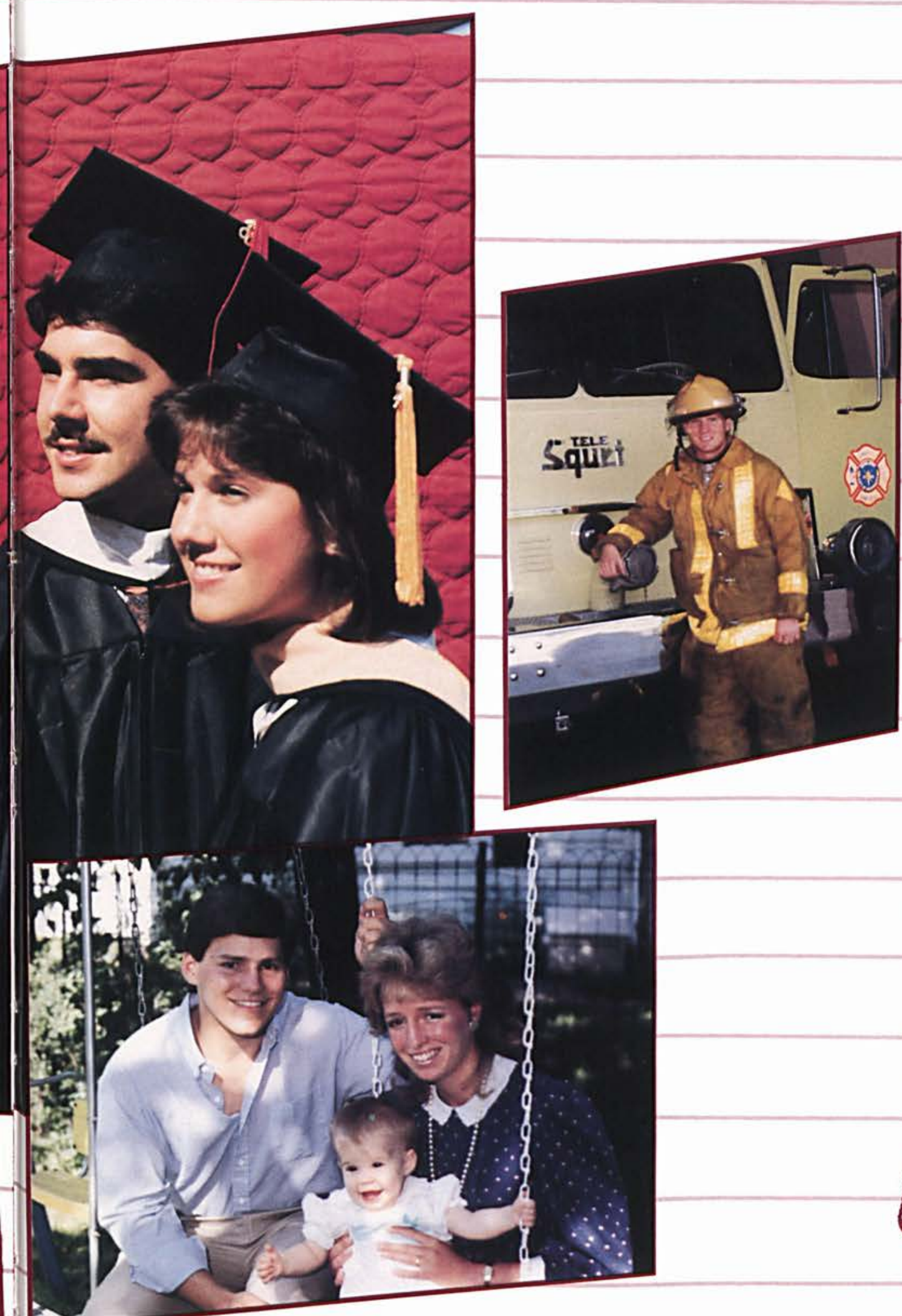

"For just as we have many members in the body and all the members do not have the same func-

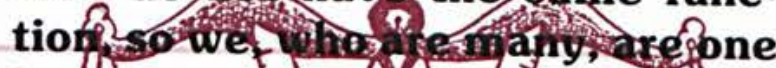
body in Christ and Individ mally members one df another. And since we have oifts that differ according to the grape given/to us, let tach exercise them accordingly: . . Let love be without hypocrisy. Abhor what is evil: Cling to what is good. Be devoted to one another brotherly love:

Give preference to one another in honor;

Not lagging behind in diligence, Fervent in spirit, Serving the Lord;" 


\section{A}

Abramdwitz, Timothy W. 100 Abresch, Cherie Ann 80 Abston, O. Diane 90

Adamson, Maudetta K. 100 Ager, Debby Ann 100

Allen, Amy 80

Allen, Amy 80

Allen, Theresa L. 100

Allipson, Andrew R. 100

Amor. Vince 100

Amos, Randy M. 90
Anderson, Catherine L. 100

Anderson, Cynthia R. 80

Anderson, Kurt D. 80

Anderson, Laurly A. 90

Anderson, Lorelei 80

Anderson, Michael A. 90

Anderson, Sarah Jo 52

Anderson, Sharon A. 80

Angst. Rachael Lee 100

Angus, John G 90

Anthony. Mare R. 21

Apple, Andrew S 100

Apple, Andrew S. 100

Armor. Robert A. 90

Arms, Brent A. 32

Armstrong. Amy L. 100

Armstrong, Lisa R. 80

Armstrong. Patricia J. 90

Atkinson, Robert C. 100

Auckland, Denise A. 80

Augenstein, Khathen 80 E. 90

Augustus, April S. 56

Austin. Lee S. 90

Averill, Rebecca J. 80

Avery, Cathy M. 100

Avey, April L. 21

Aures, Michael E. 100

B

Basb. Brian D. 100

Bachman, Brion J. 100

Bailey, Teresa Y, 100

Baise, Cindy L. 80

Baker, Debbie Jo 90

Baker, Deborah J. 80

Baker, J. Wesley 32

Baker, Jeffrey A. 90

Baker, Lois K. 52

Baldis, Susan M 80

Baldwin, Doug F. 90

Bane, Kenneth David 33

Banks, April L. 90

Bany, Jt., Williarn W. 50

Barber, Caryn $L 90$

Barber, Jeffrey A. 100

Barber. Tammy E. 80

Barker, Dannah K. 100

Barker, Gary W. 33

Barker, Joel B. 90

Barnhart, Roberta L. 100

Barr, Sarah Ann 80

Bartholomew, Krisanne 91

Barton, Tammy Jo 80

Barton, Troy D. 100

Bartus, John E. 64

Basler, Michael P. 80

Bass, Denise M. 90
Batchelder, Dina M. 80

Batencourt, David A. 100

Bauer, Janet Ann 52

Baur, Susan R. 80

Baughr, Susan A. 80

Baughman, Dawn E. 37

Baumgartner, Kerry E. 100

Bayes, L. Daniel 90

Beach, Dawn L. 100

Beach, Melissa J. 21

Beach. Timothy N. 90

Beachum, Dawn E. 90

Beachy, Kent 21

Beal, David J. 90

Beaman, Richard A. 80

Bean, Marilyn L. 80

Beattie, Karen L. 47

Beattie, Scott J. 100

Beaujean, Deborah L.
Beck, Daniel L. 100

Beck. Daniel L. 100
Becker, Jacki L. 100

Becker, Jacki L. 100

Beight, James D. 80
Beimly, Julia M. 100

Belford, David A. 16

Belford, Linda $S 90$

Belgarde, Amy Ruth 100

Bell, Debra J. 37

Bell, Wendy K. 90

Benedict, Laurie Ann 42

Benevides, Prudence L. 33

Bengtson, Lisa Marie
Bennett, David J. 80
Bennett, Rachel M. 100 Bennett, Rebekah J. 80 Bensink, Kelli L. 90

Bercaw, John A. 90

Berdy. Debbi L. 80

Bergandine, Jeffrey W. 90
Beste, Jeffery S. 61

Beste, Jeffery S. 61 . 100

Beverly. David E. 80

Bianco II, William E. 90

Biddinger, Kimberly K. 90

Bigelow, Jt, John 80

Biggs, Matthew B 64

Bigler. Cindy A. 68

Billingsley, Steve D. 90

Bishop, Peter Charles 6.5

Black. Suellen M. 80

Blake, Susan D. 65

Blaylack, Valerie A. 80

Blessing. Ann E. 56

Bliss, Nancy J. 21

Bliss, Rebecca D. 90

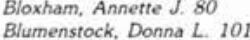

Bocciardi, John G. 101

Boersma, Joy C. 80

Bolds, Jeffrey S. 101

Bonning. Theresa D. 80

Borgman, Lani Sue 101

Borleis, Debbie R. 90

Borleis, Diane M. 91

Bosworth, Talitha A. 91

Bovey, William A 91

Bow, Brenda J. 101

Bowen, Renee Ann 80

Bowen, Tod A. 101

Bowers, Martha S. 91

Bowlen, Lisa C. 91

Bowling. Angela D. 91

Bowling, Tara L. 101

Bowling, Toni L. IoI

Bowman, Rachel Ann 21

Bowman, Rachel Ann 21

Box, Julie Beth 101

Boyd, Debbie L 91

Boyer, Colleen Ruth 52

Boyer, Scott A. 101

Boyle, Christina L. 101

Brace, Mindy 91

Bradds, Kelli D. 101

Bradman, Kristian D. 91

Bradshaw, Kevin U.

Brags. Kimberly K 91

Brandt, Sara Jean 37

Bratka, Ann lrene 56

Braun, Michelle A. 8

Bresson, Brad L. 91

Bresson, Janie M. 101

Bresson, Janie M.

Brewer, Polly A 10

Brewin, James P. 21

Briggs, Laurie Ann 65

Briggs, Susan Bea 56

Brigss, Susan Bea 56

Brock, Timothy A.

Brock, Timothy A. 81

Brooker, Jane D. Romig 21

Brooker, Scott R. 21

Brown, Diane L, 81

Brown, Lori L 91

Brown, Mark E. 101

Brown, Renee S. 101
Brown, RoShay L. 101

Brown, Ruth M. 81

Brown, Warren K. 50
Browne, Shelley Lynn 52

Browne, Shelley Lynn 52
Browning, Linda G 91

Brumm, Terri Lynn 61

Brunner, Philip N 92

Bryant, Lisa M. 101

Buchanan, David A. 101

Buck, Martha 16

Buckholz, John R. 21

Bucklew, Elizabeth A. 22

Budd, Brent 92

Bumpus, Tonya J. 92

Burchett, Brenda D. 37

Burk, David L. 101

Burke, Calvin $B 92$

Burke, Holly J. 92

Burkholder, Julie A. 101

Burr, Jocelyn Renee 50

Burrell, Kimberly J. 92

Burrows, John 81

Butcher, Jay R. 17

Butler, Jennifer L. 92

Butlet, Julie A. 81

Butziatt, Jeanne L. 81

Byrnes, Heather Lynn 53

Byrnes, Heather Lynn

C

C

Cadle, Patrick R. 92

Calder, Donald D. 17
Caldwell, R. Bradley 101

Calisti, Lee 101

Calisti, Lynne B. 81
Calkins, Gayl M. 92

Calkins, Gayl M. 92

Calle, Judy R. 92

Campbell, Callie A. 101

Campbell, Keith R.101

Campbell, Mike Alan 33

Campbell, Mike Alan 33

Canterbury. Timothy L. 10

Carafa, Christine M. 92

Carey, Richard J. 81

Carmack, Sandy H. 37

Carmichael, Wendy E. 92

Carpenter, Donna E. 101

Carpenter, Glenn W. 101

Carpenter, Kevin Lee 101

Carpenter. Sandra S. 53

Carr, Renee L. 92

Carr. Thomas A. 17

Carroll, Jennifer L 101

Carroll, R. Scott 101

Carter, Becky Lynn 68

Carter, Julie C 101

Carter. Teresa L. 22

Cassidy Tedd M

Casteel Lori R B1

Chandier, Amy 11

Chandier, Amy L. 101

Chariton, Pamela G. 101

Chase, Christina Anne 37

Chasse, Sherie D. 22

Cheek, Christine M. 92

Cherry, Doug 81

Cherry, Patricia S. 101

Chiarelli, Perry E. 81

Chitwood, Marc D. 22

Church, Elizabeth H. 1

Clark, Melanie S. 101

Clarkson, Rebecca L. 61

Clarkson, Rebecca L. 61

Cleaver, Cindy Sue 10

Clem, Deborah A. 81

Clemens, Gregory S. 2

Clifford, Karen 92

Cline, Connie S. 10

Clor, Renee C. 101

Clymer, Diane B. 102
Coates, Steven D. 81

Cobb, Jeannette D. 47

Cochran, Sally J. 37

Coffman, Erin E. 81

Coffman, Robert S. 102

Collick, Trina L. 102

Collier. Cindy A. 92

Collier, Peggy A. 92

Collins, Meredith B. 53

Colitins, Meredith B. 53

Collins, Michael S.

Collins, Paul B. 22

Comfort, Nancy $K$.

Commins, Pamela 102

Compton Sally Ann 102

Conrad Pamela F: 102

Cook, David P. 102

Cook, Mary Ruth 8.

Cook, Rachael L. 81

Cooke, Cregan S. 61

Coonser, Diane $R$. 17

Cooper, Laurie Ann 102

Cooper, Lonnie E. 92

Coronato, Teena Marie 56

Corry. David M. 81

Costly. Lynn E. 92

Coston, W. Todd 81

Cox, Norman D. 22

Cox, Steve M. 81

Cox, Tamarat D. 33

Crawford, Charlorte M. 52

Crawford, Deborah M. 52

Crawford, Kim D. 102

Creamer, Matthew 92

Creech, Cathy L. 102

Cremean, Stephen J. 22

Critcher. Curtis 43

Cronrath, Cynthia H 8

Cruise, Clancy C. 81

Crump. Bryan Lee 62

Cruver, Sherri L. 92

Cruz, Leslie M. 53

Cruz, Loralee M. 92

Cruz, Loralee N. 68

Cruz, Louanne M. 102

Cruz, Luis 102

Culbert, Rhonda 
Green, Sandra Lee 38 Greetham, Susan Lynn 48 Gregory, Bradley G. 93 Gregory, Julia A. 103 Gresh, Robert W. 93 Grider, Matthew J. 103 Grimes, Peter T 103 Grimes, Tracy E. 83 Gross, Laurie Jo 10.3 Groves, Mark L. 93 Grumbeck, Holly A. 24 Gruneisen, Virginia Ann 83 Guest, Amy 83 Guido, Cindy M. 93 Guido, Margaret E. 93 Gunther, Stacy L. 83

H

Haberli, Lori R. 83

Hack, Noel M. 17

Hackenberry. Lyn M. 83

Haga, Rebeces Jo 93

Haist, Heidi $L$ 93

Hakes, Pamela B. 83

Hale, David C. 65

Hall, Melanie G. 93

Halleck, Melissa J. 93

Hallman, Donna Sue 38

Hamilton, Joy Ann 103

Hamilton, Kelly J. 8.

Hamlin, Paul L. 93

Hammr, Keith A. 93

Hammond, Michael F. 65
Hancock, Crystal Ann 48

Hancock. Laure S. 8,3

Hanna, Nancy G. 93

Hannay, Scont R. 24

Hannay. Shemi L. 93

Hansen, Elizabeth J.83

Hanssen. Joe C 104

Happe, Judy 83

Harbaugh, Joel S. 93

Harden, Joy Ann 38

Harden, Mark 93

Hardman, Kathleen J. 93

Harman, Julie K. 104

Harper, David R. 93

Harper, Kristen D. 104
Harris, Jonathan S. 104

Harris, Kathi 83

Harris, Nova Mae 104

Hart, Christina J. 48

Hartsough, Laura A. 83

Haskins, Kevin S. 24

Haskowich, Ann K.83

Hastman, Jeri L 104

Haufler, Jennifer K 93

Hautler, Jennifer $K .93$

Havens, Jenny $L$

Hawk, $T$. Daniel 17

Hayden, Joel A. 94

Hayes, Beverly Dawn 24

Hayes, Ronald M. 104

Haynes, Karen L. 104

Haynes, Timothy L. 104

Haywood, Richard G. 83

Heacox II, Larry L. 83

Headdings, Karen Y. 53

Healey, Heather Ann 83

Hedges, Brian T. 18
Hedges, Lois K. Masters 38

Hedges, Lois K. Masters 38
Heffelfinger, Jeffrey 83

Heffelfinger, Jeffrey 8
Heflick. Holly C. 104

Hein, Stephanie J. 104

Hein, Stephanie J. 104

Heitzman, Diana L. 83

Heitzman, Diana L

Helman, Kelley Lee 53

Helmick. Cynthia J. 83

Helmick, Kelly L. 83

Helmuth, Eric D. 83

Helvey. Talisha J. 104

Hempel, Eric W. 104

Hempel, Heidi E. 25

Henderson, Nadeen K. 83

Heniser, Stacy L. 104

Henning. Linda J. 104

Henry, Lisa Beth 83

Henry, Theresa J. 94
Henthorn, Rebecca L. 83

Hermann II. Bruce D. 104

Herr. Suzanne Marie 48

Herrick, Kendall L. 84

Herroon, Lisa D. 105

Hibbard, Hope Ann 84

Hicklin, Keren A. 105

Hildebrand, Robert J. 105

Hill, Cheri A. 94

Hill, Thomas C. 61

Hines, Karla M. 84

Hinman, Mark J. 84

Hinshaw, E. Dean 105

Hochstettler, Ginger 84

Hoddelmann, Kirsten T. 94

Hoddelmann, Kristina $T .94$

Hoecke, Beth J. 84
Hoefler. Christopher J. 84

Hotf, Darido 94

Hoffmeuer, Gretchen A. 94

Hohulin, Philip J. 84

Holbrook, Sandra $L$, 94

Holland, Cheryl L 94

Hollopeter, Brenda $K .94$

Holloway, Van B. 94

Holmes, Robert 94

Holt, Cheryl A. 105

Holt, Donald J. 105

Holtlmann, Amy Sue 105

Hood, Brad M. 105

Hoover, Cynthia D. 105
Hornbacher, Corrine F. 105

Hornbeck, Joanne R. 94

Horne, Douglas V. 51

Horton, Kenneth R. 94

Horton, Linda L. 105

Hoskins, Barbara A. 65

Hoskinson Joel A. 64

Houser, Tamara $K$. 105

Howard, Deborat 4

Howard, Paula J. 105

Howder, Penelope K. 105

Howder, Scott J. 84

Howdyshell, Dorothy E. 84

Howell, Rebecca L. 105

Hoyle, Lorena M 105

Huber, Terri J. 105
Huddleston, Nancy Ann 38

Hudon, Sandra M. 105

Huebscher, Mark D. 84

Huggart, Laura S. 94

Hughes, Paul $R$. 84

Hughes, Paul R 84

Hultz, Brian A 94

Hummel Rebecce A 105

Hummel, Rebecca A.

Humphrey, David A4

Humphreys, Donald S. R. 10.5

Humphreys, Tamara D. 105

Hunn, Paula M. 84

Hunt, Judy M. 84

Hunter, Carolyn A. 54

Hurst, Lisa R. 94

Husband, Terri L. 94

Hutchison, Norma 94

Hyatt, Kristine K. 94
Hysang, Pamela L. 65

I

Imhoft, Jeffrey A. 84

Inman, Jay J. 105

Irving hold A T05

Irving. Jr., John T, 84

Irwin, Robyn A. 68

Iverson, Douglas S. 84

$J$

Jackson, Charles 84

Jackson, Susan R. 25

Jackson, Vickie Y. 94

Jacobs, Barbara L. 94

Jacobs, Becky S. 57

Jacobs, Bradley F. 105

Jacobs, James W. 94

Jacobs, Robert A. 25

Jacobson, Robert B. 2.5
James, Mark D. 94

James, Richard D. 84

Jantzi, Charles Duane 57

Jenkins, Tammy $L$

Jensen, Julie A 94

Jessop. Susan L S4

Jeunnette, Timothy $T 105$

Johnson, Amy M. 38

Johnson, Bonnie L. 105

Johnson, Diane R. 84

Johnson, Dianna L. 105

Johnson, Eric L. 94

Johnson, Ginger 1.84

Johnson, Jan R. 94

Johnson, Jill A. 105

Johnson, Jocelyn 25

Johnson, Kelly L. S4

Johnson, Kristyn 94

Johnson. Paul 25

Johnson, Paul 25 .

Johnson, SG Ross 66

Johnston, Amy 66

Johnston, Karen S 94

Johnston, Robin $L .94$

Joiner, Robert S. 105

Jones, Charles A. 44

Jones, Daniel K 105

Jones, Dean E. 94

Jones, Kathleen V. 105

ones, Kelly K. 84

Jones, Marsha J. 84

Jones, Suzanne E. 84

Joslin, Amy Lee 94

K

Kaercher, R. Gene 105

Kamphaus, Julia L. 38

Kauser, Susan L 25

Kautman Grant $E-25$

Kegel, Kathleen $L$.

Keim. Joyce L. 38

Keisling. Bruce $L$.

Keller. Gerald D 105

Kempt, Donna 105

Kennedy. Sandra F. 84

Kenney, Kathleen A. 105

Kenyon, Pamela B 94

Kester, Richard T. 84

Ketcham, David W. 84

Ketring. James $R$. 84

Keyes, Beth A. 94

Kilener, Susan J. 84

Kimble, Pamela I 84

Kimmel Metissa D 105

King. Beth A. 84

King, Darrin A. 10

King. Kendra $d .94$

King. Russell A. 84

Kingston, Thomas E. 105

Kinney. Robert W. 94

Kirkpatrick, Danielle K. 105

Kirkpatrick, Sharyl L. 106

Kirtland, Jon M. 106

Kirtland, Jr. James L. 84

Kiser, Kimberley S. 84

Kitchen, Barry L. 94

Kleinpeter. Elicia L. 106

Kline, Jeffrey W. 84

Klopp, Rebecce A 84

Klose, Kathryn A. 84

Knauff, Julie $R 106$

Knicely, Mary Beth 84

Knowles, Laurie A 94

Knowles, Temple $L .26$

Koerber, James R. 84

Kohlmeyer, James M. 26

Kohlmeyer, John M. 106

Kooyenga, Alona K. 106

Kormash, John M. 94

Kozma, Kara F. 95
Kraner, Jane Elizabeth 39

Kratche, Jane Elizabeth

Kreidler, Sonya R. 8

Krikke, Lorin K 84

Krueger, John E. 106

Krull, Kathy E, 95

Kruppa, Diane L. 95

Kuhn, Stephen A. 26

Kuntz, Karen D. 106

Kuntz, Laura K. 95

L

LaVancher, Barbara 95

Labonte, Nancy R. 54

Lachmiller, Dana S. 106

Lafferty, Steven M. 39

Lafferty, Susan J. 85

Lahaie, Daniel A. 85

Laird, Joanne J. 54

Laird, Michele D. 95

Lamb. Mark R. 106

Lamb, Stephen P. 95

Lambert, Gregory P. 26

Landis. J. Michael 95

Lane, Michael C. 85

Lanning. Edward G 18

Lash Roge Dawn 95

Lassitter Jr. Terry E 95

Latini, Mark A 26

Latorella, Beth Anne

Lotorella, Mark 106

Latorella, Robert L.

Latorella, Robert

Lauterbach, Sandra M 85

Law. John P. 106

Law. Michael E 85

Lawrence, Janet K. 106

Lawrence. Tracy Y. 95

Lawson, Julie A. 95

Layman, Charles D. 10

Leach, Jeffrey A. 85

Leach, Shari K. 95

Ledford, Angie R 85

Lee. Eun Sil 106

Lee, Marc Edward

Leed Patricia B. 106

Leedat. Patricia B. 105

Lenhart Jenniter 95 
Parr, Robert Glenn 64 Paswaters, Robert W. 107 Pate, Deborah C. 86 Patrick, Crystal Ann 97 Patrick, Jeffrey $L$. 86 Patrick, Jennifer $L 97$ Patry, Jennifer M. 97 Patterson, Holly L. 107 Pawelski, James O. 107 Paxson, Cheryl L. 97 Payne, Alyson A. 107 Payne, Donna M. 107 Payne, Lisa L. 107 Payne, Shelly $R .97$ Pearson, Becky 107 Pearson, Marianne 40 Pearson, Silas 97 Jennifer L. 107 Pedersen, Ellen M. 54 Peffer, Diane M. 45 Peio, Lisa A. 107 Penny. Christine 107 Penty, Katherine G. 54 Perkins, Melissa 107 Perkins, R. Michelle 86 Petek, Dan C. 86 Petek, Richard C. 97 Peters, Jo-Ellyn Marie 63
Peters, Rebecca J. 97 Peterson, Thomas L. 86 Petrie, Charles D. 107 Phillips, Amy L. 86 Phillips, Diana Sue 97 Phillips, Douglas T. 19 Phillips, Phyllis M. 69 Pickthorn, Tamra Sue 49 Pinkerton, Jean E. 86 Piper, Jeffrey S. 86 Pitonyak, Lynne M. 107 Pitsenbarger, Bruce J. 107 Plooy. Cheryl Ann 97 Plourde, Katrina L. 107 Ponce, Rolando 86 Ponzani, Christina J. 28 Popa, Jonathan C. 107 Potter, Laura A. 107 Potts, Kim E. 86 Prall, Lisa M. 28 Pratt, Sandra G. 55 Pratt, Thomas E. 28 Price, Amie S. 86 Prince, Tressu A. 28 Printy, Yvette 97 Pruner, Becky Lynn 97 Pugh, Douglas E. 86

Purrington, Brian R. 107

R

Racz, Steve A. 97 Radcliff, Ebbie J. 97 Raines, Lisa B. 107 Rainwater, Pamela S. 55 Raisch, Mary M. 97 Rajchel, Ferdinand H. 86 Ramaker, Debbie M. 97 Ramey, Kenneth A. 97 Rammes, Robert S. 58 Ramsey, Lynn Ann 108 Ramsier. Kimberly 0.86 Randall, Roger L. 86 Rase, Daniel H 86 Ray, Kara 86 Redding. Thomas R. 19 Reebel, Brian 97 Reed, Krists G. 97 Reed, Mark A. 97 Reed, Michele B. 97 Reed, Patricia J. 86 Reede, Jr., George E. 86 Reeder, Lawrence G. 86 Reehl, Dawn Marie 40 Reese, Christopher $A$.
Reeves, Jennifer 86 Reid, Jonathan C. 58 Reid, Lori Lee 97 Reid, Rebecca D. 86 Reigle, Mary E. 108 Reiter, Becky L. 108 Reiter, James M. 19 Reiter, James $M$. Renberg. Christine L. 108 Rendle, Cheryl A. 86 Debra R. 97 Reynolds, Kathy D. 8 Rhoades, Malina Ann 40 Rhoades, Todd A. 34 Rhoden, Lori A. 97 Rhodes, Miriam E. 63 Richards, Hamilton D. 97 Rickard, Pamela Jo 86 Riggs, Melissa 97 Rinehart, Debby K. 108 Riopell, Lisa A. 108
Ritchie, Craig D. 97
Ritenour, Mary L. 108

Ritsema, Amy 108

Rivetti, Timothy J. 86

Robalino, Joffre E. 108

Robbins, Jerry Ray 28

Roberts, Mike J. 108

Robinette, David L. 86

Robinson, James A. 86

Robinson, Jennifer Sue 35

Robinson, Lynn R. 69

Rockwell, Steve C. 58

Rodebaugh, William A. 108

Rogers, Jennifer L. 97

Rogers, Michelle L. 108

Rogers, Richard B. 63

Rogers, Susan G. 108

Rogers, Tamara $K .97$

Roget, Brian J. 63

Roggow, David M. 97

Rolfe, Renee J. 86

Romano, Catherine Ann 49

Ropp, Wiatt D. 108

Rose, Michael L., 108

Ross, Denise Charlene 58

Ross, Stephen C. 108

Rotramel, Debra K. 108

Rotramel, Sherry M. 86

Routh, Douglas 108

Roy, Tracy Alane 67

Ruby, Darren L. 86

Ruggles, Gayle L. 97

Runion, Melissa Sue 98

Runion, Melissa Sue
Rushe, Jimmy 98

Russell, Norman F. 108

Ruth, Marilyn F. 40

Ruth, Nancy L. 40

Ryan, Heidi M. 98

Ryder, Theresa F. 108

\section{$S$}

Sadler, Kerri L. 98

Sager, Sally.Jo M. 108

Salyer, Mark E. 98

Sanchez, Jose L. 108

Sand, Robert M. 28

Sandy. Jill A. 86

Saunders. Shannon M. 28

Savage, Mary Jo 55

Schakat, Timothy M. 86

Schieferstein, Scott A. 99

Schleinitz, Kevin $J 8$

Schneider, John $E$. 108

Schofield, Lois $J .108$

Schonfeld, Deborah S. 28

Schonfeld, Fay D 98

Schroder, Jewel 45

Schroll, Bryan C. 108

Schuttenberg, Monica L. 69

Schwartz, Deborah L. 108

Schwartz, Deborah S. 86

Scott, Charles V. 98

Searles, Daniel R. 86
Sechrist, Jr, Richard F. 98

Seefried, Erick 98

Seest, Lila M. 98

Seidel, Erick J. 86
Semmelroth, Judith E. 86

Semmeliroth, Juditth

Sergeant, Johin 29

Sexton, David M. 87

Shaff, Lorena H. 98

Shaffer, Gary B. 108

Shaffer, Linda 1.87

Shank, Ronette 98

Shank, Ronette 98

Sharpe, Richard P. 63

Shaull, Philip A. 98
Shaw, Kevin A. 87

Shepherd, Elizabeth A. 98

Shepherd, Kenyon L. 108

Shirey, Mark H. 108

Shook, Sharon M. 108
Shovelton, Kenneth M. 29

Shovelton, Kenneth M. 29

Shriver, Deena R.87

Shrum, Eric L. 87

Shuier, Sheri 2.87

Shulse, David E. 67

Shulse, Sandra $K 98$

Shuman, Kathryn M 87

Sickau, Lynne 98

Siefert, Marlene Kay

Simerly, Don Howard 98

Simington. Denise A 98

Simmen, Deborah A. 108

Simpson, Karla R. 98

Simpson, Kimberly K. 87

Sinclair, Rebecca E. 87

Sjoquist, Brian K. 108

Siver, Tina N. 108

Slayton, Jill M. 98

Sloan, Robin K. 98

Sloan, Tammy W. 87

Smallman, David A. 87

Smallman, Marjorie B. 10

Smart, Janae M. 98

Smiley, Allison R. 108

Smith, Benin 98

Smith, Betty Marie 67

Smith, Carmen Gayle 40

Smith, Cheryl K 108

Smith, Christopher P. 108

Smith, Dan J. 108

Smith, Jr, Ronald M.

Smith, Kristine L $L$

Smith, Liana 87

Smith, Pamela M. 87

Smith, Rhonda Lynell 98

Smith, Richard R. 98

Smith, Rodney Jennings 58

Smith, Rodney N. 29

Snodgrass, Rusty A. 108

Snodgrass, Rusty A. 108
Snook, Amy J. Dykes 6.3

Snyder, Andrea B. 87

Snyder, Bonnie B. 98

Snyder, Donna J. 88

Snyder, Rebecca Lynn 41

Sommers, David C. 109

Sommers, Dorcas 88

Sorby. Diane E. 109

Southwell, Sheila A. 88

Sparks, Jeffery W. 49

Speas, Brent D. 109

Sperry. Kevin Lee 98
Spicer, Heather J. 109

Spiegel, Lori J. 98

Spieker, John Eric 29

Sprague, Ralph Mackenzie 59

Springer, Samuel T. 88

Stackhouse, Julie $\mathrm{A} .88$

Stackhouse, Penney L. 109

Stagg. Kathy Ellen 41

Stagg, Kristen E. 98

Stalter, Susan L. 98
Stamm, Diane Elizabeth 69

Stamm, Marilyn Lee 29

Stansbury. James E. 109

Starkey, Larry Von 98

Steele, Lisa Beth 29

Steiner, Meredith A. 98

Stephens, John R. 98

Stephens, Sharon K. 109

Stevens, Andrew W. 109

Stevens, Damaris H. 109

Stevens, Stephanie Jo 109

Stith, Wendy A. 88

Stitt, Julie Ann 55

Stockham, Robin 63

Stokes, Trenton T. 109

Stoltzfus, Cynthia M. 59

Stane, Jon W. 29

Stone, Timothy J. 109

Stoner, Jr., David G. 109

Storer, Jill K. 88

Storm, Tamara Sue 98

Stowell, Cristine M. 10

Stowell, Ronald L. 88

Stowers, Deborah A. 109

Strait, Andrew $R$.

Strause, Lila L. 98

Streeter, Glenn E. 109
Stretch, Heather $R .98$

Stretch, Heather $R .98$

Summerville, Kurtis

Sundernile. Kurtis 88

Sunderman, Karen $S$

Swander, Mark A.

Swander, Mark A. 98

Swanson, Pamela M. 88

Swayze, Jill A. 88

Sweet, Kimberiy B. 110

Sweitzer, Alice M.98

Sykes, John R. 30

$T$

Tacket, Rebecca L. 98

Taddecken, Susie M. 8

Taft, Jennifer J. 110

Tansey, Carrie M. 88

Tarke. Shelley A. 88

Tate, Norman W. 110

Tavierne, Richard S. 63

Taylor, Allison K. 88

Taylor, Diane L. 88

Taylor, Gayle A. 55

Taylor, Jim L. 110

Taylor, Walter L. 89

Tengesdal, Kerri Lee M. 59 


